\title{
ANL-99/3
}

\section{ARGONNE NATIONAL LABORATORY-EAST SITE ENVIRONMENTAL REPORT FOR CALENDAR YEAR 1998}

\author{
by \\ N.W. Golchert and R.G. Kolzow \\ Environment, Safety and Health Division
}

September 1999

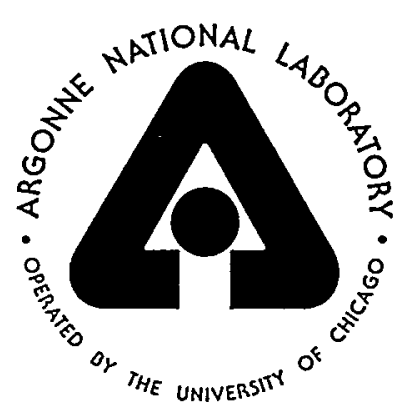

\footnotetext{
ARGONNE NATIONAL LABORATORY 9700 South Cass Avenue

Argonne, Illinois 60439
}

Preceding Report in This Series: ANL-98/2 


\section{DISCLAIMER}

Portions of this document may be illegible in electronic image products. Images are produced from the best available original document. 


\section{DISCLAIMER}

This report was prepared as an account of work sponsored by an agency of the United States Government. Neither the United States Government nor any agency thereof, nor any of their employees, make any warranty, express or implied, or assumes any legal liability or responsibility for the accuracy, completeness, or usefulness of any information, apparatus, product, or process disclosed, or represents that its use would not infringe privately owned rights. Reference herein to any specific commercial product, process, or service by trade name, trademark, manufacturer, or otherwise does not necessarily constitute or imply its endorsement, recommendation, or favoring by the United States Government or any agency thereof. The views and opinions of authors expressed herein do not necessarily state or reflect those of the United States Government or any agency thereof. 


\section{PREFACE}

This Site Environmental Report (SER) was prepared by the Environment, Safety and Health (ESH) Division at Argonne National Laboratory-East for the U.S. Department of Energy. The results of the environmental monitoring program and an assessment of the impact of site operations on the environment and the public are presented in this publication. This SER and those for recent years are available on the Internet at http://www.emo.anl.gov/annrep.

Most of the figures and tables were prepared by Jennifer Tucker of the Data Management Team.

Sample collection and field measurements were conducted under the direction of Ronald Kolzow of the ESH Monitoring and Surveillance Group by:

Michael Cole

Rob Piorkowski

The analytical separations and measurements were conducted by the Analytical Services Group of ESH by:

Radiochemistry Group

Theresa Davis

Alan Demkovich

Bill Keenan

Emo Redey

Emmer Thompson
Chemistry Group

Christos Stamoudis

Gary Griffin

Richard Kasper

Jim Riha 
The following staff made informational contributions to this report:

$\begin{array}{ll}\text { Greg Barrett } & \text { Mark Kamiya } \\ \text { Al Carbaugh } & \text { Elliot Kolsto } \\ \text { Mary Goodkind } & \text { Gregg Kulma } \\ \text { Chris Grandy } & \text { Bill Luck } \\ \text { Gary Griffin } & \text { Larry Moos } \\ \text { Bill Hannum } & \text { Geoff Pierce } \\ \text { Beth Harvey } & \text { Earl Powell } \\ \text { Richard Hart } & \text { Bob Swale } \\ \text { John Herman } & \text { Keith Trychta } \\ \text { Jim Huggins } & \text { Bob Utesch }\end{array}$

Support to prepare this report was provided by Rita M. Beaver (ESH). Editorial and document preparation services were provided by Margaret Clemmons, Pat Hollopeter, Louise Kickels, and Kerri Schroeder of ANL-E's Information and Publishing Division. 
PREFACE $\ldots \ldots \ldots \ldots \ldots \ldots \ldots \ldots \ldots \ldots \ldots \ldots \ldots \ldots \ldots \ldots \ldots \ldots \ldots \ldots$ iii

ACRONYMS $\ldots \ldots \ldots \ldots \ldots \ldots \ldots \ldots \ldots \ldots \ldots \ldots \ldots \ldots \ldots \ldots \ldots \ldots \ldots$

ABSTRACT $\ldots \ldots \ldots \ldots \ldots \ldots \ldots \ldots \ldots \ldots \ldots \ldots \ldots \ldots \ldots \ldots \ldots \ldots \ldots \ldots \ldots \ldots$

EXECUTIVE SUMMARY $\ldots \ldots \ldots \ldots \ldots \ldots \ldots \ldots \ldots \ldots \ldots \ldots \ldots \ldots$

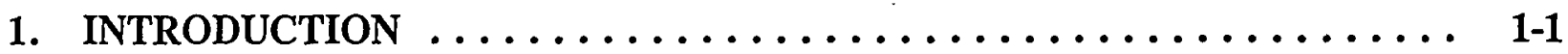

1.1. General . ...................... 1-3

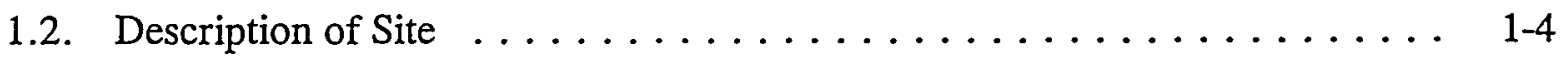

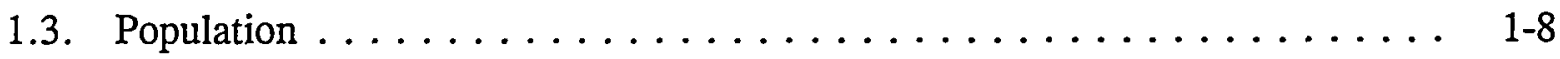

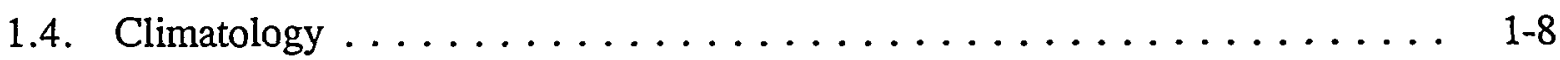

1.5. Geology . . . . . . . . . . . . . . . . . 1-12

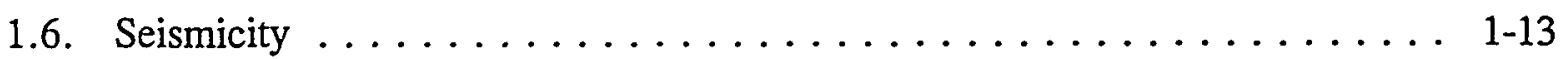

1.7. Hydrology . . . . . . . . . . . . . . . . 1-13

1.8. Water and Land Use $\ldots \ldots \ldots \ldots \ldots \ldots \ldots \ldots \ldots \ldots \ldots \ldots \ldots$

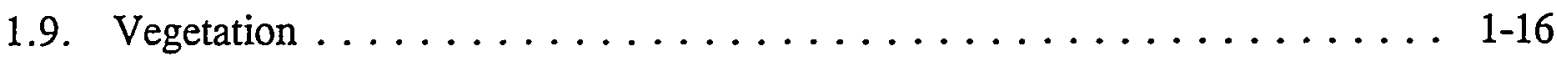

1.10. Fauna $\ldots \ldots \ldots \ldots \ldots \ldots \ldots \ldots \ldots \ldots \ldots \ldots \ldots \ldots \ldots \ldots \ldots \ldots \ldots$

1.11. Archaeology $\ldots \ldots \ldots \ldots \ldots \ldots \ldots \ldots \ldots \ldots \ldots \ldots \ldots \ldots \ldots \ldots \ldots .1-18$

1.12. Endangered Species $\ldots \ldots \ldots \ldots \ldots \ldots \ldots \ldots \ldots \ldots \ldots \ldots \ldots \ldots$

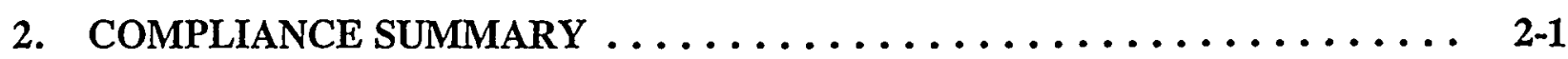

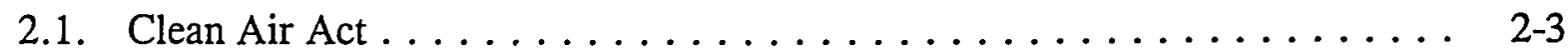

2.1.1. National Emission Standards for Hazardous

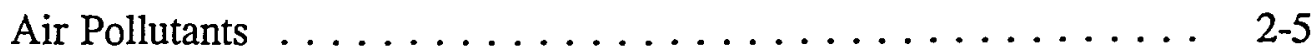

2.1.1.1. Asbestos Emissions . . . . . . . . . . . 2-5

2.1.1.2. Radionuclide Emissions $\ldots \ldots \ldots \ldots \ldots \ldots \ldots$ 2-6 
$\underline{\text { Page }}$

2.1.2. Conventional Air Pollutants ................ 2-8

2.1.3. Clean Fuel Fleet Program . . . . . . . . . . . . . . . . . 2-12

2.2. Clean Water Act . . . . . . . . . . . . . . . . . . 2-12

2.2.1. Liquid Effluent Discharge Permit . . . . . . . . . . . . 2-13

2.2.1.1. Compliance with NPDES Permit . . . . . . . . 2-13

2.2.1.2. Priority Pollutant Analysis and Biological

Toxicity Testing ................. 2-18

2.2.2. Storm Water Regulations ... . . . . . . . . . . . . . . 2-19

2.2.3. NPDES Inspections and Audits . . . . . . . . . . . . 2-21

2.2.4. General Effluent and Stream Quality Standards . . . . . . . . . . 2-21

2.2.5. Spill Prevention Control and

Countermeasures Plan . . . . . . . . . . . . . . . 2-21

2.3. Resource Conservation and Recovery Act . . . . . . . . . . . . . . . 2-22

2.3.1. Hazardous Waste Treatment and Disposal . . . . . . . . . . . . 2-22

2.3.2. Mixed Waste Handling ... . . . . . . . . . . . 2-30

2.3.3. Federal Facility Compliance Act Activities . . . . . . . . . . 2-30

2.3.4. RCRA Inspections: Hazardous Waste . . . . . . . . . . . . 2-31

2.3.5. Underground Storage Tanks . . . . . . . . . . . . . . 2-31

2.3.6. Corrective Action for Solid Waste
Management Units ..................... 2-31

2.3.7. Radioactive Waste Storage Facility ... . . . . . . . . . 2-32

2.4. Solid Waste Disposal . . . . . . . . . . . . . . . . . . 2-32

2.5. National Environmental Policy Act . . . . . . . . . . . . . . 2-33

2.6. Safe Drinking Water Act $\ldots \ldots \ldots \ldots \ldots \ldots \ldots \ldots \ldots$. . . . . . . . .

2.6.1. Applicability to ANL-E . . . . . . . . . . . . . . 2-35

2.6.2. Water Supply Monitoring ................. 2-35

2.7. Federal Insecticide, Fungicide, and Rodenticide Act . . . . . . . . . . . 2-36 
2.8. Comprehensive Environmental Response, Compensation

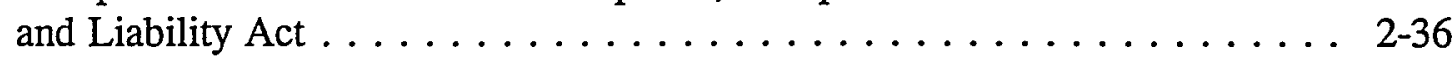

2.8.1. CERCLA Program at ANL-E . . . . . . . 2-36

2.8.2. CERCLA Remedial Actions $\ldots \ldots \ldots \ldots \ldots \ldots \ldots \ldots$ 2-38

2.8.3. Emergency Planning and Community Right to

Know Act . . . . . . . . . . . . . . . . . .

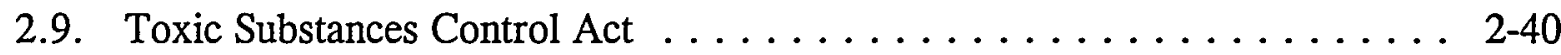

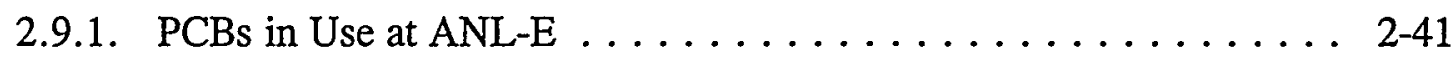

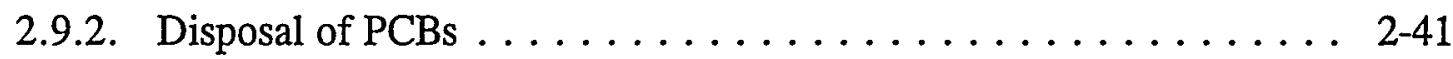

2.9.3. Storage of Radioactive PCB-Contaminated Material . . . . . . 2-41

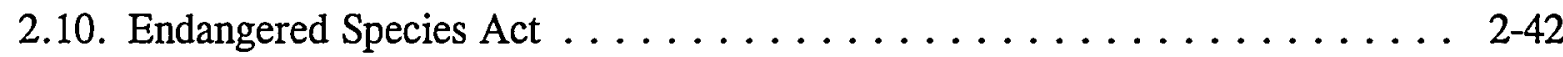

2.11. National Historic Preservation Act $\ldots \ldots \ldots \ldots \ldots \ldots \ldots . \ldots \ldots$ 2-44

2.12. Floodplain Management $\ldots \ldots \ldots \ldots \ldots \ldots \ldots \ldots \ldots \ldots \ldots \ldots \ldots \ldots$

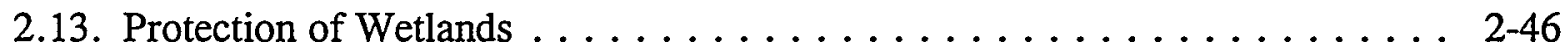

2.13.1. Sitewide Wetlands Management $\ldots \ldots \ldots \ldots \ldots \ldots \ldots .2-46$

2.13.2. U.S. Army Corps of Engineers Review $\ldots \ldots \ldots \ldots . . .2-47$

2.14. Wildlife Management and Related Monitoring $\ldots \ldots \ldots \ldots \ldots .2-48$

2.14.1. Deer Population Monitoring . . . . . . . . . . . . . . 2 2-48

2.14.2. Deer Health Monitoring $\ldots \ldots \ldots \ldots \ldots \ldots \ldots . . \ldots \ldots$

2.14.3. Deer Tissue Monitoring . . . . . . . . . . . . 2-48

2.14.4. Vegetation Damage $\ldots \ldots \ldots \ldots \ldots \ldots \ldots \ldots \ldots . \ldots \ldots$

2.15. Current Issues and Actions $\ldots \ldots \ldots \ldots \ldots \ldots \ldots \ldots \ldots \ldots \ldots . \ldots \ldots$ 2-49

2.15.1. Clean Water Act - NPDES . . . . . . . . . . . . . 2 2-49

2.15.2. RCRA - Underground Storage Tanks . . . . . . . . 2-50

2.16. Environmental Permits . . . . . . . . . . . . . . 2-50 
Page

3. ENVIRONMENTAL PROGRAM INFORMATION $\ldots \ldots \ldots \ldots \ldots \ldots \ldots$ 3-1

3.1. Environmental Programs $\ldots \ldots \ldots \ldots \ldots \ldots \ldots \ldots \ldots . \ldots \ldots$

3.2. Remedial Actions Progress in $1998 \ldots \ldots \ldots \ldots \ldots \ldots$. . . . . . . . . . .

3.3. Environmental Support Programs . . . . . . . . . . . . 3-6

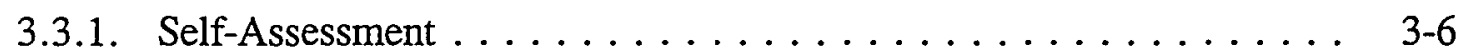

3.3.2. Environmental Training Programs . . . . . . . . . . 3-6

3.3.3. Waste Minimization and Pollution Prevention ........ 3-7

3.3.4. Site Environmental Performance Measures Program ........ . 3-11

3.3.5. Environmental Management System . . . . . . . . . . . 3-12

3.4. Environmental Monitoring Program Description . . . . . . . . . 3-12

3.4.1. Air Sampling . . . . . . . . . . . . . . . 3-13

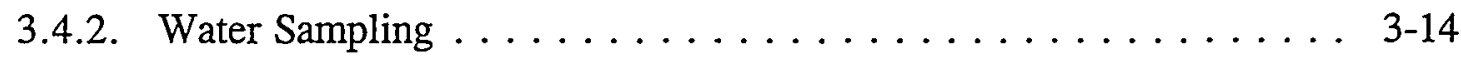

3.4.3. Bottom Sediment . . . . . . . . . . . . . . 3-16

3.4.4. External Penetrating Radiation $\ldots \ldots \ldots \ldots \ldots \ldots \ldots .16$

3.4.5. Data Management . . . . . . . . . . . . . 3-17

3.5. Compliance with DOE Order $5820.2 \mathrm{~A} \ldots \ldots \ldots \ldots \ldots \ldots \ldots$ 3-18

4. ENVIRONMENTAL RADIOLOGICAL PROGRAM INFORMATION . . . . . 4-1

4.1. Description of Monitoring Program $\ldots \ldots \ldots \ldots \ldots$ 4-3

4.2. Air . . . . . . . .

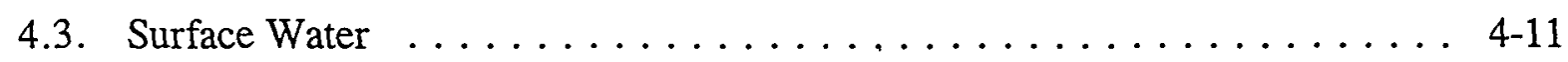

4.4. Bottom Sediment . . . . . . . . . . . . . . . . 4-17

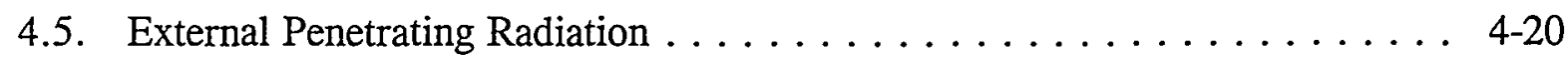

4.6. Estimates of Potential Radiation Doses $\ldots \ldots \ldots \ldots \ldots \ldots$. . . . . . . .

4.6.1. Airborne Pathway . . . . . . . . . . . . . . . . 4-24

4.6.2. Water Pathway $\ldots \ldots \ldots \ldots \ldots \ldots \ldots \ldots \ldots \ldots \ldots .40$

4.6.3. External Direct Radiation Pathway . . . . . . . . . . 4-44

4.6.4. Dose Summary . . . . . . . . . . . . . . . 4-45 


\section{ENVIRONMENTAL NONRADIOLOGICAL PROGRAM}

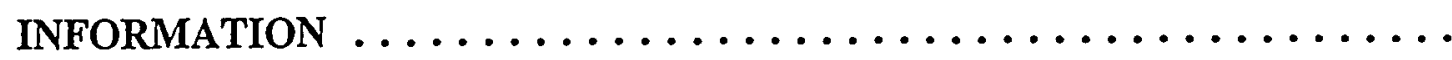

5.1. National Pollutant Discharge Elimination System

Monitoring Results

5.1.1. Influent Monitoring

5.1.2. Effluent Monitoring

5.1.2.1. Sample Collection .

5.1.2.2. Sample Analyses - NPDES

5.1.2.3. Results

5.1.2.4. Outfalls

5.2. Additional Effluent Monitoring

5.2.1. Sample Collection

5.2.2. Results

5.3. Sawmill Creek 5-33

5.3.1. Sample Collection 5-33

5.3.2. Results 5-33

6. GROUNDWATER PROTECTION .................. 6-1

6.1. Former Potable Water System $\ldots \ldots \ldots \ldots \ldots \ldots \ldots \ldots \ldots \ldots \ldots \ldots \ldots$

6.1.1. Regulatory Required Monitoring ............ 6-3

6.1.2. Informational Monitoring $\ldots \ldots \ldots \ldots \ldots \ldots \ldots \ldots \ldots$

6.1.3. Dolomite Well Monitoring . . . . . . $6.6 \ldots \ldots \ldots \ldots$

6.2. Groundwater Monitoring at Waste Management Sites . . . . . . . . 6-15

6.2.1. 317 and 319 Areas . . . . . . . . . . . . . . . . .

6.2.2. Groundwater Monitoring at the 317 and 319 Areas . . . . . . 6-20

6.2.2.1. Sample Collection . . . . . . . . . . . 6-22

6.2.2.2. Sample Analyses -317 and 319 Areas . . . . . . . 6-23

6.2.2.3. Results of Analyses . . . . . . . . . . . 6-24 
Page

6.3. Sanitary Landfill $\ldots \ldots \ldots \ldots \ldots \ldots \ldots \ldots \ldots \ldots . \ldots \ldots .43$

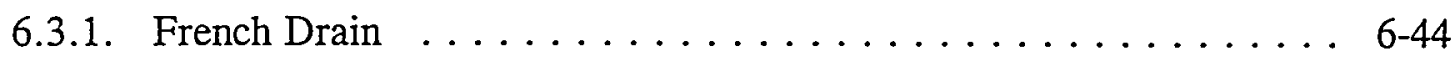

6.3.2. Monitoring Studies $\ldots \ldots \ldots \ldots \ldots \ldots \ldots \ldots \ldots .6 .44$

6.3.2.1. Sample Collection . . . . . . . . . . . . 6 6-44

6.3.2.2. Sample Analyses -800 Area $\ldots \ldots \ldots \ldots \ldots \ldots .646$

6.3.2.3. Results of Analyses . . . . . . . . . . . . . 6-47

6.4. CP-5 Reactor Area $\ldots \ldots \ldots \ldots \ldots \ldots \ldots \ldots \ldots .6 \ldots \ldots .6 \ldots$

6.5. Site Remediation Activities . . . . . . . . . . . . . . . . 6-79

6.5.1. $317 / 319$ Area $\ldots \ldots \ldots \ldots \ldots \ldots \ldots \ldots \ldots \ldots .6 .79$

6.5.2. Building $24 \ldots \ldots \ldots \ldots \ldots \ldots \ldots \ldots \ldots \ldots \ldots \ldots \ldots \ldots \ldots \ldots \ldots \ldots$

6.5.3. Building $34 \ldots \ldots \ldots \ldots \ldots \ldots \ldots \ldots \ldots \ldots \ldots \ldots \ldots \ldots \ldots$

6.5.4. Characterization Studies of the Seeps South of the 300 Area . . . . 6-81

7. QUALITY ASSURANCE $\ldots \ldots \ldots \ldots \ldots \ldots \ldots \ldots \ldots \ldots \ldots \ldots$ 7-1

7.1. Sample Collection $\ldots \ldots \ldots \ldots \ldots \ldots \ldots \ldots \ldots \ldots \ldots \ldots \ldots \ldots \ldots$ 7-3

7.2. Radiochemical Analysis and Radioactivity Measurements . . . . . . 7 7-4

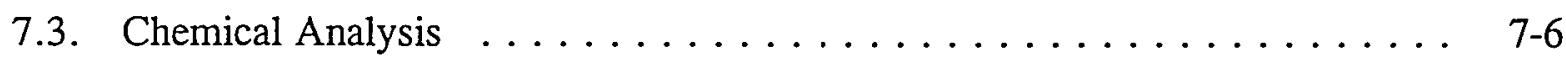

7.4. NPDES Analytical Quality Assurance $\ldots \ldots \ldots \ldots \ldots \ldots \ldots \ldots$ 7-12

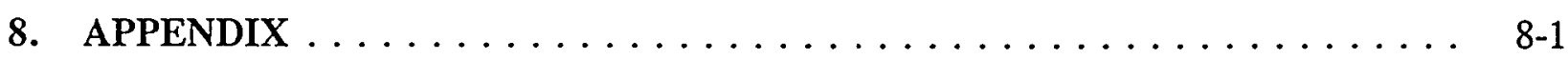

8.1. References ................... $8-3$

8.2. Distribution for $99 / 3 \ldots \ldots \ldots \ldots \ldots \ldots \ldots \ldots \ldots \ldots \ldots \ldots \ldots \ldots$ 
No.

Title

Page

1.1 Sampling Locations at Argonne National Laboratory-East . . . . . . . . . . . 1-6

1.2 Sampling Locations near Argonne National Laboratory-East . . . . . . . . . 1-7

1.3 Monthly and Annual Wind Roses at Argonne National

Laboratory-East, 1998 . . . . . . . . . . . . . . . . . . . . . . 1-10

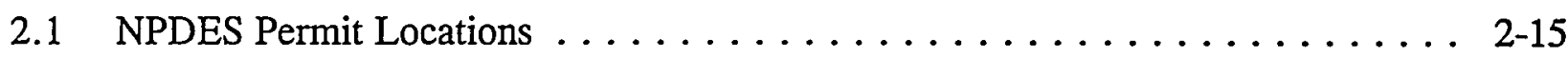

2.2 ANL-E Wastewater Treatment Plant . . . . . . . . . . . . . . 2-17

2.3 Total Number of NPDES Exceedances, 1990 to $1998 \ldots \ldots \ldots$. . . . . . . . . . 2-18

2.4 Major Treatment, Storage, and/or Disposal Areas at ANL-E . . . . . . . . . . 2-29

4.1 Comparison of Total Alpha and Beta Activities. in Perimeter Air Filter Samples . . . . . . . . . . . . . . . . 4-8

4.2 Comparison of Gamma-Ray Activity in Air Filter Samples . . . . . . . . . . 4 4-9

4.3 Selected Airborne Radionuclide Emissions . . . . . . . . . . . . . . . . . . . 4-13

4.4 Penetrating Radiation Measurements at the ANL-E Site, $1998 \ldots \ldots \ldots$. . . 4-23

4.5 Individual and Perimeter Doses from Airborne Radioactive Emissions . . . . . . . . . . . . . . . . . . . 4 4-38

4.6 Population Dose from Airborne Radioactive Emissions . . . . . . . . . . . . . 4-40

4.7 Comparison of Dose Estimate from Ingestion of Sawmill Creek Water . . . . . . . . . . . . . . . . . . 4 4-43

5.1 Average Acetone Levels in Laboratory Influent Wastewater, 1992 to $1998 \ldots \ldots \ldots \ldots \ldots$. . . . . . . . . . . . . . 5-6

5.2 Average Chloroform Levels in Laboratory Influent Wastewater, 1992 to 1998 . . . . . . . . . . . . . . . . . . . . . 5-7

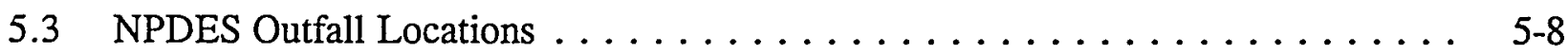

5.4 Total Dissolved Solids and Chloride in Outfall 001 Water, 1996 to 1998 . . . . 5 5-13

5.5 Total Dissolved Solids NPDES Outfall $001 \ldots \ldots \ldots \ldots$. . . . . . . . . . . .

5.6 NPDES Outfall 001 30-Day Average Copper Results, 1996 to $1998 \ldots \ldots$. . . 5-15

5.7 NPDES Outfall 001 30-Day Average Ammonia-Nitrogen Results, 1996 to 1998 . . . . . . . . . . . . . . . . . . . . 5-16

6.1 East Area/Forest Preserve Monitoring Wells $\ldots \ldots \ldots \ldots \ldots \ldots$ 6-16

6.2 Locations of Components within the $317 / 319 /$ ENE Area $\ldots \ldots \ldots \ldots \ldots$ 6-18 
No.

Title

Page

6.3 Active Monitoring and Characterization Wells in the 317 and

319 Areas, 1998 . . . . . . . . . . . . . . . . . . . . . . . . . 6-21

6.4 Concentrations of 1,1-Dichloroethane and

1,1,1-Trichloroethane in Well 317021

6.5 Trends of Selected Organics in 317 Area Manholes, $1998 \ldots \ldots \ldots$. . . . . 6-41

6.6 Active Monitoring Wells in the 800 Area Landfill . . . . . . . . . . . . . 6-45

6.7 Well 800161 Manganese Results . . . . . . . . . . . . . . . . 6-64

6.8 Well 800162 Manganese Results . . . . . . . . . . . . . . . . . 6-64

6.9 Well 800171 Manganese Results . . . . . . . . . . . . . . . 6 65

6.10 Well 800173D Chloride Results . . . . . . . . . . . . . . . 6 6-65

6.11 Well 800191 Manganese Results . . . . . . . . . . . . . . . . . . 6-66

6.12 Well 800191 Chloride Results . . . . . . . . . . . . . . . . 6-66

6.13 Well 800191 TDS Results . . . . . . . . . . . . . . . . . . . . . . 6-67

6.14 Well 800192 Iron Results . . . . . . . . . . . . . . . . . . . . 6-67

6.15 Well 800192 Manganese Results . . . . . . . . . . . . . . . . 6-68

6.16 Well 800201 Manganese Results . . . . . . . . . . . . . . . 6 6-68

6.17 Well 800202 Manganese Results . . . . . . . . . . . . . . . . . . 6.69

6.18 Active Monitoring Wells in the CP-5 Reactor Area . . . . . . . . . . 6-78

6.19 Hydrogen-3 Results in the CP-5 Monitoring Wells . . . . . . . . . . . . . 6-79

6.20 Seep Locations South of the $317 / 319$ Area $\ldots \ldots \ldots \ldots \ldots \ldots \ldots$. . . . . . . . . 
1.1 Population Distribution in the Vicinity of ANL-E, $1997 \ldots \ldots \ldots \ldots \ldots$. . . . . .

1.2 ANL-E Weather Summary, $1998 \ldots \ldots \ldots \ldots \ldots \ldots \ldots$. . . . . . . . . . . . .

2.1 Asbestos Abatement Projects: IEPA Notification, $1998 \ldots \ldots \ldots \ldots \ldots \ldots$. . . . . .

2.2 Disposal of Asbestos-Containing Materials, $1998 \ldots \ldots \ldots \ldots \ldots$ 2-8

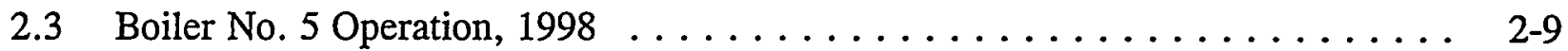

2.41998 Annual Emissions Report: Emissions Summary . . . . . . . . . . . . 2-11

2.5 Characterization of NPDES Outfalls at ANL-E, $1998 \ldots \ldots \ldots \ldots$. . . . . . . . . 2-14

2.6 Permitted Hazardous Waste Treatment and Storage Facilities, 1998 . . . . . . . . 2-24

2.7 Hazardous Waste Treatment, Storage, Disposal, or Recycle, 1998 . . . . . . . 2-26

2.8 Mixed Waste Treatment, Storage, and Disposal, $1998 \ldots \ldots \ldots \ldots$. . . . . . . 27

2.9 Generation and Disposal or Recycling of Special and Nonspecial Waste, 1998 . . . 2-34

2.10 List of Inactive Waste Disposal Sites at ANL-E Described in Various CERCLA Reports . . . . . . . . . . . 2-37

2.11 Chemical Inventories Reported under SARA Title III, 1998 . . . . . . . . . . . . 2-40

2.12 ANL-E Environmental Permits in Effect December 31, $1998 \ldots \ldots \ldots \ldots$. . . . 2-51

4.1 Total Alpha and Beta Activities in Air Filter Samples, 1998 . . . . . . . . . . 4-6

4.2 Gamma-Ray Activity in Air Filter Samples, $1998 \ldots \ldots \ldots \ldots$. . . . . . . . .

4.3 Strontium, Thorium, Uranium, and Plutonium Concentrations
in Air Filter Samples, 1998

4.4 Summary of Monitored Airborne Radioactive Emissions from ANL-E Facilities, 1998 . . . . . . . . . . . . . . . . . . . . . . . . 4-12

4.5 Radionuclides in Sawmill Creek Water, $1998 \ldots \ldots \ldots$. . . . . . . . . . 4-15

4.6 Total Radioactivity Released to Sawmill Creek, $1998 \ldots \ldots$. . . . . . . . . . 4-16

4.7 Radionuclides in Storm Water Outfalls, $1998 \ldots \ldots$. . . . . . . . . . . 4-17

4.8 Radionuclides in Des Plaines River Water, 1998 . . . . . . . . . . . . . . . . 4-18

4.9 Radionuclides in Bottom Sediment, $1998 \ldots \ldots \ldots$. . . . . . . . . . . . 4-19

4.10 Environmental Penetrating Radiation at Off-Site Locations, 1998 . . . . . . . . . . . . . . . . . . . . . . . . . . 4-21

4.11 Environmental External Penetrating Radiation at ANL-E, $1998 \ldots \ldots \ldots$. . . 4-22 
No.

Title

Page

4.12 Radiological Airborne Releases from Building 200, $1998 \ldots \ldots \ldots$. . . . 4-25

4.13 Maximum Perimeter and Individual Doses from Building 200 Air Emissions, 1998 . . . . . . . . . . . . . . . . . . . . . 4 4-26

4.14 Radiological Airborne Releases from Building 205, $1998 \ldots \ldots \ldots$. . . . 4-27

4.15 Maximum Perimeter and Individual Doses from Building 205 Air Emissions, 1998 . . . . . . . . . . . . . . . . . . . . . . . 4 4-28

4.16 Radiological Airborne Releases from Building 212, 1998 . . . . . . . . . 4-29

4.17 Maximum Perimeter and Individual Doses from Building 212 Air Emissions, 1998 . . . . . . . . . . . . . . . . . . . . . . . 4-30

4.18 Radiological Airborne Releases from Building $350,1998 \ldots \ldots \ldots$. . . . . 4-31

4.19 Maximum Perimeter and Individual Doses from Building 350 Air Emissions, 1998 . . . . . . . . . . . . . . . . . . . . . . . 4 4-32

4.20 Radiological Airborne Releases from Building 375, 1998 . . . . . . . . . . 4 4-34

4.21 Maximum Perimeter and Individual Doses from Building 375 Air Emissions, 1998 . . . . . . . . . . . . . . . . . . . . . . . 4 4-35

4.22 Radiological Airborne Releases from Building 411/415, $1998 \ldots \ldots$. . . . 4 4-36

4.23 Maximum Perimeter and Individual Doses from Building 411/415 Air Emissions, 1998 . . . . . . . . . . . . . . . . . . . . . . . 4-37

4.24 Population Dose within $80 \mathrm{~km}, 1998 \ldots \ldots \ldots \ldots \ldots$. . . . . . . . . . . . . . .

4.25 50-Year Committed Effective Dose Equivalent Factors . . . . . . . . . . . . 4-41

4.26 Radionuclide Concentrations and Dose Estimates for Sawmill Creek Water, 1998 . . . . . . . . . . . . . . . . . . . . 4-42

4.27 Summary of the Estimated Dose to the Public, $1998 \ldots \ldots \ldots \ldots$. . . . . . 4-45

4.28 Annual Average Dose Equivalent in the U.S. Population . . . . . . . . . . . 4 4-46

5.1 Laboratory Influent Wastewater, $1998 \ldots \ldots \ldots \ldots \ldots \ldots \ldots$. 5 . . . . . . .

5.2 Outfall 001A Effluent Limits and Monitoring Results, $1998 \ldots \ldots \ldots \ldots$. . . . 5-10

5.3 Outfall 001B Effluent Priority Pollutant Monitoring Results, 1998 . . . . . . . 5 5-12

5.4 Outfall 001 Monitoring Results and Effluent Limits, $1998 \ldots \ldots \ldots$. . . . . . 5-13

5.5 Outfall 001 Aquatic Toxicity Test Results, $1998 \ldots \ldots \ldots$. . . . . . . . . 5-17

5.6 Outfall 001 Aquatic Toxicity Test Results, 1991 to $1998 \ldots \ldots$. . . . . . . . 5-17 


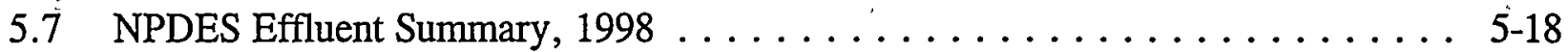

5.8 Acute Toxicity Results: Fathead Minnow, 1998 . . . . . . . . . . . . . . . 5-23

5.9 Acute Toxicity Results: Water Flea, 1998 . . . . . . . . . . . . . . . . 5 5-23

5.10 Chemical Constituents in Effluents from the ANL-E Wastewater

Treatment Plant, 1998 . . . . . . . . . . . . . . . . . . . . 5-32

5.11 Chemical Constituents in Sawmill Creek, Location 7M, $1998 \ldots \ldots \ldots$. . . . 5-34

6.1 ANL-E Former Water Supply Wells $\ldots \ldots \ldots \ldots \ldots \ldots \ldots \ldots$. 6-4 . . . . . .

6.2 Radioactivity in ANL-E Former Water Supply Wells, $1998 \ldots \ldots \ldots \ldots$. . . . 6-5

6.3 Volatile Organic Compounds in Former Water Supply Well Samples Collected February $2,1998 \ldots \ldots \ldots \ldots \ldots \ldots \ldots \ldots \ldots \ldots \ldots \ldots \ldots \ldots$

6.4 Volatile Organic Compounds in Former Water Supply Well Samples

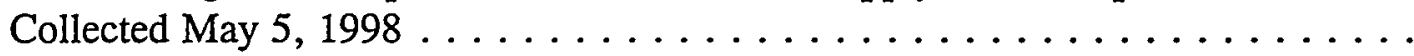

6.5 Volatile Organic Compounds in Former Water Supply Well Samples Collected August 25, $1998 \ldots \ldots \ldots \ldots \ldots \ldots \ldots$. . . . . . . . . . . . .

6.6 Volatile Organic Compounds in Former Water Supply Well Samples Collected November 10, 1998

6.7 Hydrogen-3 in Dolomite Wells, 1998 . . . . . . . . . . . . . . . 6-17

6.8 Groundwater Monitoring Wells: 317 and 319 Areas . . . . . . . . . 6-22

6.9 Groundwater Monitoring Results, 300 Area Well 317021, 1998 . . . . . . . . . 6 6-25

6.10 Groundwater Monitoring Results, 300 Area Well 317052, 1998 . . . . . . . . 6-26

6.11 Groundwater Monitoring Results, 300 Area Well 317061, 1998 . . . . . . . . . 6-27

6.12 Groundwater Monitoring Results, 300 Area Well 317101, 1998 . . . . . . . . 6-28

6.13 Groundwater Monitoring Results, 300 Area Well 317111, 1998 . . . . . . . . . 6-29

6.14 Groundwater Monitoring Results, 300 Area Well 317121D, 1998 . . . . . . . . 6-30

6.15 Groundwater Monitoring Results, 300 Area Well 319011, 1998 . . . . . . . . 6-31

6.16 Groundwater Monitoring Results, 300 Area Well 319031, 1998 . . . . . . . . . 6-32

6.17 Groundwater Monitoring Results, 300 Area Well 319032, 1998 . . . . . . . . 6-33

6.18 Groundwater Monitoring Results, 300 Area Well 319131D, 1998 . . . . . . . . 6-34

6.19 Illinois Class I Groundwater Quality Standards: Inorganics . . . . . . . . . . 6 6-36

6.20 Illinois Class I Groundwater Quality Standards: Organics . . . . . . . . 6-37

ANL-E Site Environmental Report 
No.

6.21 Volatile Organic Compounds in 317 Area:

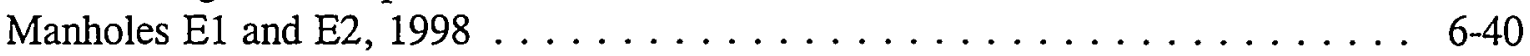

6.22 Hydrogen-3 Concentrations in Manhole Water Samples, 1998 . . . . . . . . . 6 6-43

6.23 Groundwater Monitoring Wells: 800 Area Landfill . . . . . . . . . . . . . . 6-46

6.24 Groundwater Monitoring Results, Sanitary Landfill

Well 800161, 1998 . . . . . . . . . . . . . . . . . . . . . . . . 6-48

6.25 Groundwater Monitoring Results, Sanitary Landfill

Well 800162, 1998 . . . . . . . . . . . . . . . . . . . . . . . . . . . . 6-49

6.26 Groundwater Monitoring Results, Sanitary Landfill

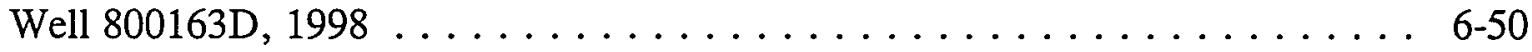

6.27 Groundwater Monitoring Results, Sanitary Landfill Well 800171, $1998 \ldots \ldots \ldots \ldots \ldots \ldots \ldots \ldots \ldots \ldots \ldots$. . . . . . . . . .

6.28 Groundwater Monitoring Results, Sanitary Landfill

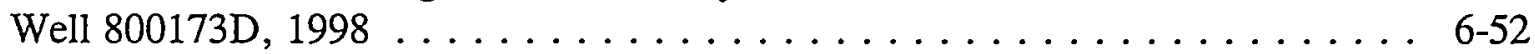

6.29 Groundwater Monitoring Results, Sanitary Landfill Well 800181, 1998 . . . . . . . . . . . . . . . . . . . . . . . . 6-53

6.30 Groundwater Monitoring Results, Sanitary Landfill Well 800183D, $1998 \ldots \ldots \ldots \ldots \ldots$. . . . . . . . . . . . . . . . 6 6-54

6.31 Groundwater Monitoring Results, Sanitary Landfill

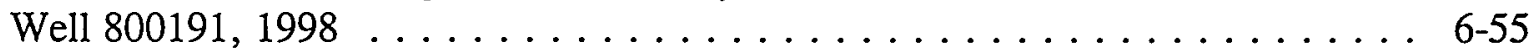

6.32 Groundwater Monitoring Results, Sanitary Landfill

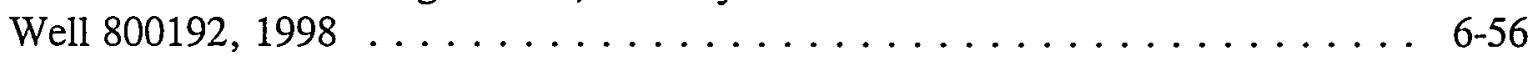

6.33 Groundwater Monitoring Results, Sanitary Landfill

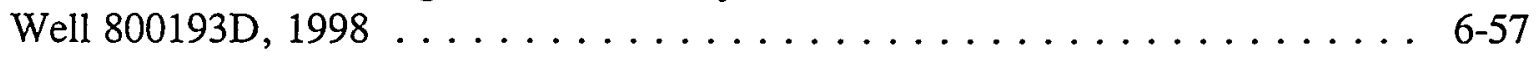

6.34 Groundwater Monitoring Results, Sanitary Landfill Well 800201,1998 . . . . . . . . . . . . . . . . . . . . . . . . 6- 6-58

6.35 Groundwater Monitoring Results, Sanitary Landfill Well 800202,1998 . . . . . . . . . . . . . . . . . . . . . . . . . . . . 6-59

6.36 Groundwater Monitoring Results, Sanitary Landfill

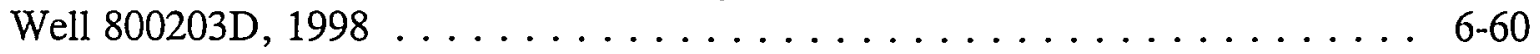

6.37 Groundwater Monitoring Results, Sanitary Landfill Well $800241,1998 \ldots \ldots \ldots \ldots$. . . . . . . . . . . . . . . . . . 6-61 
No.

6.38 Groundwater Monitoring Results, Sanitary Landfill

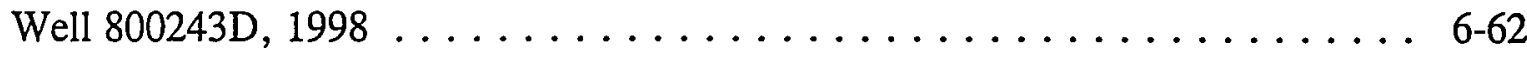

6.39 Groundwater Monitoring Results, 330 Area Well 330011, 1998 . . . . . . . . . 6-73

6.40 Groundwater Monitoring Results, 330 Area Well 330021, 1998 . . . . . . . . 6-74

6.41 Groundwater Monitoring Results, 330 Area Well 330031, $1998 \ldots \ldots \ldots$. . . 6 6-75

6.42 Groundwater Monitoring Results, 330 Area Well 330012D, $1998 \ldots \ldots$. . . . . 6-76

6.43 Groundwater Monitoring Wells: 330 Area/CP-5 Reactor . . . . . . . . . . 6-77

6.44 Contaminant Concentrations in SP01 Seep Water . . . . . . . . . . 6 6-84

6.45 Contaminant Concentrations in SP02 Seep Water . . . . . . . . . . . 6-85

6.46 Contaminant Concentrations in SP04 Seep Water . . . . . . . . . . . 6-86

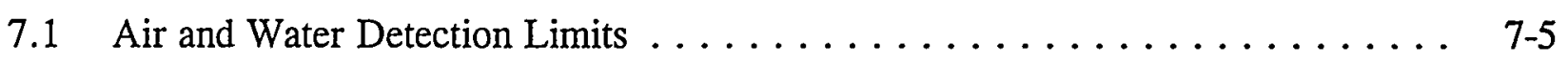

7.2 Summary of DOE-EML-QAP Samples, $1998 \ldots \ldots \ldots \ldots \ldots \ldots \ldots \ldots$. . . . . .

7.3 Standard Reference Materials Used for Inorganic Analysis $\ldots \ldots \ldots \ldots \ldots$. . . . . .

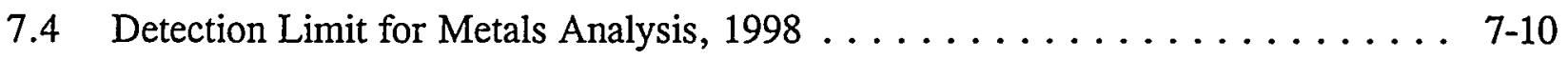

7.5 Quality Check Sample Results: Volatile Analyses, $1998 \ldots \ldots \ldots$. . . . . . 7-11

7.6 Quality Check Sample Results: Semivolatile Analyses, 1998 . . . . . . . . . 7-12 
$\mathrm{ACM}$

AEA

ANL-E

AOC

APS

ATSR

BAT

$\mathrm{BOD}_{5}$

CAA

CAAPP

CAP-88

CEDE

CERCLA

CFR

CLP

COD

COE

CP-5

CRMP

CWA

CY

D\&D

DCG

DMR

DOE

DPCHD

EA

EIS

EML

EMS

ENE

EPA

EPCRA

ERMS

ESA

ESH

ESH-ASCL

ESH-ASRL

FFCA

FWS

FY
Asbestos-Containing Material

Atomic Energy Act of 1954

Argonne National Laboratory-East

Area of Concern

Advanced Photon Source

Argonne Thermal Source Reactor

Best Available Technology

Biochemical Oxygen Demand

Clean Air Act

Clean Air Act Permit Program

Clean Air Act Assessment Package-1988

Committed Effective Dose Equivalent

Comprehensive Environmental Response, Compensation

and Liability Act

Code of Federal Regulations

Contract Laboratory Program

Chemical Oxygen Demand

U.S. Army Corps of Engineers

Chicago Pile-Five

Cultural Resources Management Plan

Clean Water Act

Calendar Year

Decontamination and Decommissioning

Derived Concentration Guide

Discharge Monitoring Report

U.S. Department of Energy

DuPage County Health Department

Environmental Assessment

Environmental Impact Statement

Environmental Measurements Laboratory

Environmental Protection Data Management System

East-Northeast

U.S. Environmental Protection Agency

Emergency Planning and Community Right to Know Act

Emissions Reduction Market System

Endangered Species Act

Environment, Safety and Health

Environment, Safety and Health/Analytical Services, Chemical Laboratory

Environment, Safety and Health/Analytical Services,

Radiochemistry Laboratory

Federal Facility Compliance Act

U.S. Fish and Wildlife Service

Fiscal Year 


$\begin{array}{ll}\text { HSWA } & \text { Hazardous and Solid Waste Amendments } \\ \text { IAC } & \text { Illinois Administrative Code } \\ \text { ICRP } & \text { International Commission on Radiological Protection } \\ \text { IDNS } & \text { Illinois Department of Nuclear Safety } \\ \text { IDPH } & \text { Illinois Department of Public Health } \\ \text { IEPA } & \text { Illinois Environmental Protection Agency } \\ \text { IHPA } & \text { Illinois Historic Preservation Agency } \\ \text { IPNS } & \text { Intense Pulsed Neutron Source } \\ \text { ISM } & \text { Integrated Safety Management } \\ \text { LEPC } & \text { Local Emergency Planning Committee } \\ \text { LLW } & \text { Low-Level Radioactive Waste } \\ \text { LUST } & \text { Leaking Underground Storage Tank } \\ \text { MSDS } & \text { Material Safety Data Sheet } \\ \text { MY } & \text { Model Year } \\ \text { NBL } & \text { New Brunswick Laboratory } \\ \text { NEPA } & \text { National Environmental Policy Act } \\ \text { NESHAP } & \text { National Emission Standards for Hazardous Air Pollutants } \\ \text { NFR } & \text { No Further Remediation } \\ \text { NHPA } & \text { National Historic Preservation Act } \\ \text { NIST } & \text { National Institute of Standards and Technology } \\ \text { NMOC } & \text { Nonmethane Organic Compounds } \\ \text { NPDES } & \text { National Pollutant Discharge Elimination System } \\ \text { NPL } & \text { National Priority List } \\ \text { NRHP } & \text { National Register of Historical Places } \\ \text { O\&M } & \text { Operation and Maintenance } \\ \text { PCB } & \text { Polychlorinated Biphenyl } \\ \text { PFS } & \text { Plant Facilities and Services } \\ \text { PQL } & \text { Practical Quantification Limit } \\ \text { PSTP } & \text { Proposed Site Treatment Plan } \\ \text { QA } & \text { Quality Assurance } \\ \text { QAP } & \text { Quality Assurance Program } \\ \text { RCRA } & \text { Resource Conservation and Recovery Act } \\ \text { RTR } & \text { Real-Time Radiography } \\ \text { SARA } & \text { Superfund Amendments and Reauthorization Act } \\ \text { SDWA } & \text { Safe Drinking Water Act } \\ \text { SER } & \text { Site Environmental Report } \\ \text { SOP } & \text { Standard Operating Procedure } \\ \text { SIP } & \text { Site Implementation Plan } \\ \text { SSI } & \text { Site Screening Investigation } \\ \text { SVOC } & \text { Semivolatile Organic Compound } \\ \text { SWMU } & \text { Solid Waste Management Unit } \\ \text { SWPPP } & \text { Storm Water Pollution Prevention Plans } \\ \text { TDS } & \text { Total Dissolved Solids } \\ \text { TLD } & \text { Thermoluminescent Dosimeter } \\ & \end{array}$




$\begin{array}{ll}\text { TOC } & \text { Total Organic Carbon } \\ \text { TOX } & \text { Total Organic Halogen } \\ \text { TRI } & \text { Toxic Release Inventory } \\ \text { TRU } & \text { Transuranic } \\ \text { TSCA } & \text { Toxic Substances Control Act } \\ \text { TSS } & \text { Total Suspended Solids } \\ \text { UST } & \text { Underground Storage Tank } \\ \text { VOC } & \text { Volatile Organic Compound } \\ \text { WIPP } & \text { Waste Isolation Pilot Plant } \\ \text { WMO } & \text { Waste Management Operations } \\ \text { WM\&PP } & \text { Waste Minimization and Pollution Prevention } \\ \text { WQS } & \text { Water Quality Standard } \\ \text { WTP } & \text { Wastewater Treatment Plant }\end{array}$


This report discusses the results of the environmental protection program at Argonne National Laboratory-East (ANL-E) for 1998. To evaluate the effects of ANL-E operations on the environment, samples of environmental media collected on the site, at the site boundary, and off the ANL-E site were analyzed and compared with applicable guidelines and standards. A variety of radionuclides were measured in air, surface water, on-site groundwater, and bottom sediment samples. In addition, chemical constituents in surface water, groundwater, and ANL-E effluent water were analyzed. External penetrating radiation doses were measured, and the potential for radiation exposure to off-site population groups was estimated. Results are interpreted in terms of the origin of the radioactive and chemical substances (i.e., natural, fallout, ANL-E, and other) and are compared with applicable environmental quality standards. A U.S. Department of Energy dose calculation methodology, based on International Commission on Radiological Protection recommendations and the U.S. Environmental Protection Agency's CAP-88 (Clean Air Act Assessment Package-1988) computer code, was used in preparing this report. The status of ANL-E environmental protection activities with respect to the various laws and regulations that govern waste handling and disposal is discussed, along with the progress of environmental corrective actions and restoration projects.

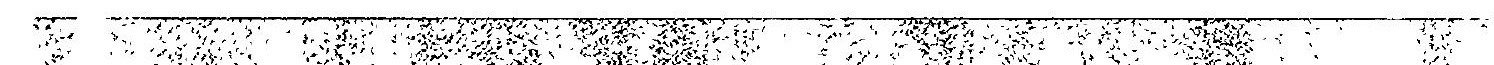


This report summarizes the ongoing environmental protection program conducted by Argonne National Laboratory-East (ANL-E) in 1998. It includes descriptions of the site, ANL-E missions and programs, the status of compliance with environmental regulations, environmental protection and restoration activities, and the environmental surveillance program. The surveillance program conducts regular monitoring for radiation, radioactive materials, and nonradiological constituents on the ANL-E site and in the surrounding region. These activities document compliance with appropriate standards and permit limits, identify trends, provide information to the public, and contribute to a better understanding of ANL-E's impact on the environment. The surveillance program supports the ANL-E policy of protecting the public, employees, and the environment from harm that could be caused by ANL-E activities and of reducing environmental impacts to the greatest degree practicable.

\section{Compliance Summary}

Radionuclide emissions, the management of asbestos, and conventional air pollutants from ANL-E facilities are regulated under the Clean Air Act. A number of airborne radiological emission points at ANL-E are subject to National Emission Standards for Hazardous Air Pollutants (NESHAP) regulations for radionuclide releases from U.S. Department of Energy (DOE) facilities (Code of Federal Regulations, Title 40, Part 61, Subpart H [40 CFR Part 61, Subpart H]). All such air emission sources were evaluated to ensure that these requirements are being properly addressed. The ANL-E individual off-site dose required to be reported by U.S. Environmental Protection Agency (EPA) regulations (40 CFR Part 61, Subpart H) in 1998 was $0.016 \mathrm{mrem} / \mathrm{yr}$. This is $0.16 \%$ of the $10 \mathrm{mrem} / \mathrm{yr}$ standard. This dose does not include contributions from radon-220 and radon-222 emissions as required by the regulations.

At ANL-E, asbestos-containing material (ACM) is frequently encountered during maintenance or renovation of existing facilities and equipment. Asbestos is removed and disposed of in strict accordance with NESHAP, Toxic Substances Control Act (TSCA), and Occupational Safety and Health Administration worker protection standards. Other applicable authorities include (1) the accreditation program of the EPA Model Accreditation Plan implementing the 
Asbestos School Hazard Abatement Reauthorization Act of 1990, which amends the TSCA asbestos provisions, and (2) the registration and licensing requirements of the Illinois Commercial and Public Building Asbestos Abatement Act, effective July 14, 1995. Approximately $181 \mathrm{~m}^{3}$ $\left(6,389 \mathrm{ft}^{3}\right)$ of ACM was removed and disposed of at off-site landfills in Illinois during 1998.

The ANL-E site contains several sources of conventional air pollutants. The steam plant and fuel dispensing facilities operate continuously and are the only significant sources of continuous air pollutants. The emergency generators at the Advanced Photon Source are also significant sources, when operational. The operating air pollution control permit for the steam plant requires continuous opacity and sulfur dioxide monitoring of the smoke stack from Boiler No. 5, the only boiler equipped to burn coal. Low-sulfur coal was burned as the fuel for the steam plant for four months during 1998, whereas natural gas was used as the fuel for the other eight months of the year. During the period coal was burned, which occurred during colder weather to supplement the gas-fired boilers, one exceedance for opacity was observed.

The principal regulatory mechanism designed to achieve the goals of the Clean Water Act is the National Pollutant Discharge Elimination System (NPDES). The authority to implement the NPDES program has been delegated to the State of Illinois. The renewal of the ANL-E NPDES permit, which became effective October 30,1994, increased the number of monitored discharge points from 9 to 28. The permit was modified on August 24, 1995, to increase temporarily some limits during the imposed three-year compliance schedule to achieve final limits. During 1998, only 2 exceedances of the NPDES permit limits were reported out of approximately 1,600 measurements.

ANL-E was granted interim status under the Resource Conservation and Recovery Act (RCRA) upon submitting a Part A permit application in 1980. The Illinois Environmental Protection Agency issued the RCRA Part B Permit on September 30, 1997. It became effective on November 4, 1997. The permit addresses 22 hazardous waste treatment and storage facilities and establishes corrective action procedures and requirements for 49 Solid Waste Management Units and 3 Areas of Concern. 
ANL-E has prepared and implemented a sitewide underground storage tank (UST) compliance plan. Thirty-eight tanks have been removed over the past several years. The ANL-E site contains 20 USTs that are in compliance with UST regulations. One UST used for fuel oil storage was removed during 1998.

The only TSCA compounds in significant quantities at ANL-E are polychlorinated biphenyls (PCBs) contained in electrical capacitors, power suppliers, and small transformers. All polemounted transformers and circuit breakers containing PCBs were replaced or retrofilled with nonPCB oil. All removal and disposal activities were conducted by licensed contractors specializing in such operations. PCB-contaminated sludge from the ANL-E wastewater treatment plant was characterized, containerized, and stored during 1994. The ANL-E PCB Item Inventory Program was initiated in 1995 to identify all suspect PCB-containing items.

DOE implementation of National Environmental Policy Act (NEPA) requirements has undergone significant changes since 1992. In 1998, most NEPA project reviews sent to DOE for review and approval were determined to be categorical exclusions. One Environmental Assessment (EA) addressing decontamination and decommissioning (D\&D) of the Argonne Thermal Source Reactor was prepared during 1998. An EA for D\&D of the Building 301 Hot Cells will be prepared in 1999.

The ANL-E Environmental Management Plan requests funds for on-site rehabilitation projects, environmental restoration projects, and waste management activities. The rehabilitation projects concentrate on upgrading or replacing existing treatment facilities. ANL-E environmental restoration activities consist of projects that assess and clean up inactive waste sites. These include two inactive landfills, three French drains (i.e., dry wells used to dispose of liquid chemicals), two inactive wastewater treatment facilities, and a number of areas that may have been contaminated with small amounts of hazardous chemicals.

On-going compliance issues at ANL-E during 1998 were the ability to meet final effluent limits for total dissolved solids (TDS) and copper; elevated levels of some routine indicator 
parameters in the groundwater at the sanitary landfill; and cleanup of environmental contamination caused by previous activities on the ANL-E site.

\section{Environmental Surveillance Program}

Airborne emissions of radioactive materials from ANL-E were monitored during 1998. The effective dose equivalents were estimated at the site perimeter and to the maximally exposed member of the public with the EPA's CAP-88 (Clean Air Act Assessment Package-1988) computer code. The estimated maximum perimeter dose was $0.18 \mathrm{mrem} / \mathrm{yr}$ in the southwest direction, while the estimated maximum dose to a member of the public was $0.027 \mathrm{mrem} / \mathrm{yr}$. This is $0.027 \%$ of the DOE radiation protection standard of $100 \mathrm{mrem} / \mathrm{yr}$ for all pathways. Approximately $20 \%$ of this estimated dose is due to the release of $239 \mathrm{Ci}$ of radon-220 in 1998. If the contribution of radon-220 is excluded from reporting, as required by 40 CFR Part 61 , Subpart $H$, the estimated dose to the maximally exposed individual would be $0.016 \mathrm{mrem} / \mathrm{yr}$. The estimated population dose from all releases to the approximately eight million people living within $80 \mathrm{~km}(50 \mathrm{mi})$ of the site was 1.69 man-rem.

Air monitoring also was conducted at ANL-E for total alpha activity, total beta activity, strontium-90, isotopic thorium, isotopic uranium, and plutonium-239. No statistically significant difference was identified between samples collected at the ANL-E perimeter and samples collected off site. Monitoring was not conducted for hazardous chemical constituents in ambient air.

The only source of radionuclides and chemical pollutants in surface water due to ANL-E releases was in Sawmill Creek below the wastewater discharge point. At various times, measurable levels of hydrogen-3, strontium-90, plutonium-239, and americium-241 were detected. Of these radionuclides, the maximum annual release was $1.26 \mathrm{Ci}$ of hydrogen- 3 . The hydrogen- 3 was added to the wastewater as part of normal ANL-E operations. The dose to a hypothetical individual using water from Sawmill Creek as his or her sole source of drinking water would be $0.026 \mathrm{mrem} / \mathrm{yr}$. However, no one uses this water for drinking, and dilution by the Des Plaines River reduces the concentrations of the measured radionuclides to levels below their respective 
detection limits downstream from ANL-E at Lemont. Sawmill Creek also is monitored for nonradiological constituents to demonstrate compliance with State of Illinois water quality standards. Iron and copper occasionally were detected above the standards.

Sediment samples were collected from Sawmill Creek, above, at, and below the point of wastewater discharge. Elevated levels of plutonium-239 (up to $0.011 \mathrm{pCi} / \mathrm{g}$ ) and americium-241 (up to $0.005 \mathrm{pCi} / \mathrm{g}$ ) were detected in the sediment below the outfall and are attributed to past ANL-E releases.

Dose rates from penetrating radiation (gamma-rays) were measured at 14 perimeter and on-site locations and at five off-site locations in 1998 using thermoluminescent dosimeters. The off-site results averaged $80 \pm 3 \mathrm{mrem} / \mathrm{yr}$, which is consistent with the long-term average. Abovebackground doses occurred at one perimeter location and were due to ANL-E operations. At the south fence, radiation from a temporary storage facility for radioactive waste resulted in an average dose of $106 \pm 10 \mathrm{mrem} / \mathrm{yr}$ for 1998 . The estimated dose from penetrating radiation to the nearest resident south of the site was $<0.01 \mathrm{mrem} / \mathrm{yr}$.

The potential radiation doses to members of the public from ANL-E operations during 1998 were estimated by combining the exposure from inhalation, ingestion, and direct radiation pathways. The inhalation pathway dominates. The highest estimated dose was approximately $0.06 \mathrm{mrem} / \mathrm{yr}$ to individuals living $500 \mathrm{~m}(1,640 \mathrm{ft})$ north of the site if they were outdoors at that location during the entire year. Doses from other pathways were calculated and were small at this location. The magnitude of the doses from ANL-E operations are well within all applicable standards and are insignificant when compared with doses received by the public from natural radiation $(\approx 300 \mathrm{mrem} / \mathrm{yr})$ or other sources, for example, medical $\mathrm{x}$-rays and consumer products $(\approx 60 \mathrm{mrem} / \mathrm{yr})$.

Radiological and chemical constituents in the groundwater were monitored in several areas of the ANL-E site in 1998. The former ANL-E domestic water supply is monitored by collecting 
quarterly samples from the three inactive supply wells and a treated water tap. All results were less than the limits established by the Safe Drinking Water Act, except for elevated levels of TDS.

Ten monitoring wells screened in the glacial till and two in the dolomite were sampled quarterly at the 317 and 319 Areas and analyzed for radiological, volatile organic, semivolatile, $\mathrm{PCB}$, and pesticide and herbicide constituents. The major organic contaminants detected were carbon tetrachloride, trichloroethene, 1,1,1-trichloroethane, 1,1-dichloroethane, and tetrachloroethene. Measurable levels of hydrogen-3, strontium-90, and cesium-137 were present in several of the wells. Remediation continued in this area. In situ treatment of soil in the 317 Area, coupled with thermally enhanced vapor extraction, was completed in 1998 to control off-site releases of contamination.

Thirteen monitoring wells at the 800 Area sanitary landfill were sampled on a quarterly basis and analyzed for metals, cyanide, phenols, total organic carbon, total organic halogens, volatile organic compounds, semivolatiles, PCBs, pesticides and herbicides, and hydrogen-3. Levels above Illinois Class I Groundwater Quality Standards for chloride, iron, lead, manganese, and TDS were found in some wells. Above-background levels of hydrogen-3 were detected in several of the wells. Trichlorofluoromethane was noted in two wells during one quarter.

An extensive quality assurance program is maintained to cover all aspects of the environmental surveillance sampling and analysis programs. Approved documents are in place, along with supporting standard operating procedures. Newly collected data were compared with recent results and historical data to ensure that deviations from previous conditions were identified and evaluated promptly. Samples at all locations were collected using well-established and documented procedures to ensure consistency. Samples were analyzed by documented standard analytical procedures. Data quality was verified by a continuing program of analytical laboratory quality control, participation in interlaboratory cross-checks, and replicate sampling and analysis. Data were managed and tracked by a dedicated computerized data management system that assigns unique sample numbers, schedules collection and analysis, checks status, and prepares tables and information for the annual report. 
ANL-E maintains a documented environmental management system that identifies responsibilities for environmental activities. ANL-E is committed to implementing that system in accordance with environmental policy. 


\section{INTRODUCTION}

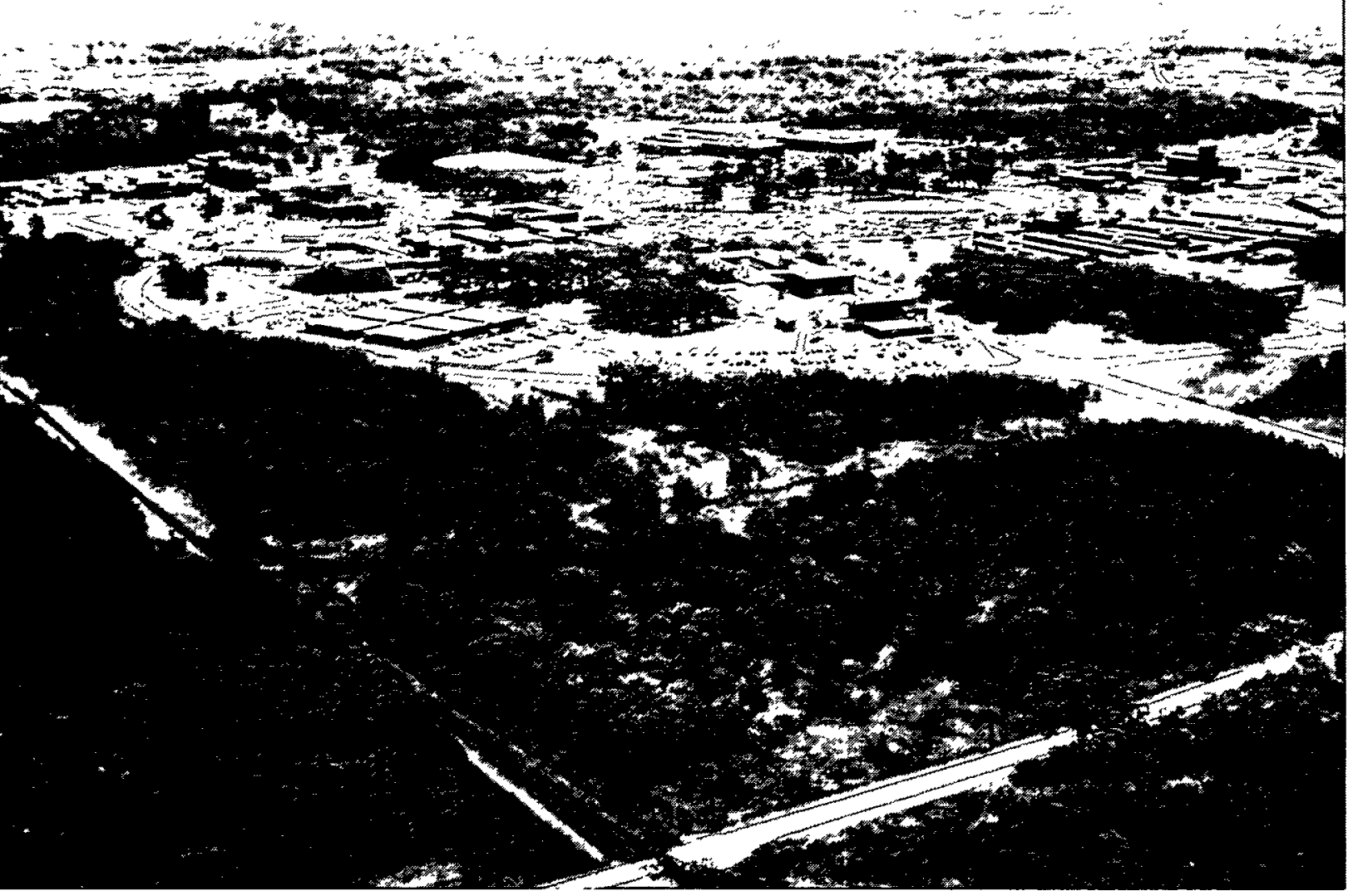

ANL-E Site Environmental Report 


\subsection{General}

This annual report for 1998 on the Argonne National Laboratory-East (ANL-E) environmental protection program was prepared to inform the U.S. Department of Energy (DOE), environmental agencies, and the public about the levels of radioactive and chemical pollutants in the vicinity of ANL-E and the amounts, if any, added to the environment by ANL-E operations. It also summarizes the compliance of ANL-E operations with applicable environmental laws and regulations and highlights significant accomplishments and problems related to environmental protection. The report was prepared in accordance with the guidelines of DOE Orders $5400.1^{1}$ and $231.1^{2}$ and supplemental DOE guidance.

ANL-E conducts a continuous environmental surveillance program on and near the site to determine the identity, magnitude, and origin of radioactive and chemical substances in the environment. The detection of any releases of such materials to the environment from ANL-E operations is of special interest because one important function of this program is verification of the adequacy of the site's pollution control systems.

ANL-E is a DOE research and development laboratory with several principal objectives. It conducts a broad program of research in the basic energy and related sciences (i.e., physical, chemical, material, computer, nuclear, biomedical, and environmental) and serves as an important engineering center for the study of nuclear and nonnuclear energy sources. Energy-related research projects conducted during 1998 included safety studies for light-water and breeder reactors; high-temperature superconductivity; improvements in the use of coal for power production (particularly high-sulfur coal); use of high-intensity synchrotron radiation for the study of materials; development of electrochemical energy sources, including fuel cells and batteries for vehicles and for energy storage; and evaluation of heat exchangers for the recovery of waste heat from engines.

Other areas of research are the use of superconducting magnets for improved nuclear particle accelerators, heavy-ion research into the properties of super-heavy elements, fundamental coal 


\section{INTRODUCTION}

chemistry studies, the immobilization of radioactive waste products for safe disposal, fundamental studies of parallel computers, and the development of "chips" for the rapid assay of gene composition. Environmental research studies include the biological activity of energy-related mutagens and carcinogens; characterization and monitoring of energy-related pollutants; and the effects of acid rain on vegetation, soil, and surface water quality. A significant number of these laboratory studies require the controlled use of radioactive and chemically toxic substances.

The principal radiological facilities at ANL-E are the Advanced Photon Source (APS); a superconducting heavy-ion linear accelerator (Argonne Tandem Linac Accelerating System [ATLAS]); a 22-MeV pulsed electron linac; several other charged-particle accelerators (principally of the Van de Graaff and Dynamitron types); a large fast neutron source (Intense Pulsed Neutron Source [IPNS]) in which high-energy protons strike a uranium target to produce neutrons; chemical and metallurgical laboratories; and several hot cells and laboratories designed for work with multicurie quantities of the actinide elements and with irradiated reactor fuel materials. The DOE New Brunswick Laboratory (NBL), a safeguards plutonium and uranium measurements and analytical chemistry laboratory, is located on the ANL-E site.

The principal nonnuclear activities at ANL-E in 1998 that could have measurable impacts on the environment include the use of a coal-fired boiler (No. 5) and the use of chlorine for water treatment. The chemical vulnerability assessment identified the storage of approximately $6,000 \mathrm{~L}$ $(1,600 \mathrm{gal})$ of sodium on site that could pose a significant chemical hazard and potential environmental impact. The major potential for environmental impact from these materials would be associated with any accidental releases caused by equipment malfunction. However, no such releases have occurred.

\subsection{Description of Site}

ANL-E occupies the central 607 ha (1,500 acres) of a 1,514-ha (3,740-acre) tract in DuPage County. The site is $43 \mathrm{~km}(27 \mathrm{mi})$ southwest of downtown Chicago and $39 \mathrm{~km}(24 \mathrm{mi})$ west of Lake Michigan. It is north of the Des Plaines River Valley, south of Interstate Highway 55 (I-55), 
and west of Illinois Highway 83. Figures 1.1 and 1.2 are maps of the site, the surrounding area, and sampling locations of the monitoring program. The 907-ha (2,240-acre) Waterfall Glen Forest Preserve surrounding the site is mostly former property that was deeded to the DuPage County Forest Preserve District in 1973 for use as a public recreational area, nature preserve, and demonstration forest. In this report, facilities are identified by the alpha-numeric designations in Figure 1.1 to facilitate their location.

The terrain of ANL-E is gently rolling, partially wooded, former prairie and farmland. The grounds contain a number of small ponds and streams. The principal stream is Sawmill Creek, which runs through the site in a southerly direction and enters the Des Plaines River about $2.1 \mathrm{~km}$ $(1.3 \mathrm{mi})$ southeast of the center of the site. The land is drained primarily by Sawmill Creek, although the extreme southern portion drains directly into the Des Plaines River, which flows along the southern boundary of the forest preserve. This river flows southwest until it joins the Kankakee River about $48 \mathrm{~km}$ (30 mi) southwest of ANL-E to form the Illinois River.

The largest topographical feature of the area is the Des Plaines River valley, which is about $1.6 \mathrm{~km}(1 \mathrm{mi})$ wide. This valley contains the river, the Chicago Sanitary and Ship Canal, and the Illinois and Michigan Canal. The elevation of the channel surface of these waterways is $180 \mathrm{~m}$ $(578 \mathrm{ft}$ ) above sea level. The bluffs that form the southern border of the site rise from the river channel at slope angles of 15 to $60^{\circ}$ and reach an average elevation of $200 \mathrm{~m}$ (650 ft) above sea level at the top. The land then slopes gradually upward and reaches the average site elevation of $220 \mathrm{~m}(725 \mathrm{ft})$ above sea level at $915 \mathrm{~m}$ (3,000 ft) from the bluffs. Several large ravines oriented in a north-south direction are located in the southern portion of the site. The bluffs and ravines generally are forested with mature deciduous trees. The remaining portion of the site changes in elevation by no more than $7.6 \mathrm{~m}(25 \mathrm{ft})$ in a horizontal distance of $150 \mathrm{~m}(500 \mathrm{ft})$. The Chicago District Pipe Line Co. and the Burlington Northern Santa Fe Railroad have rights-of-way in the southern portion of the forest preserve. 


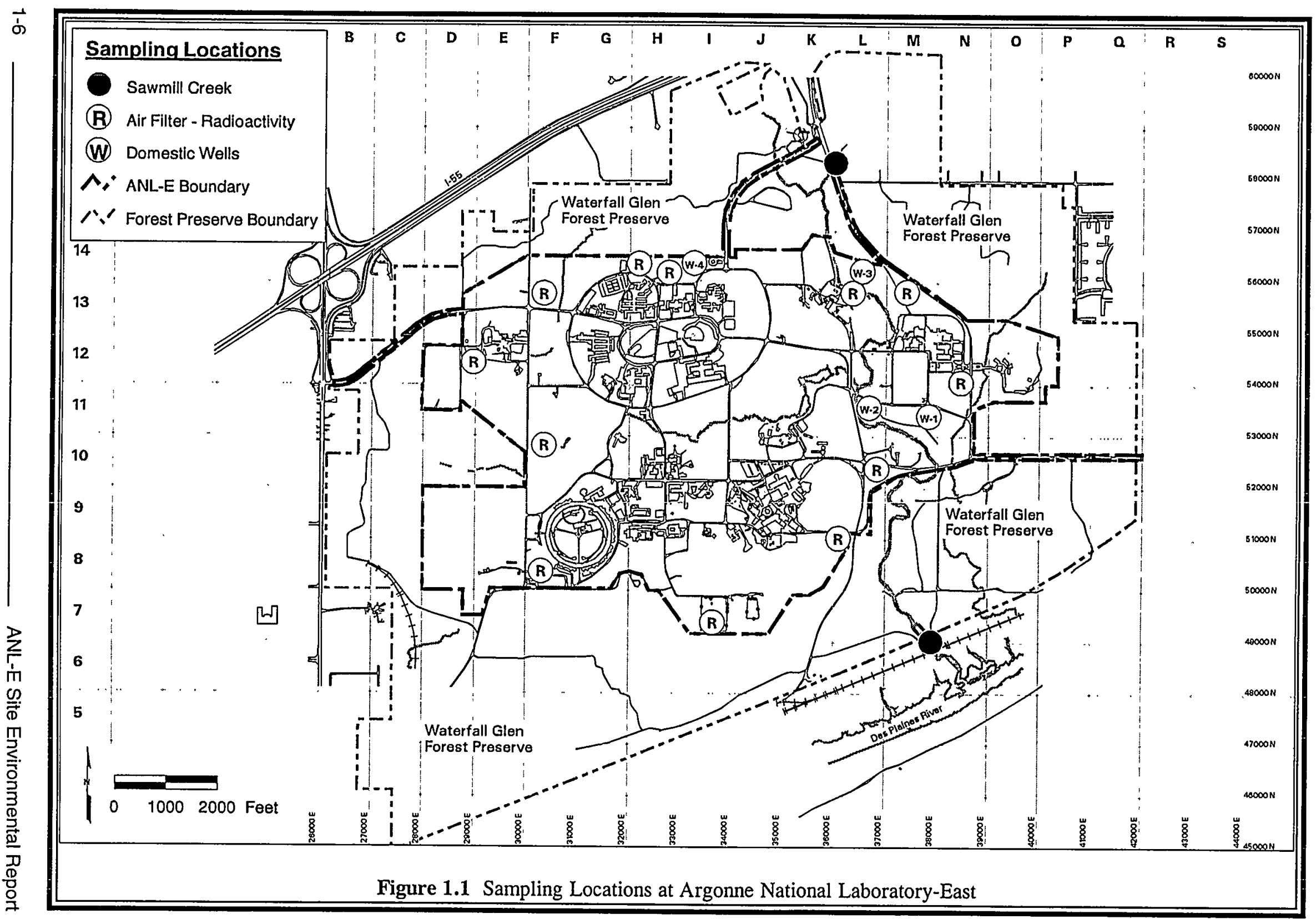




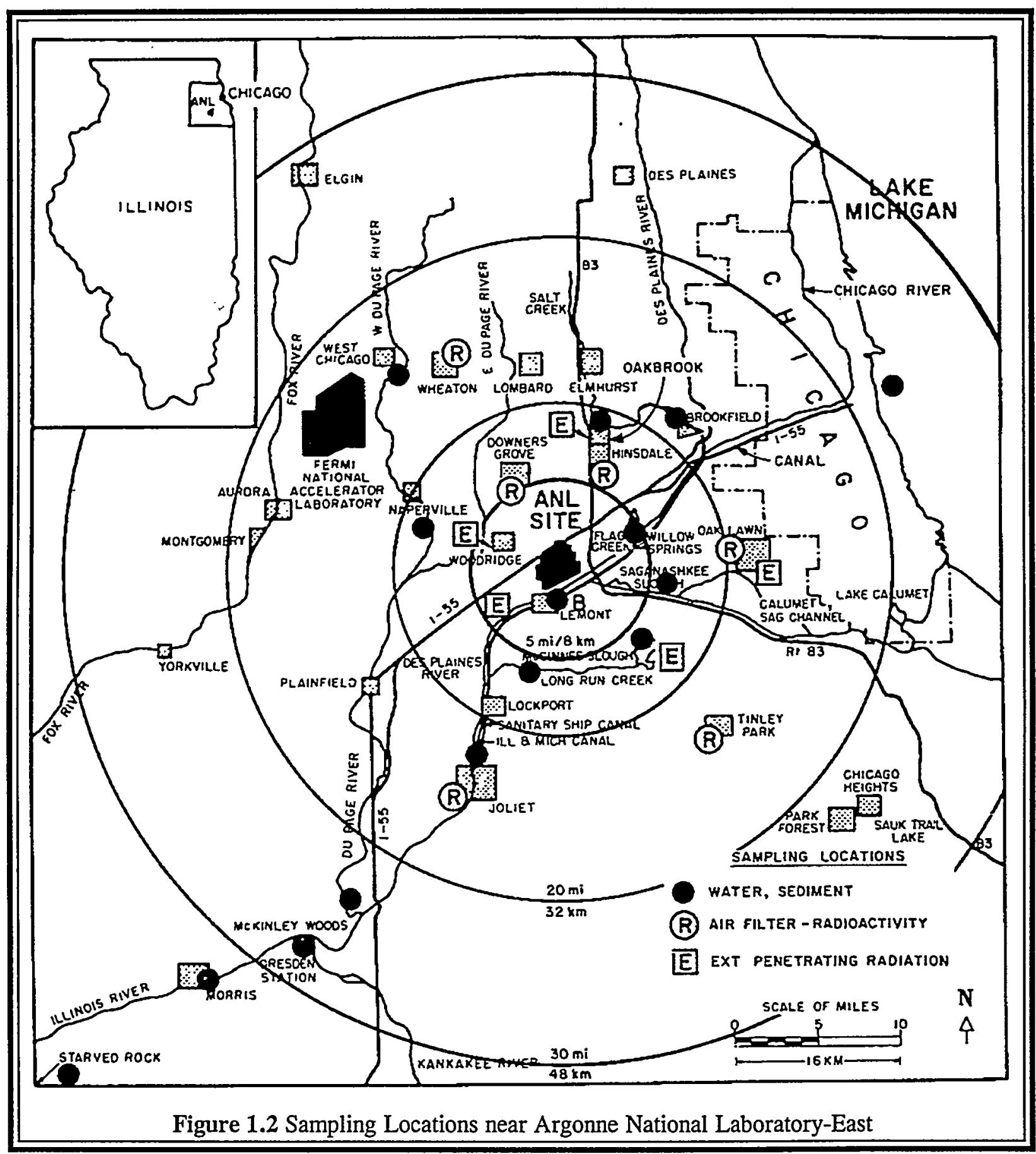




\subsection{Population}

The area around ANL-E has experienced a large population growth in the past 30 years. Large areas of farmland have been converted into housing. Table 1.1 gives the directional and annular $80-\mathrm{km}$ (50-mi) population distribution for the area, which is used to derive the population dose calculations presented later in this report. The population distribution, centered on the Chicago Pile-5 (CP-5) reactor (Location 9G in Figure 1.1), was prepared by the Risk Assessment and Safety Evaluation Group of the Environmental Assessment Division at ANL-E and represents projections to 1997, on the basis of 1990 census data.

\subsection{Climatology}

The climate of the area is representative of the upper Mississippi Valley, as moderated by Lake Michigan. Summaries of the meteorological data collected on the site from 1950 to 1964 are available ${ }^{3}$ and provide a historical sample of the climatic conditions. The most important meteorological parameters for the purposes of this report are wind direction, wind speed, temperature, and precipitation. The wind data are used to select air sampling locations and distances from sources and to calculate radiation doses from air emissions. Temperature and precipitation data are useful in interpreting some of the monitoring results. The 1998 data were obtained from the on-site ANL-E meteorological station. The 1998 average monthly and annual wind rose at the $60-\mathrm{m}(200-\mathrm{ft})$ level is shown in Figure 1.3. The wind rose is a polar coordinate plot in which the lengths of the radii represent the percentage frequency of wind speeds in classes of $2.01-6 \mathrm{~m} / \mathrm{s}(4.5-13.4 \mathrm{mph}), 6.01-10 \mathrm{~m} / \mathrm{s}(13.4-22.4 \mathrm{mph})$, and greater than $10.01 \mathrm{~m} / \mathrm{s}$ $(22.4 \mathrm{mph})$. The number in the center of the wind rose represents the percentage of observations of wind speed less than $2 \mathrm{~m} / \mathrm{s}(4.5 \mathrm{mph})$ in all directions. The direction of the radii from the center represents the direction from which the wind blows. Sixteen radii are shown on each plot at $22.5^{\circ}$ intervals; each radius represents the average wind speed for the direction covering $11.25^{\circ}$ on either side of the radius. 
TABLE 1.1

Population Distribution in the Vicinity of ANL-E, 1997

\begin{tabular}{|c|c|c|c|c|c|c|c|c|c|c|}
\hline \multirow[b]{2}{*}{ Direction } & \multicolumn{10}{|c|}{ Miles $^{\mathrm{a}}$} \\
\hline & $0-1$ & $1-2$ & $2-3$ & $3-4$ & $4-5$ & $5-10$ & $10-20$ & $20-30$ & $30-40$ & $40-50$ \\
\hline$N$ & 0 & 1,120 & 2,884 & 6,245 & 8,613 & 46,331 & 174,570 & 345,014 & 212,982 & 261,504 \\
\hline NNE & 0 & 898 & 3,573 & 6,846 & 7,168 & 44,197 & 287,496 & 463,950 & 95,266 & 2,047 \\
\hline $\mathrm{NE}$ & 0 & 748 & 2,203 & 2,255 & 2,125 & 42,131 & 642,743 & 930,802 & 0 & 0 \\
\hline ENE & 0 & 333 & 1,057 & 1,615 & 1,989 & 33,508 & 569,089 & 180,886 & 0 & 0 \\
\hline $\mathrm{E}$ & 0 & 335 & 985 & 954 & 462 & 41,692 & 463,141 & 206,619 & 9,217 & 26,320 \\
\hline ESE & 0 & 373 & 882 & 1,161 & 541 & 19,213 & 199,976 & . 291,723 & 230,482 & 87,179 \\
\hline SE & 0 & 468 & 900 & 1,192 & 1,109 & 22,696 & 131,492 & 120,061 & 34,063 & 17,926 \\
\hline SSE & 0 & 521 & 900 & 937 & 1,418 & 14,904 & 40,179 & 12,562 & 11,807 & 15,974 \\
\hline$S$ & 0 & 543 & 900 & 1,007 & 1,275 & 6,807 & 28,223 & 6,226 & 36,775 & 37,107 \\
\hline SSW & 0 & 497 & 740 & 898 & 1,063 & 18,028 & 91,686 & 17,430 & 16,371 & 6,348 \\
\hline SW & 0 & 353 & 594 & 637 & 647 & 9,521 & 48,150 & 11,398 & 16,652 & 6,793 \\
\hline WSW & 0 & 333 & 394 & 984 & 2,742 & 9,950 & 11,068 & 5,649 & 8,196 & 14,320 \\
\hline W & 0 & 370 & 2,964 & 7,810 & 9,200 & 30,181 & 65,457 & 20,082 & 16,193 & 5,718 \\
\hline WNW & 0 & 1,022 & 3,573 & 7,777 & 6,817 & 52,201 & 138,763 & 34,280 & 8,780 & 53,815 \\
\hline NW & 0 & 1,361 & 2,793 & 7,075 & 8,755 & 46,680 & 83,890 & 101,417 & 24,562 & 17,492 \\
\hline NNW & 0 & 1,361 & 2,756 & 5,798 & 9,150 & 40,435 & 200,789 & 268,137 & 144,672 & 113,070 \\
\hline Total & 0 & 10,636 & 28,098 & 53,191 & 63,074 & 478,475 & $3,176,712$ & $3,016,236$ & 866,018 & 665,613 \\
\hline Cumulative total $^{\mathrm{b}}$ & 0 & 10,636 & 38,734 & 91,925 & 154,999 & 633,474 & $3,810,186$ & $6,826,422$ & $7,692,440$ & $8,358,053$ \\
\hline
\end{tabular}

a To convert from miles to kilometers, multiply by 1.6.

b Cumulative total $=$ the total of this sector plus the totals of all previous sectors. 

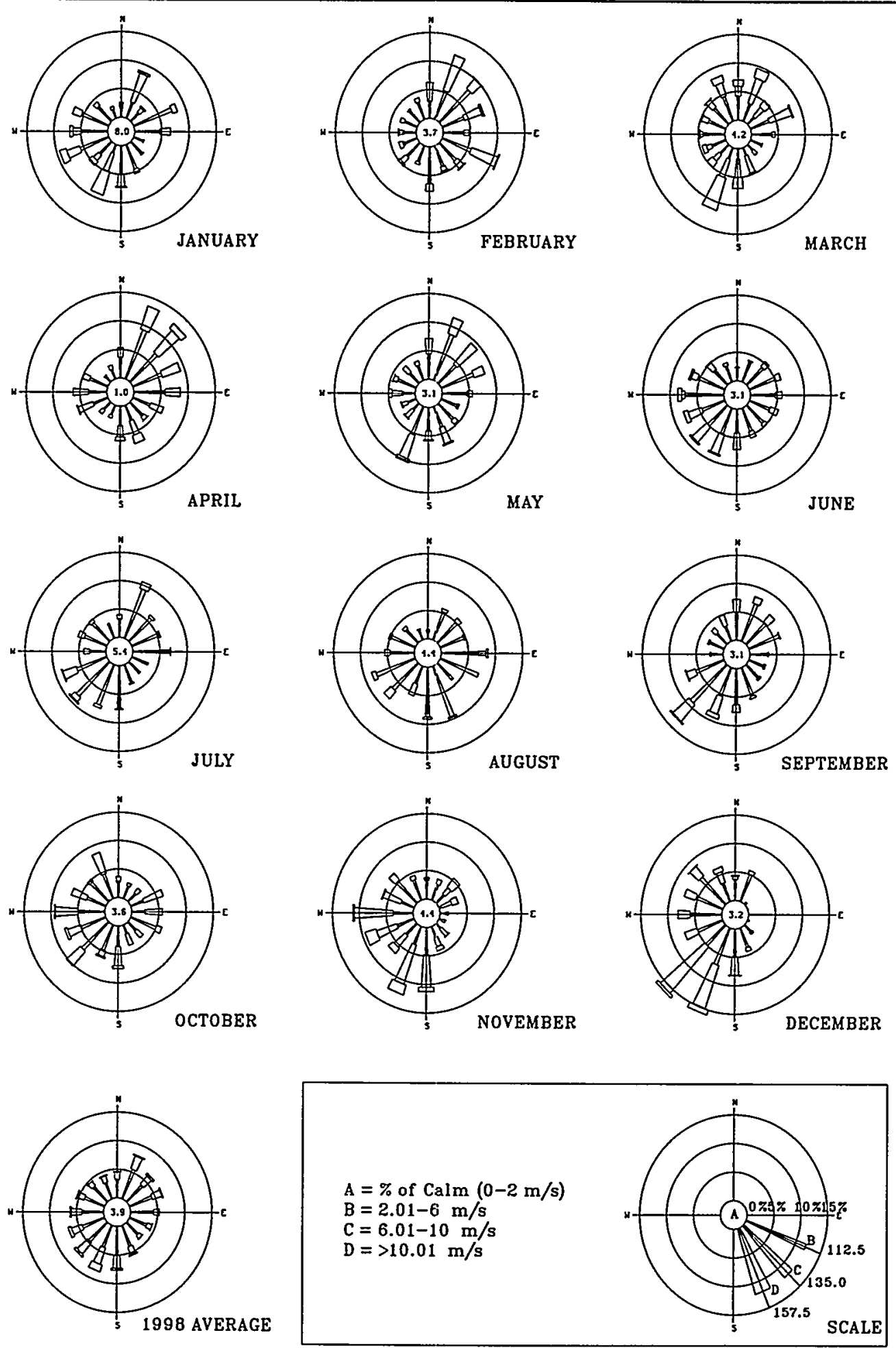

Figure 1.3 Monthly and Annual Wind Roses at Argonne National Laboratory-East, 1998 


\section{INTRODUCTION}

The annual average wind rose for 1998 is consistent with the long-term average wind direction, which usually varies from the west to south, but with a significant northeast component. Table 1.2 gives 1998 precipitation and temperature data. The monthly precipitation data for 1998 showed significant differences from the average. For each month, the precipitation total was equal to or exceeded the long-term average. The annual total is approximately $40 \%$ above the long-term average. The temperatures are generally higher where compared with the long-term averages.

\section{TABLE 1.2}

ANL-E Weather Summary, 1998

\begin{tabular}{|c|c|c|c|c|c|c|}
\hline \multirow[b]{2}{*}{ Month } & \multicolumn{3}{|c|}{$\begin{array}{l}\text { Average Precipitation } \\
\text { (cm) }\end{array}$} & \multicolumn{3}{|c|}{$\begin{array}{l}\text { Average Temperature } \\
\left({ }^{\circ} \mathrm{C}\right)\end{array}$} \\
\hline & $\begin{array}{c}\text { ANL-E } \\
1998\end{array}$ & $\begin{array}{c}\text { ANL-E } \\
\text { Historical }^{\mathrm{a}}\end{array}$ & Historical $^{\mathrm{b}}$ & $\begin{array}{c}\text { ANL-E } \\
1998\end{array}$ & $\begin{array}{c}\text { ANL-E } \\
\text { Historical }^{\mathrm{a}}\end{array}$ & Historical $^{\mathrm{b}}$ \\
\hline January & 7.04 & 3.61 & 4.06 & -1.4 & -5.9 & -5.9 \\
\hline February & 4.32 & 3.38 & 3.33 & 3.4 & -3.7 & -3.3 \\
\hline March & 10.11 & 5.56 & 6.58 & 3.6 & 0.6 & 2.2 \\
\hline April & 8.43 & 9.14 & 9.30 & 10.1 & 8.3 & 9.3 \\
\hline May & 10.11 & 7.82 & 8.00 & 18.7 & 14.5 & 15.1 \\
\hline June & 14.76 & 9.47 & 10.36 & 20.5 & 19.7 & 20.3 \\
\hline July & 9.64 & 10.97 & 9.22 & 23.0 & 21.7 & 22.8 \\
\hline August & 17.58 & 8.71 & 8.97 & 22.9 & 20.9 & 22.2 \\
\hline September & 10.22 & 7.14 & 8.51 & 20.2 & 16.8 & 18.2 \\
\hline October & 10.68 & 6.58 & 5.79 & 12.1 & 11.4 & 11.9 \\
\hline November & 4.47 & 4.37 & 5.23 & 6.7 & 2.9 & 4.3 \\
\hline December & 3.84 & 3.20 & 5.33 & -0.2 & -4.2 & -2.4 \\
\hline Total & 111.20 & 79.95 & 84.68 & & & \\
\hline
\end{tabular}

a ANL-E data obtained from Reference 3.

b Data obtained from the National Oceanic and Atmospheric Administration for the weather station at $\mathrm{O}^{\prime}$ Hare International Airport. The average is for the years 1951-1980. 


\section{INTRODUCTION}

\subsection{Geology}

The geology of the ANL-E area consists of about $30 \mathrm{~m}(100 \mathrm{ft})$ of glacial till on top of bedrock, which is Niagaran and Alexandrian dolomite, underlain by shale and older dolomites and sandstones of Ordovician and Cambrian age. The beds are nearly horizontal, although the top of the dolomite may not be horizontal. Niagaran and Alexandrian dolomite is approximately $60 \mathrm{~m}$ (200 ft) thick and widely used in DuPage County as a source of groundwater. The shale separating the upper dolomite aquifer from the underlying sandstone and dolomite aquifers retards the hydraulic connection between them. The lower aquifer has a much lower piezometric level and does not appear to be affected by pumpage from the overlying bedrock.

The southern boundary of ANL-E follows the escarpment of a broad valley, which is now occupied by the Des Plaines River and the Chicago Sanitary and Ship Canal. This valley was carved by waters flowing out of the glacial Lake Michigan about 11,000 to 14,000 years ago. The soils on the site were derived from glacial till over the past 12,000 years and are primarily of the Morley series, that is, moderately well-drained upland soils with a slope ranging from 2 to $20 \%$. The surface layer is a dark grayish-brown silt loam, the subsoil is a brown silty clay, and the underlying material is a silty clay loam glacial till. Morley soils have a relatively low organic content in the surface layer, moderately slow subsoil permeability, and a large water capacity. These soils are well suited to growing crops if good erosion control practices are used. The remaining soils along creeks, intermittent streams, bottomlands, and a few small upland areas are

of the Sawmill, Ashkum, Peotone, and Beecher series, which are generally poorly drained. They have a black to dark gray or brown silty clay loam surface layer, high organic-matter content, and a large water capacity. 


\subsection{Seismicity}

No tectonic features within $135 \mathrm{~km}$ (62 mi) of ANL-E are known to be seismically active. The longest of these features is the Sandwich Fault. Smaller local features are the Des Plaines disturbance, a few faults in the Chicago area, and a fault of apparently Cambrian age.

Although a few minor earthquakes have occurred in northern Illinois, none have been positively associated with particular tectonic features. Most of the recent local seismic activity is believed to be caused by isostatic adjustments of the earth's crust in response to glacial loading and unloading, rather than by motion along crustal plate boundaries.

Several areas of considerable seismic activity are located at moderate distances (i.e., hundreds of kilometers) from ANL-E. These areas include the New Madrid Fault zone (southeast Missouri) in the St. Louis area, the Wabash Valley Fault zone along the southern Illinois-Indiana border, and the Anna region of western Ohio. Although high-intensity earthquakes have occurred along the New Madrid Fault zone, their relationship to plate motions remains speculative at this time.

According to estimates, ground motions induced by near and distant seismic sources in northern Illinois are expected to be minimal. However, peak accelerations in the ANL-E area may exceed $10 \%$ of gravity (the approximate threshold of major damage) once in approximately 600 years, with an error range of -250 to +450 years.

\subsection{Hydrology}

Up until 1997, most groundwater supplies in the ANL-E area were derived from the Niagaran, and to some extent, the Alexandrian dolomite bedrock. Dolomite well yields are variable, but many approach $3,028 \mathrm{~L} / \mathrm{min}(800 \mathrm{gal} / \mathrm{min})$. In DuPage County, groundwater pumpage over the past 100 years has led to severe overdraft; in northeastern Illinois, the piezometric surface has been lowered in areas of heavy pumping. Delivery of Lake Michigan 


\section{INTRODUCTION}

water to the major suburban areas is expected to relieve this problem. Because the cones of depression of ANL-E wells do not extend beyond the site and adjacent forest preserve, ANL-E water use does not affect neighboring communities. With the acquisition of Lake Michigan water in 1997 , the recovery of the dolomite water table is being measured.

Two principal aquifers are used as water supplies in the vicinity of ANL-E. The upper aquifer is the Niagaran and Alexandrian dolomite, which is approximately $60 \mathrm{~m}(200 \mathrm{ft})$ thick in the ANL-E area and has a piezometric surface between 15 and $30 \mathrm{~m}$ (50 and $100 \mathrm{ft}$ ) below the ground surface for much of the site. The lower aquifer is Galesville sandstone, which lies between 150 and $450 \mathrm{~m}$ (500 and 1,500 ft) below the surface. Maquoketa shale separates the upper dolomite aquifer from the underlying sandstone aquifer. This shale retards the hydraulic connection between the two aquifers.

\subsection{Water and Land Use}

Sawmill Creek flows through the eastern portion of the site. This stream originates north of the site, flows through the property in a southerly direction, and discharges into the Des Plaines River. Two small streams, one originating on site and the other just off site, which enter the site from the western boundary, combine to form Freund Brook, which discharges into Sawmill Creek. Along the southern margin of the property, the terrain slopes abruptly downward forming forested bluffs. These bluffs are dissected by ravines containing intermittent streams that discharge some site drainage into the Des Plaines River. In addition to the streams, various ponds and cattail marshes are present on the site. A network of ditches and culverts transport surface runoff toward the smaller streams.

The greater portion of the ANL-E site is drained by Freund Brook. Two intermittent branches of Freund Brook flow from west to east, drain the interior portion of the site, and ultimately discharge into Sawmill Creek. The larger, south branch originates in a marsh adjacent to the western boundary line of the site. It traverses wooded terrain for a distance of about 
$2 \mathrm{~km}$ ( $1.5 \mathrm{mi}$ ) before discharging into the Lower Freund Pond. The upper Freund Brook branch also discharges into the Lower Freund Pond.

Sawmill Creek carried effluent water continuously from a sewage treatment plant (Marion Brook Treatment Plant) located a few kilometers north of the site until October 27, 1986, when the plant was closed. Residential and commercial development in the area have resulted in the collection and channeling of runoff water into Sawmill Creek. Treated sanitary and laboratory wastewater from ANL-E are combined and discharged into Sawmill Creek at location 7M in Figure 1.1. In 1998, this effluent averaged 3.0 million L (0.81 million gal)/day, which is slightly higher than the averages for the last few years. The combined ANL-E effluent consisted of 51\% laboratory wastewater and $49 \%$ sanitary wastewater. The water flow in Sawmill Creek upstream of the wastewater outfall averaged about 40 million L (10.8 million gal)/day during 1998 .

Sawmill Creek and the Des Plaines River above Joliet, about $21 \mathrm{~km}$ (13 mi) southwest of ANL-E, receive very little recreational or industrial use. A few people fish in these waters downstream of ANL-E, and some duck hunting takes place on the Des Plaines River. Water from the Chicago Sanitary and Ship Canal is used by ANL-E for cooling towers and by others for industrial purposes, such as hydroelectric generators and condensers, and for irrigation at the state prison near Joliet. ANL-E usage is approximately 1.1 million L (290,000 gal)/day. The canal, which receives Chicago Metropolitan Sanitary District effluent water, is used for industrial transportation and some recreational boating. Near Joliet, the river and canal combine into one waterway, which continues until it joins the Kankakee River to form the Illinois River about $48 \mathrm{~km}$ (30 mi) southwest of ANL-E. The Dresden Nuclear Power Station complex is located at the confluence of the Kankakee, Des Plaines, and Illinois Rivers. This station uses water from the Kankakee River for cooling and discharges the water into the Illinois River. The first downstream location where water is used as a community water supply system is at Peoria, which is on the Illinois River about $240 \mathrm{~km}(150 \mathrm{mi})$ downstream of ANL-E. In the vicinity of ANL-E, only subsurface water (from both shallow and deep aquifers) and Lake Michigan water are used for drinking purposes. 


\section{INTRODUCTION}

The principal recreational area near ANL-E is the Waterfall Glen Forest Preserve, which surrounds the site (see Section 1.2 and Figure 1.1). The area is used for hiking, skiing, and horseback riding. Sawmill Creek flows south through the eastern portion of the preserve on its way to the Des Plaines River. Several large forest preserves of the Forest Preserve District of Cook County are located east and southeast of ANL-E and the Des Plaines River. The preserves include the McGinnis and Saganashkee Sloughs (shown in Figure 1.2), as well as other smaller lakes. These areas are used for picnicking, boating, fishing, and hiking. A small park located in the eastern portion of the ANL-E site (Location 12-0 in Figure 1.1) is for the use of ANL-E and DOE employees. A local municipality has use of the park for athletic events.

\subsection{Vegetation}

ANL-E lies within the Prairie Peninsula of the Oak-Hickory Forest Region. The Prairie Peninsula is a mosaic of oak forest, oak openings, and tall-grass prairie occurring in glaciated portions of Illinois, northwest Indiana, southern Wisconsin, and sections of other states. Much of the natural vegetation of this area has been modified by clearing and tillage. Forests in the ANL-E region, which are predominantly oak and hickory, are somewhat limited to slopes of shallow, ill-defined ravines or low morainal ridges. Gently rolling to flat intervening areas between ridges and ravines were predominantly occupied by prairie before their use for agriculture. The prevailing successional trend on these areas, in the absence of cultivation, is toward oak-hickory forest. Forest dominated by sugar maple, red oak, and basswood may occupy more pronounced slopes. Poorly drained areas, streamside communities, and floodplains may support forests dominated by silver maple, elm, and cottonwood.

Early photographs of the site indicate that most of the land that ANL-E now occupies was actively farmed. About $75 \%$ was plowed field and $25 \%$ was pasture, open oak woodlots, and oak forests. Starting in 1953 and continuing for three seasons, some of the formerly cultivated fields were planted with jack, white, and red pine trees. Other fields are dominated by bluegrass. 
The deciduous forests on the remainder of the site are dominated by various species of oak, generally as large, old, widely spaced trees, which often do not form a complete canopy. Their large low branches indicate that they probably matured in the open, rather than in a dense forest. Other upland tree species include hickory, hawthorn, cherry, and ash.

\subsection{Fauna}

Terrestrial vertebrates that are commonly observed or likely to occur on the site include about 5 species of amphibians, 7 of reptiles, 40 of summer resident birds, and 25 of mammals. More than a hundred other bird species can be found in the area during migration or winter, but they do not nest on the site or in the surrounding region. An unusual species on the ANL-E site is the fallow deer, a European species that was introduced to the area by a private landowner prior to government acquisition of the property in 1947. A population of native white-tailed deer also inhabit the ANL-E site. The white-tailed and fallow deer populations are each maintained at a target density of $20 \mathrm{deer} / \mathrm{mi}^{2}$ under an ongoing deer management program. Terrestrial invertebrate species and plants also reside on the ANL-E site.

Freund Brook crosses the center of the site but is impounded by a beaver dam in this area. The gradient of the stream is relatively steep, and riffle habitat predominates. The substrate is coarse rock and gravel on a firm mud base. Primary production in the stream is limited by shading, but diatoms and some filamentous algae are common. Aquatic macrophytes include common arrowhead, pondweed, duckweed, and bulrush. Invertebrate fauna consist primarily of dipteran larvae, crayfish, caddisfly larvae, and midge larvae. Few fish are present because of low summer flows and high temperatures. Other aquatic habitats on the ANL-E site include additional beaver ponds, artificial ponds, ditches, and Sawmill Creek.

The biotic community of Sawmill Creek is relatively impoverished, which reflects the creek's high silt load, steep gradient, and historic release of sewage effluent from the Marion Brook sewage treatment plant north of the site. The fauna consists primarily of blackflies, midges, isopods, flatworms, segmented worms, and creek chubs. A few other species of minnows, 


\section{INTRODUCTION}

sunfishes, and catfish are also present. Clean-water invertebrates, such as mayflies and stoneflies, are rare or absent. Fish species that have been recorded in ANL-E aquatic habitats include black bullhead, bluegill, creek shub, golden shiner, goldfish, green sunfish, largemouth bass, stoneroller, and orange-spotted sunfish.

The U.S. Fish and Wildlife Service (FWS) has rated the Des Plaines River system, including ANL-E streams, as "poor". in terms of the fish species present because of domestic and industrial pollution and stream modification.

\subsection{Archaeology}

ANL-E, which is located in the Illinois and Michigan Canal National Heritage Corridor, is situated in an area known to have a long and complex cultural history. All periods listed in the cultural chronology of Illinois, with the exception of the earliest period (Paleo-Indian), have been documented in the ANL-E area either by professional cultural resource investigators or through interviews of local artifact collectors by ANL-E staff. A variety of site types, including mounds, quarries, lithis workshops, and habitation sites, have been reported by amateurs within a $25-\mathrm{km}$ (16-mi) radius.

The 46 recorded sites include prehistoric chert quarries, special purpose camps, base camps, and historical farmsteads. The range of human occupation spans several time periods (Early Archaic through Mississippian Prehistoric to Historical). Three sites have been determined to be eligible for the National Register for Historic Places (NRHP), 20 sites have been determined to be ineligible, and 23 sites have not been evaluated for eligibility.

\subsection{Endangered Species}

No federally listed threatened or endangered species are known to occur on the ANL-E site, and no critical habitat of federally listed species exists on the site. Three federally listed 
endangered species are known to inhabit the Waterfall Glen Forest Preserve that surrounds the ANL-E property or to occur in the area.

The Hine's emerald dragonfly (Somatochlora hineana), federally and state listed as endangered, occurs in locations with calcaerous seeps and wetlands along the Des Plaines River floodplain. Leafy prairie clover (Dalea foliosa), which is federally and state listed as endangered, is associated with dolomite prairie remnants of the Des Plaines River valley; two planted populations of this species occur in Waterfall Glen Forest Preserve. An unconfirmed capture of Indiana bat (Myotis sodalis), which is federally and state listed as endangered, indicates that this species may occur in the area. Additional state-listed species that occur in the area include the following:

- Endangered

- Black-crowned night heron (Nycticorax nycticorax)

- Great egret (Casmerodius alba)

- Pied-billed grebe (Podilymbus podiceps)

- Red-shouldered hawk (Buteo lineatus)

- River otter (Lutra canadensis)

- Rough marsh cress (Rorippa islandica var. hispida)

- Slender sandwort (Arenaria patula)

- White lady's slipper (Cypripedium candidum)

- Threatened

- Early fen sedge (Carex crawei)

- Kirtland's snake (Clonophis kirtlandi)

- Marsh speedwell (Veronica scutellata)

Of these, rough marsh cress, Kirtland's snake, pied-billed grebe, great egret, black-crowned night heron, and red-shouldered hawk have been observed on ANL-E property. 


\section{COMPLIANCE SUMMARY}

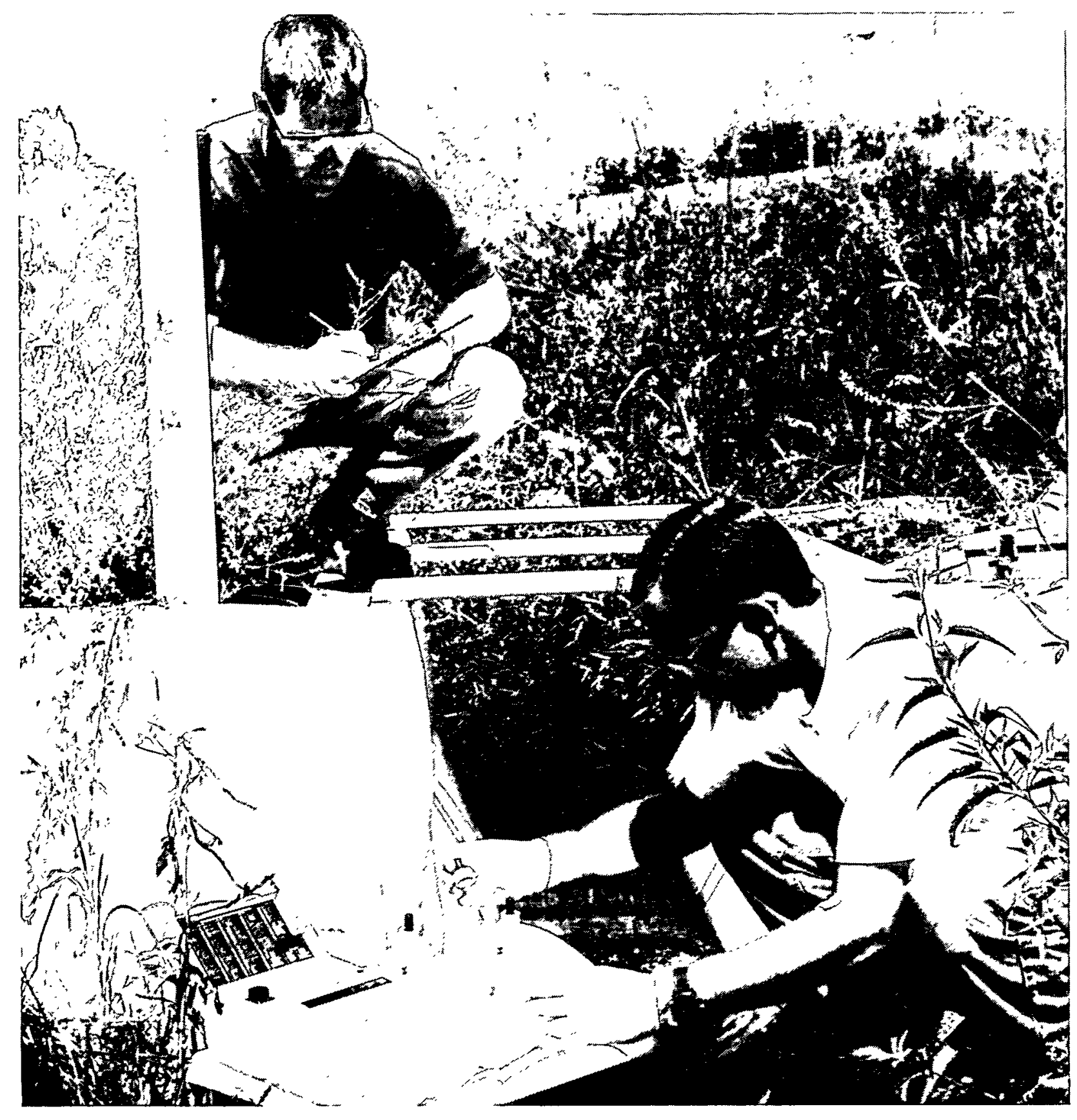


ANL-E is a government-owned, contractor-operated nonproduction facility that is subject to environmental statutes and regulations administered by the U.S. Environmental Protection Agency (EPA), the Illinois Environmental Protection Agency (IEPA), the Illinois Department of Public Health (IDPH), and the State Fire Marshal, as well as numerous DOE Orders and Executive Orders. A detailed listing of applicable regulations is contained in DOE Order 5400.1, ${ }^{1}$ which establishes DOE's policy concerning environmental compliance. The status of ANL-E during 1998 with regard to these authorities is discussed in this chapter.

To ensure compliance with both the letter and spirit of these requirements, ANL-E has made a commitment to comply with all applicable environmental requirements, as described in the following policy statement:

It is the policy of Argonne National Laboratory that its activities will be conducted in such a manner that worker and public safety, including protection of the environment, is given the highest priority. The Laboratory will comply with all applicable federal and state environmental laws, regulations, and orders.

\subsection{Clean Air Act}

The Clean Air Act (CAA) is a federal statute that specifies National Ambient Air Quality Standards, sets emission limits for air pollutants, and determines emission limits and operating criteria for a number of hazardous air pollutants. The program is implemented by individual states through a State Implementation Plan (SIP) that describes how that state will ensure compliance with the air quality standards for stationary sources.

A number of major changes to the CAA were made with the passage of the Clean Air Act Amendments of 1990. Under Title V of the Clean Air Act Amendments of 1990, ANL-E was required to submit a Clean Air Act Permit Program (CAAPP) application to the IEPA for a sitewide, federally enforceable operating permit to cover emissions of all regulated air pollutants at the facility. This permit will supersede the state air pollution control permits that are currently 


\section{COMPLIANCE SUMMARY}

in effect. All facilities designated as major emission sources for regulated air pollutants are subject to this requirement. ANL-E meets the definition of a major source because of potential emissions of oxides of nitrogen in excess of $22.68 \mathrm{t} / \mathrm{yr}$ ( 25 tons/yr) and sulfur dioxide in excess of $90.72 \mathrm{t} / \mathrm{yr}$ (100 tons/yr) at the Building 108 Central Heating Plant.

Facilities subject to Title $\mathrm{V}$ must characterize emissions of all regulated air pollutants, not only those that qualify them as major sources. In addition to oxides of nitrogen and sulfur dioxide, ANL-E also must evaluate emissions of carbon monoxide, particulates, volatile organic compounds (VOCs), hazardous air pollutants (a list of 188 chemicals, including radionuclides), and ozone-depleting substances. The air pollution control permit program requires that facilities pay annual fees on the basis of the total amount of regulated air pollutants (except carbon monoxide) they will be allowed to emit.

When the IEPA acknowledges a CAAPP application as timely and complete, the applicant receives an application shield and is in compliance with the CAA. The ANL-E CAAPP application was submitted to the IEPA on September 19, 1995; the IEPA issued a Notice of Completeness on October 26, 1995. The Notice of Completeness also means that current air pollution control permits under which operations remain unchanged do not need to be renewed. Exceptions to this are the open burning permits used for fire training and ecological management, which must be renewed annually.

On January 26, 1998, ANL-E submitted a fourth revision to the CAAPP application. This revision certified to the IEPA that ANL-E is not subject to the Emissions Reduction Market System (ERMS) scheduled to take effect in 1999. The IEPA issued a Notice of ERMS Status on March 5, 1998, which confirmed that ANL-E is not a participant in this program. In June 1998, the IEPA requested that ANL-E indicate whether it was subject to the risk management plan provisions required under Section 112(r) of the CAA. ANL-E responded that currently it is not required to develop a risk management plan for submission to the IEPA by June 21, 1999. 
As of the end of 1998, the IEPA had not initiated a technical review of the ANL-E CAAPP application. A fifth revision to the CAAPP application is currently in progress for transmittal to the IEPA during 1999.

The ANL-E site contains a large number of air emission point sources. The vast majority are laboratory ventilation systems that are exempt from state permitting requirements, except for those systems emitting radionuclides. By the end of 1998, a total of 45 air pollution control permits were in place covering all known emission points. Section 2.16 contains a list (Table 2.12) of the air pollution control permits in effect at ANL-E. No IEPA air emissions inspection was conducted in 1998.

\subsubsection{National Emission Standards for Hazardous Air Pollutants}

The National Emission Standards for Hazardous Air Pollutants (NESHAP) constitute a body of federal regulations that set forth emission limits and other requirements, such as monitoring, record keeping, and operational and reporting requirements, for activities generating emissions of certain hazardous air pollutants. The only standards affecting ANL-E operations are those for asbestos and radionuclides. By the end of 1998, the IEPA had issued a total of 24 air pollution control permits for NESHAP sources to ANL-E. In 1999, two new NESHAP operating permits will be issued for the Building 301 Hot Cell Decontamination and Decommissioning (D\&D) project and the Building 306 Chemical Photooxidation Vial Crusher.

\subsubsection{Asbestos Emissions}

Many buildings on the ANL-E site contain large amounts of asbestos-containing material (ACM) such as thermal system insulation around pipes and tanks, spray-applied surfacing material for fireproofing, floor tile, and asbestos-cement (Transite) panels. This material is removed as necessary during renovations or maintenance of equipment and facilities. The removal and disposal of this material are governed by the asbestos NESHAP. 
ANL-E maintains an asbestos abatement program designed to ensure compliance with these and other regulatory requirements. In general, $\mathrm{ACM}$ is removed from buildings either by specially trained ANL-E crews (for small-scale, short-duration projects) or by outside contractors (for large-scale insulation removal projects). All removal work is performed in accordance with both NESHAP and Occupational Safety and Health Administration requirements governing worker safety at ACM removal sites.

Approximately $181 \mathrm{~m}^{3}\left(6,389 \mathrm{ft}^{3}\right)$ of ACM was removed from ANL-E buildings during 1998. The 106 small removal projects that were completed generated $88 \mathrm{~m}^{3}\left(3,116 \mathrm{ft}^{3}\right)$ of ACM waste; the remaining $92 \mathrm{~m}^{3}\left(3,231 \mathrm{ft}^{3}\right)$ generated resulted from large removal projects. Table 2.1 provides asbestos abatement information for the large removal projects. The IEPA was notified during December 1998 that no more than $100 \mathrm{~m}^{3}\left(3,500 \mathrm{ft}^{3}\right)$ of $\mathrm{ACM}$ waste will be generated from small-scale projects during 1999.

A separate portion of the asbestos removal standards contains requirements for disposing of ACM. Off-site shipments are to be accompanied by completed shipping manifests. Asbestos disposal information is provided in Table 2.2. Until closure of the ANL-E landfill in September 1992, asbestos from small-scale projects was disposed of on site in a designated area of the landfill.

\subsubsection{Radionuclide Emissions}

The NESHAP standard for radionuclide emissions from DOE facilities (Code of Federal Regulations, Title 40, Part 61, Subpart H [40 CFR Part 61, Subpart H]) establishes the emission limits for the release of radionuclides other than radon to the air and the requirements for monitoring, reporting, and record keeping. A number of emission points at ANL-E are subject to these requirements. These points include ventilation systems for hot cell facilities for storage and handling of radioactive materials (Buildings 205 and 212), ventilation systems for particle accelerators (Building 375, IPNS facility, and the Building 411 APS linac), and several ventilation 
TABLE 2.1

Asbestos Abatement Projects: IEPA Notification, 1998

\begin{tabular}{|c|c|c|c|c|c|c|c|}
\hline \multirow{2}{*}{$\begin{array}{l}\text { Completion } \\
\text { Date }\end{array}$} & \multirow{2}{*}{$\begin{array}{l}\text { Asbestos Abatement } \\
\text { Contractor }\end{array}$} & \multicolumn{2}{|c|}{$\begin{array}{c}\text { Notification } \\
\text { Quantity } \\
\end{array}$} & \multirow[b]{2}{*}{ Material } & \multirow[b]{2}{*}{ Building } & \multirow{2}{*}{$\begin{array}{l}\text { Quantity } \\
\text { Generated } \\
\left(\mathrm{ft}^{3}\right)\end{array}$} & \multirow[b]{2}{*}{ Landfill } \\
\hline & & $(\mathrm{ft})$ & $\left(\mathrm{ft}^{2}\right)$ & & & & \\
\hline $03 / 13 / 98$ & $\begin{array}{l}\text { ANL PFS-Waste } \\
\text { Management } \\
\text { Operations }\end{array}$ & $\mathrm{NA}^{\mathrm{a}}$ & 7,030 & Ceiling tile & $360 / 362$ & 976 & Streator ${ }^{b}$ \\
\hline $03 / 15 / 98^{c}$ & $\begin{array}{l}\text { ANL PFS-Waste } \\
\text { Management } \\
\text { Operations }\end{array}$ & NA & 320 & Floor tile and mosaic & 362 & 68 & Streator \\
\hline $04 / 04 / 98$ & $\begin{array}{l}\text { Asbestos Control, } \\
\text { Inc. }\end{array}$ & NA & 2,700 & Ceiling tile & 362 & 675 & Streator \\
\hline $\begin{array}{l}09 / 10 / 98- \\
09 / 24 / 98\end{array}$ & ACS, Inc. & NA & $\begin{array}{c}8,606 \\
354\end{array}$ & $\begin{array}{l}\text { Floor tile and mastic } \\
\text { Transite panels }\end{array}$ & $\begin{array}{l}809 / \\
395\end{array}$ & 1,080 & Streator \\
\hline $11 / 17 / 98$ & JVI, Inc. & 285 & NA & $\begin{array}{l}\text { Outside steam/ } \\
\text { condensate pipe } \\
\text { insulation }\end{array}$ & Site & 324 & Streator \\
\hline \multirow[t]{2}{*}{$12 / 28 / 98$} & $\begin{array}{l}\text { Champion } \\
\text { Environmental } \\
\text { Services }\end{array}$ & $\mathrm{NA}$ & 1,400 & Floor tile & 207 & $108^{d}$ & Streator \\
\hline & & & & & Total & 3,231 & \\
\hline
\end{tabular}

a $\mathrm{NA}=$ not applicable.

b Streator Area Landfill, Streator, IL.

c Courtesy notification, nonfriable material removed intact.

d Material still on site at the time of report preparation and scheduled for disposal at Streator in 1999 was not included in the Table 2.2 total volume of asbestos waste material disposed of in 1998.

systems associated with the Building 350 NBL. In addition, many ventilation systems and fume hoods are used occasionally for processing small quantities of radioactive materials.

The amount of radioactive material released to the atmosphere from ANL-E emission sources is extremely small. The maximum off-site dose to a member of the general public for 1998 was 0.016 mrem, which, excluding radon- 220 , is $0.16 \%$ of the $10 \mathrm{mrem} / \mathrm{yr}$ EPA standard. 
TABLE 2.2

\begin{tabular}{llc}
\multicolumn{3}{c}{$\begin{array}{c}\text { Disposal of Asbestos-Containing } \\
\text { Materials, } 1998\end{array}$} \\
\hline Project Size & Landfill & $\begin{array}{c}\text { Quantity } \\
\left(\mathrm{ft}^{3}\right)\end{array}$ \\
\hline Small-scale & Streator $^{\mathrm{a}}$ & 3,116 \\
Large & Streator & 3,123 \\
& & \\
& Total & $6,239^{\mathrm{b}}$ \\
\hline
\end{tabular}

a Streator Area Landfill, Streator, IL.

b Does not include material from Building 207 floor tile removal reported in Table 2.1 .

Section 4.6.1. contains a more detailed discussion of these emission points and compliance with the standard.

\subsubsection{Conventional Air Pollutants}

The ANL-E site contains a number of sources of conventional air pollutants, including a steam plant; gasoline, methanol/gasoline blend, and ethanol/gasoline blend fuel-dispensing facilities; two alkali metal reaction booths; bulk chemical tanks; a dust collection system; a medical equipment sterilization unit; and fire training activities. Table 2.12 gives the emission sources that have been granted operating air pollution control permits by the IEPA. During 1998, three new air pollution control permits were issued by the IEPA (see Table 2.12) for conducting open burning for fire training purposes, for prescribed vegetation burning at ANL-E as part of the site landscape management plan, and for the low-level hydrochloric acid emissions from the Building 369 Salt Cake/Recovery Electrodialysis Plant. 
The operating air pollution control permit for the steam plant requires continuous opacity and $\mathrm{SO}_{2}$ monitoring of the smoke stack from Boiler No. 5, the only one of the five boilers equipped to burn coal. The permit requires submission of a quarterly report listing any exceedances beyond emission limits for this boiler [30\% opacity averaged over 6 minutes and $0.82 \mathrm{~kg}(1.8 \mathrm{lb})$ of sulfur dioxide per million Btu averaged over a 1-hour period]. Table 2.3 gives the hours that Boiler No. 5 operated on low-sulfur coal during 1998, as well as the amount of lowsulfur coal burned. Unusually warm temperatures on March 29, 1998, caused a 312-minute opacity exceedance, which resulted in low steam loads. This condition, compounded by burning wet coal, caused a high-pressure differential in the baghouse. Cleaning of the filters returned opacity levels to permitted levels. Oral and written notifications were given to the IEPA on March 31, and April 6, 1998, respectively.

\section{TABLE 2.3}

Boiler No. 5 Operation, 1998

\begin{tabular}{lcc}
\hline Month & $\begin{array}{c}\text { Operated } \\
\text { (hours) }\end{array}$ & $\begin{array}{c}\text { Low-Sulfur } \\
\text { Coal Burned } \\
\text { (tons) }\end{array}$ \\
\hline January & 744.0 & $2,435.0$ \\
February & 133.4 & 356.6 \\
March & 467.0 & $1,372.3$ \\
April & 555.5 & $1,418.3$ \\
May & 0 & 0 \\
June & 0 & 0 \\
July & 0 & 0 \\
August & 0 & 0 \\
September & 0 & 0 \\
October & 0 & 0 \\
November & 0 & 0 \\
December & 0 & 0 \\
\cline { 2 - 3 } Total & $1,899.9$ & $5,582.2$ \\
\hline
\end{tabular}




\section{COMPLIANCE SUMMARY}

The ANL-E 800 Area Landfill, which was closed in 1992, was not subject to air pollution control permitting requirements during its operation. It is not subject to 40 CFR Part 60 , Subpart WWW (Standards of Performance for Municipal Solid Waste Landfills), or Subpart Cc (Emission Guidelines and Compliance Times for Municipal Solid Waste Landfills), because it does not meet the definition of a municipal solid waste landfill. Because closed landfills are sources of emissions, in 1998, the EPA Landfill Gas Emissions Model (LandGEM) ${ }^{4}$ was used to determine levels of methane and Nonmethane Organic Compounds (NMOC) for inclusion in the ANL-E CAAPP application and emissions inventory. For 1998, the model calculated methane emissions of approximately $61.69 \mathrm{t} / \mathrm{yr}$ ( $68 \mathrm{tons} / \mathrm{yr}$ ) and NMOC emissions (from analysis of samples from gas monitoring wells) of approximately $0.02 \mathrm{t} / \mathrm{yr}(0.02 \mathrm{ton} / \mathrm{yr})$. On the basis of the timing of initial refuse placement and closure of the landfill, the model predicts that methane emissions will continue to decline over time.

Landfill gas monitoring is conducted quarterly at the 800 Area Landfill using 12 gas wells placed into the waste area and 10 gas wells at the perimeter of the 800 Area Landfill. The gas monitoring determines the levels of methane, carbon dioxide, nitrogen, and oxygen. The perimeter gas wells are monitored to determine whether or not methane is migrating from the landfill. Results indicate that methane is being generated; however, no migration of this compound has been noted.

Fuel-dispensing facilities include a commercial service station and the Building 46 Grounds and Transportation facility. Except for methanol and ethanol vapors from alternate fuel usage, these facilities have VOC emissions typical of any commercial gasoline service station. Stage II vapor recovery systems were installed at both facilities by November 1, 1994. Pursuant to Illinois Administrative Code, Title 35, Part 254 (35 IAC Part 254), ANL-E submits an emissions summary to the IEPA each May 1 for the previous calendar year. The summary for 1998 is presented in Table 2.4. 
TABLE 2.4

1998 Annual Emissions Report: Emissions Summary

\begin{tabular}{|c|c|c|c|c|c|c|}
\hline Building No. and Source & $\mathrm{CO}^{\mathrm{a}}$ & $\mathrm{NO}_{x}$ & Particulate & $\mathrm{SO}_{2}$ & vom & Lead \\
\hline 46 Ethanol/Gasoline & 0 & $\mathbf{0}$ & 0 & 0 & 15.7 & 0 \\
\hline $46 \mathrm{Methanol} /$ Gasoline & 0 & $\mathbf{0}$ & 0 & 0 & $\mathbf{0}$ & 0 \\
\hline 46 10,000 Gal Gasoline & 0 & 0 & $\mathbf{0}$ & $\mathbf{0}$ & 254 & 0 \\
\hline 108 Boiler 1 & 1,595 & 71,076 & 736 & 442 & 344 & 0 \\
\hline 108 Boiler 2 & 6 & 18,504 & 177 & 142 & 83 & 0 \\
\hline 108 Boiler 3 & 33 & 32,423 & 327 & 458 & 153 & 0 \\
\hline 108 Boiler 4 & 147 & 31,158 & 315 & 84 & 147 & 0 \\
\hline 108 Boiler 5 (coal-fired) & 28,975 & 156,588 & 439 & 122,282 & 205 & 0 \\
\hline 108 Boiler 5 (gas-fired) & 1,345 & 4,135 & 59 & 21 & 59 & 0 \\
\hline 108 Sulfuric Acid Tank ${ }^{b}$ & 0 & 0 & $-\mathbf{c}$ & 0 & 0 & 0 \\
\hline 200 M-Wing Hot Cells (R) & 0 & 0 & 0 & $\mathbf{0}$ & 0 & 0 \\
\hline 201 Ethylene Oxide Sterilizer & 0 & 0 & 0 & 0 & 22.0 & 0 \\
\hline 206 Alkali Reaction Booth $(\mathrm{R})^{\mathrm{d}}$ & 0 & 0 & 4.6 & 0 & 0 & 0 \\
\hline 212 Alpha Gamma Hot Cell (R) & o & 0 & $\mathbf{0}$ & 0 & $\mathbf{0}$ & $\mathbf{0}$ \\
\hline 212 Building Exhausts ${ }^{b}$ & 0 & 0 & - & 0 & 0 & $\mathbf{0}$ \\
\hline 3008,000 Gal Gasoline & 0 & 0 & $\mathbf{0}$ & 0 & 182 & 0 \\
\hline 300 10,000 Gal Gasoline & $\mathbf{0}$ & 0 & 0 & 0 & 833 & 0 \\
\hline 300 6,000 Gal Gasoline & 0 & 0 & 0 & 0 & 246 & 0 \\
\hline 303 Mixed Waste Storage (R) & 0 & 0 & 0 & 0 & 0 & 0 \\
\hline 306 Building Vents ( $R$ ) & 0 & 0 & $<1$ & 0 & 0 & 0 \\
\hline 306 Bulking Sheds & 0 & 0 & 3.8 & 0 & 2,058 & $\mathbf{0}$ \\
\hline 306 Vial Crusher & 0 & 0 & $\mathbf{0}$ & 0 & 9.6 & $\mathbf{0}$ \\
\hline 308 Alkali Reaction Booth ${ }^{b}$ & 0 & 0 & - & 0 & 0 & $\mathbf{0}$ \\
\hline 315 MACE Project (R) & 0 & 0 & 0 & 0 & 0 & $\mathbf{0}$ \\
\hline 317 Area French Drain Remediation & 0 & 0 & 875 & 0 & 568 & $\mathbf{0}$ \\
\hline 317 Lead Brick Cleaning (R) & 0 & 0 & $<1$ & 0 & 0 & $<1$ \\
\hline 330 CP-5 D\&D Project (R) & 0 & 0 & 0 & 0 & 0 & $\mathbf{0}$ \\
\hline 331 Rad Waste Storage (R) & 0 & 0 & 0 & 0 & 0 & 0 \\
\hline 350 NBL Pu/U Hoods (R) & 0 & 0 & 0 & 0 & 0 & 0 \\
\hline 363 Central Shop Dust Collecior & 0 & 0 & - & 0 & 0 & 0 \\
\hline 366 Grieve Oven ${ }^{b}$ & 0 & 0 & - & 0 & 0 & 0 \\
\hline 368 Woodshop Dust Collectorb & 0 & 0 & - & 0 & $\mathbf{0}$ & $\mathbf{0}$ \\
\hline 369 Salt Cake/Recov Elec. Plant ${ }^{b}$ & 0 & 0 & $\mathbf{0}$ & 0 & 0 & 0 \\
\hline 370 Alkali Reaction Booth & 0 & 0 & - & 0 & 0 & 0 \\
\hline 375 Intense Pulsed Neutron Source (R) & 0 & 0 & 0 & 0 & $\mathbf{0}$ & 0 \\
\hline 400 APS Facility (R) & 0 & 50.0 & 0 & 0 & $\mathbf{0}$ & 0 \\
\hline 400 APS Generator Caterpillar ( 1 unit) & 454 & 2,364 & 84 & 195 & 64 & 0 \\
\hline 400 APS Generator Kohler (2 units) & 2,613 & 3,525 & 138 & 724 & 125 & 0 \\
\hline 595 Lab Wastewater Plant (R) & 0 & 0 & o & 0 & 191 & 0 \\
\hline Lab Rad Hoods (R) & 0 & 0 & 0 & 0 & 0 & 0 \\
\hline PCB Tank Cleanout & 0 & 0 & $\mathbf{0}$ & 0 & 37.6 & 0 \\
\hline Torch Cut Lead-Based Paintb & 0 & 0 & - & 0 & 0 & 0 \\
\hline Transportation Research Facility & 1,643 & 844 & 59.7 & 55.3 & 139 & 0 \\
\hline WMO Portable HEPA - (4) (R) & 0 & 0 & $<1$ & 0 & $\mathbf{0}$ & 0 \\
\hline Total (lb/yr) & 36,818 & 320,666 & 3,216 & 124,403 & 5,732 & 0 \\
\hline Total (ton/yr) & 18.4092 & 160.3332 & 1.6079 & 62.2013 & 2.8662 & 0 \\
\hline CAAPP Limit (ton/yr) - Typical & 159.58 & 692.30 & 29.88 & 463.82 & 14.77 & 0.11 \\
\hline CAAPP Limit (ton/yr) - Alt 1 & 243.60 & $1,697.10$ & 38.72 & 802.03 & 18.77 & 0.11 \\
\hline CAAPP Limit (ton/yr) - Alt 2 & 307.60 & 1.405 .10 & 58.72 & 991.20 & 18.77 & 0.11 \\
\hline
\end{tabular}

2 Abbreviations: $\mathrm{CO}=$ carbon monoxide, $\mathrm{HEPA}=$ high-efficiency particulate air fitter, $\mathrm{MACE}=$ melt attack and coolability experiment, $\mathrm{NO}_{\mathrm{x}}=$ oxides of nitrogen, $\mathrm{PCB}=$ polychlorinated biphenyl, $\mathrm{Pu}=$ plutonium, $\mathrm{SO}_{\mathrm{x}}=$ sulfur dioxide, $\mathrm{U}=$ uranium. and $\mathrm{VOM}=$ volatile organic material.

b These sources have been designated as insignificant in the CAAPP application.

c A hyphen indicates no emissions for this parameter.

d $(R)=$ radionuclide source regulated by NESHAP (40 CFR Part 61 Subpart $H$ ). 


\subsubsection{Clean Fuel Fleet Program}

As mandated under the CAA and 35 IAC Part 241, vehicle acquisition requirements for the ANL-E Clean Fuel Fleet Program became effective on September 1, 1998 (considered to be the beginning of Model Year [MY] 1999). For acquisitions of MY 1999 cars and trucks (as defined by the IEPA), a specified percentage of each must be EPA-certified as clean fuel fleet vehicles. The ANL-E fleet was registered with the IEPA during November 1997, and starting with MY 1999, vehicle acquisition records are required to be submitted to the IEPA annually by November 1, following the end of the prior MY.

\subsection{Clean Water Act}

The Clean Water Act (CWA) was established in 1977 as a major amendment to the Federal Water Pollution Control Act of 1972 and was modified substantially by the Water Quality Act of 1987. Section 101 of the CWA provides for the restoration and maintenance of water quality in all waters throughout the country, with the ultimate goal of "fishable and swimmable" water quality. The act established the National Pollutant Discharge Elimination System (NPDES) permitting system, which is the regulatory mechanism designed to achieve this goal. The authority to implement the NPDES program has been delegated to those states, including Illinois, that have developed a program substantially the same and at least as stringent as the federal NPDES program.

The 1987 amendments to the CWA significantly changed the thrust of enforcement activities. Greater emphasis is placed on monitoring and control of toxic constituents in wastewater, the permitting of outfalls composed entirely of storm water, and the imposition of regulations governing sewage sludge disposal. These changes in the NPDES program resulted in much stricter discharge limits and greatly expanded the number of chemical constituents monitored in the effluent. 


\subsubsection{Liquid Effluent Discharge Permit}

The NPDES permitting process administered by the IEPA is the primary tool for enforcing the requirements of the NPDES program. Before wastewater can be discharged to any receiving stream, each wastewater discharge point (outfall) must be characterized and described in a permit application. The IEPA then issues a permit that, for each outfall, contains numeric limits or monitoring frequencies on certain pollutants likely to be present and sets forth a number of additional specific and general requirements, including sampling and analysis schedules and reporting and record keeping requirements. NPDES permits are effective for five years and must be renewed by the submission of a permit application at least 180 days prior to the expiration of the existing permit. Wastewater discharge at ANL-E is permitted by NPDES Permit No. IL 0034592. This permit was renewed during 1994 (effective October 30, 1994), modified in 1995 (effective August 24, 1995), and expires on July 1, 1999. An application to renew the existing permit was submitted to the IEPA on December 28, 1998.

Wastewater at ANL-E is generated by a number of activities and consists of sanitary wastewater (from restrooms, cafeteria sinks and sinks in certain buildings and laboratories, and steam boiler blowdown), laboratory wastewater (from laboratory sinks and floor drains in most buildings), and storm water. Water softener regenerant from boiler house activities is discharged to the DuPage County sewer system. Cooling water and cooling tower blowdown are discharged into storm water ditches that are monitored as part of the NPDES permit. The current permit authorizes the release of wastewater from 40 separate outfalls, most of which discharge directly or indirectly into Sawmill Creek. Two of the outfalls are internal sampling points that combine to form the main wastewater outfall, Outfall 001 . Table 2.5 lists these outfalls; Figure 2.1 shows their locations.

\subsubsection{Compliance with NPDES Permit}

Wastewater is processed at ANL-E in two independent treatment systems, the sanitary system and the laboratory system. The sanitary wastewater collection and treatment system 
TABLE 2.5

Characterization of NPDES Outfalls at ANL-E, 1998

\begin{tabular}{|c|c|c|}
\hline Outfall & Description & Average Flow ${ }^{a}$ \\
\hline $001 \mathrm{~A}$ & Sanitary Treatment Plant & 0.40 \\
\hline $001 \mathrm{~B}$ & Laboratory Treatment Plant & 0.41 \\
\hline 001 & Combined Outfall & 0.81 \\
\hline $003 \mathrm{~A}$ & Swimming Pool & 0.0 \\
\hline 003B & 300 Area (Condensate) & 0.092 \\
\hline $003 \mathrm{C}$ & Building 205 Footing Tile Drainage & 0.027 \\
\hline 003D\&E & Steam Trench Drainage (Condensate) & $0.025 / 0.003$ \\
\hline $003 \mathrm{~F}$ & Building 201 Fire Pond Overflow Storm Water & 0.022 \\
\hline $003 \mathrm{G}$ & North Building 201 Storm Sewer (Condensate) & 0.030 \\
\hline $003 \mathrm{H}$ & Building 212 Cooling Tower Blowdown & 0.026 \\
\hline $003 I$ & Buildings 200 and 211 Cooling Tower Blowdown & 0.027 \\
\hline $003 \mathrm{~J}$ & Building 213 and Building 213 Parking Lot Storm Water & 0.036 \\
\hline 004 & $\begin{array}{l}\text { Building } 203 \text { Cooling Tower and Building } 221 \text { Footing Drainage } \\
\text { and Storm Water }\end{array}$ & 0.030 \\
\hline $005 \mathrm{~A}$ & Westgate Road Storm Water & Storm Water Only \\
\hline 005B & 800 Area East Storm Water & Storm Water Only \\
\hline $005 \mathrm{C}$ & Building 200 West & 0.004 \\
\hline 005D & Storm Water & Storm Water Only \\
\hline $005 \mathrm{E}$ & Building 203 West Footing Drainage and Condensate & 0.036 \\
\hline 006 & Cooling Tower Blowdown and Storm Water & 0.040 \\
\hline 007 & Domestic Cooling Water for Compressor and Storm Water & 0.013 \\
\hline 008 & Transportation and Grounds Storm Water & 0.015 \\
\hline 010 & Coal Pile Runoff Emergency Overflow & Storm Water Only \\
\hline 101 & North Fence Line Marsh Storm Discharge & Storm Water Only \\
\hline 102 & 100 Area Storm Water Discharge & Storm Water Only \\
\hline 103 & Southeast 100 Area Storm Water & Storm Water Only \\
\hline 104 & Northern East Area Storm Water Discharge & Storm Water Only \\
\hline $105 A \& B$ & Building 40 Storm Water Discharge & Storm Water Only \\
\hline $106 A \& B$ & Southern East Area Storm Water Discharge & Storm Water Only \\
\hline 108 & Eastern 300 Area Storm Water and Cooling Water & 0.061 \\
\hline 110 & Shooting Range Storm Water Discharge & Storm Water Only \\
\hline 111 & 319 Landfill and Northeast 317 Area & Storm Water Only \\
\hline $112 \mathrm{~A} \& \mathrm{~B}$ & Southern and Western 317 Area & Storm Water Only \\
\hline 113 & Southern and Eastern 800 Area Landfill Storm Water Runoff & 0.035 \\
\hline 114 & Northern and Western 800 Area Landfill Storm Water Runoff & 0.031 \\
\hline 115 & 314,315 , and 316 Cooling Water, Eastern and Southern APS Area & 0.020 \\
\hline 116 & Water Treatment Plant and Storm Water & 0.019 \\
\hline
\end{tabular}

a Flow is measured in million gallons per day, except for outfalls with storm water only. 


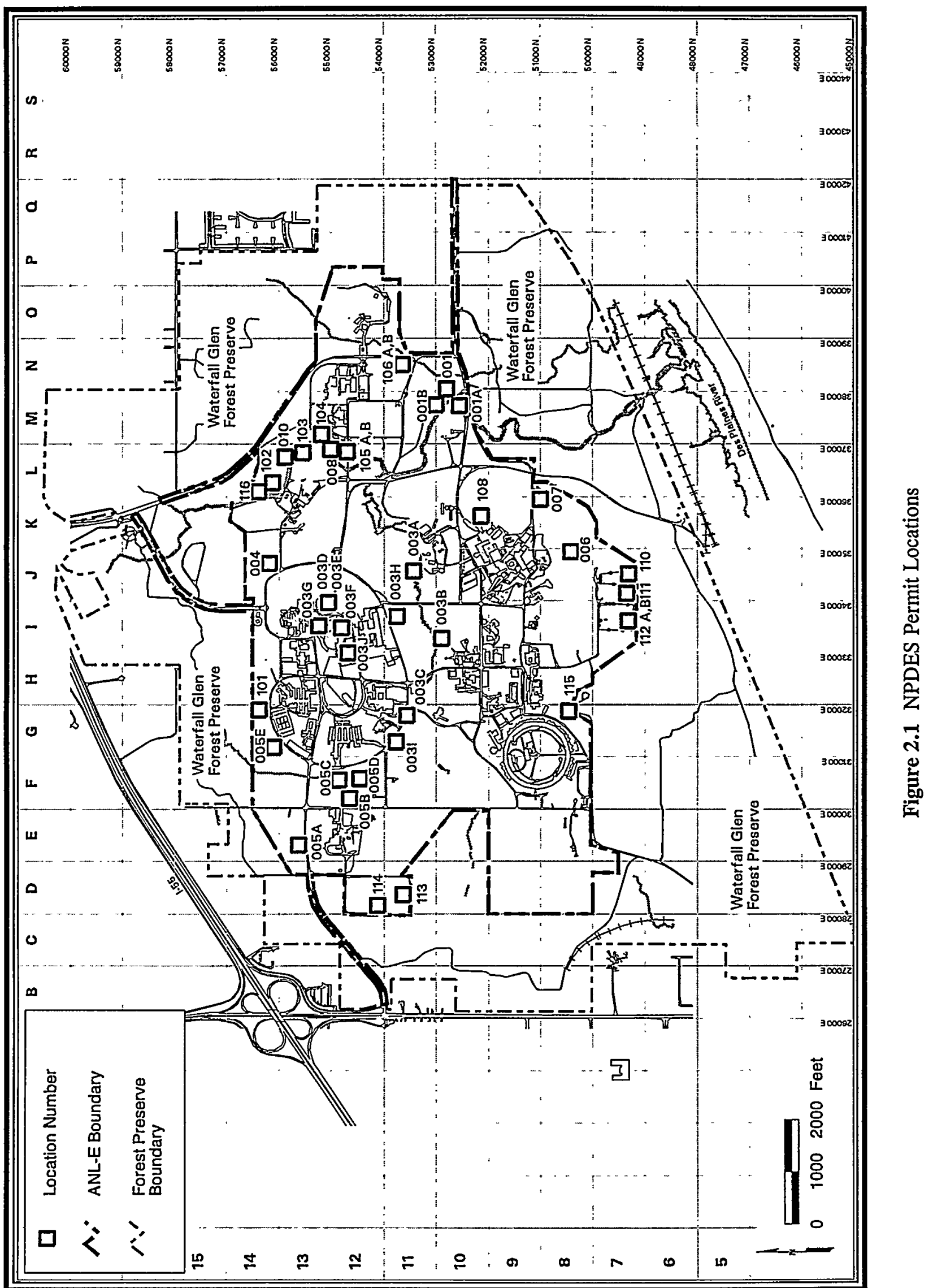

ANL-E Site Environmental Report 


\section{COMPLIANCE SUMMARY}

collects wastewater from lavatories, the cafeteria, office buildings, and other portions of the site that do not contain radioactive or hazardous materials. This wastewater is treated in a biological wastewater treatment system consisting of primary clarifiers, trickling filters, final clarifiers, and slow sand filters. Wastewater generated by research-related activities, such as laboratories and experimental equipment, flows to a series of retention tanks located in each building and discharged to the laboratory wastewater collection and treatment systems.

Figure 2.2 shows the two wastewater treatment systems that are located adjacent to each other. The volume of wastewater discharged from these facilities in 1998 averaged 1.51 million L/day ( 0.40 million gal/day) for the sanitary wastewater and 1.54 million $\mathrm{L} /$ day (0.41 million gal/day) for the laboratory process wastewater.

Results of the routine monitoring required by the NPDES permit are submitted monthly to the IEPA in a Discharge Monitoring Report (DMR). As required by the permit, any exceedance of permit limits or conditions is reported by telephone to the IEPA within 24 hours, and a written explanation of the exceedance is submitted with each DMR. During 1998, there were two exceedances of NPDES permit limits out of approximately 1,600 measurements. This result represents greater than a $99 \%$ compliance rate, similar to the 1996 and 1997 compliance rates. The total suspended solids (TSS) limit was exceeded twice at Outfall 001B in February. These exceedances probably were caused by storm runoff from the 317 Area Remediation Project and start-up testing for stress recovery and calibration at the new laboratory wastewater treatment plant (WTP).

The IEPA issued an NPDES permit modification to ANL-E, effective August 24, 1995. The permit modification gave ANL-E a provisional variance from the existing limits for ammonianitrogen, copper, and total dissolved solids (TDS) and included a compliance schedule to bring these discharges under their respective limits. The compliance schedule required ANL-E to meet the permit limits for these discharges by July 1, 1998. Efforts undertaken to achieve these specific discharge limits have included the upgrade of the ANL-E sanitary wastewater treatment facility, which was completed during 1996, the upgrade of the laboratory wastewater treatment facility, 


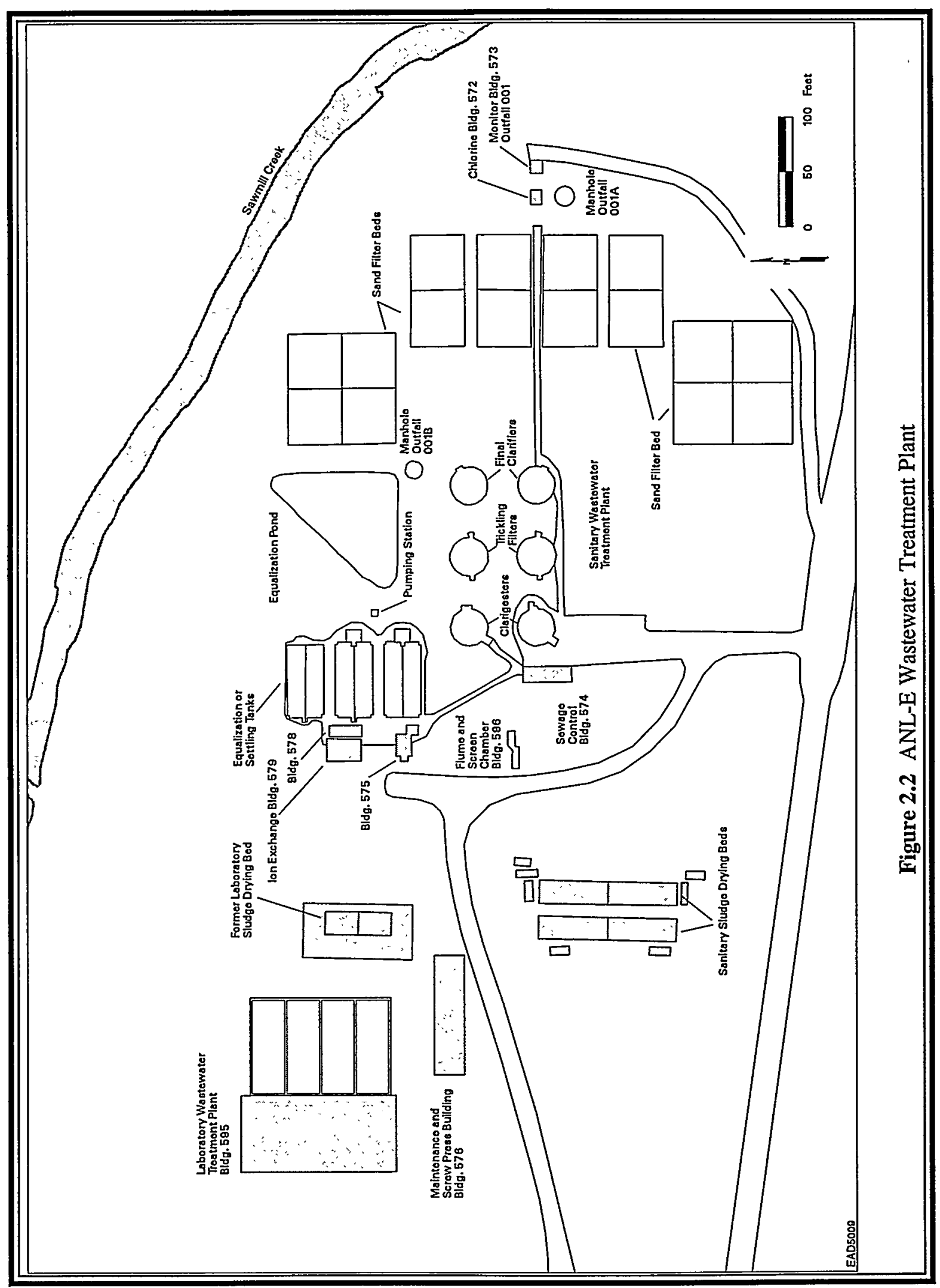


which was completed during 1997, and the incorporation of Lake Michigan water as the ANL-E source water, which was completed in January 1997. ANL-E achieved compliance with the required discharge permit limits by July 1, 1998.

Figure 2.3 presents the data for the total number of each type of exceedance over the past nine years. In general, the total number of exceedances per year has declined steadily. In 1995, the number of exceedances increased (49); this increase can be attributed, however, to the renewal of the NPDES Permit, effective October 30, 1994, which placed more restrictive limits on ANL-E discharges and increased the number of analyses required each year by approximately 600 . The more restrictive limits for copper, TDS, and ammonia-nitrogen resulted in a substantial increase of exceedances during 1995 prior to issuance of the modified permit.

\subsubsection{Priority Pollutant Analysis and Biological Toxicity Testing}

The current permit requires semiannual testing of Outfall 001B, the laboratory WTP outfall, for all the priority pollutants (a list of 124 metals and organic compounds identified by the IEPA

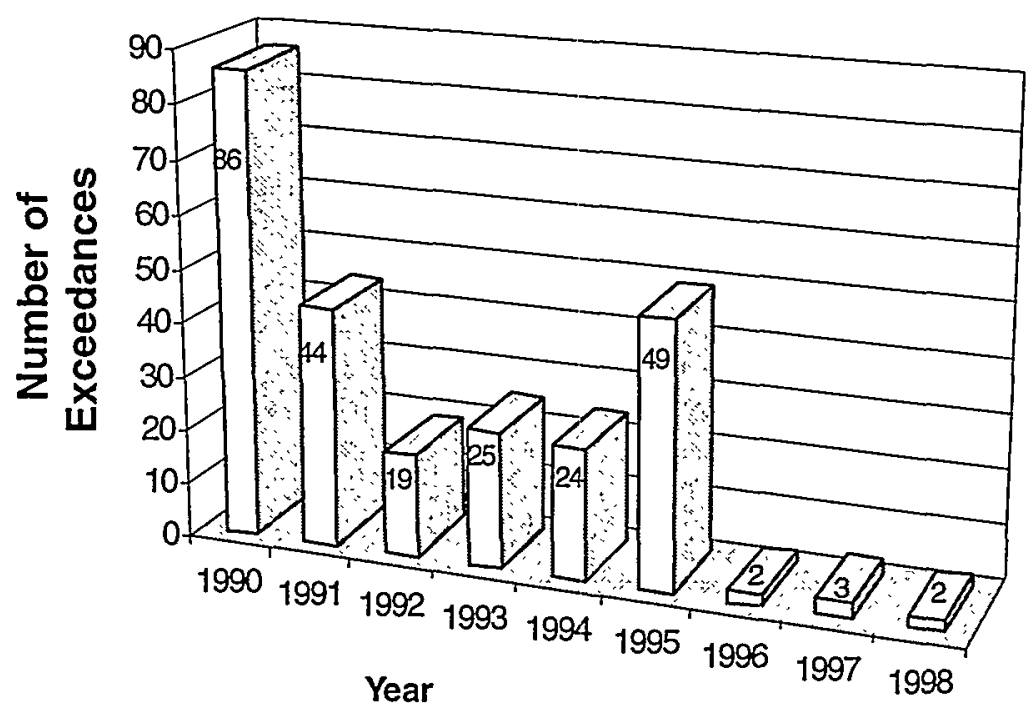

Figure 2.3 Total Number of NPDES Exceedances, 1990 to 1998 
as being of particular concern). During 1998, this sampling was conducted in June and December. Organic compound concentrations were very low. Chloroform $(3 \mu \mathrm{g} / \mathrm{L}$ and $1 \mu \mathrm{g} / \mathrm{L})$ was detected in both the June and December samples. Bromoform $(4 \mu \mathrm{g} / \mathrm{L})$, dibromodichloromethane $(2 \mu \mathrm{g} / \mathrm{L})$, and methylene chloride $(3 \mu \mathrm{g} / \mathrm{L})$ were noted in the June sample, and bromodichloromethane $(1 \mu \mathrm{g} / \mathrm{L})$ was noted in the December sample. The sources of chloroform, dibromochloromethane, bromoform, and bromodichloromethane are suspected to result from the contact of chlorinated water with organic chemicals. The presence of methylene chloride is most likely a result of the discharge of small amounts of chemicals from various research and support operations. All semivolatile concentrations were below the detection limits. Low concentrations of antimony (0.003 mg/L), copper $(0.03 \mathrm{mg} / \mathrm{L})$, cadmium $(0.0001 \mathrm{mg} / \mathrm{L})$, lead $(0.001 \mathrm{mg} / \mathrm{L})$, and zinc $(0.015 \mathrm{mg} / \mathrm{L})$ were detected. These findings are discussed further in Chapter 5.

In addition to the priority pollutant analysis, the permit requires annual biological toxicity testing of the combined effluent stream, Outfall 001. This was conducted June 8 through June 12,1998 . The data indicate that the effluent was not acutely toxic to either the fathead minnow or the water flea. Data from the past five years suggest that cessation of chlorination of ANL-E effluent can be correlated with a beneficial effect on aquatic life in the receiving streams.

Acute toxicity testing is required at Outfalls $003 \mathrm{H}, 003 \mathrm{I}, 003 \mathrm{~J}, 004,006$, and 115 twice a year, during the months of July and August. Samples were collected July 20 through 24, 1998, and August 24 through 28, 1998. The samples were tested on the fathead minnow and the water flea. Outfalls 006 and 115 were acutely toxic to the water flea. Outfall 115 was also acutely toxic to the fathead minnow. Elevated residual chlorine concentrations from cooling tower discharges may be the major contributing factor to the toxicity.

\subsubsection{Storm Water Regulations}

In November 1990, the EPA promulgated new regulations governing the permitting and discharge of storm water from industrial sites. The ANL-E site contains a large number of smallscale operations that are considered industrial activities by these regulations and are thus subject 


\section{COMPLIANCE SUMMARY}

to these requirements. An extensive storm water characterization program was initiated in 1991, and a storm water permit application identifying 15 storm water outfalls was submitted to the IEPA in 1992.

The NPDES permit issued in October 1994 includes these 15 outfalls. In addition, the permit breaks up the watersheds for prior Outfalls 003 and 005 into smaller components and requires that their corresponding point source discharges be analyzed and characterized for submission of a permit application. The permit application required the characterization to include both industrial wastewater and storm water runoff discharged from these point sources. Since 1994, three additional storm water outfall locations requiring characterization have been identified. Wastewater and storm water characterizations were completed in 1996 for the 18 outfalls identified within the subdivided watersheds. The characterization data include quantitative data; flow measurements; analyses for certain specified pollutants; and dates, durations, and precipitation volumes for monitored storm events. The resulting permit application was completed and submitted to the IEPA on September 18, 1996. The IEPA is expected to include these 18 outfalls with the reissuance of the NPDES permit in 1999.

The NPDES permit contains two special conditions requiring Storm Water Pollution Prevention Plans (SWPPPs) for both the APS construction site (Special Condition No. 12) and the remainder of the ANL-E site (Special Condition No. 11). Both of these plans were completed by the mandated date, May 1, 1995, which was 180 days after the effective date of the permit. The special conditions also require implementation of the plans by 365 days after the effective date of the permit; this was accomplished on November 1, 1995.

The same special conditions require ANL-E to inspect and report annually on the effectiveness of the SWPPP. In 1998, the annual inspection was completed on November 25, 1998. The report was submitted to the IEPA on January 11, 1999. Changes to the plan will be required throughout the life of the permit, including any reissue or extension of the permit. 


\subsubsection{NPDES Inspections and Audits}

The IEPA Maywood Regional Office conducted an NPDES Compliance Evaluation Inspection at ANL-E on March 18, 19, and 30, 1998. On September 16, 1998, the IEPA issued a Report of Compliance Evaluation Inspection to ANL-E, which identified seven findings. These items were addressed in a response prepared by ANL-E and submitted to the IEPA on October 20, 1998.

On September 28, 1998, the IEPA Maywood Regional Office conducted a water quality survey to assess the impact of ANL-E discharges into Sawmill Creek. The IEPA collected samples of Sawmill Creek at locations both upstream and downstream of ANL-E discharge points. The IEPA also conducted an assessment of the in-stream aquatic population by comparing upstream and downstream samples. A report of the findings has not been received to date.

\subsubsection{General Effluent and Stream Quality Standards}

In addition to specific NPDES permit conditions, ANL-E discharges are required to comply with general effluent limits contained in 35 IAC, Subtitle C, Chapter I, Part 304. Also, wastewater discharges must be of sufficient quality to ensure that Sawmill Creek complies with IEPA General Use Water Quality Standards found in 35 IAC, Subtitle C, Chapter I, Part 302, Subpart B. Chapter 5 of this report, which presents the results of the routine environmental monitoring program, also describes the general effluent limits and water quality standards applicable to the outfalls and discusses compliance with these standards.

\subsubsection{Spill Prevention Control and Countermeasures Plan}

ANL-E maintains a Spill Prevention Control and Countermeasures plan as required by the CWA and EPA regulations in 40 CFR Part 112. This plan describes the actions to be taken in case of oil or oil product releases to navigable waters of the United States. Persons with specific duties and responsibilities in such situations are identified, as are reporting and record keeping 


\section{COMPLIANCE SUMMARY}

requirements mandated by the regulations. Effective use of this plan is ensured by regular training. This plan was updated and provided to DOE in September 1998. No reportable spills occurred during 1998.

\subsection{Resource Conservation and Recovery Act}

The Resource Conservation and Recovery Act (RCRA) and its implementing regulations are intended to ensure that facilities that treat, store, or dispose of hazardous waste do so in a way that protects human health and the environment. The Hazardous and Solid Waste Amendments of 1984 (HSWA) created a set of restrictions on land disposal of hazardous waste. In addition, the HSWA also require that releases of hazardous waste or hazardous constituents from any Solid Waste Management Unit (SWMU) at a RCRA-permitted facility be cleaned up, regardless of when the waste was placed in the unit or whether the unit originally was intended as a waste disposal unit. The RCRA program includes regulations governing management of underground storage tanks (USTs) containing hazardous materials or petroleum products. The IEPA has been authorized to administer most aspects of the RCRA program in Illinois. The IEPA issued a RCRA Part B Permit to ANL-E and DOE on September 30, 1997. The permit became effective on November 4, 1997.

In 1998, ANL-E and DOE submitted two applications to modify the permit. The first application was submitted primarily to allow operational changes. The second application was submitted to allow ANL-E to receive for storage, the ash that results from treatment of the ANL-E mixed waste sent to the Waste Experimental Reduction Facility in Idaho, if that ash cannot otherwise be disposed of following treatment.

\subsubsection{Hazardous Waste Treatment and Disposal}

Because of the nature of the research activities conducted at ANL-E, small quantities of a large number of waste chemicals are generated. Many of these materials are classified as hazardous waste under RCRA. A small amount of these wastes also exhibit radioactivity, thereby 
making them "mixed waste." The hazardous component of mixed waste is subject to RCRA regulation by the IEPA, while the radioactive component is subject to DOE regulation under the Atomic Energy Act of 1954 (AEA). ANL-E has 25 Hazardous Waste Management Units, consisting of 17 container storage units, 4 miscellaneous treatment units, 1 tank storage unit, and 3 tank chemical treatment units. Table 2.6 provides descriptions of all of the units. No RCRA closures were conducted in 1998. Figure 2.4 shows the locations of the major hazardous and nonhazardous waste treatment, storage, and disposal areas at ANL-E.

Hazardous and mixed wastes generated, treated, and stored during 1998 are described in Tables 2.7 and 2.8, respectively. ANL-E operates several RCRA-permitted storage and treatment facilities. These facilities, designed and operated in compliance with RCRA requirements, allow for accumulation and storage of waste pending off-site disposal. Off-site treatment and disposal take place at approved hazardous waste treatment and disposal facilities. Off-site treatment options for mixed waste are extremely limited.

Three ongoing treatability studies were conducted at ANL-E during 1998. A description of each study, as well as the amount of waste treated, follows.

The Neutralization of Transuranic (TRU) Corrosive Waste with Heavy Metals Streams Study consists of treating corrosive TRU mixed waste by using a caustic solution. This study was conducted during February 1998; a total of $96 \mathrm{~kg}(212 \mathrm{lb})$ was treated. Once neutralized, the waste was solidified with sorbents approved by the DOE Waste Isolation Pilot Plant (WIPP). Any heavy metals present were solidified within the solid matrix. Approximately $50 \mathrm{~kg}(110 \mathrm{lb})$ is expected to be treated during 1999.

The Amalgamation of Radioactive Elemental Mercury Waste Stream Study consists of combining mercury with various powdered metals to determine the most suitable amalgamation method for ANL-E's mercury waste stream. Zinc, tin, and copper are being evaluated for the amalgams. This study was conducted from February through August 1998; a total of 
TABLE 2.6

Permitted Hazardous Waste Treatment and Storage Facilities, 1998

\begin{tabular}{|c|c|c|}
\hline Description & Location & Purpose \\
\hline \multicolumn{3}{|l|}{ Storage } \\
\hline Concrete Storage Pad & 317 Area & $\begin{array}{l}\text { Storage of solid radioactive waste } \\
\text { and solid radioactive mixed waste } \\
\text { (RMW) in the form of steel- } \\
\text { encased lead shielding containers } \\
\text { and containerized solid RMW. }\end{array}$ \\
\hline \multirow[t]{4}{*}{ Container Storage Area } & Building $325 \mathrm{C}$, East & $\begin{array}{l}\text { Storage of liquid and solid bulk } \\
\text { or lab-packed flammable and } \\
\text { reactive hazardous waste and } \\
\text { solid and liquid bulk PCBs and } \\
\text { miscellaneous PCB units. }\end{array}$ \\
\hline & Building 325C, West & $\begin{array}{l}\text { Storage of bulk and lab-packed } \\
\text { liquid flammable hazardous } \\
\text { waste. }\end{array}$ \\
\hline & $\begin{array}{l}\text { Building } 303 \text { Mixed Waste Storage } \\
\text { Facility }\end{array}$ & $\begin{array}{l}\text { Storage of containers of } \\
\text { ignitable, corrosive, oxidizing, } \\
\text { reactive, and solid hazardous, } \\
\text { radiological, or RWM. }\end{array}$ \\
\hline & $\begin{array}{l}\text { Building } 331 \text { Radioactive Waste } \\
\text { Storage Facility }\end{array}$ & $\begin{array}{l}\text { Storage of containers of } \\
\text { flammable, toxic, corrosive, and } \\
\text { oxidizing hazardous, } \\
\text { radiological, and RMW. }\end{array}$ \\
\hline Dry Mixed Waste Storage Area & Building 374A & $\begin{array}{l}\text { Storage of solid RMW and } \\
\text { radioactively contaminated lead } \\
\text { bricks. }\end{array}$ \\
\hline Mixed Waste Container Storage & Building 329 & $\begin{array}{l}\text { Storage of containers of bulk and } \\
\text { lab-packed ignitable mixed waste } \\
\text { or compatible waste. }\end{array}$ \\
\hline \multirow[t]{2}{*}{ Portable Storage Units } & Building 306 & $\begin{array}{l}\text { Storage of hazardous, } \\
\text { radiological, or RMW ( } 3 \text { of } \\
4 \text { units). }\end{array}$ \\
\hline & & $\begin{array}{l}\text { Bulking operations to consolidate } \\
\text { and reduce the volume of lab- } \\
\text { packed waste in containers ( } 1 \text { of } \\
4 \text { units). }\end{array}$ \\
\hline Tank Storage & Building 306 & $\begin{array}{l}\text { Storage of corrosive and toxic } \\
\text { mixed waste and radiological } \\
\text { liquid wastes }(4,000 \text { gal; } \\
\text { currently not used). }\end{array}$ \\
\hline
\end{tabular}


TABLE 2.6 (Cont.)

\begin{tabular}{|c|c|c|}
\hline Description & Location & Purpose \\
\hline \multirow[t]{5}{*}{ Waste and Storage } & Building 306 - Storage Room A-142 & Storage of ignitable RMW. \\
\hline & Building 306 - Storage Room A-150 & $\begin{array}{l}\text { Storage of solid and liquid } \\
\text { RMW. }\end{array}$ \\
\hline & Building 306 - Storage Room C-131 & $\begin{array}{l}\text { Storage of ignitable, corrosive, } \\
\text { and reactive hazardous waste. }\end{array}$ \\
\hline & Building 306 - Storage Room C-157 & $\begin{array}{l}\text { Storage of corrosive and oxidizer } \\
\text { RMW. }\end{array}$ \\
\hline & Building 306 - Storage Room D-001 & $\begin{array}{l}\text { Storage of solid RMW containing } \\
\text { toxic metal constituents. }\end{array}$ \\
\hline \multicolumn{3}{|l|}{ Treatment } \\
\hline Alkali Metal Passivation Booth & Building 206 & $\begin{array}{l}\text { Destruction of water reactive } \\
\text { alkali metals possibly } \\
\text { contaminated with radionuclides. }\end{array}$ \\
\hline Alkali Metal Passivation Booth & Building 308 & $\begin{array}{l}\text { Destruction of water reactive } \\
\text { alkali metals. }\end{array}$ \\
\hline Chemical/Photooxidation Unit & Building 306 & $\begin{array}{l}\text { Treatment of ignitable liquid } \\
\text { RMW containing organic } \\
\text { contaminants. }\end{array}$ \\
\hline $\begin{array}{l}\text { Dry Ice Pellet Decontamination } \\
\text { Unit }\end{array}$ & 317 Area & $\begin{array}{l}\text { Treatment of solid RMW having } \\
\text { radionuclide and/or RCRA metal } \\
\text { surface contamination. }\end{array}$ \\
\hline $\begin{array}{l}\text { Low-Level Waste (LLW) } \\
\text { Neutralization/Precipitation } \\
\text { System }\end{array}$ & Building 306 & $\begin{array}{l}\text { Treatment of aqueous, corrosive } \\
\text { LLW, some of which is } \\
\text { contaminated with heavy metals. }\end{array}$ \\
\hline $\begin{array}{l}\text { Mixed Waste Immobilization/ } \\
\text { Macroencapsulation Unit }\end{array}$ & Building 306 & $\begin{array}{l}\text { Treatment of solid, semisolid, } \\
\text { and organic liquid RMW } \\
\text { containing RCRA metals. }\end{array}$ \\
\hline $\begin{array}{l}\text { TRU Neutralization/ } \\
\text { Precipitation Treatment Unit }\end{array}$ & Building 306 & $\begin{array}{l}\text { Treatment of corrosive, aqueous } \\
\text { RMW containing transuranic } \\
\text { radionuclides and RCRA metals. }\end{array}$ \\
\hline
\end{tabular}


TABLE 2.7

Hazardous Waste Treatment, Storage, Disposal, or Recycle, 1998

\begin{tabular}{|c|c|c|}
\hline Waste & $\begin{array}{c}\text { Volume } \\
\text { (gal) }\end{array}$ & $\begin{array}{l}\text { Weight } \\
\text { (lb) }\end{array}$ \\
\hline \multicolumn{3}{|l|}{ Generated and Disposed of or Recycled } \\
\hline Aerosol cans & 270 & 650 \\
\hline Alkaline solutions with lead & 275 & 3,058 \\
\hline Barium-containing wastes & 110 & 220 \\
\hline Brake cleaner fluid ${ }^{\mathrm{a}}$ & 14 & 120 \\
\hline Bulked laboratory solvents & 770 & 6,157 \\
\hline Carbon filter cartridges $^{\mathrm{a}}$ & 1,000 & 16,200 \\
\hline Compressed gases & 175 & 189 \\
\hline Compressed gases $^{\mathrm{a}}$ & 400 & 600 \\
\hline Cutting oils with lead and solvents & 605 & 5,098 \\
\hline Ethanol solutions with silver & 110 & 1,007 \\
\hline Immersion cleaner fluid ${ }^{a}$ & 25 & 199 \\
\hline Labpacks of liquid chemicals & 1,893 & 19,676 \\
\hline Labpacks of solid chemicals & 1,871 & 14,968 \\
\hline Lead acid batteries $^{\mathrm{a}}$ & 218 & 6,400 \\
\hline Lead-contaminated debris & 20 & 640 \\
\hline \multicolumn{3}{|l|}{ Mercury-contaminated debris } \\
\hline Metal scrap containing cadmium & 200 & 1,321 \\
\hline Oil-based paint wastes & 30 & 300 \\
\hline Petroleum distillates & 455 & 2,810 \\
\hline Plating wastes containing lead & 330 & 2,813 \\
\hline Waste oils with solvents & 360 & 2,579 \\
\hline Water treatment chemicals & 30 & 112 \\
\hline \multicolumn{3}{|l|}{ Treated } \\
\hline Alkali metals (passivation) & 26 & 208 \\
\hline Laboratory acids (neutralized) & 16 & 160 \\
\hline \multicolumn{3}{|l|}{ Universal Hazardous Waste } \\
\hline Mercury-containing lamps ${ }^{\mathrm{a}}$ & 3,100 & 3,100 \\
\hline Nickel-cadmium batteries $^{\mathrm{a}}$ & 2 & 36 \\
\hline
\end{tabular}

${ }^{a}$ Recycled waste. 
TABLE 2.8

Mixed Waste Treatment, Storage, and Disposal, 1998

\begin{tabular}{|c|c|c|}
\hline Waste & $\begin{array}{c}\text { Volume } \\
\text { (gal) }\end{array}$ & $\begin{array}{l}\text { Weight } \\
\text { (lb) }\end{array}$ \\
\hline \multicolumn{3}{|l|}{ Generated } \\
\hline Acidic solutions & 80 & 720 \\
\hline Acidic solutions with heavy metals & 120 & 1,080 \\
\hline Alkali metals & 0.1 & 0.8 \\
\hline Aqueous solutions with heavy metals & 875 & 7,263 \\
\hline Caustic effluents & 3,440 & 30,960 \\
\hline Elemental mercury & 0.3 & 15 \\
\hline Flammable liquids & 150 & 1,050 \\
\hline Metal scrap with cadmium & 1,368 & 27,360 \\
\hline RMW debris with heavy metals & 362 & 1,480 \\
\hline RMW debris with volatile organics & 10 & 40 \\
\hline RMW lead articles & 2,244 & 201,960 \\
\hline RMW sludge with heavy metals & 60 & 600 \\
\hline RMW soil with heavy metals & 60 & 552 \\
\hline TRU acids & 10 & 90 \\
\hline TRU lead articles & 110 & 10,340 \\
\hline TRU metals with cadmium & 55 & 3,949 \\
\hline Uranyl nitrate & 0.1 & 2 \\
\hline \multicolumn{3}{|l|}{ Treated } \\
\hline Acidic solutions with heavy metals (neutralized) & 550 & 4,950 \\
\hline Alkali metals (passivation) & 110 & 880 \\
\hline Aqueous solutions with heavy metals (neutralized) & 300 & 2,490 \\
\hline Caustic effluents (neutralized) & 3,440 & 30,960 \\
\hline Elemental mercury (amalgamated) & 4.3 & 215 \\
\hline RMW acidic solutions (neutralized) & 350 & 3,150 \\
\hline TRU acids (neutralized) & 103 & 927 \\
\hline
\end{tabular}


TABLE 2.8 (Cont.)

\begin{tabular}{|c|c|c|}
\hline Waste & $\begin{array}{c}\text { Volume } \\
\text { (gal) }\end{array}$ & $\begin{array}{l}\text { Weight } \\
\text { (lb) }\end{array}$ \\
\hline \multicolumn{3}{|l|}{ In Storage } \\
\hline Acidic solutions & 25 & 225 \\
\hline Acidic solutions with heavy metals & 60 & 540 \\
\hline Alkali metals & 0.1 & 0.8 \\
\hline Aqueous solutions with heavy metals & 575 & 4,773 \\
\hline Aqueous solutions with organics & 19 & 158 \\
\hline Cyanide solution & 11 & 92 \\
\hline Elemental mercury & 0.1 & 5 \\
\hline Flammable liquids & 212 & 1,484 \\
\hline Metal scrap with cadmium & 5,916 & 118,320 \\
\hline Metal scrap with heavy metals & 137 & 4,110 \\
\hline RMW debris with chromium & 3 & 75 \\
\hline RMW debris with heavy metals & 1,591 & 6,364 \\
\hline RMW debris with volatile organics & 121 & 484 \\
\hline RMW lead articles & 14,100 & $1,269,000$ \\
\hline RMW sludges with heavy metals & 330 & 3,300 \\
\hline RMW soil with heavy metals & 160 & 1,472 \\
\hline TRU acids & 10 & 90 \\
\hline TRU cadmium & 185 & 13,283 \\
\hline TRU lead & 265 & 24,910 \\
\hline TRU sludge & 478 & 4,780 \\
\hline Uranyl nitrate & 162 & 3,240 \\
\hline
\end{tabular}




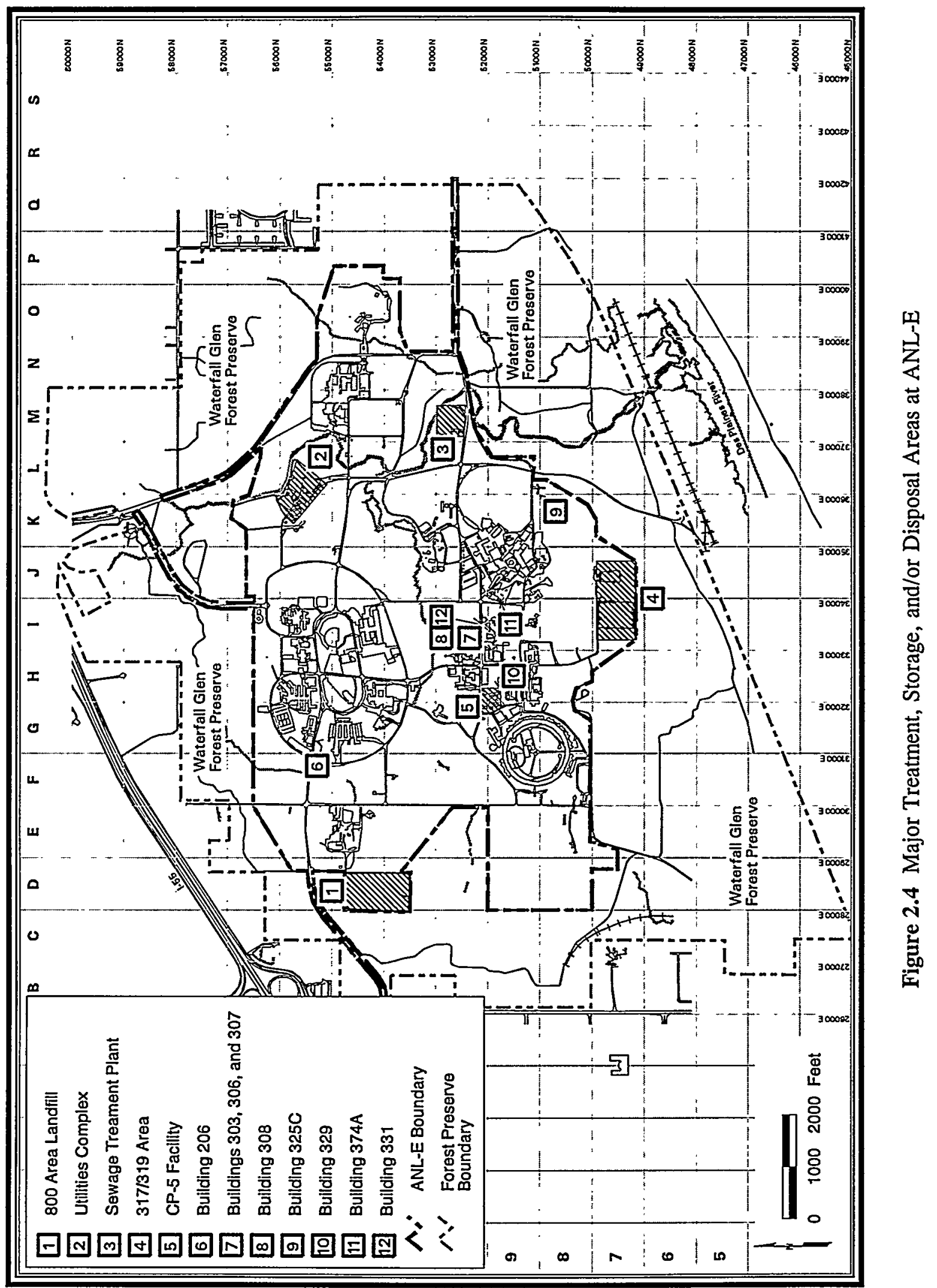


$211 \mathrm{~kg}(464 \mathrm{lb})$ was treated. Treatment residues are being managed as low-level radioactive waste (LLW). Approximately $40 \mathrm{~kg}(88 \mathrm{lb})$ is expected to be treated during 1999.

The Chemically Bonded Phosphate Ceramic Waste Forms Study involves mixing uranium mill tailings containing hazardous constituents (metals) with magnesium oxide, monopotassium dihydrogen phosphate, and water. The resulting slurry is poured into molds and allowed to set for several weeks. The study was conducted from January through March 1998; a total of 6,051 g $(13 \mathrm{lb})$ was treated. The treated media, a total of $11,364 \mathrm{~g}(25 \mathrm{lb})$, including the binder material, was returned to the generator. The Chemically Bonded Phosphate Ceramic Waste Forms Study is complete, and no further study is expected in 1999.

\subsubsection{Mixed Waste Handling}

The hazardous component of mixed waste is governed by RCRA regulations, while the radioactive component is subject to regulation under the AEA as implemented by DOE Orders. Accordingly, facilities storing or disposing of mixed waste must comply with both DOE requirements and RCRA permitting and facility standards. ANL-E generates several types of mixed waste, including acids, solvents, and sludges contaminated with radionuclides. Reactive alkali metals, primarily elemental sodium contaminated with uranium, have been treated in the Building 206 Alkali Metal Passivation Booth. The RCRA Part B Permit provides for on-site treatment in five new mixed waste treatment systems. These systems include neutralization of low-level and TRU corrosive aqueous wastes and the stabilization of sludge and soil. No off-site commercial treatment facility was used during 1998 to treat mixed waste.

\subsubsection{Federal Facility Compliance Act Activities}

The Federal Facility Compliance Act of 1992 (FFCA) amended RCRA to clarify the application of requirements and sanctions to federal facilities. The FFCA also requires that DOE prepare mixed waste treatment plans for DOE facilities that store or generate mixed waste. The Proposed Site Treatment Plan (PSTP) for mixed waste generated at ANL-E was submitted to the 
IEPA and the Illinois Department of Nuclear Safety (IDNS) in March 1995. Mixed waste at ANL-E has been managed in accordance with the PSTP as of October 1995. During 1998, ANL-E completed three treatment milestones in the PSTP for acidic wastewater without metals, elemental mercury, and reactive alkali metals. In 1998, ANL-E also identified three new waste streams generated as a result of research and development activities: lithium metal with plutonium, polychlorinated biphenyl (PCB) sludge with RCRA metals, and uranium tetrafluoride with mercury. ANL-E's RCRA Part B Permit provides for on-site treatment of certain mixed waste as required by the PSTP.

\subsubsection{RCRA Inspections: Hazardous Waste}

A RCRA Compliance Inspection was conducted by the EPA on June 25 and 26, 1998. No significant issues were identified.

\subsubsection{Underground Storage Tanks}

The ANL-E site currently contains 20 USTs that are in compliance with UST regulations; 38 tanks have been removed over the last several years. Eight of the existing tanks are being used for storage of fuel oil for emergency generators. The on-site vehicle maintenance facilities use underground diesel, gasoline, and methanol/gasoline blend tanks. The ethanol/gasoline blend is stored in an aboveground tank. One 2,080-L (550-gal) UST - used for fuel oil storage and located near former Building 829 - was removed in September 1998.

\subsubsection{Corrective Action for Solid Waste Management Units}

As mentioned previously, the HSWA requires that any RCRA Part B Permit issued must include provisions for corrective action to address major releases of hazardous constituents from any SWMU at the site, regardless of when waste was placed in the unit. The Part B Permit contains procedures and requirements that govern the corrective action of such units. The Part B Permit identifies 49 SWMUs and 5 Areas of Concern (AOCs). The majority of these sites are 


\section{COMPLIANCE SUMMARY}

believed to contain little or no residual contamination; however, a number may be required to undergo some type of corrective action. Prior to issuance of the permit, ANL-E had been working proactively and on a voluntary basis to characterize, investigate, and remediate its SWMUs, with emphasis on the 800 and 317 Areas. This remediation program will continue under the authority of the Part B Permit. The process of conducting detailed characterization studies to determine whether hazardous materials have been released from these units was begun in 1989. A summary of the preliminary results of these investigations can be found in Chapter 3. More extensive characterization and remediation currently are underway at a number of the SWMUs in accordance with IEPA-approved corrective action work plans, as discussed in Chapter 6.

\subsubsection{Radioactive Waste Storage Facility}

Building 331, ANL-E's new Radioactive Waste Storage Facility, which was converted from the Experimental Boiling Water Reactor shell, was approved for use in August 1998. The new facility is a Category 2 Non-Reactor Nuclear Facility and primarily will be used to store solid, TRU radioactive waste that is scheduled for shipment to the WIPP in New Mexico. In 1998, Waste Management Operations (WMO) shipped a substantial quantity of accumulated radioactive waste off site for disposal, thereby significantly reducing the ANL-E inventory. WMO installed a Real-time Radiography (RTR) machine to enhance safety and improve waste sorting efficiency. The RTR equipment uses x-rays to examine the internal contents of packages without exposing workers to the material. Containers with suspect hazards are then segregated for further examination.

\subsection{Solid Waste Disposal}

In September 1992, ANL-E ceased operation of its sanitary landfill, which had begun operating in 1966. The original operating permit was issued by the IEPA in 1981 in accordance with 35 IAC Part 807. Supplemental permits addressing final elevations, a groundwater monitoring program, and closure/postclosure requirements such as gas monitoring were issued by 
the IEPA on April 24, 1992, and revised on September 15, 1992, January 11, 1995, November 20, 1997, and August 25, 1998.

ANL-E generates a large volume and variety of nonhazardous special wastes. Some special waste, such as sanitary sewage sludge, is certified by ANL-E to the IEPA as "nonspecial waste" pursuant to IEPA regulations. Table 2.9 gives the nonhazardous special and nonspecial wastes generated and disposed of during 1998. All nonhazardous special and nonspecial wastes generated at ANL-E were disposed of at permitted off-site special waste landfills. The IEPA began requiring annual nonhazardous special waste reporting in 1991. The report is submitted by February 1 of each year and describes the activity of the previous year. It is a summation of all manifested nonhazardous and PCB wastes.

\subsection{National Environmental Policy Act}

The National Environmental Policy Act of 1969 (NEPA) established a national environmental policy that promotes consideration of environmental factors in federal or federally sponsored projects. NEPA requires that the environmental impacts of proposed actions with potentially significant impacts be considered in an Environmental Assessment (EA) or Environmental Impact Statement (EIS). DOE has promulgated regulations in 10 CFR Part 1021 that list classes of actions that ordinarily require those levels of documentation or that are categorically excluded from further NEPA review. No EISs were prepared during 1998 . One EA, which addressed the Argonne Thermal Source Reactor (ATSR) D\&D, was completed in 1998. DOE issued a Finding of No Significant Impact during 1998 for this project.

\subsection{Safe Drinking Water Act}

The Safe Drinking Water Act of 1974 (SDWA) established a program to ensure that public drinking water supplies are free of potentially harmful materials. This mandate is carried out through the institution of national drinking water quality standards, such as Maximum 
TABLE 2.9

Generation and Disposal or Recycling of Special and Nonspecial Waste, 1998

\begin{tabular}{|c|c|c|}
\hline Waste & Volume & $\begin{array}{c}\text { Weight } \\
\text { (lb) }\end{array}$ \\
\hline \multicolumn{3}{|l|}{ Nonhazardous Special } \\
\hline Auto "fluff" wastes & $15 \mathrm{yd}^{3}$ & 15,000 \\
\hline Contaminated soil (BIdg. 24 UST) & $80 y d^{3}$ & 160,000 \\
\hline Fly ash (boiler house) & $475 \mathrm{yd}^{3}$ & 475,000 \\
\hline Hydrogeology study debris & $385 \mathrm{gal}$ & 1,750 \\
\hline Hydrogeology study soil & 4,700 gal & 47,000 \\
\hline Hydrogeology study water & $660 \mathrm{gal}$ & 5,500 \\
\hline Medical waste & $143 \mathrm{ft}^{3}$ & 530 \\
\hline Nonhazardous liquid chemicals & $2,995 \mathrm{gal}$ & 18,476 \\
\hline Nonhazardous solid chemicals & $4,395 \mathrm{gal}$ & 20,264 \\
\hline Oily water ${ }^{\mathrm{a}}$ & $350 \mathrm{gal}$ & 2,900 \\
\hline Petroleum naphtha ${ }^{a}$ (parts washers) & $947 \mathrm{gal}$ & 6,346 \\
\hline Polypropylene polymer & $1,100 \mathrm{gal}$ & 500 \\
\hline Project debris (317 Area) & $20 \mathrm{yd}^{3}$ & 40,000 \\
\hline Used oil ${ }^{\mathrm{a}}$ & $1,550 \mathrm{gal}$ & 11,200 \\
\hline
\end{tabular}

\section{Certified Nonspecial}

1 Nonspecial fly ash ${ }^{\mathrm{a}}$

$600 \mathrm{yd}^{3} \quad 600,000$

2 Nonspecial laboratory sewage sludge

$70 \mathrm{yd}^{3}$

140,000

3 Nonspecial oily rags

4 Nonspecial sanitary sewage sludge

550 gal $\quad 2,500$

5 Nonspecial soil cuttings

$170 \mathrm{yd}^{3} \quad 340,000$

$15 \mathrm{yd}^{3} \quad 14,000$

Toxic Substances Control Act Special

\begin{tabular}{lrr} 
Asbestos & $310 \mathrm{yd}^{3}$ & 310,000 \\
PCBs & $755 \mathrm{gal}^{2}$ & 4,542 \\
\hline
\end{tabular}

a

Recycled waste. 
Contaminant Levels and Maximum Contaminant Level Goals, as well as through the imposition of wellhead protection requirements, monitoring requirements, treatment standards, and regulation of underground injection activities. The regulations implementing the SDWA in 40 CFR Parts 141-143 establish Primary and Secondary National Drinking Water Regulations that set forth requirements to protect human health (primary standards) and provide aesthetically acceptable water (secondary standards).

\subsubsection{Applicability to ANL-E}

In January 1997, ANL-E incorporated Lake Michigan water as its domestic source water, thereby replacing the dolomite water that formerly constituted its source of drinking water. The Lake Michigan water is purchased from the DuPage County Water Commission. As such, ANL-E is now a customer rather than a supplier of water. Consequently, on January 23, 1997, the DuPage County Health Department (DPCHD) notified DOE that the federal and state monitoring requirements applicable to a "non-transient, non-community" public water supply no longer are applicable. In addition, sampling, analysis, and reporting of the drinking water data to the DPCHD and the IDPH are no longer required.

\subsubsection{Water Supply Monitoring}

During 1998, ANL-E continued an informational monitoring program at the previously used dolomite domestic wells; quarterly samples were analyzed for radionuclides and VOCs. No radionuclides or VOCs were detected. Data voluntarily collected in 1997 on copper and lead levels throughout the domestic drinking water distribution system showed a substantial reduction in the leaching of copper from distribution piping. This finding, as well as the fact that federal and state monitoring requirements were no longer applicable to ANL-E, led to the discontinuation of the copper and lead monitoring program. 


\subsection{Federal Insecticide, Fungicide, and Rodenticide Act}

During 1998, all exterior pesticides and herbicides were applied by licensed contractors who provide the chemical used and who remove any unused portions. ANL-E ensures that the chemical is EPA-approved, that it is used properly, and that any residue is disposed of in accordance with applicable regulations. These activities are carried out by oversight inspections and maintenance of records. In addition, routine applications of pesticides are performed within buildings, as needed. Indoor pesticide applications are provided by IDPH-licensed contractors under the direction of Plant Facilities and Services (PFS)-Custodial Services and Marriott Management. None of these applications involve EPA "Restricted Use" products. In 1998, approximately 17,670 L (4,650 gal) of commercial-grade herbicide and $695 \mathrm{~L}$ (183 gal) of pesticide were applied throughout the ANL-E site. Fertilizer with weed control is included in the above quantity of herbicide.

\subsection{Comprehensive Environmental Response, Compensation and Liability Act}

The Comprehensive Environmental Response, Compensation and Liability Act (CERCLA) addresses the cleanup of hazardous waste disposal sites and the response to hazardous substance spills. Under CERCLA, the EPA collects site data regarding sites subject to CERCLA action through generation of a Preliminary Assessment (PA) report, followed up by a Site Screening Investigation (SSI). Sites then are ranked, on the basis of the data collected, according to their potential for affecting human health or causing environmental damage. The sites with the highest rankings are placed on the National Priority List (NPL) and are subject to mandatory cleanup actions. No ANL-E sites are included in the NPL.

\subsubsection{CERCLA Program at ANL-E}

In early 1990, the EPA requested that DOE submit SSI reports for 6 of 13 ANL-E sites for which PA reports previously had been submitted. Upon further discussions between the EPA and 
$\mathrm{DOE}$, one of the six sites was eliminated from consideration, and three adjacent units (317/319/East-Northeast [ENE]) were treated as a single site. As a result, three SSI reports were submitted to the EPA in January 1991. Table 2.10 lists the sites for which a PA report was submitted.

Inquiries into waste disposal practices during the 1950s and 1960s have identified a number of smaller waste disposal sites, some of which could contain hazardous materials. These sites are under investigation; however, their potential to affect groundwater is thought to be minimal.

\section{TABLE 2.10}

List of Inactive Waste Disposal Sites at ANL-E Described in Various CERCLA Reports

\begin{tabular}{l} 
Site Name \\
\hline On Current ANL-E Property \\
319 Area Landfill and French Drain ${ }^{\mathrm{a}, \mathrm{b}}$ \\
800 Area Landfill and French Drain ${ }^{\mathrm{a}, \mathrm{b}}$ \\
810 Area Paint Shop \\
Compressed Gas Cylinder Disposal Area, 318 Area $^{\mathrm{a}, \mathrm{b}}$ \\
Decommissioned Reactor CP-5, Building $330^{\mathrm{a}, \mathrm{b}}$ \\
French Drain, 317 Area, \\
Gasoline Spill, Gasoline Station \\
Landfill East-Northeast of the 319 Area $^{\mathrm{a}, \mathrm{b}}$ \\
Liquid Waste Treatment Facility, Building $34^{\mathrm{b}}$ \\
Mixed Waste Storage Vaults, 317 Area \\
Shock Treatment Facility, 317 Area \\
Wastewater Holding Basin, Sewage Treatment Plant ${ }^{\mathrm{b}}$ \\
On Former ANL-E Property, \\
Currently Waterfall Glen Forest Preserve \\
Reactive Waste Disposal, Underwriters Pond
\end{tabular}

a SSI report submitted to the EPA in 1991.

b RCRA SWMU. . 


\subsubsection{CERCLA Remedial Actions}

Remedial actions to clean up any release of hazardous materials from these sites could occur in a number of different ways. All but one of the CERCLA sites (see Table 2.10) are on the ANL-E site, and most are included as SWMUs in the RCRA Part B Permit. The RCRA Part B Permit, effective November 4, 1997, contains procedures and requirements that govern the corrective action of these sites. However, several of these SWMUs also contain radiological contamination that is not regulated under RCRA. Therefore, the SWMUs that are both radiologically and chemically contaminated will be cleaned up under other authorities and RCRA, as appropriate.

\subsubsection{Emergency Planning and Community Right to Know Act (Superfund Amendments and Reauthorization Act, Title III)}

Title III of the 1986 Superfund Amendments and Reauthorization Act (SARA) amendments to CERCLA created the Emergency Planning and Community Right to Know Act (EPCRA) as a free-standing provision for response to emergency situations involving hazardous materials and for making known to federal, state, and local emergency planning authorities information regarding the presence and storage of hazardous substances and their planned and unplanned environmental releases. Under EPCRA, ANL-E may be required to submit reports pursuant to Sections 302, 304, 311, 312, and 313.

- EPCRA 302: Planning Notification Required

- EPCRA 304: Extremely Hazardous Substances Release Required Notification

- EPCRA 311-312: Material Data Safety Sheet/Chemical Required Inventory

- EPCRA 313: Toxic Release Inventory (TRI) Reporting Required

Section 302 of SARA Title III requires riotification to the State Emergency Response Commission when an extremely hazardous substance is present at a facility in excess of the threshold planning quantity. 
Section 304 of SARA Title III requires that the Local Emergency Planning Committee (LEPC) and state emergency planning agencies be notified of accidental or unplanned releases of Section 302 hazardous substances to the environment. The procedures for notification are described in the Argonne Comprehensive Emergency Management Plan. No incidents occurred during 1998 that required notification of the LEPC and the Illinois Emergency Management Agency.

Under EPCRA Section 311, ANL-E is required to provide applicable emergency response agencies with Material Safety Data Sheets (MSDSs), or a list of MSDSs, for each hazardous chemical stored on site. In addition, pursuant to EPCRA Section 312, ANL-E is required to report certain information regarding inventories and the locations of hazardous chemicals to state and local emergency authorities upon request. Petroleum products need to be reported. However, chemicals used in research laboratories under the direct supervision of a technically qualified individual are exempt from reporting. This report was updated and provided to DOE on March 1, 1998. Table 2.11 lists the hazardous chemicals reported.

Section 313 of EPCRA requires facilities to prepare an annual report entitled "Toxic Chemical Release Inventory, Form R" if annual usage quantities of listed toxic chemicals exceed certain thresholds. ANL-E is not within the range of Standard Industrial Codes specified in the statute. ANL-E reports this information, however, because DOE, which is subject to Executive Order 12856 and participates in the EPA 33/50 program, directs ANL-E to do so. Threshold quantities for listed chemicals are $11,340 \mathrm{~kg}(25,000 \mathrm{lb})$ for manufactured and processed and $4,536 \mathrm{~kg}(10,000 \mathrm{lb})$ for otherwise used, as defined in Section 313. ANL-E did not file a report for Calendar Year (CY) 1997 because no listed chemicals exceeded usage thresholds for that year. In January 1998, enhancements were made to the ANL-E Chemical Management System (CMS) to track usage of TRI chemicals on a sitewide basis. This system can track the majority of chemical usage subject to TRI reporting. On the basis of the TRI report generated by the CMS, no listed chemical usage exceeded the reporting thresholds for CY 1998. 


\section{COMPLIANCE SUMMARY}

TABLE 2.11

Chemical Inventories Reported under SARA Title III, 1998

\begin{tabular}{|c|c|c|c|c|c|}
\hline \multirow[b]{2}{*}{ Compound } & \multicolumn{5}{|c|}{ Hazard Class } \\
\hline & Fire & $\begin{array}{c}\text { Sudden } \\
\text { Release of } \\
\text { Pressure } \\
\end{array}$ & Reactive & $\begin{array}{l}\text { Acute } \\
\text { Health } \\
\text { Hazard }\end{array}$ & $\begin{array}{c}\text { Chronic } \\
\text { Health } \\
\text { Hazard }\end{array}$ \\
\hline Aluminum sulfate & $-a^{a}$ & - & - & $\mathrm{X}$ & - \\
\hline Calcium oxide & - & - & - & $\mathrm{X}$ & - \\
\hline Chlorofluorocarbon 11 & - & $X$ & - & - & - \\
\hline Diesel fuel/heating oil & $\mathrm{X}$ & - & - & - & - \\
\hline Gasoline & $\mathrm{X}$ & - & - & - & - \\
\hline Lubricating oils & $\mathrm{X}$ & - & - & - & - \\
\hline Methanol/gasoline & $X$ & - & - & - & - \\
\hline $\begin{array}{l}\text { NALCO } 356 \text { amine } \\
\text { corrosion inhibitor }\end{array}$ & $\mathrm{X}$ & - & - & $\mathrm{X}$ & - \\
\hline Oils containing PCBs & - & - & - & - & $X$ \\
\hline Pyrofoam & - & - & - & - & $X$ \\
\hline Sulfuric acid & - & - & - & $X$ & - \\
\hline
\end{tabular}

a A hyphen indicates that the compound does not fall within the particular hazard class.

\subsection{Toxic Substances Control Act}

The Toxic Substances Control Act (TSCA) (United States Code, Volume 15, Section 2601 [15 U.S.C. \& 2601] et seq.) was enacted to require chemical manufacturers and processors to develop adequate data on the health and environmental effects of their chemical substances. The EPA has promulgated regulations to implement the provisions of TSCA. These regulations are found in CFR Title 40, Protection of the Environment, Chapter I: Environmental Protection Agency, Subchapter R - Toxic Substances Control Act. These regulations provide specific authorizations and prohibitions on the manufacturing, processing, and distribution in commerce of designated chemicals. Of these specially regulated substances, only asbestos and PCBs are 
found at the ANL-E site. The ANL-E safety training program addresses asbestos handling. Suspect PCB-containing items are identified through the PCB Item Inventory Program.

\subsubsection{PCBs in Use at ANL-E}

PCB items in use or in storage for reuse are tracked by the PCB Item Inventory program. All PCB items have been labeled and identified appropriately with a unique number for inventory and tracking purposes. These items are included in the ANL-E annual PCB report, which describes the location, quantity, manufacturer, and unique identification number for all PCBs on site. The PCBs in use at ANL-E are contained in capacitators and power supplies. In addition, WMO still receives PCB-contaminated equipment and oil from unknown sources in its waste stream. The regulations governing the use and disposal of PCBs are located in 40 CFR Part 761.

\subsubsection{Disposal of PCBs}

Disposal of PCBs from ANL-E operations includes materials lab-packed and bulked and aggregated solids shipped off site through WMO. Table 2.9 gives the amount of PCBs and PCB-contaminated materials shipped by ANL-E during 1998.

\subsubsection{Storage of Radioactive PCB-Contaminated Material}

Contamination from historical PCB spills has resulted in the generation of sludge from the building retention tanks and holding tanks at the laboratory WTP that is contaminated by both PCBs and low-level radioactivity. Because a disposal option is not available, it is stored for future disposal. A total of 19,178 L (5,047 gal) of PCB-contaminated sludge and debris is being kept in permitted storage. 


\section{COMPLIANCE SUMMARY}

\subsection{Endangered Species Act}

The Endangered Species Act of 1973 (ESA) is designed to protect plant and animal resources from the adverse effects of development. Under the Act, the Secretaries of the Interior and Commerce are directed to establish programs to ensure the conservation of endangered or threatened species and the critical habitat of such species. The FWS has been delegated authority to implement the requirements of the ESA.

To comply with the ESA, federal agencies are required to assess the proposed project area to determine whether any threatened or endangered species or critical habitat of these species exist. If no such species or habitat are present, this fact is to be documented in a letter to the FWS. If such species or habitat are found to exist, the FWS is to be notified, and a series of consultations and studies then will be carried out to determine the extent of impact and any special actions that must be taken to minimize this impact.

At ANL-E, the provisions of the ESA are implemented through the NEPA project review process. All proposed projects must provide a statement describing the potential impact to threatened or endangered species and critical habitat. This statement is included in the general Environmental Evaluation Notification Form. If the potential exists for an adverse impact, this impact will be assessed further and evaluated through the preparation of a more detailed NEPA document, such as an EA or EIS.

No federally listed threatened or endangered species are known to occur on the ANL-E site, and no critical habitat of federally listed species exists on the site. Three federally listed endangered species are known to inhabit the Waterfall Glen Forest Preserve that surrounds the ANL-E property or to occur in the area.

The Hine's emerald dragonfly (Somatochlora hineana), federally and state listed as endangered, occurs in locations with calcareous seeps and wetlands along the Des Plaines River floodplain. Leafy prairie clover (Dalea foliosa), which is federally and state listed as endangered, 


\section{COMPLIANCE SUMMARY}

is associated with dolomite prairie remnants of the Des Plaines River valley; two planted populations of this species occur in Waterfall Glen Forest Preserve. An unconfirmed capture of Indiana bat (Myotis sodalis), which is federally and state listed as endangered, indicates that this species may occur in the area. Additional state-listed species that occur in the area include the following:

- Endangered

- Black-crowned night heron (Nycticorax nycticorax)

- Great egret (Casmerodius alba)

- Pied-billed grebe (Podilymbus podiceps)

- Red-shouldered hawk (Buteo lineatus)

- River otter (Lutra canadensis)

- Rough marsh cress (Rorippa islandica var. hispida)

- Slender sandwort (Arenaria patula)

- White lady's slipper (Cypripedium candidum)

- Threatened

- Early fen sedge (Carex crawei)

- Kirtland's snake (Clonophis kirtlandi)

- Marsh speedwell (Veronica scutellata)

Of these, rough marsh cress, Kirtland's snake, pied-billed grebe, great egret, black-crowned night heron, and red-shouldered hawk have been observed on ANL-E property. Impacts to these species also would be assessed during the NEPA process. No project at ANL-E has ever had to be stopped, delayed, or modified as a result of a potential impact to an endangered species. In February 1997, the FWS concluded that a groundwater remediation project in the 800 and 317/319 Areas most likely would not affect the hydrology of the breeding area of the Hine's emerald dragonfly, Somatochlora hineana. To confirm that a seep in the surrounding Waterfall Glen Forest Preserve had not been contaminated by some other activity at the ANL-E site, or by a third party, the FWS requested that ANL-E take water quality and sediment samples from the 
seep, a potential breeding area for the Hine's emerald dragonfly. Samples collected in 1998 verified that the seep area was not contaminated.

\subsection{National Historic Preservation Act}

The National Historic Preservation Act (NHIPA) requires federal agencies to assess the impact of proposed projects on historic or culturally important sites, structures, or objects within the site of the proposed projects. It further requires federal agencies to assess all sites, buildings, and objects on the site to determine whether any qualify for inclusion in the NRHP. The Act also requires federal agencies to consult with the Illinois Historic Preservation Agency (IHPA) and the Advisory Council on Historic Preservation, as appropriate, when proposed actions would adversely affect properties that are eligible for listing on the NRHP.

The NHPA is implemented at ANL-E through the NEPA review process, as well as through the ANL-E digging permit process. All proposed actions must consider the potential impact to historic or culturally important artifacts and document this consideration on the Environmental Evaluation Notification Form. If the proposed site has not been surveyed for the presence of such artifacts, a cultural resources survey is conducted, and any artifacts found are carefully documented and removed. Prior to disturbing the soil, an ANL-E digging permit must be obtained from the PFS Division. Prior to digging, this permit must be signed by an individual who is familiar with the location of archaeological sites at ANL-E to document the fact that no significant cultural resources will be affected. DOE consults with the IHPA and the Advisory Council on Historic Preservation, as appropriate, if proposed actions would adversely affect properties eligible for listing on the NRHP.

A draft Cultural Resources Management Plan (CRMP) has been prepared to fulfill DOE's responsibilities under the NHPA. This draft CRMP describes the management of cultural resources at ANL-E pursuant to the NHPA and identifies a strategy toward good faith stewardship of cultural resources. Management goals for cultural resources at ANL-E reflect current issues, interests, and problems identified through internal assessment. They include protecting and 
preserving significant resources, establishing outreach programs, and continuing the integrity of the Cultural Resource Program.

Cultural resources include historic structures and properties. Much of the focus at ANL-E has been on evaluating properties rather than structures. Phase I archaeological surveys have been completed for the entire ANL-E facility, and 46 archaeological sites have been recorded. Of these, 23 sites have been tested to determine eligibility for inclusion on the NRHP. Three of the 23 sites tested are potentially eligible for the NRHP. The remainder of the 46 recorded sites have not been formally evaluated to determine whether they are eligible for inclusion under the NRHP.

A sitewide inventory of all building structures is necessary to identify those buildings that may have housed activities of historic significance such that the building potentially may be eligible for listing on the NRHP. This sitewide inventory of building structures was initiated in 1998. DOE has determined that four structures - Buildings 301, 315/316, 330, and 331 - are eligible for listing on the NRHP. The CP-5 reactor and ATSR were documented to mitigate scheduled D\&D activities.

\subsection{Floodplain Management}

Federal policy on managing floodplains is contained in Executive Order 11988 (May 24, 1977). In addition, 10 CFR Part 1022 describes DOE's implementation of this Executive Order. This Executive Order requires federal facilities to avoid, to the extent possible, adverse impacts associated with the occupancy and modifications of floodplains. To construct a project in a floodplain, DOE must demonstrate that there is no reasonable alternative to the floodplain location.

The ANL-E site is located approximately $46 \mathrm{~m}$ (150 ft) above the nearest large body of water (Des Plaines River) and thus is not subject to major flooding. A number of small areas, associated with Sawmill Creek and other small streams or low-lying areas, are subject to local flood conditions following extremely heavy precipitation. To ensure that these areas are not adversely 


\section{COMPLIANCE SUMMARY}

affected, new facility construction is not permitted within these areas, unless there is no practical alternative. Any impacts to floodplains are fully assessed in a floodplain assessment, and, as appropriate, documented in the NEPA documents prepared for a proposed project. There were no significant floodplain management issues during 1998.

\subsection{Protection of Wetlands}

Federal policy on wetland protection is contained in Executive Order 11990. In addition, 10 CFR Part 1022 describes DOE's implementation of this Executive Order. This Order requires federal agencies to identify potential impacts to wetlands resulting from proposed activities and to minimize these impacts. Where impacts cannot be avoided, action must be taken to mitigate the damage by repairing the damage or replacing the wetlands with an equal or greater amount of a man-made wetland as much like the original wetland as possible. The goal of the current federal policy in the Clean Water Action Plan is to increase the amount of wetlands by 40,486 ha $(100,00$ acres) each year.

Because of its topography and the nature of the soil at ANL-E, the site contains a significant number of natural and man-made wetlands. These range from small storm water ditches overgrown with cattails to natural depressions, beaver ponds, and man-made ponds. Potential impacts to those areas from proposed actions are assessed in wetlands assessments and NEPA documentation as appropriate.

\subsubsection{Sitewide Wetlands Management}

During 1993, an ANL-E sitewide wetlands delineation was completed. A survey was conducted to identify and delineate all jurisdictional wetlands present on site in accordance with the 1987 U.S. Army Corps of Engineers Wetlands Delineation Manual. ${ }^{5}$ The results of the survey were delineated on a site map that indicates the aerial extent of all wetlands present at ANL-E down to $500 \mathrm{~m}^{2}$ (1/8th acre). The findings are documented in an accompanying report that describes in detail the soil, vegetation, and hydrology of each wetland area delineated on the map. 
Thirty-five individual wetland areas were identified; their total area is approximately 18 ha (45 acres). The wetland areas also were digitized onto a computer-aided design file to provide ANL-E engineers with scale maps for planning and designing projects. This delineation also will be useful for determining project impacts under NEPA review. Future plans include development of a plan to address the enhancement and management of existing wetlands, wetland restoration activities, and related regulatory issues. Also, the site wetlands map needs to be updated, because much of the fieldwork for the wetlands delineation was performed in 1992, and wetland boundaries may change significantly over time.

\subsubsection{U.S. Army Corps of Engineers Review}

In February 1989, the U.S. Army Corps of Engineers (COE) issued a permit to DOE under Section 404 of the CWA addressing the construction of the APS facility at ANL-E. The permit was required because construction of the APS involved the filling of three small wetland areas, known as Wetlands $A, B$, and $E$, which totaled 0.7 ha $(1.8$ acres $)$ in size. Issuance of the permit had been contingent upon approval of a mitigation plan submitted to the COE by DOE. The plan outlined procedures for the construction of a new wetland area, Wetland $\mathrm{R}$, and also identified actions to be taken to avoid a fourth wetland, Wetland C, during APS construction activities. In addition, DOE committed to monitoring the progress of Wetlands $\mathrm{C}$ and $\mathrm{R}$ for a period of five years. The monitoring period was initiated in 1992.

During October 1996, the COE conducted a compliance inspection to assess compliance with conditions of the 1989 permit; this inspection resulted in COE's contending that the state of the APS wetlands reflected a lack of compliance with an unspecified provision of the permit. A management plan for Wetland R was submitted to the COE in January 1997; the plan was verbally approved two months later. An assessment for the cause of a water deficit was conducted at Wetland $C$. The assessment concluded that the hydrology of Wetland $C$ did not change significantly during the five-year monitoring period, and that the water deficit at the wetland could not be attributed to any-single cause. In 1998, Wetland R was treated with herbicide consistent 


\section{COMPLIANCE SUMMARY}

with the management plan. Wetland grass seeds were also collected to be used to upgrade the species types. In 1999, a report will be prepared addressing mitigation alternatives for Wetland C.

\subsection{Wildlife Management and Related Monitoring}

\subsubsection{Deer Population Monitoring}

The deer population is monitored periodically by conducting spotlight surveys to meet the requirements of deer removal permits and to provide input into wildlife management decisions. In January 1998, 27 white-tailed deer were removed, and in November 1998, 9 were removed. The purpose was to achieve a target density of $20 \mathrm{deer} / \mathrm{mi}^{2}$. No fallow deer were removed in 1998.

\subsubsection{Deer Health Monitoring}

The white-tailed deer that were removed were evaluated to assess their physical condition. A modified Kistner Scoring System was used to evaluate the fat stored in several body areas and to assess mean live and dressed weights. Overall Kistner scores have improved since the deer management program began in 1995.

\subsubsection{Deer Tissue Monitoring}

Samples taken from a deer's muscle are analyzed periodically for radionuclides to verify that deer meat donated to charity does not pose a radiological health hazard. Samples sent to the IDNS radiochemistry laboratory in December 1997 were analyzed for gamma-ray-emitting radionuclides and hydrogen-3. Naturally occurring potassium-40 was the only gamma-ray-emitting radionuclides identified above detection limits. Hydrogen-3 was not detected in any sample. 


\subsubsection{Vegetation Damage}

Vegetation is monitored periodically to determine the effects of browsing by deer on woody vegetation. These data are collected to meet conditions of Deer Population Control permits issued by the Illinois Department of Natural Resources and to provide input to wildlife management decisions. Horizontal vegetation densities at ANL-E are compared with previous ANL-E data and with data from Herrick Lake Forest Preserve, which has a lower density of deer than ANL-E. Vegetation was monitored in 1993 and 1997 and will be monitored again in 1999.

\subsection{Current Issues and Actions}

The purpose of this section is to summarize the most important issues related to environmental protection encountered during 1998.

\subsubsection{Clean Water Act - NPDES}

The most recent five-year revision of the NPDES permit became effective October 30, 1994. The new permit included a number of changes to sampling parameters for various outfalls, and ANL-E was not consistently able to meet the permit limits for TDS and copper. It also was anticipated that ANL-E would have difficulty consistently meeting the new permit limits for ammonia nitrogen. In March 1995, ANL-E requested a modification to the NPDES permit to establish interim permit limits and develop a compliance schedule to meet the new permit limits. A modified permit was issued in August 1995, which provided interim limits for TDS, copper, and ammonia nitrogen at Outfall 001 . The modified permit provided a schedule for performing certain actions as a means of attaining the final effluent limits by July 1, 1998. ANL-E achieved compliance with the required discharge permit limits by July 1, 1998.

The IEPA Maywood Regional Office conducted an NPDES Compliance Evaluation Inspection at ANL-E on March 18, 19, and 30, 1998. On September 16, 1998, the IEPA issued 
a Report of Compliance Evaluation Inspection to ANL-E identifying seven findings. ANL-E prepared a response addressing these items and submitted it to the IEPA on October 20, 1998.

\subsubsection{RCRA - Underground Storage Tanks}

In June 1998, ANL-E received a No Further Remediation (NFR) letter regarding Leaking Underground Storage Tank (LUST) Incident \#952114, for Underground Storage Tanks 20 and 21. The NFR was recorded in the DuPage County Recorder of Deeds Office on September 10, 1998, as required by 35 IAC Part 732.703(a). The letter from the Recorder of Deeds Office certifying the recording of the NFR letter was sent to the IEPA on October 23, 1998, in accordance with 35 IAC Part 732.703(b). With this action, LUST Incident \#952114 officially was closed out.

\subsection{Environmental Permits}

Table 2.12 lists all the environmental permits in effect at the end of 1998. Other portions of this chapter discuss special requirements of these permits and compliance with those requirements. The monitoring results required by these permits are discussed in those sections, as well as in Chapters 5 and 6. 


\section{TABLE 2.12}

ANL-E Environmental Permits in Effect December 31, 1998

\begin{tabular}{|c|c|c|c|c|}
\hline Type & Source & Building & Issued & $\begin{array}{c}\text { Expiration } \\
\text { Date }^{\mathrm{a}}\end{array}$ \\
\hline Air & ALEX Alkali Metal Scrubber ${ }^{b}$ & 370 & $12 / 05 / 91$ & $12 / 03 / 96$ \\
\hline Air & Alkali Metal Reaction Booth ${ }^{\mathbf{b}}$ & 308 & $02 / 15 / 89$ & $11 / 18 / 98$ \\
\hline Air & APS Emergency Generators (3) & 400 & $05 / 16 / 94$ & 03/15/99 \\
\hline Air & Argonne Service Station & 300 & $01 / 09 / 91$ & $10 / 04 / 00$ \\
\hline Air & Boiler No. 5 Low NO ${ }_{x}$ Gas Burner ${ }^{c}$ & 108 & $06 / 21 / 96$ & $12 / 28 / 98$ \\
\hline Air & Central Heating Plant & 108 & $12 / 28 / 93$ & $12 / 28 / 98$ \\
\hline Air & Central Shops Dust Collector ${ }^{b}$ & 363 & $03 / 12 / 91$ & $01 / 08 / 01$ \\
\hline Air & Ethylene Oxide Sterilizer & 201 & $03 / 27 / 91$ & $01 / 08 / 01$ \\
\hline Air & Gasoline Dispensing Facility ${ }^{d}$ & 46 & $02 / 01 / 93$ & $05 / 22 / 00$ \\
\hline Air & Grieve Oven ${ }^{\mathrm{b}, \mathrm{e}}$ & 366 & $08 / 08 / 91$ & $08 / 06 / 96$ \\
\hline Air & Hazardous Waste Storage Facility & 307 & $05 / 24 / 95$ & $04 / 26 / 00$ \\
\hline Air & Methanol/Gasoline Storage Tank & 46 & $09 / 24 / 91$ & $09 / 23 / 96$ \\
\hline Air & Open-Burning Permit - Fire Dept. ${ }^{b}$ & 333 & $01 / 22 / 98$ & $04 / 16 / 99$ \\
\hline Air & Open Burning - Vegetation & Sitewide & $10 / 29 / 98$ & $01 / 29 / 00$ \\
\hline Air & Paint Spray Booth ${ }^{\mathrm{e}, \mathrm{f}}$ & 306 & 07/03/95 & $06 / 27 / 00$ \\
\hline Air & Salt Cake/Recovery Electrodialysis Plant & 369 & 08/10/98 & $08 / 10 / 03$ \\
\hline Air & Sulfuric Acid Storage Tank ${ }^{b}$ & 108 & $01 / 17 / 91$ & $12 / 01 / 99$ \\
\hline Air & Title V (CAAPP) & Sitewide & Pending & - \\
\hline Air & Torch Cutting (Welding) Fumes ${ }^{b}$ & Sitewide & $07 / 20 / 95$ & $07 / 20 / 00$ \\
\hline Air & Transportation Research Facility & 376 & $07 / 25 / 96$ & $07 / 25 / 01$ \\
\hline Air & Wood Shop Dust Collector ${ }^{\mathrm{g}}$ & 368 & $12 / 16 / 93$ & $10 / 17 / 96$ \\
\hline Air & Waste Bulking Sheds ${ }^{\mathrm{b}}$ & 306 & $06 / 14 / 94$ & $07 / 25 / 96$ \\
\hline Hazardous Waste & RCRA Part B & Sitewide & 09/30/97 & $11 / 4 / 99$ \\
\hline Miscellaneous & Deer Population Control Permit & Sitewide & $11 / 01 / 98$ & $01 / 30 / 98$ \\
\hline Miscellaneous & Nuisance Wildlife Control & Sitewide & 02/01/98 & $01 / 01 / 99$ \\
\hline NESHAP & Advanced Photon Source & 400 & $12 / 21 / 93$ & $07 / 26 / 98$ \\
\hline NESHAP & Alkali Metal Reaction Booth & 206 & $06 / 09 / 93$ & $06 / 09 / 97$ \\
\hline NESHAP & Alpha Gamma Hot Cell Facility & 212 & $03 / 25 / 91$ & $08 / 09 / 00$ \\
\hline NESHAP & Building Exhausts ${ }^{\mathrm{b}, \mathrm{h}}$ & 212 & 07/30/91 & $07 / 23 / 96$ \\
\hline NESHAP & Building Rehab - Phase $1^{g}$ & 306 & $03 / 13 / 95$ & $07 / 25 / 96$ \\
\hline NESHAP & Building Vents & 306 & $08 / 06 / 91$ & $07 / 25 / 96$ \\
\hline NESHAP & Chemical Photooxid. Vial Crusher ${ }^{i}$ & 306 & $01 / 06 / 99$ & $01 / 06 / 04$ \\
\hline NESHAP & Continuous Wave Deuterium Demonstration ${ }^{\mathrm{e}}$ & 369 & 05/09/91 & $12 / 28 / 99$ \\
\hline NESHAP & CP-5 D\&D Project & 330 & $05 / 10 / 91$ & $12 / 08 / 96$ \\
\hline
\end{tabular}


TABLE 2.12 (Cont.)

\begin{tabular}{|c|c|c|c|c|}
\hline Type & Source & Building & Issued & $\begin{array}{c}\text { Expiration } \\
\text { Date }^{\mathrm{a}}\end{array}$ \\
\hline NESHAP & Cyclotron $^{\mathrm{e}}$ & 211 & $05 / 10 / 91$ & $12 / 01 / 99$ \\
\hline NESHAP & D\&D HEPA Filter System ${ }^{\mathrm{e}}$ & 317 & $05 / 10 / 94$ & $05 / 10 / 99$ \\
\hline NESHAP & French Drain Soil Vapor Extraction & 317 Area & $05 / 08 / 97$ & $5 / 8 / 02$ \\
\hline NESHAP & Hot Cell D\&D Project & 301 & $01 / 05 / 99$ & $01 / 05 / 04$ \\
\hline NESHAP & Intense Pulsed Neutron Source & 375 & $03 / 25 / 91$ & $08 / 09 / 00$ \\
\hline NESHAP & Janus D\&D Project ${ }^{e}$ & 202 & $06 / 12 / 96$ & $06 / 12 / 01$ \\
\hline NESHAP & Lab Wastewater Treatment Plant & 575 & $08 / 29 / 95$ & $08 / 29 / 00$ \\
\hline NESHAP & Lead Brick Cleaning (carbon dioxide) & $200 / 317$ & $06 / 20 / 95$ & $06 / 19 / 00$ \\
\hline NESHAP & Melt Attack/Coolability Experiment & 315 & $03 / 22 / 96$ & $03 / 22 / 01$ \\
\hline NESHAP & Mixed Waste Storage Facility & 303 & $05 / 18 / 95$ & $04 / 26 / 00$ \\
\hline NESHAP & M-Wing Hot Cells & 200 & $03 / 25 / 91$ & $08 / 09 / 00$ \\
\hline NESHAP & New Brunswick Lab Hoods & 350 & $04 / 25 / 91$ & $04 / 19 / 96$ \\
\hline NESHAP & PCB Tank Cleanout ${ }^{\mathrm{j}}$ & Sitewide & $08 / 16 / 95$ & 09/28/99 \\
\hline NESHAP & Rad Hoods & Sitewide & $07 / 09 / 92$ & $07 / 09 / 97$ \\
\hline NESHAP & Rad (TRU) Waste Storage Facility & 331 & $05 / 18 / 95$ & $04 / 26 / 00$ \\
\hline NESHAP & WMO HEPA Filter Systems (4) & Sitewide & $09 / 28 / 94$ & 09/28/99 \\
\hline NESHAP & WMO Portable HEPA Filters ${ }^{j}$ & 306 & $06 / 04 / 97$ & $-k$ \\
\hline Solid Waste & Landfill & 800 Area & $03 / 31 / 82$ & - \\
\hline Solid Waste & Landfill & 800 Area & $03 / 30 / 89$ & - \\
\hline Solid Waste & Landfill & 800 Area & $04 / 12 / 89$ & - \\
\hline Solid Waste & Landfill Groundwater Assessment & 800 Area & $09 / 30 / 91$ & - \\
\hline Solid Waste & Landfill Leachate Characterization & 800 Area & $09 / 30 / 91$ & - \\
\hline Solid Waste & Landfill Leachate Test Wells & 800 Area & $08 / 31 / 90$ & - \\
\hline Solid Waste & Landfill Revised Closure Plan & 800 Area & $04 / 24 / 92^{l}$ & - \\
\hline Solid Waste & Landfill Supplemental Closure Plan & 800 Area & $09 / 15 / 92$ & - \\
\hline Solid Waste & Landfill Supplemental Permit Groundwater & 800 Area & $04 / 19 / 94$ & - \\
\hline Solid Waste & Landfill Supplemental Permit Groundwater & 800 Area & $01 / 11 / 95$ & - \\
\hline Solid Waste & Landfill Supplemental Permit Groundwater & 800 Area & $11 / 20 / 97$ & - \\
\hline Solid Waste & Landfill Supplemental Permit Groundwater & 800 Area & $08 / 25 / 98$ & - \\
\hline Water & APS Wetland & 400 Area & $02 / 02 / 89$ & - \\
\hline Water & Landfill Wetlands & 800 Area & $05 / 20 / 81$ & - \\
\hline Water & Lime Sludge Application - Land Application & Sitewide & $10 / 30 / 98$ & $10 / 31 / 02$ \\
\hline Water & NPDES Permitted Outfalls & Sitewide & $10 / 31 / 94$ & 07/01/99 \\
\hline Water & NPDES Storm Water Outfalls & Sitewide & $10 / 31 / 94$ & 07/01/99 \\
\hline
\end{tabular}


TABLE 2.12 (Cont.)

a The expiration dates on NESHAP and air pollution permits are no longer valid (except for open burning), since the Notice of Completeness for the CAAPP application was received (see Section 2.1).

b These units have been designated as insignificant sources in the ANL-E Title V permit application.

c Construction permit issued; operated under Central Heating Plant permit.

d Includes ethanol/gasoline tank.

e Inactive.

$\mathrm{f}$ Permit originally issued for Building 815 .

g Construction permit issued; operated under Building 306 permit.

h Plasma spray booth added to permit 05/27/94.

i Vial Crusher originally issued under Building 306 permit.

j Construction permit issued; operated under WMO HEPA permit.

$k$ A hyphen indicates no expiration date.

I Revised September 15, 1992, and October 22, 1992. 


\section{ENVIRONMENTAL PROGRAM INFORMATION}

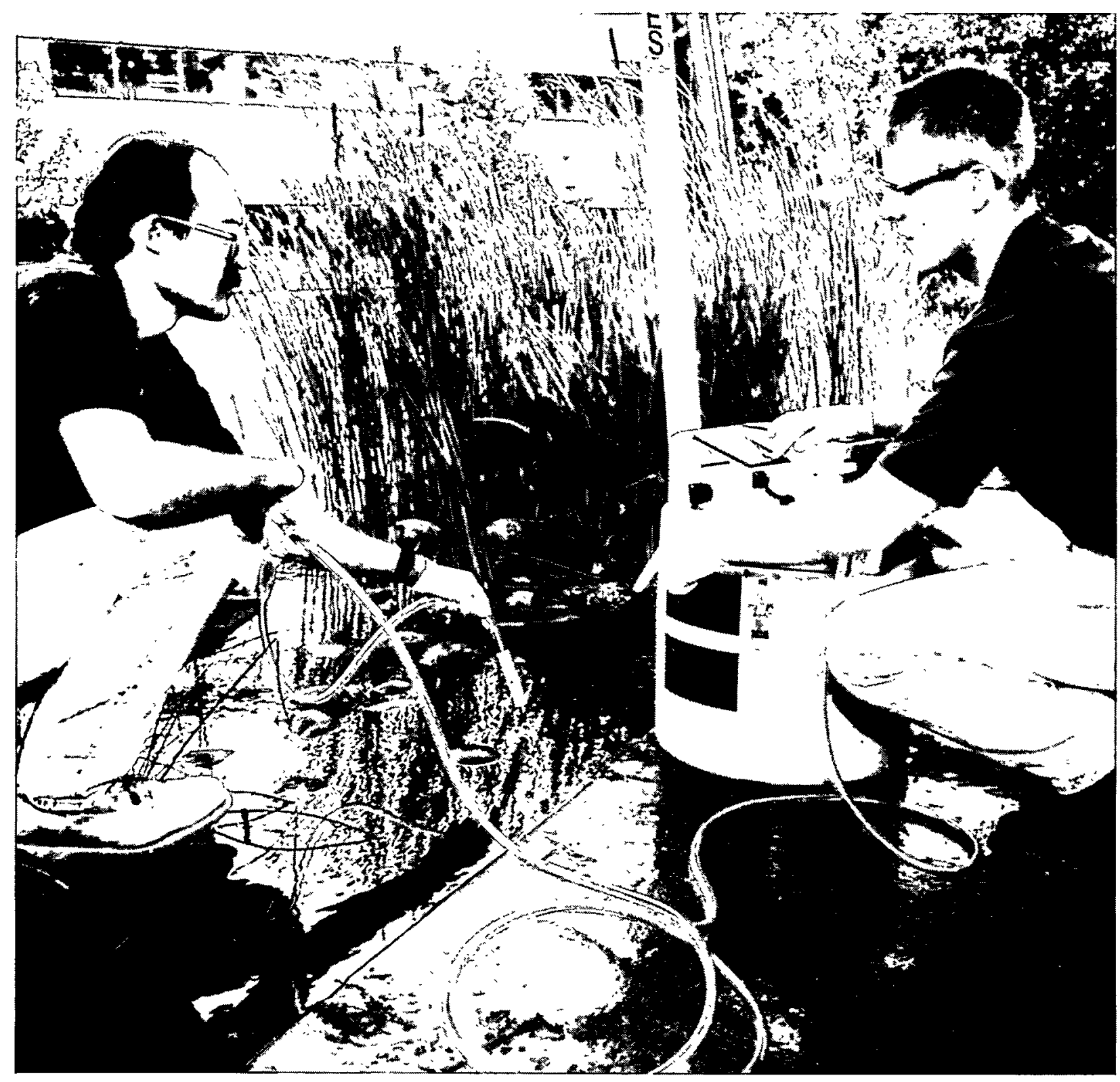




\section{ENVIRONMENTAL PROGRAM INFORMATION}




\section{ENVIRONMENTAL PROGRAM INFORMATION}

\subsection{Environmental Programs}

DOE and ANL-E policies require that all operations be conducted in compliance with applicable environmental statutes, regulations, and standards, and that environmental obligations be carried out consistently across all operations and organizations. Protection of the environment and human health and safety are always given the highest priority. A number of programs and organizations exist at ANL-E to ensure compliance with these authorities and to monitor and minimize the impact of ANL-E operations on the environment.

During 1998, a reorganization placed the site remediation, environmental compliance, and environmental monitoring programs back within the Environment, Safety and Health (ESH) Division. Their functions continued as in the past. The ANL-E Remedial Actions Project is responsible for achieving compliance with all applicable environmental authorities related to assessing and cleaning up releases of hazardous materials from inactive waste sites. The primary regulatory vehicle is the corrective action requirements specified in the RCRA Part B Permit. The environmental compliance and environmental monitoring programs are responsible for the actions conducted at ANL-E to ensure the safety of the public; protection of the environment; and compliance with applicable federal, state, and local environmental regulations and DOE orders.

\subsection{Remedial Actions Progress in 1998}

In 1998, ANL-E continued implementing its plan for accelerated remediation of waste management units. The current plan calls for completion of the planned remedial actions by the end of Fiscal Year (FY) 2003. Last year's Site Environmental Report stated that the remedial actions would be completed by FY 2001; however, because of funding limitations, the work has been extended two years, into FY 2003. The current plan for the ANL-E site is described in the

DOE document entitled Accelerating Cleanup - Paths to Closure ${ }^{6}$; the entire DOE remedial action program is described, including the ANL-E portion. 


\section{ENVIRONMENTAL PROGRAM INFORMATION}

During late 1998, ANL-E prepared a draft revision to the FY 1994 baseline document. This document describes in detail the activities required to complete the planned actions prior to FY 2003. As of the end of 1998, it was being reviewed by DOE.

Several significant remedial actions were completed in 1998. The most significant involved the treatment of soil contaminated with several spent solvents. This soil was located in the area known as the 317 Area French Drain. In the 1950s, spent solvents were poured into a gravelfilled trench (French drain) as a means of disposal. These solvents did not evaporate or degrade, as hoped, but slowly were released to underlying soil and groundwater. To remove this accumulation of solvent, a process known as soil mixing with thermally enhanced soil vapor extraction was used. This process uses a specially designed soil auger assembly to break up and blend a column of soil while a stream of steam and hot air is injected into the column. The volatile organic contaminants are stripped from the soil and captured in an off-gas treatment system. After experimenting with this system for several months, it was modified by also injecting metallic iron particles into the soil along with the air and steam. The iron particles reacted with the contaminants, thereby improving the overall removal efficiency.

A second remedial action project also was completed in 1998. This project involved the removal of an old settling tank used for treating water generated in a former boiler house in an area of the site known as the East Area. This cast-iron tank was removed successfully in one piece, and no evidence of leakage was found.

A work plan for the characterization of a former wastewater treatment plant in the East Area was completed and submitted to the IEPA for approval. This study will involve the installation of a network of groundwater monitoring wells around the former building to determine whether releases of wastewater had occurred sometime in the past.

A series of soil and groundwater samples was collected in the area situated between the 317 and 319 Areas and three off-site groundwater seeps. During 1996, two of these seeps were found to contain low concentrations of three organic solvents. Very low levels of hydrogen-3, well 


\section{ENVIRONMENTAL PROGRAM INFORMATION}

below SDWA standards, also were found in the third nearby seep. The purpose of the study was to estimate the amount of groundwater containing the chemicals and hydrogen-3 and to determine whether a link existed between on-site waste disposal activities and off-site seep discharges. The study indicated that an isolated region of groundwater exists immediately surrounding the two seeps containing the chemicals. It did not appear that this discharge was related to any current situation on the site; however, the solvents may have resulted from some past disposal activity. The hydrogen-3 appeared to be related to an on-site region of groundwater containing low levels of hydrogen-3 located downgradient of the 319 Landfill. Neither of these situations was determined to represent a hazard to human health or wildlife. Monitoring of the seeps will continue.

The FWS requested that a study be conducted to determine whether the potential breeding area of the Hines Emerald Dragonfly, a federally threatened species, contains any hazardous materials. Samples of sediment from the possible breeding area and from the groundwater seeping from the dolomite bedrock bluffs, which feed the breeding area, were collected and analyzed. No hazardous constituents were found.

A request for No Further Action was submitted to the IEPA for four SWMUs, all of which are active used-oil satellite accumulation areas. The request was based on the fact that a suitable secondary containment system is in place to prevent releases to the floor, and the past operations of the storage areas were such that the probability of a past release to underlying soil is minimal. To date, the IEPA has not issued a response.

Routine operation and maintenance (O\&M) of two groundwater extraction systems, one south of the 319 Landfill and French Drain and the second south of the 317 Area French Drain, was carried out. Monitoring of these systems indicated that they are capturing the groundwater as intended. 


\subsection{Environmental Support Programs}

\subsubsection{Self-Assessment}

In line with the principles of Integrated Safety Management (ISM), responsibility for internal self-assessment is a line management responsibility. The process focuses on the activities of individual organizations and is reported to those who have both the authority and responsibility for the organizations' performance. At the beginning of each calendar year, each organization develops an agenda of activities to be reviewed that year. A schedule is prepared, and assignments are made to manage the organization's self-assessment program. The results and conclusions of the assessment program are summarized annually and submitted to the Director of ESH/Quality Assurance (QA) Oversight. The actual performance during the year is monitored by oversight organizations to assist senior management in fulfilling its responsibilities.

For 1998, the annual summary self-assessment was documented in the form of an ISM gap analysis. The overall ANL-E self-assessment combined the division analyses that identified specific gaps between expectations and actual execution, as well as corrective actions to address these gaps.

\subsubsection{Environmental Training Programs}

ANL-E has a comprehensive environmental protection training program that includes mechanisms to identify, track, and document requirements for every employee. Environmental protection training for ANL-E personnel is provided primarily by the ESH Training Section, although ancillary training may be delivered by subject-matter experts from other organizations. Personnel training requirements are provided to respond to the requirements of DOE Orders and the U.S. Department of Transportation, as well as EPA regulations. These requirements are identified by a Job Hazards Checklist form that is completed by every employee and reviewed by each employee's supervisor. A positive answer to any one of a battery of specific questions 


\section{ENVIRONMENTAL PROGRAM INFORMATION}

triggers the training requirements specific to that question. Options also exist for division-required training, recommended training, and elective training.

Activities are managed through the Training Management System, an on-line computer-based system that tracks the training status of each employee. Environmental protection training courses and course descriptions are listed in the Training Course Catalog available from divisional representatives, the ESH Training Section, or Human Resources.

\subsubsection{Waste Minimization and Pollution Prevention}

ANL-E has a formal Waste Minimization and Pollution Prevention (WM\&PP) Program. The program's long-term strategy is identified in the ANL-E WM\&PP Strategic Plan dated November 1995. In April 1997, ANL-E finalized a Pollution Prevention Program Plan that identifies ANL-E's short-term (three-year cycle) pollution prevention goals and describes the strategies that will be employed to achieve those goals. The pollution prevention goals outlined in the ANL-E Pollution Prevention Program Plan are the same as the 1999 DOE Pollution Prevention Goals that were established in 1996 and that use CY 1993 as a baseline.

In the following paragraphs, the seven DOE Pollution Prevention Goals are presented, brief descriptions of ANL-E's progress toward each goal in 1998 are reported, and future strategies for achieving each goal are provided.

Goal 1 . Reduce by $\mathbf{5 0 \%}$ the generation of radioactive waste.

Annual Radioactive Waste Generation, 1993-1998 (ft $\left.{ }^{3}[1,000]\right)$

\begin{tabular}{lccccccc}
\hline & 1993 & 1994 & 1995 & 1996 & 1997 & 1998 & 1999 \\
\hline Generation & 10.5 & 16.9 & 19.5 & 12.3 & 6.6 & 8.6 & \\
Goal & & & & & & & 5.2 \\
\hline
\end{tabular}


In 1998, generation of LLW at ANL-E increased slightly compared with 1997. ANL-E experienced an increase in shipments of routinely generated LLW in 1998 because a waste management strategy was implemented that focuses on the expedient identification and removal of waste from the facility. This strategy is an effort to avoid the extended accumulation and deferred disposal of archived wastes by implementing proactive waste management activities.

During the past year, PFS-WMO developed data management tools that improved the tracking of "routine" and "nonroutine" LLW. Through the use of these tools, PFS-WMO can more accurately track the amount of routine LLW disposed of by ANL-E.

Depletion of existing LLW, in conjunction with the implementation of proactive waste management activities, is projected to result in the continued reduction of ANL-E LLW in the future.

Goal 2. Reduce by $50 \%$ the generation of radioactive mixed waste. Radioactive Mixed Waste Generation 1993-1998 $\left(\mathrm{ft}^{3}[1,000]\right)$

\begin{tabular}{lccccccc}
\hline & 1993 & 1994 & 1995 & 1996 & 1997 & 1998 & 1999 \\
\hline Generation & 5.0 & 0.67 & 0.71 & 0.16 & 0.3 & 0 & \\
Goal & & & & & & & 2.5 \\
\hline
\end{tabular}

Generation of mixed waste at ANL-E has continued to remain below the 1999 DOE Pollution Prevention Goal established from the 1993 baseline. The goal of reducing mixed wastes by $2.5 \mathrm{ft}^{3}$ has been surpassed. This goal for mixed waste has been achieved through a combination of treatment and source reduction. Current generation levels should be maintained by continuing to execute and improve current waste reduction activities and by implementing planned activities. 
Goal 3. Reduce by $50 \%$ the generation of hazardous waste.

Annual Hazardous Waste Generation (metric tons)

\begin{tabular}{lccccccc}
\hline & 1993 & 1994 & 1995 & 1996 & 1997 & 1998 & 1999 \\
\hline Generation & 5,588 & 2,509 & 1,246 & 1,226 & 1,452 & 359 & \\
Goal & & & & & & & 2,794 \\
\hline
\end{tabular}

Hazardous waste generation levels in 1998 continue to be below the 1999 DOE Pollution Prevention Goals derived from the 1993 baseline. ANL-E has reduced the volume of RCRArelated waste by implementing more efficient packaging procedures for chemical wastes and by implementing a proactive waste management strategy that incorporates the use of alternatives to disposal, such as recycling and reuse of materials and chemicals. ANL-E continues to encourage the use of microscale techniques within laboratories as a waste prevention strategy.

ANL-E also has addressed "State-Regulated" waste by taking advantage of new IEPA regulations that allow waste streams such as wastewater sludges and coal combustion fly ash to be certified as "nonspecial" waste. These waste streams are now tracked under the sanitary waste category. In addition, all coal combustion fly ash generated at ANL-E is being recycled at this time.

Goal 4. Reduce by $33 \%$ the generation of sanitary waste.

Annual Sanitary Waste Generation, 1993-1998 (metric tons)

\begin{tabular}{lccccccc}
\hline & 1993 & 1994 & 1995 & 1996 & 1997 & 1998 & 1999 \\
\hline Generation & 1,260 & 2,670 & 1,753 & 1,228 & 970 & 804 & \\
Goal & & & & & & & 832 \\
\hline
\end{tabular}

During 1998, ANL-E continued the downward trend of routine sanitary waste disposal with levels dropping below the 1999 DOE Pollution Prevention Goals established from the 1993 baseline. ANL-E has developed, and is implementing, aggressive waste prevention and recycling 
programs that will be used to maintain and improve upon these levels. Through the continuous improvement of recycling programs and improved data management, ANL-E will achieve this goal.

During 1998, $281 \mathrm{t}$ (310 tons) of waste, previously categorized as "State-Regulated" waste and contained within the hazardous waste generation category totals, was included in the solid nonhazardous waste totals. These wastes, consisting of fly ash and WTP sludges, were reclassified through the IEPA during 1998. Even with the addition of this tonnage, ANL-E still reduced routine sanitary waste to below the levels established by the DOE 1999 Pollution Prevention Goals.

Goal 5. Reduce by $\mathbf{5 0 \%}$ total releases and off-site transfers for treatment and disposal of toxic chemicals.

Annual Toxic Release Inventory, 1993-1998 (metric tons)

\begin{tabular}{lccccccc}
\hline & 1993 & 1994 & 1995 & 1996 & 1997 & 1998 & 1999 \\
\hline $\begin{array}{l}\text { Treatment or Disposal } \\
\text { Goal }\end{array}$ & 1.78 & 0 & 0 & 0 & 0 & 0 & \\
\hline
\end{tabular}

Since 1993, when $1.78 \mathrm{t}$ (1.96 tons) of toxic releases was recorded, ANL-E has focused on eliminating all forms of toxic releases. From 1994 through 1998, ANL-E has maintained zero generation levels.

Goal 6. Recycle $33 \%$ of sanitary waste from all operations, including cleanup and stabilization activities.

During 1998, ANL-E generated a total of 7,447 $\mathrm{t}$ (8,209 tons) of sanitary waste and materials from all operations (including cleanup and stabilization activities). ANL-E was able to recycle (reuse) 5,598 $\mathrm{t}$ (6,170 tons) of these materials. This amounts to a $75 \%$ level of recycling of sanitary waste from all ANL-E operations. To improve this recycling level, ANL-E is developing and implementing a variety of additional recycling programs for sanitary waste and 


\section{ENVIRONMENTAL PROGRAM INFORMATION}

materials originating from environmental restoration, $D \& D$, and facility construction and demolition activities. Programs have been successful in recycling fill material, roadway materials, and wood and scrap metal from routine and nonroutine activities. ANL-E will continue to work to develop, implement, and document waste stream diversion, material recycling, and other pollution prevention initiatives.

Goal 7. Affirmative Procurement: Increase procurement of EPA-designated, recycled products to $100 \%$, except where they are not commercially available competitively at a reasonable price or do not meet performance standards.

The Procurement Department estimates that in 1998, approximately $42 \%$ of ANL-E purchases of recyclable-content products were of the EPA-designated variety. This is an $11 \%$ increase from the previous year. Because of procurement tracking inefficiencies, pricing, and lack of product demand, several of the EPA-designated product types were not purchased in 1998. ANL-E is working toward this goal through a combination of an Affirmative Procurement Awareness Program, the development of an upgraded procurement tracking system, and the development and execution of ANL-E recycled product procurement procedures.

\subsubsection{Site Environmental Performance Measures Program}

Effective June 1, 1995, the prime contract between DOE and the University of Chicago to operate ANL-E made provisions for a performance fee based on performance of various research and operations activities, including ESH and Projects and Infrastructure Management performance. Performance objectives and supporting metrics have been developed to administer the contract and determine the performance fee. Each performance expectation is weighted; at the end of the performance period, a rating (outstanding, excellent, good, or marginal) is assigned. The performance fee is based on these ratings.

For the period of the performance-based contract October 1997 to September 1998, the environmental measurements were included in two Critical Few categories. One category was identified as the ESH category, and the other was entitled Projects and Infrastructure Management. 
The ratings of the measurements in the Critical Few categories directly affected the performancebased fee. The environmental measurements included improvements in the environmental review process (outstanding), compliance with environmental permit conditions (outstanding), compliance with air and water effluent limits (outstanding), compliance with environmental project schedule (excellent), compliance with environmental project cost (outstanding), and waste minimization/ pollution prevention (outstanding). The overall ratings of both categories within the Critical Few categories, based on a roll-up of the individual expectation performance ratings during the contract period, were outstanding.

\subsubsection{Environmental Management System}

It is ANL-E policy to conduct its operations in an environmentally safe and sound manner. Protection of the environment and the public are responsibilities of paramount importance and concern to ANL-E. To that end, ANL-E is firmly committed to ensuring the incorporation of national environmental protection goals in the formulation and implementation of ANL-E programs. It has an equal commitment to advance the goals of restoring and enhancing environmental quality and protecting public health. Accordingly, it is ANL-E policy to conduct its operations in compliance with the letter and spirit of applicable environmental statutes, regulations, and standards. To manage these commitments, ANL-E has structured its activities to focus on these goals. Line organizations have primary responsibility for environmental management and are supported by professional staff from the core ESH organizations, including specialists in air, water, RCRA, CERCLA, and NEPA. The ESH/QA organization provides oversight. The ANL-E program is governed by DOE Orders and IEPA regulations.

\subsection{Environmental Monitoring Program Description}

As required by DOE Order $5400.1,{ }^{1}$ ANL-E conducts a routine environmental monitoring program. This program is designed to determine the effect of ANL-E operations on the environment surrounding the site. This section describes this monitoring program. In 1998, a total of 1,977 samples were collected and 20,261 analyses were performed. A general description 


\section{ENVIRONMENTAL PROGRAM INFORMATION}

of the techniques used to sample each environmental medium is provided. This is followed by the collection procedures, the sampling schedule, and the analytical techniques used. Greater detail is provided in the ANL-E Environmental Monitoring Plan.

\subsubsection{Air Sampling}

ANL-E uses continuously operating air samplers to collect samples for the measurement of concentrations of airborne particles contaminated by radionuclides. Currently, nonradiological air contaminants in ambient air are not monitored. Particle samplers are placed at 14 locations around the ANL-E perimeter and at 6 off-site locations, approximately $8 \mathrm{~km}(5 \mathrm{mi})$ from ANL-E, to determine the ambient or background concentrations.

Airborne particle samples for measurement of total alpha, total beta, and gamma-ray emitters are collected continuously at 12 perimeter locations and at 5 off-site locations on glass fiber filter media. Average flow rates on the air samplers are about $70 \mathrm{~m}^{3} / \mathrm{h}\left(2,472 \mathrm{ft}^{3} / \mathrm{h}\right)$. Filters are changed weekly. The filters on perimeter samplers are changed by ANL-E staff, and the filters on off-site samplers are changed and mailed to ANL-E by cooperating local agencies. Additional samples of particles in air, used for radiochemical analysis of plutonium and other radionuclides, are collected at two perimeter locations and one off-site location. These samples are collected on special filter media that are changed every 10 days by ANL-E staff. The sampling units are serviced every six months, and the flow meters are recalibrated annually.

At the time of sample collection, the date and time when sampling was begun, the initial flow rate, the date and time when the sample was collected, and the final flow rate are recorded on a label attached to the sample container. The samples are then transported to ANL-E where this information is then transferred to the EMS.

Each air filter sample collected for alpha, beta, and gamma-ray analysis is cut in half. Half of each sample for any calendar week is combined with all the other perimeter samples from that week and packaged for gamma-ray spectrometry. A similar package is prepared for the off-site 


\section{ENVIRONMENTAL PROGRAM INFORMATION}

filters for each week. A 5-cm (2-in.) circle is cut from the other half of the filter, mounted in a 5-cm (2-in.) low-lip stainless-steel planchet, and counted to determine alpha and beta activity. The remainder of the filter is saved.

The air filter samples collected for radiochemical analysis are composited by location for each month. After the addition of appropriate tracers, the samples are ashed, then sequentially analyzed for plutonium, thorium, uranium, and strontium.

Stack monitoring is conducted continuously at those emission points that have a probability of releasing measurable radionuclides. The results of these measurements are used for estimating the annual off-site dose using the required EPA CAP-88 (Clean Air Act Assessment Package1988) ${ }^{7}$ atmospheric dispersion computer code and dose conversion method.

\subsubsection{Water Sampling}

Water samples are collected to determine what, if any, radionuclides or selected hazardous chemicals used or generated at ANL-E enter the environment by the water pathway. Surface water samples are collected from Sawmill Creek below the point at which ANL-E discharges its treated wastewater. The results of radiological analysis of water samples at this location are compared with upstream and off-site results to determine the ANL-E contribution. The results of the chemical analyses are compared with the applicable IEPA stream quality standards to determine whether the site is degrading the quality of the creek. These results are discussed in more detail in Chapters 4 and 5.

Surface water samples are collected from Sawmill Creek and combined into a single weekly composite sample. A continuous sampling device has been installed at this location to improve sample collection representativeness. To provide control samples, Sawmill Creek is sampled upstream of ANL-E once a month. The Des Plaines River is sampled twice a month below, and monthly above, the mouth of Sawmill Creek to determine whether radionuclides in the creek are detectable in the river. 


\section{ENVIRONMENTAL PROGRAM INFORMATION}

In addition to surface water, subsurface water samples are also collected at 34 locations. These samples are collected from monitoring wells located near areas that have the potential for adversely impacting groundwater. These areas are the 800 Area Landfill, the 317/319 waste management area, and the site of the inactive CP-5 reactor. Samples from the three on-site wells that formerly provided domestic water are also collected and analyzed for hazardous and radioactive constituents.

Subsurface water samples are collected quarterly from the monitoring wells located in the $317 / 319$ Area, the 800 Area Sanitary Landfill, and the CP-5 reactor. The monitoring wells are purged, and samples are collected from the recharged well water. These samples are analyzed for both chemical and radiological constituents, as discussed in Chapter 6. Samples are collected quarterly from the wellheads of the three ANL-E wells that formally provided the domestic water supply. The water is pumped to the surface and collected in appropriate containers, depending on the required analysis.

At the time of sample collection for radiological analysis, the sampling location, time, date, and collector identification number are recorded on a label attached to the sample container. Upon return to the laboratory, the information is transferred to the EMS system. Each sample is assigned a unique number that accompanies it through all analyses.

After the sample has been logged in, an aliquot is removed for hydrogen- 3 analysis, ( $20 \mathrm{~mL}$ [1 oz]) of concentrated nitric acid is added per gallon of water as a preservative), and the sample is filtered through Whatman No. 2 filter paper to remove any sediment present in the sample. Appropriate aliquots are then taken, depending on the analysis.

For nonradiological analysis, samples are collected and preserved using EPA-prescribed procedures. Cooling is used for organic analysis, and nitric acid is used to preserve samples to be analyzed for metals. Specific collection procedures are used for other components, and EPA methods are used. All samples are analyzed within the required holding period, or noncompliance is documented. The quality control requirements of either SW-846 ${ }^{8}$ or the Contract Laboratory 


\section{ENVIRONMENTAL PROGRAM INFORMATION}

Program (CLP) must be met, or deviations are documented. All samples are assigned a unique number that serves as a reference source for each sample. When duplicate samples are obtained, unique numbers are assigned, and an indication that duplicates exist is entered in the data management system.

\subsubsection{Bottom Sediment}

Bottom sediment accumulates small amounts of radionuclides that may be present from time to time in a stream and, as a result, acts as an accumulator of the radionuclides that were present in the water. The sediment provides evidence of radionuclides in the surface water system. These samples are not routinely analyzed for chemical constituents. Bottom sediment samples are collected annually from Sawmill Creek above, at, and several locations below the point at which ANL-E discharges its treated wastewater. Sediment is collected from each location with a stainless-steel scoop and is transferred to a glass bottle.

At the time of sample collection, the date, time, and sample collector identification are recorded on sample labels affixed to the sample container. Upon return to the laboratory, the information is transferred to the EMS system. Each sample is assigned a unique number that accompanies it through the process.

Each sample is dried for several days at $110^{\circ} \mathrm{C}\left(230^{\circ} \mathrm{F}\right)$, ball milled, and sieved through a No. 70 mesh screen. The material that does not pass the No. 70 screen is discarded. A 100-g (4 oz) portion is taken for gamma-ray spectrometric measurement, and other appropriate aliquots are used for specific radiochemical analyses.

\subsubsection{External Penetrating Radiation}

Measurements of direct penetrating radiation emanating from several sources within ANL-E are taken by using aluminum oxide thermoluminescent dosimeters (TLDs) provided by a commercial vendor. Each measurement is the average of two chips exposed in the same packet. 


\section{ENVIRONMENTAL PROGRAM INFORMATION}

Dosimeters are exposed at 14 locations at the site perimeter and on site and at five off-site locations. All dosimeters are changed quarterly. At the time of dosimeter collection, the date, time, and collector identification number are recorded on a preprinted label affixed to the container. Each sample is assigned a unique number that accompanies it through the process. After completion of the exposure period, the TLDs are mailed to the vendor for reading. When the dose information is provided to the on-site laboratory by the vendor, it is entered into the EMS system.

\subsubsection{Data Management}

ANL-E manages the large amount of data assembled in the environmental monitoring program in a very structured manner that allows a number of reports to be generated. Basic data management, including sample record keeping, is implemented with the EMS computerized record keeping program. All sample and analytical data are maintained in the EMS for eventual output in formats required for either regulatory compliance reports or for annual reports. In addition, reports are provided for trend analysis, statistical analysis, and tracking.

The ANL-E-developed EMS program is the basic data management tool; it generates sampling schedules, all other tracking and calculation routines, and the final analytical result tabulations. The EMS program is set up for the radiological portion of the monitoring program and for nonradiological monitoring for groundwater and NPDES surface water effluents.

The starting point for effluent monitoring and environmental surveillance is establishing a set of sampling locations and a sample schedule. On the basis of regulatory parameters, pathway analysis, or professional judgment, sample locations for the various media are identified and entered into the EMS. For each sample location, nine categories of data are entered into the EMS: geographic code, location description, sampling frequency, sample type, exact sampling position, last date sampled, sampling priority (same location with multiple samples), size of sample to collect, and analytes. 


\section{ENVIRONMENTAL PROGRAM INFORMATION}

Once the data are entered, the EMS program is used to generate a sampling schedule. Every week a schedule for the next week is printed out, along with uniquely numbered, preprinted labels for the sample containers. These items are provided to the staff who conduct the sampling in the field. Field data are entered into the EMS system. At the time the samples are submitted to the analytical laboratory, chain of custody documents are generated. The EMS system distributes sample data electronically (via diskette) to the ESH data management system and accepts back the analytical data (via diskette or e-mail).

As the laboratory results are compiled, the data are entered into the EMS program. This permits up-to-date tracking of all samples currently in process. When the analysis for each sample is completed and the results electronically entered into the EMS, the completed final results sample card is retained in a file as an additional QA measure.

Complete data sets for all samples are maintained by the EMS program. When all results have been completed and entered into the EMS, a final result card is generated that lists all data related to each sample. The electronic files are backed up by the ESH computer network server. The printed final result card is filed after review, then ultimately put in DOE's archives in Chicago. Final results are thus available both on line via the network and in hard copy.

\subsection{Compliance with DOE Order $5820.2 \mathrm{~A}$}

DOE Order 5820.2A, "Radioactive Waste Management," Section III-3 (k), ${ }^{9}$ requires that an environmental monitoring and surveillance program be conducted to determine any releases or migration from LLW treatment, storage, or disposal sites. Compliance with these requirements is an integral part of the ANL-E sitewide monitoring and surveillance program. Waste management operations in general are covered by relying on the perimeter air monitoring network and monitoring of the liquid effluent streams and Sawmill Creek. The analytical results are presented in Chapter 4 of this report. 
Of particular interest is monitoring of the waste management activities conducted in the 317 Area. These include air monitoring for total alpha, total beta, and gamma-ray emitters and radiochemical determinations of plutonium, uranium, thorium, and strontium-90; direct radiation measurements with TLDs; surface water discharges for hydrogen-3 and gamma-ray emitters; and subsurface water samples at all the monitoring wells with analyses for hydrogen-3, strontium-90, and gamma-ray emitters, plus selected monitoring for VOCs. The results are presented in Chapters 4 and 6 of this report. 


\section{ENVIRONMENTAL RADIOLOGICAL PROGRAM INFORMATION}

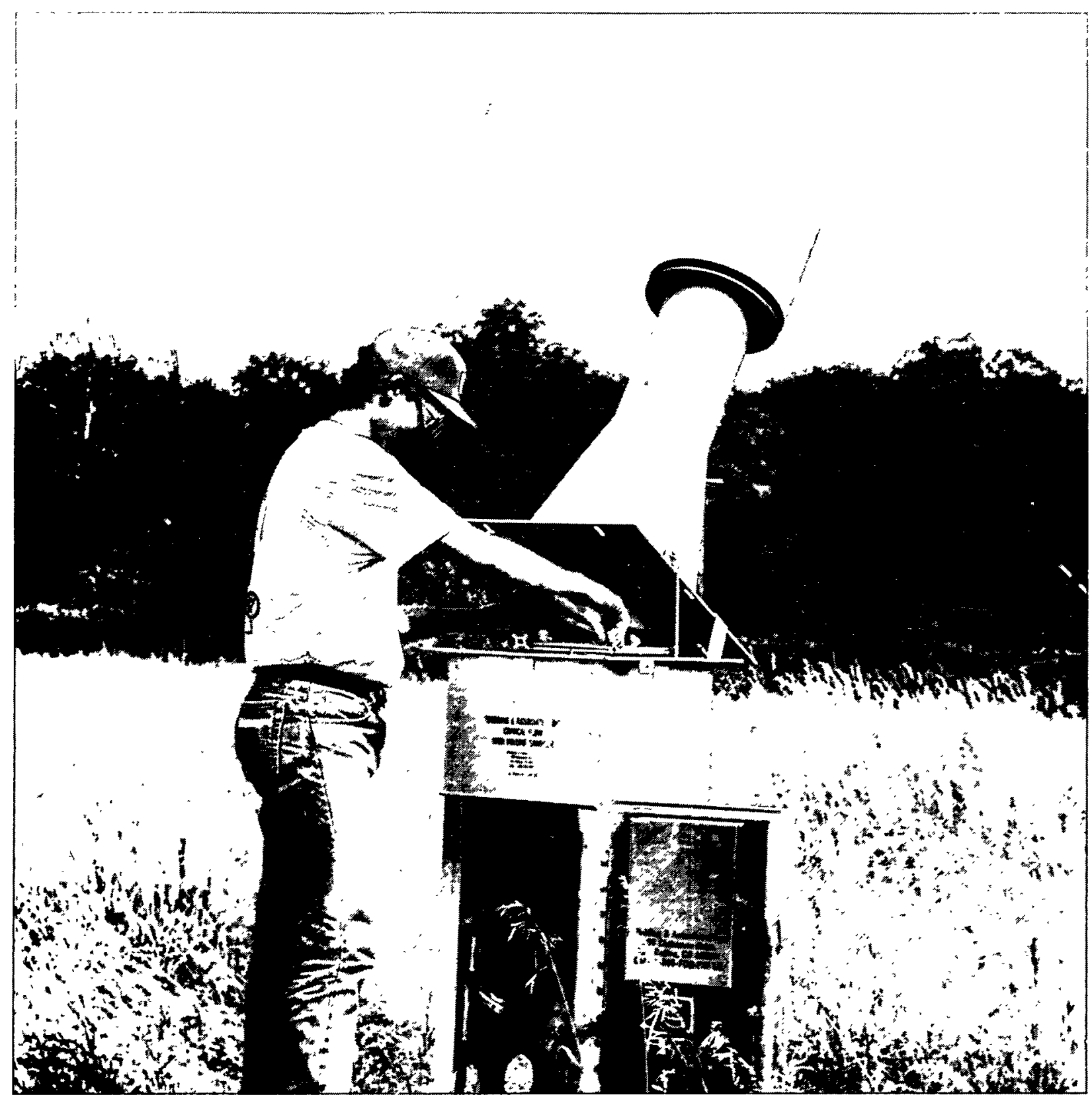




\section{ENVIRONMENTAL RADIOLOGICAL PROGRAM INFORMATION}

\subsection{Description of Monitoring Program}

The radioactivity of the environment around ANL-E in 1998 was determined by measuring radionuclide concentrations in naturally occurring materials and by measuring the external penetrating radiation dose. Sample collections and measurements were made at the site perimeter and off site for comparative purposes. Some on-site results are also reported when they are useful in interpreting perimeter and off-site results.

Because radioactivity is primarily transported by air and water, the sample collection program concentrates on these media. In addition, samples of materials from the stream beds also are analyzed. The program follows the guidance provided in the DOE Environmental Regulatory Guide. ${ }^{10}$ The results of radioactivity measurements are expressed in terms of $\mathrm{pCi} / \mathrm{L}$ for water; $\mathrm{fCi} / \mathrm{m}^{3}$ and $\mathrm{aCi} / \mathrm{m}^{3}$ for air; and $\mathrm{pCi} / \mathrm{g}$ and $\mathrm{fCi} / \mathrm{g}$ for bottom sediment. Penetrating radiation measurements are reported in units of $\mathrm{mrem} / \mathrm{yr}$, and population dose is reported in units of man-rems.

DOE has provided guidance ${ }^{11}$ for effective dose equivalent calculations for members of the public based on International Commission on Radiological Protection (ICRP) Publications 26 and 30. ${ }^{12,13}$ Those procedures have been used in preparing this report. The methodology requires that three components be calculated: (1) the committed effective dose equivalent (CEDE) from all sources of ingestion, (2) the CEDE from inhalation, and (3) the direct effective dose equivalent from external radiation. These three components were summed for comparison with the DOE effective dose equivalent limits for environmental exposure. The guidance requires that sufficient data on exposure to radionuclide sources be available to ensure that at least $90 \%$ of the total CEDE is accounted for. The primary radiation dose limit for members of the public is $100 \mathrm{mrem} / \mathrm{yr}$. The effective dose equivalents for members of the public from all routine DOE operations, natural background and medical exposures excluded, shall not exceed $100 \mathrm{mrem} / \mathrm{yr}$ and must adhere to the as-low-as-reasonably-achievable (ALARA) process or be as far below the limits as is practical, taking into account social, economic, technical, practical, and public policy considerations. 


\section{ENVIRONMENTAL RADIOLOGICAL PROGRAM INFORMATION}

Routine DOE operations are normally planned operations and exclude actual or potential accidental or unplanned releases.

The measured or calculated environmental radionuclide concentrations were converted to a 50-year CEDE with the use of the CEDE factors ${ }^{14}$ and were compared with the annual dose limits for uncontrolled areas. The CEDEs were calculated from the DOE Derived Concentration Guides (DCGs) ${ }^{11}$ for members of the public on the basis of a radiation dose of $100 \mathrm{mrem} / \mathrm{yr}$. The numerical values of the CEDE factors used in this report are provided later in this chapter (Table 4.25). Although the CEDE factors apply only to concentrations above natural levels, for comparative purposes, the calculated dose is sometimes given in this report for radioactivities that are primarily of natural origin. Occasionally, other standards are used, and their sources are identified in the text.

\subsection{Air}

The radioactive content of particles in the air was determined by collecting and analyzing air filter samples. The sampling locations are shown in Figures 1.1 and 1.2. Separate collections were made for specific radiochemical analyses and for gross alpha, gross beta, and gamma-ray spectrometry. The latter measurements were taken from samples collected continuously on laminated glass fiber filters (changed weekly) at 12 locations at the ANL-E site perimeter by using $\mathrm{PM}_{10}$ units (particles less than 10 micrometers) and at 5 off-site locations.

Samples were collected at the site perimeter to determine whether a statistically significant difference exists between perimeter measurements and measurements taken from samples collected at various off-site locations. The off-site samples establish the local background concentrations of naturally occurring or ubiquitous man-made radionuclides, such as from nuclear weapons testing fallout. Higher levels of radioactivity in the air measured at the site perimeter may indicate radioactivity releases from ANL-E, provided that the perimeter samples are greater than the background samples by an amount greater than the relative error of the measurement. The relative error is a result of natural variation in background concentrations as well as sampling and 


\section{ENVIRONMENTAL RADIOLOGICAL PROGRAM INFORMATION}

measurement error. This relative error is typically 5 to $20 \%$ of the measurement value for most of the analyses, but approaches $100 \%$ at values near the detection limit of the instrument.

Table 4.1 summarizes the total alpha and beta activities in the individual weekly samples. These measurements were made in low-background gas-flow proportional counters, and the counting efficiencies used to convert counting rates to disintegration rates were those measured for a $0.30-\mathrm{MeV}$ beta and a $5.5-\mathrm{MeV}$ alpha on filter paper. The results were obtained by measuring the samples four days after they were collected to avoid counting the natural activity due to shortlived radon and thoron decay products. This activity is normally present in air and disappears within four days by radioactive decay. The average concentrations of gamma-ray emitters, as . determined by gamma-ray spectrometry performed on composite weekly samples, are given in Table 4.2. The gamma-ray detector is a shielded germanium diode calibrated for each gammaray-emitting nuclide measured.

The alpha activity, principally due to naturally occurring nuclides, averaged the same as in the past several years and was within its normal range. The perimeter beta activity averaged $24 \mathrm{fCi} / \mathrm{m}^{3}$, which is similar to the average value for the past five years. The gamma-ray emitters listed in Table 4.2 are those that have been present in the air for the past five years and are of natural origin. The beryllium-7 concentration increases in the spring, which indicates its stratospheric origin. The concentration of lead-210 in the air is due to the radioactive decay of gaseous radon-222 and is similar to the concentration last year.

The annual average alpha and beta activities since 1985 are displayed in Figure 4.1. The elevated beta activity in 1986 was due to fallout from the Chernobyl incident. If the radionuclides attributed to the Chernobyl incident are subtracted from the annual beta average of $40 \mathrm{fCi} / \mathrm{m}^{3}$, the net would be $27 \mathrm{fCi} / \mathrm{m}^{3}$, very similar to the averages of the other years. Figure 4.2 presents the annual average concentrations of the two major gamma-ray-emitting radionuclides in air. The annual average beryllium-7 concentrations have decreased regularly since 1987 , reached a minimum in 1991, increased until 1996, and have now started to decrease. The changes in the 


\section{ENVIRONMENTAL RADIOLOGICAL PROGRAM INFORMATION}

TABLE 4.1

Total Alpha and Beta Activities in Air Filter Samples, 1998

(concentrations in $\mathrm{fCi} / \mathrm{m}^{3}$ )

\begin{tabular}{|c|c|c|c|c|c|c|c|c|}
\hline \multirow[b]{2}{*}{ Month } & \multirow[b]{2}{*}{ Location } & \multirow{2}{*}{$\begin{array}{c}\text { No. of } \\
\text { Samples }\end{array}$} & \multicolumn{3}{|c|}{ Alpha Activity } & \multicolumn{3}{|c|}{ Beta Activity } \\
\hline & & & Avg. & Min. & Max. & Avg. & Min. & Max. \\
\hline \multirow[t]{2}{*}{ January } & Perimeter & 46 & 1.1 & 0.1 & 2.0 & 33.0 & 4.3 & 53.8 \\
\hline & Off site & 18 & 1.5 & 0.5 & 2.6 & 34.3 & 4.6 & 64.5 \\
\hline \multirow[t]{2}{*}{ February } & Perimeter & 48 & 1.0 & 0.2 & 2.0 & 26.7 & 6.6 & 47.5 \\
\hline & Off site & 19 & 1.5 & 0.2 & 3.3 & 28.4 & 9.2 & 51.2 \\
\hline \multirow[t]{2}{*}{ March } & Perimeter & 45 & 1.0 & 0.2 & 1.9 & 20.6 & 3.3 & 33.1 \\
\hline & Off site & 16 & 1.1 & 0.1 & 2.8 & 19.2 & 5.9 & 50.3 \\
\hline \multirow[t]{2}{*}{ April } & Perimeter & 56 & 1.0 & 0.2 & 2.1 & 19.1 & 9.7 & 29.8 \\
\hline & Off site & 21 & 1.2 & 0.4 & 2.5 & 19.0 & 6.5 & 39.8 \\
\hline \multirow[t]{2}{*}{ May } & Perimeter & 48 & 1.3 & 0.5 & 2.2 & 20.8 & 8.9 & 31.5 \\
\hline & Off site & 16 & 1.5 & 0.4 & 6.6 & 18.1 & 10.0 & 25.8 \\
\hline \multirow[t]{2}{*}{ June } & Perimeter & 47 & 0.8 & 0.3 & 1.5 & 16.8 & 6.6 & 25.3 \\
\hline & Off site & 16 & 0.9 & 0.3 & 1.3 & 13.2 & 1.1 & 19.3 \\
\hline \multirow[t]{2}{*}{ July } & Perimeter & 58 & 1.1 & 0.1 & 2.1 & 22.1 & 8.7 & 31.4 \\
\hline & Off site & 22 & 1.2 & 0.3 & 2.2 & 18.8 & 10.6 & 30.0 \\
\hline \multirow[t]{2}{*}{ August } & Perimeter & 47 & 1.7 & 0.3 & 3.8 & 26.9 & 10.6 & 41.2 \\
\hline & Off site & 19 & 1.7 & 0.5 & 3.0 & 25.9 & 13.4 & 40.2 \\
\hline \multirow[t]{2}{*}{ September } & Perimeter & 60 & 1.5 & 0.1 & 2.6 & 28.8 & 2.4 & 40.4 \\
\hline & Off site & 24 & 1.6 & 0.1 & 4.2 & 27.8 & 6.4 & 49.5 \\
\hline \multirow[t]{2}{*}{ October } & Perimeter & 46 & 1.0 & 0.3 & 1.8 & 23.6 & 7.7 & 45.1 \\
\hline & Off site & 19 & 1.1 & 0.6 & 1.8 & 23.5 & 13.4 & 40.9 \\
\hline \multirow[t]{2}{*}{ November } & Perimeter & 30 & 1.0 & 0.3 & 1.6 & 24.9 & 9.5 & 37.4 \\
\hline & Off site & 18 & 1.2 & 0.5 & 1.9 & 26.1 & 13.9 & 37.6 \\
\hline \multirow[t]{2}{*}{ December } & Perimeter & 23 & 1.1 & 0.4 & 1.7 & 27.3 & 11.9 & 35.4 \\
\hline & Off site & 21 & 1.3 & 0.8 & 2.0 & 26.7 & 16.0 & 48.3 \\
\hline \multirow{2}{*}{$\begin{array}{l}\text { Annual } \\
\text { summary }\end{array}$} & Perimeter & 554 & $1.1 \pm 0.2$ & 0.1 & 3.8 & $24.2 \pm 2.9$ & 2.4 & 53.8 \\
\hline & Off site & 229 & $1.3 \pm 0.2$ & 0.1 & 6.6 & $23.4 \pm 3.7$ & 1.1 & 64.5 \\
\hline
\end{tabular}


TABLE 4.2

Gamma-Ray Activity in Air Filter Samples, 1998 (concentrations in $\mathrm{fCi} / \mathrm{m}^{3}$ )

\begin{tabular}{|c|c|c|c|}
\hline Month & Location & Beryllium-7 & Lead-210 \\
\hline \multirow[t]{2}{*}{ January } & Perimeter & 65 & 36 \\
\hline & Off site & 58 & 30 \\
\hline \multirow[t]{2}{*}{ February } & Perimeter & 90 & 26 \\
\hline & Off site & 72 & 24 \\
\hline \multirow[t]{2}{*}{ March } & Perimeter & 120 & 20 \\
\hline & Off site & 91 & 17 \\
\hline \multirow[t]{2}{*}{ April } & Perimeter & 148 & 16 \\
\hline & Off site & 118 & 13 \\
\hline \multirow[t]{2}{*}{ May } & Perimeter & 146 & 17 \\
\hline & Off site & 102 & 13 \\
\hline \multirow[t]{2}{*}{ June } & Perimeter & 123 & 15 \\
\hline & Off site & 65 & 9 \\
\hline \multirow[t]{2}{*}{ July } & Perimeter & 145 & 19 \\
\hline & Off site & 105 & 11 \\
\hline \multirow[t]{2}{*}{ August } & Perimeter & 136 & 22 \\
\hline & Off site & 106 & 18 \\
\hline \multirow[t]{2}{*}{ September } & Perimeter & 104 & 23 \\
\hline & Off site & 91 & 19 \\
\hline \multirow[t]{2}{*}{ October } & Perimeter & 86 & 23 \\
\hline & Off site & 67 & 15 \\
\hline \multirow[t]{2}{*}{ November } & Perimeter & 83 & 22 \\
\hline & Off site & 71 & 19 \\
\hline \multirow[t]{2}{*}{ December } & Perimeter & 58 & 26 \\
\hline & Off site & 65 & 19 \\
\hline \multirow{2}{*}{$\begin{array}{l}\text { Annual } \\
\text { summary }\end{array}$} & Perimeter & $109 \pm 20$ & $22 \pm 3$ \\
\hline & Off site & $84 \pm 12$ & $17 \pm 3$ \\
\hline \multirow[t]{2}{*}{ Dose (mrem) } & Perimeter & $(0.00027)$ & $(2.50)$ \\
\hline & Off site & $(0.00021)$ & $(1.96)$ \\
\hline
\end{tabular}




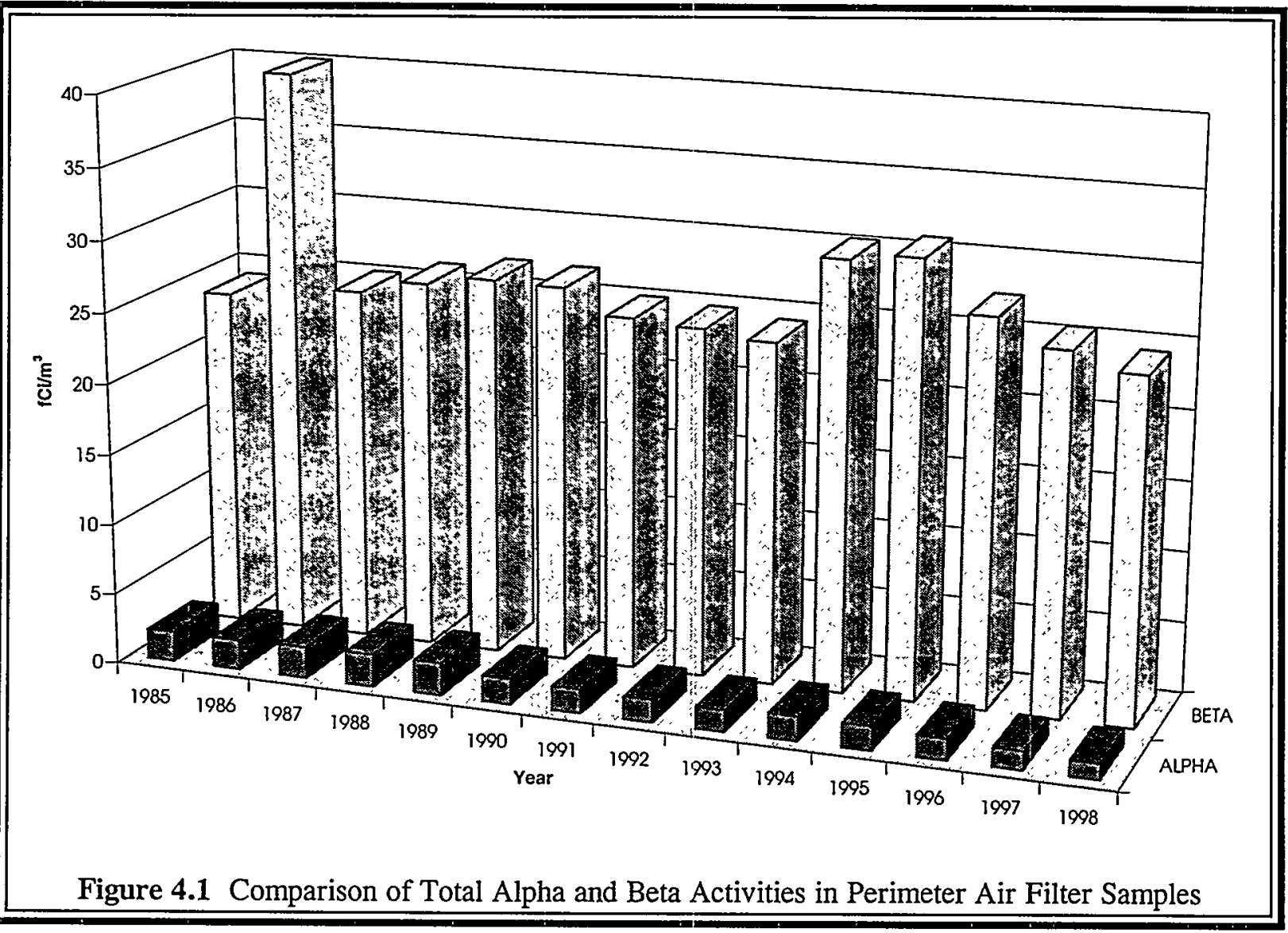

beryllium-7 air concentrations have been observed worldwide by the DOE Environmental Laboratory's Surface Air Sampling Program and are attributed to changes in solar activity. ${ }^{15}$

Samples for radiochemical analyses were collected at perimeter locations $12 \mathrm{~N}$ and $7 \mathrm{I}$ (Figure 1.1) and off the site in Downers Grove (Figure 1.2). Collections were made on polystyrene filters. The total air volume filtered for the monthly samples was approximately $20,000 \mathrm{~m}^{3}\left(700,000 \mathrm{ft}^{3}\right)$. Samples were ignited at $600^{\circ} \mathrm{C}\left(1,100^{\circ} \mathrm{F}\right)$ to remove organic matter and were prepared for analysis by vigorous treatment with hot hydrochloric, hydrofluoric, and nitric acids.

Plutonium and thorium were separated on an ion-exchange column, and the uranium was extracted from the column effluent. Following the extraction, the aqueous phase was analyzed 


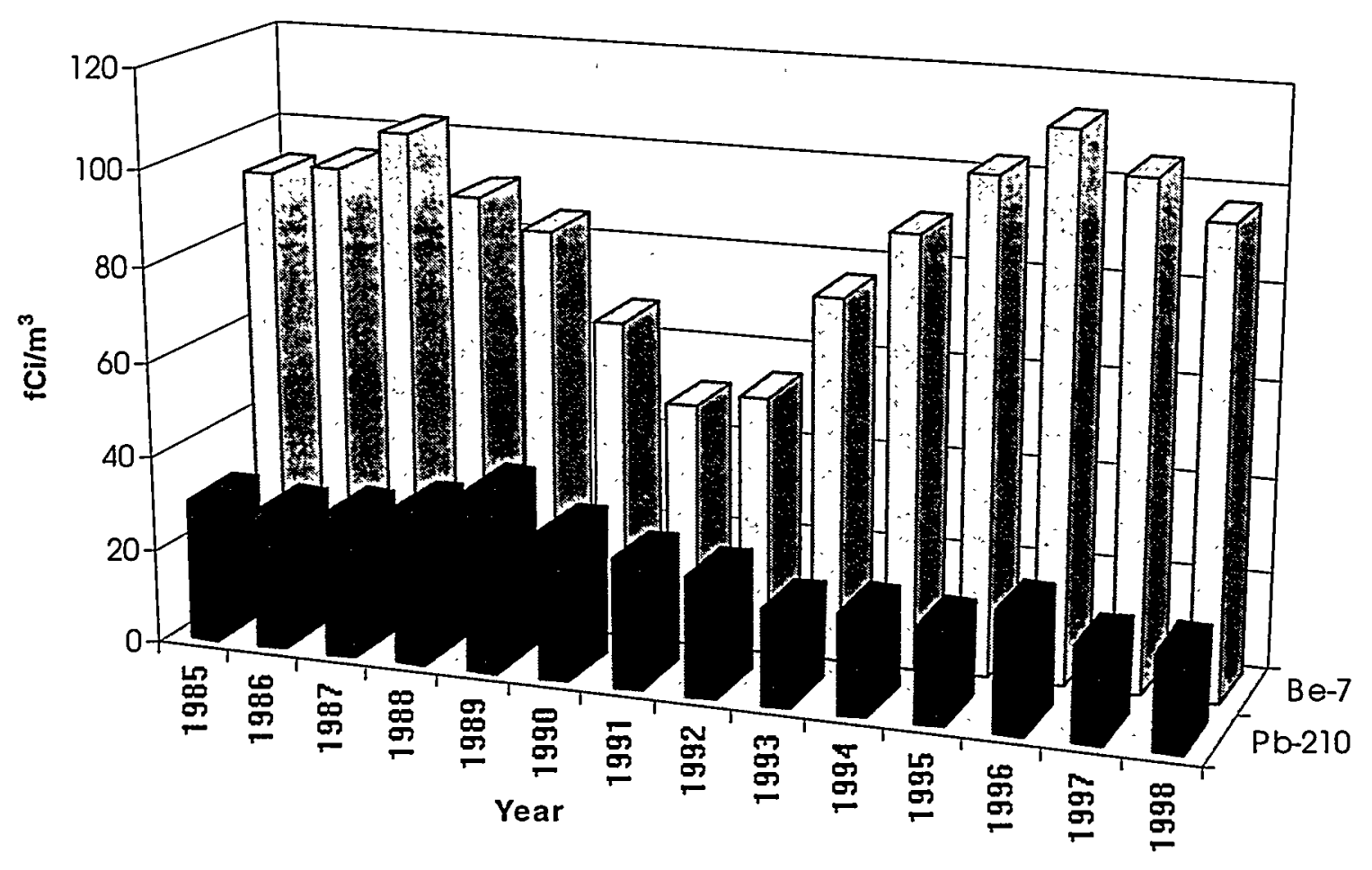

Figure 4.2 Comparison of Gamma-Ray Activity in Air Filter Samples

for radiostrontium by a standard radiochemical procedure. The separated plutonium, thorium, and uranium fractions were electrodeposited and measured by alpha spectrometry. The chemical recoveries were monitored by adding known amounts of plutonium-242, thorium-229, and uranium-236 tracers prior to ignition. Because spectrometry cannot distinguish between plutonium-239 and plutonium-240, when plutonium-239 is mentioned in this report, the alpha activity due to the plutonium-240 isotope is also included. The results are given in Table 4.3.

The strontium-90 concentrations have decreased over the past several years; consequently, during 1998, all of the results were less than the detection limit of $10 \mathrm{aCi} / \mathrm{m}^{3}$. Strontium- 89 was not observed above the detection limit of $100 \mathrm{aCi} / \mathrm{m}^{3}$. The plutonium-239 concentrations at all locations were similar to those of the last few years. The thorium and uranium concentrations were in the same range as in the past and are considered to be of natural origin. The amounts of 


\section{ENVIRONMENTAL RADIOLOGICAL PROGRAM INFORMATION}

thorium and uranium in a sample were proportional to the mass of inorganic material collected on the filter paper. The presence of most of these airborne elements can be attributed to the resuspension of soil.

The major airborne effluents released at ANL-E during 1998 are listed by location in Table 4.4; Figure 4.3 shows the annual releases of the major sources since 1985. The radon-220 releases from Building 200, due to radioactive contamination from the "proof-of-breeding" program, have been greatly reduced. The remaining emissions are from nuclear medicine studies. The hydrogen- 3 emitted from Building 212 is from hydrogen- 3 recovery studies, while short-lived activation products are emitted from the IPNS and APS. In addition to the radionuclides listed in Table 4.4, several other fission products also were released in millicurie or smaller amounts. The quantities listed in Table 4.4 were measured by on-line stack monitors in the exhaust systems of the buildings, except those for Building 350 .

\subsection{Surface Water}

All surface water samples collected in the monitoring program were acidified to $0.1 \underline{N}$ with nitric acid and filtered immediately after collection. Total nonvolatile alpha and beta activities were determined by counting the residue remaining after evaporation of the water and then applying counting efficiency corrections determined for plutonium-239 (for alpha activity) and thallium-204 (for beta activity) to obtain disintegration rates. Hydrogen-3 was measured from a separate aliquot; this activity does not appear in the results for total nonvolatile beta activity. Analyses for the radionuclides were performed by specific radiochemical separations followed by appropriate counting. One-liter aliquots were used for all analyses except for hydrogen-3 and the transuranium nuclides. Hydrogen- 3 analyses were performed by liquid scintillation counting of $9 \mathrm{~mL}(0.03 \mathrm{oz})$ of a distilled sample in a nonhazardous cocktail. Analyses for transuranium nuclides were performed on 10-L (3-gal) samples with chemical separation methods followed by alpha spectrometry. Plutonium-236 was used to determine the yields of plutonium and neptunium, which were separated from the sample together. A group separation of a fraction containing the transplutonium elements was monitored for recovery with an americium-243 tracer. Isotopic 


\section{TABLE 4.4}

Summary of Monitored Airborne Radioactive Emissions from ANL-E Facilities, 1998

\begin{tabular}{|c|c|c|c|c|}
\hline Building & Nuclide & Half-Life & $\begin{array}{l}\text { Amount } \\
\text { Released } \\
\text { (Ci) }\end{array}$ & $\begin{array}{l}\text { Amount } \\
\text { Released } \\
(\mathrm{Bq})\end{array}$ \\
\hline 200 & Radon-220 & $56 \mathrm{~s}$ & 239.2 & $8.8 \times 10^{12}$ \\
\hline 205 & $\begin{array}{l}\text { Hydrogen-3 (tritiated } \\
\text { water [HTO]) }\end{array}$ & $12.3 \mathrm{yr}$ & 30.9 & $1.1 \times 10^{12}$ \\
\hline \multirow{4}{*}{$\begin{array}{l}212 \text { (Alpha } \\
\text { Gamma Hot } \\
\text { Cell Facility) }\end{array}$} & Hydrogen-3 (HTO) & $12.3 \mathrm{yr}$ & 15.20 & $5.6 \times 10^{11}$ \\
\hline & $\begin{array}{l}\text { Hydrogen-3 (tritiated } \\
\text { hydrogen gas }[\mathrm{HT}] \text { ) }\end{array}$ & $12.3 \mathrm{yr}$ & 157.0 & $5.8 \times 10^{12}$ \\
\hline & Krypton-85 & $10.7 \mathrm{yr}$ & 2.80 & $1.0 \times 10^{11}$ \\
\hline & Radon-220 & $56 \mathrm{~s}$ & 0.16 & $5.9 \times 10^{9}$ \\
\hline \multirow[t]{8}{*}{350 (NBL) } & Uranium-234 & $2.4 \times 10^{5} \mathrm{yr}$ & $5.1 \times 10^{-7}$ & $1.9 \times 10^{3}$ \\
\hline & Uranium-238 & $4.5 \times 10^{9} \mathrm{yr}$ & $5.1 \times 10^{-7}$ & $1.9 \times 10^{3}$ \\
\hline & Plutonium-238 & $87.7 \mathrm{yr}$ & $5.0 \times 10^{-10}$ & $1.8 \times 10^{0}$ \\
\hline & Plutonium-239 & $2.4 \times 10^{4} \mathrm{yr}$ & $5.6 \times 10^{-9}$ & $2.1 \times 10^{1}$ \\
\hline & Plutonium-240 & $6.6 \times 10^{4} \mathrm{yr}$ & $1.0 \times 10^{-9}$ & $3.7 \times 10^{0}$ \\
\hline & Plutonium-241 & $14.4 \mathrm{yr}$ & $2.1 \times 10^{-8}$ & $7.8 \times 10^{2}$ \\
\hline & Plutonium-242 & $3.76 \times 10^{5} \mathrm{yr}$ & $5.6 \times 10^{-12}$ & $2.1 \times 10^{-2}$ \\
\hline & Plutonium-244 & $8.0 \times 10^{7} \mathrm{yr}$ & $1.9 \times 10^{-15}$ & $7.0 \times 10^{-5}$ \\
\hline \multirow[t]{2}{*}{375 (IPNS) } & Carbon-11 & $20 \mathrm{~m}$ & 564.8 & $2.1 \times 10^{13}$ \\
\hline & Argon- 41 & $1.8 \mathrm{~h}$ & 8.4 & $3.1 \times 10^{11}$ \\
\hline \multirow[t]{3}{*}{$411 / 415$ (APS) } & Carbon-11 & $20 \mathrm{~m}$ & 0.08 & $3.0 \times 10^{9}$ \\
\hline & Nitrogen-13 & $10 \mathrm{~m}$ & 3.72 & $1.4 \times 10^{11}$ \\
\hline & Oxygen-15 & $122 \mathrm{~s}$ & 0.40 & $1.5 \times 10^{10}$ \\
\hline
\end{tabular}




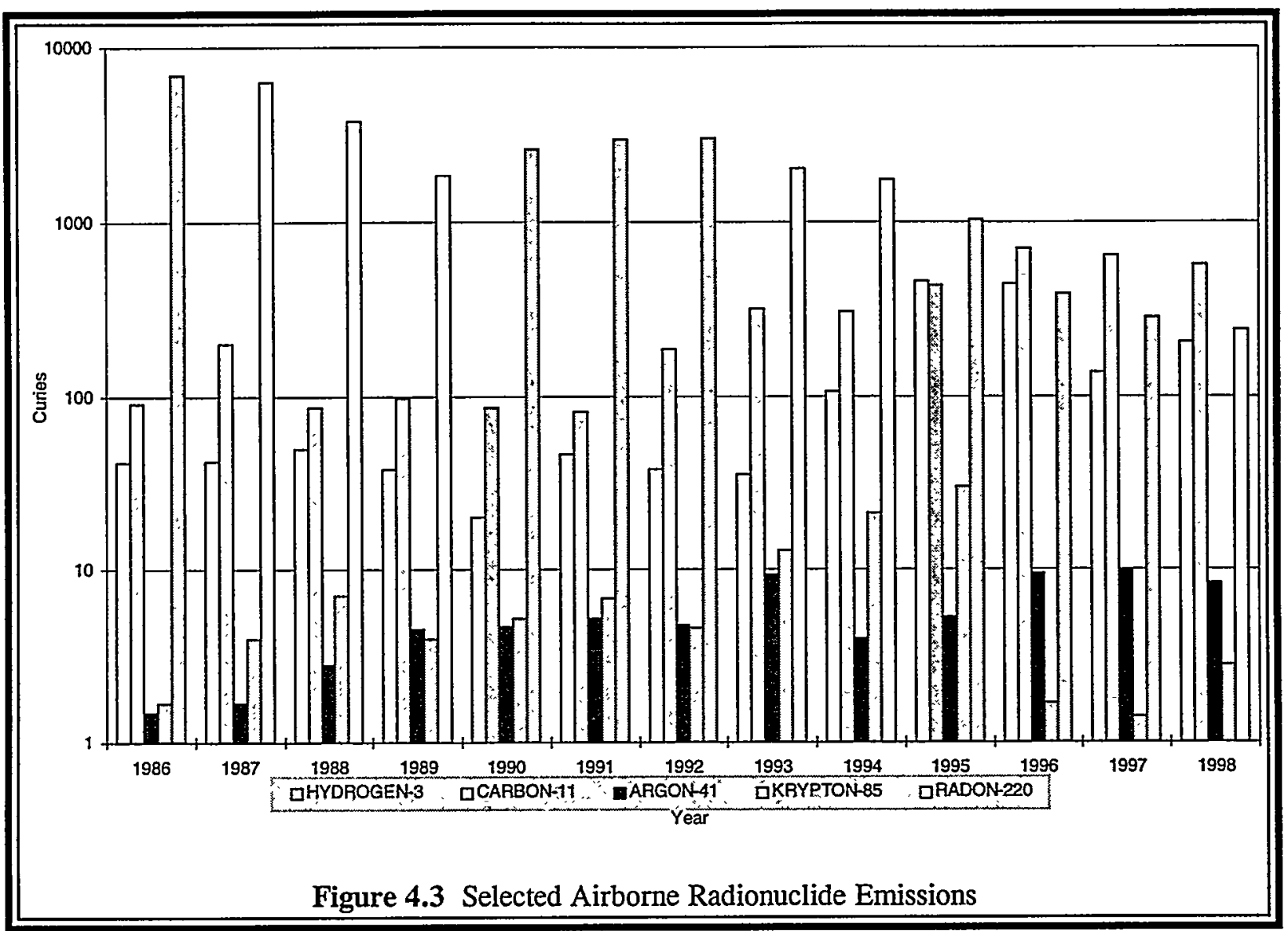

uranium concentrations were determined by alpha spectrometry by using uranium-236 as an isotopic tracer.

ANL-E wastewater is discharged into Sawmill Creek, which runs through the ANL-E grounds, drains surface water from much of the site, and flows into the Des Plaines River about $500 \mathrm{~m}(1,600 \mathrm{ft})$ downstream from the ANL-E wastewater outfall. Sawmill Creek was sampled upstream from the ANL-E site and downstream from the wastewater outfall to determine whether radioactivity was added to the stream by ANL-E wastewater or surface drainage. The sampling locations are shown in Figure 1.1. Below the wastewater outfall, daily samples were collected. Equal portions of the daily samples collected each week were combined and analyzed to obtain an average weekly concentration. Samples were collected upstream of the site once a month and were analyzed for the same radionuclides measured in the below-outfall samples. 


\section{ENVIRONMENTAL RADIOLOGICAL PROGRAM INFORMATION}

Table 4.5 gives the annual summaries of the results obtained for Sawmill Creek. Comparison of the results and $95 \%$ confidence levels of the averages for the two sampling locations shows that the following radionuclides found in the creek water can be attributed to ANL-E operations: hydrogen-3, strontium-90, plutonium-239, and americium-241; and occasionally neptunium-237, plutonium-238, and curium-244 and/or californium-249. The percentage of individual samples containing activity attributable to ANL-E was 53\% for hydrogen-3, 92\% for strontium- $90,47 \%$ for plutonium-239, and $69 \%$ for americium- 241 . The concentrations of all these nuclides are low and at a small fraction of DOE limits. If the concentrations of the radionuclides listed in Table 4.5 were increased by a factor of five, which approximates the effect of the dilution by Sawmill Creek on the ANL-E effluent water, the concentrations would still be well below the DOE limits. This demonstrates compliance with DOE Order $5400.5^{11}$ for use of the Best Available Technology (BAT) for release of liquid effluents.

Liquid wastewater from buildings or facilities that use or process radioactive materials are collected in retention tanks. When a tank is full, it is sampled and analyzed for alpha and beta radioactivity. If the radioactivity exceeds the release limits, the tank is processed by evaporation and the residue is disposed of as solid LLW. If the radioactivity is below the release limits, the wastewater is conveyed to the laboratory WTP in dedicated pipes to waste storage tanks. The release limits are based on the DCGs for plutonium-239 $(0.03 \mathrm{pCi} / \mathrm{mL})$ for alpha activity and for strontium-90 (1.0 pCi $/ \mathrm{mL})$ for beta activity. These radionuclides were selected because of their potential for release and their conservative allowable limits in the environment. The effluent monitoring program documents that no liquid releases above the DCGs have occurred and reinforces the demonstration of compliance with the use of BAT as required by DOE Order 5400.5. ${ }^{11}$

At location $7 \mathrm{M}$, below the ANL-E outfall, the annual average concentrations of most measured radionuclides were similar to recent annual averages. All the annual averages were well below the applicable standards. The annual total radioactive effluent discharged to the creek in ANL-E wastewater can be estimated from the average net concentrations and the volume of water carried by the creek. These totals are presented in Table 4.6. 
TABLE 4.5

Radionuclides in Sawmill Creek Water, 1998

\begin{tabular}{|c|c|c|c|c|c|c|c|c|}
\hline \multirow[b]{2}{*}{ Activity } & \multirow[b]{2}{*}{ Location $^{2}$} & \multirow{2}{*}{$\begin{array}{c}\text { No. of } \\
\text { Samples }\end{array}$} & \multicolumn{3}{|c|}{$\begin{array}{l}\text { Concentrations } \\
(\mathrm{pCi} / \mathrm{L})\end{array}$} & \multicolumn{3}{|c|}{$\begin{array}{c}\text { Dose } \\
\text { (mrem) }\end{array}$} \\
\hline & & & Avg. & Min. & Max. & Avg. & Min. & Max. \\
\hline Alpha & $16 K$ & 12 & $1.2 \pm 0.9$ & 0.5 & 1.7 & b & - & - \\
\hline (nonvolatile) & $7 \mathrm{M}$ & 51 & $1.3 \pm 1.4$ & $<0.1$ & 3.3 & - & - & - \\
\hline Beta & $16 \mathrm{~K}$ & 12 & $7 \pm 3$ & 6 & 11 & - & - & - \\
\hline (nonvolatile) & $7 \mathrm{M}$ & 51 & $11 \pm 5$ & 7 & 19 & - & - & - \\
\hline \multirow[t]{2}{*}{ Hydrogen-3 } & $16 \mathrm{~K}$ & 12 & $<100$ & $<100$ & 145 & $<0.0046$ & $<0.0046$ & 0.0066 \\
\hline & $7 \mathrm{M}$ & 51 & $130 \pm 206$ & $<100$ & 449 & 0.0060 & $<0.0046$ & 0.0206 \\
\hline \multirow[t]{2}{*}{ Strontium-90 } & $16 \mathrm{~K}$ & 12 & $<0.25$ & $<0.25$ & 0.31 & $<0.024$ & $<0.024$ & 0.030 \\
\hline & $7 \mathrm{M}$ & 51 & $0.47 \pm 0.32$ & $<0.25$ & 1.12 & 0.044 & $<0.024$ & 0.106 \\
\hline \multirow[t]{2}{*}{ Cesium-137 } & $16 \mathrm{~K}$ & 12 & $<1.0$ & $<1.0$ & $<1.0$ & $<0.04$ & $<0.04$ & $<0.04$ \\
\hline & $7 \mathrm{M}$ & 51 & $<1.0$ & $<1.0$ & $<1.0$ & $<0.04$ & $<0.04$ & $<0.04$ \\
\hline \multirow[t]{2}{*}{ Uranium-234 } & $16 \mathrm{~K}$ & 12 & $0.702 \pm 0.605$ & 0.334 & 1.253 & 0.133 & 0.063 & 0.238 \\
\hline & $7 \mathrm{M}$ & 51 & $0.578 \pm 0.544$ & 0.193 & 0.152 & 0.110 & 0.037 & 0.219 \\
\hline \multirow[t]{2}{*}{ Uranium-238 } & $16 \mathrm{~K}$ & 12 & $0.637 \pm 0.579$ & 0.260 & 1.162 & 0.107 & 0.044 & 0.195 \\
\hline & $7 \mathrm{M}$ & 51 & $0.520 \pm 0.480$ & 0.149 & 1.017 & 0.087 & 0.025 & 0.171 \\
\hline \multirow[t]{2}{*}{ Neptunium-237 } & $16 \mathrm{~K}$ & 12 & $<0.0010$ & $<0.0010$ & $<0.0010$ & $<0.0028$ & $<0.0028$ & $<0.0028$ \\
\hline & $7 \mathrm{M}$ & 51 & $<0.0010$ & $<0.0010$ & 0.0019 & $<0.0028$ & $<0.0028$ & 0.0055 \\
\hline \multirow[t]{2}{*}{ Plutonium-238 } & $16 \mathrm{~K}$ & 12 & $<0.0010$ & $<0.0010$ & $<0.0010$ & $<0.0028$ & $<0.0028$ & $<0.0028$ \\
\hline & $7 \mathrm{M}$ & 51 & $<0.0010$ & $<0.0010$ & 0.0045 & $<0.0028$ & $<0.0028$ & 0.0125 \\
\hline \multirow[t]{2}{*}{ Plutonium-239 } & $16 \mathrm{~K}$ & 12 & $<0.0010$ & $<0.0010$ & $<0.0010$ & $<0.0031$ & $<0.0031$ & $<0.0031$ \\
\hline & $7 \mathrm{M}$ & 51 & $0.0014 \pm 0.0029$ & $<0.0010$ & 0.0077 & 0.0045 & $<0.0031$ & 0.0241 \\
\hline \multirow[t]{2}{*}{ Americium-241 } & $16 \mathrm{~K}$ & 12 & $<0.0010$ & $<0.0010$ & 0.0012 & $<0.0033$ & $<0.0033$ & 0.0040 \\
\hline & $7 \mathrm{M}$ & 51 & $0.0039 \pm 0.0106$ & $<0.0010$ & 0.0211 & 0.0128 & $<0.0033$ & 0.0692 \\
\hline \multirow{2}{*}{$\begin{array}{l}\text { Curium-242 and } / \text { or } \\
\text { californium-252 }\end{array}$} & $16 \mathrm{~K}$ & 12 & $<0.0010$ & $<0.0010$ & 0.0014 & $<0.0007$ & $<0.0007$ & 0.0010 \\
\hline & $7 \mathrm{M}$ & 51 & $<0.0010$ & $<0.0010$ & 0.0016 & $<0.0007$ & $<0.0007$ & 0.0011 \\
\hline \multirow{2}{*}{$\begin{array}{c}\text { Curium-244 and/or } \\
\text { californium-249 }\end{array}$} & $16 \mathrm{~K}$ & 12 & $<0.0010$ & $<0.0010$ & $<0.0010$ & $<0.0034$ & $<0.0034$ & $<0.0034$ \\
\hline & $7 \mathrm{M}$ & 51 & $<0.0010$ & $<0.0010$ & 0.0044 & $<0.0034$ & $<0.0034$ & 0.0149 \\
\hline
\end{tabular}

${ }^{2}$ Location $16 \mathrm{~K}$ is upstream from the ANL-E site, and location $7 \mathrm{M}$ is downstream from the ANL-E wastewater outfall.

${ }^{b}$ A hyphen indicates no CEDEs for alpha and beta. 
TABLE 4.6

Total Radioactivity Released to

Sawmill Creek, 1998

\begin{tabular}{|c|c|c|}
\hline Radionuclide & Released (Ci) & Percent \\
\hline Hydrogen-3 & 1.264 & 99.7 \\
\hline Strontium-90 & 0.0035 & 0.3 \\
\hline Plutonium-239 & 0.000006 & $<0.1$ \\
\hline Americium-241 & 0.00004 & $<0.1$ \\
\hline Total & 1.27 & \\
\hline
\end{tabular}

On the basis of the results of the Storm Water Characterization Study (see Section 2.2.2), two perimeter surface water locations were identified that contained measurable levels of radionuclides. They were south of the 319 Area, Location 7J, and south of the 800 Area Landfill, Location 11D (see Figure 1.1). Samples were scheduled to be collected quarterly and analyzed for hydrogen- 3 and strontium- 90 and by gamma-ray spectrometry. The results are presented in Table 4.7.

The source of the radionuclides at Location 7J appears to be leachate from the 319 Area Landfill. A subsurface barrier wall and leachate collection system were constructed south of the 319 Landfill in November 1995 and became operational in 1996. Since the construction and operation of the leachate collection system, radionuclide concentrations in surface water at Location $7 \mathrm{~J}$ have decreased substantially. The hydrogen-3 at Location $11 \mathrm{D}$ is probably also from the leachate; the decrease in the concentration from earlier years is due to the completion of the clay cap on the 800 Area Landfill in the fall of 1993.

Because Sawmill Creek empties into the Des Plaines River, data on the radioactivity in this river is important in assessing the contribution of ANL-E wastewater to environmental radioactivity. The Des Plaines River was sampled, twice a month below and once a month above the mouth of Sawmill Creek, to determine whether the radioactivity in the creek had any effect on the radioactivity in the river. 


\section{TABLE 4.7}

Radionuclides in Storm Water Outfalls, 1998 (concentrations in $\mathrm{pCi} / \mathrm{L}$ )

\begin{tabular}{lcccc}
\hline $\begin{array}{c}\text { Date } \\
\text { Collected }\end{array}$ & $\begin{array}{c}\text { Location 7J } \\
\text { Hydrogen-3 }\end{array}$ & $\begin{array}{c}\text { Location 7J } \\
\text { Strontium-90 }\end{array}$ & $\begin{array}{c}\text { Location 7J } \\
\text { Cesium-137 }\end{array}$ & $\begin{array}{c}\text { Location 11D } \\
\text { Hydrogen-3 }\end{array}$ \\
\hline January 5 & $<100$ & 1.3 & $<1$ & 329 \\
April 2 & 718 & 2.0 & $<1$ & 496 \\
August 11 & Dry & Dry & Dry & Dry \\
October 19 & 184 & 3.5 & $<1$ & 225 \\
\hline
\end{tabular}

Table 4.8 presents annual summaries of the results obtained for these two locations. The average nonvolatile alpha, beta, and uranium concentrations in the river were very similar to past averages and remained in the normal range. Results were quite similar above and below the creek for all radionuclides, because the activity in Sawmill Creek was reduced by dilution to the point that it was not detectable in the Des Plaines River.

\subsection{Bottom Sediment}

The radioactive content of bottom sediment was measured in Sawmill Creek. A grab sample technique was used to obtain bottom sediments. After drying, grinding, and mixing 100-g (4-oz) portions of each, bottom sediment samples were analyzed by the same methods described in Section 4.2 for air filter residues. The plutonium and americium were separated from the same $10-\mathrm{g}(0.35-\mathrm{g})$ aliquot of soil. Results are given in terms of the oven-dried $\left(110^{\circ} \mathrm{C}\left[230^{\circ} \mathrm{F}\right]\right)$ weight.

A set of sediment samples was collected on August 20, 1998, from the Sawmill Creek bed, above, at the outfall, and at several locations below the point at which ANL-E discharges its treated wastewater (location 7M in Figure 1.1). The results, as listed in Table 4.9, show that the concentrations in the samples collected above the $7 \mathrm{M}$ outfall are similar to those of the off-site samples collected in past years. The plutonium, americium, and cesium-137 concentrations are 


\section{TABLE 4.8}

Radionuclides in Des Plaines River Water, 1998

\begin{tabular}{|c|c|c|c|c|c|c|c|c|}
\hline \multirow[b]{2}{*}{ Activity } & \multirow[b]{2}{*}{ Location ${ }^{2}$} & \multirow{2}{*}{$\begin{array}{l}\text { No. of } \\
\text { Samples }\end{array}$} & \multicolumn{3}{|c|}{$\begin{array}{l}\text { Concentrations } \\
(\mathrm{pCi} / \mathrm{L})\end{array}$} & \multicolumn{3}{|c|}{$\begin{array}{c}\text { Dose } \\
\text { (mrem) }\end{array}$} \\
\hline & & & Avg. & Min. & Max. & Avg. & Min. & Max. \\
\hline \multirow{2}{*}{$\begin{array}{l}\text { Alpha } \\
\text { (nonvolatile) }\end{array}$} & A & 12 & $1.0 \pm 1.0$ & 0.2 & 1.7 & . & - & - \\
\hline & B & 24 & $0.9 \pm 0.7$ & 0.1 & 1.6 & - & - & - \\
\hline \multirow{2}{*}{$\begin{array}{l}\text { Beta } \\
\text { (nonvolatile) }\end{array}$} & A & 12 & $13 \pm 5$ & 10 & 17 & - & - & - \\
\hline & B & 24 & $13 \pm 6$ & 8 & 19 & - & - & - \\
\hline \multirow[t]{2}{*}{ Hydrogen-3 } & A & 12 & $<100$ & $<100$ & 106 & $<0.0046$ & $<0.0046$ & 0.0049 \\
\hline & B & 24 & $<100$ & $<100$ & $<100$ & $<0.0046$ & $<0.0046$ & $<0.0046$ \\
\hline \multirow[t]{2}{*}{ Strontium-90 } & A & 12 & $0.25 \pm 0.13$ & $<0.25$ & 0.35 & 0.024 & $<0.024$ & 0.034 \\
\hline & B & 24 & $0.25 \pm 0.13$ & $<0.25$ & 0.35 & 0.024 & $<0.024$ & 0.033 \\
\hline \multirow[t]{2}{*}{ Uranium-234 } & A & 12 & $0.526 \pm 0.486$ & 0.145 & 0.885 & 0.100 & 0.028 & 0.168 \\
\hline & B & 24 & $0.537 \pm 0.452$ & 0.149 & 0.962 & 0.102 & 0.028 & 0.183 \\
\hline \multirow[t]{2}{*}{ Uranium-238 } & A & 12 & $0.464 \pm 0.469$ & 0.103 & 0.796 & 0.078 & 0.017 & 0.134 \\
\hline & B & 24 & $0.459 \pm 0.405$ & 0.124 & 0.827 & 0.077 & 0.021 & 0.139 \\
\hline \multirow[t]{2}{*}{ Neptunium-237 } & A & 12 & $<0.0010$ & $<0.0010$ & 0.0035 & $<0.0028$ & $<0.0028$ & 0.0101 \\
\hline & B & 12 & $<0.0010$ & $<0.0010$ & $<0.0010$ & $<0.0028$ & $<0.0028$ & $<0.0028$ \\
\hline \multirow[t]{2}{*}{ Plutonium-238 } & A & 12 & $<0.0010$ & $<0.0010$ & $<0.0010$ & $<0.0028$ & $<0.0028$ & $<0.0028$ \\
\hline & B & 12 & $<0.0010$ & $<0.0010$ & $<0.0010$ & $<0.0028$ & $<0.0028$ & $<0.0028$ \\
\hline \multirow[t]{2}{*}{ Plutonium-239 } & A & 12 & $<0.0010$ & $<0.0010$ & $<0.0010$ & $<0.0031$ & $<0.0031$ & $<0.0031$ \\
\hline & B & 12 & $<0.0010$ & $<0.0010$ & $<0.0010$ & $<0.0031$ & $<0.0031$ & $<0.0031$ \\
\hline \multirow[t]{2}{*}{ Americium-241 } & A & 12 & $<0.0010$ & $<0.0010$ & $<0.0010$ & $<0.0033$ & $<0.0033$ & $<0.0033$ \\
\hline & B & 12 & $<0.0010$ & $<0.0010$ & $<0.0010$ & $<0.0033$ & $<0.0033$ & $<0.0033$ \\
\hline \multirow{2}{*}{$\begin{array}{l}\text { Curium-242 and/or } \\
\text { califomium- } 252\end{array}$} & A & 12 & $<0.0010$ & $<0.0010$ & $<0.0010$ & $<0.0007$ & $<0.0007$ & $<0.0007$ \\
\hline & B & 12 & $<0.0010$ & $<0.0010$ & $<0.0010$ & $<0.0007$ & $<0.0007$ & $<0.0007$ \\
\hline \multirow{2}{*}{$\begin{array}{c}\text { Curium- } 244 \text { and/or } \\
\text { califomium- } 249\end{array}$} & A & 12 & $<0.0010$ & $<0.0010$ & $<0.0010$ & $<0.0034$ & $<0.0034$ & $<0.0034$ \\
\hline & B & 12 & $<0.0010$ & $<0.0010$ & $<0.0010$ & $<0.0034$ & $<0.0034$ & $<0.0034$ \\
\hline
\end{tabular}

2 Location A, near Willow Springs, is upstream and location B, near Lemont, is downstream from the mouth of Sawmill Creek. See Figure 1.2.

${ }^{b} A$ hyphen indicates no CEDEs for alpha and beta. 


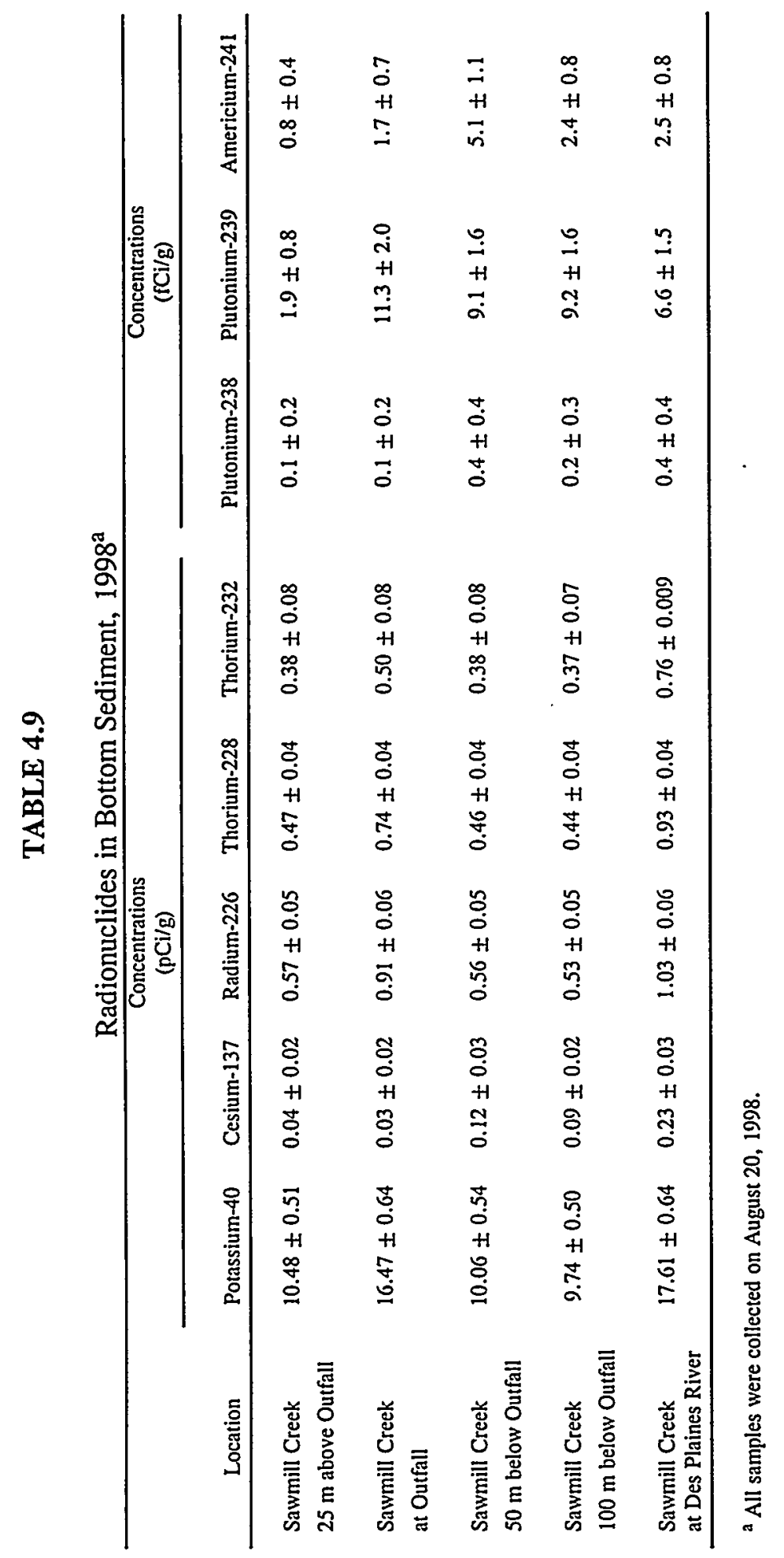




\section{ENVIRONMENTAL RADIOLOGICAL PROGRAM INFORMATION}

elevated below the outfall, which indicates that their origin is in ANL-E wastewater. Plutonium results varied widely among locations and were strongly dependent on the retentiveness of the bottom material. The changes in concentrations of these nuclides with time and location indicate the dynamic nature of the sediment material in this area.

\subsection{External Penetrating Radiation}

Levels of external penetrating radiation at and in the vicinity of the ANL-E site were measured with aluminum oxide TLD chips provided and read by a commercial vendor. Each measurement reported represents the average of two chips exposed in the same packet. Dosimeters were exposed at 14 locations at the site boundary and on the site. Readings were also taken at five off-site locations (Figure 1.2) for comparative purposes.

The results are summarized in Tables 4.10 and 4.11, and the site boundary and on-site readings are shown in Figure 4.4. Measurements were taken during the four successive exposure periods shown in the tables, and the results were calculated in terms of annual dose for ease in comparing measurements made for different elapsed times. The uncertainty of the averages given in the tables is the $95 \%$ confidence limit calculated from the standard deviation of the average.

The off-site results averaged $80 \pm 3 \mathrm{mrem} / \mathrm{yr}$ and were similar to last year's off-site average of $82 \pm 2 \mathrm{mrem} / \mathrm{yr} .{ }^{16}$ To compare boundary results for individual sampling periods, the standard deviation of the 20 individual off-site results is useful. This value is $8 \mathrm{mrem} / \mathrm{yr}$; thus, individual results in the range of $80 \pm 16 \mathrm{mrem} / \mathrm{yr}$ may be considered to be the average natural background with a $95 \%$ probability.

The site boundary location at 7I had dose rates consistently above the average background. This was the result of radiation from ANL-E's 317 Area in the northern half of grid 7I. Waste is packaged and temporarily kept in this area before removal for permanent disposal off site. In 1998, the dose at this perimeter fence location was approximately $106 \pm 10 \mathrm{mrem} / \mathrm{yr}$. 


\section{ENVIRONMENTAL RADIOLOGICAL PROGRAM INFORMATION}

TABLE 4.10

Environmental Penetrating Radiation at Off-Site Locations, 1998

\begin{tabular}{lccccc}
\hline & \multicolumn{5}{c}{$\begin{array}{c}\text { Dose Rate (mrem/yr) } \\
\text { Period of Measurement }\end{array}$} \\
\cline { 2 - 6 } \multicolumn{1}{c}{ Location } & Jan. 7-March 30 & March 30-July 7 & July 7-Oct. 1 & Oct. 1-Jan. 7 & Average \\
\hline Lemont & 78 & 87 & 86 & 83 & $84 \pm 4$ \\
Oak Brook & 96 & 83 & 71 & 73 & $81 \pm 11$ \\
Orland Park & 73 & 77 & 79 & 83 & $78 \pm 4$ \\
Woodridge & 75 & 83 & 94 & 86 & $85 \pm 8$ \\
Willow Springs & 75 & 70 & 65 & 83 & $73 \pm 8$ \\
& $79 \pm 8$ & $80 \pm 6$ & $79 \pm 10$ & $82 \pm 4$ & $80 \pm 3$ \\
Average & & & & & \\
\hline
\end{tabular}

Approximately $300 \mathrm{~m}$ (960 ft) south of the fence in grid 6I, the measured dose dropped to $89 \pm 8 \mathrm{mrem} / \mathrm{yr}$, which is within the normal background range.

In the past, an elevated on-site dose had been measured at Location $9 \mathrm{H}$, next to the CP-5 reactor, where irradiated hardware from the CP-5 reactor was stored. During the past few years, considerable cleanup of the CP-5 reactor yard has occurred as part of the CP-5 reactor D\&D project. The dose at Location $9 \mathrm{H}$ decreased from about $1,200 \mathrm{mrem} / \mathrm{yr}$ in 1989 to $170 \mathrm{mrem} / \mathrm{yr}$ in 1998. The cleanup was completed in 1994; the residual dose is from sources in the building, which is currently undergoing $D \& D$ and the occasional use of the yard to stage radioactive waste from the $\mathrm{D} \& \mathrm{D}$ pending shipment off site.

\subsection{Estimates of Potential Radiation Doses}

The radiation doses at the site boundary and off the site that could have been received by the public from radioactive materials and radiation leaving the site were calculated. Calculations were performed for three exposure pathways-airborne, water, and direct radiation from external sources. 


\section{ENVIRONMENTAL RADIOLOGICAL PROGRAM INFORMATION}

TABLE 4.11

Environmental Penetrating Radiation at ANL-E, 1998

\begin{tabular}{|c|c|c|c|c|c|}
\hline \multirow[b]{2}{*}{ Location $^{a}$} & \multicolumn{5}{|c|}{$\begin{array}{c}\text { Dose Rate (mrem/yr) } \\
\text { Period of Measurement }\end{array}$} \\
\hline & Jan. 7-March 30 & March 30-July 7 & July 7-Oct. 1 & Oct. 1-Jan. 7 & Average \\
\hline 14G - Boundary & 79 & 92 & 92 & 82 & $86 \pm 7$ \\
\hline $14 \mathrm{I}$ - Boundary & 65 & 81 & 60 & 86 & $73 \pm 12$ \\
\hline 14L - Boundary & 82 & 86 & 48 & 66 & $71 \pm 17$ \\
\hline $6 \mathrm{I}-200 \mathrm{~m} \mathrm{~N}$ of Quarry Road & 78 & 87 & 92 & 98 & $89 \pm 8$ \\
\hline $\begin{array}{l}\text { 71 - Center, Waste Storage Area } \\
\text { Facility } 317\end{array}$ & 3,047 & 2,982 & 3,873 & 3,046 & $3,237 \pm 417$ \\
\hline 71 - Boundary & 97 & 106 & 121 & 101 & $106 \pm 10$ \\
\hline $8 \mathrm{H}$ - Boundary & 86 & 92 & 85 & 72 & $84 \pm 8$ \\
\hline $8 \mathrm{H}-65 \mathrm{~m} \mathrm{~S}$ of Building 316 & 78 & 79 & 45 & 94 & $74 \pm 20$ \\
\hline $\begin{array}{c}8 \mathrm{H}-200 \mathrm{~m} \mathrm{NW} \text { of Waste } \\
\text { Storage Area (heliport) }\end{array}$ & 84 & 67 & 84 & 70 & $76 \pm 9$ \\
\hline $\begin{array}{l}\text { 8H - Boundary, Center, } \\
\text { St. Patrick Cemetery }\end{array}$ & 83 & 89 & 85 & 75 & $83 \pm 6$ \\
\hline $9 \mathrm{H}-50 \mathrm{~m} \mathrm{SE}$ of CP-5 & 216 & 239 & 123 & 102 & $170 \pm 66$ \\
\hline $\begin{array}{l}\text { 9/10 I - } 65 \mathrm{~m} \text { NE of Building 350, } \\
230 \mathrm{~m} \mathrm{NE} \text { of Building } 316\end{array}$ & 63 & 61 & 65 & 72 & $65 \pm 5$ \\
\hline 9/10 EF - Boundary & 76 & 74 & 87 & 93 & $83 \pm 9$ \\
\hline $10 / 11 \mathrm{~K}$ - Facilities & 53 & 79 & 42 & 57 & $58 \pm 15$ \\
\hline
\end{tabular}

a See Figure 1.1. 


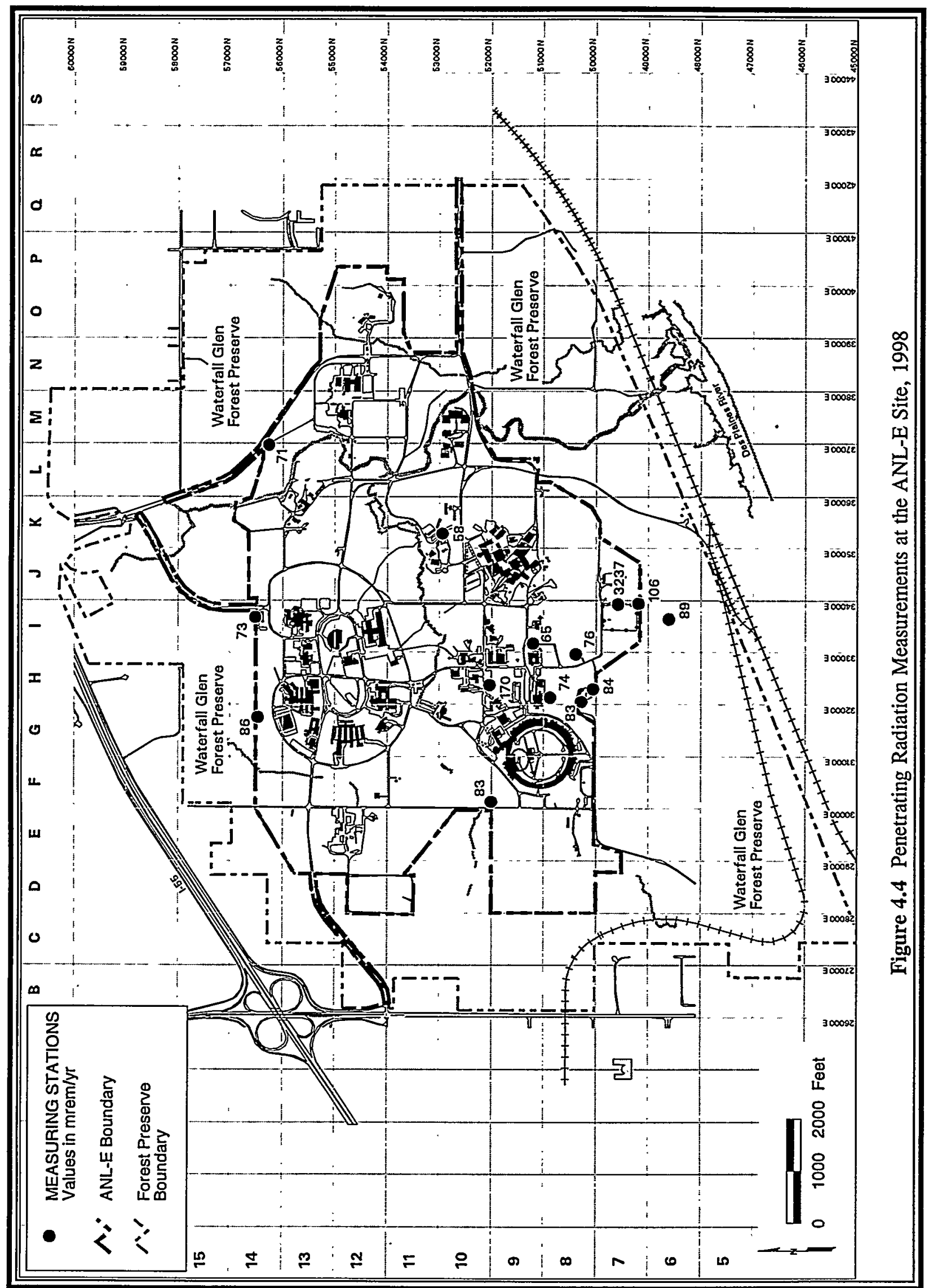

ANL-E Site Environmental Report 


\subsubsection{Airborne Pathway}

Guidance issued by $\mathrm{DOE}^{11}$ stipulates that $\mathrm{DOE}$ facilities with airborne releases of radioactive materials are subject to $40 \mathrm{CFR}$ Part 61 , Subpart $\mathrm{H},{ }^{17}$ which requires the use of the EPA's CAP-88 code ${ }^{7}$ to calculate the dose for radionuclides released to the air and to demonstrate compliance with the regulation. The dose limit applicable for 1998 for the air pathway is a 10 -mrem/yr effective dose equivalent. The CAP-88 computer code uses a modified Gaussian plume equation to estimate both horizontal and vertical dispersion of radionuclides released to the air from stacks or area sources. For 1998, doses were calculated for hydrogen-3, carbon-11, nitrogen-13, oxygen-15, argon- 41 , krypton- 85 , radon-220 plus daughters, and a number of actinide radionuclides. The annual release rates are those listed in Table 4.4; separate calculations were performed for each of the six release points. The wind speed and direction data shown in Figure 1.3 were used for these calculations. In the past, the wind stability classes had been determined by the temperature differences between the $10-\mathrm{m}(33-\mathrm{ft})$ and $60-\mathrm{m}(197-\mathrm{ft})$ levels. To improve the determination of stability levels, the categories were obtained from daytime measurements of solar radiation and nighttime measurements of the standard deviation of the horizontal wind speed. Doses were calculated for an area extending out to $80 \mathrm{~km}$ (50 mi) from ANL-E. The population distribution of the 16 compass segments and 10 distance increments given in Table 1.1 was used. The dose rate was calculated at the midpoint of each interval and integrated over the entire area to give the annual population cumulative dose.

Distances from the specific facilities that exhaust radiological airborne emissions (see Table 4.4) to the fence line (perimeter) and nearest resident were determined in the 16 compass segments. Calculations also were performed to evaluate the major airborne pathways: ingestion, inhalation, and immersion, both at the point of maximum perimeter exposure and to the maximally exposed resident. The perimeter and resident doses and the maximum doses are listed, respectively, for releases from Buildings 200 (Tables 4.12 and 4.13), Building 205 (Tables 4.14 and 4.15), Building 212 (Tables 4.16 and 4.17), Building 350 (Tables 4.18 and 4.19), 


\section{ENVIRONMENTAL RADIOLOGICAL PROGRAM INFORMATION}

TABLE 4.12

Radiological Airborne Releases from Building 200, 1998

\begin{tabular}{lcccc}
\hline Direction & $\begin{array}{c}\text { Distance to } \\
\text { Perimeter } \\
(\mathrm{m})\end{array}$ & $\begin{array}{c}\text { Dose }^{\mathrm{a}} \\
(\mathrm{mrem} / \mathrm{yr})\end{array}$ & $\begin{array}{c}\text { Distance to Nearest } \\
\text { Resident } \\
(\mathrm{m})\end{array}$ & $\begin{array}{c}\text { Dose }^{\mathrm{a}} \\
(\mathrm{mrem} / \mathrm{yr})\end{array}$ \\
\hline N & 500 & $5.1 \times 10^{-2}$ & 1,000 & $1.4 \times 10^{-2}$ \\
NNE & 600 & $4.0 \times 10^{-2}$ & 1,100 & $1.3 \times 10^{-2}$ \\
NE & 750 & $2.3 \times 10^{-2}$ & 2,600 & $2.5 \times 10^{-3}$ \\
ENE & 1,700 & $5.0 \times 10^{-3}$ & 3,100 & $1.7 \times 10^{-3}$ \\
E & 2,400 & $3.5 \times 10^{-3}$ & 3,500 & $1.9 \times 10^{-3}$ \\
ESE & 2,200 & $2.9 \times 10^{-3}$ & 3,600 & $1.3 \times 10^{-3}$ \\
SE & 2,100 & $2.4 \times 10^{-3}$ & 4,000 & $8.4 \times 10^{-4}$ \\
SSE & 2,000 & $3.6 \times 10^{-3}$ & 4,000 & $1.1 \times 10^{-3}$ \\
S & 1,500 & $3.0 \times 10^{-3}$ & 4,000 & $6.1 \times 10^{-4}$ \\
SSW & 1,000 & $1.6 \times 10^{-2}$ & 2,500 & $3.4 \times 10^{-3}$ \\
SW & 800 & $3.4 \times 10^{-2}$ & 2,200 & $6.9 \times 10^{-3}$ \\
WSW & 1,100 & $1.0 \times 10^{-2}$ & 1,500 & $6.1 \times 10^{-3}$ \\
W & 750 & $1.8 \times 10^{-2}$ & 1,500 & $6.2 \times 10^{-3}$ \\
WNW & 800 & $1.2 \times 10^{-2}$ & 1,300 & $5.6 \times 10^{-3}$ \\
NW & 600 & $1.8 \times 10^{-2}$ & 1,100 & $6.9 \times 10^{-3}$ \\
NNW & 600 & $2.5 \times 10^{-2}$ & 800 & $1.5 \times 10^{-2}$ \\
\hline & & & &
\end{tabular}

a Source term: radon-220 $=239.2 \mathrm{Ci}$ (plus daughters). 
TABLE 4.13

Maximum Perimeter and Individual Doses

from Building 200 Air Emissions, 1998

(dose in mrem/yr)

\begin{tabular}{lll}
\hline \multicolumn{1}{c}{ Pathway } & $\begin{array}{c}\text { Perimeter } \\
(500 \mathrm{~m} \mathrm{~N})\end{array}$ & $\begin{array}{c}\text { Individual } \\
(800 \mathrm{~m} \mathrm{NNW})\end{array}$ \\
\hline Ingestion & $7.5 \times 10^{-14}$ & $2.7 \times 10^{-14}$ \\
Inhalation & $5.0 \times 10^{-2}$ & $1.5 \times 10^{-2}$ \\
Air immersion & $3.5 \times 10^{-4}$ & $9.2 \times 10^{-5}$ \\
Ground surface & $2.5 \times 10^{-5}$ & $9.1 \times 10^{-6}$ \\
Total & $5.1 \times 10^{-2}$ & $1.5 \times 10^{-2}$ \\
Radionuclide & & \\
& & \\
Thallium-208 & $3.0 \times 10^{-4}$ & $7.8 \times 10^{-5}$ \\
Bismuth-212 & $6.0 \times 10^{-3}$ & $2.1 \times 10^{-3}$ \\
Lead-212 & $3.0 \times 10^{-2}$ & $1.1 \times 10^{-2}$ \\
Radon-220 & $1.4 \times 10^{-2}$ & $2.1 \times 10^{-3}$ \\
& & \\
Total & $5.1 \times 10^{-2}$ & $1.5 \times 10^{-2}$ \\
\hline
\end{tabular}


TABLE 4.14

Radiological Airborne Releases from Building 205, 1998

\begin{tabular}{|c|c|c|c|c|}
\hline Direction & $\begin{array}{l}\text { Distance to } \\
\text { Perimeter } \\
\text { (m) }\end{array}$ & $\begin{array}{c}D^{D o s e}{ }^{a} \\
(\mathrm{mrem} / \mathrm{yr})\end{array}$ & $\begin{array}{c}\text { Distance to } \\
\text { Nearest Resident } \\
\text { (m) }\end{array}$ & $\begin{array}{c}\text { Dose }^{\mathrm{a}} \\
\text { (mrem/yr) }\end{array}$ \\
\hline $\mathrm{N}$ & 850 & $1.3 \times 10^{-3}$ & 1,300 & $6.3 \times 10^{-4}$ \\
\hline NNE & 1,000 & $9.9 \times 10^{-4}$ & 2,100 & $2.9 \times 10^{-4}$ \\
\hline $\mathrm{NE}$ & 1,200 & $6.7 \times 10^{-4}$ & 2,700 & $1.7 \times 10^{-4}$ \\
\hline ENE & 2,400 & $2.0 \times 10^{-4}$ & 3,000 & $1.4 \times 10^{-4}$ \\
\hline $\mathrm{E}$ & 2,200 & $3.0 \times 10^{-4}$ & 2,400 & $1.5 \times 10^{-4}$ \\
\hline ESE & 2,000 & $2.5 \times 10^{-4}$ & 3,500 & $9.9 \times 10^{-5}$ \\
\hline SE & 1,800 & $2.3 \times 10^{-4}$ & 3,900 & $6.7 \times 10^{-5}$ \\
\hline SSE & 1,500 & $4.3 \times 10^{-4}$ & 4,000 & $8.6 \times 10^{-5}$ \\
\hline$S$ & 1,300 & $2.8 \times 10^{-4}$ & 3,900 & $5.0 \times 10^{-5}$ \\
\hline SSW & 1,100 & $9.8 \times 10^{-4}$ & 2,400 & $2.7 \times 10^{-4}$ \\
\hline SW & 900 & $2.3 \times 10^{-3}$ & 2,100 & $7.1 \times 10^{-4}$ \\
\hline WSW & 1,100 & $7.3 \times 10^{-4}$ & 1,800 & $3.3 \times 10^{-4}$ \\
\hline W & 1,300 & $4.8 \times 10^{-4}$ & 1,800 & $3.6 \times 10^{-4}$ \\
\hline WNW & 1,100 & $5.8 \times 10^{-4}$ & 1,700 & $2.9 \times 10^{-4}$ \\
\hline NW & 1,100 & $5.3 \times 10^{-4}$ & 1,500 & $3.2 \times 10^{-4}$ \\
\hline NNW & 900 & $8.3 \times 10^{-4}$ & 1,500 & $3.6 \times 10^{-4}$ \\
\hline
\end{tabular}

a Source term: hydrogen-3 $=30.9 \mathrm{Ci}$. 


\section{TABLE 4.15}

Maximum Perimeter and Individual Doses from Building 205 Air Emissions, 1998

(dose in $\mathrm{mrem} / \mathrm{yr}$ )

\begin{tabular}{lcc}
\hline \multicolumn{1}{c}{ Pathway } & $\begin{array}{c}\text { Perimeter } \\
(900 \mathrm{~m} \mathrm{SW})\end{array}$ & $\begin{array}{c}\text { Individual } \\
(2,100 \mathrm{~m} \mathrm{SW})\end{array}$ \\
\hline Ingestion & $5.3 \times 10^{-4}$ & $1.7 \times 10^{-4}$ \\
Inhalation & $1.7 \times 10^{-3}$ & $5.4 \times 10^{-4}$ \\
Air immersion & $-^{\mathrm{a}}$ & - \\
Ground surface & - & - \\
Total & $2.3 \times 10^{-3}$ & $7.1 \times 10^{-4}$ \\
Radionuclide & & \\
& & \\
Hydrogen-3 & $2.3 \times 10^{-3}$ & $7.1 \times 10^{-4}$ \\
\hline
\end{tabular}

a A hyphen indicates no exposure by this pathway. 
TABLE 4.16

Radiological Airborne Releases from Building 212, 1998

\begin{tabular}{lcccc}
\hline Direction & $\begin{array}{c}\text { Distance to } \\
\text { Perimeter } \\
(\mathrm{m})\end{array}$ & $\begin{array}{c}\text { Dose }^{\mathrm{a}} \\
(\mathrm{mrem} / \mathrm{yr})\end{array}$ & $\begin{array}{c}\text { Distance to Nearest } \\
\text { Resident } \\
(\mathrm{m})\end{array}$ & $\begin{array}{c}\text { Dose }^{\mathrm{a}} \\
(\mathrm{mrem} / \mathrm{yr})\end{array}$ \\
\hline N & 800 & $6.9 \times 10^{-3}$ & 2,000 & $1.7 \times 10^{-3}$ \\
NNE & 1,000 & $5.1 \times 10^{-3}$ & 2,500 & $1.2 \times 10^{-3}$ \\
NE & 1,300 & $3.0 \times 10^{-3}$ & 2,000 & $1.6 \times 10^{-3}$ \\
ENE & 1,500 & $2.3 \times 10^{-3}$ & 2,500 & $1.0 \times 10^{-3}$ \\
E & 1,600 & $2.7 \times 10^{-3}$ & 2,800 & $1.1 \times 10^{-3}$ \\
ESE & 1,200 & $3.1 \times 10^{-3}$ & 2,500 & $9.6 \times 10^{-4}$ \\
SE & 1,400 & $1.9 \times 10^{-3}$ & 3,500 & $4.4 \times 10^{-4}$ \\
SSE & 1,400 & $2.5 \times 10^{-3}$ & 4,500 & $4.1 \times 10^{-4}$ \\
S & 1,500 & $1.1 \times 10^{-3}$ & 5,000 & $1.9 \times 10^{-4}$ \\
SSW & 1,600 & $2.8 \times 10^{-3}$ & 5,000 & $5.0 \times 10^{-4}$ \\
SW & 1,400 & $5.0 \times 10^{-3}$ & 2,400 & $2.4 \times 10^{-3}$ \\
WSW & 1,300 & $2.9 \times 10^{-3}$ & 2,300 & $1.2 \times 10^{-3}$ \\
W & 1,700 & $2.0 \times 10^{-3}$ & 2,200 & $1.4 \times 10^{-3}$ \\
WNW & 1,500 & $1.7 \times 10^{-3}$ & 2,000 & $1.1 \times 10^{-3}$ \\
NW & 1,300 & $1.9 \times 10^{-3}$ & 2,000 & $1.0 \times 10^{-3}$ \\
NNW & 1,000 & $3.5 \times 10^{-3}$ & 2,000 & $1.2 \times 10^{-3}$ \\
\hline
\end{tabular}

a Source terms: hydrogen-3 (HT) $=15.20 \mathrm{Ci}$ hydrogen-3 $(\mathrm{HTO})=157.00 \mathrm{Ci}$

krypton-85 $=2.80 \mathrm{Ci}$

radon-220 $=0.16 \mathrm{Ci}$. 


\section{ENVIRONMENTAL RADIOLOGICAL PROGRAM INFORMATION}

TABLE 4.17

Maximum Perimeter and Individual Doses from Building 212 Air Emissions, 1998 (dose in mrem/yr)

\begin{tabular}{lll}
\hline \multicolumn{1}{c}{ Pathway } & $\begin{array}{c}\text { Perimeter } \\
(800 \mathrm{~m} \mathrm{~N})\end{array}$ & $\begin{array}{c}\text { Individual } \\
(2,400 \mathrm{~m} \mathrm{SW})\end{array}$ \\
\hline Ingestion & $1.6 \times 10^{-3}$ & $5.8 \times 10^{-4}$ \\
Inhalation & $5.2 \times 10^{-3}$ & $1.9 \times 10^{-3}$ \\
Air immersion & $9.3 \times 10^{-7}$ & $3.3 \times 10^{-7}$ \\
Ground surface & $3.8 \times 10^{-8}$ & $1.0 \times 10^{-8}$ \\
Total & $6.9 \times 10^{-3}$ & $2.4 \times 10^{-3}$ \\
Radionuclide & & \\
& & \\
Hydrogen-3 & $6.9 \times 10^{-3}$ & $2.4 \times 10^{-3}$ \\
Krypton-85 & $1.4 \times 10^{-6}$ & $4.9 \times 10^{-7}$ \\
Radon-220 & $2.3 \times 10^{-6}$ & $1.9 \times 10^{-8}$ \\
& & \\
Total & $6.9 \times 10^{-3}$ & $2.4 \times 10^{-3}$ \\
\hline
\end{tabular}




\section{TABLE 4.18}

Radiological Airborne Releases from Building 350, 1998

\begin{tabular}{lcccc}
\hline Direction & $\begin{array}{c}\text { Distance to } \\
\text { Perimeter } \\
(\mathrm{m})\end{array}$ & $\begin{array}{c}\text { Dose }^{\mathrm{a}} \\
(\mathrm{mrem} / \mathrm{yr})\end{array}$ & $\begin{array}{c}\text { Distance to Nearest } \\
\text { Resident } \\
(\mathrm{m})\end{array}$ & $\begin{array}{c}\text { Dose }^{\mathrm{a}} \\
(\mathrm{mrem} / \mathrm{yr})\end{array}$ \\
\hline N & 1,700 & $7.7 \times 10^{-6}$ & 2,200 & $5.4 \times 10^{-6}$ \\
NNE & 1,800 & $7.5 \times 10^{-6}$ & 3,200 & $3.2 \times 10^{-6}$ \\
NE & 2,200 & $4.9 \times 10^{-6}$ & 3,100 & $3.0 \times 10^{-6}$ \\
ENE & 2,000 & $5.5 \times 10^{-6}$ & 3,100 & $2.9 \times 10^{-6}$ \\
E & 1,700 & $8.6 \times 10^{-6}$ & 2,500 & $3.9 \times 10^{-6}$ \\
ESE & 900 & $1.5 \times 10^{-5}$ & 3,000 & $2.9 \times 10^{-6}$ \\
SE & 900 & $1.1 \times 10^{-5}$ & 3,000 & $2.5 \times 10^{-6}$ \\
SSE & 700 & $2.0 \times 10^{-5}$ & 2,700 & $3.4 \times 10^{-6}$ \\
S & 600 & $7.7 \times 10^{-6}$ & 2,700 & $1.6 \times 10^{-6}$ \\
SSW & 400 & $2.8 \times 10^{-5}$ & 2,500 & $5.3 \times 10^{-6}$ \\
SW & 600 & $3.3 \times 10^{-5}$ & 2,700 & $6.5 \times 10^{-6}$ \\
WSW & 800 & $1.6 \times 10^{-5}$ & 2,100 & $4.9 \times 10^{-6}$ \\
W & 900 & $9.4 \times 10^{-6}$ & 2,200 & $4.0 \times 10^{-6}$ \\
WNW & 1,000 & $6.7 \times 10^{-6}$ & 2,100 & $3.1 \times 10^{-6}$ \\
NW & 1,900 & $3.4 \times 10^{-6}$ & 2,400 & $2.6 \times 10^{-6}$ \\
NNW & 1,900 & $4.7 \times 10^{-6}$ & 2,200 & $3.8 \times 10^{-6}$ \\
\hline
\end{tabular}

a Source terms: uranium-234 $=5.1 \times 10^{-7} \mathrm{Ci}$ uranium-238 $=5.1 \times 10^{-7} \mathrm{Ci}$ plutonium-238 $=5.0 \times 10^{-10} \mathrm{Ci}$ plutonium-239 $=5.6 \times 10^{-9} \mathrm{Ci}$ plutonium-240 $=1.0 \times 10^{-9} \mathrm{Ci}$ plutonium-241 $=2.1 \times 10^{-8} \mathrm{Ci}$ plutonium-242 $=5.6 \times 10^{-12} \mathrm{Ci}$ plutonium-244 $=1.9 \times 10^{-15} \mathrm{Ci}$. 


\section{TABLE 4.19}

Maximum Perimeter and Individual Doses from Building 350 Air Emissions, 1998

(dose in mrem/yr)

\begin{tabular}{|c|c|c|}
\hline Pathway & $\begin{array}{c}\text { Perimeter } \\
(600 \mathrm{~m} \mathrm{SW})\end{array}$ & $\begin{array}{c}\text { Individual } \\
(2,700 \mathrm{~m} \mathrm{SW})\end{array}$ \\
\hline Ingestion & $2.5 \times 10^{-7}$ & $5.0 \times 10^{-8}$ \\
\hline Inhalation & $3.2 \times 10^{-5}$ & $6.4 \times 10^{-6}$ \\
\hline Air immersion & $2.0 \times 10^{-14}$ & $4.0 \times 10^{-15}$ \\
\hline Ground surface & $4.4 \times 10^{-9}$ & $9.0 \times 10^{-10}$ \\
\hline Total & $3.3 \times 10^{-5}$ & $6.5 \times 10^{-6}$ \\
\hline \multicolumn{3}{|l|}{ Radionuclide } \\
\hline Uranium-234 & $1.7 \times 10^{-5}$ & $3.4 \times 10^{-6}$ \\
\hline Uranium-238 & $1.5 \times 10^{-5}$ & $3.0 \times 10^{-6}$ \\
\hline Plutonium-238 & $4.0 \times 10^{-8}$ & $8.0 \times 10^{-9}$ \\
\hline Plutonium-239 & $4.8 \times 10^{-7}$ & $9.6 \times 10^{-8}$ \\
\hline Plutonium-240 & $8.6 \times 10^{-8}$ & $1.7 \times 10^{-8}$ \\
\hline Plutonium-241 & $2.8 \times 10^{-8}$ & $5.5 \times 10^{-9}$ \\
\hline Plutonium-242 & $4.6 \times 10^{-10}$ & $9.1 \times 10^{-11}$ \\
\hline Plutonium-244 & $1.6 \times 10^{-13}$ & $3.1 \times 10^{-14}$ \\
\hline Total & $3.3 \times 10^{-5}$ & $6.5 \times 10^{-6}$ \\
\hline
\end{tabular}


Building 375 (Tables 4.20 and 4.21), and Building 411 (Tables 4.22 and 4.23). The doses given in these tables are the committed whole body effective dose equivalents.

A significant D\&D program was completed for the M-Wing hot cells in Building 200, which constituted the source of the radon-220 emissions. Cleanup of the major source of the radon-220, cell M-1, was completed in 1995 . This has resulted in a decrease of radon-220 emissions: 3,000 $\mathrm{Ci}$ in $1992 ; 2,023 \mathrm{Ci}$ in $1993 ; 1,750 \mathrm{Ci}$ in $1994 ; 1,033 \mathrm{Ci}$ in 1995; $388 \mathrm{Ci}$ in 1996; 286.6 $\mathrm{Ci}$ in 1997; and $239.2 \mathrm{Ci}$ in 1998. The present radon-220 emissions will be reduced because of the termination of the nuclear medical program that separates radium-224 from the thorium-228 parent and continued D\&D of other cells.

In the past, the dominant emission source was radon-220 from Building 200. However, with the D\&D of the M-Wing hot cells, the residual emissions from Building 200 account for only $19 \%$ of the off-site dose, while the IPNS facility in Building 375 accounts for $77 \%$ of the dose. The remainder of the emissions account for the other $4 \%$. The highest perimeter dose was in the southwest direction with a maximum dose of $0.18 \mathrm{mrem} / \mathrm{yr}$ (location $7 \mathrm{H}$ in Figure 1.1). The major component of this dose is air immersion of carbon-11 $(0.16 \mathrm{mrem} / \mathrm{yr})$. The completion of the D\&D activities in Building 200 and the subsequent reduction in radon-220 emissions resulted in a shift of the maximum perimeter dose from the north to the south. The major contributors to this perimeter dose are emissions from the IPNS in Building 375.

The full-time resident who would receive the largest annual dose $(0.027 \mathrm{mrem} / \mathrm{yr})$ is located approximately $0.8 \mathrm{~km}(0.5 \mathrm{mi})$ north-northwest of the site boundary. The major contributor to the whole body dose is the inhalation dose from lead-212 $(0.011 \mathrm{mrem} / \mathrm{yr})$. If radon-220 plus daughters were excluded from the calculation, as required by NESHAP, ${ }^{17}$ the maximally exposed resident would receive a dose of $0.016 \mathrm{mrem} / \mathrm{yr}$, primarily carbon-11 from the IPNS facility (Building 375).

The individual doses to the maximally exposed member of the public and the maximum fence line dose are shown in Figure 4.5. The decrease in individual and population doses since 
TABLE 4.20

Radiological Airborne Releases from Building 375 (IPNS), 1998

\begin{tabular}{lcccc}
\hline & $\begin{array}{c}\text { Distance to } \\
\text { Perimeter } \\
(\mathrm{m})\end{array}$ & $\begin{array}{c}\text { Dose }^{\mathrm{a}} \\
(\mathrm{mrem} / \mathrm{yr})\end{array}$ & $\begin{array}{c}\text { Distance to Nearest } \\
\text { Resident } \\
(\mathrm{m})\end{array}$ & $\begin{array}{c}\text { Dose }^{\mathrm{a}} \\
(\mathrm{mrem} / \mathrm{yr})\end{array}$ \\
\hline Nirection & 1,600 & $2.8 \times 10^{-2}$ & 3,200 & $7.6 \times 10^{-3}$ \\
NNE & 1,700 & $2.9 \times 10^{-2}$ & 3,100 & $8.6 \times 10^{-3}$ \\
NE & 1,700 & $2.6 \times 10^{-2}$ & 2,700 & $9.9 \times 10^{-3}$ \\
ENE & 1,500 & $2.7 \times 10^{-2}$ & 2,500 & $1.0 \times 10^{-2}$ \\
E & 600 & $1.6 \times 10^{-1}$ & 2,500 & $1.5 \times 10^{-2}$ \\
ESE & 600 & $1.2 \times 10^{-1}$ & 2,500 & $1.0 \times 10^{-2}$ \\
SE & 600 & $8.8 \times 10^{-2}$ & 2,500 & $7.4 \times 10^{-3}$ \\
SSE & 600 & $1.3 \times 10^{-1}$ & 3,000 & $7.1 \times 10^{-3}$ \\
S & 800 & $3.6 \times 10^{-2}$ & 3,000 & $3.7 \times 10^{-3}$ \\
SSW & 800 & $1.0 \times 10^{-1}$ & 3,500 & $7.0 \times 10^{-3}$ \\
SW & 800 & $1.4 \times 10^{-1}$ & 4,000 & $6.6 \times 10^{-3}$ \\
WSW & 1,500 & $2.7 \times 10^{-2}$ & 2,700 & $9.2 \times 10^{-3}$ \\
W & 2,200 & $1.5 \times 10^{-2}$ & 2,700 & $9.5 \times 10^{-3}$ \\
WNW & 1,500 & $1.9 \times 10^{-2}$ & 2,600 & $7.3 \times 10^{-3}$ \\
NW & 2,200 & $8.8 \times 10^{-3}$ & 2,500 & $6.9 \times 10^{-3}$ \\
NNW & 1,800 & $1.5 \times 10^{-2}$ & 2,200 & $1.0 \times 10^{-2}$ \\
\hline & & & &
\end{tabular}

a Source terms: carbon-11 $=564.8 \mathrm{Ci}$ argon- $41=8.4 \mathrm{Ci}$. 
TABLE 4.21

\begin{tabular}{|c|c|c|}
\hline \multicolumn{3}{|c|}{$\begin{array}{c}\text { Maximum Perimeter and Individual Doses from } \\
\text { Building } 375 \text { (IPNS) Air Emissions, } 1998 \\
\text { (dose in mrem/yr) }\end{array}$} \\
\hline Pathway & $\begin{array}{l}\text { Perimeter } \\
(600 \mathrm{~m} \mathrm{E})\end{array}$ & $\begin{array}{l}\text { Individual } \\
(2,400 \mathrm{~m} \mathrm{E})\end{array}$ \\
\hline Ingestion & $-{ }^{a}$ & - \\
\hline Inhalation & $6.7 \times 10^{-3}$ & $6.4 \times 10^{-4}$ \\
\hline Air immersion & $1.4 \times 10^{-1}$ & $1.4 \times 10^{-2}$ \\
\hline Ground surface & $5.7 \times 10^{-3}$ & $6.4 \times 10^{-4}$ \\
\hline Total & $1.6 \times 10^{-1}$ & $1.5 \times 10^{-2}$ \\
\hline \multicolumn{3}{|l|}{ Radionuclide } \\
\hline Carbon-11 & $1.6 \times 10^{-1}$ & $1.5 \times 10^{-2}$ \\
\hline Argon-41 & $2.9 \times 10^{-3}$ & $3.3 \times 10^{-4}$ \\
\hline Total & $1.6 \times 10^{-1}$ & $1.5 \times 10^{-2}$ \\
\hline
\end{tabular}

a A hyphen indicates no exposure by this pathway. 


\section{TABLE 4.22}

Radiological Airborne Releases from Building 411/415 (APS), 1998

\begin{tabular}{|c|c|c|c|c|}
\hline Direction & $\begin{array}{l}\text { Distance to } \\
\text { Perimeter } \\
\text { (m) }\end{array}$ & $\begin{array}{c}\text { Dose }^{\mathrm{a}} \\
(\mathrm{mrem} / \mathrm{yr})\end{array}$ & $\begin{array}{c}\text { Distance to } \\
\text { Nearest Resident } \\
\text { (m) }\end{array}$ & $\begin{array}{c}\text { Dose }^{\mathrm{a}} \\
\text { (mrem/yr) }\end{array}$ \\
\hline $\mathrm{N}$ & 1,500 & $1.8 \times 10^{-4}$ & 2,000 & $9.9 \times 10^{-5}$ \\
\hline NNE & 1,600 & $1.7 \times 10^{-4}$ & 2,100 & $9.6 \times 10^{-5}$ \\
\hline $\mathrm{NE}$ & 2,200 & $7.7 \times 10^{-5}$ & 3,100 & $3.6 \times 10^{-5}$ \\
\hline ENE & 2,500 & $5.2 \times 10^{-5}$ & 3,300 & $2.8 \times 10^{-5}$ \\
\hline$E$ & 1,600 & $1.8 \times 10^{-4}$ & 3,400 & $3.0 \times 10^{-5}$ \\
\hline ESE & 1,500 & $1.6 \times 10^{-4}$ & 3,500 & $2.1 \times 10^{-5}$ \\
\hline SE & 400 & $1.3 \times 10^{-3}$ & 3,000 & $2.4 \times 10^{-5}$ \\
\hline SSE & 400 & $1.9 \times 10^{-3}$ & 3,000 & $3.2 \times 10^{-5}$ \\
\hline$S$ & 350 & $1.0 \times 10^{-3}$ & 2,500 & $2.6 \times 10^{-5}$ \\
\hline SSW & 400 & $2.4 \times 10^{-3}$ & 2,800 & $4.9 \times 10^{-5}$ \\
\hline SW & 550 & $1.8 \times 10^{-3}$ & 3,000 & $5.0 \times 10^{-5}$ \\
\hline WSW & 800 & $5.4 \times 10^{-4}$ & 1,400 & $1.8 \times 10^{-4}$ \\
\hline W & 800 & $5.4 \times 10^{-4}$ & 1,500 & $1.6 \times 10^{-4}$ \\
\hline WNW & 500 & $8.4 \times 10^{-4}$ & 1,400 & $1.3 \times 10^{-4}$ \\
\hline NW & 350 & $1.3 \times 10^{-3}$ & 1,600 & $8.7 \times 10^{-5}$ \\
\hline NNW & 1,500 & $1.2 \times 10^{-4}$ & 2,000 & $6.5 \times 10^{-5}$ \\
\hline a Source terms: & $\begin{array}{l}\text { carbon-11 } \\
\text { nitrogen-13 } \\
\text { oxygen-15 }\end{array}$ & $\begin{array}{l}=0.08 \mathrm{Ci} \\
=3.72 \mathrm{Ci} \\
=0.40 \mathrm{Ci}\end{array}$ & & \\
\hline
\end{tabular}


TABLE 4.23

Maximum Perimeter and Individual Doses

from Building 411/415 (APS) Air Emissions, 1998

(dose in $\mathrm{mrem} / \mathrm{yr}$ )

\begin{tabular}{lcc}
\hline \multicolumn{1}{c}{ Pathway } & $\begin{array}{c}\text { Perimeter } \\
(400 \mathrm{~m} \mathrm{SSW})\end{array}$ & $\begin{array}{c}\text { Individual } \\
(1,400 \mathrm{~m} \mathrm{WSW})\end{array}$ \\
\hline Ingestion & $-^{\mathrm{a}}$ & - \\
Inhalation & $7.0 \times 10^{-5}$ & $5.4 \times 10^{-6}$ \\
Air immersion & $2.3 \times 10^{-3}$ & $1.7 \times 10^{-4}$ \\
Ground surface & $4.1 \times 10^{-5}$ & $3.6 \times 10^{-6}$ \\
Total & & \\
& $2.4 \times 10^{-3}$ & $1.8 \times 10^{-4}$ \\
Radionuclide & & \\
Carbon-11 & $5.3 \times 10^{-5}$ & $4.5 \times 10^{-6}$ \\
$\quad$ Nitrogen-13 & $2.2 \times 10^{-3}$ & $1.7 \times 10^{-4}$ \\
Oxygen-15 & $1.5 \times 10^{-4}$ & $5.5 \times 10^{-6}$ \\
Total & & \\
\hline
\end{tabular}

a A hyphen indicates no exposure by this pathway. 


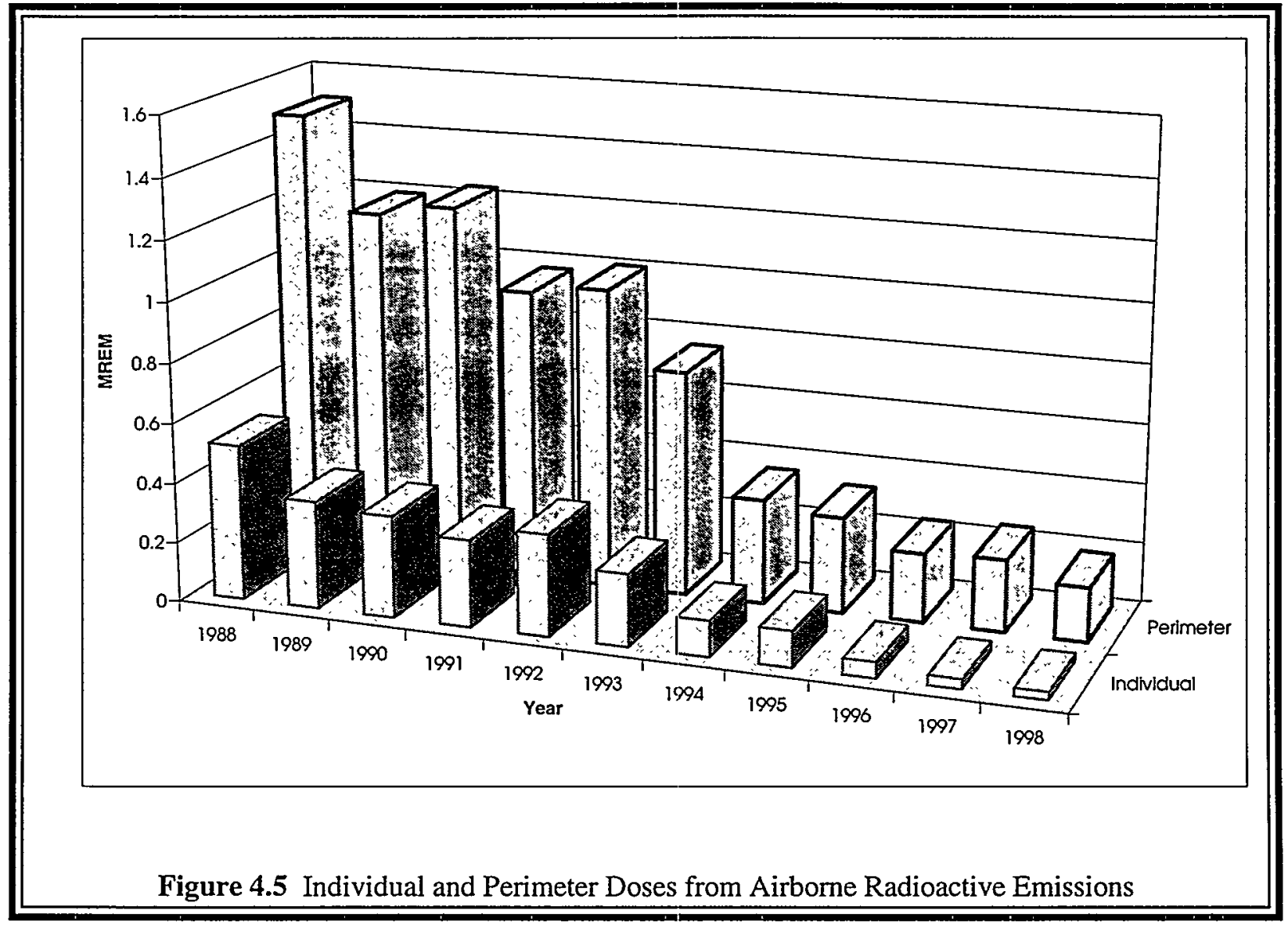

1988 are due in part to the decrease of radon-220 emissions as a result of the cleanup of the Building $200 \mathrm{M}$-Wing hot cells.

The population data in Table 1.1 were used to calculate the cumulative population dose from gaseous radioactive effluents from ANL-E operations. The results are given in Table 4.24, along with the natural external radiation dose. The natural radiation dose listed is the product of the $80-\mathrm{km}(50-\mathrm{mi})$ population and the natural radiation dose of $300 \mathrm{mrem} / \mathrm{yr}{ }^{18}$ It is assumed that this dose is representative of the entire area within an $80-\mathrm{km}(50-\mathrm{mi})$ radius. The population dose resulting from ANL-E operations since 1987 is shown in Figure 4.6.

The potential radiation exposures by the inhalation pathways also were calculated by the methodology specified in DOE Order 5400.5. ${ }^{11}$ The total quantity for each radionuclide inhaled, in microcuries $(\mu \mathrm{Ci})$, is calculated by multiplying the annual average air concentrations by the 
TABLE 4.24

\begin{tabular}{lr}
\multicolumn{2}{c}{ Population Dose within $80 \mathrm{~km}, 1998$} \\
\hline \multicolumn{1}{c}{ Radionuclide } & Man-rem \\
\hline Hydrogen-3 & 0.37 \\
Carbon-11 & 0.70 \\
Nitrogen-13 & $<0.01$ \\
Oxygen-15 & $<0.01$ \\
Argon-41 & 0.05 \\
Krypton-85 & $<0.01$ \\
Thallium-208 & $<0.01$ \\
Lead-212 & 0.55 \\
Bismuth-212 & 0.06 \\
Radon-220 & $<0.01$ \\
Uranium-234 & $<0.01$ \\
Uranium-238 & $<0.01$ \\
Plutonium-238 & $<0.01$ \\
Plutonium-239 & $<0.01$ \\
Plutonium-240 & $<0.01$ \\
Plutonium-241 & $<0.01$ \\
Plutonium-242 & $<0.01$ \\
Plutonium-244 & $<0.01$ \\
Total & 1.69 \\
Natural & $2.5 \times 10^{6}$ \\
\hline &
\end{tabular}

general public breathing rate of $8,400 \mathrm{~m}^{3} / \mathrm{yr} .{ }^{19}$ This annual intake is then multiplied by the CEDE for the appropriate lung retention class. ${ }^{11}$ Because the $\mathrm{CEDE}$ factors are in units of $\mathrm{rem} / \mu \mathrm{Ci}$, this calculation gives the 50-year CEDE. Table 4.25 lists the applicable CEDE factors.

The calculated doses in Tables 4.2 and 4.3 were derived by using this procedure. Because they are all essentially at perimeter locations, these doses represent the fence line values for those radionuclides measured. In most cases, these doses also are the same as the off-site measurements and represent the ambient dose for the area from these nuclides. No doses were calculated for the total alpha and total beta measurements because the guidance does not provide CEDE factors for such measurements. 


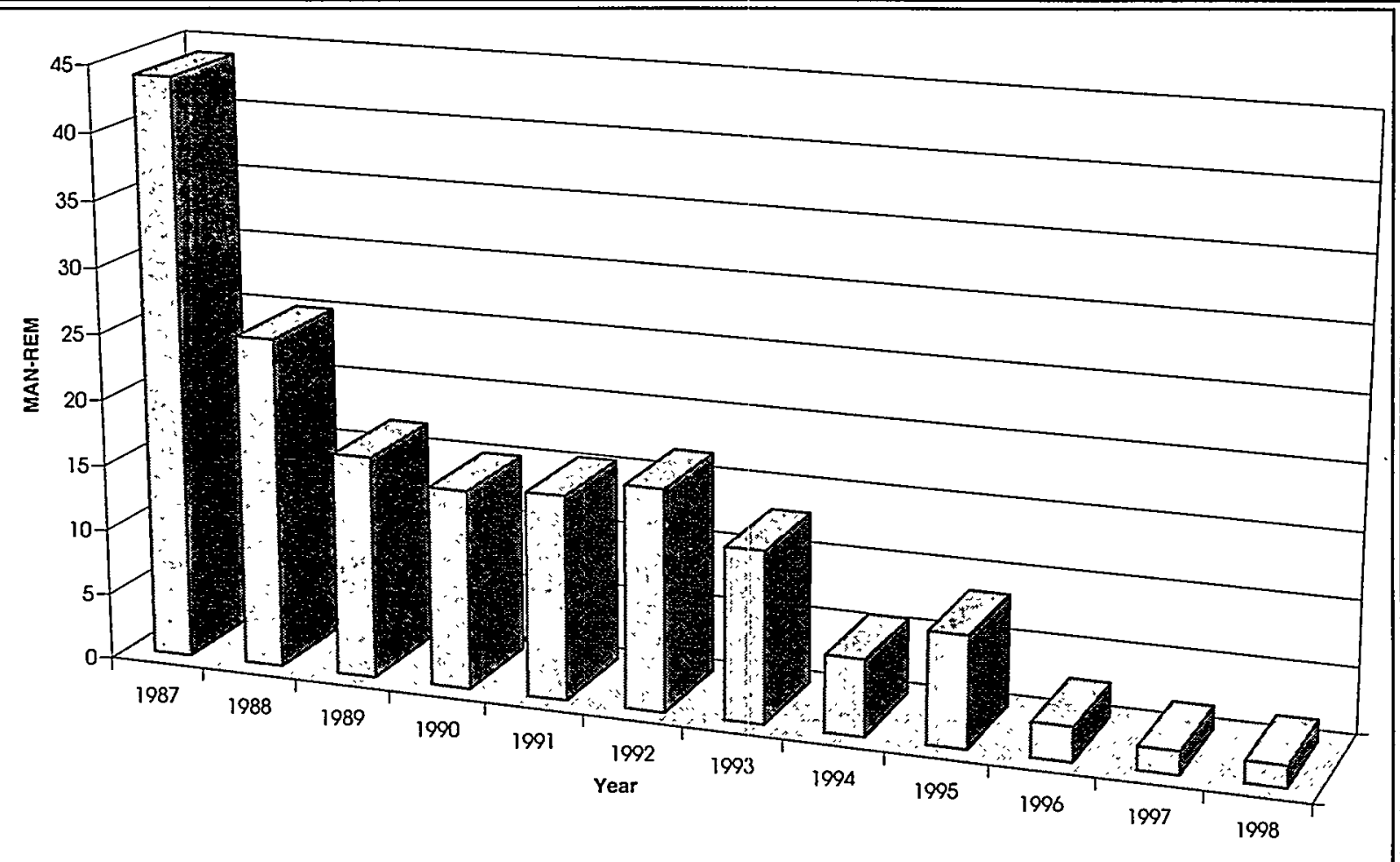

Figure 4.6 Population Dose from Airborne Radioactive Emissions

\subsubsection{Water Pathway}

Following the methodology outlined in DOE Order $5400.5,{ }^{11}$ the annual intake of radionuclides (in $\mu \mathrm{Ci}$ ) ingested with water is obtained by multiplying the concentration of radionuclides in microcuries per milliliter $(\mu \mathrm{Ci} / \mathrm{mL})$ by the average annual water consumption of a member of the general public $\left(7.3 \times 10^{5} \mathrm{~mL}\right)$. This annual intake is then multiplied by the CEDE factor for ingestion (Table 4.25) to obtain the dose received in that year. This procedure was carried out for all radionuclides, and the individual results were summed to obtain the total ingestion dose.

The only significant location where radionuclides attributable to ANL-E operations could be found in off-site water was Sawmill Creek below the wastewater outfall (see Table 4.5). Although this water is not used for drinking purposes, the 50-year effective dose equivalent was calculated 


\section{TABLE 4.25}

\begin{tabular}{|c|c|c|}
\hline Nuclide & Ingestion & Inhalation \\
\hline Hydrogen-3 & $6.3 \times 10^{-5}$ & $9.6 \times 10^{-5}$ \\
\hline Beryllium-7 & $-\mathrm{a}$ & $2.7 \times 10^{-4}$ \\
\hline Carbon-11 & - & $8.0 \times 10^{-6}$ \\
\hline Strontium-90 & 0.13 & 1.32 \\
\hline Cesium-137 & 0.05 & 0.032 \\
\hline Lead-210 & - & 13.2 \\
\hline Radium-226 & 1.1 & - \\
\hline Thorium-228 & - & 310 \\
\hline Thorium-230 & - & 260 \\
\hline Thorium-232 & - & 1,100 \\
\hline Uranium-234 & 0.26 & 130 \\
\hline Uranium-235 & 0.25 & 120 \\
\hline Uranium-238 & 0.23 & 120 \\
\hline Neptunium-237 & 3.90 & - \\
\hline Plutonium-238 & 3.80 & - \\
\hline Plutonium-239 & 4.30 & 330 \\
\hline Americium-241 & 4.50 & - \\
\hline Curium-242 & 0.11 & - \\
\hline Curium-244 & 2.30 & - \\
\hline Californium-249 & 4.60 & - \\
\hline Californium-252 & 0.94 & - \\
\hline
\end{tabular}

a A hyphen indicates value not required.

for a hypothetical individual ingesting water at the radionuclide concentrations measured at that location. Those radionuclides added to Sawmill Creek by ANL-E wastewater, their net concentrations in the creek, and the corresponding dose rates (if water at these concentrations were used as the sole water supply by an individual) are given in Table 4.26. The dose rates were all well below the standards for the general population. It should be emphasized that Sawmill Creek is not used for drinking, swimming, or boating. Inspection of the area shows that there are fish in the stream; however, they do not constitute a significant source of food for any individual. 


\section{ENVIRONMENTAL RADIOLOGICAL PROGRAM INFORMATION}

TABLE 4.26

Radionuclide Concentrations and Dose Estimates

for Sawmill Creek Water, 1998

\begin{tabular}{lccc}
\hline & $\begin{array}{c}\text { Total Released } \\
(\mathrm{Ci})\end{array}$ & $\begin{array}{c}\text { Net Avg. } \\
\text { Concentration } \\
(\mathrm{pCi} / \mathrm{L})\end{array}$ & $\begin{array}{c}\text { Dose } \\
(\mathrm{mrem})\end{array}$ \\
\hline Hydrogen-3 & 1.264 & 80 & 0.0037 \\
Strontium-90 & 0.0035 & 0.22 & 0.0209 \\
Plutonium-239 & 0.000006 & 0.0004 & 0.0001 \\
Americium-241 & 0.00004 & 0.0029 & 0.0009 \\
& & & 0.0256 \\
\hline
\end{tabular}

Figure 4.7 is a plot of the estimated dose an individual would receive if ingesting Sawmill Creek water.

As indicated in Table 4.5, occasional Sawmill Creek samples (fewer than 10\%) contained traces of cesium-137, plutonium-238, curium-242 and 244, or californium-249 and 252; however, the averages were only slightly greater than the detection limit. The annual dose to an individual consuming water at these concentrations can be calculated with the same method used for those radionuclides more commonly found in creek water; this method of averaging, however, probably overestimates the true concentration. Annual doses range from $3 \times 10^{-3}$ to $6 \times 10^{-5} \mathrm{mrem} / \mathrm{yr}$ for these radionuclides.

DOE Order $5400.5^{11}$ requires an evaluation of the dose to aquatic organisms from liquid effluents. The dose limit is $1 \mathrm{rad} /$ day or $365 \mathrm{rad} / \mathrm{yr}$. The location that could result in the highest dose to aquatic organisms is in Sawmill Creek downstream of the point where ANL-E discharges its treated wastewater. Inspection of the creek at this location indicates the presence of small bluegill and carp (about $100 \mathrm{~g}$ [4 oz] each). A dose can be estimated by using the annual average concentrations of the radionuclides listed in Table 4.5. The sum of the exposure from these radionuclides is estimated to be about $4 \times 10^{-6} \mathrm{rad} / \mathrm{yr}$, which is well within the DOE standard. This value, therefore, demonstrates compliance with that portion of the order. 


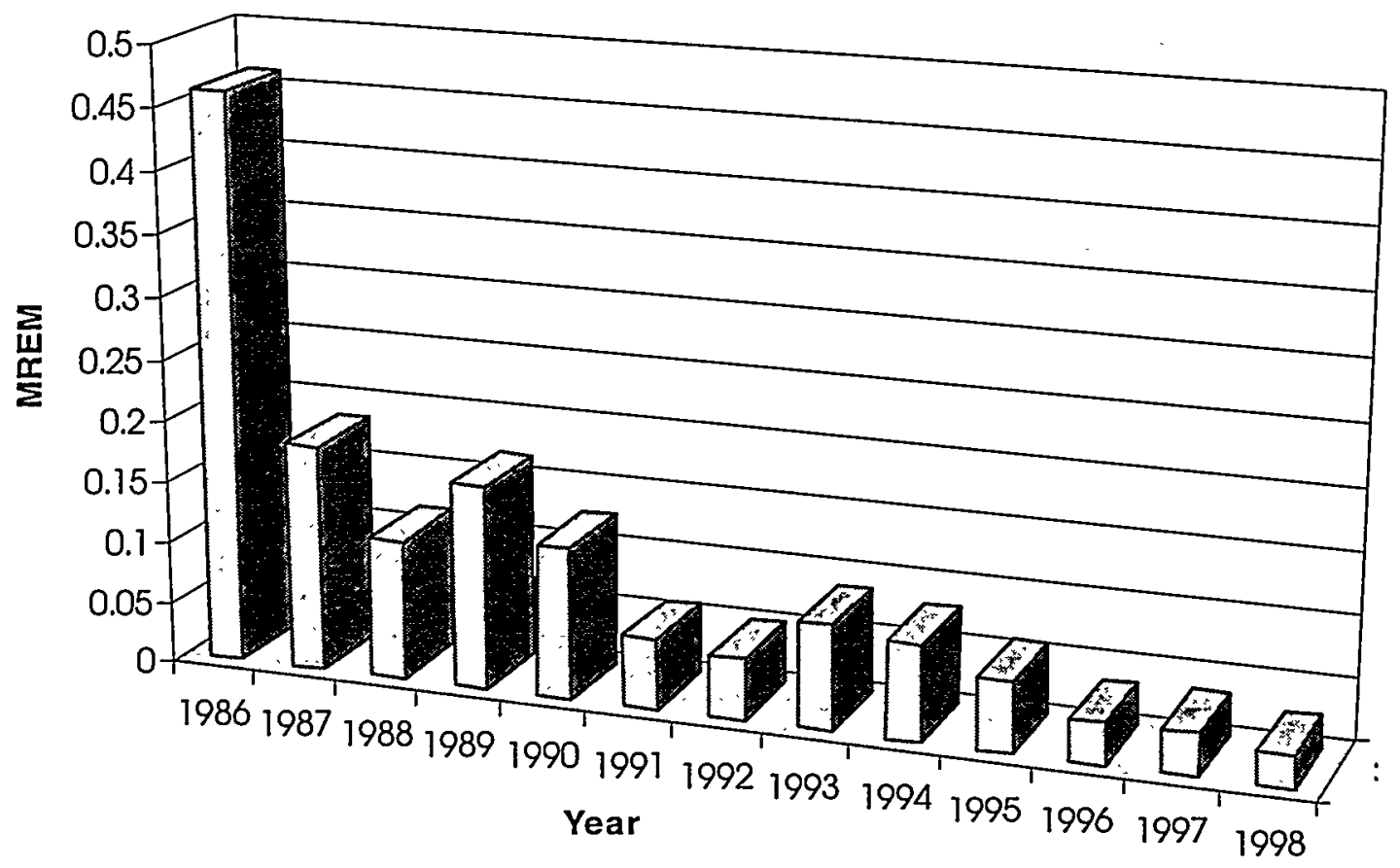

Figure 4.7 Comparison of Dose Estimate from Ingestion of Sawmill Creek Water

The EPA has established drinking water standards on the basis of a maximum dose of $4 \mathrm{mrem} / \mathrm{yr}$ for man-made beta particle and photon-emitting radionuclides. ${ }^{20}$ The EPA standard is $2 \times 10^{4} \mathrm{pCi} / \mathrm{L}$ for hydrogen- 3 and $8 \mathrm{pCi} / \mathrm{L}$ for strontium- 90 . The net concentrations in Table 4.26 correspond to $0.40 \%$ (hydrogen- 3 ) and $2.8 \%$ (strontium- 90 ) of the EPA standards. No specific EPA standards exist for the transuranic nuclides.

Sawmill Creek flows into the Des Plaines River. The flow rate of Sawmill Creek (see Section 1.6) is about $0.28 \mathrm{~m}^{3} / \mathrm{s}\left(10 \mathrm{ft}^{3} / \mathrm{s}\right)$; the flow rate of the Des Plaines River in the vicinity of ANL-E is about $25 \mathrm{~m}^{3} / \mathrm{s}\left(900 \mathrm{ft}^{3} / \mathrm{s}\right)$. Applying this ratio to the concentration of radionuclides in Sawmill Creek listed in Table 4.26, the dose to a hypothetical individual ingesting water from the Des Plaines River at Lemont would be about $0.0003 \mathrm{mrem} / \mathrm{yr}$. Significant additional dilution occurs further downstream. Very few people, either directly or indirectly, use the 
Des Plaines River as a source of drinking water. If 100 people used Des Plaines River water at the hypothetical concentration at Lemont, the estimated population dose would be about $10^{-5}$ man-rem.

\subsubsection{External Direct Radiation Pathway}

The TLD measurements given in Section 4.5 were used to calculate the radiation dose from external sources. Above-normal fence line doses attributable to ANL-E operations were found at the southern boundary near the Waste Storage Facility (Location 7I).

At Location 7I, the fence line dose from ANL-E was approximately $106 \pm 10 \mathrm{mrem} / \mathrm{yr}$. Approximately $300 \mathrm{~m}$ (960 ft) south of the fence line (grid 61), the measured dose was $89 \pm 8 \mathrm{mrem} / \mathrm{yr}$, slightly higher than the off-site average ( $80 \pm 3 \mathrm{mrem} / \mathrm{yr})$. No individuals live in this area. The closest residents are about $1.6 \mathrm{~km}(1 \mathrm{mi})$ south of the fence line. At this distance, the calculated dose rate from the Waste Storage Facility was $0.001 \mathrm{mrem} / \mathrm{yr}$, if the energy of the radiation were that of a $0.66-\mathrm{MeV}$ cesium- 137 gamma-ray, and approximately $0.003 \mathrm{mrem} / \mathrm{yr}$, if the energy were that of a $1.33-\mathrm{MeV}$ cobalt- 60 gamma-ray.

At the fence line, where higher doses were measured, the land is wooded and unoccupied. All of these dose calculations are based on full-time, outdoor exposure. Actual exposures to individuals would be substantially less because some of the individuals are indoors (which provides shielding) or away from their dwellings for part of the time.

In addition to the permanent resident in the area, occasionally visitors may conduct activities around ANL-E that could result in exposure to radiation from this site. Examples of these activities could be cross-country skiing, horseback riding, or running in the fire lane next to the perimeter fence. If the individual spent 10 minutes per week adjacent to the 317 Area, the dose would be $0.003 \mathrm{mrem} / \mathrm{yr}$ at the 317 Area fence (location 7I) from ANL-E operations. 


\section{ENVIRONMENTAL RADIOLOGICAL PROGRAM INFORMATION}

\subsubsection{Dose Summary}

The total effective dose equivalent received by off-site residents during 1998 was a combination of the individual doses received through the separate pathways. Radionuclides that contributed through the air pathway are hydrogen-3, carbon-11, nitrogen-13, oxygen-15, argon-41, krypton-85, radon-220 (plus daughters), and actinides. The highest dose was approximately $0.027 \mathrm{mrem} / \mathrm{yr}$ to individuals living north of the site if they were outdoors at that location during the entire year. The total annual population dose to the entire area within an $80-\mathrm{km}(50-\mathrm{mi})$ radius was 1.69 man-rem. The dose pathways are presented in Table 4.27 and compared with the applicable standards.

To receive the maximum public dose, an individual would need to live north of the site at the point of maximum air and direct radiation exposure and use only water from Sawmill Creek below the ANL-E wastewater outfall. This is a very conservative and unlikely situation. To put the maximum individual dose of $0.063 \mathrm{mrem} / \mathrm{yr}$ attributable to ANL-E operations into perspective, comparisons can be made with annual average doses received by the public from natural or accepted sources of radiation. These values are listed in Table 4.28. The magnitude of the doses received from ANL-E operations is insignificant compared with these sources. Therefore, the monitoring program results establish that the radioactive emissions from ANL-E are very low and do not endanger the health or safety of those living in the vicinity of the site.

\section{TABLE 4.27}

Summary of the Estimated Dose to the Public, 1998 (mrem/yr)

\begin{tabular}{|c|c|c|}
\hline Pathway & ANL-E Estimate & Applicable Standard \\
\hline Air (less radon) & 0.016 & 10 (EPA) \\
\hline Air total & 0.027 & 100 (DOE) \\
\hline Water & 0.026 & 100 (DOE) \\
\hline Direct radiation & 0.010 & 100 (DOE) \\
\hline Maximum public & 0.063 & 100 (DOE) \\
\hline
\end{tabular}


TABLE 4.28

Annual Average Dose Equivalent in the U.S. Population ${ }^{\mathrm{a}}$

\begin{tabular}{lc}
\hline \multicolumn{1}{c}{ Source } & $\begin{array}{c}\text { Dose } \\
\text { (mrem) }\end{array}$ \\
\hline Natural & \\
Radon & 200 \\
Internal (potassium-40 and radium-226) & 39 \\
Cosmic & 28 \\
Terrestrial & 28 \\
Medical & \\
Diagnostic X-rays & 39 \\
Nuclear medicine & 14 \\
Consumer Products & \\
Domestic water supplies, & 10 \\
$\quad$ building materials, etc. & \\
Occupational (medical radiology, industrial & \\
radiography, research, etc.) & 1 \\
Nuclear fuel cycle & $<1$ \\
Fallout & $<1$ \\
Other miscellaneous sources & $<1$ \\
Total & 360 \\
\hline
\end{tabular}

a National Council on Radiation Protection and Measurements Report No. $93 .^{18}$ 


\section{ENVIRONMENTAL NONRADIOLOGICAL PROGRAM INFORMATION}

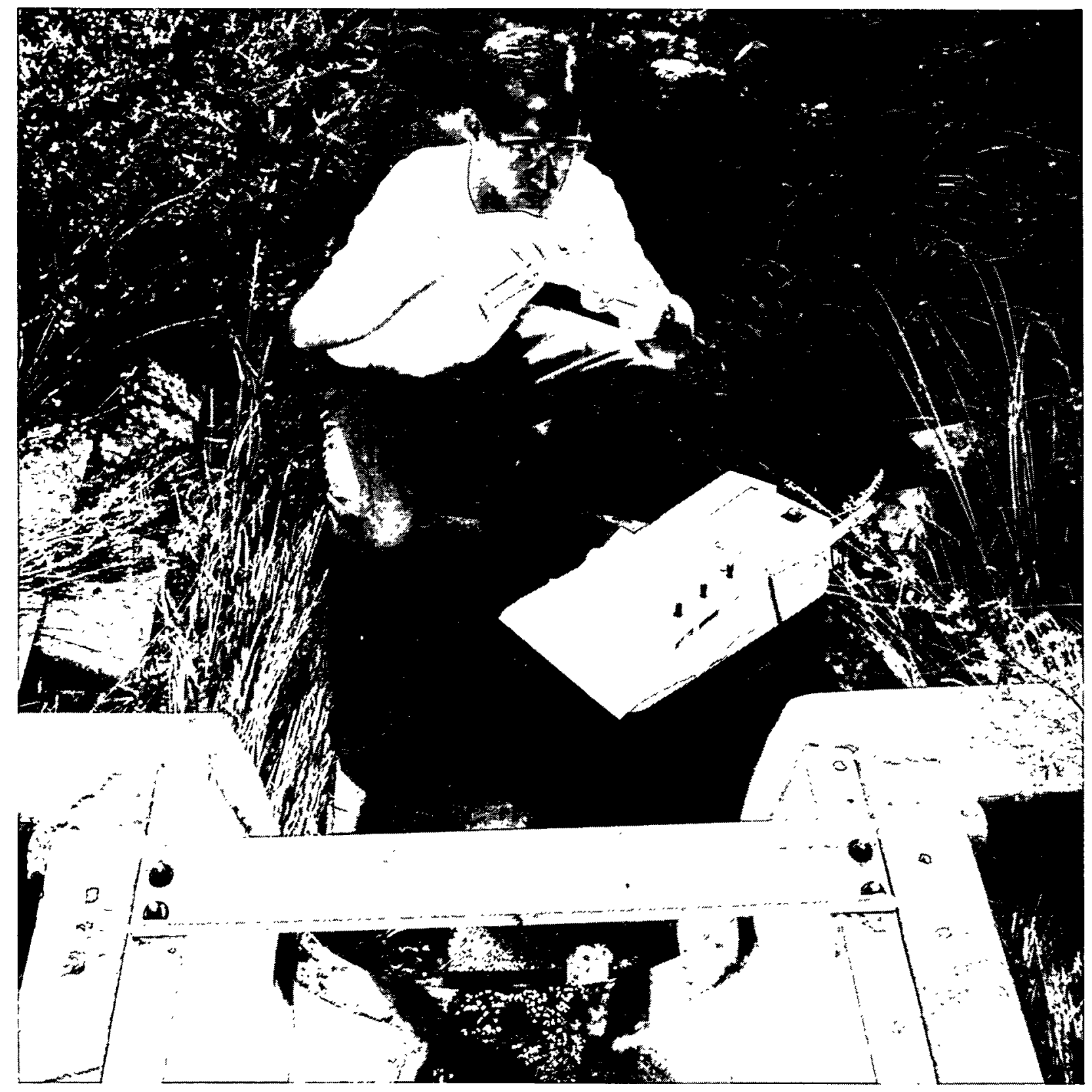




\section{ENVIRONMENTAL NONRADIOLOGICAL PROGRAM INFORMATION}

The nonradiological monitoring program involves the collection and analysis of surface water and groundwater samples from numerous locations throughout the site. The amount of nonradiological pollutants released to the air from ANL-E is extremely small, except for the boiler house, which is equipped with dedicated monitoring equipment for sulfur dioxide and opacity. One exceedance for opacity was noted during 1998 over a period of 1,900 hours of coal-burning operation of Boiler No. 5, the coal-burning boiler. Chapter 3 provides a detailed discussion of the environmental monitoring program.

Surface water samples for nonradiological chemical analyses are collected from NPDESpermitted outfalls and Sawmill Creek. ${ }^{21}$ Analyses conducted on the samples from the NPDES outfalls vary, depending on the permit-mandated monitoring requirements for each outfall. The results of the analyses are compared with the permit limits for each outfall to determine whether they comply with the permit. In addition to being published in this report, the NPDES monitoring results are transmitted monthly to the IEPA in an official DMR.

In addition to the permit-required monitoring, other analyses are conducted on samples collected from the combined wastewater outfall (NPDES Outfall 001) to provide a more complete evaluation of the impact of the wastewater on the environment. Water samples from Sawmill Creek are also collected and analyzed for a number of inorganic constituents. The results of these additional analyses of the main outfall and receiving streams are then compared with IEPA General Effluent Standards and Stream Quality Standards listed in IAC, Title 35, Subtitle C, Chapter I. ${ }^{22}$

\subsection{National Pollutant Discharge Elimination System Monitoring Results}

\subsubsection{Influent Monitoring}

Since 1989 , analyses of the laboratory wastewater influent have shown the presence of a variety of VOCs with variable concentrations. Although the practice is not authorized, it is suspected that limited quantities of VOCs are disposed of in the laboratory drain through 


\section{ENVIRONMENTAL NONRADIOLOGICAL PROGRAM INFORMATION}

laboratory sinks located throughout the site. In addition, VOCs are known to be discharged into the laboratory sewer from the 317/319 Lift Station, which pumps contaminated groundwater generated by ANL-E's RCRA corrective actions. The results of the analysis of laboratory wastewater influent are shown in Table 5.1.

The 1998 results for laboratory influent wastewater are quite similar to those for 1997. Table 5.1 shows the 1998 results for the most common compounds detected. Bromoform, bromodichloromethane, chloroform, and dibromachloromethane are halomethanes that are produced as the result of contact of the chlorinated water supply with organic chemicals. Research activity probably accounts for the presence of other volatiles.

Historically, the more persistent VOCs were consistently noted but at lower ranges of concentration. Acetone was detected in 11 samples, and levels ranged up to $76 \mu \mathrm{g} / \mathrm{L}$, which is substantially lower than the 1997 maximum value of $599 \mu \mathrm{g} / \mathrm{L}$. Infrequent trace levels of other

\section{TABLE 5.1}

Laboratory Influent Wastewater, 1998

(concentrations in $\mu \mathrm{g} / \mathrm{L}$ )

\begin{tabular}{lccccc}
\hline \multicolumn{1}{c}{ Month } & Acetone & Chloroform & $\begin{array}{c}\text { Bromodi- } \\
\text { chloroethane }\end{array}$ & $\begin{array}{c}\text { Dibromo- } \\
\text { chloromethane }\end{array}$ & Bromoform \\
\hline January & 17 & 4 & 4 & 3 & $<1$ \\
February & 2 & 3 & 3 & 2 & $<1$ \\
March & 53 & 8 & 4 & 3 & $<1$ \\
April & $<1$ & 4 & 3 & 2 & $<1$ \\
May & 46 & 20 & 4 & 9 & 12 \\
June & 8 & 7 & 9 & 15 & 14 \\
July & 29 & 12 & 3 & 12 & 35 \\
August & 14 & 74 & 3 & 3 & 9 \\
September & 76 & 11 & 3 & 6 & 8 \\
October & 36 & 5 & 3 & 7 & 5 \\
November & 22 & 5 & 6 & 9 & 26 \\
December & 72 & 7 & 18 & 29 & \\
\hline
\end{tabular}




\section{ENVIRONMENTAL NONRADIOLOGICAL PROGRAM INFORMATION}

chemicals, that is, acetaldehyde, 2-butanone, carbon tetrachloride, ethyl ether, ethanol, isopropyltoluene, methylene chloride, trichloroethene, and 1,1,1-trichloroethane, were also noted.

Figures 5.1 and 5.2 present comparisons of the 1992 through 1998 laboratory influent wastewater results for the two more persistent VOCs. The persistent presence of acetone is likely due to laboratory activities such as rinsing glassware. Disposing of chemicals down laboratory drains is not authorized at ANL-E. ANL-E conducts a waste generator education program as part of its site safety awareness training program, in which proper handling and disposal of chemicals are explained.

\subsubsection{Effluent Monitoring}

Effluent samples are collected from ANL-E point source discharges (outfalls) as specified by the NPDES permit. The permit specifies the frequency of sample collection and the specific parameters to be monitored for each individual outfall. Sample collection, preservation, holding times, and analytical methods are specified by the EPA as codified in 40 CFR Part 136, Tables $1 \mathrm{~B} \& 2 .{ }^{23}$

A small amount of process wastewater, primarily cooling tower blowdown and cooling water, is discharged directly to a number of small streams and ditches throughout the site. This wastewater does not contain significant amounts of contaminants and does not require treatment before discharge. These discharge points are included in the site NPDES permit as separate regulated outfalls.

The NPDES outfall locations are shown in Figure 5.3. Outfalls 001A and 001B, the two internal monitoring points representing the effluent from the sanitary system and laboratory system, respectively, are both located at the WTP. Their flows combine to form Outfall 001, which also is located at the treatment facility. The combined stream flows through an outfall pipe that discharges into Sawmill Creek approximately $1,100 \mathrm{~m}(3,500 \mathrm{ft})$ south of the treatment plant. 


\section{ENVIRONMENTAL NONRADIOLOG\|CAL PROGRAM INFORMATION}

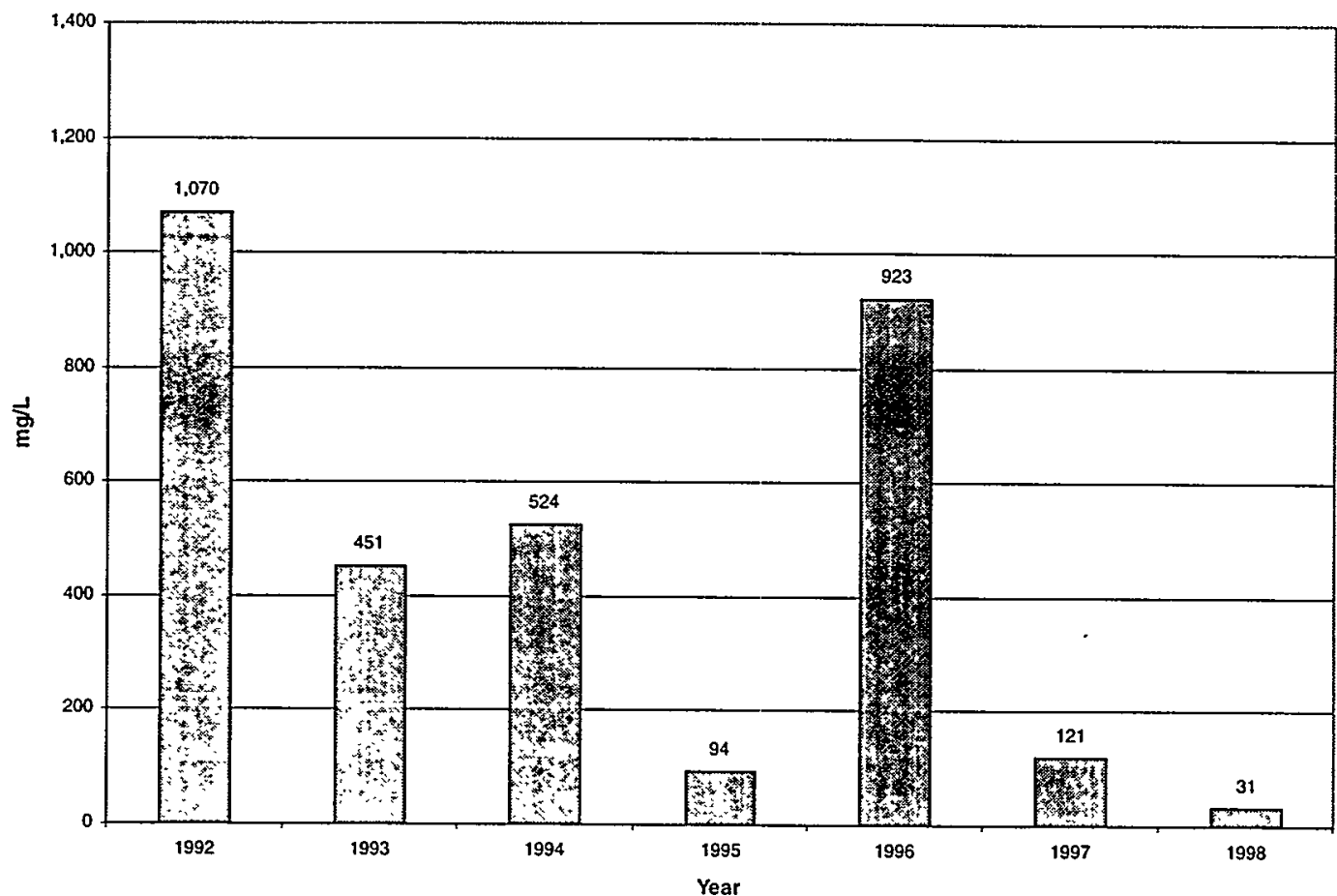

Figure 5.1 Average Acetone Levels in Laboratory Influent Wastewater, 1992 to 1998

\subsubsection{Sample Collection}

All samples are collected in specially cleaned and labeled bottles with appropriate preservatives added. Custody seals and chain of custody sheets also are used. All samples are analyzed within the required holding time. Samples are collected at locations $001 \mathrm{~A}, 001 \mathrm{~B}$, and 001 on a weekly basis, consistent with permit requirements. Similarly, samples are collected at the other locations in accordance with the NPDES permit.

\subsubsection{Sample Analyses - NPDES}

NPDES sample analyses were performed in accordance with standard operating procedures (SOPs) that were issued as controlled documents. These SOPs cite protocols that can be found in 40 CFR Part 136, "Test Procedures for the Analysis of Pollutants under the Clean Water Act."23 


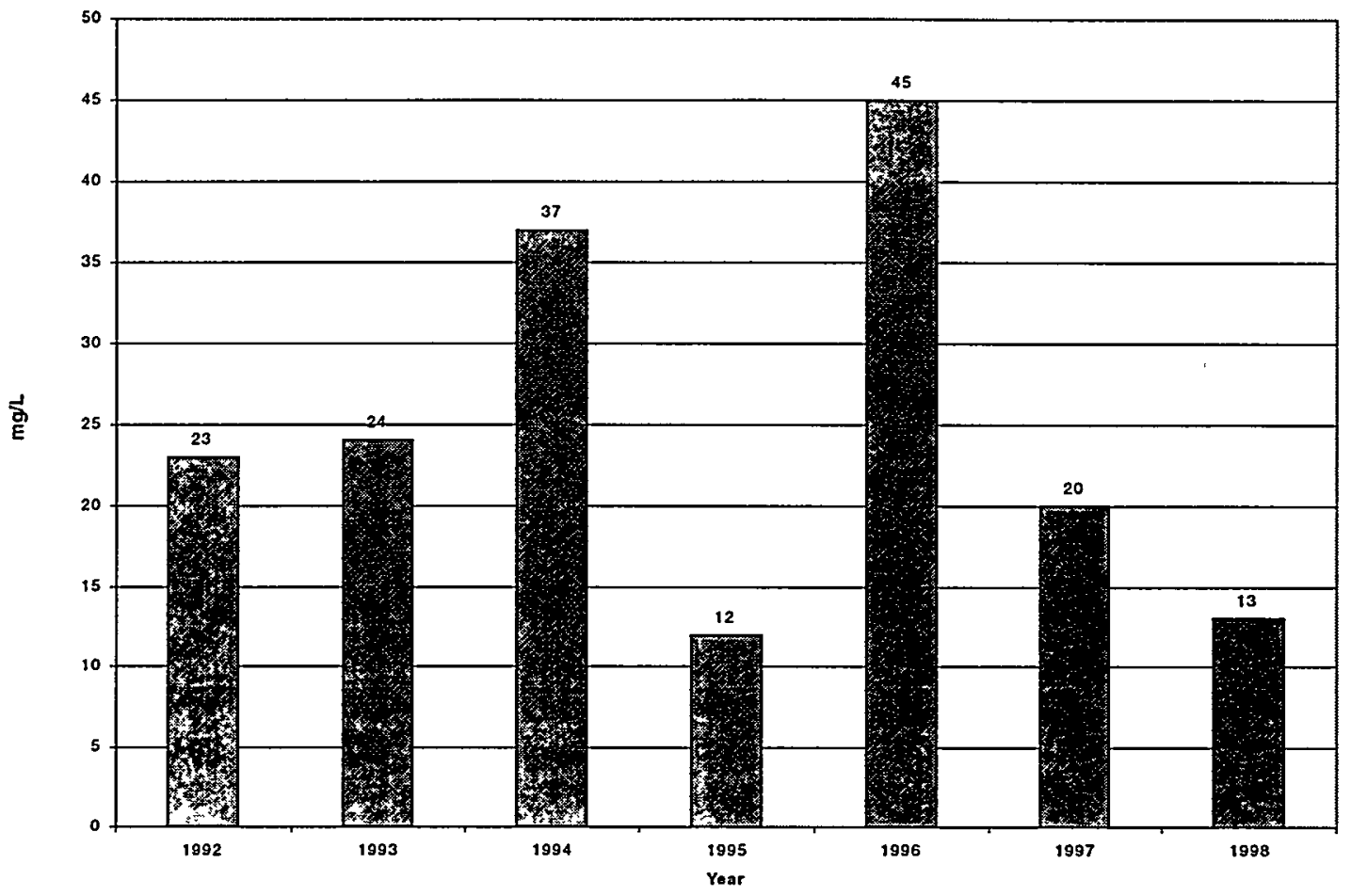

Figure 5.2 Average Chloroform Levels in Laboratory Influent Wastewater, 1992 to 1998

Six metal analyses were performed by using flame atomic absorption spectroscopy. Mercury was determined by cold vapor atomic absorption spectroscopy. Hexavalent chromium determination and chemical oxygen demand (COD) were performed by using a colorimetric technique. Five-day biochemical oxygen demand $\left(\mathrm{BOD}_{5}\right)$ was determined by using a dissolved oxygen probe. TSS, TDS, and fats, oils, and grease were determined gravimetrically. Sulfate determination was performed by using a turbidimetric technique; chloride was determined by titrimetry. Ammonia nitrogen was determined by distillation, followed by an ion-selective electrode finish. Five VOC concentrations were determined by using a purge and trap sample pretreatment, followed by gas chromatography-mass spectroscopy detection. The PCB aroclor-1260 concentrations were determined by solvent extraction, followed by gas chromatography-electron capture detection. Beta radioactivity was performed by using a gas flow proportional counting technique. Hydrogen- 3 concentrations were determined by distillation, followed by a beta liquid scintillation counting technique. 


\section{ENVIRONMENTAL NONRADIOLOGICAL PROGRAM INFORMATION}

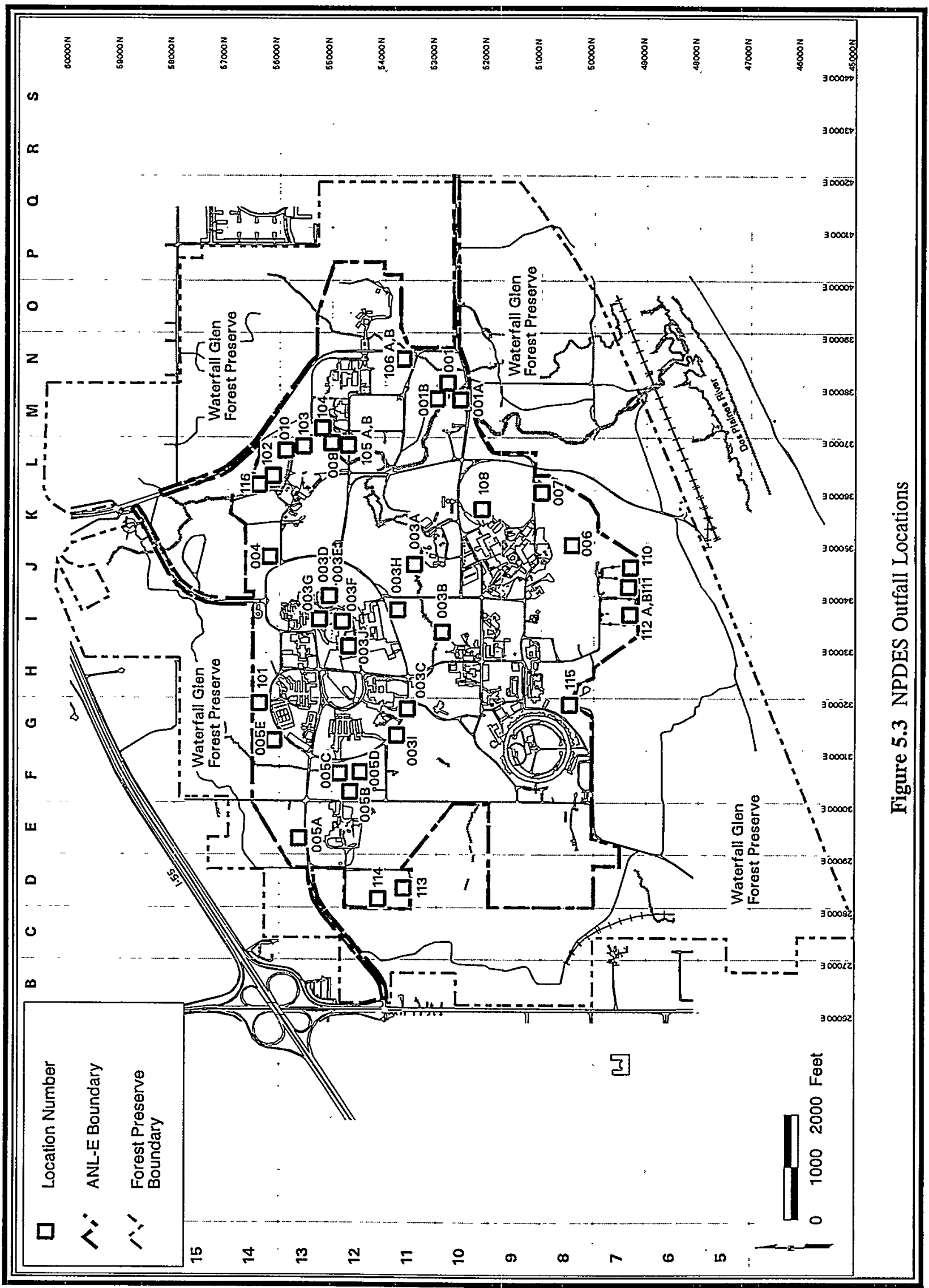




\section{ENVIRONMENTAL NONRADIOLOGICAL PROGRAM INFORMATION}

Semiannually, NPDES Outfall $001 \mathrm{~B}$ is sampled and analyzed for priority pollutant compounds. VOCs were determined by using a purge and trap sample pretreatment, followed by gas chromatography-mass spectroscopy detection. Semivolatile organic compounds (SVOCs) were determined by solvent extraction, followed by gas chromatography-mass spectroscopy detection. PCBs and pesticides were determined by solvent extraction, followed by gas chromatographyelectron capture detection. Thirteen metals were determined by graphite furnace atomic absorption and flame atomic absorption spectroscopy. Cyanide and phenol were determined by distillation, followed by a spectrophotometric finish.

NPDES Outfall 001 is sampled and analyzed annually for acute aquatic toxicity parameters. NPDES Outfalls 003H, 003I, 003J, 004, 006, and 115 are tested in July and August for aquatic toxicity. An off-site contractor laboratory performs both the sample collection and analyses. The testing is performed by diluting a series of ANL-E effluent samples with Sawmill Creek receiving water, into which species of fish and invertebrates are introduced. Survival is measured over two to four days, and statistically significant mortality is reported as a function of effluent concentration.

\subsubsection{Results}

During 1998, approximately $99 \%$ of all NPDES analyses were in compliance with their applicable permit limits, as compared with 1991 through 1997, when rates ranged from 96 to 99\%. Specific limit exceedances are discussed later in this section, as well as in Chapter 2. A discussion of the analytical results for each outfall follows.

\subsubsection{Outfalls}

Outfall 001A. This outfall consists of treated sanitary wastewater and various wastewater streams from the boiler house area, including coal pile storm water runoff. The effectiveness of the sanitary wastewater treatment systems is evaluated by weekly monitoring for BODs, $\mathrm{pH}$, and TSS. The limits for BODs are a monthly average of $10 \mathrm{mg} / \mathrm{L}$ and a maximum value of $20 \mathrm{mg} / \mathrm{L}$. 


\section{ENVIRONMENTAL NONRADIOLOGICAL PROGRAM INFORMATION}

The permit limits for TSS are a maximum concentration of $24 \mathrm{mg} / \mathrm{L}$ and a monthly average of $12 \mathrm{mg} / \mathrm{L}$. The $\mathrm{pH}$ must range between values of 6 and 9 . All samples collected and analyzed for these parameters were within the permit limits during 1998.

The permit requires weekly monitoring for total chromium, copper, iron, lead, manganese, zinc, and oil and grease. Table 5.2 gives the effluent limits for these parameters and monitoring results. Two limits are listed; one is a maximum limit for any single sample, and the other is for the average of all samples collected during the month. The constituents in Table 5.2 are present in the coal pile runoff that may discharge to the sanitary sewage system. No limits were exceeded during 1998.

Outfall 001B. This outfall consists of processed wastewater from the laboratory wastewater system. The permit requires that weekly samples be collected and analyzed for BODs, TSS, mercury, $\mathrm{pH}$, and COD.

The limits established for BODs are a daily maximum of $20 \mathrm{mg} / \mathrm{L}$ and a 30-day average of $10 \mathrm{mg} / \mathrm{L}$. The permit also contains BOD mass loading limits of $52 \mathrm{~kg}(114 \mathrm{lb}) /$ day as a daily

\section{TABLE 5.2}

Outfall 001A Effluent Limits and Monitoring Results, 1998 (concentrations in $\mathrm{mg} / \mathrm{L}$ )

\begin{tabular}{lccccc}
\hline Constituent & Minimum & Average & $\begin{array}{c}\text { Average } \\
\text { Limit }\end{array}$ & Maximum & $\begin{array}{c}\text { Maximum } \\
\text { Limit }\end{array}$ \\
\hline Chromium & $-^{\mathrm{a}}$ & $<0.02$ & 1.00 & $<0.02$ & 2.00 \\
Copper & $<0.010$ & 0.027 & 0.50 & 0.044 & 1.00 \\
Iron & 0.033 & 0.157 & 2.00 & 0.51 & 4.00 \\
Lead & - & $<0.10$ & 0.20 & $<0.10$ & 0.40 \\
Manganese & $<0.015$ & 0.029 & 1.00 & 0.293 & 2.00 \\
Zinc & 0.035 & 0.086 & 1.00 & 0.149 & 2.00 \\
Oil and grease & - & $<5.0$ & 15.0 & $<5.0$ & 30.0 \\
\hline
\end{tabular}

a A hyphen indicates no minimum values. 


\section{ENVIRONMENTAL NONRADIOLOGICAL PROGRAM INFORMATION}

maximum and $26 \mathrm{~kg}(57 \mathrm{lb}) /$ day as a 30-day average. The mass loading represents the weight of material discharged per day and is a function of concentration and flow. The daily maximum limit for TSS is $24 \mathrm{mg} / \mathrm{L}$; the 30-day average is $12 \mathrm{mg} / \mathrm{L}$. The TSS mass loading limits are 62 and $31 \mathrm{~kg} /$ day (136 and $68 \mathrm{lb} /$ day), respectively. Two exceedances of the TSS concentration limit occurred in 1998. This most likely was the result of start-up testing of the upgraded laboratory WTP, that is, clarigester adjustment by the addition of alum and polymer to form a sludge blanket.

The daily maximum concentration limit for mercury is $6 \mu \mathrm{g} / \mathrm{L}$; the 30 -day average is $3 \mu \mathrm{g} / \mathrm{L}$. The corresponding loading values are $0.02 \mathrm{~kg} / \mathrm{day}(0.034 \mathrm{lb} / \mathrm{day})$ and $0.01 \mathrm{~kg} / \mathrm{day}(0.017 \mathrm{lb} / \mathrm{day})$. No exceedances of the mercury loading and concentration limits were noted during 1998.

No concentration limits have been established for COD. The once-per-week grab samples give a rough indication of the organic and inorganic contents of this stream. The values obtained in 1998 ranged from less than 10 to $41 \mathrm{mg} / \mathrm{L}$.

A special condition at location $001 \mathrm{~B}$ requires monitoring for the 124 priority pollutants listed in the permit during the months of June and December. The June sampling is to be conducted at the same time that aquatic toxicity testing of Outfall 001 is conducted. Samples were collected on June 10, 1998, and December 8, 1998, and analyzed within the required holding times.

Analysis of these samples indicated that very small amounts of a few chemicals were present. The results for SVOCs, PCBs, and pesticides were all less than the detection limits. The results for metals were similar to concentrations found in ANL-E treated drinking water. The samples contained some VOCs at very low levels. The majority of compounds detected were halomethanes. Table 5.3 lists the concentrations of volatile organics identified in these samples. Currently, no permit limits or effluent standards with which to compare these results are available for these compounds. 


\section{ENVIRONMENTAL NONRADIOLOGICAL PROGRAM INFORMATION}

TABLE 5.3

Outfall 001B Effluent Priority Pollutant Monitoring Results, 1998

(concentrations in $\mu \mathrm{g} / \mathrm{L}$ )

\begin{tabular}{lcc}
\hline \multicolumn{1}{c}{ Compound } & $\begin{array}{c}\text { Concentration in } \\
\text { June Sample }\end{array}$ & $\begin{array}{c}\text { Concentration in } \\
\text { December Sample }\end{array}$ \\
\hline Bromodichloromethane & $<1$ & 1 \\
Bromoform & 4 & $<1$ \\
Chloroform & 3 & 1 \\
Dibromochloromethane & 2 & $<1$ \\
Methylene chloride & 3 & $<1$ \\
\hline
\end{tabular}

Outfall 001. After the treatment processes, the effluents from both the laboratory and sanitary WTP are combined to form one point source discharge. The combined effluent flows through a $1,100-\mathrm{m}(3,500-\mathrm{ft})$ outfall pipe where it is eventually discharged into Sawmill Creek.

Samples of the combined effluent are collected weekly or monthly as grab samples or 24-hour composite samples as specified in the NPDES permit. The samples are analyzed for a variety of metals, ammonia nitrogen, chlorides, sulfates, TDS, $\mathrm{pH}$, and beta radioactivity. The permit requires analysis of the combined effluent once a week for TDS, chloride, and sulfate. Table 5.4 gives the results, limits, and number of exceedances.

Elevated TDS levels are believed to be related to discharges from boiler blowdown, which contains high levels of TDS, road salt, and cooling tower blowdown. For the past several years, chemical analysis for chloride has indicated a close relationship between TDS levels and chloride levels. Figure 5.4 shows the results of TDS and chloride analyses for 1996 through 1998. A significant decrease in TDS levels was noted during 1997 and 1998. This decrease can be attributed to ANL-E's new domestic source water, Lake Michigan, which is characterized by low TDS levels (200 to 400 ppm). Elevated levels were noted during the 1998 heating season (January through March). Figure 5.5 shows the weekly TDS levels at Outfall 001 just prior to incorporation of Lake Michigan water during 1997. The modified NPDES permit incorporated an interim TDS limit $(1,500 \mathrm{mg} / \mathrm{L})$ and a compliance schedule for achieving final TDS effluent limits at 
TABLE 5.4

Outfall 001 Monitoring Results and Effluent Limits, 1998 (concentrations in $\mathrm{mg} / \mathrm{L}$ )

\begin{tabular}{|c|c|c|c|c|c|}
\hline Constituent & Minimum & Average & Maximum & Limit & Exceedances \\
\hline Copper & 0.010 & 0.025 & 0.056 & $1.0^{\mathrm{a}} / 0.051^{\mathrm{b}}$ & 0 \\
\hline TDS & 498 & 709 & 1,142 & $1,500^{\mathrm{a}} / 1,000^{\mathrm{b}}$ & 0 \\
\hline Ammonia nitrogen & $<0.1$ & 1.1 & 2.8 & $\begin{array}{l}\text { Monitor only } y^{\mathrm{a}} / 10.0 \text { (November-March) }^{\mathrm{b}} \\
\text { Monitor only } \mathrm{y}^{\mathrm{a} / 3.0} \text { (April-October) }^{\mathrm{b}}\end{array}$ & 0 \\
\hline
\end{tabular}

a Interim limit effective August 24, 1995.

b Final limit effective July 1, 1998.

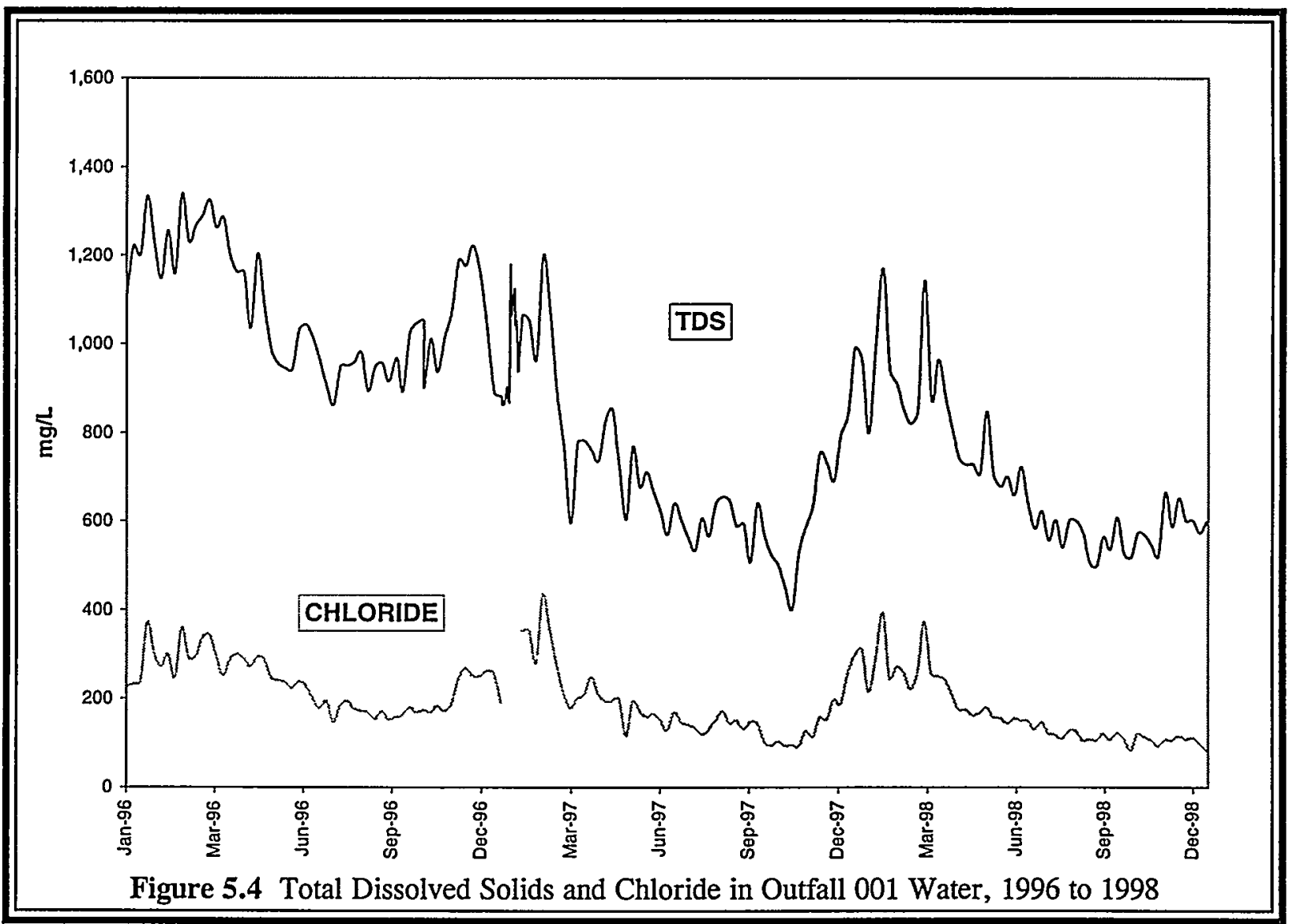




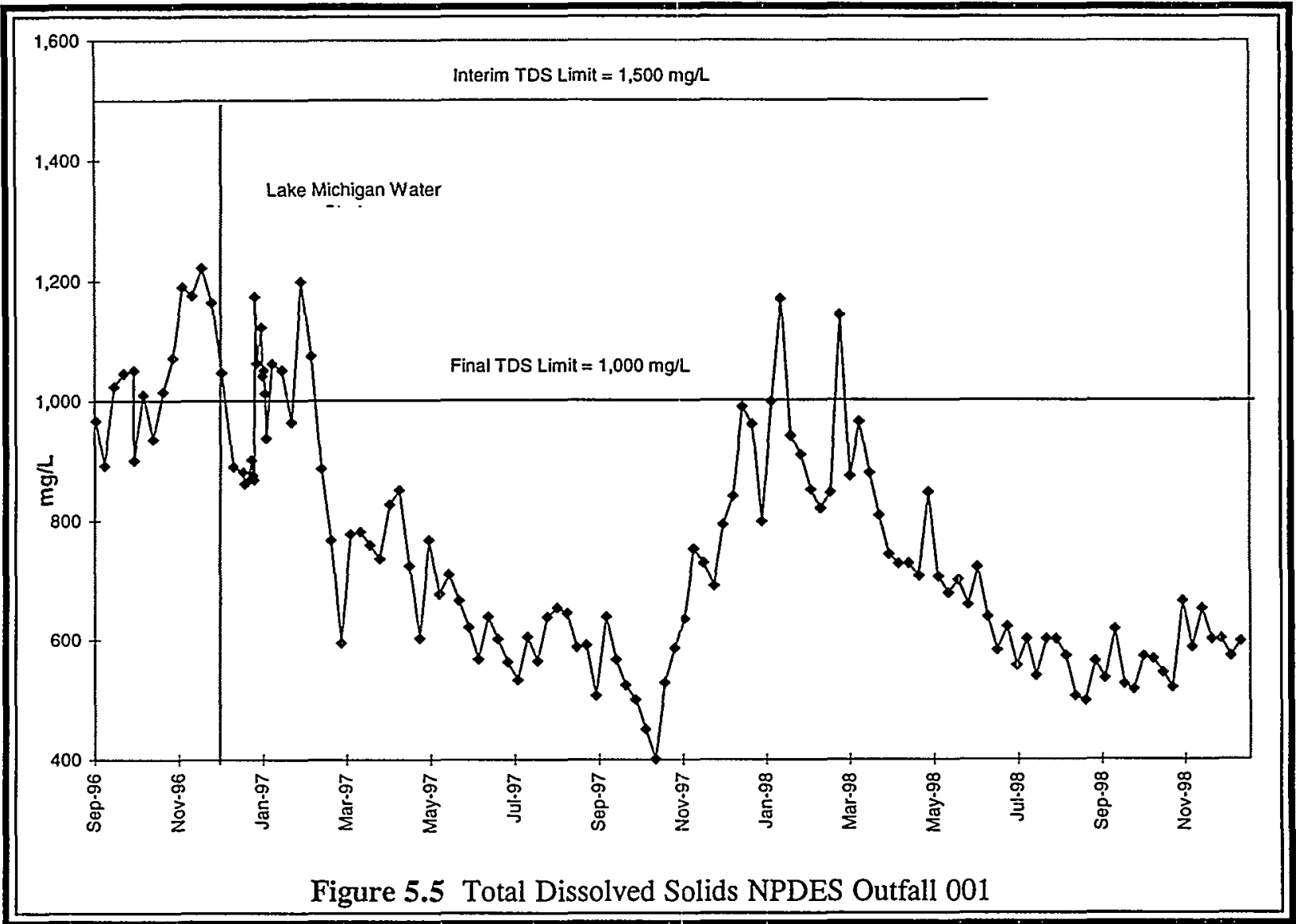

Outfall 001. The final TDS limit of $1,000 \mathrm{mg} / \mathrm{L}$ became effective on July 1,1998 . Limits for TDS, chloride, and sulfate were not exceeded during 1998.

Copper levels have decreased since 1997. The changeover in the domestic water supply from groundwater to Lake Michigan water during 1997 appears to have played a role in reducing the amount of copper in the wastewater. Lake Michigan water causes less corrosion of domestic water distribution copper piping than the previously used groundwater source. Figure 5.6 shows the 1996 through 1998 monthly average copper levels at Outfall 001. The modified NPDES permit (effective August 24,1995$)$ incorporated an interim upper limit $(1.0 \mathrm{mg} / \mathrm{L}$ daily maximum) and a compliance schedule for achieving final copper effluent limits at Outfall 001. The final limits were effective July 1, 1998. No copper exceedances occurred during 1998. 


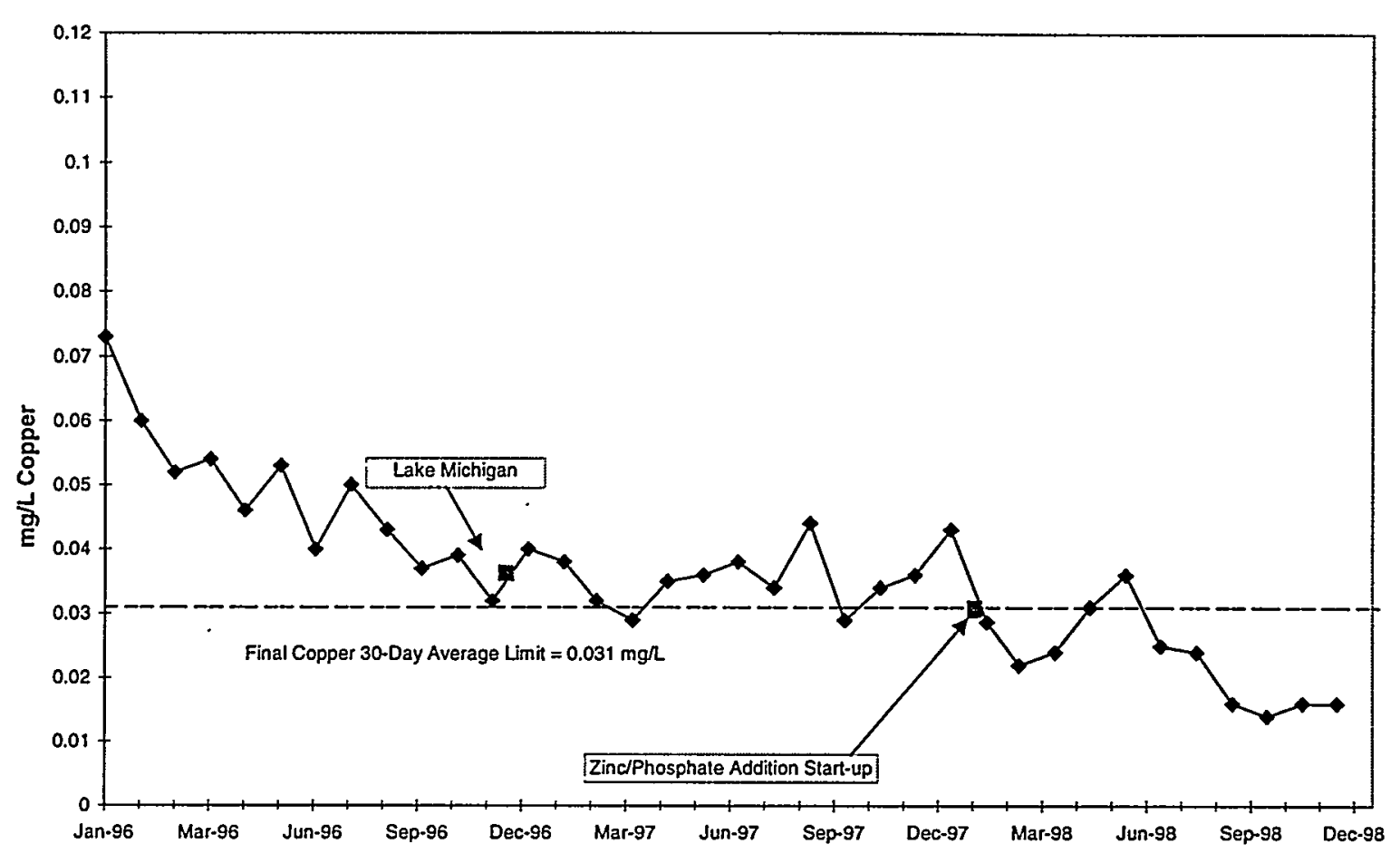

Figure 5.6 NPDES Outfall 001 30-Day Average Copper Results, 1996 to 1998

The upgrade of the sanitary WTP, completed in 1996, has enhanced the treatment of ammonia nitrogen. Figure 5.7 shows a decrease in the monthly average ammonia nitrogen levels prior to and after the sanitary WTP upgrade. Improved mechanical operation of the trickling filters results in a more even dispersion of the wastewater. Also, dome covers on the trickling filters allow the trickling filters to hold a constant temperature and aerobic conditions by providing a constant flow of air across the filter area. The modified NPDES permit (effective August 24, 1995) incorporated interim ammonia nitrogen limits (monitor only) and a compliance schedule for achieving final ammonia nitrogen effluent limits at Outfall 001. Final limits were effective July 1, 1998. No ammonia nitrogen exceedances occurred during 1998.

The permit requires that a biological toxicity screening test be performed on wastewater from Outfall 001 in June of each year. The toxicity testing is run on two trophic levels of aquatic 


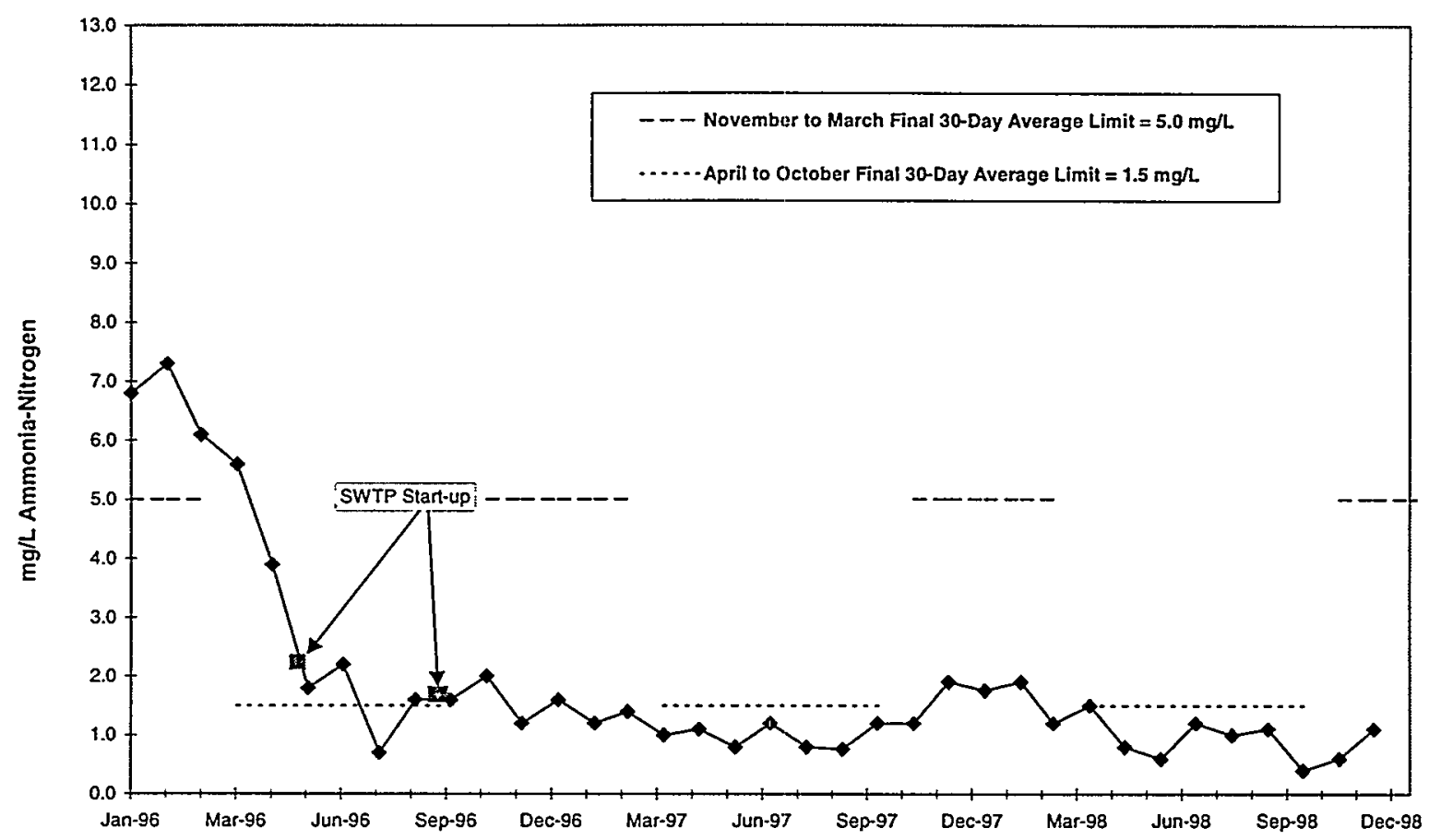

Figure 5.7 NPDES Outfall 001 30-Day Average Ammonia-Nitrogen Results, 1996 to 1998

species for acute toxicity. The 1998 testing was conducted on samples collected June 8-12; the water flea (Ceriodaphnia dubia) and fathead minnow (Pimephales promelas) were used.

No toxicity was observed to the fathead minnows or to the water flea. The concentration of wastewater that produces $50 \%$ mortality in the test population (i.e., the $\mathrm{LC}_{50}$ ) for both species is greater than $100 \%$; that is, concentrations higher than those found in the effluent would be required for half to be killed. Table 5.5 summarizes the results from the toxicity tests for 1998 . Table 5.6 summarizes the test results from 1991 to 1998.

The permit also requires that weekly $\mathrm{pH}$, ammonia nitrogen, dissolved iron, manganese, and zinc measurements be made. No exceedances of these parameters were noted in 1998. Monthly monitoring for lead, hexavalent and trivalent chromium, and beta radioactivity is required. 


\section{TABLE 5.5}

Outfall 001 Aquatic Toxicity Test Results, 1998

\begin{tabular}{ccc}
\hline Test & End Point & $\begin{array}{c}96 / 48-\text { Hour } \\
\text { LC }_{50} \\
(\%)\end{array}$ \\
\hline $\begin{array}{c}\text { 96-hour fathead minnow } \\
\text { acute toxicity }\end{array}$ & Survival & $>100.0$ \\
$\begin{array}{c}\text { 48-hour water flea } \\
\text { acute toxicity }\end{array}$ & Survival & $>100.0$ \\
\hline
\end{tabular}

TABLE 5.6

Outfall 001 Aquatic Toxicity Test Results, 1991 to 1998

\begin{tabular}{|c|c|c|c|c|c|c|c|c|}
\hline Test & $\begin{array}{l}1991 \\
(\%)\end{array}$ & $\begin{array}{l}1992 \\
(\%)\end{array}$ & $\begin{array}{c}1993 \\
(\%)\end{array}$ & $\begin{array}{c}1994 \\
(\%)\end{array}$ & $\begin{array}{l}1995 \\
(\%)\end{array}$ & $\begin{array}{c}1996 \\
(\%)\end{array}$ & $\begin{array}{l}1997 \\
(\%)\end{array}$ & $\begin{array}{c}1998 \\
(\%)\end{array}$ \\
\hline Minnow, acute, $\mathrm{LC}_{50}$ & 61.6 & $<6.2$ & 100.0 & 100.0 & $>100$ & $>100$ & $>100$ & $>100$ \\
\hline Water flea, acute, $\mathrm{LC}_{50}$ & 17.1 & 35.4 & 100.0 & 100.0 & $>100$ & $>100$ & $>100$ & $>100$ \\
\hline Minnow, chronic, survival, NOEC ${ }^{a}$ & 50.0 & 100.0 & 50.0 & 100.0 & b & - & - & - \\
\hline Minnow, chronic, survival, LOEC ${ }^{c}$ & 100.0 & 100.0 & 100.0 & 100.0 & - & - & - & - \\
\hline Minnow, chronic, growth, NOEC & 50.0 & 100.0 & 50.0 & 100.0 & - & - & - & - \\
\hline Water flea, chronic, survival, NOEC & 50.0 & 50.0 & 50.0 & 100.0 & - & - & - & - \\
\hline Water flea, chronic, survival, LOEC & 100.0 & 100.0 & 100.0 & 100.0 & - & - & - & - \\
\hline Water flea, chronic, reproduction, NOEC & 50.0 & 50.0 & 25.0 & 100.0 & - & - & - & - \\
\hline Algal growth, LOEC & 6.2 & 6.2 & 100.0 & 100.0 & - & - & - & - \\
\hline Algal growth, NOEC & 3.1 & $<6.25$ & 100.0 & 100.0 & - & - & - & - \\
\hline
\end{tabular}

a NOEC = no observable effect concentration; the highest concentration of the effluent at which no adverse effect is observed.

b A hyphen indicates that no analysis was performed because of a change in the permit.

c LOEC = lowest observable effect concentration; the lowest concentration of the effluent at which an adverse effect is observed.

Outfall 003A. This potential discharge is located approximately $25 \mathrm{~m}(75 \mathrm{ft})$ north of the swimming pool and is a vitrified clay pipe that was originally used as the discharge point for all the swimming pool activities (filter backwash, draining, and overflow). Table 5.7 presents the sampling requirements and effluent limits. 
TABLE 5.7

NPDES Effluent Summary, 1998

\begin{tabular}{|c|c|c|c|c|c|}
\hline \multirow[b]{2}{*}{$\begin{array}{l}\text { Discharge } \\
\text { Location }\end{array}$} & \multirow[b]{2}{*}{$\begin{array}{c}\text { No. of } \\
\text { Samples }\end{array}$} & \multirow[b]{2}{*}{$\begin{array}{c}\text { Permit } \\
\text { Constituent }\end{array}$} & \multicolumn{2}{|c|}{ Limit } & \multirow{2}{*}{$\begin{array}{c}\text { No. } \\
\text { Exceeding } \\
\text { Limit }\end{array}$} \\
\hline & & & $\begin{array}{l}\text { 30-Day } \\
\text { Average }\end{array}$ & $\begin{array}{c}\text { Daily } \\
\text { Maximum }\end{array}$ & \\
\hline \multirow[t]{4}{*}{$003 \mathrm{~A}$} & 0 & Flow & \multicolumn{2}{|c|}{ None } & 0 \\
\hline & & $\mathrm{pH}$ & \multicolumn{2}{|c|}{$6-9$} & 0 \\
\hline & & TSS & 15 & 30 & 0 \\
\hline & & TRC & \multicolumn{2}{|c|}{0.05} & 0 \\
\hline \multirow[t]{3}{*}{ 003B } & 12 & Flow & \multicolumn{2}{|c|}{ None } & 0 \\
\hline & & $\mathrm{pH}$ & \multicolumn{2}{|c|}{$6-9$} & 0 \\
\hline & & Temperature & \multicolumn{2}{|c|}{$<2.8^{\circ} \mathrm{C}$ rise } & 0 \\
\hline \multirow[t]{2}{*}{$003 C$} & 12 & Flow & \multicolumn{2}{|c|}{ None } & 0 \\
\hline & & $\mathrm{pH}$ & \multicolumn{2}{|c|}{$6-9$} & 0 \\
\hline \multirow[t]{3}{*}{ 003D } & 12 & Flow & \multicolumn{2}{|c|}{ None } & 0 \\
\hline & & $\mathrm{pH}$ & \multicolumn{2}{|c|}{$6-9$} & 0 \\
\hline & & Temperature & \multicolumn{2}{|c|}{$<2.8^{\circ} \mathrm{C}$ rise } & 0 \\
\hline \multirow[t]{3}{*}{ O03E } & 11 & Flow & \multicolumn{2}{|c|}{ None } & 0 \\
\hline & & $\mathrm{pH}$ & \multicolumn{2}{|c|}{$6-9$} & 0 \\
\hline & & Temperature & \multicolumn{2}{|c|}{$<2.8^{\circ} \mathrm{C}$ rise } & 0 \\
\hline \multirow[t]{4}{*}{$003 \mathrm{~F}$} & 12 & Flow & \multicolumn{2}{|c|}{ None } & 0 \\
\hline & & $\mathrm{pH}$ & \multicolumn{2}{|c|}{$6-9$} & 0 \\
\hline & & Temperature & \multicolumn{2}{|c|}{$<2.8^{\circ} \mathrm{C}$ rise } & 0 \\
\hline & & TDS & \multicolumn{2}{|c|}{ Monitor only } & $\mathrm{NA}^{\mathrm{a}}$ \\
\hline \multirow[t]{3}{*}{$003 \mathrm{G}$} & 12 & Flow & \multicolumn{2}{|c|}{ None } & 0 \\
\hline & & $\mathrm{pH}$ & \multicolumn{2}{|c|}{$6-9$} & 0 \\
\hline & & Temperature & & $\mathrm{C}$ rise & 0 \\
\hline $003 \mathrm{H}$ & 12 & Flow & & & 0 \\
\hline & & $\mathrm{pH}$ & & & 0 \\
\hline & & Temperature & & C rise & 0 \\
\hline & & TDS & Mo & r only & NA \\
\hline
\end{tabular}


TABLE 5.7 (Cont.)

\begin{tabular}{|c|c|c|c|c|c|}
\hline \multirow[b]{2}{*}{$\begin{array}{c}\text { Discharge } \\
\text { Location }\end{array}$} & \multirow[b]{2}{*}{$\begin{array}{c}\text { No. of } \\
\text { Samples }\end{array}$} & \multirow[b]{2}{*}{$\begin{array}{c}\text { Permit } \\
\text { Constituent }\end{array}$} & \multicolumn{2}{|c|}{ Limit } & \multirow{2}{*}{$\begin{array}{c}\text { No. } \\
\text { Exceeding } \\
\text { Limit }\end{array}$} \\
\hline & & & $\begin{array}{l}\text { 30-Day } \\
\text { Average }\end{array}$ & $\begin{array}{c}\text { Daily } \\
\text { Maximum }\end{array}$ & \\
\hline \multirow[t]{5}{*}{$003 I$} & 12 & Flow & \multicolumn{2}{|c|}{ None } & 0 \\
\hline & & $\mathrm{pH}$ & \multicolumn{2}{|c|}{$6-9$} & 0 \\
\hline & & Temperature & \multicolumn{2}{|c|}{$<2.8^{\circ} \mathrm{C}$ rise } & 0 \\
\hline & & TDS & \multicolumn{2}{|c|}{ Monitor only } & $\mathrm{NA}$ \\
\hline & & Oil and grease & \multicolumn{2}{|c|}{ Monitor only } & $\mathrm{NA}$ \\
\hline \multirow[t]{4}{*}{$003 \mathrm{~J}$} & 12 & Flow & \multicolumn{2}{|c|}{ None } & 0 \\
\hline & & $\mathrm{pH}$ & \multicolumn{2}{|c|}{$6-9$} & 0 \\
\hline & & Temperature & \multicolumn{2}{|c|}{$<2.8^{\circ} \mathrm{C}$ rise } & 0 \\
\hline & & TDS & \multicolumn{2}{|c|}{ Monitor only } & NA \\
\hline \multirow[t]{3}{*}{004} & 12 & Flow & \multicolumn{2}{|c|}{ None } & 0 \\
\hline & & $\mathrm{pH}$ & \multicolumn{2}{|c|}{$6-9$} & 0 \\
\hline & & TSS & 15 & 30 & 0 \\
\hline \multirow[t]{4}{*}{$005 \mathrm{C}$} & 12 & Flow & \multicolumn{2}{|c|}{ None } & 0 \\
\hline & & $\mathrm{pH}$ & \multicolumn{2}{|c|}{$6-9$} & 0 \\
\hline & & Temperature & \multicolumn{2}{|c|}{$<2.8^{\circ} \mathrm{C}$ rise } & 0 \\
\hline & & Oil and grease & \multicolumn{2}{|c|}{ Monitor only } & NA \\
\hline \multirow[t]{2}{*}{ 005E } & 12 & Flow & \multicolumn{2}{|c|}{ None } & 0 \\
\hline & & $\mathrm{pH}$ & \multicolumn{2}{|c|}{$6-9$} & 0 \\
\hline \multirow[t]{5}{*}{006} & 12 & Flow & \multicolumn{2}{|c|}{ None } & 0 \\
\hline & & $\mathrm{pH}$ & \multicolumn{2}{|c|}{$6-9$} & 0 \\
\hline & & TSS & 15 & 30 & 0 \\
\hline & & TDS & Mo & I only & NA \\
\hline & & Temperature & $<2$ & $\mathrm{C}$ rise & 0 \\
\hline 007 & 20 & Flow & & & 0 \\
\hline & 20 & $\mathrm{pH}$ & & & 0 \\
\hline & 20 & Temperature & $<2$ & $C$ rise & 0 \\
\hline & 44 & TRC & & & 0 \\
\hline & 12 & Oil and grease & Mo & r only & NA \\
\hline 008 & 12 & Flow & & & 0 \\
\hline & & $\mathrm{pH}$ & & & 0 \\
\hline & & VOC & Mo & r only & NA \\
\hline
\end{tabular}


TABLE 5.7 (Cont.)

\begin{tabular}{|c|c|c|c|c|c|}
\hline \multirow[b]{2}{*}{$\begin{array}{l}\text { Discharge } \\
\text { Location }\end{array}$} & \multirow[b]{2}{*}{$\begin{array}{c}\text { No. of } \\
\text { Samples }\end{array}$} & \multirow[b]{2}{*}{$\begin{array}{c}\text { Permit } \\
\text { Constituent }\end{array}$} & \multicolumn{2}{|c|}{ Limit } & \multirow{2}{*}{$\begin{array}{l}\text { No. } \\
\text { Exceeding } \\
\text { Limit }\end{array}$} \\
\hline & & & $\begin{array}{l}\text { 30-Day } \\
\text { Average }\end{array}$ & $\begin{array}{c}\text { Daily } \\
\text { Maximum }\end{array}$ & \\
\hline \multirow[t]{12}{*}{010} & 0 & Flow & \multicolumn{2}{|c|}{ None } & 0 \\
\hline & & $\mathrm{pH}$ & \multicolumn{2}{|c|}{$6-9$} & 0 \\
\hline & & TSS & 15 & 30 & 0 \\
\hline & & Total iron & 2 & 4 & 0 \\
\hline & & Dissolved iron & & 1.0 & 0 \\
\hline & & Lead & & 0.1 & 0 \\
\hline & & Zinc & & 1.0 & 0 \\
\hline & & Manganese & & 1.0 & 0 \\
\hline & & Hexavalent chromium & 0.011 & 0.016 & 0 \\
\hline & & Trivalent chromium & 0.519 & 2.0 & 0 \\
\hline & & Copper & 0.031 & 0.051 & 0 \\
\hline & & Oil and grease & 15 & 30 & 0 \\
\hline \multirow[t]{3}{*}{108} & 12 & Flow & \multicolumn{2}{|c|}{ None } & 0 \\
\hline & & $\mathrm{pH}$ & \multicolumn{2}{|c|}{$6-9$} & 0 \\
\hline & & Temperature & \multicolumn{2}{|c|}{$<2.8^{\circ} \mathrm{C}$ rise } & 0 \\
\hline \multirow[t]{2}{*}{111} & 2 & Flow & \multicolumn{2}{|c|}{ None } & 0 \\
\hline & & Hydrogen-3 & \multicolumn{2}{|c|}{ Monitor only } & NA \\
\hline \multirow[t]{2}{*}{$112 \mathrm{~A}$} & 2 & Flow & \multicolumn{2}{|c|}{ None } & 0 \\
\hline & & Hydrogen-3 & \multicolumn{2}{|c|}{ Monitor only } & NA \\
\hline \multirow[t]{2}{*}{$112 B$} & 2 & Flow & \multicolumn{2}{|c|}{ None } & 0 \\
\hline & & Hydrogen-3 & \multicolumn{2}{|c|}{ Monitor only } & NA \\
\hline \multirow[t]{4}{*}{113} & 6 & Flow & \multicolumn{2}{|c|}{ None } & 0 \\
\hline & & Hydrogen-3 & \multicolumn{2}{|c|}{ Monitor only } & $\mathrm{NA}$ \\
\hline & & PCB 1260 & \multicolumn{2}{|c|}{ Monitor only } & $\mathrm{NA}$ \\
\hline & & $\begin{array}{l}\text { Lead, copper, } \\
\text { nickel, zinc }\end{array}$ & \multicolumn{2}{|c|}{ Monitor only } & NA \\
\hline \multirow[t]{4}{*}{114} & 6 & Flow & \multicolumn{2}{|c|}{ None } & 0 \\
\hline & & Hydrogen-3 & \multicolumn{2}{|c|}{ Monitor only } & $\mathrm{NA}$ \\
\hline & & PCB 1260 & \multicolumn{2}{|c|}{ Monitor only } & NA \\
\hline & & $\begin{array}{l}\text { Lead, copper, } \\
\text { nickel, zinc }\end{array}$ & \multicolumn{2}{|c|}{ Monitor only } & NA \\
\hline
\end{tabular}


TABLE 5.7 (Cont.)

\begin{tabular}{|c|c|c|c|c|c|}
\hline \multirow[b]{2}{*}{$\begin{array}{c}\text { Discharge } \\
\text { Location }\end{array}$} & \multirow[b]{2}{*}{$\begin{array}{c}\text { No. of } \\
\text { Samples }\end{array}$} & \multirow[b]{2}{*}{$\begin{array}{c}\text { Permit } \\
\text { Constituent }\end{array}$} & \multicolumn{2}{|c|}{ Limit } & \multirow{2}{*}{$\begin{array}{c}\text { No. } \\
\text { Exceeding } \\
\text { Limit }\end{array}$} \\
\hline & & & $\begin{array}{l}\text { 30-Day } \\
\text { Average }\end{array}$ & $\begin{array}{c}\text { Daily } \\
\text { Maximum }\end{array}$ & \\
\hline \multirow[t]{4}{*}{115} & 12 & Flow & \multicolumn{2}{|c|}{ None } & 0 \\
\hline & & $\mathrm{pH}$ & \multicolumn{2}{|c|}{$6-9$} & 0 \\
\hline & & Temperature & \multicolumn{2}{|c|}{$<2.8^{\circ} \mathrm{C}$ rise } & 0 \\
\hline & & TDS & \multicolumn{2}{|c|}{ Monitor only } & NA \\
\hline \multirow[t]{3}{*}{116} & 12 & Flow & \multicolumn{2}{|c|}{ None } & 0 \\
\hline & & $\mathrm{pH}$ & \multicolumn{2}{|c|}{$6-9$} & 0 \\
\hline & & TRC & \multicolumn{2}{|c|}{0.05} & 0 \\
\hline
\end{tabular}

By July 1995, discharge of chlorinated water from Outfall 003A had been completely eliminated by installation of a sump collection system that captures all the flow and discharges into the sanitary drain system.

Outfall 003B. This outfall is located approximately $150 \mathrm{~m}(500 \mathrm{ft})$ northeast of Building 308 and is composed of storm water runoff and condensate from the buildings in the watershed of the outfall. The discharge point is a 1-m (3-ft) concrete pipe to a tributary brook flowing north to the Freund Brook. Table 5.7 gives the sampling requirements and effluent limits. No exceedances occurred during 1998.

Outfall 003C. The discharge from this outfall is made up of footing tile drainage and storm water runoff. The discharge point is a $0.65-\mathrm{m}$ (2-ft) concrete pipe discharging into Freund Brook approximately $50 \mathrm{~m}$ (150 ft) upstream of the gas station, south of Building 205. The sampling requirements and effluent limits are given in Table 5.7. No exceedances occurred during 1998.

Outfalls 003D and 003E. These two discharge points are from the steam trench around Inner Circle Drive and discharge into the north fork of Freund Brook approximately $150 \mathrm{~m}$ 


\section{ENVIRONMENTAL NONRADIOLOGICAL PROGRAM INFORMATION}

(500 ft) east of the intersection of Inner Circle Drive and Eastwood Extension. Table 5.7 gives the sampling requirements and effluent limits. No exceedances occurred during 1998.

Outfall 003F. This outfall is intended to discharge excess water from the fire pond during storm events. The building discharges cooling tower water to the fire pond; the rate is generally insufficient to result in a discharge at this outfall. When the rate is sufficient, the discharge is through a cement raceway to the south fork of the north branch of Freund Brook. Table 5.7 gives the sampling requirements and effluent limits. No exceedances occurred during 1998.

Outfall 003G. Footing tile drainage from the Inner Circle steam trench is pumped to the storm sewer passing around the northeastern portion of Building 201 and discharges into the northern fork of the southern branch of Freund Brook. Condensate leaks in the steam trench produce discharge on a regular basis to the storm sewer. Table 5.7 gives the sampling requirements and effluent limits. No exceedances occurred during 1998.

Outfall $003 \mathrm{H}$. This discharge originates from the footing tile drainage around Building 212 and storm water collected from around Buildings 212 and 214 and their associated parking lots. The cooling tower located on the south roof of Building 212 discharges into the tile drainage system and is the source of the industrial discharge. Table 5.7 gives the sampling requirements and effluent limits. No exceedances occurred during 1998.

Special Condition No. 9 of the NPDES permit requires acute toxicity testing on the effluent from Outfalls $003 \mathrm{H}, 003 \mathrm{I}, 003 \mathrm{~J}, 004,006$, and 115. The testing is performed on the fathead minnow and the water flea. The testing is performed on a biannual basis during the months of July and August. These outfalls were sampled during the periods of July 20-24 and August $24-28,1998$. Outfall $003 \mathrm{H}$ was not acutely toxic to the fathead minnow or water flea. The results. are summarized in Tables 5.8 and 5.9.

Outfall 003l. This outfall collects storm water from Buildings 200 and 211 and the western portion of Building 205 areas and also accumulates cooling tower discharge from the cooling tower 
TABLE 5.8

Acute Toxicity Results: Fathead Minnow, 1998

\begin{tabular}{|c|c|c|c|}
\hline $\begin{array}{c}\text { NPDES } \\
\text { Outfall }\end{array}$ & $\begin{array}{c}\text { 96-Hour } \mathrm{LC}_{50} \\
\text { July } 20-24,1998 \\
(\%)\end{array}$ & $\begin{array}{c}\text { 96-Hour } \mathrm{LC}_{50} \\
\text { August } 24-28,1998 \\
(\%)\end{array}$ & Comments \\
\hline $003 \mathrm{H}$ & $>100$ & $>100$ & Not acutely toxic \\
\hline $003 I$ & $>100$ & $>100$ & Not acutely toxic \\
\hline $003 \mathrm{~J}$ & $>100$ & $>100$ & Not acutely toxic \\
\hline 004 & $>100$ & $>100$ & Not acutely toxic \\
\hline 006 & $>100$ & $>100$ & Not acutely toxic \\
\hline 115 & 80.3 & $>100$ & Acutely toxic \\
\hline
\end{tabular}

TABLE 5.9

Acute Toxicity Results: Water Flea, 1998

\begin{tabular}{lccl}
\hline & $48-\mathrm{Hour} \mathrm{LC}_{50}$ & $\begin{array}{c}\text { 48-Hour } \mathrm{LC}_{50} \\
\text { August } 24-28,1998 \\
(\%)\end{array}$ & \multicolumn{1}{c}{ Comments } \\
\hline $\begin{array}{l}\text { NPDES } \\
\text { Jutfall }\end{array}$ & $(\%)$ & $>100$ & Not acutely toxic \\
\hline $003 \mathrm{H}$ & $>100$ & $>100$ & Not acutely toxic \\
$003 \mathrm{I}$ & $>100$ & $>100$ & Not acutely toxic \\
$003 \mathrm{~J}$ & $>100$ & $>100$ & Not acutely toxic \\
004 & $>100$ & 42.4 & Acutely toxic \\
006 & 42.4 & 20.4 & Acutely toxic \\
115 & 60.0 & &
\end{tabular}

located behind Building 200. Table 5.7 gives the sampling requirements and effluent limits. No exceedances were noted during 1998. Results of acute toxicity tests for Outfall $003 \mathrm{I}$ are presented in Tables 5.8 and 5.9. Outfall 003I was not acutely toxic to the fathead minnow or water flea.

Outfall 003J. This outfall collects storm water from the Building 213 area and parking lot. The storm water passes through a storm sewer around Building 201. Cooling tower blowdown is the industrial discharge to this system. The sampling requirements and effluent limits are given in Table 5.7. No exceedances were noted during 1998. Results of acute toxicity tests for 


\section{ENVIRONMENTAL NONRADIOLOGICAL PROGRAM INFORMATION}

Outfall 003J are presented in Tables 5.8 and 5.9. Outfall 003J was not acutely toxic to the fathead minnow or water flea.

Outfall 004. This outfall discharges storm water from the Buildings 202, 203, and 221 areas and cooling water from Building 221. The discharge is to a drainage ditch and sewer system that pass around the northeastern portion of Outer Circle Drive and to a ditch leading north to the fence line, east of the Visitor's Center. Table 5.7 gives the sampling requirements and effluent limits. No exceedances were noted during 1998. Flow at the outfall was minimal. Results of acute toxicity tests for Outfall 004 are presented in Tables 5.8 and 5.9. Outfall 004 was not acutely toxic to the fathead minnow or water flea.

Outfall 005A. This outfall discharges runoff from the northwestern portion of the 800 Area. The flow passes under Westgate Road, east of the West Gate, and flows toward the northwestern fence line. This is a storm water only outfall.

Outfall 005B. The outfall for this watershed discharges runoff collected from the major portion of the 800 Area. The flow is collected from the parking lots and roadways and flows by storm sewers to the east, where it is discharged to the marsh located on the eastern side of Kearney Road. This is a storm water only outfall.

Outfall 005C. This outfall collects storm water from the northern side and the loading dock area of Building 200. The Building 200 once-through cooling water systems discharge to this outfall, which passes through sewers to the west of the loading dock and to the beaver pond west of Building 200. The sampling requirements and effluent limits are given in Table 5.7. No exceedances occurred during 1998.

Outfall 005D. The Building $200 \mathrm{M}$-Wing loading dock area storm water runoff is collected in a storm sewer and passes west to a beaver pond located west of Building 200. The discharge is through a $1-\mathrm{m}(3-\mathrm{ft})$ corrugated pipe into the pond. This is a storm water only discharge. 


\section{ENVIRONMENTAL NONRADIOLOGICAL PROGRAM INFORMATION}

Outfall 005E. This outfall discharges footing tile drainage from the west sides of Buildings 203 and 208. It also discharges storm water collected from the same area. The industrial discharge arises from cup drains and compressors discharging into the footing tile sumps. The sampling requirements and effluent limits are given in Table 5.7. No exceedances occurred during 1998.

Outfall 006. Cooling towers at Building 350 and the 377 Area discharge into the drainage ditch that flows south of the Canal Water Treatment Plant, bends south, and flows to the south fence line. The permit requires monthly sampling for $\mathrm{pH}$, TSS, and temperature. The limits are given in Table 5.7. No exceedances of NPDES limits occurred in 1998. Results of acute toxicity tests for Outfall 006 are presented in Tables 5.8 and 5.9. As in 1995 and 1996, Outfall 006 was acutely toxic to water fleas. As in 1996 and 1997, it was not acutely toxic to the fathead minnow.

Outfall 007. The watershed for Outfall 007 includes the southeastern section of the 300 Area and extends from Building 370 east to Building 366 and north to Building 367 . Water is collected in catchment basins and conveyed toward the southeast to a point approximately $30 \mathrm{~m}$ (100 ft) southeast of Building 366, where it is discharged into a ditch on the south side of Old Bluff Road. This ditch runs along the roadside for $15 \mathrm{~m}$ (50 ft), at which point it turns south and runs to the fence line where it is discharged to the forest preserve. The once-through cooling water of compressors is the industrial component of this outfall. Table 5.7 gives the sampling requirements and effluent limits. No exceedances occurred during 1998.

Outfall 008. The watershed for this outfall includes the area around the new Vehicle Maintenance and Grounds Building 46. Runoff is collected in storm water grates and catchments and conveyed through sewers to the discharge point in Sawmill Creek, which is located directly west of Building 24. Industrial activity in this small watershed involves operations associated with the maintenance of all facility vehicles; grounds, maintenance, and storage of the equipment associated with these activities; and fueling for the vehicles. Five VOCs are monitored once a month. Low levels $(0.01$ to $0.02 \mu \mathrm{g} / \mathrm{L})$ of tetrachloroethylene are consistently noted at this outfall. A characterization study will be performed in this area to determine the source and extent of 


\section{ENVIRONMENTAL NONRADIOLOGICAL PROGRAM INFORMATION}

contamination (see Section 6.5.2). The only NPDES limit that applies at this point is $\mathrm{pH}$. No exceedances were noted during 1998.

Outfall 010. This outfall is for the coal pile storage area runoff collection system overflow line. The collection system consists of a trench on the north and west sides of the coal pile; a sump is located at the extreme southern end of the western trench line. The overflow line comes into use only when the runoff reaches the level at which the trench system would overflow; the line was put into place to ensure against overflow conditions. During normal operations, the water is pumped to the equalization basin located in the western part of the 100 Area. The industrial activity associated with this outfall is solely the coal pile operation. The berm and trench system in place to collect runoff has been improved to eliminate discharge from the outfall.

This outfall is sampled once per day when flow occurs. Analyses are performed for $\mathrm{pH}$, TSS, TDS, iron, lead, zinc, manganese, trivalent and hexavalent chromium, copper, and oil and grease. No flow occurred at this site during 1998.

Outfall 101. The drainage to this outfall is through ditches along the streets and sewer conduits from the parking lot to a marsh located between Outer Circle Drive and the fence line to the outfall; the conduits consist of a $0.65-\mathrm{m}$ (2-ft) corrugated metal pipe with a Palmer-Bowlus flume. The drainage then discharges on the other side of the fence line into the forest preserve. The sources of storm water runoff to the outfall are the Building 203 parking lot and loading dock and the excess equipment storage area on the north side of Outer Circle Drive. This is a storm water only discharge.

Outfall 102. This watershed includes portions of the 100 Area. Large amounts of paved areas are associated with the industrial activities for the production of steam such as those areas associated with the WTP, the lime sludge pond, and the tarmac around the boiler house. The contributing runoff flows are collected from storm water inlet grates and catch basins, through storm sewers to a discharge point consisting of a $0.30-\mathrm{m}(1-\mathrm{ft})$ corrugated metal pipe extending out of the bank of Sawmill Creek. This is a storm water only discharge. 


\section{ENVIRONMENTAL NONRADIOLOGICAL PROGRAM INFORMATION}

Outfall 103. The watershed for Outfall 103 includes the southern and southeastern extreme portions of the 100 Area and the area south of the coal pile. These areas drain into a storm sewer that runs due east of the coal pile toward Sawmill Creek. The outfall is located at the outlet of a $0.35-\mathrm{m}$ (1.2-ft) corrugated metal pipe culvert located approximately $50 \mathrm{~m}(150 \mathrm{ft})$ from the creek. Activities that are industrial in nature take place in and around the utilities area and consist of boiler house steam generation, storage of plastic and metal, loading dock activities, a flue gas scrubber and cooling pond (no longer in use), steam condensate return storagè (two tanks), and the southern access road to the coal pile storage area. This is a storm water only discharge.

Outfall 104. This outfall includes the buildings and parking areas remaining in the East Area, excluding Buildings 40 and 46. Buildings 4, 5, and 6 and their smaller attendant buildings are included. The area is served by a number of roadways leading to and from these buildings; contributing storm grate inlets are located on the roadways and parking areas. This is a storm water only discharge.

Outfalls 105A and 105B. Two discharge points are located within this watershed. The contributing sources of storm water for this watershed include runoff from the Building 40 area, elevated water tower tanks, and scrub vegetation areas on the west side of Tech Road. Industrial activity within this watershed includes receiving, loading, parking and storage areas, and oilcontaining transformers. These are storm water only discharges.

Outfalls 106A and 106B. The watershed for these outfalls encompasses the largest portion of the East Area, most of which is now demolished and the buildings razed. A portion of the eastern end of the Shipping and Receiving Area is part of this watershed, that is, Building 33, which has electrical transformers located outside of it, and a portion of Argonne Park. Like Outfall 105 above, this watershed is served by two distinct outfalls. The industrial activities within this watershed involve the receiving and shipping areas with loading docks and the transformer area. These are storm water only discharges. 


\section{ENVIRONMENTAL NONRADIOLOGICAL PROGRAM INFORMATION}

Outfall 108. This watershed encompasses a portion of the 300 Area. The drainage area includes the parking areas north of Building 360, the buildings in and around Building 360, excluding Buildings 370 and 390 and the southern and western ends of the 300 Area, and the paved parking and loading dock areas in and around the eastern portions of the 300 Area (surrounding Building 363). Ongoing industrial activities in this watershed are shipping and receiving, a metals reclaim dumpster (Building 363), loading dock activities, and numerous outdoor equipment storage areas. Table 5.7 gives the sampling requirements and effluent limits. No exceedances occurred during 1998.

Outfall 110. The watershed for this outfall includes the 320 shooting range (inactive since March 1993) and the area just south of the range. No other industrial activities take place within this watershed at present. Past industrial activity involved use of the shooting range for practice by the security force. This is a storm water only discharge.

Outfall 111. This outfall is located on the south fence line of the site due south of the old, closed 319 Area Landfill, between the watershed for Outfall 110 and the watershed for Outfalls 112A and 112B. This watershed encompasses the 319 Area Landfill, the 318 Area (landfill area for compressed gases), and portions of the 317 Area, primarily the paved area. In addition, the roadways for access to these areas drain to this outfall through a small ditch running along the southern extreme of the 319 Area Landfill, turning south to the fence line, and then to the outfall location, which is a $0.65-\mathrm{m}(2-\mathrm{ft})$ corrugated metal pipe culvert that passes under the fence and discharges into the forest preserve. Industrial activities within this watershed consist of 317 Area radioactive waste storage and remediation activities, the 319 Area Landfill, and associated roadways for access. This outfall is sampled semiannually for flow and hydrogen- 3 and has no permit limits. Hydrogen-3 results were less than $100 \mathrm{pCi} / \mathrm{L}$ during January 1998 and $222 \mathrm{pCi} / \mathrm{L}$ during October 1998.

Outfalls $112 \mathrm{~A}$ and 112B. The contributing sources of storm water within this watershed receive runoff from the southern and western sections of the 317 Area radioactive waste storage. Runoff flow is generally toward the south in sheet flow from the source areas; the eastern portions 


\section{ENVIRONMENTAL NONRADIOLOGICAL PROGRAM INFORMATION}

consolidate at the fence line at the southeastern corner of the 317 Area and pass under the fence through rough concrete fill. The western and central portions of the drainage area sheet flow consolidate in the same manner and pass under the fence through the same material, approximately $50 \mathrm{~m}(150 \mathrm{ft})$ to the west. Both flows discharge into large gullies in the forest preserve and form one flow approximately $100 \mathrm{~m}(328 \mathrm{ft})$ south of the ANL-E fence line. Industrial activity within this watershed consists of 317 Area radioactive waste storage and remediation activities, loading activities at Building 350, and the associated roadways for access. These outfalls are sampled semiannually for flow and hydrogen-3 and have no permit limits. Hydrogen-3 results were less than $100 \mathrm{pCi} / \mathrm{L}$ during January and October 1998.

Outfall 113. This outfall is the discharge point for runoff from the eastern, southern, and southwestern sections of the closed 800 Area Landfill. The outfall is located in a ditch on the extreme southern end of the landfill, approximately $50 \mathrm{~m}$ (150 ft) from the southwestern corner of the landfill fence line. This discharge flows under the fence in the ditch and empties into the creek that flows south from the wetland marsh west of the site. The marsh is the headwaters of one leg of the Freund Brook system that runs through the middle of the ANL-E site and discharges into Sawmill Creek. Industrial activity within this watershed is limited to the landfill. This outfall was sampled monthly when discharging and has no permit limits. Flow occurred during six months in 1998.

Outfall 114. This outfall is the discharge point for runoff coming from the northern and northwestern sections of the closed 800 Area Landfill. The outfall is located in a ditch on the extreme western side of the landfill, approximately halfway between the northern and southern boundaries of the landfill. The flow proceeds along the western edge of the landfill where water is added from the marsh. The flow eventually combines with the ditch from the Outfall 113 flow and then passes into the creek that flows south from the wetland marsh west of the ANL-E site. Industrial activity within this watershed is limited to the landfill. This outfall was sampled monthly when discharging and has no permit limits. Flow occurred during six months in 1998. 


\section{ENVIRONMENTAL NONRADIOLOGICAL PROGRAM INFORMATION}

Outfall 115. This watershed encompasses the APS site and the southern areas around the Building 314,315 , and 316 complex. The APS flow drains into ditches that discharge through a cement culvert into a collection pond located on the southeastern portion of the APS site. The $0.65-\mathrm{m}$ (2-ft) sewer conduit from the Building 314, 315, and 316 complex discharges into the same collection pond approximately $10 \mathrm{~m}(30 \mathrm{ft})$ east of the ditch culvert. The flow from this pond discharges south through a culvert into another pond, flows through this pond, and discharges through a 1-m (3-ft) corrugated metal pipe culvert under the south fence line into the forest preserve. Industrial activities within the watershed involve the APS; all roadways associated with APS; loading docks in the APS buildings; and the Building 314, 315, and 316 complex storage, loading areas, and cooling water discharges. Table 5.7 gives the sampling requirements and effluent limits. No exceedances occurred during 1998.

Results of acute toxicity tests for Outfall 115 are presented in Tables 5.8 and Table 5.9. Outfall 115 was acutely toxic to the water flea and fathead minnow. Residual chlorine concentration was elevated on the first 24-hour composite sample during July. Residual chlorine measurements were lower during the August sampling period.

Outfall 116. This outfall was originally intended as a storm water discharge point only; however, it also contains non-storm-water discharges as well. The source of the discharge was traced back and found to be potable water from the domestic water treatment plant located uphill from the rest of the main utilities area. This source was investigated for corrective action and the flow stopped. The watershed for this outfall contains sections of the domestic water treatment plant, including the garage and storage area, the area around Well 5 , and the associated access roads for the domestic water treatment plant. Flow is conducted through storm water sewers and discharged at the outfall, which is a $0.25-\mathrm{m}(0.82-\mathrm{ft})$ vitrified clay pipe with a cement raceway into Sawmill Creek. Industrial activities for this watershed include parking, loading, and materials storage around the domestic water treatment plant; domestic water treatment plant operation, including bulk chemical storage (brine tank) and transformers (Building 129); outdoor equipment storage area and four flammable materials storage cabinets (Building 130); outdoor materials storage (Buildings 107 and 163); well operation and maintenance (Building 160); and the 
associated roadways for these activities. Table 5.7 gives the sampling requirements and effluent limits. No exceedances occurred during 1998.

\subsection{Additional Effluent Monitoring}

To characterize the wastewater from the ANL-E site more fully, composite samples of the combined effluent from the WTP were collected each week and analyzed for the constituents shown in Table 5.10. The results were then compared with IEPA General Effluent Limits found in 35 IAC, Subtitle C, Part $304 .^{24}$

\subsubsection{Sample Collection}

Samples for analysis of inorganic constituents were collected daily from Outfall 001 located at the WTP by using a refrigerated time proportional sampler. A portion of the sample was transferred to a clean bottle, a security seal was affixed, and chain of custody was maintained. Five daily samples were composited on an equal volume basis to produce a weekly sample that is then analyzed.

\subsubsection{Results}

Fifteen metals were detected by inductively coupled plasma emission spectroscopy, flame atomic absorption spectroscopy, and graphite furnace atomic absorption spectroscopy. Mercury was analyzed using cold vapor atomic absorption spectroscopy, and fluoride was determined by a specific ion electrode. Table 5.10 gives the results for 1998. None of the annual average results exceeded General Effluent Limits. ${ }^{24}$ One maximum concentration for mercury exceeded the corresponding General Effluent Limit. The cause for the elevated mercury is unknown but may be the result of residual mercury in the laboratory sewer system prior to changeover to the new laboratory wastewater treatment system. 


\section{ENVIRONMENTAL NONRADIOLOGICAL PROGRAM INFORMATION}

\section{TABLE 5.10}

Chemical Constituents in Effluents from the ANL-E

Wastewater Treatment Plant, 1998

\begin{tabular}{|c|c|c|c|c|c|}
\hline \multirow[b]{2}{*}{ Constituent } & \multirow{2}{*}{$\begin{array}{c}\text { No. of } \\
\text { Samples }\end{array}$} & \multicolumn{4}{|c|}{$\begin{array}{l}\text { Concentrations } \\
(\mathrm{mg} / \mathrm{L})\end{array}$} \\
\hline & & Average & Minimum & Maximum & Limit \\
\hline Arsenic & 52 & 0.0025 & 0.0025 & 0.0026 & 0.25 \\
\hline Barium & 52 & 0.0223 & 0.0180 & 0.0291 & 2.0 \\
\hline Beryllium & 52 & & & $<0.0002^{\mathrm{a}}$ & $-b$ \\
\hline Cadmium & 52 & 0.0001 & $<0.0001$ & 0.0004 & 0.15 \\
\hline Chromium & 52 & & & $<0.0440$ & 1.0 \\
\hline Cobalt & 52 & & & $<0.0260$ & - \\
\hline Copper & 52 & 0.0203 & $<0.0170$ & 0.0377 & 0.5 \\
\hline Fluoride & 52 & 0.8241 & 0.5640 & 1.1000 & 15.0 \\
\hline Iron & 52 & 0.1128 & 0.0370 & 0.2983 & 2.0 \\
\hline Lead & 52 & 0.0010 & $<0.0010$ & 0.0016 & 0.2 \\
\hline Manganese & 52 & 0.0221 & 0.0170 & 0.1561 & 1.0 \\
\hline Mercury & 52 & 0.0002 & $<0.0001$ & 0.0052 & 0.0005 \\
\hline Nickel & 52 & & & $<0.0400$ & 1.0 \\
\hline Silver & 52 & 0.0007 & $<0.0005$ & 0.0018 & 0.1 \\
\hline Thallium & 52 & & & $<0.0015$ & - \\
\hline Vanadium & 52 & & & $<0.0240$ & - \\
\hline Zinc & 52 & 0.0926 & 0.0542 & 0.1662 & 1.0 \\
\hline $\mathrm{pH}$ (units) & 52 & $N A^{c}$ & 6.06 & 7.76 & $6.0-9.0$ \\
\hline
\end{tabular}

a If all values are less than the detection limit for a constituent, only the maximum value is given.

b A hyphen indicates no effluent limit for this constituent.

c $\mathrm{NA}=$ not applicable. 


\subsection{Sawmill Creek}

Sawmill Creek is a small natural stream that is fed primarily by storm water runoff. During periods of low precipitation, the creek above ANL-E has a very low flow. At these times, a major portion of the water in Sawmill Creek south of the site consists of ANL-E wastewater and discharges to assorted storm drains. To determine the impact ANL-E wastewaters have on Sawmill Creek, samples of the creek downstream of all ANL-E discharge points were collected and analyzed. The results were then compared with IEPA General Use Water Quality Standards found in 35 IAC, Subtitle C, Part $302 .^{25}$

\subsubsection{Sample Collection}

A proportional sampler was used to collect a daily sample at a point well downstream of the combined wastewater discharge point where thorough mixing of the ANL-E effluent and Sawmill Creek water is assured. Samples were collected in precleaned, labeled bottles and security seals were used. After $\mathrm{pH}$ measurement, the daily samples were acidified and then combined into equal volume weekly composites and analyzed for the same set of inorganic constituents as those in Table 5.10.

Fifteen metals were determined by inductively coupled plasma emission spectroscopy, flame atomic absorption spectroscopy, and graphite furnace atomic absorption spectroscopy. Mercury was analyzed with cold vapor atomic absorption spectroscopy. Fluoride was determined by a specific ion electrode.

\subsubsection{Results}

The results obtained are shown in Table 5.11 Unlike previous years, the annual average concentration for copper did not exceed the Water Quality Standard (WQS). This can be attributed to the conversion to Lake Michigan water, which has resulted in a gradual reduction in leaching of copper from the domestic water distribution system. The maximum concentrations for copper 


\section{ENVIRONMENTAL NONRADIOLOGICAL PROGRAM INFORMATION}

TABLE 5.11

Chemical Constituents in Sawmill Creek, Location $7 \mathrm{M}^{\mathrm{a}}, 1998$

\begin{tabular}{|c|c|c|c|c|c|}
\hline \multirow[b]{2}{*}{ Constituent } & \multirow{2}{*}{$\begin{array}{l}\text { No. of } \\
\text { Samples }\end{array}$} & \multicolumn{4}{|c|}{$\begin{array}{l}\text { Concentrations } \\
(\mathrm{mg} / \mathrm{L})\end{array}$} \\
\hline & & Average & Minimum & Maximum & Limit \\
\hline Arsenic & 51 & 0.0025 & 0.0025 & 0.0028 & $0.36^{b}$ \\
\hline Barium & 51 & 0.0455 & 0.0253 & 0.0794 & 5.0 \\
\hline Beryllium & 51 & & & $<0.0002^{c}$ & $-d$ \\
\hline Cadmium & 51 & 0.0005 & $<0.0001$ & 0.0077 & $0.03^{b}$ \\
\hline Chromium & 51 & 0.0440 & 0.0440 & 0.0440 & $3.6^{\mathrm{b}}$ \\
\hline Cobalt & 51 & & & $<0.0260$ & - \\
\hline Copper & 51 & 0.0211 & 0.0170 & 0.0564 & $0.041^{b}$ \\
\hline Fluoride & 51 & 0.4557 & 0.2320 & 0.9000 & 1.4 \\
\hline Iron & 51 & 0.6889 & 0.1671 & 2.7080 & 1.0 \\
\hline Lead & 51 & 0.0053 & $<0.0010$ & 0.0311 & $0.3^{b}$ \\
\hline Manganese & 51 & 0.1316 & 0.0170 & 0.7191 & 1.0 \\
\hline Mercury & 51 & 0.0001 & $<0.0001$ & 0.0003 & $0.0026^{b}$ \\
\hline Nickel & 51 & 0.0403 & 0.0400 & 0.0498 & 1.0 \\
\hline Silver & 51 & & & $<0.0008$ & 0.005 \\
\hline Thallium & 51 & & & $<0.0015$ & - \\
\hline Vanadium & 51 & & & $<0.0240$ & - \\
\hline Zinc & 51 & 0.1060 & 0.0365 & 0.2535 & 1.0 \\
\hline $\mathrm{pH}$ (units) & 50 & $N A^{e}$ & 6.75 & 8.36 & $6.5-9.0$ \\
\hline
\end{tabular}

a Location $7 \mathrm{M}$ is $15 \mathrm{~m}(50 \mathrm{ft})$ downstream from the ANL-E wastewater outfall.

b The acute standard for the chemical constituent is listed.

c If all values are less than the detection limit for a constituent, only the maximum value is given.

d A hyphen indicates no effluent limit for this constituent.

e $\mathrm{NA}=$ not applicable. 


\section{ENVIRONMENTAL NONRADIOLOGICAL PROGRAM INFORMATION}

and iron exceeded the WQS. The levels of copper are gradually declining. The average copper level was significantly lower in 1998 when compared with 1997 and 1996 results (i.e., 0.031 and 0.038 average, respectively). The cause of elevated iron levels is unknown, but may be the result of inadequate retention time of high flows that are known to contain increased coal pile runoff discharges. 
5. ENVIRONMENTAL NONRADIOLOGICAL PROGRAM INFORMATION 


\section{GROUNDWATER PROTECTION}

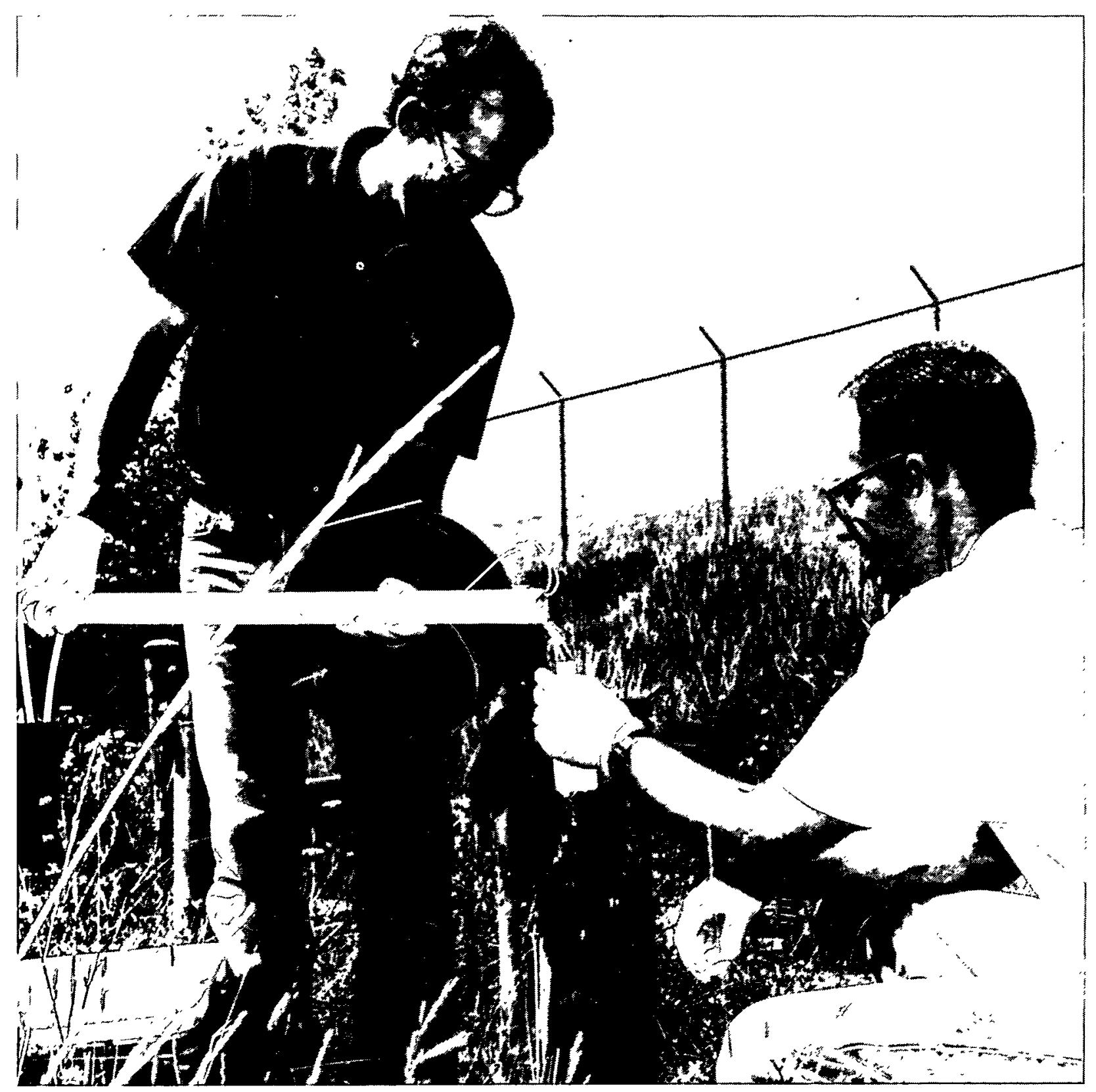


The groundwater below the ANL-E site is monitored through the collection and analysis of samples obtained from the former on-site water supply wells and from a series of groundwater monitoring wells located near several sites that have the potential for affecting groundwater. Regulations establishing comprehensive water quality standards for the protection of groundwater have been enacted - IEPA Groundwater Quality Standards, 35 IAC, Subtitle F, Part $620 .{ }^{26}$ In addition, demonstration of compliance with the groundwater protection requirements in DOE Order $5400.1,{ }^{1}$ as related to sitewide characterization studies and monitoring well requirements, is presented in this chapter. The permit for the 800 Area Landfill requires a groundwater monitoring program; the program was initiated in July 1992.

\subsection{Former Potable Water System}

Domestic water for ANL-E was supplied by four wells (see Section 1.7 and Table 6.1) until December 1996, when Lake Michigan water was obtained. The well locations are shown in Figure 1.1. Lake Michigan water was obtained to provide better quality drinking water. The dolomite water from the on-site wells had deteriorated in quality to where the TDS content of the supply water was approaching $800 \mathrm{mg} / \mathrm{L}$, which made it difficult to consistently meet the 1,000-mg/L TDS discharge limit at NPDES Outfall 001. Lake Michigan water has a TDS of approximately $200 \mathrm{mg} / \mathrm{L}$. In addition, Lake Michigan water is lower in bicarbonate, which makes it less corrosive on the piping system.

\subsubsection{Regulatory Required Monitoring}

The responsibility for conducting any regulatory required monitoring is that of the supplier of the domestic water. Because ANL-E water is provided by the DuPage Water Commission, it is responsible for any monitoring. Therefore, ANL-E did not conduct any required monitoring in 1998. 
TABLE 6.1

ANL-E Former Water Supply Wells

\begin{tabular}{|c|c|c|c|c|c|c|}
\hline $\begin{array}{l}\text { Well } \\
\text { No. }\end{array}$ & Location & $\begin{array}{c}\text { Well } \\
\text { Elevation } \\
\text { (m AMSL) }^{\mathrm{a}}\end{array}$ & $\begin{array}{c}\text { Bedrock } \\
\text { Elevation } \\
\text { (m AMSL) }\end{array}$ & $\begin{array}{l}\text { Well Depth } \\
\text { (m bgs) }^{\mathrm{b}}\end{array}$ & $\begin{array}{l}\text { Inner } \\
\text { Diameter } \\
\text { (m) }\end{array}$ & $\begin{array}{l}\text { Year } \\
\text { Drilled }\end{array}$ \\
\hline 1 & Building 31 & 204.5 & 184.4 & 86.6 & 0.30 & 1948 \\
\hline 2 & Building 32 & 202.4 & 183.2 & 91.4 & 0.30 & 1948 \\
\hline 3 & Building 163 & 210.0 & 182.9 & 96.9 & 0.30 & 1955 \\
\hline 4 & Building 264 & 218.2 & 181.4 & 103.6 & 0.36 & 1959 \\
\hline
\end{tabular}

a $\mathrm{AMSL}=$ above mean sea level.

b bgs = below ground surface.

\subsubsection{Informational Monitoring}

Samples were collected quarterly at the wellhead, except for Well 2, which is no longer operational, and analyzed to determine the presence of several types of radioactive constituents and VOCs in ANL-E groundwater. Samples from each well were tested for total alpha, total beta, hydrogen-3, and strontium-90. Samples also were analyzed annually for radium-226, radium-228, and isotopic uranium. Alpha and beta radioactivity were determined by a gas flow proportional counting technique. Hydrogen-3 was determined by distillation followed by a beta liquid scintillation counting technique. Strontium-90 was determined by ion-exchange separations followed by proportional counting. The results are presented in Table 6.2. If these wells constituted the ANL-E drinking water source, the following EPA limits established for the nuclides measured in Table 6.2 would apply:

$\begin{array}{ll}\text { Gross alpha particle activity } & =15 \mathrm{pCi} / \mathrm{L} \\ \text { Gross beta particle activity } & =50 \mathrm{pCi} / \mathrm{L} \\ \text { Hydrogen-3 } & =2 \times 10^{4} \mathrm{pCi} / \mathrm{L} \\ \text { Strontium-90 } & =8 \mathrm{pCi} / \mathrm{L}\end{array}$




\section{TABLE 6.2}

Radioactivity in ANL-E Former Water Supply Wells, 1998 (concentrations in $\mathrm{pCi} / \mathrm{L}$ )

\begin{tabular}{|c|c|c|c|c|c|}
\hline $\begin{array}{l}\text { Type of } \\
\text { Activity }\end{array}$ & Location & $\begin{array}{c}\text { No. of } \\
\text { Samples }\end{array}$ & Average & Minimum & Maximum \\
\hline Alpha & Well 1 & 4 & 4.3 & 3.1 & 6.2 \\
\hline \multirow[t]{3}{*}{ (nonvolatile) } & Well 3 & 4 & 4.4 & 2.3 & 8.3 \\
\hline & Well 4 & 4 & 3.4 & 2.5 & 3.8 \\
\hline & Tap & 4 & 0.3 & 0.2 & 0.5 \\
\hline Beta & Well 1 & 4 & 9.7 & 8.8 & 10.5 \\
\hline \multirow[t]{3}{*}{ (nonvolatile) } & Well 3 & 4 & 12.4 & 11.3 & 14.5 \\
\hline & Well 4 & 4 & 12.6 & 12.2 & 12.8 \\
\hline & Tap & 4 & 2.7 & 2.6 & 2.7 \\
\hline \multirow[t]{4}{*}{ Hydrogen-3 } & Well 1 & 4 & $<100$ & $<100$ & $<100$ \\
\hline & Well 3 & 4 & $<100$ & $<100$ & $<100$ \\
\hline & Well 4 & 4 & $<100$ & $<100$ & $<100$ \\
\hline & Tap & 4 & $<100$ & $<100$ & $<100$ \\
\hline \multirow[t]{4}{*}{ Strontium-90 } & Well 1 & 4 & $<0.25$ & $<0.25$ & $<0.25$ \\
\hline & Well 3 & 4 & $<0.25$ & $<0.25$ & $<0.25$ \\
\hline & Well 4 & 4 & $<0.25$ & $<0.25$ & $<0.25$ \\
\hline & Tap & 4 & 0.40 & 0.37 & 0.44 \\
\hline \multirow[t]{4}{*}{ Radium-226 } & Well 1 & 1 & - & - & 0.90 \\
\hline & Well 3 & 1 & - & - & 1.30 \\
\hline & Well 4 & 1 & - & - & 1.60 \\
\hline & Tap & 1 & - & - & 0.30 \\
\hline \multirow[t]{4}{*}{ Radium-228 } & Well 1 & 1 & - & - & 0.50 \\
\hline & Well 3 & 1 & - & - & 0.80 \\
\hline & Well 4 & 1 & - & - & 0.50 \\
\hline & Tap & 1 & - & - & $<0.01$ \\
\hline \multirow[t]{4}{*}{ Uranium-234 } & Well 1 & 1 & - & - & 1.21 \\
\hline & Well 3 & 1 & - & - & 0.28 \\
\hline & Well 4 & 1 & - & - & 0.19 \\
\hline & Tap & 1 & - & - & 0.12 \\
\hline \multirow[t]{4}{*}{ Uranium-235 } & Well 1 & 1 & - & - & 0.04 \\
\hline & Well 3 & 1 & - & - & $<0.01$ \\
\hline & Well 4 & 1 & - & - & $<0.01$ \\
\hline & Tap & 1 & - & - & $<0.01$ \\
\hline \multirow[t]{4}{*}{ Uranium-238 } & Well 1 & 1 & - & - & 0.81 \\
\hline & Well 3 & 1 & - & - & 0.15 \\
\hline & Well 4 & 1 & - & - & 0.10 \\
\hline & Tap & 1 & - & - & 0.08 \\
\hline
\end{tabular}




\section{GROUNDWATER PROTECTION}

All the radiological results were in the normal range of concentrations for the various constituents, except for strontium-90 in tap water. The concentration of strontium-90 in tap water was $3 \%$ of the EPA drinking water standard.

VOC samples were collected quarterly, and the results are presented in Tables 6.3 through 6.6. Samples were analyzed for SDWA volatile compounds and quantified by EPA Method 524.2. ${ }^{27}$ The detection limit reported in the tables is the Practical Quantification Limit (PQL), which is defined as 10 times the method detection limit. The tap water samples indicated the presence of three VOCs (dichlorobromomethane, chlorodibromomethane, and chloroform). These compounds are known to be associated with chlorination of drinking water, that is, trihalomethanes. The VOC results presented support the determination that no VOCs have migrated from remediation sites.

\subsubsection{Dolomite Well Monitoring}

Past analytical data tracked the presence of hydrogen-3 in ANL-E domestic Well 1 and at a lower concentration in Well 2. It is speculated that the source of the hydrogen-3 was liquid waste placed in an unlined holding pond in the wastewater treatment area (location $10 \mathrm{M}$ in Figure 1.1) in the 1950s. The tritiated water appears to have migrated through the glacial till to the dolomite aquifer and was drawn into the wells. Well 1, which is about $200 \mathrm{~m}$ (650 ft) north of the wastewater treatment area, had higher hydrogen-3 concentrations than Well 2 , which is about $300 \mathrm{~m}(1,000 \mathrm{ft})$ from the treatment area. Although the normal subsurface water flow gradient is toward the south-southeast, the cone of depression created by pumping these wells would overpower the normal flow pattern.

With the conversion of local well water to Lake Michigan water in early 1997, the water table elevations began to recover. A concern was raised that potentially the subsurface migration of radionuclides, particularly hydrogen-3, could change direction because of the lack of the influence of pumping. Since hydrogen-3 from the 570 Pond was already known to have migrated to the dolomite, a monitoring network of three ANL-E and six forest preserve wells was 


\section{TABLE 6.3}

Volatile Organic Compounds in Former Water Supply Well Samples Collected February 2, 1998

(concentrations in $\mathrm{mg} / \mathrm{L}$ )

\begin{tabular}{|c|c|c|c|c|}
\hline Constituent & Well 1 & Well 3 & Well 4 & Tap \\
\hline Benzene & $<0.0005$ & $<0.0005$ & $<0.0005$ & $<0.0005$ \\
\hline Vinyl chloride & $<0.0005$ & $<0.0005$ & $<0.0005$ & $<0.0005$ \\
\hline Carbon tetrachloride & $<0.0005$ & $<0.0005$ & $<0.0005$ & $<0.0005$ \\
\hline 1,2-Dichloroethane & $<0.0005$ & $<0.0005$ & $<0.0005$ & $<0.0005$ \\
\hline Trichloroethylene & $<0.0005$ & $<0.0005$ & $<0.0005$ & $<0.0005$ \\
\hline 1,1-Dichloroethylene & $<0.0005$ & $<0.0005$ & $<0.0005$ & $<0.0005$ \\
\hline 1,1,1-Trichloroethylene & $<0.0005$ & $<0.0005$ & $<0.0005$ & $<0.0005$ \\
\hline p-Dichlorobenzene & $<0.0005$ & $<0.0005$ & $<0.0005$ & $<0.0005$ \\
\hline Bromobenzene & $<0.001$ & $<0.001$ & $<0.001$ & $<0.001$ \\
\hline Dichlorobromomethane & $<0.0005$ & $<0.0005$ & $<0.0005$ & 0.0050 \\
\hline Bromoform & $<0.0005$ & $<0.0005$ & $<0.0005$ & $<0.001$ \\
\hline Bromomethane & $<0.002$ & $<0.002$ & $<0.002$ & $<0.002$ \\
\hline Chlorobenzene & $<0.0005$ & $<0.0005$ & $<0.0005$ & $<0.0005$ \\
\hline Chlorodibromomethane & $<0.0005$ & $<0.0005$ & $<0.0005$ & 0.0030 \\
\hline Chloroethane & $<0.002$ & $<0.002$ & $<0.002$ & $<0.002$ \\
\hline Chloroform & $<0.0005$ & $<0.0005$ & $<0.0005$ & 0.0100 \\
\hline Chloromethane & $<0.002$ & $<0.002$ & $<0.002$ & $<0.002$ \\
\hline o-Chlorotoluene & $<0.001$ & $<0.001$ & $<0.001$ & $<0.001$ \\
\hline p-Chlorotoluene & $<0.001$ & $<0.001$ & $<0.001$ & $<0.001$ \\
\hline Dibromomethane & $<0.001$ & $<0.001$ & $<0.001$ & $<0.001$ \\
\hline m-Dichlorobenzene & $<0.001$ & $<0.001$ & $<0.001$ & $<0.001$ \\
\hline o-Dichlorobenzene & $<0.0005$ & $<0.0005$ & $<0.0005$ & $<0.0005$ \\
\hline 1,1-Dichloroethane & $<0.001$ & $<0.001$ & $<0.001$ & $<0.001$ \\
\hline cis-1,2-Dichloroethylene & $<0.0005$ & $<0.0005$ & $<0.0005$ & $<0.0005$ \\
\hline trans-1,2-Dichloroethylene & $<0.0005$ & $<0.0005$ & $<0.0005$ & $<0.0005$ \\
\hline Dichloromethane & $<0.0005$ & $<0.0005$ & $<0.0005$ & $<0.0005$ \\
\hline 1,2-Dichloropropane & $<0.0005$ & $<0.0005$ & $<0.0005$ & $<0.0005$ \\
\hline 1,3-Dichloropropane & $<0.001$ & $<0.001$ & $<0.001$ & $<0.001$ \\
\hline 2,2-Dichloropropane & $<0.001$ & $<0.001$ & $<0.001$ & $<0.001$ \\
\hline 1,1-Dichloropropene & $<0.001$ & $<0.001$ & $<0.001$ & $<0.001$ \\
\hline 1,3-Dichloropropene & $<0.001$ & $<0.001$ & $<0.001$ & $<0.001$ \\
\hline Ethylbenzene & $<0.0005$ & $<0.0005$ & $<0.0005$ & $<0.0005$ \\
\hline Styrene & $<0.0005$ & $<0.0005$ & $<0.0005$ & $<0.0005$ \\
\hline 1,1,1,2-Tetrachloroethane & $<0.001$ & $<0.001$ & $<0.001$ & $<0.001$ \\
\hline 1,1,2,2-Tetrachloroethane & $<0.001$ & $<0.001$ & $<0.001$ & $<0.001$ \\
\hline
\end{tabular}


TABLE 6.3 (Cont.)

\begin{tabular}{|c|c|c|c|c|}
\hline Constituent & Well 1 & Well 3 & Well 4 & Tap \\
\hline Tetrachloroethylene & $<0.0005$ & $<0.0005$ & $<0.0005$ & $<0.0005$ \\
\hline Toluene & $<0.0005$ & $<0.0005$ & $<0.0005$ & $<0.0005$ \\
\hline 1,1,2-Trichloroethane & $<0.0005$ & $<0.0005$ & $<0.0005$ & $<0.0005$ \\
\hline 1,2,3-Trichloropropane & $<0.001$ & $<0.001$ & $<0.001$ & $<0.001$ \\
\hline $\mathrm{m}$ and $\mathrm{p}$-Xylene & $<0.0005$ & $<0.0005$ & $<0.0005$ & $<0.0005$ \\
\hline o-Xylene & $<0.0005$ & $<0.0005$ & $<0.0005$ & $<0.0005$ \\
\hline 1,2-Dibromo-3-Chloropropane & $<0.010$ & $<0.010$ & $<0.010$ & $<0.010$ \\
\hline Ethylenedibromide & $<0.010$ & $<0.010$ & $<0.010$ & $<0.010$ \\
\hline Bromochloromethane & $<0.001$ & $<0.001$ & $<0.001$ & $<0.001$ \\
\hline n-Butylbenzene & $<0.001$ & $<0.001$ & $<0.001$ & $<0.001$ \\
\hline sec-Butylbenzene & $<0.001$ & $<0.001$ & $<0.001$ & $<0.001$ \\
\hline tert-Butylbenzene & $<0.001$ & $<0.001$ & $<0.001$ & $<0.001$ \\
\hline Dichlorodifluoromethane & $<0.001$ & $<0.001$ & $<0.001$ & $<0.001$ \\
\hline Fluorotrichloromethane & $<0.001$ & $<0.001$ & $<0.001$ & $<0.001$ \\
\hline Hexachlorobutadiene & $<0.001$ & $<0.001$ & $<0.001$ & $<0.001$ \\
\hline Isopropylbenzene & $<0.001$ & $<0.001$ & $<0.001$ & $<0.001$ \\
\hline p-Isopropyltoluene & $<0.001$ & $<0.001$ & $<0.001$ & $<0.001$ \\
\hline Naphthalene & $<0.001$ & $<0.001$ & $<0.001$ & $<0.001$ \\
\hline n-Propylbenzene & $<0.001$ & $<0.001$ & $<0.001$ & $<0.001$ \\
\hline 1,2,3-Trichlorobenzene & $<0.001$ & $<0.001$ & $<0.001$ & $<0.001$ \\
\hline 1,2,4-Trichlorobenzene & $<0.0005$ & $<0.0005$ & $<0.0005$ & $<0.0005$ \\
\hline 1,2,4-Trimethylbenzene & $<0.001$ & $<0.001$ & $<0.001$ & $<0.001$ \\
\hline 1,3,5-Trimethylbenzene & $<0.001$ & $<0.001$ & $<0.001$ & $<0.001$ \\
\hline
\end{tabular}




\section{TABLE 6.4}

Volatile Organic Compounds in Former Water Supply Well Samples Collected May 5, 1998

(concentrations in $\mathrm{mg} / \mathrm{L}$ )

\begin{tabular}{|c|c|c|c|c|}
\hline Constituent & Well 1 & Well 3 & Well 4 & Tap \\
\hline Benzene & $<0.0005$ & $<0.0005$ & $<0.0005$ & $<0.0005$ \\
\hline Vinyl chloride & $<0.0005$ & $<0.0005$ & $<0.0005$ & $<0.0005$ \\
\hline Carbon tetrachloride & $<0.0005$ & $<0.0005$ & $<0.0005$ & $<0.0005$ \\
\hline 1,2-Dichloroethane & $<0.0005$ & $<0.0005$ & $<0.0005$ & $<0.0005$ \\
\hline Trichloroethylene & $<0.0005$ & $<0.0005$ & $<0.0005$ & $<0.0005$ \\
\hline 1,1-Dichloroethylene & $<0.0005$ & $<0.0005$ & $<0.0005$ & $<0.0005$ \\
\hline 1,1,1-Trichloroethylene & $<0.0005$ & $<0.0005$ & $<0.0005$ & $<0.0005$ \\
\hline p-Dichlorobenzene & $<0.0005$ & $<0.0005$ & $<0.0005$ & $<0.0005$ \\
\hline Bromobenzene & $<0.001$ & $<0.001$ & $<0.001$ & $<0.001$ \\
\hline Dichlorobromomethane & $<0.0005$ & $<0.0005$ & $<0.0005$ & 0.0070 \\
\hline Bromoform & $<0.0005$ & $<0.0005$ & $<0.0005$ & $<0.001$ \\
\hline Bromomethane & $<0.002$ & $<0.002$ & $<0.002$ & $<0.002$ \\
\hline Chlorobenzene & $<0.0005$ & $<0.0005$ & $<0.0005$ & $<0.0005$ \\
\hline Chlorodibromomethane & $<0.0005$ & $<0.0005$ & $<0.0005$ & 0.0030 \\
\hline Chloroethane & $<0.002$ & $<0.002$ & $<0.002$ & $<0.002$ \\
\hline Chloroform & $<0.0005$ & $<0.0005$ & $<0.0005$ & 0.0130 \\
\hline Chloromethane & $<0.002$ & $<0.002$ & $<0.002$ & $<0.002$ \\
\hline o-Chlorotoluene & $<0.001$ & $<0.001$ & $<0.001$ & $<0.001$ \\
\hline p-Chlorotoluene & $<0.001$ & $<0.001$ & $<0.001$ & $<0.001$ \\
\hline Dibromomethane & $<0.001$ & $<0.001$ & $<0.001$ & $<0.001$ \\
\hline m-Dichlorobenzene & $<0.001$ & $<0.001$ & $<0.001$ & $<0.001$ \\
\hline o-Dichlorobenzene & $<0.0005$ & $<0.0005$ & $<0.0005$ & $<0.0005$ \\
\hline 1,1-Dichloroethane & $<0.001$ & $<0.001$ & $<0.001$ & $<0.001$ \\
\hline cis-1,2-Dichloroethylene & $<0.0005$ & $<0.0005$ & $<0.0005$ & $<0.0005$ \\
\hline trans-1,2-Dichloroethylene & $<0.0005$ & $<0.0005$ & $<0.0005$ & $<0.0005$ \\
\hline Dichloromethane & $<0.0005$ & $<0.0005$ & $<0.0005$ & $<0.0005$ \\
\hline 1,2-Dichloropropane & $<0.0005$ & $<0.0005$ & $<0.0005$ & $<0.0005$ \\
\hline 1,3-Dichloropropane & $<0.001$ & $<0.001$ & $<0.001$ & $<0.001$ \\
\hline 2,2-Dichloropropane & $<0.001$ & $<0.001$ & $<0.001$ & $<0.001$ \\
\hline 1,1-Dichloropropene & $<0.001$ & $<0.001$ & $<0.001$ & $<0.001$ \\
\hline 1,3-Dichloropropene & $<0.001$ & $<0.001$ & $<0.001$ & $<0.001$ \\
\hline Ethylbenzene & $<0.0005$ & $<0.0005$ & $<0.0005$ & $<0.0005$ \\
\hline Styrene & $<0.0005$ & $<0.0005$ & $<0.0005$ & $<0.0005$ \\
\hline 1,1,1,2-Tetrachloroethane & $<0.001$ & $<0.001$ & $<0.001$ & $<0.001$ \\
\hline 1,1,2,2-Tetrachloroethane & $<0.001$ & $<0.001$ & $<0.001$ & $<0.001$ \\
\hline
\end{tabular}


TABLE 6.4 (Cont.)

\begin{tabular}{|c|c|c|c|c|}
\hline Constituent & Well 1 & Well 3 & Well 4 & Tap \\
\hline Tetrachloroethylene & $<0.0005$ & $<0.0005$ & $<0.0005$ & $<0.0005$ \\
\hline Toluene & $<0.0005$ & $<0.0005$ & $<0.0005$ & $<0.0005$ \\
\hline 1,1,2-Trichloroethane & $<0.0005$ & $<0.0005$ & $<0.0005$ & $<0.0005$ \\
\hline 1,2,3-Trichloropropane & $<0.001$ & $<0.001$ & $<0.001$ & $<0.001$ \\
\hline $\mathrm{m}$ and $\mathrm{p}$-Xylene & $<0.0005$ & $<0.0005$ & $<0.0005$ & $<0.001$ \\
\hline o-Xylene & $<0.0005$ & $<0.0005$ & $<0.0005$ & $<0.0005$ \\
\hline 1,2-Dibromo-3-Chloropropane & $<0.010$ & $<0.010$ & $<0.010$ & $<0.010$ \\
\hline Ethylenedibromide & $<0.010$ & $<0.010$ & $<0.010$ & $<0.010$ \\
\hline Bromochloromethane & $<0.001$ & $<0.001$ & $<0.001$ & $<0.001$ \\
\hline n-Butylbenzene & $<0.001$ & $<0.001$ & $<0.001$ & $<0.001$ \\
\hline sec-Butylbenzene & $<0.001$ & $<0.001$ & $<0.001$ & $<0.001$ \\
\hline tert-Butylbenzene & $<0.001$ & $<0.001$ & $<0.001$ & $<0.001$ \\
\hline Dichlorodifluoromethane & $<0.001$ & $<0.001$ & $<0.001$ & $<0.001$ \\
\hline Fluorotrichloromethane & $<0.001$ & $<0.001$ & $<0.001$ & $<0.001$ \\
\hline Hexachlorobutadiene & $<0.001$ & $<0.001$ & $<0.001$ & $<0.001$ \\
\hline Isopropylbenzene & $<0.001$ & $<0.001$ & $<0.001$ & $<0.001$ \\
\hline p-Isopropyltoluene & $<0.001$ & $<0.001$ & $<0.001$ & $<0.001$ \\
\hline Naphthalene & $<0.001$ & $<0.001$ & $<0.001$ & $<0.001$ \\
\hline n-Propylbenzene & $<0.001$ & $<0.001$ & $<0.001$ & $<0.001$ \\
\hline 1,2,3-Trichlorobenzene & $<0.001$ & $<0.001$ & $<0.001$ & $<0.001$ \\
\hline 1,2,4-Trichlorobenzene & $<0.0005$ & $<0.0005$ & $<0.0005$ & $<0.0005$ \\
\hline 1,2,4-Trimethylbenzene & $<0.001$ & $<0.001$ & $<0.001$ & $<0.001$ \\
\hline 1,3,5-Trimethylbenzene & $<0.001$ & $<0.001$ & $<0.001$ & $<0.001$ \\
\hline
\end{tabular}


TABLE 6.5

Volatile Organic Compounds in Former Water Supply Well Samples 'Collected August 25, 1998

(concentrations in $\mathrm{mg} / \mathrm{L}$ )

\begin{tabular}{|c|c|c|c|c|}
\hline Constituent & Well 1 & Well 3 & Well 4 & Tap \\
\hline Benzene & $<0.0005$ & $<0.0005$ & $<0.0005$ & $<0.0005$ \\
\hline Vinyl chloride & $<0.0005$ & $<0.0005$ & $<0.0005$ & $<0.0005$ \\
\hline Carbon tetrachloride & $<0.0005$ & $<0.0005$ & $<0.0005$ & $<0.0005$ \\
\hline 1,2-Dichloroethane & $<0.0005$ & $<0.0005$ & $<0.0005$ & $<0.0005$ \\
\hline Trichloroethylene & $<0.0005$ & $<0.0005$ & $<0.0005$ & $<0.0005$ \\
\hline 1,1-Dichloroethylene & $<0.0005$ & $<0.0005$ & $<0.0005$ & $<0.0005$ \\
\hline 1,1,1-Trichloroethylene & $<0.0005$ & $<0.0005$ & $<0.0005$ & $<0.0005$ \\
\hline p-Dichlorobenzene & $<0.0005$ & $<0.0005$ & $<0.0005$ & $<0.0005$ \\
\hline Bromobenzene & $<0.001$ & $<0.001$ & $<0.001$ & $<0.001$ \\
\hline Dichlorobromomethane & $<0.0005$ & $<0.0005$ & $<0.0005$ & 0.0100 \\
\hline Bromoform & $<0.0005$ & $<0.0005$ & $<0.0005$ & $<0.001$ \\
\hline Bromomethane & $<0.002$ & $<0.002$ & $<0.002$ & $<0.002$ \\
\hline Chlorobenzene & $<0.0005$ & $<0.0005$ & $<0.0005$ & $<0.0005$ \\
\hline Chlorodibromomethane & $<0.0005$ & $<0.0005$ & $<0.0005$ & 0.0030 \\
\hline Chloroethane & $<0.002$ & $<0.002$ & $<0.002$ & $<0.002$ \\
\hline Chloroform & $<0.0005$ & $<0.0005$ & $<0.0005$ & 0.0260 \\
\hline Chloromethane & $<0.002$ & $<0.002$ & $<0.002$ & $<0.002$ \\
\hline o-Chlorotoluene & $<0.001$ & $<0.001$ & $<0.001$ & $<0.001$ \\
\hline p-Chlorotoluene & $<0.001$ & $<0.001$ & $<0.001$ & $<0.001$ \\
\hline Dibromomethane & $<0.001$ & $<0.001$ & $<0.001$ & $<0.001$ \\
\hline m-Dichlorobenzene & $<0.001$ & $<0.001$ & $<0.001$ & $<0.001$ \\
\hline o-Dichlorobenzene & $<0.0005$ & $<0.0005$ & $<0.0005$ & $<0.0005$ \\
\hline 1,1-Dichloroethane & $<0.001$ & $<0.001$ & $<0.001$ & $<0.001$ \\
\hline cis-1,2-Dichloroethylene & $<0.0005$ & $<0.0005$ & $<0.0005$ & $<0.0005$ \\
\hline trans-1,2-Dichloroethylene & $<0.0005$ & $<0.0005$ & $<0.0005$ & $<0.0005$ \\
\hline Dichloromethane & $<0.0005$ & $<0.0005$ & $<0.0005$ & $<0.0005$ \\
\hline 1,2-Dichloropropane & $<0.0005$ & $<0.0005$ & $<0.0005$ & $<0.0005$ \\
\hline 1,3-Dichloropropane & $<0.001$ & $<0.001$ & $<0.001$ & $<0.001$ \\
\hline 2,2-Dichloropropane & $<0.001$ & $<0.001$ & $<0.001$ & $<0.001$ \\
\hline 1,1-Dichloropropene & $<0.001$ & $<0.001$ & $<0.001$ & $<0.001$ \\
\hline 1,3-Dichloropropene & $<0.001$ & $<0.001$ & $<0.001$ & $<0.001$ \\
\hline Ethylbenzene & $<0.0005$ & $<0.0005$ & $<0.0005$ & $<0.0005$ \\
\hline Styrene & $<0.0005$ & $<0.0005$ & $<0.0005$ & $<0.0005$ \\
\hline 1,1,1,2-Tetrachloroethane & $<0.001$ & $<0.001$ & $<0.001$ & $<0.001$ \\
\hline 1,1,2,2-Tetrachloroethane & $<0.001$ & $<0.001$ & $<0.001$ & $<0.001$ \\
\hline
\end{tabular}


TABLE 6.5 (Cont.)

\begin{tabular}{lllll}
\hline \multicolumn{1}{c}{ Constituent } & Well 1 & Well 3 & Well 4 & Tap \\
\hline Tetrachloroethylene & & & & \\
Toluene & $<0.0005$ & $<0.0005$ & $<0.0005$ & $<0.0005$ \\
1,1,2-Trichloroethane & $<0.0005$ & $<0.0005$ & $<0.0005$ & $<0.0005$ \\
1,2,3-Trichloropropane & $<0.0005$ & $<0.0005$ & $<0.0005$ & $<0.0005$ \\
m and p-Xylene & $<0.001$ & $<0.001$ & $<0.001$ & $<0.001$ \\
o-Xylene & $<0.0005$ & $<0.0005$ & $<0.0005$ & $<0.001$ \\
1,2-Dibromo-3-Chloropropane. & $<0.0005$ & $<0.0005$ & $<0.0005$ & $<0.0005$ \\
Ethylenedibromide & $<0.010$ & $<0.010$ & $<0.010$ & $<0.010$ \\
Bromochloromethane & $<0.010$ & $<0.010$ & $<0.010$ & $<0.010$ \\
n-Butylbenzene & $<0.001$ & $<0.001$ & $<0.001$ & $<0.001$ \\
sec-Butylbenzene & $<0.001$ & $<0.001$ & $<0.001$ & $<0.001$ \\
tert-Butylbenzene & $<0.001$ & $<0.001$ & $<0.001$ & $<0.001$ \\
Dichlorodifluoromethane & $<0.001$ & $<0.001$ & $<0.001$ & $<0.001$ \\
Fluorotrichloromethane & $<0.001$ & $<0.001$ & $<0.001$ & $<0.001$ \\
Hexachlorobutadiene & $<0.001$ & $<0.001$ & $<0.001$ & $<0.001$ \\
Isopropylbenzene & $<0.001$ & $<0.001$ & $<0.001$ & $<0.001$ \\
p-Isopropyltoluene & $<0.001$ & $<0.001$ & $<0.001$ & $<0.001$ \\
Naphthalene & $<0.001$ & $<0.001$ & $<0.001$ & $<0.001$ \\
n-Propylbenzene & $<0.001$ & $<0.001$ & $<0.001$ & $<0.001$ \\
1,2,3-Trichlorobenzene & $<0.001$ & $<0.001$ & $<0.001$ & $<0.001$ \\
1,2,4-Trichlorobenzene & $<0.001$ & $<0.001$ & $<0.001$ & $<0.001$ \\
1,2,4-Trimethylbenzene & $<0.0005$ & $<0.0005$ & $<0.0005$ & $<0.0005$ \\
1,3,5-Trimethylbenzene & $<0.001$ & $<0.001$ & $<0.001$ & $<0.001$ \\
\hline & $<0.001$ & $<0.001$ & $<0.001$ & $<0.001$ \\
\hline & & & &
\end{tabular}


TABLE 6.6

Volatile Organic Compounds in Former Water Supply Well Samples

Collected November 10, 1998

(concentrations in $\mathrm{mg} / \mathrm{L}$ )

\begin{tabular}{|c|c|c|c|c|}
\hline Constituent & Well 1 & Well 3 & Well 4 & Tap \\
\hline Benzene & $<0.0005$ & $<0.0005$ & $<0.0005$ & $<0.0005$ \\
\hline Vinyl chloride & $<0.0005$ & $<0.0005$ & $<0.0005$ & $<0.0005$ \\
\hline Carbon tetrachloride & $<0.0005$ & $<0.0005$ & $<0.0005$ & $<0.0005$ \\
\hline 1,2-Dichloroethane & $<0.0005$ & $<0.0005$ & $<0.0005$ & $<0.0005$ \\
\hline Trichloroethylene & $<0.0005$ & $<0.0005$ & $<0.0005$ & $<0.0005$ \\
\hline 1,1-Dichloroethylene & $<0.0005$ & $<0.0005$ & $<0.0005$ & $<0.0005$ \\
\hline 1,1,1-Trichloroethylene & $<0.0005$ & $<0.0005$ & $<0.0005$ & $<0.0005$ \\
\hline p-Dichlorobenzene & $<0.0005$ & $<0.0005$ & $<0.0005$ & $<0.0005$ \\
\hline Bromobenzene & $<0.001$ & $<0.001$ & $<0.001$ & $<0.001$ \\
\hline Dichlorobromomethane & $<0.0005$ & $<0.0005$ & $<0.0005$ & 0.0060 \\
\hline Bromoform & $<0.0005$ & $<0.0005$ & $<0.0005$ & $<0.001$ \\
\hline Bromomethane & $<0.002$ & $<0.002$ & $<0.002$ & $<0.002$ \\
\hline Chlorobenzene & $<0.0005$ & $<0.0005$ & $<0.0005$ & $<0.0005$ \\
\hline Chlorodibromomethane & $<0.0005$ & $<0.0005$ & $<0.0005$ & 0.0030 \\
\hline Chloroethane & $<0.002$ & $<0.002$ & $<0.002$ & $<0.002$ \\
\hline Chloroform & $<0.0005$ & $<0.0005$ & $<0.0005$ & 0.0110 \\
\hline Chloromethane & $<0.002$ & $<0.002$ & $<0.002$ & $<0.002$ \\
\hline o-Chlorotoluene & $<0.001$ & $<0.001$ & $<0.001$ & $<0.001$ \\
\hline p-Chlorotoluene & $<0.001$ & $<0.001$ & $<0.001$ & $<0.001$ \\
\hline Dibromomethane & $<0.001$ & $<0.001$ & $<0.001$ & $<0.001$ \\
\hline m-Dichlorobenzene & $<0.001$ & $<0.001$ & $<0.001$ & $<0.001$ \\
\hline o-Dichlorobenzene & $<0.0005$ & $<0.0005$ & $<0.0005$ & $<0.0005$ \\
\hline 1,1-Dichloroethane & $<0.001$ & $<0.001$ & $<0.001$ & $<0.001$ \\
\hline cis-1,2-Dichloroethylene & $<0.0005$ & $<0.0005$ & $<0.0005$ & $<0.0005$ \\
\hline trans-1,2-Dichloroethylene & $<0.0005$ & $<0.0005$ & $<0.0005$ & $<0.0005$ \\
\hline Dichloromethane & $<0.0005$ & $<0.0005$ & $<0.0005$ & $<0.0005$ \\
\hline 1,2-Dichloropropane & $<0.0005$ & $<0.0005$ & $<0.0005$ & $<0.0005$ \\
\hline 1,3-Dichloropropane & $<0.001$ & $<0.001$ & $<0.001$ & $<0.001$ \\
\hline 2,2-Dichloropropane & $<0.001$ & $<0.001$ & $<0.001$ & $<0.001$ \\
\hline 1,1-Dichloropropene & $<0.001$ & $<0.001$ & $<0.001$ & $<0.001$ \\
\hline 1,3-Dichloropropene & $<0.001$ & $<0.001$ & $<0.001$ & $<0.001$ \\
\hline Ethylbenzene & $<0.0005$ & $<0.0005$ & $<0.0005$ & $<0.0005$ \\
\hline Styrene & $<0.0005$ & $<0.0005$ & $<0.0005$ & $<0.0005$ \\
\hline $1,1,1,2$-Tetrachloroethane & $<0.001$ & $<0.001$ & $<0.001$ & $<0.001$ \\
\hline
\end{tabular}


TABLE 6.6 (Cont.)

\begin{tabular}{|c|c|c|c|c|}
\hline Constituent & Well 1 & Well 3 & Well 4 & Tap \\
\hline 1,1,2,2-Tetrachloroethane & $<0.001$ & $<0.001$ & $<0.001$ & $<0.001$ \\
\hline Tetrachloroethylene & $<0.0005$ & $<0.0005$ & $<0.0005$ & $<0.0005$ \\
\hline Toluene & $<0.0005$ & $<0.0005$ & $<0.0005$ & $<0.0005$ \\
\hline 1,1,2-Trichloroethane & $<0.0005$ & $<0.0005$ & $<0.0005$ & $<0.0005$ \\
\hline 1,2,3-Trichloropropane & $<0.001$ & $<0.001$ & $<0.001$ & $<0.001$ \\
\hline $\mathrm{m}$ and $\mathrm{p}$-Xylene & $<0.0005$ & $<0.0005$ & $<0.0005$ & $<0.005$ \\
\hline o-Xylene & $<0.0005$ & $<0.0005$ & $<0.0005$ & $<0.0005$ \\
\hline 1,2-Dibromo-3-Chloropropane & $<0.010$ & $<0.010$ & $<0.010$ & $<0.010$ \\
\hline Ethylenedibromide & $<0.010$ & $<0.010$ & $<0.010$ & $<0.010$ \\
\hline Bromochloromethane & $<0.001$ & $<0.001$ & $<0.001$ & $<0.001$ \\
\hline n-Butylbenzene & $<0.001$ & $<0.001$ & $<0.001$ & $<0.001$ \\
\hline sec-Butylbenzene & $<0.001$ & $<0.001$ & $<0.001$ & $<0.001$ \\
\hline tert-Butylbenzene & $<0.001$ & $<0.001$ & $<0.001$ & $<0.001$ \\
\hline Dichlorodifluoromethane & $<0.001$ & $<0.001$ & $<0.001$ & $<0.001$ \\
\hline Fluorotrichloromethane & $<0.001$ & $<0.001$ & $<0.001$ & $<0.001$ \\
\hline Hexachlorobutadiene & $<0.001$ & $<0.001$ & $<0.001$ & $<0.001$ \\
\hline Isopropylbenzene & $<0.001$ & $<0.001$ & $<0.001$ & $<0.001$ \\
\hline p-Isopropyltoluene & $<0.001$ & $<0.001$ & $<0.001$ & $<0.001$ \\
\hline Naphthalene & $<0.001$ & $<0.001$ & $<0.001$ & $<0.001$ \\
\hline n-Propylbenzene & $<0.001$ & $<0.001$ & $<0.001$ & $<0.001$ \\
\hline 1,2,3-Trichlorobenzene & $<0.001$ & $<0.001$ & $<0.001$ & $<0.001$ \\
\hline 1,2,4-Trichlorobenzene & $<0.0005$ & $<0.0005$ & $<0.0005$ & $<0.0005$ \\
\hline 1,2,4-Trimethylbenzene & $<0.001$ & $<0.001$ & $<0.001$ & $<0.001$ \\
\hline 1,3,5-Trimethylbenzene & $<0.001$ & $<0.001$ & $<0.001$ & $<0.001$ \\
\hline
\end{tabular}


established to monitor the magnitude and direction of any hydrogen-3 movement. The well locations are shown in Figure 6.1. After the initial sets of samples were collected and analyzed for hydrogen-3, samples were collected quarterly. Table 6.7 shows the results for 1998 . Hydrogen-3 results from Well $570091 \mathrm{D}$, which is directly below the 570 Pond, continue to show low concentrations of hydrogen-3, along with well ANL-20, which is about $100 \mathrm{~m}$ (300 ft) northeast of the 570 Pond. The result from HP \#10 collected June 19, appears to be suspect since no other results from this well indicated the presence of hydrogen-3. This sampling network will be continued as part of the monitoring program.

\subsection{Groundwater Monitoring at Waste Management Sites}

ANL-E has occupied its current site since 1948. Since that time, waste generated by ANL-E was placed in a number of on-site disposal units; these ranged from ditches filled with construction and demolition debris during the 1950s, to a modern sanitary landfill used for nonhazardous solid waste disposal until September 1992. Several of these units contain significant amounts of hazardous materials and, therefore, represent a potential threat to the environment. Groundwater below these sites is monitored routinely to assess the amount and nature of hazardous chemical releases from these units. Routinely monitored sites include the sanitary landfill in the 800 Area and the 317/319 Area, which consists of seven separate waste management units located within a small geographical area. The site of the CP-5 reactor is also monitored periodically to determine whether any radionuclides are being released from this unit.

\subsubsection{7 and 319 Areas}

The 317 and 319 Areas contain seven separate current or former units that have been used in the past for handling or disposal of various types of waste. The 317 Area is currently an active radioactive waste processing and storage area. It consists of a series of in-ground and aboveground concrete structures used for storage of containers of dry radioactive or mixed (radioactive

and chemically hazardous) waste. It also contains a small building used for decontamination of metal objects, such as lead bricks, tools, metal objects, etc. In the past, the 317 Area was used 


\section{GROUNDWATER PROTECTION}

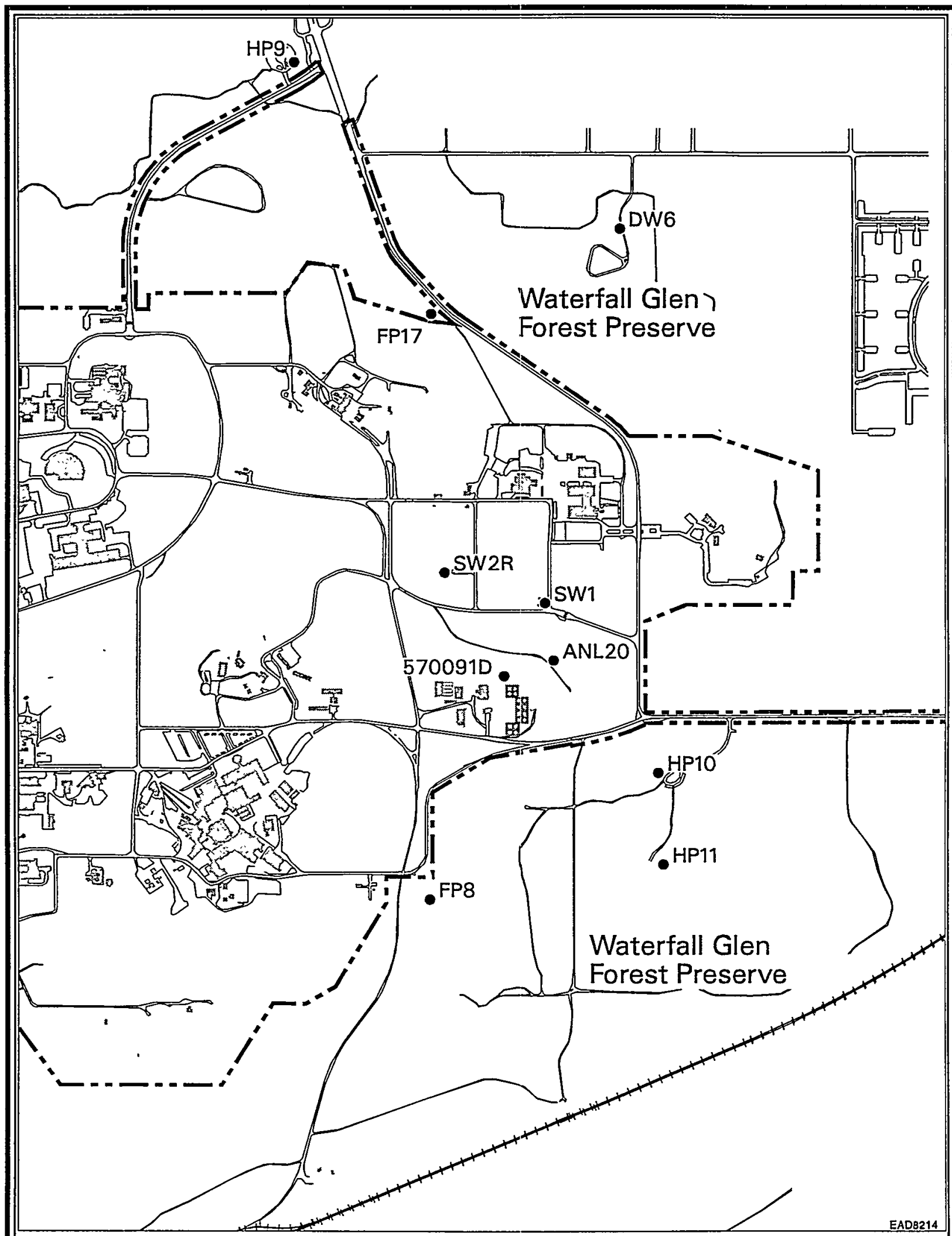

Figure 6.1 East Area/Forest Preserve Monitoring Wells 
TABLE 6.7

Hydrogen-3 in Dolomite Wells, 1998 (concentrations in $\mathrm{pCi} / \mathrm{L}$ )

Date Collected

\begin{tabular}{|c|c|c|c|c|c|}
\hline Well & June 19,1998 & July 24, 1998 & July 27,1998 & July 29,1998 & October 27,1998 \\
\hline \multicolumn{6}{|c|}{ Waterfall Glen } \\
\hline DW \#6 & $<100$ & $<100$ & $<100$ & $<100$ & $<100$ \\
\hline HP \#9 & $<100$ & $<100$ & $<100$ & $<100$ & $<100$ \\
\hline HP \#10 & $695(664)^{a}$ & $<100$ & $<100$ & $<100(<100)^{\mathrm{a}}$ & $<100$ \\
\hline HP \#11 & $<100$ & $<100$ & $<100$ & $<100$ & $<100$ \\
\hline FP \#8 & $-b$ & - & - & $<100$ & $<100$ \\
\hline FP \#17 & - & - & - & $<100$ & $<100$ \\
\hline \multicolumn{6}{|l|}{ ANL-E } \\
\hline 570091D & - & - & 335 (294) & 285 & 235 \\
\hline ANL-20 & - & - & - & 123 & $<100$ \\
\hline SW2R & - & - & - & $<100$ & $<100$ \\
\hline
\end{tabular}

a Duplicate result.

b A hyphen indicates not sampled.

for disposal of various liquid chemical wastes in a unit known as a French drain. The drain consisted of a shallow trench filled with gravel into which an unknown quantity of liquid wastes was poured. This unit was operational during the late 1950s. Because of these past disposal practices, there is a region of contaminated soil in the northern half of the 317 Area. The contaminants are primarily VOCs such as cleaning solvents. The groundwater below this area also contains low concentrations of these chemicals. General features in the 317/319 Area are identified in Figure 6.2.

The 319 Area contains an inactive landfill that was used for disposal of a variety of solid wastes generated on site prior to 1969. It was not intended for disposal of radioactive waste; however, a small amount of radioactive material was detected during sampling activities completed several years ago. The only radionuclide found to be migrating from the landfill is hydrogen-3, a radioactive isotope of hydrogen. The presence of hydrogen-3 in the vicinity of the 319 Landfill is discussed in Section 6.5.4. The 319 waste burial area consists of two distinct segments: the 


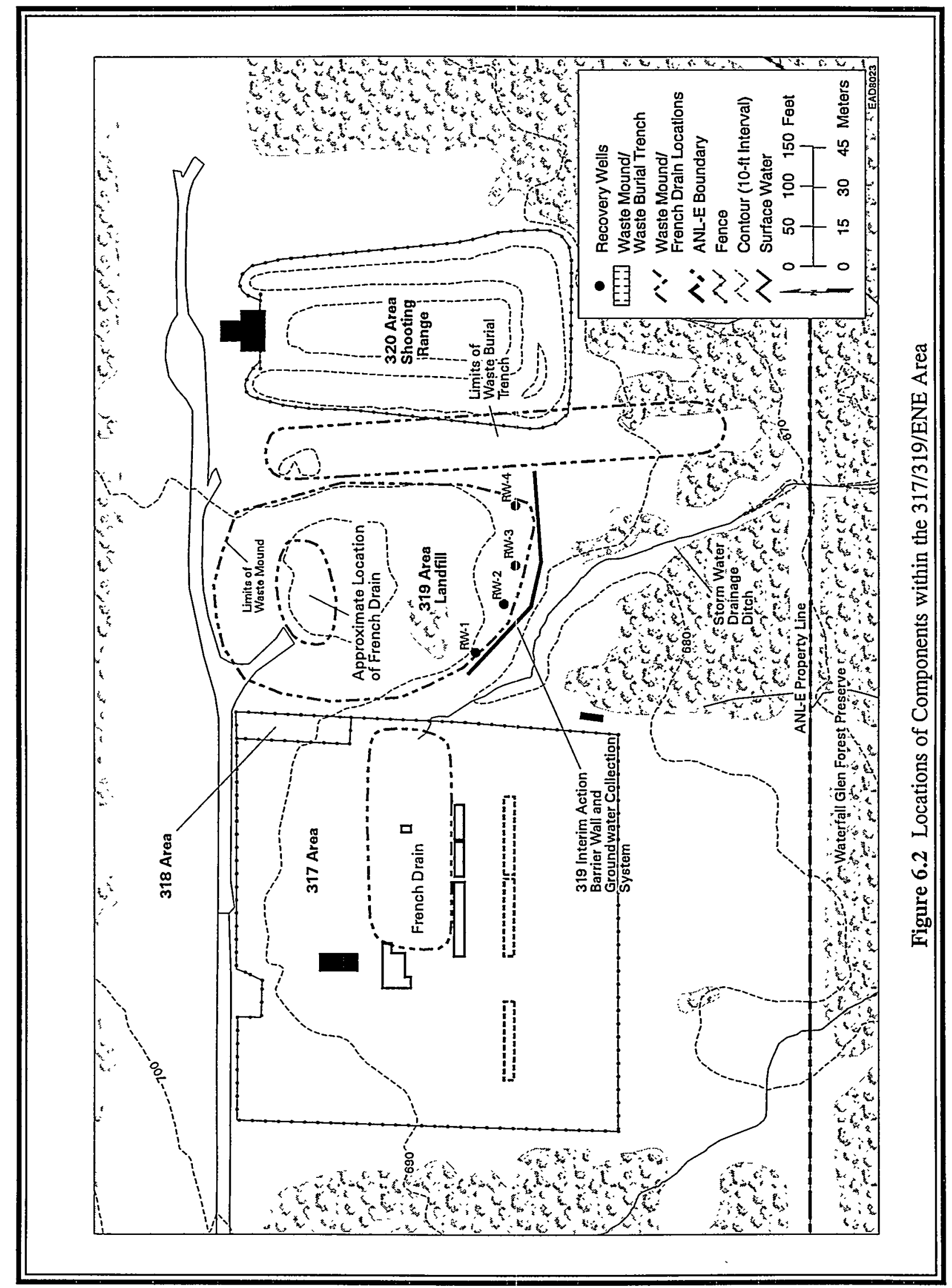




\section{GROUNDWATER PROTECTION}

waste mound, where the bulk of the waste was buried, and an adjacent burial trench, which contains a much smaller amount of mostly inert waste. This landfill also contains a French drain that was used for several years after the French drain in the 317 Area was closed. The presence of liquid chemical wastes from the French drain, as well are hydrogen-3 in the waste mound, have resulted in the generation of a plume of contaminated groundwater extending from the waste mound to the south, toward the Des Plaines River.

During late 1996, a series of small natural groundwater discharge points (groundwater seeps) was discovered approximately $183 \mathrm{~m}(600 \mathrm{ft})$ south of the 319 Area. Two of these seeps were found to contain very low levels of three VOCs. These two seeps and one additional seep, which normally does not contain VOCs, were found to contain hydrogen-3 at concentrations below all applicable standards. Since their discovery, these seeps have been monitored on a regular basis. A characterization study was completed in 1998 to identify the source and migration pathways for the hydrogen-3 and VOCs. The hydrogen-3 appears to be emanating from the 319 Landfill and is likely an extension of the on-site hydrogen-3 plume, albeit at much lower concentrations than measured on site. The source of VOCs was not clearly discerned, though it is likely that they also emanated from some past waste disposal activities in the 319 or 317 Area. The current region of VOC-contaminated groundwater is limited to a small area immediately northeast of the contaminated seeps.

Cleanup of the 317 and 319 Areas has been underway since the late 1980s. It is being carried out as a series of interrelated actions that will ultimately remove or contain the contaminants so that they will no longer migrate away from the waste disposal units. Several remedial actions are already in place and functioning as designed. These actions include a leachate and groundwater collection system for the 319 Landfill, removal of four waste storage vaults contaminated with radioactive materials, sealing of an underground drainage sewer, installation of 13 groundwater extraction wells south of the 317 Area, and construction of a concrete cover over a region containing buried compressed gas cylinders (318 Area). In addition, routine sampling and analysis of groundwater and surface water have continued. These actions have been discussed in previous annual reports. The remedial actions continued during 1998. A project to 


\section{GROUNDWATER PROTECTION}

remove VOCs from the soil in the 317 French Drain area was completed. This project utilized innovative remedial technologies to remove approximately $80 \%$ of the VOCs from several locations within the French drain area. A work plan for installation of a phytoremediation system was completed and transmitted to the IEPA for review. Phytoremediation involves the use of green plants (trees, grasses, and flowering plants) to remove by evapotranspiration or to degrade contaminants in soil and groundwater. This system will be installed in the 317 French Drain area as well as downgradient of the 317 and 319 Areas.

The results of the routine O\&M of the groundwater collection systems in the 317 and 319 Areas and the monitoring of the off-site groundwater seeps were transmitted to the IEPA on a quarterly basis through the submittal of Quarterly Progress Reports. The results of this monitoring are also summarized in this report.

\subsubsection{Groundwater Monitoring at the 317 and 319 Areas}

Ten active monitoring wells (some of which are clustered or nested) are installed at the locations shown in Figure 6.3. Well data are listed in Table 6.8. The wide range in water level elevations shown in Table 6.8 is not unusual and results from some of the wells being screened at different depths in different saturated zones. This variation in water level also may be indicative of "perched" (i.e., discontinuous) groundwater conditions within the glacial till. Samples are collected quarterly following EPA sampling protocols listed in the RCRA Ground-Water Monitoring Technical Enforcement Guidance Document. ${ }^{28}$

Groundwater monitoring in the 317 and 319 Areas has been conducted since 1986. Wells 319011, 317021, and 319031 were installed in September 1986; 317061 in August 1987; 317101 and 317111 in September 1988; and 319032 and 317052 were installed in June 1989. These wells were all completed in the glacial till. In addition, 317121D and 319131D were installed in November 1989 and reach the dolomite aquifer at about $25 \mathrm{~m}(80 \mathrm{ft})$ below the surface. 


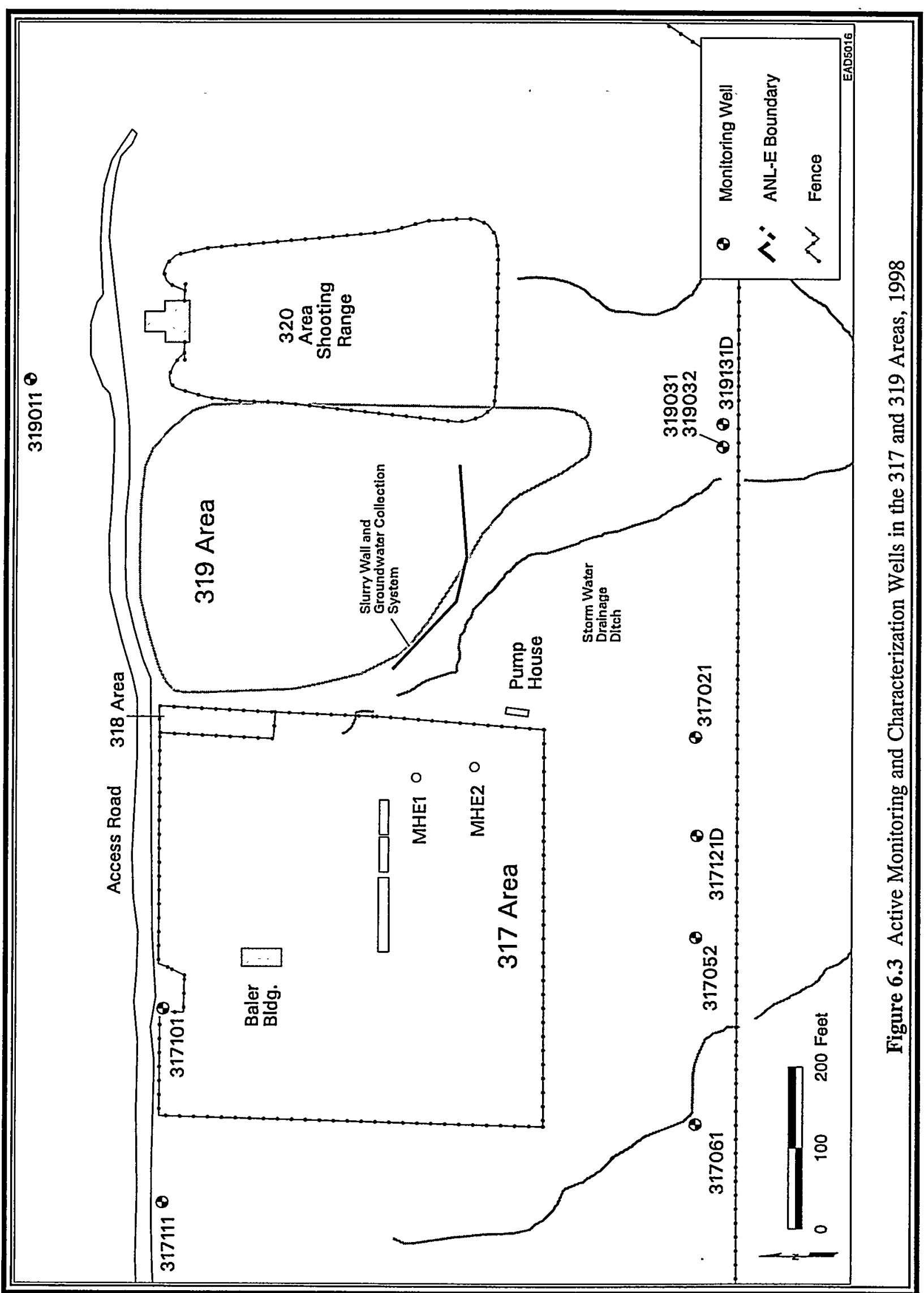

ANL-E Site Environmental Report 


\section{GROUNDWATER PROTECTION}

\section{TABLE 6.8}

\begin{tabular}{lccccc}
\multicolumn{6}{c}{ Groundwater Monitoring Wells: 317 and 319 Areas } \\
\hline $\begin{array}{c}\text { ID } \\
\text { Number }\end{array}$ & $\begin{array}{c}\text { Well } \\
\text { Depth } \\
\text { (m bgs) }\end{array}$ & $\begin{array}{c}\text { Ground } \\
\text { Elevation } \\
\text { (m AMSL) }\end{array}$ & $\begin{array}{c}\text { Monitoring } \\
\text { Zone } \\
\text { (m AMSL) }\end{array}$ & $\begin{array}{c}\text { Well } \\
\text { Type }^{\mathrm{a}}\end{array}$ & $\begin{array}{c}\text { Date } \\
\text { Drilled }\end{array}$ \\
\hline 319011 & 12.19 & 209.8 & $199.1-197.6$ & $0.05 / \mathrm{PVC}$ & $9 / 86$ \\
317021 & 12.19 & 209.2 & $198.5-197.0$ & $0.05 / \mathrm{PVC}$ & $9 / 86$ \\
319031 & 12.50 & 204.3 & $194.8-191.8$ & $0.05 / \mathrm{PVC}$ & $9 / 86$ \\
319032 & 7.62 & 204.3 & $198.2-196.7$ & $0.05 / \mathrm{PVC}$ & $8 / 89$ \\
317051 & 6.10 & 208.3 & $205.3-202.2$ & $0.05 / \mathrm{PVC}$ & $7 / 87$ \\
317053 & 6.71 & 208.3 & $203.1-201.6$ & $0.05 / \mathrm{PVC}$ & $8 / 89$ \\
317052 & 4.27 & 208.3 & $207.1-204.0$ & $0.05 / \mathrm{PVC}$ & $8 / 89$ \\
317061 & 12.19 & 207.5 & $196.9-195.3$ & $0.05 / \mathrm{PVC}$ & $7 / 87$ \\
317101 & 11.89 & 211.0 & $202.2-199.1$ & $0.05 / \mathrm{PVC}$ & $8 / 89$ \\
317111 & 11.89 & 210.3 & $201.4-198.4$ & $0.05 / \mathrm{PVC}$ & $8 / 89$ \\
$317121 D^{\mathrm{b}}$ & 24.08 & 207.6 & $185.0-183.5$ & $0.15 / \mathrm{CS}$ & $9 / 88$ \\
$319131 \mathrm{D}$ & 21.03 & 203.5 & $184.0-182.5$ & $0.15 / \mathrm{CS}$ & $9 / 88$ \\
\hline
\end{tabular}

a Inner diameter $(\mathrm{m})$ /well material $(\mathrm{PVC}=$ polyvinyl chloride, $\mathrm{CS}=$ carbon steel).

b Wells identified by a " $D$ " are deeper wells monitoring the dolomite bedrock aquifer.

Wells 317101 and 317111 are upgradient of the 317 storage area, and 319011 is upgradient of the 319 Area Landfill. A sand lens present at 5 to $8 \mathrm{~m}$ ( 15 to $25 \mathrm{ft}$ ) is monitored by 317052 and 319032. This layer is also intercepted by 317101 .

In addition to wells in this area, two manholes associated with the vault sewer system were monitored on a monthly basis. Figure 6.3 shows the locations of the manholes.

\subsubsection{Sample Collection}

The monitoring wells are sampled using the protocol listed in the RCRA Ground-Water Monitoring Technical Enforcement Guidance Document. ${ }^{28}$ The volume of the water in the casing is determined by measuring the water depth from the surface and the depth to the bottom of the 


\section{GROUNDWATER PROTECTION}

well. This latter measurement also determines whether siltation has occurred, which might restrict water movement in the screened area. For those wells in the glacial till that do not recharge rapidly, the well is emptied and the volume of water removed is compared with the calculated volume. In most cases, these volumes are nearly identical. The well is then sampled by bailing with a dedicated Teflon bailer. The field parameters for these samples ( $\mathrm{pH}$, specific conductance, redox potential, and temperature) are measured statically. For those samples in the porous, saturated zone that recharges rapidly, three well volumes are purged using dedicated submersible pumps, while the field parameters are measured continuously. These parameters stabilize quickly in these wells. In the case of the dolomite wells, samples are collected as soon as these readings stabilize. Samples for VOCs, SVOCs, PCBs and pesticides, metals, and radioactivity are collected in that order. The samples are placed in precleaned bottles, labeled, and preserved.

During each sampling event, one well is selected for replicate sampling. An effort is made to vary this selection so that replicates are obtained at every well over time. In addition, a field blank is also obtained.

\subsubsection{Sample Analyses -317 and 319 Areas}

The 317 and 319 Area groundwater chemical analyses were performed using SOPs written, reviewed, and issued as controlled documents by members of ESH-Analytical Services, Chemistry Laboratory (ESH-ASCL). These SOP reference protocols are from SW-846, 3rd edition, Test Methods for Evaluating Solid Waste: Physical/Chemical Methods. ${ }^{8}$ Fifteen metals were routinely determined and were measured using flame atomic absorption spectroscopy, inductively coupled plasma atomic emission spectrometry, and graphite furnace atomic absorption spectroscopy. Mercury was determined by cold vapor atomic absorption spectroscopy. Chloride was determined by titrimetry. VOCs were determined by using a purge and trap sample pretreatment followed by gas chromatography-mass spectroscopy detection. SVOCs were determined by solvent extraction followed by gas chromatography-mass spectrometry detection. PCBs and pesticides were determined by solvent extraction followed by gas chromatography-electron capture detection. In the case of organic compound analyses, efforts were made to identify compounds that were 


\section{GROUNDWATER PROTECTION}

present but not included on the method list. This was accomplished, and standard solutions of these compounds were prepared and analyzed.

The 317 and 319 Area groundwater radiological analyses were performed using SOPs written, reviewed, and issued as controlled documents by members of ESH-Analytical Services, Radiochemistry Laboratory (ESH-ASRL). Cesium-137 was determined by gamma-ray spectrometry. Hydrogen-3 was determined by distillation followed by a beta liquid scintillation counting technique. Strontium-90 was determined by an ion-exchange separation followed by a proportional counting technique.

\subsubsection{Results of Analyses}

Descriptions of each well, the field parameters measured during sample collection, and the results of chemical and radiological analyses of samples from the wells in the 317 and 319 Areas are contained in Tables 6.9 through 6.18. All radiological and inorganic analytical results are shown in these tables. The analytical methods used for organic compounds could identify and quantify all the compounds contained in the CLP Target Compound List. However, the vast majority of these compounds were not detected in the samples. To simplify the format of these tables, those results less than the detection limit are not included. Only those constituents that were present in amounts great enough to quantify are shown. The detection limits for the organic compounds listed were typically 1 to $5 \mu \mathrm{g} / \mathrm{L}$.

Field Parameters. The purging of wells to produce water representative of the groundwater being studied was followed by measuring the field parameters. For the wells reported in this study, temperature, $\mathrm{pH}$, redox potential, and specific conductance remained fairly constant after two well volumes were removed. On the basis of this information, sampling was conducted after the removal of three well volumes. The field parameters listed in the tables are the final readings obtained at the time of sampling. Wells $319011,317021,317061,317111$, and 319031 usually dry up after one well volume is removed. Therefore, field parameters were 
TABLE 6.9

Groundwater Monitoring Results, 300 Area Well 317021, 1998

\begin{tabular}{|c|c|c|c|c|c|}
\hline \multirow[b]{2}{*}{ Parameter } & \multirow[b]{2}{*}{ Unit } & \multicolumn{4}{|c|}{ Date of Sampling } \\
\hline & & $03 / 18 / 98$ & $05 / 29 / 98$ & $09 / 23 / 98$ & $12 / 09 / 98$ \\
\hline Water elevation ${ }^{a}$ & $\mathrm{~m}$ & 199.23 & 199.31 & 199.10 & 199.90 \\
\hline Temperature & ${ }^{\circ} \mathrm{C}$ & 10.2 & 12.9 & 11.6 & 10.8 \\
\hline $\mathrm{pH}$ & $\mathrm{pH}$ & 7.34 & 7.34 & 7.40 & 7.44 \\
\hline Redox & $\mathrm{mV}$ & -14 & -24 & -13 & -25 \\
\hline Conductivity & $\mu \mathrm{mhos} / \mathrm{cm}$ & 869 & 914 & 1,057 & 964 \\
\hline Chloride $^{\mathrm{b}}$ & $\mathrm{mg} / \mathrm{L}$ & 25 & 37 & 73 & 52 \\
\hline Arsenic $^{\mathrm{b}}$ & $\mathrm{mg} / \mathrm{L}$ & $<0.0025$ & $<0.0025$ & $<0.0025$ & $<0.0025$ \\
\hline Barium $^{b}$ & $\mathrm{mg} / \mathrm{L}$ & 0.0339 & 0.0427 & 0.0459 & 0.0366 \\
\hline Beryllium $^{b}$ & $\mathrm{mg} / \mathrm{L}$ & $<0.0002$ & $<0.0002$ & $<0.0002$ & $<0.0002$ \\
\hline Cadmium $^{b}$ & $\mathrm{mg} / \mathrm{L}$ & $<0.0001$ & $<0.0001$ & $<0.0001$ & $<0.0001$ \\
\hline Chromium $^{b}$ & $\mathrm{mg} / \mathrm{L}$ & $<0.044$ & $<0.044$ & $<0.044$ & $<0.044$ \\
\hline Cobalt ${ }^{\mathrm{b}}$ & $\mathrm{mg} / \mathrm{L}$ & $<0.026$ & $<0.026$ & $<0.026$ & $<0.026$ \\
\hline Copper $^{b}$ & $\mathrm{mg} / \mathrm{L}$ & $<0.017$ & $<0.017$ & $<0.017$ & $<0.017$ \\
\hline Iron $^{\mathrm{b}}$ & $\mathrm{mg} / \mathrm{L}$ & $<0.037$ & $<0.037$ & $<0.037$ & $<0.037$ \\
\hline Lead $^{b}$ & $\mathrm{mg} / \mathrm{L}$ & $<0.001$ & $<0.001$ & $<0.001$ & $<0.001$ \\
\hline Manganese $^{b}$ & $\mathrm{mg} / \mathrm{L}$ & $<0.017$ & $<0.017$ & $<0.017$ & $<0.017$ \\
\hline Mercury ${ }^{b}$ & $\mathrm{mg} / \mathrm{L}$ & $<0.0001$ & $<0.0001$ & $<0.0001$ & $<0.0001$ \\
\hline Nickel $^{\mathrm{b}}$ & $\mathrm{mg} / \mathrm{L}$ & $<0.04$ & $<0.04$ & $<0.04$ & $<0.04$ \\
\hline Silver ${ }^{b}$ & $\mathrm{mg} / \mathrm{L}$ & $<0.0005$ & $<0.0005$ & $<0.0005$ & $<0.0005$ \\
\hline Thallium $^{\mathrm{b}}$ & $\mathrm{mg} / \mathrm{L}$ & $<0.0015$ & $<0.0015$ & $<0.0015$ & $<0.0015$ \\
\hline Vanadium $^{\mathrm{b}}$ & $\mathrm{mg} / \mathrm{L}$ & $<0.024$ & $<0.024$ & $<0.024$ & $<0.024$ \\
\hline Zinc $^{b}$ & $\mathrm{mg} / \mathrm{L}$ & 0.018 & $<0.011$ & $<0.011$ & 0.034 \\
\hline Cesium-137 & $\mathrm{pCi} / \mathrm{L}$ & $<1.0$ & $<1.0$ & $<1.0$ & $<1.0$ \\
\hline Hydrogen-3 & $\mathrm{pCi} / \mathrm{L}$ & $<100$ & 138 & 114 & 205 \\
\hline Strontium-90 & $\mathrm{pCi} / \mathrm{L}$ & $<0.25$ & $<0.25$ & $<0.25$ & $<0.25$ \\
\hline 1,1,1-Trichloroethane & $\mu \mathrm{g} / \mathrm{L}$ & 21 & 21 & 10 & 16 \\
\hline 1,1-Dichloroethane & $\mu \mathrm{g} / \mathrm{L}$ & 3 & 5 & 5 & 7 \\
\hline Carbon tetrachloride & $\mu \mathrm{g} / \mathrm{L}$ & 2 & 1 & $-c$ & - \\
\hline Tetrachloroethene & $\mu \mathrm{g} / \mathrm{L}$ & 1 & 1 & - & - \\
\hline Trichloroethene & $\mu \mathrm{g} / \mathrm{L}$ & 3 & 2 & 1 & 1 \\
\hline
\end{tabular}

a Well point elevation $=197.27 \mathrm{~m}$ mean sea level (MSL); ground surface elevation $=209.17 \mathrm{~m}$ (MSL); casing material $=$ PVC.

b Filtered sample.

c A hyphen indicates that the measured value was less than the detection limit. 


\section{TABLE 6.10}

Groundwater Monitoring Results, 300 Area Well 317052, 1998

\begin{tabular}{|c|c|c|c|c|c|c|}
\hline \multirow[b]{2}{*}{ Parameter } & \multirow[b]{2}{*}{ Units } & \multicolumn{5}{|c|}{ Date of Sampling } \\
\hline & & $03 / 19 / 98$ & $05 / 28 / 98$ & $09 / 23 / 98$ & $12 / 09 / 98$ & $12 / 09 / 98$ \\
\hline Water elevation ${ }^{2}$ & $\mathrm{~m}$ & 206.50 & 205.25 & 204.79 & 205.36 & 205.36 \\
\hline Temperature & ${ }^{\circ} \mathrm{C}$ & 7.3 & 11.1 & 15.0 & 12.8 & 12.8 \\
\hline $\mathrm{pH}$ & $\mathrm{pH}$ & 7.86 & 7.52 & 7.39 & 7.60 & 7.60 \\
\hline Redox & $\mathrm{mV}$ & 46 & -31 & -15 & -26 & -26 \\
\hline Conductivity & $\mu \mathrm{mhos} / \mathrm{cm}$ & 708 & 719 & 780 & 753 & 753 \\
\hline Chloride $^{\mathrm{b}}$ & $\mathrm{mg} / \mathrm{L}$ & 2 & 3 & 3 & 5 & 6 \\
\hline Arsenic $^{b}$ & $\mathrm{mg} / \mathrm{L}$ & $<0.0025$ & $<0.0025$ & $<0.0025$ & $<0.0025$ & $<0.0025$ \\
\hline Barium $^{b}$ & $\mathrm{mg} / \mathrm{L}$ & 0.0262 & 0.0224 & 0.0293 & 0.0203 & 0.0204 \\
\hline Beryllium ${ }^{b}$ & $\mathrm{mg} / \mathrm{L}$ & $<0.0002$ & $<0.0002$ & $<0.0002$ & $<0.0002$ & $<0.0002$ \\
\hline Cadmium ${ }^{b}$ & $\mathrm{mg} / \mathrm{L}$ & $<0.0001$ & $<0.0001$ & $<0.0001$ & $<0.0001$ & $<0.0001$ \\
\hline Chromium $^{b}$ & $\mathrm{mg} / \mathrm{L}$ & $<0.044$ & $<0.044$ & $<0.044$ & $<0.044$ & $<0.044$ \\
\hline Cobalt $^{\mathrm{b}}$ & $\mathrm{mg} / \mathrm{L}$ & $<0.026$ & $<0.026$ & $<0.026$ & $<0.026$ & $<0.026$ \\
\hline Copper ${ }^{b}$ & $\mathrm{mg} / \mathrm{L}$ & $<0.017$ & $<0.017$ & $<0.017$ & $<0.017$ & $<0.017$ \\
\hline Iron $^{b}$ & $\mathrm{mg} / \mathrm{L}$ & $<0.037$ & $<0.037$ & $<0.037$ & $<0.037$ & $<0.037$ \\
\hline Lead $^{b}$ & $\mathrm{mg} / \mathrm{L}$ & $<0.001$ & $<0.001$ & $<0.001$ & $<0.001$ & $<0.001$ \\
\hline Manganese $^{\mathrm{b}}$ & $\mathrm{mg} / \mathrm{L}$ & $<0.017$ & $<0.017$ & $<0.017$ & $<0.017$ & $<0.017$ \\
\hline Mercury ${ }^{b}$ & $\mathrm{mg} / \mathrm{L}$ & $<0.0001$ & $<0.0001$ & $<0.0001$ & $<0.0001$ & $<0.0001$ \\
\hline Nickel $^{\mathrm{b}}$ & $\mathrm{mg} / \mathrm{L}$ & $<0.04$ & $<0.04$ & $<0.04$ & $<0.04$ & $<0.04$ \\
\hline Silver ${ }^{b}$ & $\mathrm{mg} / \mathrm{L}$ & $<0.0005$ & $<0.0005$ & 0.0006 & $<0.0005$ & $<0.0005$ \\
\hline Thallium $^{\mathrm{b}}$ & $\mathrm{mg} / \mathrm{L}$ & $<0.0015$ & $<0.0015$ & $<0.0015$ & $<0.0015$ & $<0.0015$ \\
\hline Vanadium $^{\mathrm{b}}$ & $\mathrm{mg} / \mathrm{L}$ & $<0.024$ & $<0.024$ & $<0.024$ & 0.044 & $<0.024$ \\
\hline Zinc $^{b}$ & $\mathrm{mg} / \mathrm{L}$ & 0.012 & $<0.011$ & $<0.011$ & $<0.011$ & 0.012 \\
\hline Cesium-137 & $\mathrm{pCi} / \mathrm{L}$ & $<1.0$ & 2.1 & $<1.0$ & 1.2 & $<1.0$ \\
\hline Hydrogen-3 & $\mathrm{pCi} / \mathrm{L}$ & $<100$ & $<100$ & $<100$ & 195 & $<100$ \\
\hline Strontium-90 & $\mathrm{pCi} / \mathrm{L}$ & $<0.25$ & $<0.25$ & $<0.25$ & $<0.25$ & $<0.25$ \\
\hline
\end{tabular}

a Well point elevation = $204.04 \mathrm{~m}(\mathrm{MSL})$; ground surface elevation = $208.32 \mathrm{~m}(\mathrm{MSL})$; casing material = PVC.

b Filtered sample. 


\section{GROUNDWATER PROTECTION}

TABLE 6.11

Groundwater Monitoring Results, 300 Area Well 317061, 1998

\begin{tabular}{|c|c|c|c|c|c|}
\hline \multirow[b]{2}{*}{ Parameter } & \multirow[b]{2}{*}{ Unit } & \multicolumn{4}{|c|}{ Date of Sampling } \\
\hline & & $03 / 19 / 98$ & $05 / 29 / 98$ & $09 / 23 / 98$ & $12 / 09 / 98$ \\
\hline Water elevation ${ }^{\mathrm{a}}$ & $\mathrm{m}$ & 199.71 & 199.85 & 198.89 & 198.86 \\
\hline Temperature & ${ }^{\circ} \mathrm{C}$ & 10.1 & 11.4 & 10.8 & 10.4 \\
\hline $\mathrm{pH}$ & $\mathrm{pH}$ & 7.17 & 7.18 & 7.17 & 8.11 \\
\hline Redox & $\mathrm{mV}$ & -5 & -16 & -5 & -53 \\
\hline Conductivity & $\mu \mathrm{mhos} / \mathrm{cm}$ & 1,101 & 1,118 & 1,116 & 1,120 \\
\hline Chloride $^{b}$ & $\mathrm{mg} / \mathrm{L}$ & 61 & 76 & 71 & 69 \\
\hline Arsenic $^{\mathrm{b}}$ & $\mathrm{mg} / \mathrm{L}$ & $<0.0025$ & $<0.0025$ & $<0.0025$ & $<0.0025$ \\
\hline Barium $^{b}$ & $\mathrm{mg} / \mathrm{L}$ & 0.0624 & 0.0571 & 0.0559 & 0.0458 \\
\hline Beryllium $^{\mathrm{b}}$ & $\mathrm{mg} / \mathrm{L}$ & $<0.0002$ & $<0.0002$ & $<0.0002$ & $<0.0002$ \\
\hline Cadmium $^{\mathrm{b}}$ & $\mathrm{mg} / \mathrm{L}$ & $<0.0001$ & $<0.0001$ & $<0.0001$ & $<0.0001$ \\
\hline Chromium $^{b}$ & $\mathrm{mg} / \mathrm{L}$ & $<0.044$ & $<0.044$ & $<0.044$ & $<0.044$ \\
\hline Cobalt ${ }^{\mathrm{b}}$ & $\mathrm{mg} / \mathrm{L}$ & $<0.026$ & $<0.026$ & $<0.026$ & $<0.026$ \\
\hline Copper ${ }^{b}$ & $\mathrm{mg} / \mathrm{L}$ & $<0.017$ & $<0.017$ & $<0.017$ & $<0.017$ \\
\hline Iron $^{\mathrm{b}}$ & $\mathrm{mg} / \mathrm{L}$ & 0.044 & $<0.037$ & 0.074 & $<0.037$ \\
\hline Lead $^{b}$ & $\mathrm{mg} / \mathrm{L}$ & $<0.001$ & $<0.001$ & $<0.001$ & $<0.001$ \\
\hline Manganese $^{b}$ & $\mathrm{mg} / \mathrm{L}$ & $<0.017$ & $<0.017$ & $<0.017$ & $<0.017$ \\
\hline Mercuryb & $\mathrm{mg} / \mathrm{L}$ & $<0.0001$ & $<0.0001$ & $<0.0001$ & $<0.0001$ \\
\hline Nickel $^{\mathrm{b}}$ & $\mathrm{mg} / \mathrm{L}$ & $<0.04$ & $<0.04$ & $<0.04$ & $<0.04$ \\
\hline Silver $^{b}$ & $\mathrm{mg} / \mathrm{L}$ & $<0.0005$ & $<0.0005$ & $<0.0005$ & $<0.0005$ \\
\hline Thallium $^{\mathrm{b}}$ & $\mathrm{mg} / \mathrm{L}$ & $<0.0015$ & $<0.0015$ & $<0.0015$ & $<0.0015$ \\
\hline Vanadium $^{\mathrm{b}}$ & $\mathrm{mg} / \mathrm{L}$ & $<0.024$ & $<0.024$ & $<0.024$ & $<0.024$ \\
\hline Zinc $^{b}$ & $\mathrm{mg} / \mathrm{L}$ & 0.012 & 0.015 & $<0.011$ & 0.016 \\
\hline Cesium-137 & $\mathrm{pCi} / \mathrm{L}$ & 1.2 & 1.2 & $<1.0$ & $<1.0$ \\
\hline Hydrogen-3 & $\mathrm{pCi} / \mathrm{L}$ & $<100$ & $<100$ & 129 & 116 \\
\hline Strontium-90 & $\mathrm{pCi} / \mathrm{L}$ & $<0.25$ & $<0.25$ & $<0.25$ & $<0.25$ \\
\hline 1,1,1-Trichloroethane & $\mu \mathrm{g} / \mathrm{L}$ & $-c$ & - & 10 & - \\
\hline 1,1-Dichloroethane & $\mu \mathrm{g} / \mathrm{L}$ & - & - & 5 & - \\
\hline
\end{tabular}

a Well point elevation = $195.35 \mathrm{~m}$ (MSL); ground surface elevation $207.54 \mathrm{~m}$ (MSL); casing material = PVC.

b Filtered sample.

${ }^{c}$ A hyphen indicates that the measured value was less than the detection limit. 


\section{GROUNDWATER PROTECTION}

TABLE 6.12

Groundwater Monitoring Results, 300 Area Well 317101, 1998

\begin{tabular}{|c|c|c|c|c|c|c|}
\hline \multirow[b]{2}{*}{ Parameter } & \multirow[b]{2}{*}{ Unit } & \multicolumn{5}{|c|}{ Date of Sampling } \\
\hline & & $03 / 18 / 98$ & $03 / 18 / 98$ & $05 / 28 / 98$ & $09 / 23 / 98$ & $12 / 08 / 98$ \\
\hline Water elevation ${ }^{\mathrm{a}}$ & $\mathrm{m}$ & 203.07 & 203.07 & 204.06 & 202.84 & 202.75 \\
\hline Temperature & ${ }^{\circ} \mathrm{C}$ & 11.4 & 11.4 & 11.6 & 11.7 & 11.9 \\
\hline $\mathrm{pH}$ & $\mathrm{pH}$ & 7.08 & 7.08 & 7.03 & 7.12 & 7.04 \\
\hline Redox & $\mathrm{mV}$ & 1 & 1 & -7 & 2 & -2 \\
\hline Conductivity & $\mu \mathrm{mhos} / \mathrm{cm}$ & 2,980 & 2,980 & 2,660 & 2,510 & 2,780 \\
\hline Chloride & $\mathrm{mg} / \mathrm{L}$ & 687 & 681 & 581 & 537 & 650 \\
\hline Arsenic $^{b}$ & $\mathrm{mg} / \mathrm{L}$ & $<0.0025$ & $<0.0025$ & $<0.0025$ & $<0.0025$ & $<0.0025$ \\
\hline Barium ${ }^{b}$ & $\mathrm{mg} / \mathrm{L}$ & 0.0929 & 0.0840 & 0.0802 & 0.0851 & 0.0804 \\
\hline Beryllium $^{\mathrm{b}}$ & $\mathrm{mg} / \mathrm{L}$ & $<0.0002$ & $<0.0002$ & $<0.0002$ & $<0.0002$ & $<0.0002$ \\
\hline Cadmium $^{b}$ & $\mathrm{mg} / \mathrm{L}$ & $<0.0001$ & $<0.0001$ & $<0.0001$ & $<0.0001$ & $<0.0001$ \\
\hline Chromium $^{b}$ & $\mathrm{mg} / \mathrm{L}$ & $<0.044$ & $<0.044$ & $<0.044$ & $<0.044$ & $<0.044$ \\
\hline Cobalt ${ }^{b}$ & $\mathrm{mg} / \mathrm{L}$ & $<0.026$ & $<0.026$ & $<0.026$ & $<0.026$ & $<0.026$ \\
\hline Copper $^{b}$ & $\mathrm{mg} / \mathrm{L}$ & $<0.017$ & $<0.017$ & $<0.017$ & $<0.017$ & $<0.017$ \\
\hline Iron $^{b}$ & $\mathrm{mg} / \mathrm{L}$ & $<0.037$ & $<0.037$ & $<0.037$ & $<0.037$ & $<0.037$ \\
\hline Lead $^{b}$ & $\mathrm{mg} / \mathrm{L}$ & $<0.001$ & $<0.001$ & $<0.001$ & $<0.001$ & $<0.001$ \\
\hline Manganese $^{b}$ & $\mathrm{mg} / \mathrm{L}$ & $<0.017$ & $<0.017$ & 0.034 & 0.025 & 0.025 \\
\hline Mercury ${ }^{b}$ & $\mathrm{mg} / \mathrm{L}$ & $<0.0001$ & $<0.0001$ & $<0.0001$ & $<0.0001$ & $<0.0001$ \\
\hline Nickel $\mathrm{b}^{\mathrm{b}}$ & $\mathrm{mg} / \mathrm{L}$ & $<0.04$ & $<0.04$ & $<0.04$ & $<0.04$ & $<0.04$ \\
\hline Silver $\mathbf{b}$ & $\mathrm{mg} / \mathrm{L}$ & $<0.0005$ & $<0.0005$ & $<0.0005$ & $<0.0005$ & $<0.0005$ \\
\hline Thallium $^{b}$ & $\mathrm{mg} / \mathrm{L}$ & $<0.0015$ & $<0.0015$ & $<0.0015$ & $<0.0015$ & $<0.0015$ \\
\hline Vanadium $^{\mathrm{b}}$ & $\mathrm{mg} / \mathrm{L}$ & $<0.024$ & $<0.024$ & $<0.024$ & $<0.024$ & $<0.024$ \\
\hline Zinc $^{b}$ & $\mathrm{mg} / \mathrm{L}$ & 0.032 & 0.016 & $<0.011$ & 0.011 & $<0.011$ \\
\hline Cesium-137 & $\mathrm{pCi} / \mathrm{L}$ & $<1.0$ & 1.4 & $<1.0$ & $<1.0$ & $<1.0$ \\
\hline Hydrogen-3 & $\mathrm{pCi} / \mathrm{L}$ & $<100$ & $<100$ & $<100$ & $<100$ & $<100$ \\
\hline Strontium-90 & $\mathrm{pCi} / \mathrm{L}$ & $<0.25$ & $<0.25$ & $<0.25$ & $<0.25$ & $<0.25$ \\
\hline
\end{tabular}

a Well point elevation $=198.66 \mathrm{~m}(\mathrm{MSL})$; ground surface elevation = $211.04 \mathrm{~m}(\mathrm{MSL})$; casing material $=$ PVC.

b Filtered sample. 


\section{GROUNDWATER PROTECTION}

\section{TABLE 6.13}

Groundwater Monitoring Results, 300 Area Well 317111, 1998

\begin{tabular}{|c|c|c|c|c|c|c|}
\hline \multirow[b]{2}{*}{ Parameter } & \multirow[b]{2}{*}{ Unit } & \multicolumn{5}{|c|}{ Date of Sampling } \\
\hline & & $03 / 18 / 98$ & $05 / 28 / 98$ & $05 / 28 / 98$ & $09 / 23 / 98$ & $12 / 08 / 98$ \\
\hline Water elevation ${ }^{\mathrm{a}}$ & $\mathrm{m}$ & 203.71 & 204.60 & 204.60 & 203.10 & 202.97 \\
\hline Temperature & ${ }^{\circ} \mathrm{C}$ & 10.9 & 11.0 & 11.0 & 11.1 & 10.8 \\
\hline $\mathrm{pH}$ & $\mathrm{pH}$ & 6.98 & 7.08 & 7.08 & 7.25 & 7.08 \\
\hline Redox & $\mathrm{mV}$ & 5 & -12 & -12 & -8 & -1 \\
\hline Conductivity & $\mu \mathrm{mhos} / \mathrm{cm}$ & 1,491 & 1,537 & 1,537 & 1,515 & 1,560 \\
\hline Chloride $^{b}$ & $\mathrm{mg} / \mathrm{L}$ & 250 & 269 & 275 & 269 & 325 \\
\hline Arsenic $^{b}$ & $\mathrm{mg} / \mathrm{L}$ & $<0.0025$ & $<0.0025$ & $<0.0025$ & $<0.0025$ & $<0.0025$ \\
\hline Barium $^{b}$ & $\mathrm{mg} / \mathrm{L}$ & 0.0738 & 0.0874 & 0.0841 & 0.0902 & 0.0691 \\
\hline Beryllium $^{\mathrm{b}}$ & $\mathrm{mg} / \mathrm{L}$ & $<0.0002$ & $<0.0002$ & $<0.0002$ & $<0.0002$ & $<0.0002$ \\
\hline Cadmium $^{\mathrm{b}}$ & $\mathrm{mg} / \mathrm{L}$ & $<0.0001$ & $<0.0001$ & $<0.0001$ & $<0.0001$ & $<0.0001$ \\
\hline Chromium $^{b}$ & $\mathrm{mg} / \mathrm{L}$ & $<0.044$ & $<0.044$ & $<0.044$ & $<0.044$ & $<0.044$ \\
\hline Cobalt $^{b}$ & $\mathrm{mg} / \mathrm{L}$ & $<0.026$ & $<0.026$ & $<0.026$ & $<0.026$ & $<0.026$ \\
\hline Copper ${ }^{b}$ & $\mathrm{mg} / \mathrm{L}$ & $<0.017$ & $<0.017$ & $<0.017$ & $<0.017$ & $<0.017$ \\
\hline Iron $^{b}$ & $\mathrm{mg} / \mathrm{L}$ & 0.066 & $<0.037$ & $<0.037$ & $<0.037$ & $<0.037$ \\
\hline Lead $^{\text {b }}$ & $\mathrm{mg} / \mathrm{L}$ & $<0.001$ & $<0.001$ & $<0.001$ & $<0.001$ & 0.001 \\
\hline Manganese $^{b}$ & $\mathrm{mg} / \mathrm{L}$ & 0.0349 & 0.0307 & 0.0347 & 0.0398 & 0.0784 \\
\hline Mercury $^{b}$ & $\mathrm{mg} / \mathrm{L}$ & $<0.0001$ & $<0.0001$ & $<0.0001$ & $<0.0001$ & $<0.0001$ \\
\hline Nickel $^{b}$ & $\mathrm{mg} / \mathrm{L}$ & $<0.04$ & $<0.04$ & $<0.04$ & $<0.04$ & $<0.04$ \\
\hline Silver $^{b}$ & $\mathrm{mg} / \mathrm{L}$ & $<0.0005$ & $<0.0005$ & $<0.0005$ & $<0.0005$ & $<0.0005$ \\
\hline Thallium $^{\mathrm{b}}$ & $\mathrm{mg} / \mathrm{L}$ & $<0.0015$ & $<0.0015$ & $<0.0015$ & $<0.0015$ & $<0.0015$ \\
\hline Vanadium $^{\mathrm{b}}$ & $\mathrm{mg} / \mathrm{L}$ & $<0.024$ & $<0.024$ & $<0.024$ & $<0.024$ & $<0.024$ \\
\hline Zinc $^{b}$ & $\mathrm{mg} / \mathrm{L}$ & $<0.011$ & $<0.011$ & $<0.011$ & $<0.011$ & 0.014 \\
\hline Cesium-137 & $\mathrm{pCi} / \mathrm{L}$ & 1.6 & $<1.0$ & 1.1 & $<1.0$ & $<1.0$ \\
\hline Hydrogen-3 & $\mathrm{pCi} / \mathrm{L}$ & $<100$ & $<100$ & $<100$ & $<100$ & $<100$ \\
\hline Strontium-90 & $\mathrm{pCi} / \mathrm{L}$ & $<0.25$ & $<0.25$ & $<0.25$ & $<0.25$ & $<0.25$ \\
\hline
\end{tabular}

a Well point elevation $=198.37 \mathrm{~m}(\mathrm{MSL})$; ground surface elevation $=210.25 \mathrm{~m}(\mathrm{MSL})$; casing material $=$ PVC.

b Filtered sample. 
TABLE 6.14

Groundwater Monitoring Results, 300 Area Well 317121D, 1998

\begin{tabular}{|c|c|c|c|c|c|}
\hline \multirow[b]{2}{*}{ Parameter } & \multirow[b]{2}{*}{ Unit } & \multicolumn{4}{|c|}{ Date of Sampling } \\
\hline & & $03 / 19 / 98$ & $05 / 28 / 98$ & $09 / 24 / 98$ & $12 / 09 / 98$ \\
\hline Water elevation ${ }^{\mathrm{a}}$ & $\mathrm{m}$ & 186.41 & 186.44 & 186.38 & 186.38 \\
\hline Temperature & ${ }^{\circ} \mathrm{C}$ & 10.8 & 12.3 & 11.2 & 10.8 \\
\hline $\mathrm{pH}$ & $\mathrm{pH}$ & 11.77 & 11.54 & 10.17 & 11.12 \\
\hline Redox & $\mathrm{mV}$ & -256 & -247 & -167 & -248 \\
\hline Conductivity & $\mu \mathrm{mhos} / \mathrm{cm}$ & 1,174 & 686 & 466 & 786 \\
\hline Chloride $^{b}$ & $\mathrm{mg} / \mathrm{L}$ & 38 & 37 & 37 & 41 \\
\hline Arsenic $^{\mathrm{b}}$ & $\mathrm{mg} / \mathrm{L}$ & $<0.0025$ & $<0.0025$ & $<0.0025$ & $<0.0025$ \\
\hline Barium $^{b}$ & $\mathrm{mg} / \mathrm{L}$ & 0.0360 & 0.0857 & 0.0959 & 0.1111 \\
\hline Beryllium ${ }^{b}$ & $\mathrm{mg} / \mathrm{L}$ & $<0.0002$ & $<0.0002$ & $<0.0002$ & $<0.0002$ \\
\hline Cadmium $^{b}$ & $\mathrm{mg} / \mathrm{L}$ & $<0.0001$ & $<0.0001$ & $<0.0001$ & $<0.0001$ \\
\hline Chromium $^{\mathrm{b}}$ & $\mathrm{mg} / \mathrm{L}$ & $<0.044$ & $<0.044$ & $<0.044$ & $<0.044$ \\
\hline Cobalt $^{\mathrm{b}}$ & $\mathrm{mg} / \mathrm{L}$ & $<0.026$ & $<0.026$ & $<0.026$ & $<0.026$ \\
\hline Copper $^{b}$ & $\mathrm{mg} / \mathrm{L}$ & $<0.017$ & $<0.017$ & $<0.017$ & $<0.017$ \\
\hline Iron $^{b}$ & $\mathrm{mg} / \mathrm{L}$ & $<0.037$ & $<0.037$ & $<0.037$ & $<0.037$ \\
\hline Lead $^{\mathbf{b}}$ & $\mathrm{mg} / \mathrm{L}$ & $<0.001$ & $<0.001$ & $<0.001$ & $<0.001$ \\
\hline Manganese ${ }^{b}$ & $\mathrm{mg} / \mathrm{L}$ & $<0.017$ & $<0.017$ & $<0.017$ & $<0.017$ \\
\hline Mercury ${ }^{b}$ & $\mathrm{mg} / \mathrm{L}$ & $<0.0001$ & $<0.0001$ & $<0.0001$ & $<0.0001$ \\
\hline Nickel ${ }^{\mathrm{b}}$ & $\mathrm{mg} / \mathrm{L}$ & $<0.04$ & $<0.04$ & $<0.04$ & $<0.04$ \\
\hline Silver ${ }^{b}$ & $\mathrm{mg} / \mathrm{L}$ & $<0.0005$ & $<0.0005$ & $<0.0005$ & $<0.0005$ \\
\hline Thallium $^{\mathrm{b}}$ & $\mathrm{mg} / \mathrm{L}$ & $<0.0015$ & $<0.0015$ & $<0.0015$ & $<0.0015$ \\
\hline Vanadium $^{b}$ & $\mathrm{mg} / \mathrm{L}$ & $<0.024$ & $<0.024$ & $<0.024$ & $<0.024$ \\
\hline $\operatorname{Zinc}^{\mathrm{b}}$ & $\mathrm{mg} / \mathrm{L}$ & $<0.011$ & $<0.011$ & $<0.011$ & $<0.011$ \\
\hline Cesium-137 & $\mathrm{pC} \mathrm{i} / \mathrm{L}$ & $<1.0$ & 1.1 & $<1.0$ & $<1.0$ \\
\hline Hydrogen-3 & $\mathrm{pCi} / \mathrm{L}$ & $<100$ & $<100$ & 124 & $<100$ \\
\hline Strontium-90 & $\mathrm{pCi} / \mathrm{L}$ & $<0.25$ & $<0.25$ & $<0.25$ & $<0.25$ \\
\hline
\end{tabular}

a Well point elevation $=183.49 \mathrm{~m}$ (MSL); ground surface elevation $=207.57 \mathrm{~m}$ (MSL); casing material = steel.

b Filtered samples. 


\section{GROUNDWATER PROTECTION}

TABLE 6.15

Groundwater Monitoring Results, 300 Area Well 319011, 1998

\begin{tabular}{|c|c|c|c|c|c|}
\hline \multirow[b]{2}{*}{ Parameter } & \multirow[b]{2}{*}{ Unit } & \multicolumn{4}{|c|}{ Date of Sampling } \\
\hline & & $03 / 18 / 98$ & $05 / 29 / 98$ & $09 / 23 / 98$ & $12 / 08 / 98$ \\
\hline Water elevation ${ }^{\mathrm{a}}$ & $\mathrm{m}$ & 199.97 & 202.21 & 200.55 & 199.10 \\
\hline Temperature & ${ }^{\circ} \mathrm{C}$ & 10.2 & 12.9 & 11.1 & 10.3 \\
\hline $\mathrm{pH}$ & $\mathrm{pH}$ & 7.23 & 7.25 & 7.18 & 7.15 \\
\hline Redox & $\mathrm{mV}$ & -5 & -12 & -1 & -8 \\
\hline Conductivity & $\mu \mathrm{mhos} / \mathrm{cm}$ & 1,211 & 1,056 & 1,161 & 1,107 \\
\hline Chloride $^{b}$ & $\mathrm{mg} / \mathrm{L}$ & 53 & 53 & 40 & 47 \\
\hline Arsenic $^{b}$ & $\mathrm{mg} / \mathrm{L}$ & $<0.0025$ & $<0.0025$ & $<0.0025$ & $<0.0025$ \\
\hline Barium $^{b}$ & $\mathrm{mg} / \mathrm{L}$ & 0.0391 & 0.0416 & 0.0409 & 0.0544 \\
\hline Beryllium ${ }^{\mathrm{b}}$ & $\mathrm{mg} / \mathrm{L}$ & $<0.0002$ & $<0.0002$ & $<0.0002$ & $<0.0002$ \\
\hline Cadmium $^{b}$ & $\mathrm{mg} / \mathrm{L}$ & $<0.0001$ & $<0.0001$ & $<0.0001$ & $<0.0001$ \\
\hline Chromium $^{b}$ & $\mathrm{mg} / \mathrm{L}$ & $<0.044$ & $<0.044$ & $<0.044$ & $<0.044$ \\
\hline Cobalt $^{\mathrm{b}}$ & $\mathrm{mg} / \mathrm{L}$ & $<0.026$ & $<0.026$ & $<0.026$ & $<0.026$ \\
\hline Copper ${ }^{b}$ & $\mathrm{mg} / \mathrm{L}$ & $<0.017$ & $<0.017$ & $<0.017$ & $<0.017$ \\
\hline Iron ${ }^{b}$ & $\mathrm{mg} / \mathrm{L}$ & $<0.037$ & $<0.037$ & $<0.037$ & $<0.037$ \\
\hline Lead $^{b}$ & $\mathrm{mg} / \mathrm{L}$ & $<0.001$ & $<0.001$ & $<0.001$ & $<0.001$ \\
\hline Manganese $^{b}$ & $\mathrm{mg} / \mathrm{L}$ & $<0.017$ & 0.057 & 0.083 & 0.026 \\
\hline Mercury ${ }^{b}$ & $\mathrm{mg} / \mathrm{L}$ & $<0.0001$ & $<0.0001$ & $<0.0001$ & $<0.0001$ \\
\hline Nickel $^{b}$ & $\mathrm{mg} / \mathrm{L}$ & $<0.04$ & $<0.04$ & $<0.04$ & $<0.04$ \\
\hline Silver $^{b}$ & $\mathrm{mg} / \mathrm{L}$ & $<0.0005$ & $<0.0005$ & $<0.0005$ & $<0.0005$ \\
\hline Thallium $^{b}$ & $\mathrm{mg} / \mathrm{L}$ & $<0.0015$ & $<0.0015$ & $<0.0015$ & $<0.0015$ \\
\hline Vanadium ${ }^{b}$ & $\mathrm{mg} / \mathrm{L}$ & $<0.024$ & $<0.024$ & $<0.024$ & $<0.024$ \\
\hline $\operatorname{Zinc}^{\mathrm{b}}$ & $\mathrm{mg} / \mathrm{L}$ & 0.022 & $<0.011$ & $<0.011$ & 0.016 \\
\hline Cesium-137 & $\mathrm{pCi} / \mathrm{L}$ & $<1.0$ & $<1.0$ & $<1.0$ & $<1.0$ \\
\hline Hydrogen-3 & $\mathrm{pCi} / \mathrm{L}$ & $<100$ & $<100$ & $<100$ & $<100$ \\
\hline Strontium-90 & $\mathrm{pCi} / \mathrm{L}$ & $<0.25$ & $<0.25$ & $<0.25$ & $<0.25$ \\
\hline
\end{tabular}

a Well point elevation $=197.60 \mathrm{~m}(\mathrm{MSL})$; ground surface elevation $=209.81 \mathrm{~m}(\mathrm{MSL})$; casing material $=$ PVC.

b Filtered sample. 
TABLE 6.16

Groundwater Monitoring Results, 300 Area Well 319031, 1998

\begin{tabular}{|c|c|c|c|}
\hline \multirow[b]{2}{*}{ Parameter } & \multirow[b]{2}{*}{ Unit } & \multicolumn{2}{|c|}{ Date of Sampling } \\
\hline & & $03 / 18 / 98$ & $05 / 28 / 98$ \\
\hline Water elevation ${ }^{\mathrm{a}}$ & $\mathrm{m}$ & 193.19 & 193.12 \\
\hline Temperature & ${ }^{\circ} \mathrm{C}$ & 10.4 & 11.5 \\
\hline $\mathrm{pH}$ & $\mathrm{pH}$ & 7.29 & 7.12 \\
\hline Redox & $\mathrm{mV}$ & -11 & -80 \\
\hline Conductivity & $\mu \mathrm{mhos} / \mathrm{cm}$ & 1,040 & 981 \\
\hline Chloride $^{\mathrm{b}}$ & $\mathrm{mg} / \mathrm{L}$ & 29 & 26 \\
\hline Arsenic $^{b}$ & $\mathrm{mg} / \mathrm{L}$ & $<0.0025$ & $<0.0025$ \\
\hline Barium $^{b}$ & $\mathrm{mg} / \mathrm{L}$ & 0.0526 & 0.0541 \\
\hline Beryllium $^{\mathrm{b}}$ & $\mathrm{mg} / \mathrm{L}$ & $<0.0002$ & $<0.0002$ \\
\hline Cadmium $^{b}$ & $\mathrm{mg} / \mathrm{L}$ & $<0.0001$ & $<0.0001$ \\
\hline Chromium $^{\mathrm{b}}$ & $\mathrm{mg} / \mathrm{L}$ & $<0.044$ & $<0.044$ \\
\hline Cobalt $^{\mathrm{b}}$ & $\mathrm{mg} / \mathrm{L}$ & $<0.026$ & $<0.026$ \\
\hline Copper $^{b}$ & $\mathrm{mg} / \mathrm{L}$ & $<0.017$ & $<0.017$ \\
\hline Iron ${ }^{b}$ & $\mathrm{mg} / \mathrm{L}$ & $<0.037$ & $<0.037$ \\
\hline Lead $^{b}$ & $\mathrm{mg} / \mathrm{L}$ & $<0.001$ & $<0.001$ \\
\hline Manganese ${ }^{b}$ & $\mathrm{mg} / \mathrm{L}$ & $<0.017$ & $<0.017$ \\
\hline Mercuryb & $\mathrm{mg} / \mathrm{L}$ & $<0.0001$ & $<0.0001$ \\
\hline Nickel ${ }^{b}$ & $\mathrm{mg} / \mathrm{L}$ & $<0.04$ & $<0.04$ \\
\hline Silver ${ }^{b}$ & $\mathrm{mg} / \mathrm{L}$ & $<0.0005$ & $<0.0005$ \\
\hline Thallium $^{b}$ & $\mathrm{mg} / \mathrm{L}$ & $<0.0015$ & $<0.0015$ \\
\hline Vanadium $^{\mathrm{b}}$ & $\mathrm{mg} / \mathrm{L}$ & $<0.024$ & $<0.024$ \\
\hline Zinc $^{\mathrm{b}}$ & $\mathrm{mg} / \mathrm{L}$ & 0.063 & 0.018 \\
\hline Cesium-137 & $\mathrm{pCi} / \mathrm{L}$ & 1.6 & $<1.0$ \\
\hline Hydrogen-3 & $\mathrm{pCi} / \mathrm{L}$ & 914 & 899 \\
\hline Strontium-90 & $\mathrm{pCi} / \mathrm{L}$ & 0.29 & $<0.25$ \\
\hline 1,1,1-Trichloroethane & $\mu \mathrm{g} / \mathrm{L}$ & 3 & 4 \\
\hline Trichloroethene & $\mu \mathrm{g} / \mathrm{L}$ & 5 & 4 \\
\hline
\end{tabular}

a Well point elevation $=191.78 \mathrm{~m}$ (MSL); ground surface elevation $=204.28 \mathrm{~m}$ (MSL); casing material $=$ PVC.

b Filtered sample. 


\section{GROUNDWATER PROTECTION}

TABLE 6.17

Groundwater Monitoring Results, 300 Area Well 319032, 1998

\begin{tabular}{|c|c|c|c|c|c|c|}
\hline \multirow[b]{2}{*}{ Parameter } & \multirow[b]{2}{*}{ Unit } & \multicolumn{5}{|c|}{ Date of Sampling } \\
\hline & & $03 / 18 / 98$ & $05 / 28 / 98$ & $09 / 23 / 98$ & $09 / 23 / 98$ & $12 / 08 / 98$ \\
\hline Water elevation ${ }^{\mathrm{a}}$ & $\mathrm{m}$ & 198.57 & 198.04 & 197.37 & 197.37 & 197.30 \\
\hline Temperature & ${ }^{\circ} \mathrm{C}$ & 10.0 & 11.1 & 11.0 & 11.0 & 11.2 \\
\hline $\mathrm{pH}$ & $\mathrm{pH}$ & 7.22 & 7.17 & 7.25 & 7.25 & 7.14 \\
\hline Redox & $\mathrm{mV}$ & -7 & -16 & -7 & -7 & -8 \\
\hline Conductivity & $\mu \mathrm{mhos} / \mathrm{cm}$ & 1,068 & 933 & 1,044 & 1,044 & 1,047 \\
\hline Chloride $\mathrm{b}^{\mathrm{b}}$ & $\mathrm{mg} / \mathrm{L}$ & 19 . & 21 & 20 & 19 & 24 \\
\hline Arsenic $^{\mathrm{b}}$ & $\mathrm{mg} / \mathrm{L}$ & $<0.0025$ & $<0.0025$ & $<0.0025$ & $<0.0025$ & $<0.0025$ \\
\hline Barium $^{b}$ & $\mathrm{mg} / \mathrm{L}$ & 0.0596 & 0.0675 & 0.0671 & 0.0640 & 0.0453 \\
\hline Beryllium ${ }^{b}$ & $\mathrm{mg} / \mathrm{L}$ & $<0.0002$ & $<0.0002$ & $<0.0002$ & $<0.0002$ & $<0.0002$ \\
\hline Cadmium ${ }^{b}$ & $\mathrm{mg} / \mathrm{L}$ & $<0.0001$ & $<0.0001$ & $<0.0001$ & $<0.0001$ & $<0.0001$ \\
\hline Chromium $^{\mathrm{b}}$ & $\mathrm{mg} / \mathrm{L}$ & $<0.044$ & $<0.044$ & $<0.044$ & $<0.044$ & $<0.044$ \\
\hline Cobalt ${ }^{\mathrm{b}}$ & $\mathrm{mg} / \mathrm{L}$ & $<0.026$ & $<0.026$ & $<0.026$ & $<0.026$ & $<0.026$ \\
\hline Copper ${ }^{b}$ & $\mathrm{mg} / \mathrm{L}$ & $<0.017$ & $<0.017$ & $<0.017$ & 0.018 & $<0.017$ \\
\hline Iron ${ }^{b}$ & $\mathrm{mg} / \mathrm{L}$ & $<0.037$ & $<0.037$ & $<0.037$ & $<0.037$ & $<0.037$ \\
\hline Lead $^{b}$ & $\mathrm{mg} / \mathrm{L}$ & $<0.001$ & $<0.001$ & $<0.001$ & $<0.001$ & $<0.001$ \\
\hline Manganese $^{b}$ & $\mathrm{mg} / \mathrm{L}$ & $<0.017$ & $<0.017$ & $<0.017$ & $<0.017$ & $<0.017$ \\
\hline Mercury & $\mathrm{mg} / \mathrm{L}$ & $<0.0001$ & $<0.0001$ & $<0.0001$ & $<0.0001$ & $<0.0001$ \\
\hline Nickel $^{\mathrm{b}}$ & $\mathrm{mg} / \mathrm{L}$ & $<0.04$ & $<0.04$ & $<0.04$ & $<0.04$ & $<0.04$ \\
\hline Silver ${ }^{b}$ & $\mathrm{mg} / \mathrm{L}$ & $<0.0005$ & $<0.0005$ & 0.0005 & $<0.0005$ & $<0.0005$ \\
\hline Thallium $^{b}$ & $\mathrm{mg} / \mathrm{L}$ & $<0.0015$ & $<0.0015$ & $<0.0015$ & $<0.0015$ & $<0.0015$ \\
\hline Vanadium ${ }^{b}$ & $\mathrm{mg} / \mathrm{L}$ & $<0.024$ & $<0.024$ & $<0.024$ & $<0.024$ & $<0.024$ \\
\hline Zinc $^{b}$ & $\mathrm{mg} / \mathrm{L}$ & 0.054 & 0.011 & $<0.011$ & $<0.011$ & 0.012 \\
\hline Cesium-137 & $\mathrm{pCi} / \mathrm{L}$ & $<1.0$ & $<1.0$ & $<1.0$ & $<1.0$ & $<1.0$ \\
\hline Hydrogen-3 & $\mathrm{pCi} / \mathrm{L}$ & 514 & 691 & 514 & 497 & 511 \\
\hline Strontium-90 & $\mathrm{pCi} / \mathrm{L}$ & $<0.25$ & $<0.25$ & $<0.25$ & $<0.25$ & $<0.25$ \\
\hline
\end{tabular}

a Well point elevation = $196.66 \mathrm{~m}$ (MSL); ground surface elevation = $204.28 \mathrm{~m}$ (MSL); casing material = PVC.

b Filtered sample. 
TABLE 6.18

Groundwater Monitoring Results, 300 Area Well 319131D, 1998

\begin{tabular}{|c|c|c|c|c|c|}
\hline \multirow[b]{2}{*}{ Parameter } & \multirow[b]{2}{*}{ Unit } & \multicolumn{4}{|c|}{ Date of Sampling } \\
\hline & & $03 / 19 / 98$ & $05 / 28 / 98$ & $09 / 24 / 98$ & $12 / 08 / 98$ \\
\hline Water elevation $^{a}$ & $\mathrm{~m}$ & 184.68 & 184.75 & 184.36 & 184.40 \\
\hline Temperature & ${ }^{\circ} \mathrm{C}$ & 10.8 & 12.4 & 11.2 & 10.2 \\
\hline $\mathrm{pH}$ & $\mathrm{pH}$ & 7.25 & 7.15 & 7.39 & 7.40 \\
\hline Redox & $\mathrm{mV}$ & -8 & -15 & -14 & -21 \\
\hline Conductivity & $\mu \mathrm{mhos} / \mathrm{cm}$ & 1,126 & 960 & 1,113 & 1,121 \\
\hline Chloride $^{b}$ & $\mathrm{mg} / \mathrm{L}$ & 50 & 44 & 53 & 57 \\
\hline Arsenic ${ }^{b}$ & $\mathrm{mg} / \mathrm{L}$ & $<0.0025$ & $<0.0025$ & $<0.0025$ & $<0.0025$ \\
\hline Barium $^{b}$ & $\mathrm{mg} / \mathrm{L}$ & 0.0700 & 0.0717 & 0.0729 & 0.0680 \\
\hline Beryllium ${ }^{\mathrm{b}}$ & $\mathrm{mg} / \mathrm{L}$ & $<0.0002$ & $<0.0002$ & $<0.0002$ & $<0.0002$ \\
\hline Cadmium $^{\mathrm{b}}$ & $\mathrm{mg} / \mathrm{L}$ & $<0.0001$ & $<0.0001$ & $<0.0001$ & $<0.0001$ \\
\hline Chromium $^{\mathrm{b}}$ & $\mathrm{mg} / \mathrm{L}$ & $<0.044$ & $<0.044$ & $<0.044$ & $<0.044$ \\
\hline Cobalt $^{\mathrm{b}}$ & $\mathrm{mg} / \mathrm{L}$ & $<0.026$ & $<0.026$ & $<0.026$ & $<0.026$ \\
\hline Copper ${ }^{b}$ & $\mathrm{mg} / \mathrm{L}$ & $<0.017$ & $<0.017$ & $<0.017$ & $<0.017$ \\
\hline Iron ${ }^{b}$ & $\mathrm{mg} / \mathrm{L}$ & $<0.037$ & 0.057 & $<0.037$ & $<0.037$ \\
\hline Lead $^{b}$ & $\mathrm{mg} / \mathrm{L}$ & $<0.001$ & $<0.001$ & $<0.001$ & $<0.001$ \\
\hline Manganese $^{b}$ & $\mathrm{mg} / \mathrm{L}$ & 0.017 & 0.039 & $<0.017$ & $<0.017$ \\
\hline Mercury ${ }^{b}$ & $\mathrm{mg} / \mathrm{L}$ & $<0.0001$ & $<0.0001$ & $<0.0001$ & $<0.0001$ \\
\hline Nickel $^{\mathrm{b}}$ & $\mathrm{mg} / \mathrm{L}$ & $<0.04$ & $<0.04$ & $<0.04$ & $<0.04$ \\
\hline Silver ${ }^{b}$ & $\mathrm{mg} / \mathrm{L}$ & $<0.0005$ & $<0.0005$ & $<0.0005$ & $<0.0005$ \\
\hline Thallium $^{\mathrm{b}}$ & $\mathrm{mg} / \mathrm{L}$ & $<0.0015$ & $<0.0015$ & $<0.0015$ & $<0.0015$ \\
\hline Vanadium $^{b}$ & $\mathrm{mg} / \mathrm{L}$ & $<0.024$ & $<0.024$ & $<0.024$ & $<0.024$ \\
\hline $\operatorname{Zinc}^{\mathrm{b}}$ & $\mathrm{mg} / \mathrm{L}$ & $<0.011$ & 0.034 & $<0.011$ & $<0.011$ \\
\hline Cesium-137 & $\mathrm{pCi} / \mathrm{L}$ & $<1.0$ & $<1.0$ & $<1.0$ & $<1.0$ \\
\hline Hydrogen-3 & $\mathrm{pCi} / \mathrm{L}$ & 1285 & 743 & 1332 & 1303 \\
\hline Strontium-90 & $\mathrm{pCi} / \mathrm{L}$ & $<0.25$ & $<0.25$ & $<0.25$ & $<0.25$ \\
\hline
\end{tabular}

a Well point elevation $=182.88 \mathrm{~m}(\mathrm{MSL})$; ground surface elevation $=203.56 \mathrm{~m}$ (MSL); casing material $=$ steel.

b Filtered sample. 
measured on one well volume. As in past years, 319031 was dry during the third and fourth quarters. It is unlikely that any nearby residents use this water for domestic use.

Inorganic Parameters. ANL-E chose a conservative approach for evaluating the monitoring results by selecting as the standard of comparison the Illinois Groundwater Quality Standards for Class I: Potable Resource Groundwater, 31 IAC, Section 620.410. The standards are presented in Tables 6.19 and 6.20. In 1998, all samples for metals analyses were field-filtered prior to preservation with acid (an IEPA requirement for the IEPA-approved groundwater monitoring program at the 800 Area Landfill, Section 6.3.2.3).

As noted in previous years, no elevated levels, with respect to the WQS for inorganics, were noted with the exception of $\mathrm{pH}$ at dolomite well 317121D and chloride at Wells 317101 and 317111. The $\mathrm{pH}$ changes drastically between the purging of two to five volumes of water. In each case, the last value obtained was recorded. Wells 317101 and 317111 exceeded the WQS for chloride each quarter. Chloride levels ranged from 250 to $687 \mathrm{mg} / \mathrm{L}$. Several wells had elevated levels of barium and manganese, but they were well below the WQS. Barium concentrations ranged from 0.02 to $0.11 \mathrm{mg} / \mathrm{L}$, and manganese concentrations ranged from less than 0.017 to $0.083 \mathrm{mg} / \mathrm{L}$. The source of the elevated barium and manganese levels is unknown. Elevated levels of barium and manganese have been reported in previous annual reports. ${ }^{20}$

Organic Parameters. Each well was sampled quarterly and analyzed for VOCs. In 1996 and 1997, VOCs were noted in nine wells. In 1998, VOCs were detected in only three wells 317021, 317061, and 319031. These wells are located south of the 317 Area and the 319 Area, near the south perimeter fence. The concentrations of VOCs in the wells were very low. Wells 317021 and 319031 showed persistent VOC levels, as in the past. Well 319031 is frequently dry but contains organic constituents when water is present. Well 319031 was dry during the third and fourth quarters. VOCs were detected in 317061 only during the third quarter. No organic WQSs were exceeded. The reduction in the number of wells with detectable VOCs may be due to the extensive Soil Treatment Project in the 317 Area completed during 1998. 
TABLE 6.19
Illinois Class I Groundwater Quality
Standards: Inorganics
(Concentrations in $\mathrm{mg} / \mathrm{L}$, except
radionuclides and $\mathrm{pH}$ )

\begin{tabular}{|c|c|}
\hline Constituent & Standard \\
\hline Antimony & 0.006 \\
\hline Arsenic & 0.05 \\
\hline Barium & 2 \\
\hline Beryllium & 0.004 \\
\hline Boron & 2 \\
\hline Cadmium & 0.005 \\
\hline Chloride & 200 \\
\hline Chromium & 0.1 \\
\hline Cobalt & 1 \\
\hline Copper & 0.65 \\
\hline Cyanide & 0.2 \\
\hline Fluoride & 4 \\
\hline Iron & 5 \\
\hline Lead & 0.0075 \\
\hline Manganese & 0.15 \\
\hline Mercury & 0.002 \\
\hline Nickel & 0.1 \\
\hline Nitrate, as N & 10 \\
\hline Radium-226 & $20 \mathrm{pCi} / \mathrm{L}$ \\
\hline Radium-228 & $20 \mathrm{pCi} / \mathrm{L}$ \\
\hline Selenium & 0.05 \\
\hline Silver & 0.05 \\
\hline Sulfate & 400 \\
\hline Thallium & 0.002 \\
\hline TDS & 1,200 \\
\hline Zinc & 5 \\
\hline $\mathrm{pH}$ & $6.5-9.0$ \\
\hline
\end{tabular}


TABLE 6.20

Illinois Class I Groundwater Quality

Standards: Organics

(concentrations in $\mathrm{mg} / \mathrm{L}$ )

\begin{tabular}{ll}
\hline Constituent & Standard \\
\hline & \\
Alachlor & 0.002 \\
Aldicarb & 0.003 \\
Atrazine & 0.003 \\
Benzene. & 0.005 \\
Benzo(a)pyrene & 0.0002 \\
Carbofuran & 0.04 \\
Carbon tetrachloride & 0.005 \\
Chlordane & 0.002 \\
Dalapon & 0.2 \\
Dichloromethane & 0.005 \\
Di(2-ethyhexyl)phthalate & 0.006 \\
Dinoseb & 0.007 \\
Endothall & 0.1 \\
Endrin & 0.002 \\
Ethylene dibromide & 0.00005 \\
Heptachlor & 0.0004 \\
Heptachlor epoxide & 0.0002 \\
Hexachlorocyclopentadiene & 0.05 \\
Lindane & 0.0002 \\
2,4-D & 0.07 \\
o-Dichlorobenzene & 0.6 \\
p-Dichlorobenzene & 0.075 \\
1,2-Dibromo-3-Chloropropane & 0.0002 \\
1,2-Dichloroethane & 0.005 \\
1,1-Dichloroethene & 0.007 \\
cis-1,2-Dichloroethylene & 0.07 \\
trans-1,2-Dichloroethylene & 0.1 \\
1,2-Dichloropropane & 0.005 \\
Ethylbenzene & 0.7 \\
Methoxychlor & 0.04 \\
Monochlorobenzene & 0.1 \\
Pentachlorophenol & 0.001 \\
&
\end{tabular}


TABLE 6.20 (Cont.)

\begin{tabular}{ll}
\hline Constituent & Standard \\
\hline Phenols & 0.1 \\
Picloram & 0.5 \\
PCBs (decachlorobiphenyl) & 0.0005 \\
Simazine & 0.004 \\
Styrene & 0.1 \\
2,4-5-TP (Silvex) & 0.05 \\
Tetrachloroethylene & 0.005 \\
Toluene & 1 \\
Toxaphene & 0.003 \\
1,1,1-Trichloroethane & 0.2 \\
1,1,2-Trichloroethane & 0.005 \\
1,2,4-Trichlorobenzene & 0.07 \\
Trichloroethylene & 0.005 \\
Vinyl chloride & 0.002 \\
Xylenes & 10 \\
\hline
\end{tabular}

Over $6,500 \mathrm{~m}^{3}\left(8,500 \mathrm{yd}^{3}\right)$ of VOC-contaminated soil was treated using an innovative treatment approach developed by ANL-E for reduction of VOCs.

Once during the year, the wells were sampled and analyzed for SVOCs, PCBs, pesticides, and herbicides. None of these parameters were found in 1998.

Figure 6.4 shows the results for 317021 . The major components are 1,1,1-trichloroethane (TCA) and 1,1-dichloroethane; the latter can be a decomposition product of TCA. As shown in Figure 6.4 , the concentrations roughly parallel each other, and the levels are remarkably constant until 1991, at which time a substantial increase is seen. The previous consistency would indicate that this well is sampling a large area of contaminated water that is unaffected by seasonal water level changes. The large increase in the summer and fall of 1991 is clearly related to a period of intense drought and also could be related to restricted flow of normal dilution water. Trace levels of carbon tetrachloride, tetrachloroethene, and trichloroethene (TCE) were also found in this well 


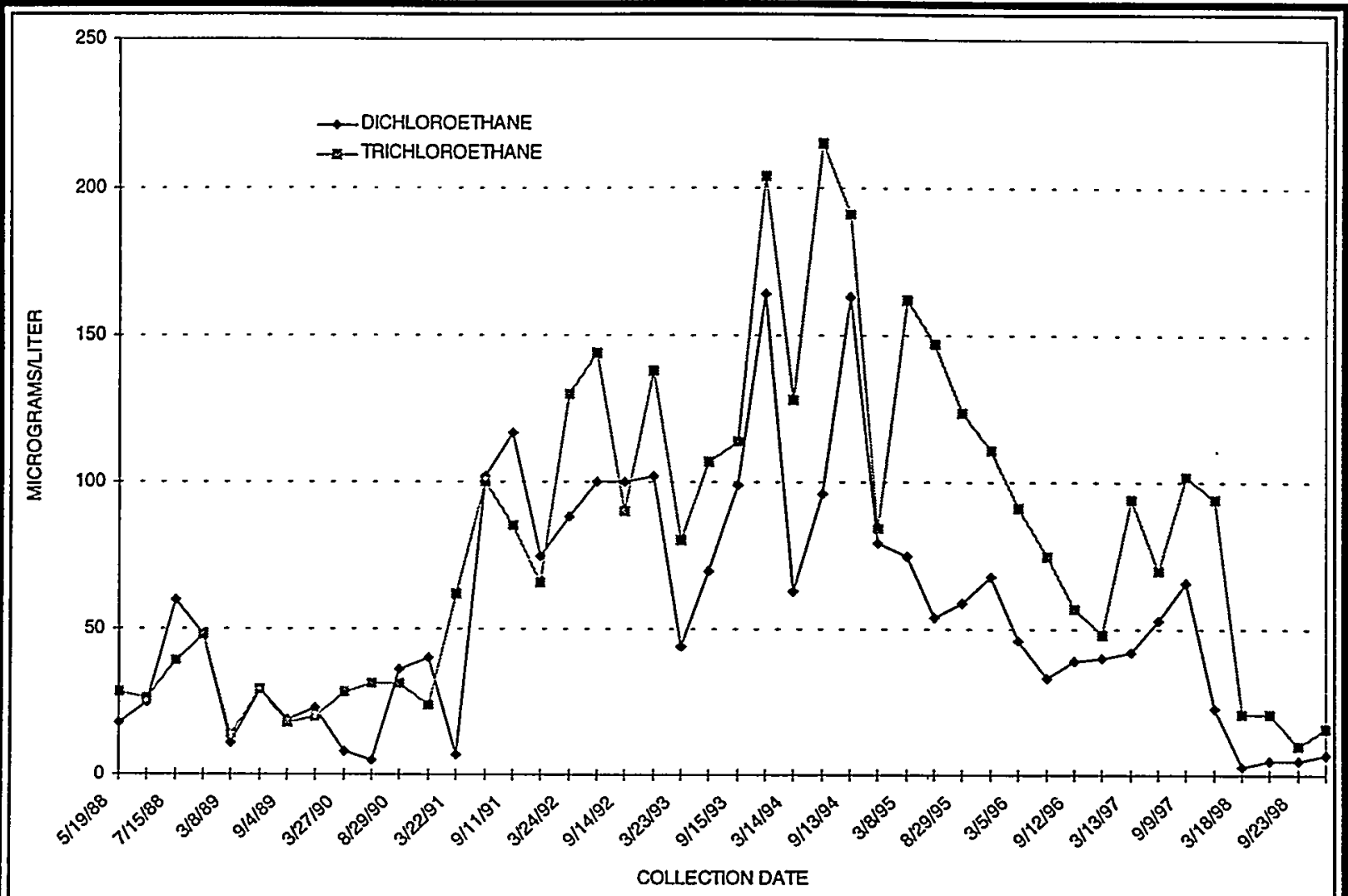

Figure 6.4 Concentration of 1,1-Dichloroethane and 1,1,1-Trichloroethane in Well 317021

but at levels well below the WQS. The well is immediately below a former sewer line that was known to be contaminated. The sewer line was permanently closed in 1986 and sealed in 1997.

Manholes E1 and E2, in the 317 Area were sampled monthly and analyzed for VOCs. The results are presented in Table 6.21. Contributors of groundwater into Manholes E1 and E2 include 757 to $1,136 \mathrm{~L} /$ day (200 to $300 \mathrm{gal} /$ day) from the 319 Area groundwater collection system, 7,571 $\mathrm{L} /$ day (2,000 gal/day) from the 317 Area groundwater collection system (October 1997), and groundwater from existing foundation drains around storage vaults. In May 1997, grouting and sealing a footing drain system in the southeastern portion of the 317 Area to prevent the migration of contaminated groundwater off site was completed. Approximately $183 \mathrm{~m}(600 \mathrm{ft})$ of underground pipe and bedding material was sealed in the 317 Area south of the deactivated South Vault system. At a future date, all underground piping immediately south of the Deep Vault, Map Tube Vault, and North Vault will be grouted and sealed. 
TABLE 6.21

Volatile Organic Compounds in the 317 Arrea: Manholes E1 and E2, 1998 (concentrations in $\mu \mathrm{g} / \mathrm{L}$ )

\begin{tabular}{|c|c|c|c|c|c|c|c|c|c|c|c|c|c|c|}
\hline \multirow[b]{2}{*}{ Date } & \multicolumn{2}{|c|}{ Chloroform } & \multicolumn{2}{|c|}{$\begin{array}{c}\text { Tetra- } \\
\text { chloroethene }\end{array}$} & \multicolumn{2}{|c|}{$\begin{array}{l}\text { Trichloro- } \\
\text { ethene }\end{array}$} & \multicolumn{2}{|c|}{$\begin{array}{c}\text { cis-1,2- } \\
\text { Dichloro- } \\
\text { ethene }\end{array}$} & \multicolumn{2}{|c|}{$\begin{array}{c}1,1- \\
\text { Dichloro- } \\
\text { ethane }\end{array}$} & \multicolumn{2}{|c|}{$\begin{array}{c}\text { Carbon } \\
\text { Tetrachloride }\end{array}$} & \multicolumn{2}{|c|}{$\begin{array}{c}\text { 1,1,1- } \\
\text { Trichloro- } \\
\text { ethane }\end{array}$} \\
\hline & EI & E2 & E1 & E2 & E1 & E2 & E1 & E2 & E1 & E2 & E1 & E2 & E1 & E2 \\
\hline $1 / 14 / 98$ & 277 & 11 & 40 & 10 & 84 & 6 & 15 & 6 & 9 & 6 & 342 & 15 & 11 & 4 \\
\hline $2 / 12 / 98$ & 229 & 207 & 56 & 113 & 57 & 21 & 18 & 18 & 18 & 13 & 340 & 174 & 26 & 19 \\
\hline $3 / 4 / 98$ & 518 & 64 & 82 & 42 & 73 & 16 & 24 & 7 & 24 & 18 & 588 & 54 & 41 & 31 \\
\hline $4 / 3 / 98$ & 166 & 6 & 17 & 4 & 26 & 14 & 13 & 14 & 39 & 45 & 199 & 10 & 41 & 35 \\
\hline $5 / 7 / 98$ & 517 & 19 & 31 & 20 & 68 & 14 & 11 & 9 & 33 & 15 & 445 & 26 & 47 & 36 \\
\hline $6 / 4 / 98$ & 32 & 2 & 5 & 7 & 20 & 17 & 10 & 10 & 47 & 49 & 34 & 6 & 68 & 73 \\
\hline $7 / 8 / 98$ & 28 & 27 & 10 & 10 & 14 & 17 & 9 & 11 & 39 & 44 & 49 & 45 & 47 & 53 \\
\hline $8 / 7 / 98$ & 282 & 3 & 27 & 3 & 56 & 11 & 16 & 7 & 43 & 51 & 266 & 6 & 49 & 60 \\
\hline $9 / 8 / 98$ & 129 & 89 & 17 & 15 & 32 & 22 & 14 & 10 & 67 & 55 & 93 & 80 & 57 & 45 \\
\hline $10 / 7 / 98$ & 110 & 44 & 21 & 9 & 25 & 10 & 11 & 7 & 27 & 6 & 110 & 46 & 34 & 9 \\
\hline $11 / 5 / 98$ & 220 & 3 & 25 & 2 & 44 & 3 & 18 & 4 & 8 & 6 & 215 & 4 & 11 & 9 \\
\hline $12 / 3 / 98$ & 280 & 18 & 104 & 10 & 26 & 7 & 15 & 12 & 7 & 1 & 560 & 24 & 7 & $<1$ \\
\hline
\end{tabular}

In general, volatile constituent concentrations decreased from levels noted in previous years. In addition, the ratios of the decreases in concentrations between Manhole E1 and Manhole E2 (see Figure 6.5 and Table 6.21) changed significantly in 1998; most likely these changes can be attributed to the dilution of Manhole E2 water. Remediation activities in the 317 and 319 Areas has resulted in Manhole E2 receiving increased groundwater flows from these areas. Starting in October 1997, as part of the 317 Area remediation project, additional 317 Area groundwater was pumped at a rate of over 4,542 L/day (1,200 gal/day) to Manhole E2.

Chloroform is a degradation product of carbon tetrachloride. Cis-1,2-dichloroethene $(1,2-D C E)$ is a degradation product of TCE. The fact that both the original and breakdown products are present in most samples indicates an ongoing release of these compounds into the groundwater, such as from highly contaminated soils. Trace levels of acetone, benzene, dichlorofluoromethane, methylene chloride, trans-1,2-DCE, tribromoethene, 1,2-dibromoethene, 1,2-dichloroethane, vinyl chloride, and 4-methyl-2-pentanone have been detected, but at very low levels and not on a consistent basis. The source of these compounds is believed to be the French drains previously described in Section 6.2.1. Extensive characterization activities described in 

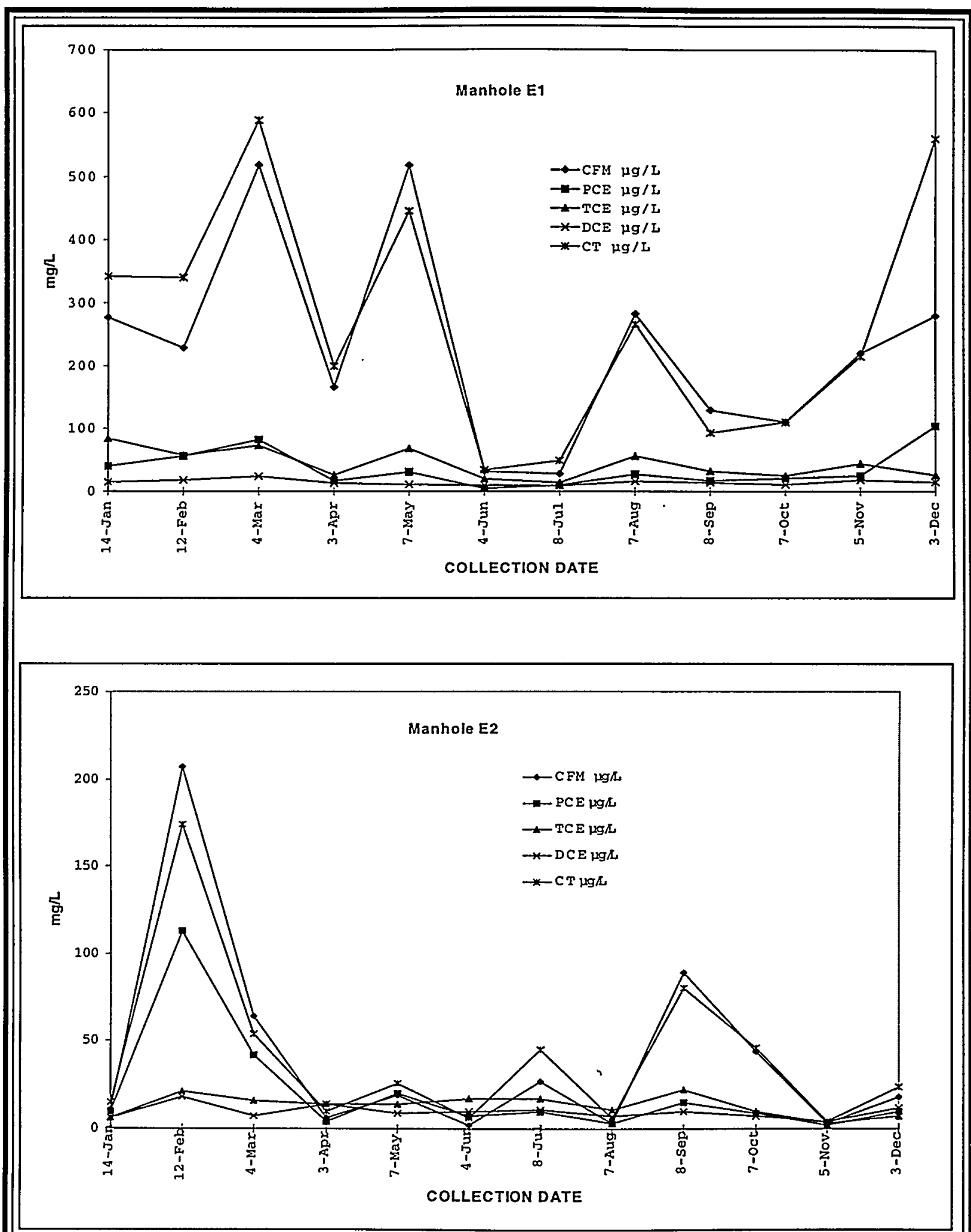

Figure 6.5 Trends of Selected Organics in 317 Area Manholes, 1998

ANL-E Site Environmental Report 


\section{GROUNDWATER PROTECTION}

Section 6.5.2 continue to better define the nature, rate, and extent of contamination at this location.

Radioactive Constituents. Samples collected quarterly from the monitoring wells in the 317 and 319 Areas were analyzed for hydrogen-3, strontium-90, and gamma-ray emitters. The results are presented in Tables 6.9 to 6.18. Evidence of possible off-site migration of radionuclides is noted by the low concentrations of hydrogen-3, cesium-137, and strontium-90 in wells located near the south perimeter fence in the 317 and 319 Areas. Hydrogen-3 was detected in $317021,317052,317061$, and 317121D, located south of the 317 Area. Hydrogen-3 was also detected in 319031, 319032, and 319131D, which are located near the south 319 Area perimeter fence. Cesium-137 was detected in 317052, 317061, and 317121 located south of the 317 Area near the south perimeter fence. Cesium-137 was also detected in 317101 and 317111, which are upgradient of the 317 Area. A small amount of cesium-137 was also detected in 319031, which is south of the 319 Area near the south perimeter fence. Strontium- 90 was detected during one quarter in 319031, which is near the south perimeter fence; this well was dry for two quarters. Wells 319031,319032 , and 319131D are directly below a small drainage swale from the 319 Area that has contained water intermittently with measurable concentrations of hydrogen-3 and strontium-90. All concentrations are well below any applicable standards.

Water from the 317 Area and 319 Area groundwater collection systems is pumped to Manhole 2E. Manhole $1 \mathrm{E}$ is connected to the footing drain system around the operating vaults. In addition to VOCs, the manhole water is analyzed for hydrogen-3 and gamma-ray emitting radionuclides. Table 6.22 gives the hydrogen- 3 results. Although the hydrogen- 3 concentrations are relatively high, the volume is fairly low. Since hydrogen-3 concentrations are generally higher in Manhole 2E, the source of the hydrogen-3 appears to be from the groundwater pumping system. In contrast, the VOCs, see Table 6.21, are generally higher in Manhole $1 \mathrm{E}$, which implies that the source of the VOCs is the 317 Area French Drain. No gamma-ray-emitting radionuclides were detected in any samples. 
TABLE 6.22

Hydrogen-3 Concentrations in Manhole

Water Samples, 1998

(Concentrations in $\mathrm{pCi} / \mathrm{L}$ )

\begin{tabular}{lcc}
\hline $\begin{array}{c}\text { Date } \\
\text { Collected }\end{array}$ & Manhole 1E & Manhole 2E \\
\hline March 4 & 20,680 & 20,090 \\
April 3 & 30,140 & 53,730 \\
May 7 & 16,270 & 22,930 \\
June 4 & 17,160 & 86,670 \\
July 8 & 19,270 & 21,670 \\
August 7 & 14,900 & 14,010 \\
September 8 & 13,550 & 45,140 \\
October 7 & 12,890 & 15,920 \\
November 5 & 11,600 & 13,560 \\
December 3 & 24,820 & 104,900 \\
\hline
\end{tabular}

Monitoring was also conducted quarterly at an artesian well located about $2,000 \mathrm{~m}(6,000 \mathrm{ft})$ southwest of the 317 Area (location $3 E$ in Figure 1.1). All hydrogen-3 concentrations were less than the detection limit of $100 \mathrm{pCi} / \mathrm{L}$. This indicates that any subsurface contaminant movement has not extended to this location and indicates a western limit to movement.

\subsection{Sanitary Landfill}

The 800 Area is the site of the ANL-E sanitary landfill. The 8.8-ha (21.8-acre) landfill is located on the western edge of ANL-E property (Figure 1.1). The landfill has received waste since 1966 and was operated under IEPA Permit No. 1981-29-OP, which was issued on September 18, 1981. The landfill received general refuse, construction debris, boiler house ash, and other nonradioactive solid waste until September 1992. The landfill is now being closed pursuant to Permit No. 1992-002-SP and Supplemental Permit Nos. 1994-506-SP, 1997-295-SP, and 1998-017-SP. 


\section{GROUNDWATER PROTECTION}

\subsubsection{French Drain}

The landfill area was used for the disposal of certain types of liquid wastes from 1969 to 1978. The wastes were poured into a French drain that consisted of a corrugated steel pipe placed in a gravel-filled pit dug into an area previously filled with waste. The liquid waste was poured into the drain and allowed to permeate into the gravel, and thence into the soil and fill material. Available documentation indicates that $109,000 \mathrm{~L}$ (29,000 gal) of liquid waste was placed in this drain. Some of the wastes disposed of in this manner are now defined as hazardous wastes. The presence of volatile and other toxic organic compounds has been confirmed by soil gas surveys and leachate sampling conducted at the landfill. Measurable amounts of these materials were identified in soil vapor leachate but not groundwater near the landfill.

\subsubsection{Monitoring Studies}

During October 1992, 15 stainless-steel wells, 800161 through 800203D, were installed around the landfill as part of the IEPA-approved closure plan. Wells 800172 and 800182 are consistently dry. The 13 active wells are required to be monitored as part of the IEPA-approved groundwater monitoring program, effective January 1995 . These wells are set in five clusters; each cluster consists of a shallow, medium, and deep well (see Figure 6.6 and Table 6.23). Wells 800241 and $800243 \mathrm{D}$, installed during 1995, were formally incorporated into the 800 Area Landfill Groundwater Monitoring Program by IEPA Supplemental Permit No. 1998-017-SP, effective August 25, 1998. The analytical data collected from these wells is to be evaluated in order to determine their appropriateness for use as upgradient wells for the shallow and deep series wells. Informational monitoring of these wells commenced during July 1998.

\subsubsection{Sample Collection}

The same procedure for well water sample collection previously described for the 300 Area was used for this area. Each well is sampled annually for semivolatiles, PCBs, pesticides, and herbicides. Also, during the second quarter, in accordance with the IEPA-approved groundwater 


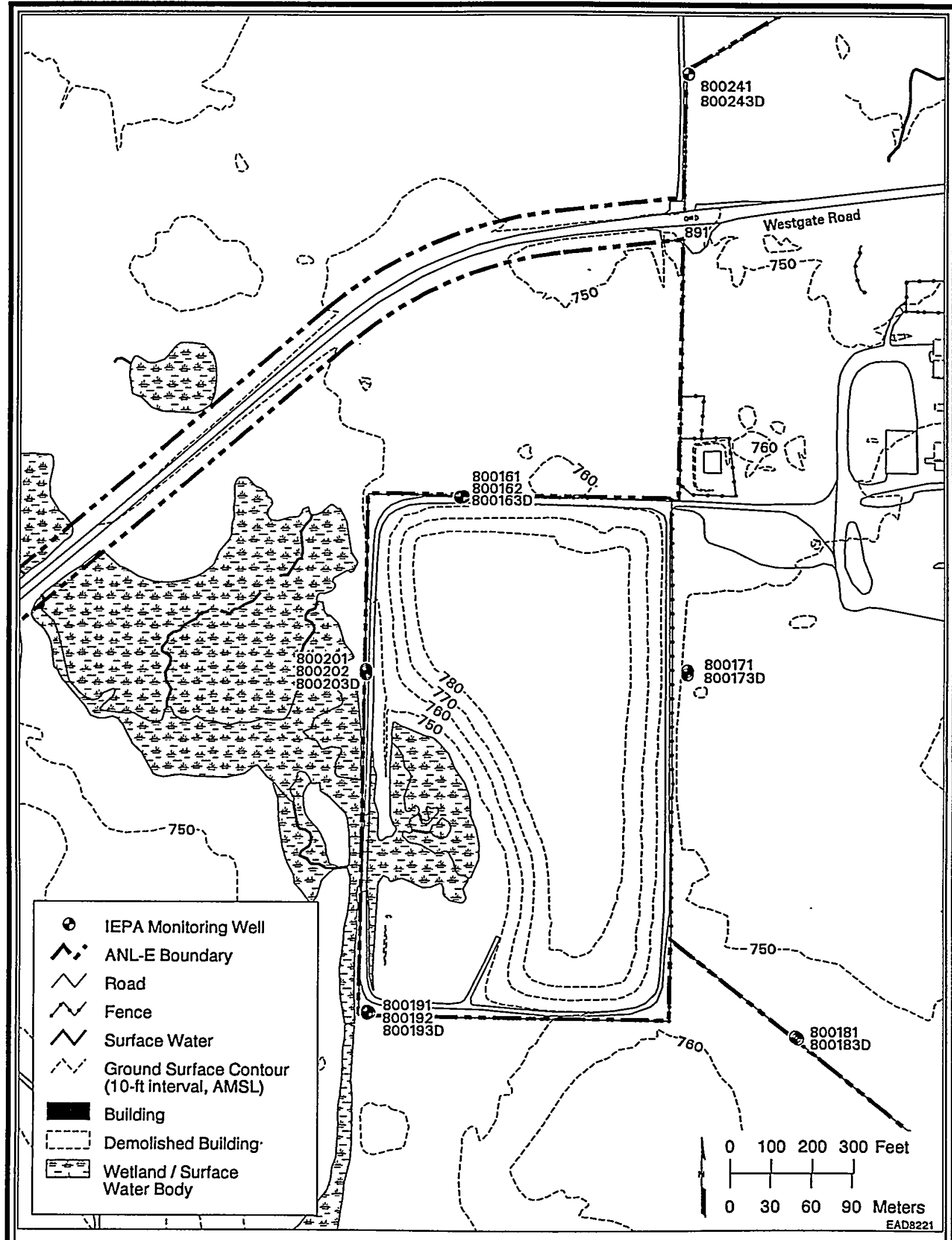

Figure 6.6 Active Monitoring Wells in the 800 Area Landfill 
TABLE 6.23

Groundwater Monitoring Wells: 800 Area Landfill

\begin{tabular}{lrcccc}
\hline $\begin{array}{c}\text { ID } \\
\text { Number }^{\mathrm{a}}\end{array}$ & $\begin{array}{c}\text { Well } \\
\text { Depth } \\
\text { (m bgs) }\end{array}$ & $\begin{array}{c}\text { Ground } \\
\text { Elevation } \\
\text { (m AMSL) }\end{array}$ & $\begin{array}{c}\text { Monitoring } \\
\text { Zone } \\
\text { (m AMSL) }\end{array}$ & $\begin{array}{c}\text { Well } \\
\text { Type }^{\mathrm{b}}\end{array}$ & $\begin{array}{c}\text { Date } \\
\text { Drilled }\end{array}$ \\
\hline 800161 & 7.94 & 230.8 & $224.3-222.8$ & $0.05 / \mathrm{SS}$ & $10 / 92$ \\
800162 & 20.76 & 230.7 & $211.5-210.0$ & $0.05 / \mathrm{SS}$ & $10 / 92$ \\
$800163 \mathrm{D}$ & 47.00 & 230.8 & $186.8-183.8$ & $0.05 / \mathrm{SS}$ & $9 / 92$ \\
800171 & 7.71 & 228.4 & $222.2-220.7$ & $0.05 / \mathrm{SS}$ & $10 / 92$ \\
$800173 \mathrm{D}$ & 39.08 & 228.4 & $192.4-189.3$ & $0.05 / \mathrm{SS}$ & $10 / 92$ \\
800181 & 11.01 & 230.5 & $221.0-219.5$ & $0.05 / \mathrm{SS}$ & $10 / 92$ \\
$800183 \mathrm{D}$ & 49.68 & 230.4 & $183.7-180.7$ & $0.05 / \mathrm{SS}$ & $10 / 92$ \\
800191 & 4.62 & 227.4 & $224.3-222.8$ & $0.05 / \mathrm{SS}$ & $10 / 92$ \\
800192 & 18.67 & 227.4 & $210.2-208.7$ & $0.05 / \mathrm{SS}$ & $10 / 92$ \\
$800193 \mathrm{D}$ & 45.48 & 227.4 & $185.0-181.9$ & $0.05 / \mathrm{SS}$ & $10 / 92$ \\
800201 & 10.74 & 227.9 & $218.7-217.2$ & $0.05 / \mathrm{SS}$ & $10 / 92$ \\
800202 & 18.52 & 227.9 & $210.9-209.4$ & $0.05 / \mathrm{SS}$ & $10 / 92$ \\
$800203 \mathrm{D}$ & 38.47 & 227.9 & $192.5-189.5$ & $0.05 / \mathrm{SS}$ & $9 / 92$ \\
800241 & 4.90 & 226.1 & $224.3-221.3$ & $0.05 / \mathrm{SS}$ & $3 / 95$ \\
$800243 \mathrm{D}$ & 35.50 & 226.1 & $193.9-190.8$ & $0.05 / \mathrm{SS}$ & $4 / 95$ \\
\hline
\end{tabular}

a Wells identified by a " $D$ " are deeper wells monitoring the dolomite bedrock aquifer.

b Inner diameter $(\mathrm{m}) /$ well material (SS = stainless steel).

monitoring plan, both filtered and unfiltered samples for numerous parameters (e.g., metals, chloride, sulfate) are required. Volatile organics are monitored each quarter, although only required by permit during the second quarter.

\subsubsection{Sample Analyses - 800 Area}

The 800 Area sample analyses were performed using SOPs written, reviewed, and issued as controlled documents by members of ESH-ASCL, PFS-Utilities Laboratory, and ESH-ASRL. These SOPs reference protocols in SW-846. ${ }^{8}$ Fifteen metals were routinely determined and 
analyzed by using flame atomic absorption spectroscopy, inductively coupled plasma atomic emission spectroscopy, and graphite furnace atomic absorption spectroscopy. Mercury was determined by cold vapor atomic absorption spectroscopy. VOCs were determined by using a purge and trap sample pretreatment, followed by gas chromatography-mass spectroscopy detection. SVOCs were determined by solvent extraction followed by gas chromatography-mass spectroscopy detection. PCBs and pesticides were determined by solvent extraction followed by gas chromatography-electron capture detection. In the case of organic compound analyses, efforts were made to identify compounds that were present but not included on the method list. This was accomplished, and standard solutions of these compounds were prepared and analyzed. TDS were determined gravimetrically. Sulfate determination was performed by using a turbidimetric technique, while chloride was determined by titrimetry. Ammonia-nitrogen was determined by using distillation followed by an ion-selective electrode technique.

Some analyses were performed at an off-site contractor laboratory. SW- $846^{8}$ procedures were specified and used. Cyanide and phenol were determined by distillation followed by a spectrophotometric finish. Total organic carbon (TOC) and total organic halogen (TOX) were determined by combustion techniques followed by infrared detection and coulometric titration, respectively. Chlorinated organic compounds and carbamate pesticides were analyzed by extractions followed by gas and liquid chromotography techniques, respectively.

The 800 Area groundwater radiological analyses were performed using SOPs written, reviewed, and issued as controlled documents by members of ESH-ASRL. Hydrogen-3 was determined by distillation followed by a beta liquid scintillation counting technique.

\subsubsection{Results of Analyses}

Descriptions of each well, field parameters measured during sample collection, and the results of chemical and radiological analysis of samples from the wells in the 800 Area are presented in Tables 6.24 to 6.38 . All radiological and inorganic analysis results are shown in 
TABLE 6.24

Groundwater Monitoring Results, Sanitary Landfill Well 800161, 1998

\begin{tabular}{|c|c|c|c|c|c|}
\hline \multirow[b]{2}{*}{ Parameter } & \multirow[b]{2}{*}{ Unit } & \multicolumn{4}{|c|}{ Date of Sampling } \\
\hline & & $01 / 07 / 98$ & $04 / 09 / 98$ & $07 / 08 / 98$ & $10 / 13 / 98$ \\
\hline Water elevation ${ }^{\mathrm{a}}$ & $\mathrm{m}$ & 226.35 & 229.53 & 227.84 & 226.65 \\
\hline Temperature & ${ }^{\circ} \mathrm{C}$ & 11.2 & 9.6 & 13.0 & 11.9 \\
\hline $\mathrm{pH}$ & $\mathrm{pH}$ & 7.06 & 6.90 & 7.16 & 6.97 \\
\hline Redox & $\mathrm{mV}$ & -1 & 1 & -58 & 4 \\
\hline Conductivity & $\mu$ mhos $/ \mathrm{cm}$ & 1,388 & 1,383 & 1,359 & 1,374 \\
\hline Chloride $^{b}$ & $\mathrm{mg} / \mathrm{L}$ & 79 & 72 & 66 & 66 \\
\hline Sulfate ${ }^{b}$ & $\mathrm{mg} / \mathrm{L}$ & 148 & 126 & 133 & 132 \\
\hline TDS $^{\mathrm{b}}$ & $\mathrm{mg} / \mathrm{L}$ & 844 & 853 & 854 & 868 \\
\hline Cyanide (total) ${ }^{c}$ & $\mathrm{mg} / \mathrm{L}$ & $<0.01$ & $<0.01$ & $<0.01$ & $<0.01$ \\
\hline Arsenic ${ }^{c}$ & $\mathrm{mg} / \mathrm{L}$ & $-d$ & 0.0061 & - & - \\
\hline Barium $^{c}$ & $\mathrm{mg} / \mathrm{L}$ & - & 0.1802 & - & - \\
\hline Boron ${ }^{c}$ & $\mathrm{mg} / \mathrm{L}$ & - & 0.1242 & - & - \\
\hline Cadmium ${ }^{c}$ & $\mathrm{mg} / \mathrm{L}$ & - & $<0.0001$ & - & - \\
\hline Chromium $^{c}$ & $\mathrm{mg} / \mathrm{L}$ & - & $<0.044$ & - & - \\
\hline Cobalt & $\mathrm{mg} / \mathrm{L}$ & - & $<0.026$ & - & - \\
\hline Copper ${ }^{\mathrm{E}}$ & $\mathrm{mg} / \mathrm{L}$ & - & $<0.017$ & - & - \\
\hline Iron $^{c}$ & $\mathrm{mg} / \mathrm{L}$ & - & 8.167 & - & - \\
\hline Lead $^{\mathrm{c}}$ & $\mathrm{mg} / \mathrm{L}$ & - & 0.0074 & - & - \\
\hline Manganese ${ }^{c}$ & $\mathrm{mg} / \mathrm{L}$ & - & 0.6935 & - & - \\
\hline Mercury ${ }^{c}$ & $\mathrm{mg} / \mathrm{L}$ & - & $<0.0001$ & - & - \\
\hline Nickele & $\mathrm{mg} / \mathrm{L}$ & - & $<0.04$ & - & - \\
\hline Selenium ${ }^{c}$ & $\mathrm{mg} / \mathrm{L}$ & - & $<0.003$ & - & - \\
\hline Silver ${ }^{c}$ & $\mathrm{mg} / \mathrm{L}$ & - & $<0.0005$ & - & - \\
\hline $\operatorname{Zinc}^{c}$ & $\mathrm{mg} / \mathrm{L}$ & - & 0.0506 & - & - \\
\hline Ammonia nitrogen ${ }^{\mathrm{b}}$ & $\mathrm{mg} / \mathrm{L}$ & $<0.2$ & $<0.1$ & $<0.1$ & 0.1 \\
\hline Arsenic $^{b}$ & $\mathrm{mg} / \mathrm{L}$ & $<0.0025$ & $<0.0025$ & $<0.0025$ & 0.0041 \\
\hline Barium ${ }^{b}$ & $\mathrm{mg} / \mathrm{L}$ & 0.1612 & 0.1466 & 0.1572 & 0.1438 \\
\hline Berylliumb & $\mathrm{mg} / \mathrm{L}$ & $<0.0002$ & $<0.0002$ & $<0.0002$ & $<0.0002$ \\
\hline Cadmium ${ }^{\mathrm{b}}$ & $\mathrm{mg} / \mathrm{L}$ & $<0.0001$ & $<0.0001$ & $<0.0001$ & $<0.0001$ \\
\hline Chromium $^{b}$ & $\mathrm{mg} / \mathrm{L}$ & $<0.044$ & $<0.044$ & $<0.044$ & $<0.044$ \\
\hline Cobalt $^{\mathrm{b}}$ & $\mathrm{mg} / \mathrm{L}$ & $<0.026$ & $<0.026$ & $<0.026$ & $<0.026$ \\
\hline Copper ${ }^{b}$ & $\mathrm{mg} / \mathrm{L}$ & $<0.017$ & $<0.017$ & $<0.017$ & $<0.017$ \\
\hline Iron $^{b}$ & $\mathrm{mg} / \mathrm{L}$ & $<0.037$ & 1.350 & 0.074 & 0.044 \\
\hline Lead $^{b}$ & $\mathrm{mg} / \mathrm{L}$ & $<0.001$ & $<0.001$ & $<0.001$ & $<0.001$ \\
\hline Manganese $^{b}$ & $\mathrm{mg} / \mathrm{L}$ & 0.7314 & 0.4913 & 0.6838 & 0.7982 \\
\hline Mercury ${ }^{b}$ & $\mathrm{mg} / \mathrm{L}$ & $<0.0001$ & $<0.0001$ & $<0.0001$ & $<0.0001$ \\
\hline Nickel $^{\mathrm{b}}$ & $\mathrm{mg} / \mathrm{L}$ & $<0.04$ & $<0.04$ & $<0.04$ & $<0.04$ \\
\hline Silver ${ }^{b}$ & $\mathrm{mg} / \mathrm{L}$ & $<0.0005$ & 0.0005 & $<0.0005$ & $<0.0005$ \\
\hline Thallium $^{\mathrm{b}}$ & $\mathrm{mg} / \mathrm{L}$ & $<0.0015$ & $<0.0015$ & $<0.0015$ & $<0.0015$ \\
\hline Vanadium $^{b}$ & $\mathrm{mg} / \mathrm{L}$ & $<0.024$ & $<0.024$ & $<0.024$ & $<0.024$ \\
\hline Zinc $^{b}$ & $\mathrm{mg} / \mathrm{L}$ & 0.0700 & 0.0411 & 0.0223 & 0.1439 \\
\hline Nitrate & $\mathrm{mg} / \mathrm{L}$ & - & $<0.1$ & - & - \\
\hline Phenols & $\mathrm{mg} / \mathrm{L}$ & 0.005 & $<0.005$ & $<0.005$ & 0.005 \\
\hline Hydrogen-3 & $\mathrm{pCi} / \mathrm{L}$ & 470 & 209 & 258 & 296 \\
\hline Chloride & $\mathrm{mg} / \mathrm{L}$ & - & 72 & - & - \\
\hline Fluoride & $\mathrm{mg} / \mathrm{L}$ & - & 0.254 & - & - \\
\hline Sulfate & $\mathrm{mg} / \mathrm{L}$ & - & 128 & - & - \\
\hline TOCs & $\mathrm{mg} / \mathrm{L}$ & 4.3 & 3.4 & 3.8 & 4.3 \\
\hline TOCs & $\mathrm{mg} / \mathrm{L}$ & 4.3 & 4.0 & 3.9 & 4.4 \\
\hline TOCs & $\mathrm{mg} / \mathrm{L}$ & 4.4 & 3.6 & 3.7 & 4.6 \\
\hline TOCs & $\mathrm{mg} / \mathrm{L}$ & 4.6 & 3.6 & 3.8 & 4.3 \\
\hline TOXs & $\mathrm{mg} / \mathrm{L}$ & 0.0960 & 0.0770 & 0.0220 & 0.0590 \\
\hline TOXs & $\mathrm{mg} / \mathrm{L}$ & 0.0430 & 0.0670 & 0.0400 & 0.0370 \\
\hline
\end{tabular}

a Well point elevation $=222.83 \mathrm{~m}(\mathrm{MSL})$; ground surface elevation $=230.76 \mathrm{~m}(\mathrm{MSL})$; casing material $=$ stainless steel.

b Filtered sample

c Unfiltered sample.

d A hyphen indicates that samples were not collected. 


\section{TABLE 6.25}

Groundwater Monitoring Results, Sanitary Landfill Well 800162, 1998

\begin{tabular}{|c|c|c|c|c|c|c|}
\hline \multirow[b]{2}{*}{ Parameter } & \multirow[b]{2}{*}{ Unit } & \multicolumn{5}{|c|}{ Date of Sampling } \\
\hline & & $01 / 07 / 98$ & $04 / 09 / 98$ & $07 / 08 / 98$ & $07 / 08 / 98$ & $10 / 13 / 98$ \\
\hline Water elevation ${ }^{\mathrm{a}}$ & $\mathbf{m}$ & 218.09 & 218.85 & 218.82 & 218.82 & 218.51 \\
\hline Temperature & ${ }^{\circ} \mathrm{C}$ & 10.7 & 10.8 & 12.1 & 12.1 & 11.2 \\
\hline $\mathrm{pH}$ & $\mathrm{pH}$ & 7.13 & 6.96 & 7.17 & 7.17 & 7.14 \\
\hline Redox & $\mathrm{mV}$ & -5 & -1 & -63 & -63 & -1 \\
\hline Conductivity & $\mu \mathrm{mhos} / \mathrm{cm}$ & 1,003 & 1,028 & 1,062 & 1,062 & 1,052 \\
\hline Chloride ${ }^{b}$ & $\mathrm{mg} / \mathrm{L}$ & 57 & 57 & 52 & 49 & 50 \\
\hline Sulfate ${ }^{b}$ & $\mathrm{mg} / \mathrm{L}$ & 75 & 35 & 34 & 65 & 39 \\
\hline $\mathrm{TDS}^{\mathrm{b}}$ & $\mathrm{mg} / \mathrm{L}$ & 597 & 635 & 668 & 659 & 659 \\
\hline Cyanide (total) ${ }^{c}$ & $\mathrm{mg} / \mathrm{L}$ & $<0.01$ & $<0.01$ & $<0.01$ & $<0.01$ & $<0.01$ \\
\hline Arsenic ${ }^{c}$ & $\mathrm{mg} / \mathrm{L}$ & d & 0.0034 & - & - & - \\
\hline Barium ${ }^{c}$ & $\mathrm{mg} / \mathrm{L}$ & - & 0.0637 & - & - & - \\
\hline Boron $^{c}$ & $\mathrm{mg} / \mathrm{L}$ & - & 0.1239 & - & - & - \\
\hline Cadmium $^{c}$ & $\mathrm{mg} / \mathrm{L}$ & - & $<0.0001$ & - & - & - \\
\hline Chromium $^{c}$ & $\mathrm{mg} / \mathrm{L}$ & - & $<0.044$ & - & - & - \\
\hline Cobalt ${ }^{2}$ & $\mathrm{mg} / \mathrm{L}$ & - & $<0.026$ & - & - & - \\
\hline Copper ${ }^{c}$ & $\mathrm{mg} / \mathrm{L}$ & - & $<0.017$ & - & - & - \\
\hline Iron $^{c}$ & $\mathrm{mg} / \mathrm{L}$ & - & 1.525 & - & - & - \\
\hline Lead $^{c}$ & $\mathrm{mg} / \mathrm{L}$ & - & $<0.001$ & - & - & - \\
\hline Manganese $^{c}$ & $\mathrm{mg} / \mathrm{L}$ & - & 0.3418 & - & - & - \\
\hline Mercuryc & $\mathrm{mg} / \mathrm{L}$ & - & $<0.0001$ & - & - & - \\
\hline Nickel $^{c}$ & $\mathrm{mg} / \mathrm{L}$ & - & $<0.04$ & - & - & - \\
\hline Selenium $^{c}$ & $\mathrm{mg} / \mathrm{L}$ & - & $<0.003$ & - & - & - \\
\hline Silver & $\mathrm{mg} / \mathrm{L}$ & - & $<0.0005$ & - & - & - \\
\hline Zinc $^{c}$ & $\mathrm{mg} / \mathrm{L}$ & - & $<0.011$ & - & - & - \\
\hline Ammonia nitrogen ${ }^{b}$ & $\mathrm{mg} / \mathrm{L}$ & 0.3 & 0.2 & 0.2 & 0.1 & 0.2 \\
\hline Arsenic ${ }^{b}$ & $\mathrm{mg} / \mathrm{L}$ & 0.0027 & 0.0025 & 0.0027 & 0.0028 & 0.0030 \\
\hline Barium ${ }^{b}$ & $\mathrm{mg} / \mathrm{L}$ & 0.0645 & 0.0630 & 0.0678 & 0.0580 & 0.0642 \\
\hline Beryllium & $\mathrm{mg} / \mathrm{L}$ & $<0.0002$ & $<0.0002$ & $<0.0002$ & $<0.0002$ & $<0.0002$ \\
\hline Cadmium ${ }^{b}$ & $\mathrm{mg} / \mathrm{L}$ & $<0.0001$ & $<0.0001$ & $<0.0001$ & $<0.0001$ & $<0.0001$ \\
\hline Chromium $^{b}$ & $\mathrm{mg} / \mathrm{L}$ & $<0.044$ & $<0.044$ & $<0.044$ & $<0.044$ & $<0.044$ \\
\hline Cobalt $^{b}$ & $\mathrm{mg} / \mathrm{L}$ & $<0.026$ & $<0.026$ & $<0.026$ & $<0.026$ & $<0.026$ \\
\hline Copper ${ }^{b}$ & $\mathrm{mg} / \mathrm{L}$ & $<0.017$ & $<0.017$ & $<0.017$ & $<0.017$ & $<0.017$ \\
\hline Iron ${ }^{b}$ & $\mathrm{mg} / \mathrm{L}$ & 1.9220 & 1.5550 & 1.6800 & 1.0060 & 1.5160 \\
\hline Lead $^{b}$ & $\mathrm{mg} / \mathrm{L}$ & $<0.001$ & $<0.001$ & $<0.001$ & $<0.001$ & 0.001 \\
\hline Manganese $^{b}$ & $\mathrm{mg} / \mathrm{L}$ & 0.3518 & 0.3698 & 0.3156 & 0.3070 & 0.2846 \\
\hline Mercuryb & $\mathrm{mg} / \mathrm{L}$ & $<0.0001$ & $<0.0001$ & $<0.0001$ & $<0.0001$ & $<0.0001$ \\
\hline Nickel $^{\mathrm{b}}$ & $\mathrm{mg} / \mathrm{L}$ & $<0.04$ & $<0.04$ & $<0.04$ & $<0.04$ & $<0.04$ \\
\hline Silver $^{\mathrm{b}}$ & $\mathrm{mg} / \mathrm{L}$ & $<0.0005$ & $<0.0005$ & $<0.0005$ & $<0.0005$ & $<0.0005$ \\
\hline Thallium $^{\mathrm{b}}$ & $\mathrm{mg} / \mathrm{L}$ & $<0.0015$ & $<0.0015$ & $<0.0015$ & $<0.0015$ & $<0.0015$ \\
\hline Vanadium $^{b}$ & $\mathrm{mg} / \mathrm{L}$ & $<0.024$ & $<0.024$ & $<0.024$ & $<0.024$ & $<0.024$ \\
\hline Zinc $^{b}$ & $\mathrm{mg} / \mathrm{L}$ & $<0.011$ & $<0.011$ & $<0.011$ & $<0.011$ & $<0.011$ \\
\hline Nitrate & $\mathrm{mg} / \mathrm{L}$ & - & $<0.1$ & - & - & - \\
\hline Phenols & $\mathrm{mg} / \mathrm{L}$ & 0.006 & 0.006 & $<0.005$ & 0.007 & $<0.005$ \\
\hline Hydrogen-3 & $\mathrm{pCi} / \mathrm{L}$ & $<100$ & $<100$ & $<100$ & 114 & $<100$ \\
\hline Chloride & $\mathrm{mg} / \mathrm{L}$ & - & 55 & - & - & - \\
\hline Fluoride & $\mathrm{mg} / \mathrm{L}$ & - & 0.264 & - & - & - \\
\hline Sulfate & $\mathrm{mg} / \mathrm{L}$ & - & 33 & - & - & - \\
\hline TOCs & $\mathrm{mg} / \mathrm{L}$ & 3.2 & 3.4 & 4.2 & 3.2 & 3.0 \\
\hline TOCs & $\mathrm{mg} / \mathrm{L}$ & 3.2 & 3.5 & 3.3 & 3.2 & 3.0 \\
\hline TOCs & $\mathrm{mg} / \mathrm{L}$ & 3.2 & 3.1 & 4.3 & 3.3 & 3.1 \\
\hline TOCs & $\mathrm{mg} / \mathrm{L}$ & 3.2 & 3.7 & 3.3 & 3.2 & 3.1 \\
\hline TOXs & $\mathrm{mg} / \mathrm{L}$ & 0.0180 & 0.0110 & 0.0150 & 0.0150 & 0.0330 \\
\hline TOXs & $\mathrm{mg} / \mathrm{L}$ & 0.0300 & 0.0140 & 0.0210 & 0.0120 & 0.0130 \\
\hline Trichlorofluoromethane & $\mu \mathrm{g} / \mathrm{L}$ & $<1$ & 1 & $<1$ & $<1$ & $<1$ \\
\hline
\end{tabular}

a Well point elevation $=209.40 \mathrm{~m}(\mathrm{MSL})$; ground surface elevation $=230.73 \mathrm{~m}$ (MSL); casing material = stainless steel.

b Filtered sample.

c Unfiltered sample.

d A hyphen indicates that samples were not collected. 


\section{GROUNDWATER PROTECTION}

\section{TABLE 6.26}

Groundwater Monitoring Results, Sanitary Landfill Well 800163D, 1998

\begin{tabular}{|c|c|c|c|c|c|c|}
\hline \multirow[b]{2}{*}{ Parameter } & \multirow[b]{2}{*}{ Unit } & \multicolumn{5}{|c|}{ Date of Sampling } \\
\hline & & $01 / 09 / 98$ & $01 / 09 / 98$ & $04 / 09 / 98$ & $07 / 08 / 98$ & $10 / 13 / 98$ \\
\hline Water elevation ${ }^{a}$ & $\mathrm{~m}$ & 192.56 & 192.56 & 192.91 & 192.79 & 192.63 \\
\hline Temperature & ${ }^{\circ} \mathrm{C}$ & 10.5 & 10.5 & 11.6 & 12.3 & 11.2 \\
\hline $\mathrm{pH}$ & $\mathrm{pH}$ & 6.96 & 6.96 & 6.77 & 7.08 & 7.21 \\
\hline Redox & $\mathrm{mV}$ & 4 & 4 & 8 & -44 & -5 \\
\hline Conductivity & $\mu \mathrm{mhos} / \mathrm{cm}$ & 1,331 & 1,331 & 1,311 & 1,346 & 1,347 \\
\hline Chloride $^{b}$ & $\mathrm{mg} / \mathrm{L}$ & 122 & 119 & 106 & 131 & 126 \\
\hline Sulfate $e^{b}$ & $\mathrm{mg} / \mathrm{L}$ & 196 & 193 & 181 & 168 & 170 \\
\hline $\operatorname{TDS}^{\mathbf{b}}$ & $\mathrm{mg} / \mathrm{L}$ & 840 & 823 & 874 & 926 & 971 \\
\hline Cyanide (total) $^{c}$ & $\mathrm{mg} / \mathrm{L}$ & $<0.01$ & $<0.01$ & $<0.01$ & $<0.01$ & $<0.01$ \\
\hline Arsenic ${ }^{c}$ & $\mathrm{mg} / \mathrm{L}$ & $-d$ & - & 0.0092 & - & - \\
\hline Barium $^{\mathrm{c}}$ & $\mathrm{mg} / \mathrm{L}$ & - & - & 0.0666 & - & - \\
\hline Boron $^{c}$ & $\mathrm{mg} / \mathrm{L}$ & - & - & 0.2124 & - & - \\
\hline Cadmium $^{\mathrm{c}}$ & $\mathrm{mg} / \mathrm{L}$ & - & - & $<0.0001$ & - & - \\
\hline Chromium $^{\mathrm{e}}$ & $\mathrm{mg} / \mathrm{L}$ & - & - & $<0.044$ & - & - \\
\hline Cobalt & $\mathrm{mg} / \mathrm{L}$ & - & - & $<0.026$ & - & - \\
\hline Copper $^{c}$ & $\mathrm{mg} / \mathrm{L}$ & - & - & $<0.017$ & - & - \\
\hline Iron $^{c}$ & $\mathrm{mg} / \mathrm{L}$ & - & - & 6.4320 & - & - \\
\hline Lead $^{c}$ & $\mathrm{mg} / \mathrm{L}$ & - & - & 0.0010 & - & - \\
\hline Manganese $^{c}$ & $\mathrm{mg} / \mathrm{L}$ & - & - & 0.0567 & - & - \\
\hline Mercury ${ }^{c}$ & $\mathrm{mg} / \mathrm{L}$ & - & - & $<0.0001$ & - & - \\
\hline Nickel $^{c}$ & $\mathrm{mg} / \mathrm{L}$ & - & - & $<0.04$ & - & - \\
\hline Selenium $^{c}$ & $\mathrm{mg} / \mathrm{L}$ & - & - & $<0.003$ & - & - \\
\hline Silver ${ }^{c}$ & $\mathrm{mg} / \mathrm{L}$ & - & - & $<0.0005$ & - & - \\
\hline $\operatorname{Zinc}^{c}$ & $\mathrm{mg} / \mathrm{L}$ & - & - & $<0.011$ & - & - \\
\hline Ammonia nitrogen ${ }^{b}$ & $\mathrm{mg} / \mathrm{L}$ & 0.6 & $<0.2$ & 0.5 & 0.4 & 0.6 \\
\hline Arsenic $^{\mathbf{b}}$ & $\mathrm{mg} / \mathrm{L}$ & 0.0043 & 0.0046 & 0.0042 & 0.0025 & 0.0036 \\
\hline Barium $^{b}$ & $\mathrm{mg} / \mathrm{L}$ & 0.0577 & 0.0597 & 0.0500 & 0.0554 & 0.0572 \\
\hline Beryllium $^{b}$ & $\mathrm{mg} / \mathrm{L}$ & $<0.0002$ & $<0.0002$ & $<0.0002$ & $<0.0002$ & $<0.0002$ \\
\hline Cadmium $^{b}$ & $\mathrm{mg} / \mathrm{L}$ & $<0.0001$ & $<0.0001$ & $<0.0001$ & $<0.0001$ & $<0.0001$ \\
\hline Chromium $^{b}$ & $\mathrm{mg} / \mathrm{L}$ & $<0.044$ & $<0.044$ & $<0.044$ & $<0.044$ & $<0.044$ \\
\hline Cobalt ${ }^{b}$ & $\mathrm{mg} / \mathrm{L}$ & $<0.026$ & $<0.026$ & $<0.026$ & $<0.026$ & $<0.026$ \\
\hline Copper & $\mathrm{mg} / \mathrm{L}$ & $<0.017$ & $<0.017$ & $<0.017$ & $<0.017$ & $<0.017$ \\
\hline Iron ${ }^{b}$ & $\mathrm{mg} / \mathrm{L}$ & 2.4830 & 2.4920 & 1.8790 & 1.0660 & 1.7150 \\
\hline Lead $^{b}$ & $\mathrm{mg} / \mathrm{L}$ & $<0.001$ & $<0.001$ & $<0.001$ & $<0.001$ & $<0.001$ \\
\hline Manganese ${ }^{b}$ & $\mathrm{mg} / \mathrm{L}$ & 0.0534 & 0.0544 & 0.0466 & 0.0526 & 0.0508 \\
\hline Mercuryb & $\mathrm{mg} / \mathrm{L}$ & $<0.0001$ & $<0.0001$ & $<0.0001$ & $<0.0001$ & $<0.0001$ \\
\hline Nickel ${ }^{b}$ & $\mathrm{mg} / \mathrm{L}$ & $<0.04$ & $<0.04$ & $<0.04$ & $<0.04$ & $<0.04$ \\
\hline Silver $^{b}$ & $\mathrm{mg} / \mathrm{L}$ & $<0.0005$ & $<0.0005$ & 0.0006 & $<0.0005$ & $<0.0005$ \\
\hline Thallium $^{\mathbf{b}}$ & $\mathrm{mg} / \mathrm{L}$ & $<0.0015$ & $<0.0015$ & $<0.0015$ & $<0.0015$ & $<0.0015$ \\
\hline Vanadium $^{b}$ & $\mathrm{mg} / \mathrm{L}$ & $<0.024$ & $<0.024$ & $<0.024$ & $<0.024$ & $<0.024$ \\
\hline Zinc $^{b}$ & $\mathrm{mg} / \mathrm{L}$ & $<0.011$ & $<0.011$ & $<0.011$ & $<0.011$ & $<0.011$ \\
\hline Nitrate & $\mathrm{mg} / \mathrm{L}$ & - & - & $<0.1$ & - & - \\
\hline Phenols & $\mathrm{mg} / \mathrm{L}$ & $<0.005$ & $<0.005$ & $<0.005$ & $<0.005$ & $<0.005$ \\
\hline Hydrogen-3 & $\mathrm{pCi} / \mathrm{L}$ & $<100$ & $<100$ & $<100$ & $<100$ & $<100$ \\
\hline Chloride & $\mathrm{mg} / \mathrm{L}$ & - & - & 116 & - & - \\
\hline Fluoride & $\mathrm{mg} / \mathrm{L}$ & - & - & 0.350 & - & - \\
\hline Sulfate & $\mathrm{mg} / \mathrm{L}$ & - & - & 181 & - & - \\
\hline TOCs & $\mathrm{mg} / \mathrm{L}$ & 4.3 & 3.6 & 2.4 & 2.2 & 2.3 \\
\hline TOCs & $\mathrm{mg} / \mathrm{L}$ & 3.9 & 3.4 & 2.1 & 3.5 & 2.3 \\
\hline TOCs & $\mathrm{mg} / \mathrm{L}$ & 3.6 & 3.7 & 2.2 & 2.2 & 2.4 \\
\hline TOCs & $\mathrm{mg} / \mathrm{L}$ & 3.6 & 3.8 & 2.0 & 2.2 & 2.3 \\
\hline TOXs & $\mathrm{mg} / \mathrm{L}$ & 0.0560 & 0.0320 & 0.0390 & 0.0400 & 0.0330 \\
\hline TOXs & $\mathrm{mg} / \mathrm{L}$ & 0.0760 & 0.0250 & 0.0310 & 0.0270 & 0.0230 \\
\hline Methylene chloride & $\mu \mathrm{g} / \mathrm{L}$ & $<1$ & $<1$ & $<1$ & $<1$ & $<1$ \\
\hline Toluene & $\mu \mathrm{g} / \mathrm{L}$ & $<1$ & $<1$ & 1 & $\leq 1$ & $<1$ \\
\hline
\end{tabular}

\footnotetext{
a Well point elevation $=183.77 \mathrm{~m}(\mathrm{MSL})$; ground surface elevation $=230.76 \mathrm{~m}$ (MSL); casing material $=$ stainless steel.

b Filtered sample.

c Unfiltered sample.

d A hyphen indicates that samples were not collected.
} 
TABLE 6.27

Groundwater Monitoring Results, Sanitary Landfill Well 800171, 1998

\begin{tabular}{|c|c|c|c|c|c|}
\hline \multirow[b]{2}{*}{ Parameter } & \multirow[b]{2}{*}{ Unit } & \multicolumn{4}{|c|}{ Date of Sampling } \\
\hline & & $01 / 08 / 98$ & $04 / 09 / 98$ & $07 / 09 / 98$ & $10 / 14 / 98$ \\
\hline Water elevation ${ }^{\mathrm{a}}$ & $\mathrm{m}$ & 227.01 & 227.23 & 226.02 & 225.68 \\
\hline Temperature & ${ }^{\circ} \mathrm{C}$ & 11.2 & 9.7 & 11.7 & 12.9 \\
\hline $\mathrm{pH}$ & $\mathrm{pH}$ & 6.86 & 6.83 & 6.89 & 6.71 \\
\hline Redox & $\mathrm{mV}$ & 10 & 4 & -4 & 11 \\
\hline Conductivity & $\mu \mathrm{mhos} / \mathrm{cm}$ & 1,298 & 826 & 1,401 & 1,479 \\
\hline Chloride $^{b}$ & $\mathrm{mg} / \mathrm{L}$ & 24 & 21 & 33 & 31 \\
\hline Sulfate ${ }^{b}$ & $\mathrm{mg} / \mathrm{L}$ & 192 & 197 & 189 & 201 \\
\hline TDS $^{b}$ & $\mathrm{mg} / \mathrm{L}$ & 773 & 593 & 969 & 984 \\
\hline Cyanide (total) ${ }^{c}$ & $\mathrm{mg} / \mathrm{L}$ & $<0.01$ & $<0.01$ & $<0.01$ & $<0.01$ \\
\hline Arsenic ${ }^{c}$ & $\mathrm{mg} / \mathrm{L}$ & $-d$ & 0.0095 & - & - \\
\hline Barium $^{\mathrm{c}}$ & $\mathrm{mg} / \mathrm{L}$ & - & 0.1543 & - & - \\
\hline Boron $^{\mathrm{c}}$ & $\mathrm{mg} / \mathrm{L}$ & - & 0.3411 & - & - \\
\hline Cadmium $^{c}$ & $\mathrm{mg} / \mathrm{L}$ & - & 0.0002 & - & - \\
\hline Chromium $^{c}$ & $\mathrm{mg} / \mathrm{L}$ & - & $<0.044$ & - & - \\
\hline Cobalt & $\mathrm{mg} / \mathrm{L}$ & - & $<0.026$ & - & - \\
\hline Copper ${ }^{c}$ & $\mathrm{mg} / \mathrm{L}$ & - & 0.0235 & - & - \\
\hline $\operatorname{Iron}^{\mathrm{c}}$ & $\mathrm{mg} / \mathrm{L}$ & - & 20.49 & - & - \\
\hline Lead ${ }^{\mathrm{c}}$ & $\mathrm{mg} / \mathrm{L}$ & - & 0.0186 & - & - \\
\hline Manganese ${ }^{c}$ & $\mathrm{mg} / \mathrm{L}$ & - & 0.7503 & - & - \\
\hline Mercury $^{c}$ & $\mathrm{mg} / \mathrm{L}$ & - & $<0.0001$ & - & - \\
\hline Nickel $^{\mathrm{c}}$ & $\mathrm{mg} / \mathrm{L}$ & - & $<0.04$ & - & - \\
\hline Selenium ${ }^{c}$ & $\mathrm{mg} / \mathrm{L}$ & - & $<0.003$ & - & - \\
\hline Silver ${ }^{c}$ & $\mathrm{mg} / \mathrm{L}$ & - & $<0.0005$ & - & - \\
\hline Zinc $^{\mathrm{c}}$ & $\mathrm{mg} / \mathrm{L}$ & - & 0.0964 & - & - \\
\hline Ammonia nitrogen ${ }^{b}$ & $\mathrm{mg} / \mathrm{L}$ & 0.2 & $<0.1$ & $<0.1$ & $<0.1$ \\
\hline Arsenic $^{b}$ & $\mathrm{mg} / \mathrm{L}$ & 0.0050 & 0.0033 & $<0.0025$ & 0.0025 \\
\hline Barium $^{b}$ & $\mathrm{mg} / \mathrm{L}$ & 0.0505 & 0.0413 & 0.0781 & 0.0737 \\
\hline Berylliumb & $\mathrm{mg} / \mathrm{L}$ & $<0.0002$ & $<0.0002$ & $<0.0002$ & $<0.0002$ \\
\hline Cadmium ${ }^{\mathrm{b}}$ & $\mathrm{mg} / \mathrm{L}$ & $<0.0001$ & $<0.0001$ & $<0.0001$ & $<0.0001$ \\
\hline Chromium $^{b}$ & $\mathrm{mg} / \mathrm{L}$ & $<0.044$ & $<0.044$ & $<0.044$ & $<0.044$ \\
\hline Cobalt $^{\mathrm{b}}$ & $\mathrm{mg} / \mathrm{L}$ & $<0.026$ & $<0.026$ & $<0.026$ & $<0.026$ \\
\hline Copper ${ }^{b}$ & $\mathrm{mg} / \mathrm{L}$ & $<0.017$ & $<0.017$ & $<0.017$ & $<0.017$ \\
\hline Iron ${ }^{b}$ & $\mathrm{mg} / \mathrm{L}$ & $<0.037$ & $<0.037$ & $<0.037$ & 0.138 \\
\hline Lead $^{b}$ & $\mathrm{mg} / \mathrm{L}$ & $<0.001$ & $<0.001$ & $<0.001$ & $<0.001$ \\
\hline Manganese $^{b}$ & $\mathrm{mg} / \mathrm{L}$ & 0.0808 & 0.0772 & 0.2252 & 0.2478 \\
\hline Mercury ${ }^{b}$ & $\mathrm{mg} / \mathrm{L}$ & $<0.0001$ & $<0.0001$ & $<0.0001$ & $<0.0001$ \\
\hline Nickel $^{b}$ & $\mathrm{mg} / \mathrm{L}$ & $<0.04$ & $<0.04$ & $<0.04$ & $<0.04$ \\
\hline Silver ${ }^{b}$ & $\mathrm{mg} / \mathrm{L}$ & $<0.0005$ & $<0.0005$ & $<0.0005$ & 0.0010 \\
\hline Thallium $^{6}$ & $\mathrm{mg} / \mathrm{L}$ & $<0.0015$ & $<0.0015$ & $<0.0015$ & $<0.0015$ \\
\hline Vanadium ${ }^{b}$ & $\mathrm{mg} / \mathrm{L}$ & $<0.024$ & $<0.024$ & $<0.024$ & $<0.024$ \\
\hline $\operatorname{Zinc}^{\mathrm{b}}$ & $\mathrm{mg} / \mathrm{L}$ & 0.0236 & 0.0158 & 0.0228 & 0.0254 \\
\hline Nitrate & $\mathrm{mg} / \mathrm{L}$ & - & 0.28 & - & - \\
\hline Phenols & $\mathrm{mg} / \mathrm{L}$ & $<0.005$ & $<0.005$ & 0.010 & $<0.005$ \\
\hline Hydrogen-3 & $\mathrm{pCi} / \mathrm{L}$ & $<100$ & $<100$ & 113 & 102 \\
\hline Chloride & $\mathrm{mg} / \mathrm{L}$ & - & 26 & - & - \\
\hline Fluoride & $\mathrm{mg} / \mathrm{L}$ & - & 0.182 & - & - \\
\hline Sulfate & $\mathrm{mg} / \mathrm{L}$ & - & 193 & - & - \\
\hline TOCs & $\mathrm{mg} / \mathrm{L}$ & 3.0 & 2.6 & 2.8 & 2.4 \\
\hline TOCs & $\mathrm{mg} / \mathrm{L}$ & 3.2 & 2.5 & 2.7 & 2.3 \\
\hline TOCs & $\mathrm{mg} / \mathrm{L}$ & 3.2 & 2.6 & 2.6 & 2.3 \\
\hline TOCs & $\mathrm{mg} / \mathrm{L}$ & 3.2 & 2.6 & 2.6 & 2.4 \\
\hline TOXs & $\mathrm{mg} / \mathrm{L}$ & 0.0160 & $<0.0100$ & 0.0210 & 0.0200 \\
\hline TOXs & $\mathrm{mg} / \mathrm{L}$ & 0.0240 & $<0.0100$ & 0.0210 & 0.0310 \\
\hline Trichloroethene & $\mu \mathrm{g} / \mathrm{L}$ & $<1$ & $<1$ & 1 & 1 \\
\hline
\end{tabular}

a Well point elevation $=220.71 \mathrm{~m}(\mathrm{MSL})$; ground surface elevation $=228.42 \mathrm{~m}$ (MSL); casing material $=$ stainless steel.

b Filtered sample.

c Unfiltered sample.

d A hyphen indicates that samples were not collected. 


\section{GROUNDWATER PROTECTION}

TABLE 6.28

Groundwater Monitoring Results, Sanitary Landfill Well 800173D, 1998

\begin{tabular}{|c|c|c|c|c|c|}
\hline \multirow[b]{2}{*}{ Parameter } & \multirow[b]{2}{*}{ Unit } & \multicolumn{4}{|c|}{ Date of Sampling } \\
\hline & & $01 / 09 / 98$ & $04 / 09 / 98$ & $07 / 09 / 98$ & $10 / 14 / 98$ \\
\hline Water elevation $^{2}$ & m & 192.54 & 192.82 & 192.76 & 192.53 \\
\hline Temperature & ${ }^{\circ} \mathrm{C}$ & 9.8 & 11.7 & 12.1 & 11.2 \\
\hline $\mathrm{pH}$ & pH & 7.26 & 6.94 & 7.22 & 7.07 \\
\hline Redox & $\mathrm{mV}$ & 13 & 1 & -9 & -9 \\
\hline Conductivity & $\mu \mathrm{mhos} / \mathrm{cm}$ & 1,483 & 1,506 & 1,495 & 1,491 \\
\hline Chlorideb & $\mathrm{mg} / \mathrm{L}$ & 191 & 192 & 206 & 216 \\
\hline Sulfate ${ }^{b}$ & $\mathrm{mg} / \mathrm{L}$ & 102 & 99 & 88 & 95 \\
\hline TDS $^{b}$ & $\mathrm{mg} / \mathrm{L}$ & 879 & 918 & 981 & 913 \\
\hline Cyanide (total) $^{\mathrm{c}}$ & $\mathrm{mg} / \mathrm{L}$ & $<0.01$ & $<0.01$ & $<0.01$ & $<0.01$ \\
\hline Arsenic $^{c}$ & $\mathrm{mg} / \mathrm{L}$ & $-{ }^{d}$ & 0.0048 & - & - \\
\hline Barium $^{c}$ & $\mathrm{mg} / \mathrm{L}$ & - & 0.1239 & - & - \\
\hline Boron ${ }^{\mathrm{e}}$ & $\mathrm{mg} / \mathrm{L}$ & - & 0.1850 & - & - \\
\hline Cadmium $^{\mathrm{c}}$ & $\mathrm{mg} / \mathrm{L}$ & - & $<0.0001$ & - & - \\
\hline Chromium $^{c}$ & $\mathrm{mg} / \mathrm{L}$ & - & $<0.044$ & - & - \\
\hline Cobalt ${ }^{\mathfrak{}}$ & $\mathrm{mg} / \mathrm{L}$ & - & 0.0524 & - & - \\
\hline Copper $^{c}$ & $\mathrm{mg} / \mathrm{L}$ & - & $<0.017$ & - & - \\
\hline $\operatorname{Iron}^{c}$ & $\mathrm{mg} / \mathrm{L}$ & - & 6.13 & - & - \\
\hline Lead $^{c}$ & $\mathrm{mg} / \mathrm{L}$ & - & 0.0028 & - & - \\
\hline Manganese $^{c}$ & $\mathrm{mg} / \mathrm{L}$ & - & 0.1689 & - & - \\
\hline Mercuryc & $\mathrm{mg} / \mathrm{L}$ & - & $<0.0001$ & - & - \\
\hline Nickel $^{c}$ & $\mathrm{mg} / \mathrm{L}$ & - & $<0.040$ & - & - \\
\hline Selenium $^{c}$ & $\mathrm{mg} / \mathrm{L}$ & - & $<0.003$ & - & - \\
\hline Silver ${ }^{c}$ & $\mathrm{mg} / \mathrm{L}$ & - & 0.0006 & - & - \\
\hline Zinc $^{c}$ & $\mathrm{mg} / \mathrm{L}$ & - & 0.0205 & - & - \\
\hline Ammonia nitrogen ${ }^{b}$ & $\mathrm{mg} / \mathrm{L}$ & 0.7 & 0.7 & 0.6 & 0.8 \\
\hline Arsenic ${ }^{b}$ & $\mathrm{mg} / \mathrm{L}$ & 0.0040 & 0.0042 & 0.0053 & 0.0057 \\
\hline Barium $^{b}$ & $\mathrm{mg} / \mathrm{L}$ & 0.0915 & 0.0808 & 0.0932 & 0.0890 \\
\hline Beryllium $^{\mathrm{b}}$ & $\mathrm{mg} / \mathrm{L}$ & $<0.0002$ & $<0.0002$ & $<0.0002$ & $<0.0002$ \\
\hline Cadmium $^{\mathrm{b}}$ & $\mathrm{mg} / \mathrm{L}$ & $<0.0001$ & $<0.0001$ & $<0.0001$ & $<0.0001$ \\
\hline Chromium $^{b}$ & $\mathrm{mg} / \mathrm{L}$ & $<0.044$ & $<0.044$ & $<0.044$ & $<0.044$ \\
\hline Cobalt $^{b}$ & $\mathrm{mg} / \mathrm{L}$ & $<0.026$ & 0.035 & $<0.026$ & $<0.026$ \\
\hline Copper $^{b}$ & $\mathrm{mg} / \mathrm{L}$ & $<0.017$ & $<0.017$ & $<0.017$ & $<0.017$ \\
\hline Iron ${ }^{b}$ & $\mathrm{mg} / \mathrm{L}$ & 2.3820 & 2.4800 & 3.7530 & 3.1880 \\
\hline Lead $^{b}$ & $\mathrm{mg} / \mathrm{L}$ & $<0.001$ & $<0.001$ & $<0.001$ & $<0.001$ \\
\hline Manganese $^{\mathrm{b}}$ & $\mathrm{mg} / \mathrm{L}$ & 0.0950 & 0.0860 & 0.0918 & 0.0935 \\
\hline Mercuryb & $\mathrm{mg} / \mathrm{L}$ & $<0.0001$ & $<0.0001$ & $<0.0001$ & $<0.0001$ \\
\hline Nickel ${ }^{\mathrm{b}}$ & $\mathrm{mg} / \mathrm{L}$ & $<0.04$ & $<0.04$ & $<0.04$ & $<0.04$ \\
\hline Silver ${ }^{b}$ & $\mathrm{mg} / \mathrm{L}$ & $<0.0005$ & 0.0005 & $<0.0005$ & 0.0006 \\
\hline Thallium $^{\mathrm{b}}$ & $\mathrm{mg} / \mathrm{L}$ & $<0.0015$ & $<0.0015$ & $<0.0015$ & $<0.0015$ \\
\hline Vanadium $^{b}$ & $\mathrm{mg} / \mathrm{L}$ & $<0.024$ & $<0.024$ & $<0.024$ & $<0.024$ \\
\hline $\operatorname{Zinc}^{b}$ & $\mathrm{mg} / \mathrm{L}$ & 0.019 & $<0.011$ & $<0.011$ & $<0.011$ \\
\hline Nitrate & $\mathrm{mg} / \mathrm{L}$ & - & 0.18 & - & - \\
\hline Phenols & $\mathrm{mg} / \mathrm{L}$ & 0.006 & $<0.005$ & $<0.005$ & 0.008 \\
\hline Hydrogen-3 & $\mathrm{pCi} / \mathrm{L}$ & $<100$ & $<100$ & $<100$ & $<100$ \\
\hline Chloride & $\mathrm{mg} / \mathrm{L}$ & - & 189 & - & - \\
\hline Fluoride & $\mathrm{mg} / \mathrm{L}$ & - & 0.344 & - & - \\
\hline Sulfate & $\mathrm{mg} / \mathrm{L}$ & - & 97 & - & - \\
\hline TOCs & $\mathrm{mg} / \mathrm{L}$ & 7.2 & 4.4 & 4.8 & 5.0 \\
\hline TOCs & $\mathrm{mg} / \mathrm{L}$ & 7.0 & 4.4 & 4.8 & 4.8 \\
\hline TOCs & $\mathrm{mg} / \mathrm{L}$ & 7.6 & 4.4 & 4.5 & 4.8 \\
\hline TOCs & $\mathrm{mg} / \mathrm{L}$ & 7.8 & 4.2 & 4.8 & 4.8 \\
\hline TOXs & $\mathrm{mg} / \mathrm{L}$ & 0.0550 & 0.0310 & 0.0360 & 0.1000 \\
\hline TOXs & $\mathrm{mg} / \mathrm{L}$ & 0.0800 & 0.0310 & 0.0200 & 0.0820 \\
\hline
\end{tabular}

a Well point elevation $=189.34 \mathrm{~m}(\mathrm{MSL})$; ground surface elevation $=228.42 \mathrm{~m}$ (MSL); casing material $=$ stainless steel.

b Filtered sample.

c Unfiltered sample.

d A hyphen indicates that samples were not collected. 
TABLE 6.29

Groundwater Monitoring Results, Sanitary Landfill Well 800181, 1998

\begin{tabular}{|c|c|c|c|c|c|}
\hline \multirow[b]{2}{*}{ Parameter } & \multirow[b]{2}{*}{ Unit } & \multicolumn{4}{|c|}{ Date of Sampling } \\
\hline & & $01 / 08 / 98$ & $04 / 10 / 98$ & $07 / 09 / 98$ & $10 / 14 / 98$ \\
\hline Water elevation ${ }^{a}$ & $\mathrm{~m}$ & 222.35 & 222.50 & 222.28 & 222.22 \\
\hline Temperature & ${ }^{\circ} \mathrm{C}$ & 9.7 & 10.0 & 10.8 & 10.2 \\
\hline $\mathrm{pH}$ & $\mathrm{pH}$ & 7.19 & 6.99 & 7.38 & 7.25 \\
\hline Redox & $\mathrm{mV}$ & -9 & -5 & -53 & -8 \\
\hline Conductivity & $\mu \mathrm{mhos} / \mathrm{cm}$ & 1,463 & 1,264 & 1,211 & 1,225 \\
\hline Chloride $^{b}$ & $\mathrm{mg} / \mathrm{L}$ & 4 & 4 & 4 & 4 \\
\hline Sulfate ${ }^{b}$ & $\mathrm{mg} / \mathrm{L}$ & 211 & 225 & 211 & 209 \\
\hline $\mathrm{TDS}^{\mathrm{b}}$ & $\mathrm{mg} / \mathrm{L}$ & 898 & 864 & 858 & 810 \\
\hline Cyanide (total) ${ }^{c}$ & $\mathrm{mg} / \mathrm{L}$ & $<0.01$ & $<0.01$ & $<0.01$ & $<0.01$ \\
\hline Arsenic ${ }^{c}$ & $\mathrm{mg} / \mathrm{L}$ & $-d$ & 0.0124 & - & - \\
\hline Barium $^{c}$ & $\mathrm{mg} / \mathrm{L}$ & - & 0.3538 & - & - \\
\hline Boron ${ }^{c}$ & $\mathrm{mg} / \mathrm{L}$ & - & 0.2151 & - & - \\
\hline Cadmium $^{c}$ & $\mathrm{mg} / \mathrm{L}$ & - & 0.0001 & - & - \\
\hline Chromium $^{c}$ & $\mathrm{mg} / \mathrm{L}$ & - & $<0.044$ & - & - \\
\hline Cobalt $^{c}$ & $\mathrm{mg} / \mathrm{L}$ & - & $<0.026$ & - & - \\
\hline Copper ${ }^{c}$ & $\mathrm{mg} / \mathrm{L}$ & - & 0.0367 & - & - \\
\hline Iron $^{c}$ & $\mathrm{mg} / \mathrm{L}$ & - & 31.89 & - & - \\
\hline Lead $^{c}$ & $\mathrm{mg} / \mathrm{L}$ & - & 0.0207 & - & - \\
\hline Manganese $^{c}$ & $\mathrm{mg} / \mathrm{L}$ & - & 0.7436 & - & - \\
\hline Mercuryc & $\mathrm{mg} / \mathrm{L}$ & - & $<0.0001$ & - & - \\
\hline Nickele & $\mathrm{mg} / \mathrm{L}$ & - & 0.0468 & - & - \\
\hline Selenium ${ }^{c}$ & $\mathrm{mg} / \mathrm{L}$ & - & $<0.003$ & - & - \\
\hline Silver $^{c}$ & $\mathrm{mg} / \mathrm{L}$ & - & $<0.0005$ & - & - \\
\hline Zinc $c^{c}$ & $\mathrm{mg} / \mathrm{L}$ & - & 0.1136 & - & - \\
\hline Ammonia nitrogen ${ }^{b}$ & $\mathrm{mg} / \mathrm{L}$ & 0.4 & 0.1 & $<0.1$ & $<0.1$ \\
\hline Arsenic $^{b}$ & $\mathrm{mg} / \mathrm{L}$ & $<0.0025$ & $<0.0025$ & $<0.0025$ & $<0.0025$ \\
\hline Barium ${ }^{\mathbf{b}}$ & $\mathrm{mg} / \mathrm{L}$ & 0.1084 & 0.1035 & 0.1113 & 0.0930 \\
\hline Beryllium & $\mathrm{mg} / \mathrm{L}$ & $<0.0002$ & $<0.0002$ & $<0.0002$ & $<0.0002$ \\
\hline Cadmium ${ }^{b}$ & $\mathrm{mg} / \mathrm{L}$ & $<0.0001$ & $<0.0001$ & $<0.0001$ & $<0.0001$ \\
\hline Chromium $^{b}$ & $\mathrm{mg} / \mathrm{L}$ & $<0.044$ & $<0.044$ & $<0.044$ & $<0.044$ \\
\hline Cobalt ${ }^{b}$ & $\mathrm{mg} / \mathrm{L}$ & $<0.026$ & $<0.026$ & $<0.026$ & $<0.026$ \\
\hline Copper $^{b}$ & $\mathrm{mg} / \mathrm{L}$ & $<0.017$ & $<0.017$ & $<0.017$ & $<0.017$ \\
\hline Iron $^{b}$ & $\mathrm{mg} / \mathrm{L}$ & $<0.037$ & $<0.037$ & $<0.037$ & $<0.037$ \\
\hline Lead $^{b}$ & $\mathrm{mg} / \mathrm{L}$ & $<0.001$ & $<0.001$ & $<0.001$ & $<0.001$ \\
\hline Manganese $^{b}$ & $\mathrm{mg} / \mathrm{L}$ & $<0.017$ & 0.080 & $<0.017$ & $<0.017$ \\
\hline Mercury ${ }^{b}$ & $\mathrm{mg} / \mathrm{L}$ & $<0.0001$ & $<0.0001$ & $<0.0001$ & $<0.0001$ \\
\hline Nickel ${ }^{b}$ & $\mathrm{mg} / \mathrm{L}$ & $<0.04$ & $<0.04$ & $<0.04$ & $<0.04$ \\
\hline Silver ${ }^{b}$ & $\mathrm{mg} / \mathrm{L}$ & $<0.0005$ & $<0.0005$ & $<0.0005$ & $<0.0005$ \\
\hline Thallium $^{\mathrm{b}}$ & $\mathrm{mg} / \mathrm{L}$ & $<0.0015$ & $<0.0015$ & $<0.0015$ & $<0.0015$ \\
\hline Vanadium $^{b}$ & $\mathrm{mg} / \mathrm{L}$ & $<0.024$ & $<0.024$ & $<0.024$ & $<0.024$ \\
\hline $\operatorname{Zinc}^{b}$ & $\mathrm{mg} / \mathrm{L}$ & 0.021 & $<0.011$ & $<0.011$ & $<0.011$ \\
\hline Nitrate & $\mathrm{mg} / \mathrm{L}$ & - & 0.22 & - & - \\
\hline Phenols & $\mathrm{mg} / \mathrm{L}$ & $<0.005$ & 0.006 & $<0.005$ & $<0.005$ \\
\hline Hydrogen-3 & $\mathrm{pCi} / \mathrm{L}$ & $<100$ & $<100$ & $<100$ & $<100$ \\
\hline Chloride & $\mathrm{mg} / \mathrm{L}$ & - & 4 & - & - \\
\hline Fluoride & $\mathrm{mg} / \mathrm{L}$ & - & 0.24 & - & - \\
\hline Sulfate & $\mathrm{mg} / \mathrm{L}$ & - & 219 & - & - \\
\hline TOCs & $\mathrm{mg} / \mathrm{L}$ & 2.1 & 1.4 & 1.4 & 1.1 \\
\hline TOCs & $\mathrm{mg} / \mathrm{L}$ & 1.9 & 1.3 & 1.3 & 1.1 \\
\hline TOCs & $\mathrm{mg} / \mathrm{L}$ & 1.8 & 1.2 & 1.2 & 1.1 \\
\hline TOCs & $\mathrm{mg} / \mathrm{L}$ & 2.1 & 1.2 & 1.3 & 1.1 \\
\hline TOXs & $\mathrm{mg} / \mathrm{L}$ & $<0.01$ & $<0.01$ & $<0.01$ & $<0.01$ \\
\hline TOXs & $\mathrm{mg} / \mathrm{L}$ & $<0.01$ & $<0.01$ & $<0.01$ & $<0.01$ \\
\hline
\end{tabular}

3 Well point elevation $=219.52 \mathrm{~m}$ (MSL); ground surface elevation $=230.52 \mathrm{~m}$ (MSL); casing material $=$ stainless steel.

b Filtered sample.

c Unfiltered sample.

d A hyphen indicates that samples were not collected. 
TABLE 6.30

Groundwater Monitoring Results, Sanitary Landfill Well 800183D, 1998

\begin{tabular}{|c|c|c|c|c|c|}
\hline \multirow[b]{2}{*}{ Parameter } & \multirow[b]{2}{*}{ Unit } & \multicolumn{4}{|c|}{ Date of Sampling } \\
\hline & & $01 / 08 / 98$ & $04 / 10 / 98$ & $07 / 09 / 98$ & $10 / 14 / 98$ \\
\hline Water elevation $^{\mathrm{a}}$ & $\mathrm{m}$ & 192.63 & 192.69 & 192.73 & 192.59 \\
\hline Temperature & ${ }^{\circ} \mathrm{C}$ & 11.1 & 11.8 & 12.2 & 11.3 \\
\hline $\mathrm{pH}$ & $\mathrm{pH}$ & 7.65 & 7.04 & 7.34 & 7.29 \\
\hline Redox & $\mathrm{mv}$ & -1 & -6 & -39 & -9 \\
\hline Conductivity & $\mu \mathrm{mhos} / \mathrm{cm}$ & 1,288 & 1,286 & 1,283 & 1,292 \\
\hline Chloride & $\mathrm{mg} / \mathrm{L}$ & 109 & 104 & 106 & 117 \\
\hline Sulfate & $\mathrm{mg} / \mathrm{L}$ & 190 & 205 & 94 & 201 \\
\hline $\mathrm{TDS}^{\mathrm{b}}$ & $\mathrm{mg} / \mathrm{L}$ & 817 & 888 & 924 & 864 \\
\hline Cyanide (total) ${ }^{c}$ & $\mathrm{mg} / \mathrm{L}$ & $<0.01$ & $<0.01$ & $<0.01$ & $<0.01$ \\
\hline Arsenic $^{c}$ & $\mathrm{mg} / \mathrm{L}$ & d & 0.0028 & - & - \\
\hline Barium ${ }^{c}$ & $\mathrm{mg} / \mathrm{L}$ & - & 0.0510 & - & - \\
\hline Boron $^{c}$ & $\mathrm{mg} / \mathrm{L}$ & - & 0.2042 & - & - \\
\hline Cadmium ${ }^{\mathbf{c}}$ & $\mathrm{mg} / \mathrm{L}$ & - & $<0.0001$ & - & - \\
\hline Chromium ${ }^{c}$ & $\mathrm{mg} / \mathrm{L}$ & - & $<0.044$ & - & - \\
\hline Cobalt $^{\mathbf{}}$ & $\mathrm{mg} / \mathrm{L}$ & - & $<0.026$ & - & - \\
\hline Copper $^{c}$ & $\mathrm{mg} / \mathrm{L}$ & - & $<0.017$ & - & - \\
\hline Iron $^{c}$ & $\mathrm{mg} / \mathrm{L}$ & - & 1.5070 & - & - \\
\hline Lead $^{\mathrm{c}}$ & $\mathrm{mg} / \mathrm{L}$ & - & $<0.001$ & - & - \\
\hline Manganese ${ }^{c}$ & $\mathrm{mg} / \mathrm{L}$ & - & 0.0209 & - & - \\
\hline Mercuryc & $\mathrm{mg} / \mathrm{L}$ & - & $<0.0001$ & - & - \\
\hline Nickel $^{c}$ & $\mathrm{mg} / \mathrm{L}$ & - & $<0.04$ & - & - \\
\hline Selenium $^{c}$ & $\mathrm{mg} / \mathrm{L}$ & - & $<0.003$ & - & - \\
\hline Silver $^{c}$ & $\mathrm{mg} / \mathrm{L}$ & - & $<0.0005$ & - & - \\
\hline Zinc $^{c}$ & $\mathrm{mg} / \mathrm{L}$ & - & $<0.011$ & - & - \\
\hline Ammonia nitrogen ${ }^{b}$ & $\mathrm{mg} / \mathrm{L}$ & 0.9 & 0.8 & 0.9 & 1.0 \\
\hline Arsenic ${ }^{b}$ & $\mathrm{mg} / \mathrm{L}$ & $<0.0025$ & $<0.0025$ & $<0.0025$ & $<0.0025$ \\
\hline Barium $^{b}$ & $\mathrm{mg} / \mathrm{L}$ & 0.0481 & 0.0443 & 0.0470 & 0.0442 \\
\hline Beryllium ${ }^{b}$ & $\mathrm{mg} / \mathrm{L}$ & $<0.0002$ & $<0.0002$ & $<0.0002$ & $<0.0002$ \\
\hline Cadmium $^{b}$ & $\mathrm{mg} / \mathrm{L}$ & $<0.0001$ & $<0.0001$ & $<0.0001$ & $<0.0001$ \\
\hline Chromium $^{b}$ & $\mathrm{mg} / \mathrm{L}$ & $<0.044$ & $<0.044$ & $<0.044$ & $<0.044$ \\
\hline Cobalt ${ }^{\mathrm{b}}$ & $\mathrm{mg} / \mathrm{L}$ & $<0.026$ & $<0.026$ & $<0.026$ & $<0.026$ \\
\hline Copper ${ }^{b}$ & $\mathrm{mg} / \mathrm{L}$ & $<0.017$ & $<0.017$ & $<0.017$ & $<0.017$ \\
\hline Iron & $\mathrm{mg} / \mathrm{L}$ & 0.7853 & 0.8138 & 0.8658 & 0.8277 \\
\hline Lead $^{b}$ & $\mathrm{mg} / \mathrm{L}$ & $<0.001$ & $<0.001$ & $<0.001$ & $<0.001$ \\
\hline Manganese $\mathrm{e}^{\mathrm{b} .}$ & $\mathrm{mg} / \mathrm{L}$ & 0.019 & $<0.017$ & $<0.017$ & $<0.017$ \\
\hline Mercury ${ }^{b}$ & $\mathrm{mg} / \mathrm{L}$ & $<0.0001$ & $<0.0001$ & $<0.0001$ & $<0.0001$ \\
\hline Nickel $^{\mathrm{b}}$ & $\mathrm{mg} / \mathrm{L}$ & $<0.04$ & $<0.04$ & $<0.04$ & $<0.04$ \\
\hline Silver ${ }^{b}$ & $\mathrm{mg} / \mathrm{L}$ & $<0.0005$ & $<0.0005$ & $<0.0005$ & 0.0006 \\
\hline Thallium $^{\mathrm{b}}$ & $\mathrm{mg} / \mathrm{L}$ & $<0.0015$ & $<0.0015$ & $<0.0015$ & $<0.0015$ \\
\hline Vanadium $^{b}$ & $\mathrm{mg} / \mathrm{L}$ & $<0.024$ & $<0.024$ & $<0.024$ & $<0.024$ \\
\hline $\operatorname{Zinc}^{b}$ & $\mathrm{mg} / \mathrm{L}$ & $<0.011$ & $<0.011$ & $<0.011$ & $<0.011$ \\
\hline Nitrate & $\mathrm{mg} / \mathrm{L}$ & - & 0.55 & - & - \\
\hline Phenols & $\mathrm{mg} / \mathrm{L}$ & 0.007 & $<0.005$ & 0.025 & $<0.005$ \\
\hline Hydrogen-3 & $\mathrm{pCi} / \mathrm{L}$ & $<100$ & $<100$ & $<100$ & $<100$ \\
\hline Chloride & $\mathrm{mg} / \mathrm{L}$ & - & 106 & - & - \\
\hline Fluoride & $\mathrm{mg} / \mathrm{L}$ & - & 0.324 & - & - \\
\hline Sulfate & $\mathrm{mg} / \mathrm{L}$ & - & 201 & - & - \\
\hline TOCs & $\mathrm{mg} / \mathrm{L}$ & 3.0 & 1.5 & 1.7 & 1.8 \\
\hline TOCs & $\mathrm{mg} / \mathrm{L}$ & 3.0 & 1.5 & 1.7 & 1.7 \\
\hline TOCs & $\mathrm{mg} / \mathrm{L}$ & 2.8 & 1.6 & 1.6 & 1.7 \\
\hline TOCs & $\mathrm{mg} / \mathrm{L}$ & 2.8 & 1.5 & 1.6 & 1.6 \\
\hline TOXs & $\mathrm{mg} / \mathrm{L}$ & 0.0460 & 0.0160 & 0.0340 & 0.0320 \\
\hline TOXs & $\mathrm{mg} / \mathrm{L}$ & 0.0190 & 0.0160 & 0.0490 & 0.0380 \\
\hline
\end{tabular}

a Well point elevation $=180.69 \mathrm{~m}$ (MSL); ground surface elevation $=230.37 \mathrm{~m}(\mathrm{MSL})$; casing material $=$ stainless steel.

b Filtered sample.

c Unfiltered sample.

d A hyphen indicates that samples were not collected. 


\section{GROUNDWATER PROTECTION}

TABLE 6.31

Groundwater Monitoring Results, Sanitary Landfill Well 800191, 1998

\begin{tabular}{|c|c|c|c|c|c|c|}
\hline \multirow[b]{2}{*}{ Parameter } & \multirow[b]{2}{*}{ Unit } & \multicolumn{5}{|c|}{ Date of Sampling } \\
\hline & & $01 / 07 / 98$ & $04 / 06 / 98$ & $07 / 08 / 98$ & $10 / 15 / 98$ & $10 / 15 / 98$ \\
\hline Water elevation ${ }^{\mathrm{a}}$ & $\mathrm{m}$ & 226.08 & 225.87 & 226.19 & 225.53 & 225.53 \\
\hline Temperature & ${ }^{\circ} \mathrm{C}$ & 10.0 & 10.9 & 11.6 & 13.7 & 13.7 \\
\hline $\mathrm{pH}$ & $\mathrm{pH}$ & 6.89 & 6.74 & 6.82 & 7.02 & 7.02 \\
\hline Redox & $\mathrm{mV}$ & 7 & 11 & -36 & 1 & 1 \\
\hline Conductivity & $\mu \mathrm{mhos} / \mathrm{cm}$ & 2,440 & 2,320 & 2,000 & 1,705 & 1,705 \\
\hline Chloride $^{\mathrm{b}}$ & $\mathrm{mg} / \mathrm{L}$ & 390 & 225 & 178 & 212 & 212 \\
\hline Sulfate ${ }^{b}$ & $\mathrm{mg} / \mathrm{L}$ & 220 & 201 & 188 & 187 & 185 \\
\hline $\operatorname{TDS}^{b}$ & $\mathrm{mg} / \mathrm{L}$ & 1287 & 1603 & 1540 & 1202 & 1239 \\
\hline Cyanide (total) ${ }^{\mathrm{c}}$ & $\mathrm{mg} / \mathrm{L}$ & $<0.01$ & $<0.01$ & $<0.01$ & $<0.01$ & $<0.01$ \\
\hline Arsenic $^{c}$ & $\mathrm{mg} / \mathrm{L}$ & $-d$ & 0.0065 & - & - & - \\
\hline Barium $^{c}$ & $\mathrm{mg} / \mathrm{L}$ & - & 0.2596 & - & - & - \\
\hline Boron $^{c}$ & $\mathrm{mg} / \mathrm{L}$ & - & 0.1778 & - & - & - \\
\hline Cadmium $^{\mathrm{c}}$ & $\mathrm{mg} / \mathrm{L}$ & - & 0.0006 & - & - & - \\
\hline Chromium ${ }^{c}$ & $\mathrm{mg} / \mathrm{L}$ & - & $<0.044$ & - & - & - \\
\hline Cobalt ${ }^{\mathrm{C}}$ & $\mathrm{mg} / \mathrm{L}$ & - & $<0.026$ & - & - & - \\
\hline Copper & $\mathrm{mg} / \mathrm{L}$ & - & 0.0437 & - & - & - \\
\hline Iron ${ }^{c}$ & $\mathrm{mg} / \mathrm{L}$ & - & 32.7 & - & - & - \\
\hline Lead ${ }^{\mathrm{c}}$ & $\mathrm{mg} / \mathrm{L}$ & - & 0.0247 & - & - & - \\
\hline Manganese $^{c}$ & $\mathrm{mg} / \mathrm{L}$ & - & 2.1 & - & - & - \\
\hline Mercury $^{c}$ & $\mathrm{mg} / \mathrm{L}$ & - & $<0.0001$ & - & - & - \\
\hline Nickele $^{c}$ & $\mathrm{mg} / \mathrm{L}$ & - & $<0.04$ & - & - & - \\
\hline Selenium ${ }^{c}$ & $\mathrm{mg} / \mathrm{L}$ & - & $<0.003$ & - & - & - \\
\hline Silver & $\mathrm{mg} / \mathrm{L}$ & - & 0.0006 & - & - & - \\
\hline Zinc $^{c}$ & $\mathrm{mg} / \mathrm{L}$ & - & 0.1252 & - & - & - \\
\hline Ammonia nitrogen ${ }^{b}$ & $\mathrm{mg} / \mathrm{L}$ & $<0.2$ & 0.7 & 0.4 & 0.4 & 0.4 \\
\hline Arsenic $^{b}$ & $\mathrm{mg} / \mathrm{L}$ & $<0.0025$ & $<0.0025$ & $<0.0025$ & $<0.0025$ & $<0.0025$ \\
\hline Barium $^{b}$ & $\mathrm{mg} / \mathrm{L}$ & 0.0833 & 0.0926 & 0.0880 & 0.0771 & 0.0778 \\
\hline Beryllium ${ }^{b}$ & $\mathrm{mg} / \mathrm{L}$ & $<0.0002$ & $<0.0002$ & $<0.0002$ & $<0.0002$ & $<0.0002$ \\
\hline Cadmium $^{b}$ & $\mathrm{mg} / \mathrm{L}$ & $<0.0001$ & $<0.0001$ & $<0.0001$ & $<0.0001$ & $<0.0001$ \\
\hline Chromium $^{b}$ & $\mathrm{mg} / \mathrm{L}$ & $<0.044$ & $<0.044$ & $<0.044$ & $<0.044$ & $<0.044$ \\
\hline Cobalt ${ }^{\mathbf{b}}$ & $\mathrm{mg} / \mathrm{L}$ & $<0.026$ & $<0.026$ & $<0.026$ & $<0.026$ & $<0.026$ \\
\hline Copper $^{b}$ & $\mathrm{mg} / \mathrm{L}$ & $<0.017$ & $<0.017$ & $<0.017$ & $<0.017$ & $<0.017$ \\
\hline Iron $^{b}$ & $\mathrm{mg} / \mathrm{L}$ & 0.2262 & 6.1100 & 3.2360 & 3.2400 & 3.3480 \\
\hline Lead $^{b}$ & $\mathrm{mg} / \mathrm{L}$ & $<0.001$ & $<0.001$ & $<0.001$ & $<0.001$ & $<0.001$ \\
\hline Manganese $^{b}$ & $\mathrm{mg} / \mathrm{L}$ & 1.8920 & 1.6350 & 1.7420 & 1.4580 & 1.4410 \\
\hline Mercury $^{b}$ & $\mathrm{mg} / \mathrm{L}$ & $<0.0001$ & $<0.0001$ & $<0.0001$ & $<0.0001$ & $<0.0001$ \\
\hline Nickel $^{b}$ & $\mathrm{mg} / \mathrm{L}$ & $<0.04$ & $<0.04$ & $<0.04$ & $<0.04$ & $<0.04$ \\
\hline Silver $^{b}$ & $\mathrm{mg} / \mathrm{L}$ & $<0.0005$ & $<0.0005$ & $<0.0005$ & $<0.0005$ & $<0.0005$ \\
\hline Thallium $^{b}$. & $\mathrm{mg} / \mathrm{L}$ & $<0.0015$ & $<0.0015$ & $<0.0015$ & $<0.0015$ & $<0.0015$ \\
\hline Vanadium $^{\mathbf{b}}$ & $\mathrm{mg} / \mathrm{L}$ & $<0.024$ & $<0.024$ & $<0.024$ & $<0.024$ & $<0.024$ \\
\hline $\operatorname{Zinc}^{b}$ & $\mathrm{mg} / \mathrm{L}$ & 0.0443 & 0.0159 & 0.0233 & 0.0120 & 0.0192 \\
\hline Nitrate & $\mathrm{mg} / \mathrm{L}$ & - & $<0.1$ & - & - & - \\
\hline Phenols & $\mathrm{mg} / \mathrm{L}$ & 0.014 & $<0.005$ & $<0.005$ & 0.044 & $<0.005$ \\
\hline Hydrogen-3 & $\mathrm{pCi} / \mathrm{L}$ & 119 & $<100$ & 146 & 210 & 231 \\
\hline Chloride & $\mathrm{mg} / \mathrm{L}$ & - & 234 & - & - & - \\
\hline Fluoride & $\mathrm{mg} / \mathrm{L}$ & - & 0.244 & - & - & - \\
\hline Sulfate & $\mathrm{mg} / \mathrm{L}$ & - & 213 & - & - & - \\
\hline TOCs & $\mathrm{mg} / \mathrm{L}$ & 8.0 & 6.1 & 5.5 & 5.7 & 5.6 \\
\hline TOCs & $\mathrm{mg} / \mathrm{L}$ & 8.2 & 5.9 & 6.1 & 5.6 & 5.3 \\
\hline TOCs & $\mathrm{mg} / \mathrm{L}$ & 7.7 & 5.9 & 6.0 & 5.9 & 5.6 \\
\hline TOCs & $\mathrm{mg} / \mathrm{L}$ & 7.5 & 6.0 & 5.5 & 5.5 & 5.6 \\
\hline TOXs & $\mathrm{mg} / \mathrm{L}$ & 0.1600 & 0.1000 & 0.0620 & 0.0540 & 0.0290 \\
\hline TOXs & $\mathrm{mg} / \mathrm{L}$ & 0.1600 & 0.0680 & 0.0360 & 0.0330 & 0.0410 \\
\hline
\end{tabular}

a Well point elevation $=222.77 \mathrm{~m}$ (MSL); ground surface elevation $=227.38 \mathrm{~m}(\mathrm{MSL})$; casing material $=$ stainless steel.

b Filtered sample.

c Unfiltered sample.

d A hyphen indicates that samples were not collected. 
TABLE 6.32

Groundwater Monitoring Results, Sanitary Landfill Well 800192, 1998

\begin{tabular}{|c|c|c|c|c|c|}
\hline \multirow[b]{2}{*}{ Parameter } & \multirow[b]{2}{*}{ Unit } & \multicolumn{4}{|c|}{ Date of Sampling } \\
\hline & & $01 / 08 / 98$ & $04 / 06 / 98$ & $07 / 08 / 98$ & $10 / 15 / 98$ \\
\hline Water elevation $^{2}$ & $\mathrm{~m}$ & 222.51 & 222.61 & 222.20 & 222.01 \\
\hline Temperature & ${ }^{\circ} \mathrm{C}$ & 10.6 & 11.5 & 11.4 & 11.5 \\
\hline $\mathrm{pH}$ & $\mathrm{pH}$ & 6.70 & 6.93 & 6.98 & 6.85 \\
\hline Redox & $\mathrm{mV}$ & 20 & 1 & -49 & 5 \\
\hline Conductivity & $\mu \mathrm{mhos} / \mathrm{cm}$ & 1,454 & 1,452 & 1,464 & 1,483 \\
\hline Chloride ${ }^{b}$ & $\mathrm{mg} / \mathrm{L}$ & 51 & 51 & 59 & 69 \\
\hline Sulfate ${ }^{b}$ & $\mathrm{mg} / \mathrm{L}$ & 110 & 134 & 131 & 134 \\
\hline TDS $^{\mathrm{b}}$ & $\mathrm{mg} / \mathrm{L}$ & 931 & 981 & 1071 & 1065 \\
\hline Cyanide (total) ${ }^{c}$ & $\mathrm{mg} / \mathrm{L}$ & $<0.01$ & $<0.01$ & $<0.01$ & $<0.01$ \\
\hline Arsenic ${ }^{c}$ & $\mathrm{mg} / \mathrm{L}$ & $-d$ & 0.0064 & - & - \\
\hline Barium $^{c}$ & $\mathrm{mg} / \mathrm{L}$ & - & 0.4729 & - & - \\
\hline Boron $^{c}$ & $\mathrm{mg} / \mathrm{L}$ & - & 0.0996 & - & - \\
\hline Cadmium $^{c}$ & $\mathrm{mg} / \mathrm{L}$ & - & 0.0005 & - & - \\
\hline Chromium $^{\mathrm{c}}$ & $\mathrm{mg} / \mathrm{L}$ & - & $<0.044$ & - & - \\
\hline Cobalt ${ }^{\mathfrak{c}}$ & $\mathrm{mg} / \mathrm{L}$ & - & $<0.026$ & - & - \\
\hline Copper $^{\mathbf{c}}$ & $\mathrm{mg} / \mathrm{L}$ & - & $<0.017$ & - & - \\
\hline Iron $^{c}$ & $\mathrm{mg} / \mathrm{L}$ & - & 12.96 & - & - \\
\hline Lead $^{c}$ & $\mathrm{mg} / \mathrm{L}$ & - & 0.0121 & - & - \\
\hline Manganese $\mathrm{C}^{\mathrm{C}}$ & $\mathrm{mg} / \mathrm{L}$ & - & 0.2605 & - & - \\
\hline Mercuryc & $\mathrm{mg} / \mathrm{L}$ & - & $<0.0001$ & - & - \\
\hline Nickel $^{\mathrm{c}}$ & $\mathrm{mg} / \mathrm{L}$ & - & $<0.04$ & - & - \\
\hline Selenium $^{c}$ & $\mathrm{mg} / \mathrm{L}$ & - & $<0.003$ & - & - \\
\hline Silver ${ }^{c}$ & $\mathrm{mg} / \mathrm{L}$ & - & 0.0010 & - & - \\
\hline Zinc $^{c}$ & $\mathrm{mg} / \mathrm{L}$ & - & $<0.011$ & - & - \\
\hline Ammonia nitrogen ${ }^{b}$ & $\mathrm{mg} / \mathrm{L}$ & 1.2 & 1.0 & 1.0 & 0.8 \\
\hline Arsenic $^{\mathrm{b}}$ & $\mathrm{mg} / \mathrm{L}$ & 0.0029 & $<0.0025$ & $<0.0025$ & $<0.0025$ \\
\hline Barium $^{b}$ & $\mathrm{mg} / \mathrm{L}$ & 0.3727 & 0.3476 & 0.3990 & 0.4372 \\
\hline Berylliumb & $\mathrm{mg} / \mathrm{L}$ & $<0.0002$ & $<0.0002$ & $<0.0002$ & $<0.0002$ \\
\hline Cadmium $^{\mathrm{b}}$ & $\mathrm{mg} / \mathrm{L}$ & $<0.0001$ & $<0.0001$ & $<0.0001$ & $<0.0001$ \\
\hline Chromium $^{b}$ & $\mathrm{mg} / \mathrm{L}$ & $<0.044$ & $<0.044$ & $<0.044$ & $<0.044$ \\
\hline Cobalt $^{\mathrm{b}}$ & $\mathrm{mg} / \mathrm{L}$ & $<0.026$ & $<0.026$ & $<0.026$ & $<0.026$ \\
\hline Copper ${ }^{b}$ & $\mathrm{mg} / \mathrm{L}$ & $<0.017$ & $<0.017$ & $<0.017$ & $<0.017$ \\
\hline Iron $^{b}$ & $\mathrm{mg} / \mathrm{L}$ & 6.2070 & 8.2550 & 4.2950 & 7.5380 \\
\hline Lead $^{b}$ & $\mathrm{mg} / \mathrm{L}$ & $<0.001$ & $<0.001$ & $<0.001$ & $<0.001$ \\
\hline Manganese & $\mathrm{mg} / \mathrm{L}$ & 0.2752 & 0.1755 & 0.2189 & 0.2283 \\
\hline Mercury ${ }^{b}$ & $\mathrm{mg} / \mathrm{L}$ & $<0.0001$ & $<0.0001$ & $<0.0001$ & $<0.0001$ \\
\hline Nickel $\mathrm{b}^{\mathrm{E}}$ & $\mathrm{mg} / \mathrm{L}$ & $<0.04$ & $<0.04$ & $<0.04$ & $<0.04$ \\
\hline Silver ${ }^{b}$ & $\mathrm{mg} / \mathrm{L}$ & $<0.0005$ & $<0.0005$ & $<0.0005$ & $<0.0005$ \\
\hline Thallium $^{\mathbf{b}}$ & $\mathrm{mg} / \mathrm{L}$ & $<0.0015$ & $<0.0015$ & $<0.0015$ & $<0.0015$ \\
\hline Vanadium $^{\mathrm{b}}$ & $\mathrm{mg} / \mathrm{L}$ & $<0.024$ & $<0.024$ & $<0.024$ & $<0.024$ \\
\hline $\operatorname{Zinc}^{b}$ & $\mathrm{mg} / \mathrm{L}$ & 0.012 & $<0.011$ & $<0.011$ & $<0.011$ \\
\hline Nitrate & $\mathrm{mg} / \mathrm{L}$ & - & $<0.1$ & - & - \\
\hline Phenols & $\mathrm{mg} / \mathrm{L}$ & $<0.005$ & $<0.005$ & 0.011 & $<0.005$ \\
\hline Hydrogen-3 & $\mathrm{pCi} / \mathrm{L}$ & 277 & 285 & 373 & 356 \\
\hline Chloride & $\mathrm{mg} / \mathrm{L}$ & - & 57 & - & - \\
\hline Fluoride & $\mathrm{mg} / \mathrm{L}$ & - & 0.234 & - & - \\
\hline Sulfate & $\mathrm{mg} / \mathrm{L}$ & - & 138 & - & - \\
\hline TOCs & $\mathrm{mg} / \mathrm{L}$ & 10.5 & 9.5 & 8.0 & 8.8 \\
\hline TOCs & $\mathrm{mg} / \mathrm{L}$ & 9.2 & 8.4 & 8.1 & 8.3 \\
\hline TOCs & $\mathrm{mg} / \mathrm{L}$ & 10.0 & 8.9 & 8.2 & 8.3 \\
\hline TOCs & $\mathrm{mg} / \mathrm{L}$ & 9.4 & 8.7 & 8.1 & 8.2 \\
\hline TOXs & $\mathrm{mg} / \mathrm{L}$ & 0.0160 & 0.0150 & 0.0530 & 0.0150 \\
\hline TOXs & $\mathrm{mg} / \mathrm{L}$ & 0.0210 & 0.0160 & 0.0450 & $<0.0100$ \\
\hline
\end{tabular}

a Well point elevation $=208.71 \mathrm{~m}(\mathrm{MSL})$; ground surface elevation $=227.38 \mathrm{~m}$ (MSL); casing material $=$ stainless steel.

b Filtered sample.

c Unfiltered sample.

d A hyphen indicates that samples were not collected. 
TABLE 6.33

Groundwater Monitoring Results, Sanitary Landfill Well 800193D, 1998

\begin{tabular}{|c|c|c|c|c|c|c|}
\hline \multirow[b]{2}{*}{ Parameter } & \multirow[b]{2}{*}{ Unit } & \multicolumn{5}{|c|}{ Date of Sampling } \\
\hline & & $01 / 08 / 98$ & $04 / 06 / 98$ & $04 / 06 / 98$ & $07 / 08 / 98$ & $10 / 15 / 98$ \\
\hline Water elevation ${ }^{2}$ & $\mathbf{m}$ & 192.60 & 192.73 & 192.73 & 192.76 & 192.56 \\
\hline Temperature & ${ }^{\circ} \mathrm{C}$ & 11.1 & 11.7 & 11.7 & 11.9 & 11.3 \\
\hline $\mathrm{pH}$ & $\mathrm{pH}$ & 7.07 & 7.01 & 7.01 & 7.12 & 7.11 \\
\hline Redox & $\mathrm{mV}$ & -3 & -4 & -4 & -38 & -5 \\
\hline Conductivity & $\mu \mathrm{mhos} / \mathrm{cm}$ & 1,332 & 1,328 & 1,328 & 1,326 & 1,336 \\
\hline Chloride $^{b}$ & $\mathrm{mg} / \mathrm{L}$ & 102 & 102 & 106 & 115 & 120 \\
\hline Sulfate ${ }^{b}$ & $\mathrm{mg} / \mathrm{L}$ & 210 & 208 & 205 & 192 & 193 \\
\hline TDS $^{b}$ & $\mathrm{mg} / \mathrm{L}$ & 860 & 844 & 845 & 952 & 891 \\
\hline Cyanide (total) $^{\mathbf{c}}$ & $\mathrm{mg} / \mathrm{L}$ & $<0.01$ & $<0.01$ & $<0.01$ & $<0.01$ & $<0.01$ \\
\hline Arsenic ${ }^{c}$ & $\mathrm{mg} / \mathrm{L}$ & $-d$ & $<0.0025$ & $<0.0025$ & - & - \\
\hline Barium $^{c}$ & $\mathrm{mg} / \mathrm{L}$ & - & 0.0656 & 0.0865 & - & - \\
\hline Boron $^{c}$ & $\mathrm{mg} / \mathrm{L}$ & - & 0.2145 & 0.2146 & - & - \\
\hline Cadmium $^{c}$ & $\mathrm{mg} / \mathrm{L}$ & - & $<0.0001$ & $<0.0001$ & - & - \\
\hline Chromium $^{\mathrm{c}}$ & $\mathrm{mg} / \mathrm{L}$ & - & $<0.044$ & $<0.044$ & - & - \\
\hline Cobalt ${ }^{\mathbb{E}}$ & $\mathrm{mg} / \mathrm{L}$ & - & $<0.026$ & $<0.026$ & - & - \\
\hline Copper ${ }^{c}$ & $\mathrm{mg} / \mathrm{L}$ & - & $<0.017$ & $<0.017$ & - & - \\
\hline Iron $^{c}$ & $\mathrm{mg} / \mathrm{L}$ & - & 1.6320 & 2.6370 & - & - \\
\hline Lead $^{c}$ & $\mathrm{mg} / \mathrm{L}$ & - & $<0.001$ & $<0.001$ & - & - \\
\hline Manganese ${ }^{c}$ & $\mathrm{mg} / \mathrm{L}$ & - & 0.0272 & 0.0299 & - & - \\
\hline Mercuryc & $\mathrm{mg} / \mathrm{L}$ & - & $<0.0001$ & $<0.0001$ & - & - \\
\hline Nickel $^{\mathfrak{c}}$ & $\mathrm{mg} / \mathrm{L}$ & - & $<0.04$ & $<0.04$ & - & - \\
\hline Selenium ${ }^{c}$ & $\mathrm{mg} / \mathrm{L}$ & - & $<0.003$ & $<0.003$ & - & - \\
\hline Silvere & $\mathrm{mg} / \mathrm{L}$ & - & 0.0011 & $<0.0005$ & - & - \\
\hline Zinc $^{c}$ & $\mathrm{mg} / \mathrm{L}$ & - & $<0.011$ & $<0.011$ & - & - \\
\hline Ammonia nitrogen ${ }^{\mathrm{b}}$ & $\mathrm{mg} / \mathrm{L}$ & 0.9 & 0.8 & 0.5 & 0.6 & 0.7 \\
\hline Arsenic $^{b}$ & $\mathrm{mg} / \mathrm{L}$ & $<0.0025$ & $<0.0025$ & $<0.0025$ & $<0.0025$ & $<0.0025$ \\
\hline Barium $^{b}$ & $\mathrm{mg} / \mathrm{L}$ & 0.0575 & 0.0566 & 0.0533 & 0.0671 & 0.0633 \\
\hline Berylliumb & $\mathrm{mg} / \mathrm{L}$ & $<0.0002$ & $<0.0002$ & $<0.0002$ & $<0.0002$ & $<0.0002$ \\
\hline Cadmiumb & $\mathrm{mg} / \mathrm{L}$ & $<0.0001$ & $<0.0001$ & $<0.0001$ & $<0.0001$ & $<0.0001$ \\
\hline Chromium $^{\mathrm{b}}$ & $\mathrm{mg} / \mathrm{L}$ & $<0.044$ & $<0.044$ & $<0.044$ & $<0.044$ & $<0.044$ \\
\hline Cobalt $^{b}$ & $\mathrm{mg} / \mathrm{L}$ & $<0.026$ & $<0.026$ & $<0.026$ & $<0.026$ & $<0.026$ \\
\hline Copper ${ }^{b}$ & $\mathrm{mg} / \mathrm{L}$ & $<0.017$ & $<0.017$ & $<0.017$ & $<0.017$ & $<0.017$ \\
\hline Iron ${ }^{b}$ & $\mathrm{mg} / \mathrm{L}$ & 1.0850 & 0.9902 & 0.9943 & 1.0120 & 0.6872 \\
\hline Lead $^{\text {b }}$ & $\mathrm{mg} / \mathrm{L}$ & $<0.001$ & $<0.001$ & $<0.001$ & $<0.001$ & $<0.001$ \\
\hline Manganese $e^{b}$ & $\mathrm{mg} / \mathrm{L}$ & 0.0258 & 0.0229 & 0.0207 & 0.0262 & 0.0279 \\
\hline Mercury ${ }^{b}$ & $\mathrm{mg} / \mathrm{L}$ & $<0.0001$ & $<0.0001$ & $<0.0001$ & $<0.0001$ & $<0.0001$ \\
\hline Nickel $^{b}$ & $\mathrm{mg} / \mathrm{L}$ & $<0.04$ & $<0.04$ & $<0.04$ & $<0.04$ & $<0.04$ \\
\hline Silver ${ }^{b}$ & $\mathrm{mg} / \mathrm{L}$ & $<0.0005$ & $<0.0005$ & $<0.0005$ & $<0.0005$ & $<0.0005$ \\
\hline Thallium ${ }^{b}$ & $\mathrm{mg} / \mathrm{L}$ & $<0.0015$ & $<0.0015$ & $<0.0015$ & $<0.0015$ & $<0.0015$ \\
\hline Vanadium ${ }^{b}$ & $\mathrm{mg} / \mathrm{L}$ & $<0.024$ & $<0.024$ & $<0.024$ & $<0.024$ & $<0.024$ \\
\hline Zinc $^{b}$ & $\mathrm{mg} / \mathrm{L}$ & $<0.011$ & $<0.011$ & $<0.011$ & $<0.011$ & $<0.011$ \\
\hline Nitrate & $\mathrm{mg} / \mathrm{L}$ & - & $<0.1$ & - & - & - \\
\hline Phenols & $\mathrm{mg} / \mathrm{L}$ & $<0.005$ & $<0.005$ & $<0.005$ & $<0.005$ & 0.005 \\
\hline Hydrogen-3 & $\mathrm{pCi} / \mathrm{L}$ & $<100$ & $<100$ & $<100$ & $<100$ & $<100$ \\
\hline Chloride & $\mathrm{mg} / \mathrm{L}$ & - & 106 & 105 & - & - \\
\hline Fluoride & $\mathrm{mg} / \mathrm{L}$ & - & 0.340 & 0.330 & - & - \\
\hline Sulfate & $\mathrm{mg} / \mathrm{L}$ & - & 221 & 211 & - & - \\
\hline TOCs & $\mathrm{mg} / \mathrm{L}$ & 3.3 & 2.1 & 1.9 & 2.5 & 5.3 \\
\hline TOCs & $\mathrm{mg} / \mathrm{L}$ & 2.8 & 2.0 & 1.8 & 2.1 & 2.2 \\
\hline TOCs & $\mathrm{mg} / \mathrm{L}$ & 2.7 & 2.1 & 1.9 & 2.5 & 6.8 \\
\hline TOCs & $\mathrm{mg} / \mathrm{L}$ & 3.0 & 2.1 & 1.9 & 2.3 & 2.2 \\
\hline TOXs & $\mathrm{mg} / \mathrm{L}$ & 0.0320 & 0.0270 & 0.0900 & 0.0370 & 0.0410 \\
\hline TOXs & $\mathrm{mg} / \mathrm{L}$ & 0.0510 & 0.0150 & 0.0240 & 0.0390 & 0.0670 \\
\hline
\end{tabular}

a Well point elevation $=181.91 \mathrm{~m}(\mathrm{MSL}) ;$ ground surface elevation $=227.38 \mathrm{~m}(\mathrm{MSL})$; casing material $=$ stainless steel.

b Filtered sample.

c Unfiltered sample.

d A hyphen indicates that samples were not collected. 
TABLE 6.34

Groundwater Monitoring Results, Sanitary Landfill Well 800201, 1998

\begin{tabular}{|c|c|c|c|c|c|}
\hline \multirow[b]{2}{*}{ Parameter } & \multirow[b]{2}{*}{ Unit } & \multicolumn{4}{|c|}{ Date of Sampling } \\
\hline & & $01 / 07 / 98$ & $04 / 06 / 98$ & $07 / 08 / 98$ & $10 / 13 / 98$ \\
\hline Water elevation ${ }^{a}$ & $\mathrm{~m}$ & 223.17 & 224.62 & 224.16 & 223.75 \\
\hline Temperature & ${ }^{\circ} \mathrm{C}$ & 10.5 & 10.5 & 11.0 & 10.4 \\
\hline $\mathrm{pH}$ & $\mathrm{pH}$ & 7.04 & 6.85 & 7.05 & 7.17 \\
\hline Redox & $\mathrm{mV}$ & -1 & 5 & -49 & -4 \\
\hline Conductivity & $\mu \mathrm{mhos} / \mathrm{cm}$ & 1,097 & 1,119 & 1,104 & 1,114 \\
\hline Chloride ${ }^{b}$ & $\mathrm{mg} / \mathrm{L}$ & 6 & 7 & 7 & 8 \\
\hline Sulfate ${ }^{b}$ & $\mathrm{mg} / \mathrm{L}$ & 66 & 63 & 73 & 77 \\
\hline $\mathrm{TDS}^{\mathrm{b}}$ & $\mathrm{mg} / \mathrm{L}$ & 703 & 704 & 725 & 739 \\
\hline Cyanide (total) ${ }^{c}$ & $\mathrm{mg} / \mathrm{L}$ & $<0.01$ & $<0.01$ & $<0.01$ & $<0.01$ \\
\hline Arsenic $^{c}$ & $\mathrm{mg} / \mathrm{L}$ & d & 0.0178 & - & - \\
\hline Barium $^{c}$ & $\mathrm{mg} / \mathrm{L}$ & - & 0.3676 & - & - \\
\hline Boron ${ }^{c}$ & $\mathrm{mg} / \mathrm{L}$ & - & 0.1228 & - & - \\
\hline Cadmium $^{c}$ & $\mathrm{mg} / \mathrm{L}$ & - & 0.0002 & - & - \\
\hline Chromium $^{c}$ & $\mathrm{mg} / \mathrm{L}$ & - & 0.0516 & - & - \\
\hline Cobalt ${ }^{c}$ & $\mathrm{mg} / \mathrm{L}$ & - & $<0.026$ & - & - \\
\hline Copper & $\mathrm{mg} / \mathrm{L}$ & - & 0.0241 & - & - \\
\hline Iron $^{c}$ & $\mathrm{mg} / \mathrm{L}$ & - & 22.23 & - & - \\
\hline Lead $^{\mathrm{c}}$ & $\mathrm{mg} / \mathrm{L}$ & - & 0.0106 & - & - \\
\hline Manganese $^{c}$ & $\mathrm{mg} / \mathrm{L}$ & - & 0.9024 & - & - \\
\hline Mercuryc & $\mathrm{mg} / \mathrm{L}$ & - & $<0.0001$ & - & - \\
\hline Nickel $^{c}$ & $\mathrm{mg} / \mathrm{L}$ & - & 0.0578 & - & - \\
\hline Selenium $^{c}$ & $\mathrm{mg} / \mathrm{L}$ & - & $<0.003$ & - & - \\
\hline Silver ${ }^{c}$ & $\mathrm{mg} / \mathrm{L}$ & - & $<0.0005$ & - & - \\
\hline Zinc $^{c}$ & $\mathrm{mg} / \mathrm{L}$ & - & 0.0868 & - & - \\
\hline Ammonia nitrogen $^{b}$ & $\mathrm{mg} / \mathrm{L}$ & 3.5 & 4.0 & 3.5 & 4.0 \\
\hline Arsenic $^{b}$ & $\mathrm{mg} / \mathrm{L}$ & 0.0032 & 0.0095 & 0.0028 & 0.0054 \\
\hline Barium $^{b}$ & $\mathrm{mg} / \mathrm{L}$ & 0.2593 & 0.2786 & 0.2472 & 0.2531 \\
\hline Beryllium ${ }^{b}$ & $\mathrm{mg} / \mathrm{L}$ & $<0.0002$ & $<0.0002$ & $<0.0002$ & $<0.0002$ \\
\hline Cadmium ${ }^{\mathrm{b}}$ & $\mathrm{mg} / \mathrm{L}$ & $<0.0001$ & $<0.0001$ & $<0.0001$ & $<0.0001$ \\
\hline Chromium $^{b}$ & $\mathrm{mg} / \mathrm{L}$ & $<0.044$ & $<0.044$ & $<0.044$ & $<0.044$ \\
\hline Cobalt ${ }^{b}$ & $\mathrm{mg} / \mathrm{L}$ & $<0.026$ & $<0.026$ & $<0.026$ & $<0.026$ \\
\hline Copper ${ }^{b}$ & $\mathrm{mg} / \mathrm{L}$ & $<0.017$ & $<0.017$ & $<0.017$ & $<0.017$ \\
\hline Iron $^{b}$ & $\mathrm{mg} / \mathrm{L}$ & 1.5900 & 5.6970 & 1.8220 & 1.4960 \\
\hline Lead $^{b}$ & $\mathrm{mg} / \mathrm{L}$ & $<0.001$ & $<0.001$ & $<0.001$ & $<0.001$ \\
\hline Manganese $^{b}$ & $\mathrm{mg} / \mathrm{L}$ & 0.4704 & 0.3779 & 0.5231 & 0.5368 \\
\hline Mercury ${ }^{b}$ & $\mathrm{mg} / \mathrm{L}$ & $<0.0001$ & $<0.0001$ & $<0.0001$ & $<0.0001$ \\
\hline Nickel $^{b}$ & $\mathrm{mg} / \mathrm{L}$ & $<0.04$ & $<0.04$ & $<0.04$ & $<0.04$ \\
\hline Silver ${ }^{b}$ & $\mathrm{mg} / \mathrm{L}$ & $<0.0005$ & $<0.0005$ & $<0.0005$ & 0.0008 \\
\hline Thallium $^{\mathrm{b}}$ & $\mathrm{mg} / \mathrm{L}$ & $<0.0015$ & $<0.0015$ & $<0.0015$ & $<0.0015$ \\
\hline Vanadium $^{b}$ & $\mathrm{mg} / \mathrm{L}$ & $<0.024$ & $<0.024$ & $<0.024$ & $<0.024$ \\
\hline $\operatorname{Zinc}^{\mathrm{b}}$ & $\mathrm{mg} / \mathrm{L}$ & 0.0331 & 0.0127 & 0.0340 & 0.0118 \\
\hline Nitrate & $\mathrm{mg} / \mathrm{L}$ & - & 0.18 & - & - \\
\hline Phenols & $\mathrm{mg} / \mathrm{L}$ & $<0.005$ & $<0.005$ & 0.018 & $<0.005$ \\
\hline Hydrogen-3 & $\mathrm{pCi} / \mathrm{L}$ & $<100$ & $<100$ & $<100$ & $<100$ \\
\hline Chloride & $\mathrm{mg} / \mathrm{L}$ & - & 6 & - & - \\
\hline Fluoride & $\mathrm{mg} / \mathrm{L}$ & - & 0.216 & - & - \\
\hline Sulfate & $\mathrm{mg} / \mathrm{L}$ & - & 69 & - & - \\
\hline TOCs & $\mathrm{mg} / \mathrm{L}$ & 30.8 & 31.2 & 28.5 & 30.9 \\
\hline TOCs & $\mathrm{mg} / \mathrm{L}$ & 31.0 & 29.9 & 27.5 & 31.1 \\
\hline TOCs & $\mathrm{mg} / \mathrm{L}$ & 31.6 & 29.4 & 28.7 & 30.8 \\
\hline TOCs & $\mathrm{mg} / \mathrm{L}$ & 33.2 & 32.8 & 28.3 & 31.0 \\
\hline TOXs & $\mathrm{mg} / \mathrm{L}$ & 0.023 & $<0.10$ & 0.012 & 0.016 \\
\hline TOXs & $\mathrm{mg} / \mathrm{L}$ & $<0.10$ & $<0.10$ & 0.016 & 0.013 \\
\hline
\end{tabular}

a Well point elevation $=217.20 \mathrm{~m}(\mathrm{MSL})$; ground surface elevation $=227.93 \mathrm{~m}(\mathrm{MSL})$; casing materjal = stainless steel.

b Filtered sample.

c Unfiltered sample.

d A hyphen indicates that samples were not collected. 


\section{GROUNDWATER PROTECTION}

TABLE 6.35

Groundwater Monitoring Results, Sanitary Landfill Well 800202, 1998

\begin{tabular}{|c|c|c|c|c|c|}
\hline \multirow[b]{2}{*}{ Parameter } & \multirow[b]{2}{*}{ Unit } & \multicolumn{4}{|c|}{ Date of Sampling } \\
\hline & & $01 / 09 / 98$ & $04 / 06 / 98$ & $07 / 08 / 98$ & $10 / 13 / 98$ \\
\hline Water elevation ${ }^{\mathrm{a}}$ & $\mathrm{m}$ & 217.48 & 218.03 & 218.14 & 217.85 \\
\hline Temperature & ${ }^{\circ} \mathrm{C}$ & 10.3 & 10.8 & 11.6 & 10.7 \\
\hline $\mathrm{pH}$ & $\mathrm{pH}$ & 6.92 & 6.95 & 7.07 & 7.16 \\
\hline Redox & $\mathrm{mV}$ & 6 & -1 & -54 & -3 \\
\hline Conductivity & $\mu \mathrm{mhos} / \mathrm{cm}$ & 1,062 & 1,066 & 1,065 & 1,059 \\
\hline Chloride $^{b}$ & $\mathrm{mg} / \mathrm{L}$ & 12 & 18 & 18 & 17 \\
\hline Sulfate ${ }^{b}$ & $\mathrm{mg} / \mathrm{L}$ & 76 & 79 & 71 & 76 \\
\hline $\mathrm{TDS}^{\mathrm{b}}$ & $\mathrm{mg} / \mathrm{L}$ & 658 & 659 & 646 & 665 \\
\hline Cyanide (total) $^{c}$ & $\mathrm{mg} / \mathrm{L}$ & $<0.01$ & $<0.01$ & $<0.01$ & $<0.01$ \\
\hline Arsenic $^{c}$ & $\mathrm{mg} / \mathrm{L}$ & $-d$ & 0.0095 & - & - \\
\hline Barium ${ }^{c}$ & $\mathrm{mg} / \mathrm{L}$ & - & 0.2112 & - & - \\
\hline Boron ${ }^{c}$ & $\mathrm{mg} / \mathrm{L}$ & - & 0.1200 & - & - \\
\hline Cadmium $^{c}$ & $\mathrm{mg} / \mathrm{L}$ & - & $<0.0001$ & - & - \\
\hline Chromium ${ }^{c}$ & $\mathrm{mg} / \mathrm{L}$ & - & $<0.044$ & - & - \\
\hline Cobalt ${ }^{c}$ & $\mathrm{mg} / \mathrm{L}$ & - & $<0.026$ & - & - \\
\hline Copper & $\mathrm{mg} / \mathrm{L}$ & - & $<0.017$ & - & - \\
\hline Iron $^{c}$ & $\mathrm{mg} / \mathrm{L}$ & - & 4.7770 & - & - \\
\hline Lead $^{c}$ & $\mathrm{mg} / \mathrm{L}$ & - & 0.0011 & - & - \\
\hline Manganese ${ }^{c}$ & $\mathrm{mg} / \mathrm{L}$ & - & 0.1986 & - & - \\
\hline Mercury $^{c}$ & $\mathrm{mg} / \mathrm{L}$ & - & $<0.0001$ & - & - \\
\hline Nickel $^{c^{c}}$ & $\mathrm{mg} / \mathrm{L}$ & - & $<0.04$ & - & - \\
\hline Selenium $^{c}$ & $\mathrm{mg} / \mathrm{L}$ & - & $<0.003$ & - & - \\
\hline Silver ${ }^{c}$ & $\mathrm{mg} / \mathrm{L}$ & - & 0.0009 & - & - \\
\hline Zinc $^{c}$ & $\mathrm{mg} / \mathrm{L}$ & - & $<0.011$ & - & - \\
\hline Ammonia nitrogen ${ }^{b}$ & $\mathrm{mg} / \mathrm{L}$ & $<0.2$ & 1.5 & 1.5 & 2.0 \\
\hline Arsenic $^{\mathrm{b}}$ & $\mathrm{mg} / \mathrm{L}$ & 0.0042 & 0.0065 & 0.0106 & 0.0056 \\
\hline Barium $^{b}$ & $\mathrm{mg} / \mathrm{L}$ & 0.1769 & 0.1830 & 0.1727 & 0.1832 \\
\hline Beryllium $^{b}$ & $\mathrm{mg} / \mathrm{L}$ & $<0.0002$ & $<0.0002$ & $<0.0002$ & $<0.0002$ \\
\hline Cadmium $^{\mathrm{b}}$ & $\mathrm{mg} / \mathrm{L}$ & $<0.0001$ & $<0.0001$ & $<0.0001$ & $<0.0001$ \\
\hline Chromium $^{b}$ & $\mathrm{mg} / \mathrm{L}$ & $<0.044$ & $<0.044$ & $<0.044$ & $<0.044$ \\
\hline Cobalt ${ }^{b}$ & $\mathrm{mg} / \mathrm{L}$ & $<0.026$ & $<0.026$ & $<0.026$ & $<0.026$ \\
\hline Copper $^{b}$ & $\mathrm{mg} / \mathrm{L}$ & $<0.017$ & $<0.017$ & $<0.017$ & $<0.017$ \\
\hline Iron & $\mathrm{mg} / \mathrm{L}$ & 3.5350 & 4.4140 & 4.2950 & 4.4610 \\
\hline Lead $^{b}$ & $\mathrm{mg} / \mathrm{L}$ & $<0.001$ & $<0.001$ & $<0.001$ & $<0.001$ \\
\hline Manganese $^{\mathrm{b}}$ & $\mathrm{mg} / \mathrm{L}$ & 0.2209 & 0.1914 & 0.1686 & 0.1882 \\
\hline Mercuryb & $\mathrm{mg} / \mathrm{L}$ & $<0.0001$ & $<0.0001$ & $<0.0001$ & $<0.0001$ \\
\hline Nickel $^{\mathrm{b}}$ & $\mathrm{mg} / \mathrm{L}$ & $<0.04$ & $<0.04$ & $<0.04$ & $<0.04$ \\
\hline Silver ${ }^{b}$ & $\mathrm{mg} / \mathrm{L}$ & $<0.0005$ & $<0.0005$ & $<0.0005$ & 0.0005 \\
\hline Thallium $^{\mathbf{b}}$ & $\mathrm{mg} / \mathrm{L}$ & $<0.0015$ & $<0.0015$ & $<0.0015$ & $<0.0015$ \\
\hline Vanadium $^{b}$ & $\mathrm{mg} / \mathrm{L}$ & $<0.024$ & $<0.024$ & $<0.024$ & $<0.024$ \\
\hline Zinc $^{b}$ & $\mathrm{mg} / \mathrm{L}$ & $<0.011$ & $<0.011$ & $<0.011$ & $<0.011$ \\
\hline Nitrate & $\mathrm{mg} / \mathrm{L}$ & - & 0.14 & - & - \\
\hline Phenols & $\mathrm{mg} / \mathrm{L}$ & 0.006 & $<0.005$ & 0.039 & $<0.005$ \\
\hline Hydrogen-3 & $\mathrm{pC} \mathrm{i} / \mathrm{L}$ & $<100$ & $<100$ & $<100$ & $<100$ \\
\hline Chloride & $\mathrm{mg} / \mathrm{L}$ & - & 15 & - & - \\
\hline Fluoride & $\mathrm{mg} / \mathrm{L}$ & - & 0.240 & - & - \\
\hline Sulfate & $\mathrm{mg} / \mathrm{L}$ & - & 82 & - & - \\
\hline TOCs & $\mathrm{mg} / \mathrm{L}$ & 12.6 & 12.4 & 12.9 & 12.1 \\
\hline TOCs & $\mathrm{mg} / \mathrm{L}$ & 12.4 & 14.8 & 12.4 & 11.9 \\
\hline TOCs & $\mathrm{mg} / \mathrm{L}$ & 12.5 & 12.6 & 12.5 & 11.9 \\
\hline TOCs & $\mathrm{mg} / \mathrm{L}$ & 12.5 & 12.9 & 11.7 & 12.0 \\
\hline TOXs & $\mathrm{mg} / \mathrm{L}$ & 0.017 & $<0.010$ & 0.011 & 0.013 \\
\hline TOXs & $\mathrm{mg} / \mathrm{L}$ & 0.012 & $<0.010$ & $<0.010$ & 0.016 \\
\hline
\end{tabular}

a Well point elevation $=217.20 \mathrm{~m}(\mathrm{MSL})$; ground surface elevation $=227.93 \mathrm{~m}$ (MSL); casing material = stainless steel.

b Filtered sample.

c Unfiltered sample.

d A hyphen indicates that samples were not collected. 
TABLE 6.36

Groundwater Monitoring Results, Sanitary Landfill Well 800203D, 1998

\begin{tabular}{|c|c|c|c|c|c|}
\hline \multirow[b]{2}{*}{ Parameter } & \multirow[b]{2}{*}{ Unit } & \multicolumn{4}{|c|}{ Date of Sampling } \\
\hline & & $01 / 09 / 98$ & $04 / 06 / 98$ & $07 / 08 / 98$ & $10 / 13 / 98$ \\
\hline Water elevation ${ }^{\mathrm{a}}$ & $\mathrm{m}$ & 192.55 & 192.76 & 192.80 & 192.65 \\
\hline Temperature & ${ }^{\circ} \mathrm{C}$ & 10.4 & 11.1 & 12.2 & 10.9 \\
\hline $\mathrm{pH}$ & $\mathrm{pH}$ & 7.00 & 7.04 & 7.15 & 7.29 \\
\hline Redox & $\mathrm{mV}$ & 1 & -6 & -58 & -15 \\
\hline Conductivity & $\mu \mathrm{mhos} / \mathrm{cm}$ & 1,138 & 1,117 & 1,176 & 1,147 \\
\hline Chloride ${ }^{b}$ & $\mathrm{mg} / \mathrm{L}$ & 78 & 71 & 144 & 84 \\
\hline Sulfate ${ }^{b}$ & $\mathrm{mg} / \mathrm{L}$ & 65 & 63 & 68 & 66 \\
\hline $\mathrm{TDS}^{\mathrm{b}}$ & $\mathrm{mg} / \mathrm{L}$ & 675 & 690 & 762 & 675 \\
\hline Cyanide (total) ${ }^{\mathbf{c}}$ & $\mathrm{mg} / \mathrm{L}$ & $<0.01$ & $<0.01$ & $<0.01$ & $<0.01$ \\
\hline Arsenic & $\mathrm{mg} / \mathrm{L}$ & $-d$ & 0.0047 & - & - \\
\hline Arsenic $^{c}$ & $\mathrm{mg} / \mathrm{L}$ & - & 0.2456 & - & - \\
\hline Barium $^{c}$ & $\mathrm{mg} / \mathrm{L}$ & - & 0.2063 & - & - \\
\hline Boron ${ }^{c}$ & $\mathrm{mg} / \mathrm{L}$ & - & $<0.0001$ & - & - \\
\hline Cadmium $^{c}$ & $\mathrm{mg} / \mathrm{L}$ & - & $<0.044$ & - & - \\
\hline Chromium $^{c}$ & $\mathrm{mg} / \mathrm{L}$ & - & $<0.026$ & - & - \\
\hline Cobalt ${ }^{c}$ & $\mathrm{mg} / \mathrm{L}$ & - & $<0.017$ & - & - \\
\hline Copper ${ }^{c}$ & $\mathrm{mg} / \mathrm{L}$ & - & 2.18 & - & _- \\
\hline Iron $^{c}$ & $\mathrm{mg} / \mathrm{L}$ & - & $<0.001$ & - & - \\
\hline Lead $^{\mathrm{C}}$ & $\mathrm{mg} / \mathrm{L}$ & - & 0.0452 & - & - \\
\hline Manganese ${ }^{c}$ & $\mathrm{mg} / \mathrm{L}$ & - & $<0.0001$ & - & - \\
\hline Mercuryc & $\mathrm{mg} / \mathrm{L}$ & - & $<0.04$ & - & - \\
\hline Nickel $^{c}$ & $\mathrm{mg} / \mathrm{L}$ & - & $<0.003$ & - & - \\
\hline Selenium $^{c}$ & $\mathrm{mg} / \mathrm{L}$ & - & $<0.0005$ & - & - \\
\hline Silver ${ }^{\mathfrak{C}}$ & $\mathrm{mg} / \mathrm{L}$ & - & 0.0162 & - & - \\
\hline $\operatorname{Zinc}^{c}$ & $\mathrm{mg} / \mathrm{L}$ & $<0.2$ & 2.0 & 1.5 & 2.0 \\
\hline Arsenic $^{b}$ & $\mathrm{mg} / \mathrm{L}$ & 0.0040 & 0.0028 & 0.0045 & 0.0044 \\
\hline Barium $^{b}$ & $\mathrm{mg} / \mathrm{L}$ & 0.1185 & 0.1084 & 0.1185 & 0.1129 \\
\hline Beryllium ${ }^{\mathrm{b}}$ & $\mathrm{mg} / \mathrm{L}$ & $<0.0002$ & $<0.0002$ & $<0.0002$ & $<0.0002$ \\
\hline Cadmium ${ }^{b}$ & $\mathrm{mg} / \mathrm{L}$ & $<0.0001$ & $<0.0001$ & $<0.0001$ & $<0.0001$ \\
\hline Chromium ${ }^{b}$ & $\mathrm{mg} / \mathrm{L}$ & $<0.044$ & $<0.044$ & $<0.044$ & $<0.044$ \\
\hline Cobalt $^{b}$ & $\mathrm{mg} / \mathrm{L}$ & $<0.026$ & $<0.026$ & $<0.026$ & $<0.026$ \\
\hline Copper $^{b}$ & $\mathrm{mg} / \mathrm{L}$ & $<0.017$ & $<0.017$ & $<0.017$ & $<0.017$ \\
\hline Iron & $\mathrm{mg} / \mathrm{L}$ & 1.5030 & 0.9493 & 1.8090 & 1.7080 \\
\hline Lead $^{b}$ & $\mathrm{mg} / \mathrm{L}$ & $<0.001$ & $<0.001$ & $<0.001$ & $<0.001$ \\
\hline Manganese ${ }^{b}$ & $\mathrm{mg} / \mathrm{L}$ & 0.0483 & 0.0373 & 0.0403 & 0.0506 \\
\hline Mercuryb & $\mathrm{mg} / \mathrm{L}$ & $<0.0001$ & $<0.0001$ & $<0.0001$ & $<0.0001$ \\
\hline Nickel $^{\mathrm{b}}$ & $\mathrm{mg} / \mathrm{L}$ & $<0.04$ & $<0.04$ & $<0.04$ & $<0.04$ \\
\hline Silver ${ }^{b}$ & $\mathrm{mg} / \mathrm{L}$ & $<0.0005$ & $<0.0005$ & $<0.0005$ & $<0.0005$ \\
\hline Thallium $^{\mathrm{b}}$ & $\mathrm{mg} / \mathrm{L}$ & $<0.0015$ & $<0.0015$ & $<0.0015$ & $<0.0015$ \\
\hline Vanadium ${ }^{b}$ & $\mathrm{mg} / \mathrm{L}$ & $<0.024$ & $<0.024$ & $<0.024$ & $<0.024$ \\
\hline Zinc $^{b}$ & $\mathrm{mg} / \mathrm{L}$ & $<0.011$ & $<0.011$ & $<0.011$ & $<0.011$ \\
\hline Nitrate & $\mathrm{mg} / \mathrm{L}$ & - & $<0.1$ & - & - \\
\hline Phenols & $\mathrm{mg} / \mathrm{L}$ & 0.007 & $<0.005$ & $<0.005$ & $<0.005$ \\
\hline Hydrogen-3 & $\mathrm{pCi} / \mathrm{L}$ & $<100$ & $<100$ & $<100$ & $<100$ \\
\hline Chloride & $\mathrm{mg} / \mathrm{L}$ & - & 74 & - & - \\
\hline Fluoride & $\mathrm{mg} / \mathrm{L}$ & - & 0.416 & - & - \\
\hline Sulfate & $\mathrm{mg} / \mathrm{L}$ & - & 66 & - & - \\
\hline TOCs & $\mathrm{mg} / \mathrm{L}$ & 5.5 & 3.7 & 5.0 & 5.0 \\
\hline TOCs & $\mathrm{mg} / \mathrm{L}$ & 5.2 & 3.8 & 5.0 & 4.8 \\
\hline TOCs & $\mathrm{mg} / \mathrm{L}$ & 5.4 & 3.7 & 5.0 & 4.9 \\
\hline TOCs & $\mathrm{mg} / \mathrm{L}$ & 5.5 & 4.3 & 4.9 & 4.9 \\
\hline TOXs & $\mathrm{mg} / \mathrm{L}$ & 0.0310 & 0.0280 & 0.0400 & 0.0470 \\
\hline TOXs & $\mathrm{mg} / \mathrm{L}$ & 0.0150 & 0.0400 & 0.0420 & 0.0590 \\
\hline
\end{tabular}

a Well point elevation $=189.47 \mathrm{~m}(\mathrm{MSL})$; ground surface elevation $=227.93 \mathrm{~m}(\mathrm{MSL})$; casing material $=$ stainless steel.

b Filtered sample.

c Unfiltered sample.

d A hyphen indicates that samples were not collected. 
TABLE 6.37

Groundwater Monitoring Results, Sanitary

Landfill Well 800241, 1998

\begin{tabular}{|c|c|c|c|}
\hline \multirow[b]{2}{*}{ Parameter } & \multirow[b]{2}{*}{ Unit } & \multicolumn{2}{|c|}{ Date of Sampling } \\
\hline & & $07 / 09 / 98$ & $10 / 14 / 98$ \\
\hline Water elevation ${ }^{a}$ & m & 225.83 & 224.83 \\
\hline Temperature & ${ }^{\circ} \mathrm{C}$ & 11.6 & 13.5 \\
\hline $\mathrm{pH}$ & $\mathrm{pH}$ & 7.19 & 7.01 \\
\hline Redox & $\mathrm{mV}$ & -63 & 3 \\
\hline Conductivity & $\mu \mathrm{mhos} / \mathrm{cm}$ & 2,320 & 2,280 \\
\hline Chloride $^{b}$ & $\mathrm{mg} / \mathrm{L}$ & 562 & 537 \\
\hline Sulfate $^{b}$ & $\mathrm{mg} / \mathrm{L}$ & 161 & 161 \\
\hline $\mathrm{TDS}^{\mathbf{b}}$ & $\mathrm{mg} / \mathrm{L}$ & 1,643 & 1,526 \\
\hline Cyanide (total) ${ }^{c}$ & $\mathrm{mg} / \mathrm{L}$ & $<0.01$ & $<0.01$ \\
\hline Arsenic ${ }^{c}$ & $\mathrm{mg} / \mathrm{L}$ & d & - \\
\hline Barium $^{c}$ & $\mathrm{mg} / \mathrm{L}$ & - & - \\
\hline Boron ${ }^{c}$ & $\mathrm{mg} / \mathrm{L}$ & - & - \\
\hline Cadmium $^{c}$ & $\mathrm{mg} / \mathrm{L}$ & - & - \\
\hline Chromium $^{\mathrm{c}}$ & $\mathrm{mg} / \mathrm{L}$ & - & - \\
\hline Cobalt ${ }^{c}$ & $\mathrm{mg} / \mathrm{L}$ & - & - \\
\hline Copper & $\mathrm{mg} / \mathrm{L}$ & - & - \\
\hline Iron ${ }^{c}$ & $\mathrm{mg} / \mathrm{L}$ & - & - \\
\hline Lead $^{c}$ & $\mathrm{mg} / \mathrm{L}$ & - & - \\
\hline Manganese $^{c}$ & $\mathrm{mg} / \mathrm{L}$ & - & - \\
\hline Mercuryc & $\mathrm{mg} / \mathrm{L}$ & - & - \\
\hline Nickele & $\mathrm{mg} / \mathrm{L}$ & - & - \\
\hline Selenium $^{c}$ & $\mathrm{mg} / \mathrm{L}$ & - & - \\
\hline Silver & $\mathrm{mg} / \mathrm{L}$ & - & - \\
\hline Zinc $^{c}$ & $\mathrm{mg} / \mathrm{L}$ & - & - \\
\hline Ammonia nitrogen ${ }^{b}$ & $\mathrm{mg} / \mathrm{L}$ & 0.2 & 0.1 \\
\hline Arsenic ${ }^{b}$ & $\mathrm{mg} / \mathrm{L}$ & $<0.0025$ & 0.0026 \\
\hline Barium $^{b}$ & $\mathrm{mg} / \mathrm{L}$ & 0.0901 & 0.0986 \\
\hline Beryllium $^{\mathrm{b}}$ & $\mathrm{mg} / \mathrm{L}$ & $<0.0002$ & $<0.0002$ \\
\hline Cadmium ${ }^{b}$ & $\mathrm{mg} / \mathrm{L}$ & $<0.0001$ & $<0.0001$ \\
\hline Chromium $^{b}$ & $\mathrm{mg} / \mathrm{L}$ & $<0.044$ & $<0.044$ \\
\hline Cobalt ${ }^{b}$ & $\mathrm{mg} / \mathrm{L}$ & $<0.026$ & $<0.026$ \\
\hline Copper ${ }^{b}$ & $\mathrm{mg} / \mathrm{L}$ & $<0.017$ & $<0.017$ \\
\hline Iron ${ }^{b}$ & $\mathrm{mg} / \mathrm{L}$ & 0.7778 & 0.3911 \\
\hline Lead $^{b}$ & $\mathrm{mg} / \mathrm{L}$ & $<0.001$ & $<0.001$ \\
\hline Manganese $^{b}$ & $\mathrm{mg} / \mathrm{L}$ & 0.2619 & 0.2621 \\
\hline Mercury ${ }^{b}$ & $\mathrm{mg} / \mathrm{L}$ & $<0.0001$ & $<0.0001$ \\
\hline Nickel $^{b}$ & $\mathrm{mg} / \mathrm{L}$ & 0.0433 & $<0.0400$ \\
\hline Silver & $\mathrm{mg} / \mathrm{L}$ & $<0.0005$ & $<0.0005$ \\
\hline Thallium $^{b}$ & $\mathrm{mg} / \mathrm{L}$ & $<0.0015$ & $<0.0015$ \\
\hline Vanadium $^{b}$ & $\mathrm{mg} / \mathrm{L}$ & $<0.024$ & $<0.024$ \\
\hline Zinc $^{b}$ & $\mathrm{mg} / \mathrm{L}$ & $<0.011$ & $<0.011$ \\
\hline Nitrate & $\mathrm{mg} / \mathrm{L}$ & - & - \\
\hline Phenols & $\mathrm{mg} / \mathrm{L}$ & 0.007 & $<0.006$ \\
\hline Hydrogen-3 & $\mathrm{pCi} / \mathrm{L}$ & $<100$ & $<100$ \\
\hline Chloride & $\mathrm{mg} / \mathrm{L}$ & - & - \\
\hline Fluoride & $\mathrm{mg} / \mathrm{L}$ & - & - \\
\hline Sulfate & $\mathrm{mg} / \mathrm{L}$ & - & - \\
\hline TOCs & $\mathrm{mg} / \mathrm{L}$ & 2.1 & 1.4 \\
\hline TOCs & $\mathrm{mg} / \mathrm{L}$ & 1.2 & 1.7 \\
\hline TOCs & $\mathrm{mg} / \mathrm{L}$ & 1.2 & 1.4 \\
\hline TOCs & $\mathrm{mg} / \mathrm{L}$ & 1.3 & 1.4 \\
\hline TOXs & $\mathrm{mg} / \mathrm{L}$ & 0.094 & 0.060 \\
\hline TOXs & $\mathrm{mg} / \mathrm{L}$ & 0.057 & 0.066 \\
\hline
\end{tabular}

a Well point elevation $=221.15 \mathrm{~m}(\mathrm{MSL})$; ground surface elevation = $226.10 \mathrm{~m}$ (MSL); casing material = stainless steel.

b Filtered sample.

c Unfiltered sample.

d A hyphen indicates that samples were not collected. 


\section{GROUNDWATER PROTECTION}

TABLE 6.38

Groundwater Monitoring Results, Sanitary Landfill Well 800243D, 1998

\begin{tabular}{|c|c|c|c|}
\hline \multirow[b]{2}{*}{ Parameter } & \multirow[b]{2}{*}{ Unit } & \multicolumn{2}{|c|}{ Date of Sampling } \\
\hline & & $07 / 09 / 98$ & $10 / 14 / 98$ \\
\hline Water elevation $^{\mathrm{a}}$ & $\mathrm{m}$ & 193.29 & 193.16 \\
\hline Temperature & ${ }^{\circ} \mathrm{C}$ & 11.3 & 10.7 \\
\hline $\mathrm{pH}$ & $\mathrm{pH}$ & 6.97 & 7.08 \\
\hline Redox & $\mathrm{mV}$ & -44 & -5 \\
\hline Conductivity & $\mu \mathrm{mhos} / \mathrm{cm}$ & 987 & 899 \\
\hline Chloride ${ }^{\mathrm{b}}$ & $\mathrm{mg} / \mathrm{L}$ & 24 & 17 \\
\hline Sulfate ${ }^{b}$ & $\mathrm{mg} / \mathrm{L}$ & 40 & 43 \\
\hline TDS $^{b}$ & $\mathrm{mg} / \mathrm{L}$ & 589 & 509 \\
\hline Cyanide (total) ${ }^{\mathrm{c}}$ & $\mathrm{mg} / \mathrm{L}$ & $<0.01$ & $<0.01$ \\
\hline Arsenic $^{c}$ & $\mathrm{mg} / \mathrm{L}$ & $-d$ & - \\
\hline Barium $^{c}$ & $\mathrm{mg} / \mathrm{L}$ & - & - \\
\hline Boron ${ }^{\mathfrak{c}}$ & $\mathrm{mg} / \mathrm{L}$ & - & - \\
\hline Cadmium $^{c}$ & $\mathrm{mg} / \mathrm{L}$ & - & - \\
\hline Chromium ${ }^{c}$ & $\mathrm{mg} / \mathrm{L}$ & - & - \\
\hline Cobalt ${ }^{c}$ & $\mathrm{mg} / \mathrm{L}$ & - & - \\
\hline Copper ${ }^{c}$ & $\mathrm{mg} / \mathrm{L}$ & - & - \\
\hline Iron ${ }^{c}$ & $\mathrm{mg} / \mathrm{L}$ & - & - \\
\hline Lead $^{c}$ & $\mathrm{mg} / \mathrm{L}$ & - & - \\
\hline Manganese $^{c}$ & $\mathrm{mg} / \mathrm{L}$ & - & - \\
\hline Mercuryc ${ }^{c}$ & $\mathrm{mg} / \mathrm{L}$ & - & - \\
\hline Nickel $^{c}$ & $\mathrm{mg} / \mathrm{L}$ & - & - \\
\hline Selenium ${ }^{\mathrm{c}}$ & $\mathrm{mg} / \mathrm{L}$ & - & - \\
\hline Silver $^{c}$ & $\mathrm{mg} / \mathrm{L}$ & - & - \\
\hline $\operatorname{Zinc}^{c}$ & $\mathrm{mg} / \mathrm{L}$ & - & - \\
\hline Ammonia nitrogen ${ }^{b}$ & $\mathrm{mg} / \mathrm{L}$ & 0.5 & 0.4 \\
\hline Arsenic $^{b}$ & $\mathrm{mg} / \mathrm{L}$ & $<0.0025$ & 0.0030 \\
\hline Barium $^{b}$ & $\mathrm{mg} / \mathrm{L}$ & 0.1856 & 0.1660 \\
\hline Beryllium ${ }^{b}$ & $\mathrm{mg} / \mathrm{L}$ & $<0.0002$ & $<0.0002$ \\
\hline Cadmium ${ }^{b}$ & $\mathrm{mg} / \mathrm{L}$ & $<0.0001$ & $<0.0001$ \\
\hline Chromium $^{\mathbf{b}}$ & $\mathrm{mg} / \mathrm{L}$ & $<0.044$ & $<0.044$ \\
\hline Cobalt ${ }^{\mathrm{b}}$ & $\mathrm{mg} / \mathrm{L}$ & $<0.026$ & $<0.026$ \\
\hline Copper ${ }^{b}$ & $\mathrm{mg} / \mathrm{L}$ & $<0.017$ & $<0.017$ \\
\hline Iron ${ }^{b}$ & $\mathrm{mg} / \mathrm{L}$ & 0.9432 & 0.5772 \\
\hline Lead $^{b}$ & $\mathrm{mg} / \mathrm{L}$ & $<0.001$ & $<0.001$ \\
\hline Manganese ${ }^{b}$ & $\mathrm{mg} / \mathrm{L}$ & 1.4930 & 0.6744 \\
\hline Mercury ${ }^{\mathrm{b}}$ & $\mathrm{mg} / \mathrm{L}$ & $<0.0001$ & $<0.0001$ \\
\hline Nickel $^{\mathrm{b}}$ & $\mathrm{mg} / \mathrm{L}$ & $<0.04$ & $<0.04$ \\
\hline Silver $^{\mathrm{b}}$ & $\mathrm{mg} / \mathrm{L}$ & $<0.0005$ & 0.0011 \\
\hline Thallium $^{\mathrm{b}}$ & $\mathrm{mg} / \mathrm{L}$ & $<0.0015$ & $<0.0015$ \\
\hline Vanadium $^{\mathrm{b}}$ & $\mathrm{mg} / \mathrm{L}$ & $<0.024$ & $<0.024$ \\
\hline Zinc $^{b}$ & $\mathrm{mg} / \mathrm{L}$ & $<0.011$ & $<0.011$ \\
\hline Nitrate & $\mathrm{mg} / \mathrm{L}$ & - & - \\
\hline Phenols & $\mathrm{mg} / \mathrm{L}$ & 0.01 & $<0.005$ \\
\hline Hydrogen-3 & $\mathrm{pCi} / \mathrm{L}$ & $<100$ & $<100$ \\
\hline Chloride & $\mathrm{mg} / \mathrm{L}$ & - & - \\
\hline Fluoride & $\mathrm{mg} / \mathrm{L}$ & - & - \\
\hline Sulfate & $\mathrm{mg} / \mathrm{L}$ & - & - \\
\hline TOCs & $\mathrm{mg} / \mathrm{L}$ & 2.7 & 1.4 \\
\hline TOCs & $\mathrm{mg} / \mathrm{L}$ & 2.4 & 1.5 \\
\hline TOCs & $\mathrm{mg} / \mathrm{L}$ & 2.0 & 1.4 \\
\hline TOCs & $\mathrm{mg} / \mathrm{L}$ & 2.4 & 2.4 \\
\hline TOXs & $\mathrm{mg} / \mathrm{L}$ & $<0.0100$ & 0.0190 \\
\hline TOXs & $\mathrm{mg} / \mathrm{L}$ & $<0.0100$ & 0.0150 \\
\hline
\end{tabular}

a Well point elevation $=190.56 \mathrm{~m}$ (MSL); ground surface elevation = $226.10 \mathrm{~m}$ (MSL); casing material = stainless steel.

b Filtered sample.

c Unfiltered sample.

d A hyphen indicates that samples were not collected. 


\section{GROUNDWATER PROTECTION}

these tables. The analytical methods used for organic compounds could identify and quantify all the compounds contained in the CLP Target Compound List. However, the vast majority of these compounds were not detected in the samples. Only those constituents that were present in amounts great enough to quantify are shown. The detection limits for the organic compounds listed were typically 1 to $5 \mu \mathrm{g} / \mathrm{L}$. Figures 6.7 to 6.17 show the trends for exceedances of the WQS for wells monitored as part of the IEPA-approved groundwater monitoring program for the sanitary landfill. Results represent filtered samples only because filtered samples are collected each quarter for the constituents presented.

On April 24, 1992, January 11, 1995, November 20, 1997, and August 25, 1998, the IEPA issued supplemental permits to ANL-E that, in part, approved a groundwater monitoring program for the sanitary landfill. The program should be capable of identifying any releases from the facility and demonstrating compliance with the applicable groundwater quality standards. Under the January 1995 and August 1998 supplemental permits, the IEPA chose 15 groundwater monitoring points $(800161,800162$, 800163D, 800171, 800173D, 800181, 800183D, 800191, $800192,800193 \mathrm{D}, 800201,800202,800203 \mathrm{D}, 800241$, and $800243 \mathrm{D})$ to be sampled on a quarterly basis commencing January 1995. Parameters to be monitored include field parameters, filtered routine indicator parameters, unfiltered routine indicator parameters, unfiltered inorganic parameters, and volatile organic parameters. Volatile organic parameters are to be monitored only during the second quarter of monitoring. Routine indicator parameters are collected each quarter. Inorganic parameters are unfiltered prior to analysis and are collected only during the second quarter.

ANL-E chose a conservative approach for evaluating the inorganic monitoring results by selecting as the standard of comparison the Illinois Groundwater Quality Standards for Class I: Potable Resource Groundwater, 35 IAC Part 620.410. The most common constituents at levels above the WQS (see Table 6.19) are chloride, iron, TDS, and manganese. This is consistent with results reported in prior years using the previous well monitoring network. 


\section{GROUNDWATER PROTECTION}
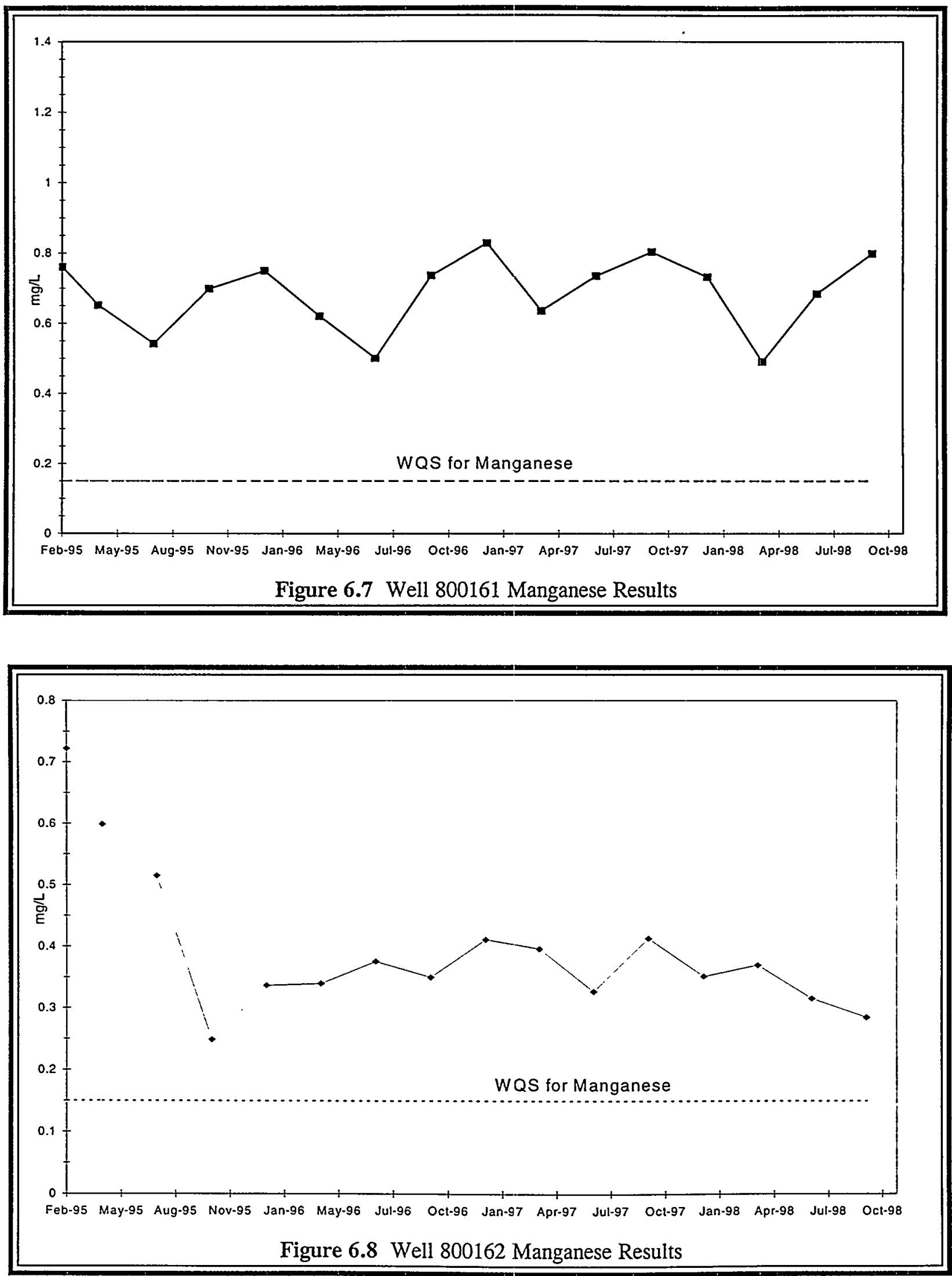

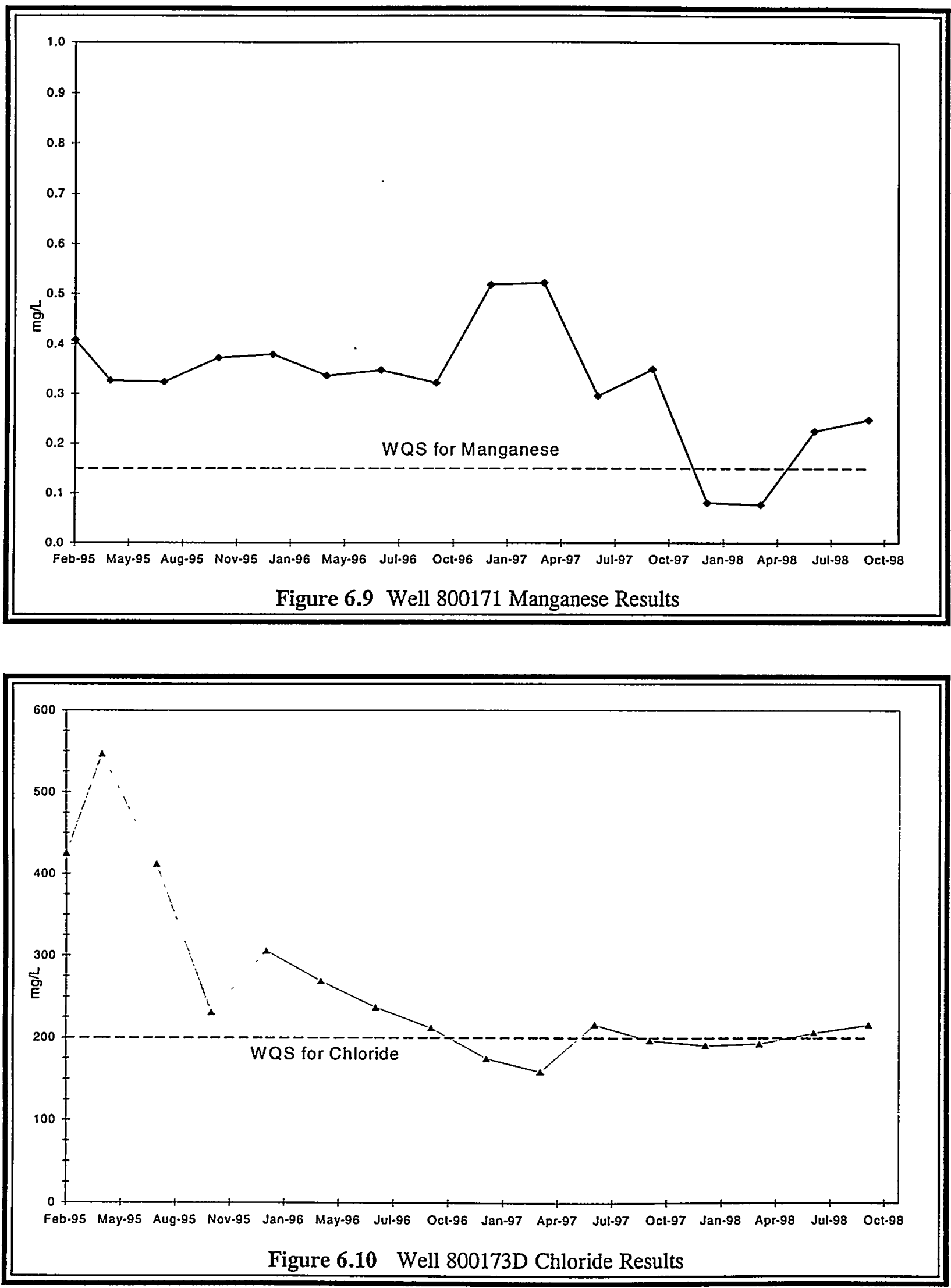

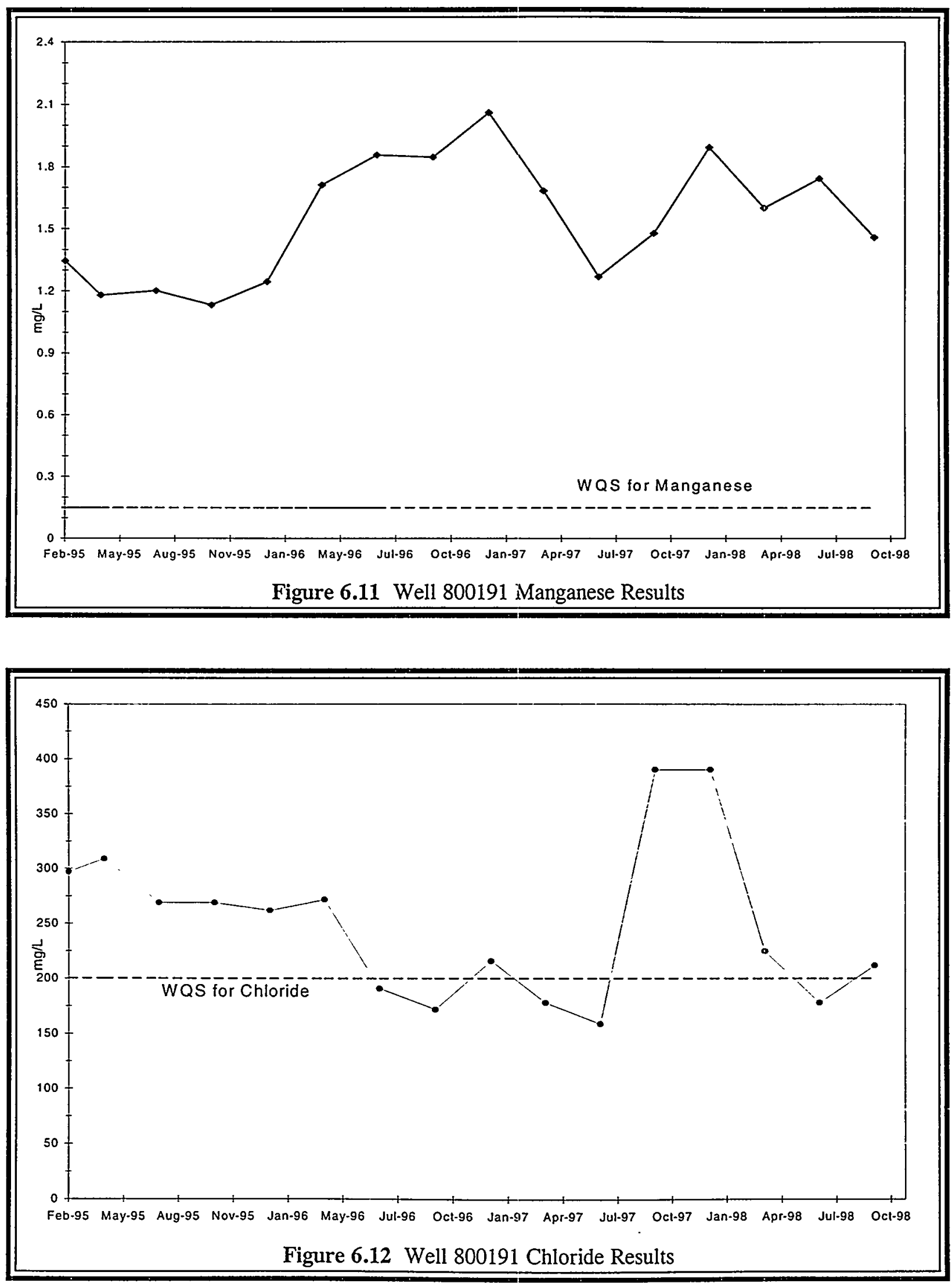


\section{GROUNDWATER PROTECTION}
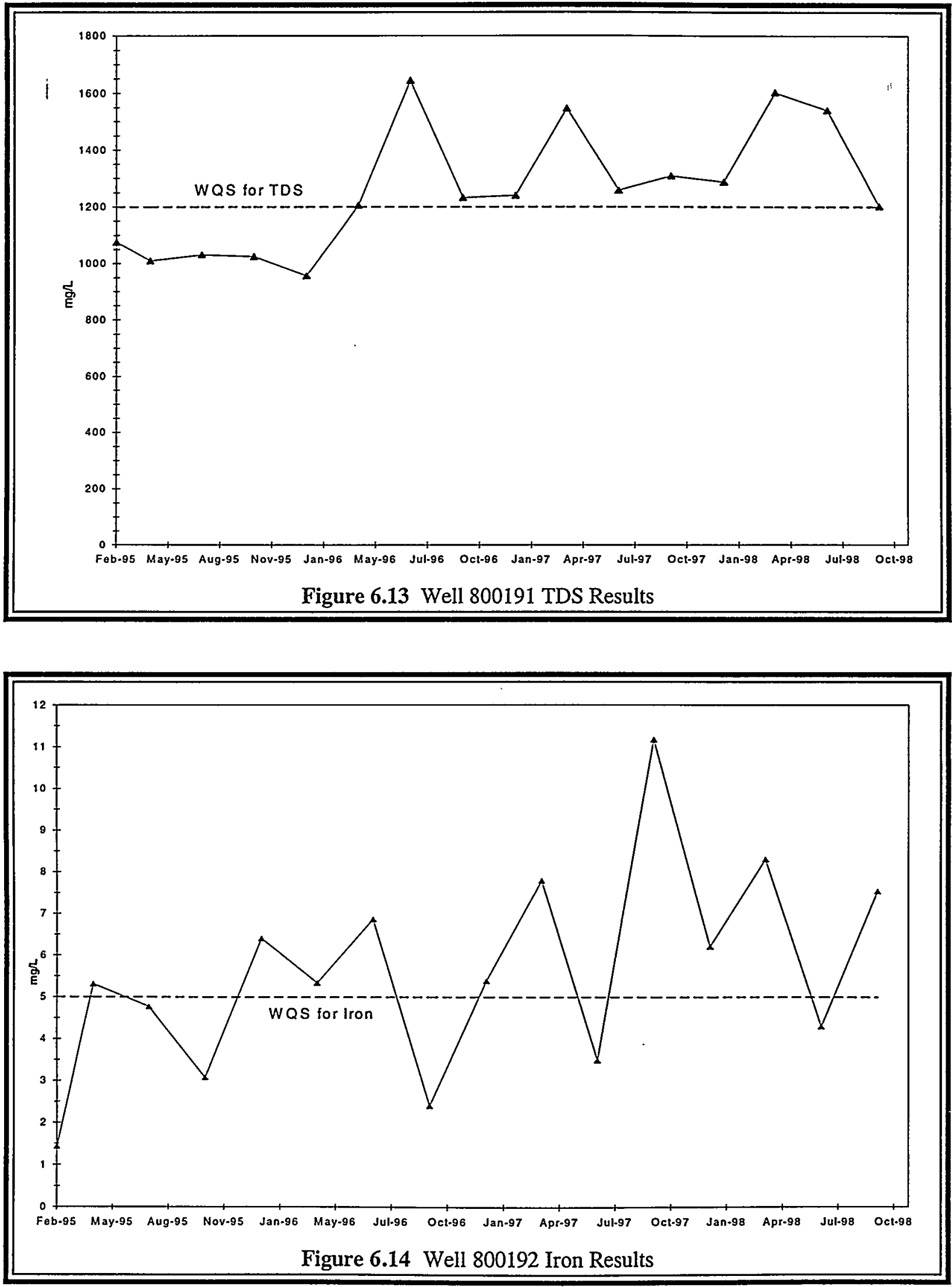

ANL-E Site Environmental Report 


\section{GROUNDWATER PROTECTION}
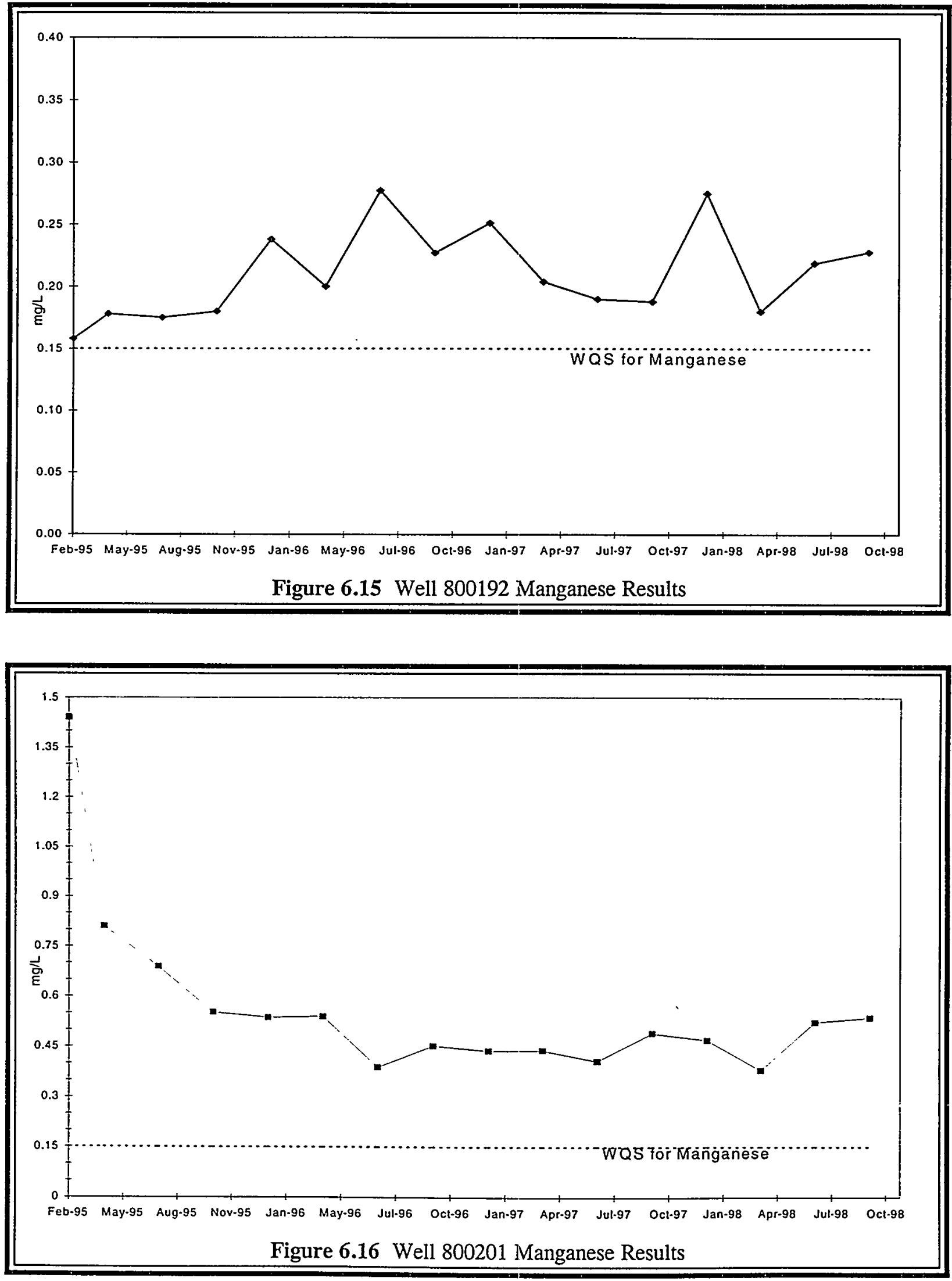


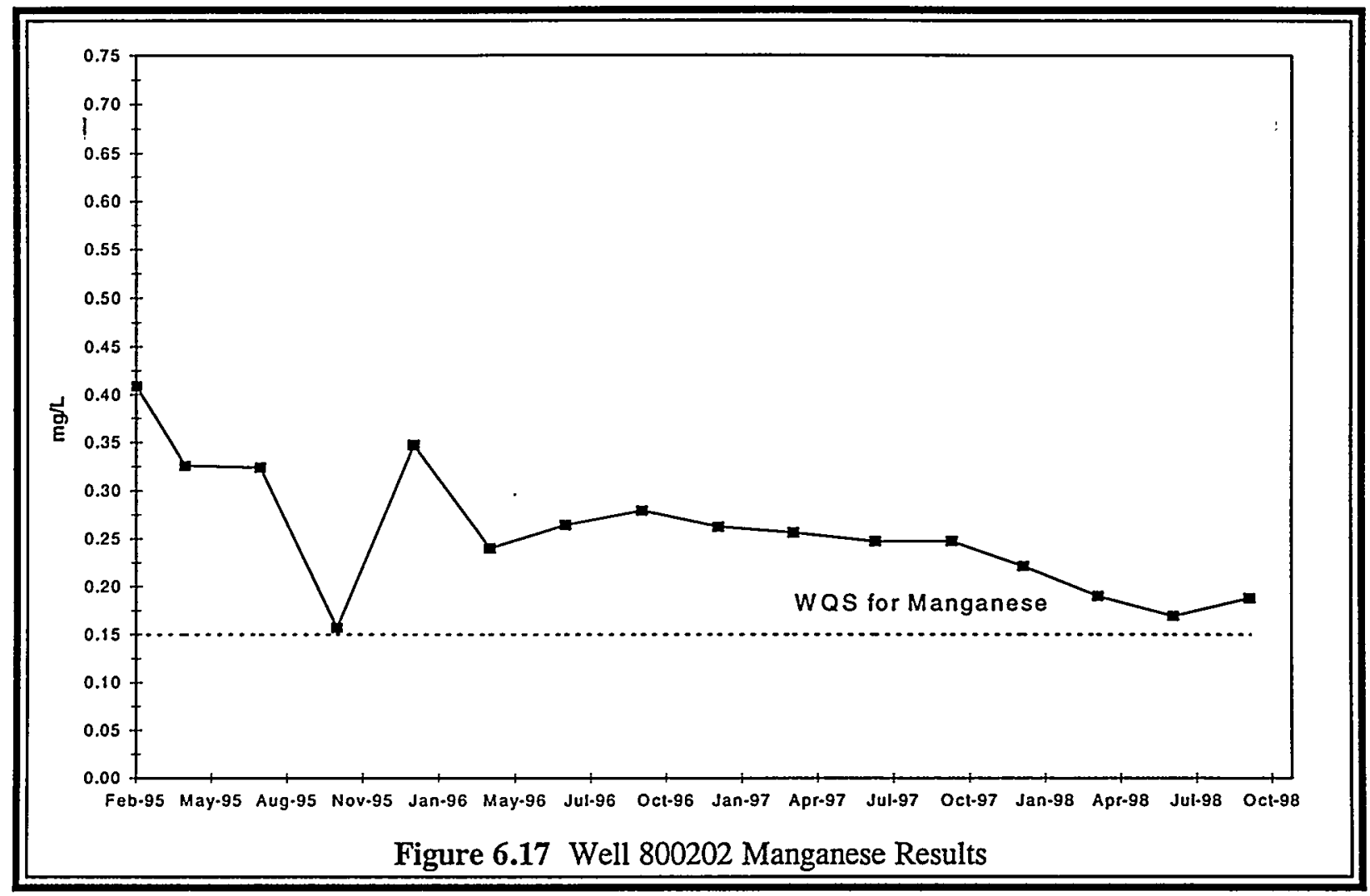

Field Parameters. Field parameters include such items as well and water depth information, $\mathrm{pH}$, specific conductance, and temperature of water. These parameters are measured each quarter. No standards exist for comparative purposes, with the exception of $\mathrm{pH}$. However, results are consistent from quarter to quarter and similar to results obtained in previous years.

Filtered Routine Indicator Parameters. Filtered routine indicator parameters include ammonia as nitrogen, arsenic, cadmium, chloride, iron, lead, manganese, mercury, sulfate, and TDS. These parameters are measured each quarter. Ammonia, arsenic, cadmium, lead, mercury, and sulfate were all less than the WQS. Chloride exceeded the WQS (200 mg/L) in 800173D, 800191 , and 800241 at least once during the year. Chloride levels in these wells ranged from 206 to $562 \mathrm{mg} / \mathrm{L}$. Well 800241 is considered an upgradient well. Elevated chloride levels in this well are probably due to road salt intrusion. 


\section{GROUNDWATER PROTECTION}

As in 1997, iron concentrations exceeded the WQS $(5 \mathrm{mg} / \mathrm{L})$ at least once during the year in 800191,800192 , and 800201 . Iron levels in these wells ranged from 6 to $8 \mathrm{mg} / \mathrm{L}$.

Manganese concentrations exceeded the WQS $(0.15 \mathrm{mg} / \mathrm{L})$ during at least one quarter in $800161,800162,800171,800191,800192,800201,800202,800241$, and 800243D. Manganese levels in these wells ranged from 0.18 to $1.9 \mathrm{mg} / \mathrm{L}$. Manganese appears to be elevated over the entire 800 Landfill area, and similar concentrations have been measured in monitoring wells several miles from the 800 Area Landfill.

Wells 800191 and 800241 contained concentrations of TDS above the WQS $(1,200 \mathrm{mg} / \mathrm{L})$. TDS levels in these wells ranged from 1,202 to $1,643 \mathrm{mg} / \mathrm{L}$.

Unfiltered Routine Indicator Parameters. These specific parameters include cyanide, phenols (total recoverable), TOC, and TOX and are measured each quarter. All measured unfiltered routine indicator parameters were less than the appropriate WQS values, where applicable.

Unfiltered Inorganic Parameters. These parameters are measured only during the second quarter and include arsenic, barium, boron, cadmium, chloride, chromium, cobalt, copper, cyanide, fluoride, iron, lead, manganese, mercury, nickel, nitrate as nitrogen, selenium, silver, sulfate, and zinc.

Chloride concentrations exceeded the WQS (200 mg/L) in 800191 only.

Iron concentrations exceeded the WQS (5 mg/L) in 800161, 800163D, 800171, 800173D, $800181,800191,800192$, and 800201. Iron levels in these wells ranged from 6 to $32 \mathrm{mg} / \mathrm{L}$. The iron exceedances are probably due to the requirement that these samples are unfiltered.

Lead concentrations exceeded the WQS $(0.0075 \mathrm{mg} / \mathrm{L})$ in $800171,800181,800191,800192$, and 800201 . Lead levels in these wells ranged from 0.0106 to $0.0247 \mathrm{mg} / \mathrm{L}$. 


\section{GROUNDWATER PROTECTION}

Manganese concentrations exceeded the WQS $(0.15 \mathrm{mg} / \mathrm{L})$ in $800161,800162,800171$, 800173D, 800181, 800191, 800192, 800201, and 800202. Manganese levels in these wells ranged from 0.20 to $2.1 \mathrm{mg} / \mathrm{L}$. Elevated manganese levels appear to be normal for this area.

Organic Parameters. The unfiltered organic parameters were all below their respective detection limits except for trichlorofluoromethane in 800161 and $800163 \mathrm{D}$ at $1.0 \mu \mathrm{g} / \mathrm{L}$. The PQL is $5 \mu \mathrm{g} / \mathrm{L}$. The PQL is the lowest concentration that can be reliably achieved within specific limits of precision and accuracy during routine operating conditions.

Radioactive Constituents. Samples collected from the 800 Area sanitary landfill monitoring wells were also analyzed for hydrogen-3. The results are shown in Tables 6.24 to 6.38. Although the disposal of radioactive materials was prohibited in the sanitary landfill, very low concentrations of hydrogen-3 were detected in 800161, 800171, 800191, and 800192, probably because of inadvertent disposal of radioactivity in ANL-E trash. These results are consistent with 1997 results. A trace level of hydrogen-3 was also detected in 800162 , but only during two quarters. However, the presence of hydrogen-3 as tritiated water allows information to be obtained on the subsurface water flow pathway in the sanitary landfill area. The data indicate that the principal direction of subsurface water flow is to the south-southeast, with a small component to the northwest. This is consistent with the estimated subsurface water flow based on water level measurements and general flow patterns in the area.

\subsection{CP-5 Reactor Area}

The CP-5 reactor is an inactive research reactor located in Building 330 (see Figure 1.1). The CP-5 5-MW research reactor was used from 1954 until operations ceased in 1979. In addition to the reactor vessel, the CP-5 complex contained several large cooling towers and an outdoor equipment yard for storing equipment and supplies. The reactor and associated yard area are in the process of being decommissioned. A single exploratory monitoring well was installed in 1989 in the yard immediately behind the reactor building, just outside the reactor fuel storage area of the complex. Two new wells were installed as part of a full characterization study of this site, 


\section{GROUNDWATER PROTECTION}

which took place during 1993. The three wells have been sampled quarterly since 1995 and analyzed for radionuclides, metals, VOCs, SVOCs, pesticides, herbicides, and PCBs. A new deep well was installed during June 1997 to determine whether there had been any vertical migration of hydrogen-3 in the groundwater from the CP-5 reactor. The results are shown in Tables 6.39 to 6.42 . Table 6.43 characterizes all wells in this area (see Figure 6.18 for locations).

Well 330011 is installed in a relatively porous, saturated region of soil and as a result, recharges quickly. Purging the well by removing several well volumes of water does not lower the water level appreciably. The water has a higher conductivity and temperature than similar wells at other locations. As in past years, the manganese WQS $(0.15 \mathrm{mg} / \mathrm{L})$ was exceeded three quarters, and levels ranged from 0.02 to $0.46 \mathrm{mg} / \mathrm{L}$. Low levels of barium were noted each quarter; all levels were well below the WQS of $2 \mathrm{mg} / \mathrm{L}$. As in past years, barium was detected each quarter in 330021; all levels were well below the appropriate WQS.

Manganese and nickel exceeded the WQS $(0.15$ and $0.10 \mathrm{mg} / \mathrm{L}$, respectively) each quarter in 330031 . Manganese levels ranged from 0.27 to $0.45 \mathrm{mg} / \mathrm{L}$, and nickel levels ranged from 0.26 to $0.70 \mathrm{mg} / \mathrm{L}$. The source of nickel is unknown. Similar manganese concentrations have been measured at distances from the CP-5 reactor (see Section 6.3.2.3). Chloride concentrations exceeded the WQS (200 mg/L) each quarter, and chloride levels ranged from 326 to $400 \mathrm{mg} / \mathrm{L}$. Barium was detected at levels well below the WQS each quarter.

Barium, iron, and manganese were detected each quarter in 330012D; all levels were well below the appropriate WQS. Arsenic was detected only during the second quarter at a level well below the WQS $(0.05 \mathrm{mg} / \mathrm{L})$.

Each sample collected from 330011 in 1998 contained low concentrations of trichlorofluoromethane and dichlorofluoromethane; concentrations ranged from 1 to $2 \mu \mathrm{g} / \mathrm{L}$. These results are lower than those noted from 1991 through 1997. Well 330012D contained very low concentrations of dichlorofluoromethane each quarter; concentrations ranged from 0.3 to $0.9 \mu \mathrm{g} / \mathrm{L}$ but are not included in the table. 
TABLE 6.39

Groundwater Monitoring Results, 330 Area Well 330011, 1998

\begin{tabular}{|c|c|c|c|c|c|}
\hline \multirow[b]{2}{*}{ Parameter } & \multirow[b]{2}{*}{ Unit } & \multicolumn{4}{|c|}{ Date of Sampling } \\
\hline & & $03 / 19 / 98$ & $06 / 01 / 98$ & $09 / 24 / 98$ & $12 / 15 / 98$ \\
\hline Water elevation $^{\mathrm{a}}$ & $\mathrm{m}$ & 225.98 & 225.20 & 225.61 & 225.68 \\
\hline Temperature & ${ }^{\circ} \mathrm{C}$ & 13.6 & 15.7 & 19.2 & 17.9 \\
\hline $\mathrm{pH}$ & $\mathrm{pH}$ & 7.08 & 6.91 & 7.04 & 6.88 \\
\hline Redox & $\mathrm{mV}$ & 1 & -5 & 6 & 11 \\
\hline Conductivity & $\mu \mathrm{mhos} / \mathrm{cm}$ & 1,119 & 1,080 & 1,142 & 1,062 \\
\hline Chloride $^{b}$ & $\mathrm{mg} / \mathrm{L}$ & 31 & 25 & 28 & 31 \\
\hline Arsenic $^{b}$ & $\mathrm{mg} / \mathrm{L}$ & $<0.0025$ & $<0.0025$ & $<0.0025$ & $<0.0025$ \\
\hline Barium $^{b}$ & $\mathrm{mg} / \mathrm{L}$ & 0.0519 & 0.0549 & 0.0568 & 0.0538 \\
\hline Beryllium $^{b}$ & $\mathrm{mg} / \mathrm{L}$ & $<0.0002$ & $<0.0002$ & $<0.0002$ & $<0.0002$ \\
\hline Cadmium $^{b}$ & $\mathrm{mg} / \mathrm{L}$ & $<0.0001$ & $<0.0001$ & 0.0001 & $<0.0001$ \\
\hline Chromium $^{\mathrm{b}}$ & $\mathrm{mg} / \mathrm{L}$ & $<0.044$ & $<0.044$ & $<0.044$ & $<0.044$ \\
\hline Cobalt $^{b}$ & $\mathrm{mg} / \mathrm{L}$ & $<0.026$ & $<0.026$ & $<0.026$ & $<0.026$ \\
\hline Copper ${ }^{b}$ & $\mathrm{mg} / \mathrm{L}$ & $<0.017$ & $<0.017$ & $<0.017$ & $<0.017$ \\
\hline $\operatorname{Iron}^{b}$ & $\mathrm{mg} / \mathrm{L}$ & $<0.037$ & $<0.037$ & $<0.037$ & $<0.037$ \\
\hline Lead $^{b}$ & $\mathrm{mg} / \mathrm{L}$ & $<0.001$ & $<0.001$ & $<0.001$ & $<0.001$ \\
\hline Manganese ${ }^{b}$ & $\mathrm{mg} / \mathrm{L}$ & 0.1955 & 0.0174 & 0.2218 & 0.4563 \\
\hline Mercury ${ }^{b}$ & $\mathrm{mg} / \mathrm{L}$ & $<0.0001$ & $<0.0001$ & $<0.0001$ & $<0.0001$ \\
\hline Nickel $^{b}$ & $\mathrm{mg} / \mathrm{L}$ & $<0.04$ & $<0.04$ & $<0.04$ & $<0.04$ \\
\hline Silver ${ }^{\mathrm{b}}$ & $\mathrm{mg} / \mathrm{L}$ & $<0.0005$ & $<0.0005$ & $<0.0005$ & $<0.0005$ \\
\hline Thallium $^{\mathrm{b}}$ & $\mathrm{mg} / \mathrm{L}$ & $<0.0015$ & $<0.0015$ & $<0.0015$ & $<0.0015$ \\
\hline Vanadium ${ }^{\mathrm{b}}$ & $\mathrm{mg} / \mathrm{L}$ & $<0.024$ & $<0.024$ & $<0.024$ & $<0.024$ \\
\hline Zinc $^{b}$ & $\mathrm{mg} / \mathrm{L}$ & $<0.011$ & $<0.011$ & $<0.011$ & $<0.011$ \\
\hline Cesium-137 & $\mathrm{pCi} / \mathrm{L}$ & $<1.0$ & $<1.0$ & $<1.0$ & 1.1 \\
\hline Hydrogen-3 & $\mathrm{pCi} / \mathrm{L}$ & 792 & 821 & 683 & 927 \\
\hline Strontium- 90 & $\mathrm{pCi} / \mathrm{L}$ & 0.44 & 0.51 & 0.43 & 0.66 \\
\hline Dichlorofluoromethane & $\mu \mathrm{g} / \mathrm{L}$ & 1 & 1 & 1 & 2 \\
\hline Trichlorofluoromethane & $\mu \mathrm{g} / \mathrm{L}$ & 2 & 2 & 1 & 1 \\
\hline
\end{tabular}

a Well point elevation $=221.00 \mathrm{~m}$ (MSL); ground surface elevation $=227.10 \mathrm{~m}$ (MSL); casing material $=$ steel.

b Filtered sample. 
TABLE 6.40

Groundwater Monitoring Results, 330 Area Well 330021, 1998

\begin{tabular}{|c|c|c|c|c|c|}
\hline \multirow[b]{2}{*}{ Parameter } & \multirow[b]{2}{*}{ Unit } & \multicolumn{4}{|c|}{ Date of Sampling } \\
\hline & & $03 / 20 / 98$ & $06 / 01 / 98$ & $09 / 24 / 98$ & $12 / 15 / 98$ \\
\hline Water elevation $^{\mathrm{a}}$ & $\mathrm{m}$ & 227.54 & 225.83 & 225.79 & 226.13 \\
\hline Temperature & ${ }^{\circ} \mathrm{C}$ & 7.3 & 10.7 & 14.0 & 12.5 \\
\hline $\mathrm{pH}$ & $\mathrm{pH}$ & 7.42 & 7.45 & 7.48 & 7.33 \\
\hline Redox & $\mathrm{mV}$ & -18 & -35 & -18 & -18 \\
\hline Conductivity & $\mu \mathrm{mhos} / \mathrm{cm}$ & 648 & 738 & 788 & 786 \\
\hline Chloride $^{b}$ & $\mathrm{mg} / \mathrm{L}$ & 3 & 4 & 5 & 6 \\
\hline Arsenic $^{\mathrm{b}}$ & $\mathrm{mg} / \mathrm{L}$ & $<0.0025$ & $<0.0025$ & $<0.0025$ & $<0.0025$ \\
\hline Barium $^{b}$ & $\mathrm{mg} / \mathrm{L}$ & 0.0311 & 0.0320 & 0.0286 & 0.0249 \\
\hline Beryllium $^{b}$ & $\mathrm{mg} / \mathrm{L}$ & $<0.0002$ & $<0.0002$ & $<0.0002$ & $<0.0002$ \\
\hline Cadmium $^{b}$ & $\mathrm{mg} / \mathrm{L}$ & $<0.0001$ & $<0.0001$ & $<0.0001$ & $<0.0001$ \\
\hline Chromium $^{b}$ & $\mathrm{mg} / \mathrm{L}$ & $<0.044$ & $<0.044$ & $<0.044$ & $<0.044$ \\
\hline Cobalt $^{\mathrm{b}}$ & $\mathrm{mg} / \mathrm{L}$ & $<0.026$ & $<0.026$ & $<0.026$ & $<0.026$ \\
\hline Copper ${ }^{b}$ & $\mathrm{mg} / \mathrm{L}$ & $<0.017$ & $<0.017$ & $<0.017$ & $<0.017$ \\
\hline Iron ${ }^{b}$ & $\mathrm{mg} / \mathrm{L}$ & $<0.037$ & $<0.037$ & $<0.037$ & $<0.037$ \\
\hline Lead $^{b}$ & $\mathrm{mg} / \mathrm{L}$ & $<0.001$ & $<0.001$ & $<0.001$ & $<0.001$ \\
\hline Manganese $^{\mathrm{b}}$ & $\mathrm{mg} / \mathrm{L}$ & $<0.017$ & $<0.017$ & $<0.017$ & $<0.017$ \\
\hline Mercury ${ }^{b}$ & $\mathrm{mg} / \mathrm{L}$ & $<0.0001$ & $<0.0001$ & $<0.0001$ & $<0.0001$ \\
\hline Nickel $^{\mathrm{b}}$ & $\mathrm{mg} / \mathrm{L}$ & $<0.04$ & $<0.04$ & $<0.04$ & $<0.04$ \\
\hline Silver ${ }^{b}$ & $\mathrm{mg} / \mathrm{L}$ & $<0.0005$ & $<0.0005$ & $<0.0005$ & $<0.0005$ \\
\hline Thallium $^{\mathrm{b}}$ & $\mathrm{mg} / \mathrm{L}$ & $<0.0015$ & $<0.0015$ & $<0.0015$ & $<0.0015$ \\
\hline Vanadium $^{\mathrm{b}}$ & $\mathrm{mg} / \mathrm{L}$ & $<0.024$ & $<0.024$ & $<0.024$ & $<0.024$ \\
\hline $\operatorname{Zinc}^{b}$ & $\mathrm{mg} / \mathrm{L}$ & $<0.011$ & $<0.011$ & $<0.011$ & $<0.011$ \\
\hline Cesium-137 & $\mathrm{pCi} / \mathrm{L}$ & $<1.0$ & 1.0 & $<1.0$ & $<1.0$ \\
\hline Hydrogen-3 & $\mathrm{pCi} / \mathrm{L}$ & $<100$ & 197 & 199 & 173 \\
\hline Strontium-90 & $\mathrm{pCi} / \mathrm{L}$ & $<0.25$ & $<0.25$ & $<0.25$ & $<0.25$ \\
\hline
\end{tabular}

a Well point elevation $=221.95 \mathrm{~m}(\mathrm{MSL})$; ground surface elevation $=227.75 \mathrm{~m}$ (MSL); casing material $=$ stainless steel.

b Filtered sample. 


\section{GROUNDWATER PROTECTION}

TABLE 6.41

Groundwater Monitoring Results, 330 Area Well 330031, 1998

\begin{tabular}{|c|c|c|c|c|c|}
\hline \multirow[b]{2}{*}{ Parameter } & \multirow[b]{2}{*}{ Unit } & \multicolumn{4}{|c|}{ Date of Sampling } \\
\hline & & $03 / 19 / 98$ & $06 / 01 / 98$ & $09 / 24 / 98$ & $12 / 15 / 98$ \\
\hline Water elevation $^{\mathrm{a}}$ & $\mathrm{m}$ & 226.18 & 225.38 & 225.48 & 225.71 \\
\hline Temperature & ${ }^{\circ} \mathrm{C}$ & 7.8 & 11.1 & 15.7 & 12.9 \\
\hline $\mathrm{pH}$ & $\mathrm{pH}$ & 7.12 & 7.00 & 7.09 & 7.04 \\
\hline Redox & $\mathrm{mV}$ & -2 & -10 & 3 & -1.9 \\
\hline Conductivity & $\mu \mathrm{mhos} / \mathrm{cm}$ & 2,120 & 2,080 & 2,190 & 2,080 \\
\hline Chloride $^{b}$ & $\mathrm{mg} / \mathrm{L}$ & 374 & 400 & 377 & 326 \\
\hline Arsenic ${ }^{b}$ & $\mathrm{mg} / \mathrm{L}$ & $<0.0025$ & $<0.0025$ & $<0.0025$ & $<0.0025$ \\
\hline Barium $^{b}$ & $\mathrm{mg} / \mathrm{L}$ & 0.0629 & 0.0636 & 0.0727 & 0.0509 \\
\hline Beryllium $^{b}$ & $\mathrm{mg} / \mathrm{L}$ & $<0.0002$ & $<0.0002$ & $<0.0002$ & $<0.0002$ \\
\hline Cadmium $^{b}$ & $\mathrm{mg} / \mathrm{L}$ & $<0.0001$ & $<0.0001$ & $<0.0001$ & $<0.0001$ \\
\hline Chromium $^{b}$ & $\mathrm{mg} / \mathrm{L}$ & $<0.044$ & $<0.044$ & $<0.044$ & $<0.044$ \\
\hline Cobalt $^{b}$ & $\mathrm{mg} / \mathrm{L}$ & $<0.026$ & $<0.026$ & $<0.026$ & $<0.026$ \\
\hline Copper $^{b}$ & $\mathrm{mg} / \mathrm{L}$ & $<0.017$ & $<0.017$ & $<0.017$ & $<0.017$ \\
\hline $\operatorname{Iron}^{\mathrm{b}}$ & $\mathrm{mg} / \mathrm{L}$ & 0.4008 & 0.4011 & 0.8277 & 0.4094 \\
\hline Lead $^{b}$ & $\mathrm{mg} / \mathrm{L}$ & $<0.001$ & $<0.001$ & $<0.001$ & $<0.001$ \\
\hline Manganese $^{b}$ & $\mathrm{mg} / \mathrm{L}$ & 0.2845 & 0.2741 & 0.4385 & 0.4475 \\
\hline Mercury ${ }^{b}$ & $\mathrm{mg} / \mathrm{L}$ & $<0.0001$ & $<0.0001$ & $<0.0001$ & $<0.0001$ \\
\hline Nickel $^{\mathrm{b}}$ & $\mathrm{mg} / \mathrm{L}$ & 0.2612 & 0.5052 & 0.5933 & 0.6978 \\
\hline Silver $^{b}$ & $\mathrm{mg} / \mathrm{L}$ & $<0.0005$ & $<0.0010$ & $<0.0005$ & $<0.0005$ \\
\hline Thallium $^{\mathrm{b}}$ & $\mathrm{mg} / \mathrm{L}$ & $<0.0015$ & $<0.0015$ & $<0.0015$ & $<0.0015$ \\
\hline Vanadium $^{\mathrm{b}}$ & $\mathrm{mg} / \mathrm{L}$ & $<0.024$ & $<0.024$ & $<0.024$ & $<0.024$ \\
\hline Zinc $^{b}$ & $\mathrm{mg} / \mathrm{L}$ & $<0.011$ & 0.012 & $<0.011$ & $<0.011$ \\
\hline Cesium-137 & $\mathrm{pCi} / \mathrm{L}$ & $<1.0$ & 1.9 & $<1.0$ & $<1.0$ \\
\hline Hydrogen-3 & $\mathrm{pCi} / \mathrm{L}$ & 156 & 300 & 212 & 229 \\
\hline Strontium-90 & $\mathrm{pCi} / \mathrm{L}$ & $<0.25$ & $<0.25$ & $<0.25$ & $<0.25$ \\
\hline
\end{tabular}

a Well point elevation $=221.95 \mathrm{~m}$ (MSL); ground surface elevation $=227.13 \mathrm{~m}(\mathrm{MSL})$; casing material $=$ stainless steel.

b Filtered sample. 


\section{GROUNDWATER PROTECTION}

TABLE 6.42

Groundwater Monitoring Results, 330 Area Well 330012D, 1998

\begin{tabular}{|c|c|c|c|c|c|c|}
\hline \multirow[b]{2}{*}{ Parameter } & \multirow[b]{2}{*}{ Unit } & \multicolumn{5}{|c|}{ Date of Sampling } \\
\hline & & $03 / 19 / 98$ & 03/19/98 & $06 / 01 / 98$ & $09 / 24 / 98$ & $12 / 15 / 98$ \\
\hline Water elevation ${ }^{2}$ & $\mathrm{~m}$ & 191.18 & 191.18 & 191.44 & 191.29 & 191.30 \\
\hline Temperature & ${ }^{\circ} \mathrm{C}$ & 12.6 & 12.6 & 13.7 & 13.0 & 12.9 \\
\hline $\mathrm{pH}$ & $\mathrm{pH}$ & 7.19 & 7.19 & 7.01 & 7.26 & 6.73 \\
\hline Redox & $\mathrm{mV}$ & -6 & -6 & -12 & -6 & 20 \\
\hline Conductivity & $\mu \mathrm{mhos} / \mathrm{cm}$ & 1,162 & 1,162 & 1,332 & 1,182 & 1,139 \\
\hline Chloride $^{b}$ & $\mathrm{mg} / \mathrm{L}$ & 43 & 44 & 42 & 51 & 45 \\
\hline Arsenic $^{b}$ & $\mathrm{mg} / \mathrm{L}$ & $<0.0025$ & 0.0029 & 0.0033 & $<0.0025$ & $<0.0025$ \\
\hline Barium $^{b}$ & $\mathrm{mg} / \mathrm{L}$ & 0.0744 & 0.0075 & 0.0751 & 0.0670 & 0.0706 \\
\hline Beryllium $^{b}$ & $\mathrm{mg} / \mathrm{L}$ & $<0.0002$ & $<0.0002$ & $<0.0002$ & $<0.0002$ & $<0.0002$ \\
\hline Cadmium $^{\mathrm{b}}$ & $\mathrm{mg} / \mathrm{L}$ & $<0.0001$ & $<0.0001$ & $<0.0001$ & $<0.0001$ & $<0.0001$ \\
\hline Chromium $^{b}$ & $\mathrm{mg} / \mathrm{L}$ & $<0.044$ & $<0.044$ & $<0.044$ & $<0.044$ & $<0.044$ \\
\hline Cobalt $^{\mathrm{b}}$ & $\mathrm{mg} / \mathrm{L}$ & $<0.026$ & $<0.026$ & $<0.026$ & $<0.026$ & $<0.026$ \\
\hline Copper $^{b}$ & $\mathrm{mg} / \mathrm{L}$ & $<0.017$ & $<0.017$ & $<0.017$ & $<0.017$ & $<0.017$ \\
\hline Iron $^{b}$ & $\mathrm{mg} / \mathrm{L}$ & 0.4521 & 0.5608 & 0.5021 & 0.3948 & 0.4825 \\
\hline Lead $^{\mathrm{b}}$ & $\mathrm{mg} / \mathrm{L}$ & $<0.001$ & $<0.001$ & $<0.001$ & $<0.001$ & $<0.001$ \\
\hline Manganese ${ }^{b}$ & $\mathrm{mg} / \mathrm{L}$ & 0.0611 & 0.0626 & 0.0309 & 0.0733 & 0.0512 \\
\hline Mercury ${ }^{b}$ & $\mathrm{mg} / \mathrm{L}$ & $<0.0001$ & $<0.0001$ & $<0.0001$ & $<0.0001$ & $<0.0001$ \\
\hline Nickel $^{b}$ & $\mathrm{mg} / \mathrm{L}$ & $<0.04$ & $<0.04$ & $<0.04$ & $<0.04$ & $<0.04$ \\
\hline Silver ${ }^{b}$ & $\mathrm{mg} / \mathrm{L}$ & $<0.0005$ & $<0.0005$ & $<0.0005$ & $<0.0005$ & $<0.0005$ \\
\hline Thallium $^{\mathrm{b}}$ & $\mathrm{mg} / \mathrm{L}$ & $<0.001$ & $<0.0015$ & $<0.0015$ & $<0.0015$ & $<0.0015$ \\
\hline Vanadium ${ }^{\mathrm{b}}$ & $\mathrm{mg} / \mathrm{L}$ & $<0.024$ & $<0.024$ & $<0.024$ & $<0.024$ & $<0.024$ \\
\hline Zinc $^{\mathrm{b}}$ & $\mathrm{mg} / \mathrm{L}$ & $<0.011$ & $<0.011$ & $<0.011$ & $<0.011$ & $<0.011$ \\
\hline Cesium-137 & $\mathrm{pCi} / \mathrm{L}$ & 1.3 & $<1.0$ & $<1.0$ & $<1.0$ & $<1.0$ \\
\hline Hydrogen-3 & $\mathrm{pCi} / \mathrm{L}$ & 157 & 181 & $<100$ & 384 & 184 \\
\hline Strontium-90 & $\mathrm{pCi} / \mathrm{L}$ & 0.39 & 0.43 & $<0.25$ & 0.49 & 0.28 \\
\hline
\end{tabular}

a Well point elevation $=185.65 \mathrm{~m}(\mathrm{MSL})$; ground surface elevation $=227.13 \mathrm{~m}(\mathrm{MSL})$; casing material $=$ stainless steel.

b Filtered sample. 
6. GROUNDWATER PROTECTION

\section{TABLE 6.43}

Groundwater Monitoring Wells: 330 Area/CP-5 Reactor

\begin{tabular}{lccccc}
\hline $\begin{array}{c}\text { WD } \\
\text { Number }\end{array}$ & $\begin{array}{c}\text { Well } \\
\text { (m bgs) }\end{array}$ & $\begin{array}{c}\text { Ground } \\
\text { Elevation } \\
\text { (m AMSL) }\end{array}$ & $\begin{array}{c}\text { Monitoring } \\
\text { Zone } \\
\text { (m AMSL) }\end{array}$ & $\begin{array}{c}\text { Well } \\
\text { Type }^{\mathrm{a}}\end{array}$ & $\begin{array}{c}\text { Date } \\
\text { Drilled }\end{array}$ \\
\hline 330011 & 6.1 & 227.10 & $224.2-221.1$ & $0.05 / \mathrm{PVC}$ & $8 / 89$ \\
330021 & 5.8 & 227.75 & $226.3-221.7$ & $0.05 / \mathrm{SS}$ & $9 / 93$ \\
330031 & 5.2 & 227.13 & $225.6-221.0$ & $0.05 / \mathrm{SS}$ & $9 / 93$ \\
$330012 \mathrm{D}$ & 41.5 & 227.13 & $191.7-185.6$ & $0.05 / \mathrm{SS}$ & $6 / 97$ \\
\hline \multicolumn{7}{c}{} \\
a Inner diameter (m)/well material (PVC $=$ polyvinyl chloride, \\
SS = stainless steel).
\end{tabular}

As in previous years, hydrogen-3 was detected in 330011, 330021, and 330031 each quarter. The levels of hydrogen- 3 ranged from less than 100 to $927 \mathrm{pCi} / \mathrm{L}$. Hydrogen-3 was also detected each quarter in samples from 330012D at low levels of less than 100 to $384 \mathrm{pCi} / \mathrm{L}$. Strontium-90 was detected in 330011 and $330012 \mathrm{D}$, and the levels ranged from less than 0.25 to $0.66 \mathrm{pCi} / \mathrm{L}$. Cesium-137 was detected occasionally, and the levels ranged from less than 1.0 to $1.9 \mathrm{pCi} / \mathrm{L}$.

The CP-5 was a heavy-water-moderated reactor. During its operational life, several incidents occurred that released small amounts of this heavy water containing high concentrations of hydrogen-3 to the environment. In addition, the normal operation released significant amounts of water vapor containing hydrogen- 3 from the main ventilation system that may have condensed and fallen to the ground in the form of precipitation. These activities are believed to be responsible for the residual amounts of hydrogen-3 now found in the groundwater. All the hydrogen-3 monitoring results for the CP-5 wells are plotted in Figure 6.19. The source of the strontium-90 and cesium-137 is not known. 


\section{GROUNDWATER PROTECTION}

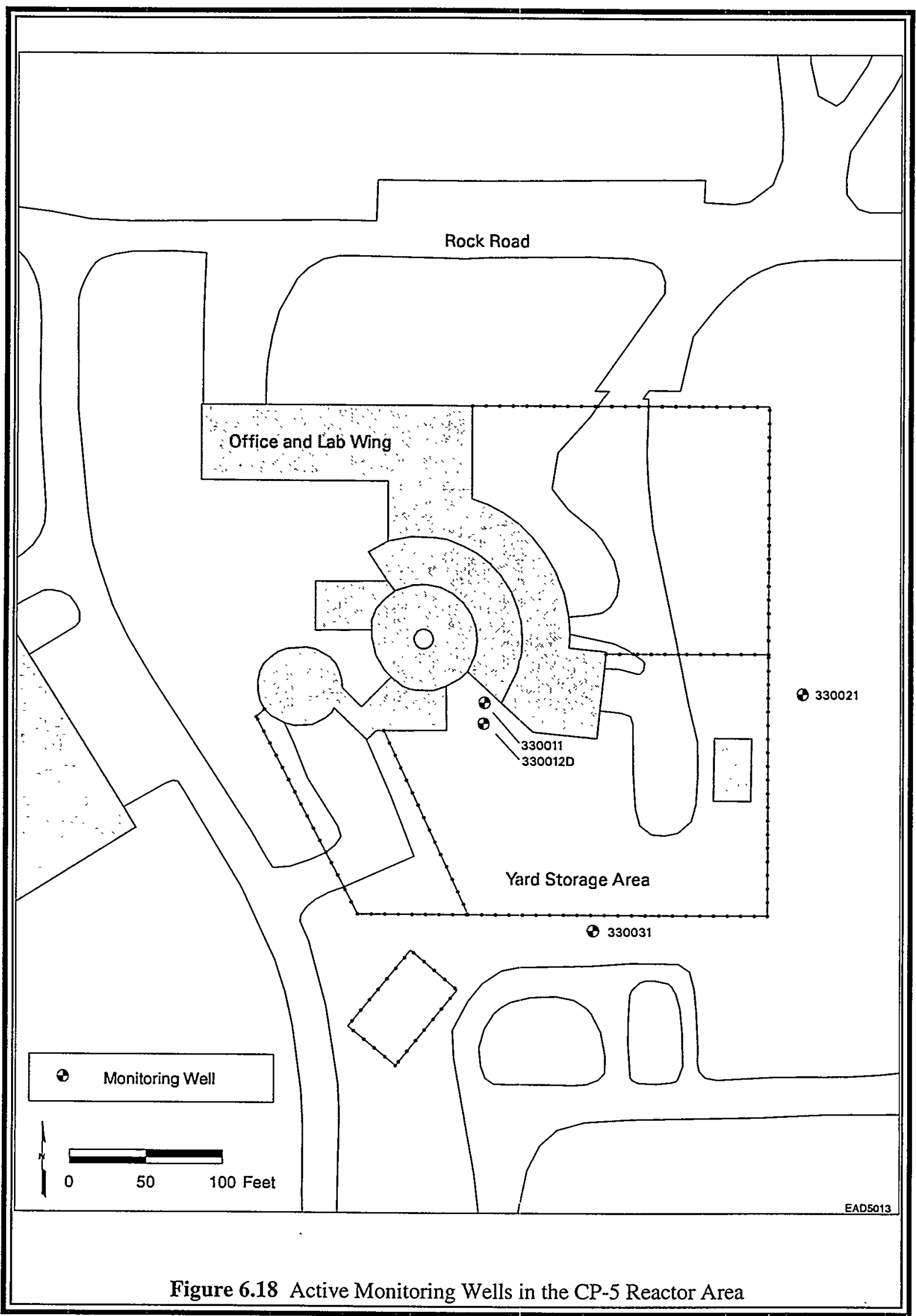




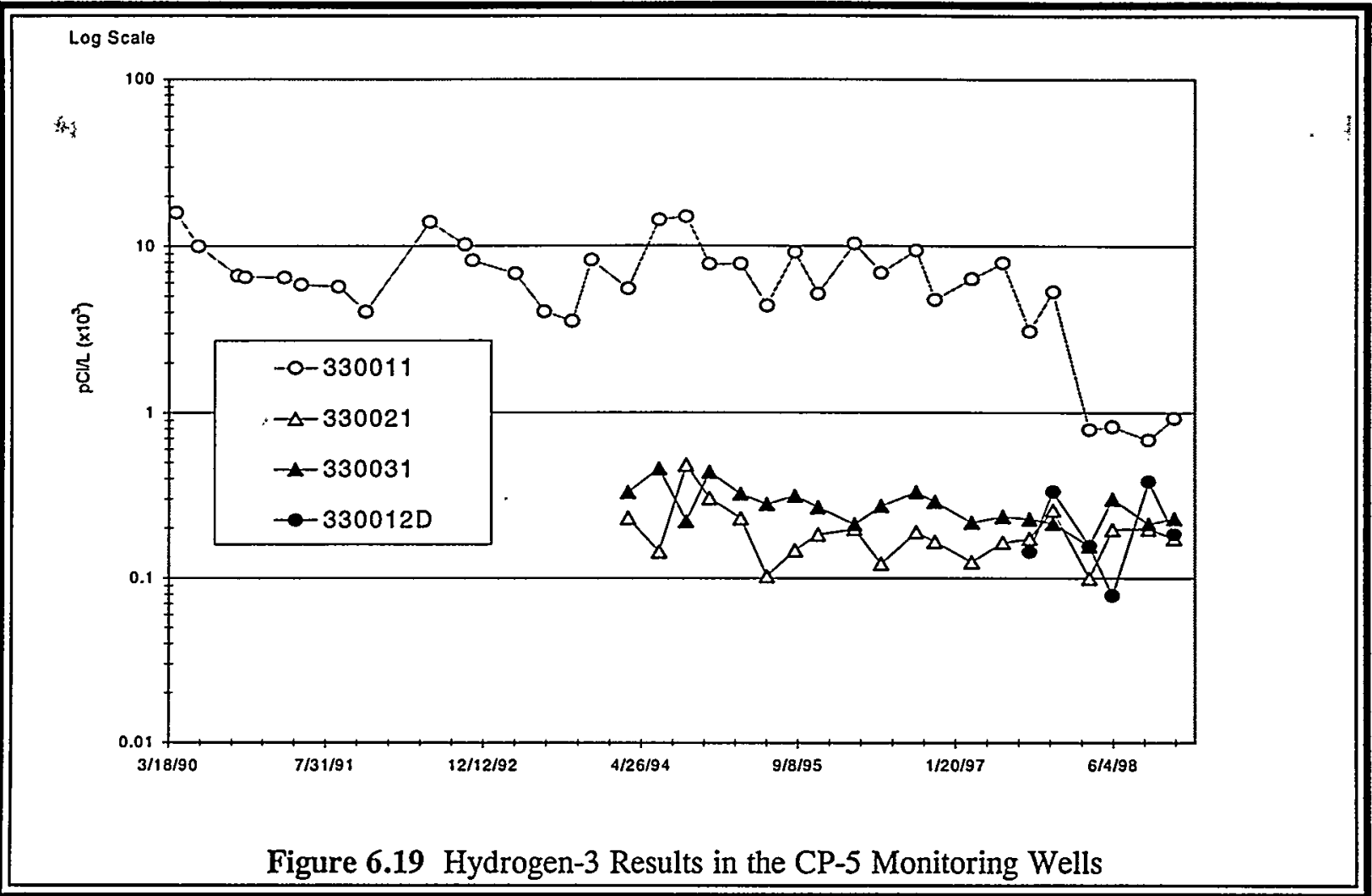

\subsection{Site Remediation Activities}

\subsubsection{7/319 Area}

The cleanup of contaminants in the soil and groundwater in the 317 and 319 Areas has been ongoing for several years. An extensive site characterization project, known as a RCRA Facility Assessment, was completed in 1997. This study identified the nature and extent of contaminants in the various media present. On the basis of the information generated by this study, a series of remedial actions was completed prior to 1998 . These actions included the construction of a subsurface barrier wall and a leachate collection system and groundwater collection system south of the 319 Landfill waste mound. These actions have dramatically lowered the amount of hydrogen-3 present in storm water runoff downstream of the 319 Landfill. In the 317 Area, a belowground drain line, known as the East Vaults Footing Drain, was partially plugged and sealed to prevent migration of contaminated groundwater. In addition, 13 groundwater extraction wells 


\section{GROUNDWATER PROTECTION}

were installed south of the 317 Area to intercept contaminated groundwater before it flows off site. A small unit (318 Area) used for disposal of an undetermined number of small compressed gas cylinders, which were found to be damaged or leaking, was closed by the construction of a protective concrete cover. Also, four in-ground concrete radioactive waste storage vaults that are no longer needed were decontaminated and demolished in place.

Remedial actions in the 317 Area continued during 1998. The principal action completed was the treatment of contaminated soil in the vicinity of the 317 Area French Drain. An innovative treatment technology was used to remove VOCs from the soil. This technology, known as soil mixing with thermally enhanced soil vapor extraction, utilized a large hydraulic soil mixing apparatus to break up and mix a column of soil up to a depth of $9 \mathrm{~m}(30 \mathrm{ft})$. Once the soil was mixed, a mixture of hot air and steam was injected into the soil column, thereby driving the volatile organic contaminants off of the soil and into the hot air stream. The VOC-laden off-gas was captured in a hood and directed to a gas treatment system that removed the organic contaminants from the gas stream. In addition to this process, ANL-E developed a "polishing" treatment system that was integrated with the soil mixing process. This polishing treatment reduced the final concentration of organics to well below that which would have been left in place by the soil mixing alone. This integrated treatment process was used to treat the highly contaminated regions of the 317 Area French Drain. Approximately $80 \%$ of the contaminants present in the 317 Area French drain were removed. The remaining contaminants will be treated by phytoremediation (see Section 6.2.1).

\subsubsection{Building 24}

Building 24 was a former boiler house that also served as a storage building after removal of the boiler. It was located in the East Area of the ANL-E site. It briefly housed a small research reactor used for training purposes. In recent years, it was used to store a variety of equipment and materials. 


\section{GROUNDWATER PROTECTION}

The internal drainage system for the building included a belowground settling tank that discharged to the storm drainage system. This tank contained small amounts of sludge that contained very low amounts of hazardous chemicals and radioactive materials. This tank was removed during 1998, and soil surrounding and underlying the tank was removed and shipped off site for disposal. Samples of soil were collected and revealed that there was no leakage from the tank. The excavation was then filled, thus completing the remedial action.

Two of the soil samples from beneath the tank were found to contain several VOCs. These compounds were not related to the operation of the settling tank itself. The discovery of these compounds indicates that a previously unknown region of contaminated soil exists in the East Area. A characterization study will be performed to determine the extent of this contamination.

\subsubsection{Building 34}

A work plan for the characterization of the area surrounding a former wastewater treatment facility in the East Area was prepared and transmitted to the IEPA. This study will determine whether residual contamination of soil or groundwater exists in this area.

\subsubsection{Characterization Studies of the Seeps South of the 300 Area}

In spring 1996, during the RCRA Facility Investigation of the 317/319 Area, a series of groundwater seeps was discovered in a network of steeply eroded ravines in the Waterfall Glen Forest Preserve south and southeast of the 317 and 319 Areas. Three seeps (SP01, SP02, and SP04) are located about $200 \mathrm{~m}$ (600 ft) south of the 319 Area; two other seeps (SP03 and SP05) are located about $360 \mathrm{~m}(1,200 \mathrm{ft})$ south of the 317 Area. The locations are shown in Figure 6.20. The seeps are in ravines that are located in a pristine, heavily wooded section of the forest preserve; they carry storm water discharges from the 317 and 319 Areas. Water emanating from the seeps flows to the nearby ravine, where it forms a small rivulet in the bottom of the ravine. Approximately $30 \mathrm{~m}$ (100 ft) downstream of the seep area, the affected water from the seeps is no 


\section{GROUNDWATER PROTECTION}

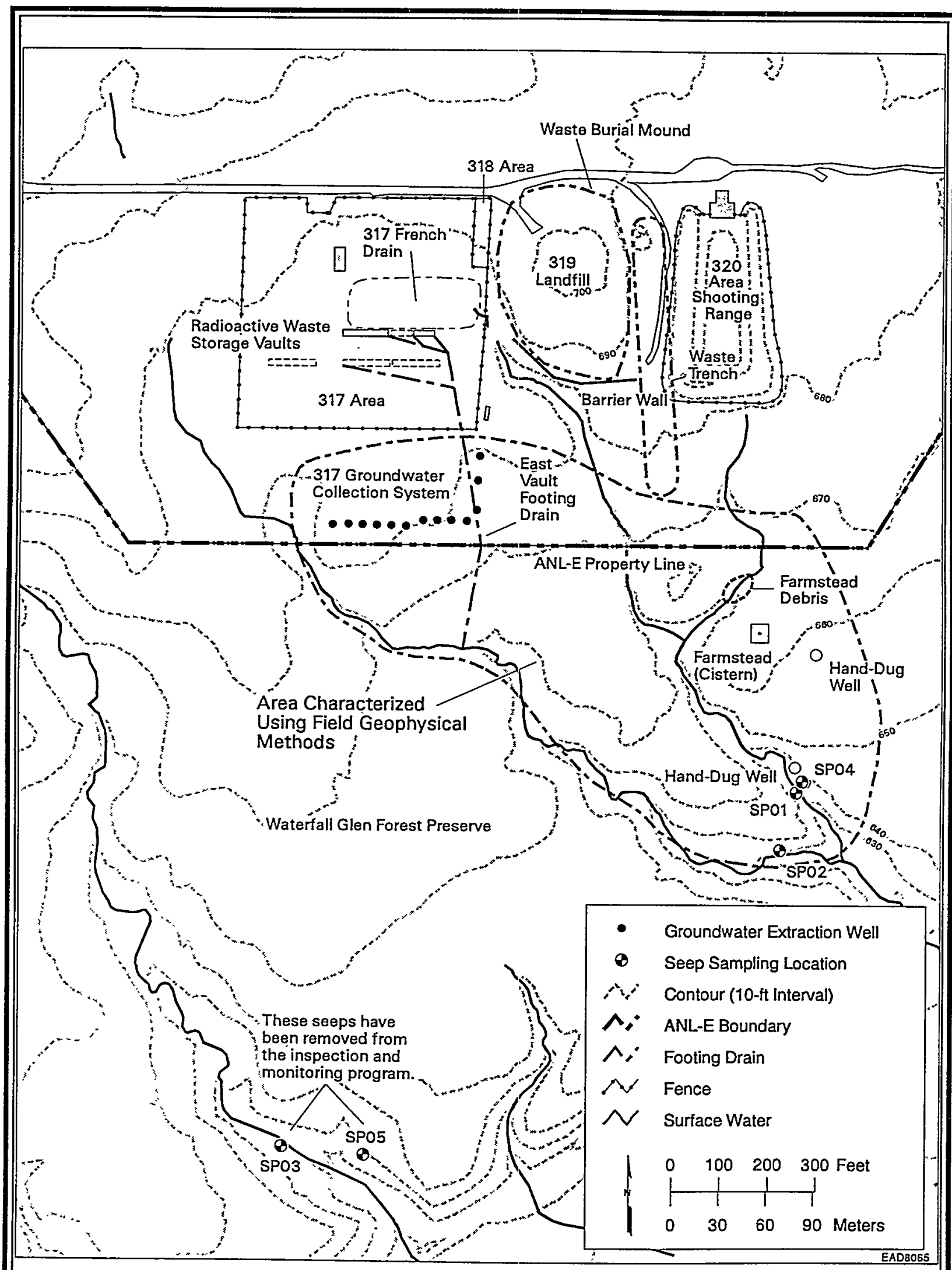

Figure 6.20 Seep Locations South of the 317/319 Area 


\section{GROUNDWATER PROTECTION}

longer visible because it drains back into the soil in the bed of the ravine. During extended dry weather conditions, the flow disappears completely. The IEPA has designated this area as AOC-G - Off-Site Groundwater Seeps (South of the 317/319/ENE Area).

Samples were collected at three different times from the five seep locations and analyzed for metals, VOCs, and selected radionuclides. Two groundwater seeps contained measurable levels of three VOCs - carbon tetrachloride, chloroform, and tetrachloroethene. Carbon tetrachloride and tetrachloroethene concentrations exceeded the Class I Groundwater Quality Standards. The other three seeps did not contain any quantifiable VOCs. Three of the five seeps, including the two containing the VOCs, were found to contain hydrogen-3 in measurable concentrations. Since the initial samples were collected, monthly samples were obtained through the end of 1997, and quarterly samples collected to the end of 1998. The concentrations of hydrogen-3 and the three VOCs for all the samples that were collected are summarized in Table 6.44 for SP01, Table 6.45 for SP02, and in Table 6.46 for SP04. Samples from the two other seeps, SP03 and SP05, appeared to be at background levels for the parameters of interest.

In general, the VOC concentrations have been relatively constant over the monitoring period. For SP01, carbon tetrachloride concentrations have been present in essentially every sample and have been in the $10-$ to $20-\mu \mathrm{g} / \mathrm{L}$ range. Chloroform concentrations were mostly below the detection limit, while tetrachloroethene was always below the detection limit. All VOC concentrations in seep water from SP02 were below the detection limits. The carbon tetrachloride concentrations in the water from seep SP04 had the highest values, typically in the 200- to $300-\mu \mathrm{g} / \mathrm{L}$ range; the highest single result was $340 \mu \mathrm{g} / \mathrm{L}$. Chloroform concentrations averaged about $30 \mu \mathrm{g} / \mathrm{L}$, while tetrachloroethene was about $7 \mu \mathrm{g} / \mathrm{L}$.

The hydrogen- 3 concentrations varied significantly with time. Seep water from both SP01 and SP02 ranged in concentration from the detection limit to approximately $2,500 \mathrm{pCi} / \mathrm{L}$. No seasonal pattern appears to exist. Only a few hydrogen-3 concentrations in the seep water from SP04 were above the detection limit. The hydrogen-3 concentrations appear to be less predictable than the VOC concentrations. 
TABLE 6.44

Contaminant Concentrations in SP01 Seep Water

\begin{tabular}{|c|c|c|c|c|}
\hline $\begin{array}{c}\text { Date } \\
\text { Collected } \\
\end{array}$ & $\begin{array}{l}\text { Hydrogen-3 } \\
(\mathrm{pCi} / \mathrm{L})\end{array}$ & $\begin{array}{c}\text { Carbon } \\
\text { Tetrachloride } \\
(\mu \mathrm{g} / \mathrm{L})\end{array}$ & $\begin{array}{c}\text { Chloroform } \\
(\mu \mathrm{g} / \mathrm{L})\end{array}$ & $\begin{array}{c}\text { Tetrachloroethene } \\
(\mu \mathrm{g} / \mathrm{L})\end{array}$ \\
\hline May 3, 1996 & $<540$ & 85 & 13 & $<5$ \\
\hline July 12,1996 & NA & 82 & 25 & $<5$ \\
\hline August 29, 1996 & 580 & 56 & 14 & $<5$ \\
\hline December 29, 1996 & 1,688 & 10 & $<5$ & $<5$ \\
\hline January 24, 1997 & 1,880 & 7 & $<5$ & $<5$ \\
\hline February 27, 1997 & 1,540 & 9 & $<5$ & $<5$ \\
\hline March 18, 1997 & 1,950 & $<5$ & $<5^{\circ}$ & $<5$ \\
\hline April 23, 1997 & 2,090 & $N A^{a}$ & $\mathrm{NA}$ & NA \\
\hline May 27, 1997 & 2,310 & 8 & $<5$ & $<5$ \\
\hline June 17,1997 & 2,190 & 9 & $<5$ & $<5$ \\
\hline July 23,1997 & 2,050 & 10 & $<5$ & $<5$ \\
\hline August 31, 1997 & 1,640 & 9 & $<5$ & $<5$ \\
\hline September 25, 1997 & 540 & $<5$ & $<5$ & $<5$ \\
\hline October 29, 1997 & 790 & 11 & $<5$ & $<5$ \\
\hline November 26, 1997 & 790 & 15 & 5 & $<5$ \\
\hline December 19, 1997 & 420 & 13 & $<5$ & $<5$ \\
\hline January 12,1998 & 1,190 & 10 & $<5$ & $<5$ \\
\hline March 5, 1998 & 1,730 & 10 & $<5$ & $<5$ \\
\hline April 30, 1998 & 860 & 8 & $<5$ & $<5$ \\
\hline August 13, 1998 & 530 & 10 & $<5$ & $<5$ \\
\hline November 23, 1998 & 870 & 14 & $<5$ & $<5$ \\
\hline
\end{tabular}

a $\mathrm{NA}=$ not applicable. 


\section{GROUNDWATER PROTECTION}

TABLE 6.45

Contaminant Concentrations in SP02 Seep Water

\begin{tabular}{lcccc}
\hline \multicolumn{1}{c}{$\begin{array}{c}\text { Date } \\
\text { Collected }\end{array}$} & $\begin{array}{c}\text { Hydrogen-3 } \\
(\mathrm{pCi} / \mathrm{L})\end{array}$ & $\begin{array}{c}\text { Carbon } \\
\text { Tetrachloride } \\
(\mu \mathrm{g} / \mathrm{L})\end{array}$ & $\begin{array}{c}\text { Chloroform } \\
(\mu \mathrm{g} / \mathrm{L})\end{array}$ & $\begin{array}{c}\text { Tetrachloroethene } \\
(\mu \mathrm{g} / \mathrm{L})\end{array}$ \\
\hline May 3, 1996 & $<528$ & $<5$ & $<5$ & $<5$ \\
July 12, 1996 & $<528$ & $<5$ & $<5$ & $<5$ \\
December 29, 1996 & 1,660 & $<5$ & $<5$ & $<5$ \\
March 18, 1997 & 420 & $<5$ & $<5$ & $<5$ \\
June 17, 1997 & NA & $<5$ & $<5$ & $<5$ \\
September 25, 1997 & 2,560 & $<5$ & $<5$ & $<5$ \\
October 29, 1997 & Dry & Dry & Dry & Dry \\
November 26, 1997 & 950 & $<5$ & $<5$ & $<5$ \\
December 19, 1997 & 2,640 & $<5$ & $<5$ & $<5$ \\
January 12, 1998 & 2,690 & $<5$ & $<5$ & $<5$ \\
March 5, 1998 & 2,180 & $<5$ & $<5$ & $<5$ \\
April 30, 1998 & $<320$ & $<5$ & $<5$ & $<5$ \\
August 13, 1998 & 640 & $<5$ & $<5$ & $<5$ \\
November 23, 1998 & 760 & $<5$ & $<5$ & $<5$ \\
\hline
\end{tabular}




\section{GROUNDWATER PROTECTION}

TABLE 6.46

Contaminant Concentrations in SP04 Seep Water

\begin{tabular}{|c|c|c|c|c|}
\hline $\begin{array}{c}\text { Date } \\
\text { Collected } \\
\end{array}$ & $\begin{array}{c}\text { Hydrogen-3 } \\
(\mathrm{pCi} / \mathrm{L})\end{array}$ & $\begin{array}{c}\text { Carbon } \\
\text { Tetrachloride } \\
(\mu \mathrm{g} / \mathrm{L}) \\
\end{array}$ & $\begin{array}{c}\text { Chloroform } \\
(\mu \mathrm{g} / \mathrm{L})\end{array}$ & $\begin{array}{c}\text { Tetrachloroethene } \\
(\mu \mathrm{g} / \mathrm{L})\end{array}$ \\
\hline July 12,1996 & $<531$ & 340 & 24 & 6 \\
\hline August 29, 1996 & $N A^{a}$ & 120 & 15 & $<5$ \\
\hline December 29, 1996 & $<330$ & 230 & 36 & 5 \\
\hline January 24, 1997 & 430 & 230 & 29 & 6 \\
\hline February 27, 1997 & 880 & 290 & 29 & 7 \\
\hline March 18, 1997 & $<370$ & 67 & 8 & $<5$ \\
\hline April 23, 1997 & $<370$ & 170 & 30 & 6 \\
\hline May 27, 1997 & $<360$ & 270 & 24 & 9 \\
\hline June 17, 1997 & $<360$ & 260 & 30 & 6 \\
\hline July 23, 1997 & $<420$ & 240 & 35 & 8 \\
\hline August 31,1997 & $<350$ & 240 & 28 & 5 \\
\hline September 25, 1997 & $<350$ & 220 & 31 & 6 \\
\hline October 29, 1997 & $<310$ & 330 & 37 & 8 \\
\hline November 26, 1997 & $<360$ & 280 & 31 & 8 \\
\hline December 19, 1997 & $<360$ & 260 & 31 & 7 \\
\hline January 12, 1998 & $<350$ & 240 & 31 & $<5$ \\
\hline March 5, 1998 & $<380$ & 200 & 29 & 8 \\
\hline April 30, 1998 & $<320$ & 200 & 27 & 7 \\
\hline August 13, 1998 & $<200$ & 270 & 33 & 8 \\
\hline November 23, 1998 & 380 & 260 & 28 & 6 \\
\hline
\end{tabular}

a $\mathrm{NA}=$ not applicable. 


\section{GROUNDWATER PROTECTION}

In addition to the monitoring activities associated with the seeps, a more focused investigation was conducted during 1997. The investigation consisted of shallow soil, subsurface soil and groundwater sampling, as well as utilization of geophysical methods, geologic mapping of ravine exposures, and aquifer pump testing. The study data indicate that the source of the VOCs in the seeps is located on the ANL-E site; the highest concentrations are located immediately east and north of SP01, SP02, and SP04. This region can be traced upgradient, toward the 319 Landfill and French Drain, where lower concentrations of these VOCs have been found. It appears that the VOCs in the seeps and in groundwater near the seeps originated as a spill or other release from the 319 Landfill.

The presence of hydrogen- 3 in the seep water supports the hypothesis that the 319 Area is the source of the contamination, because groundwater beneath the landfill contains hydrogen- 3 at much higher concentrations. Hydrogen-3 was also detected in the 317 Area groundwater but at much lower concentrations. In addition, the mix of VOCs in groundwater under the 319 Landfill is different than the mix under the 317 Area but consistent with the mix found at the seeps. Geophysical characterization of the area indicates that there is a groundwater divide between the 317 and 319 Areas. The depth of contamination in the study areas is less well understood because the sampling techniques limited the sample collection depth to the upper regions of the glacial till. Because of the presence of the highly impermeable Lemont Drift underlying the more permeable Wadsworth till, the affected groundwater is almost certain to be limited to the upper permeable zones in the Wadsworth till. The seep monitoring and the area characterization study appear to have adequately described the source and pathway of the hydrogen-3 and VOC contaminants. 


\section{GROUNDWATER PROTECTION}




\section{QUALITY ASSURANCE}

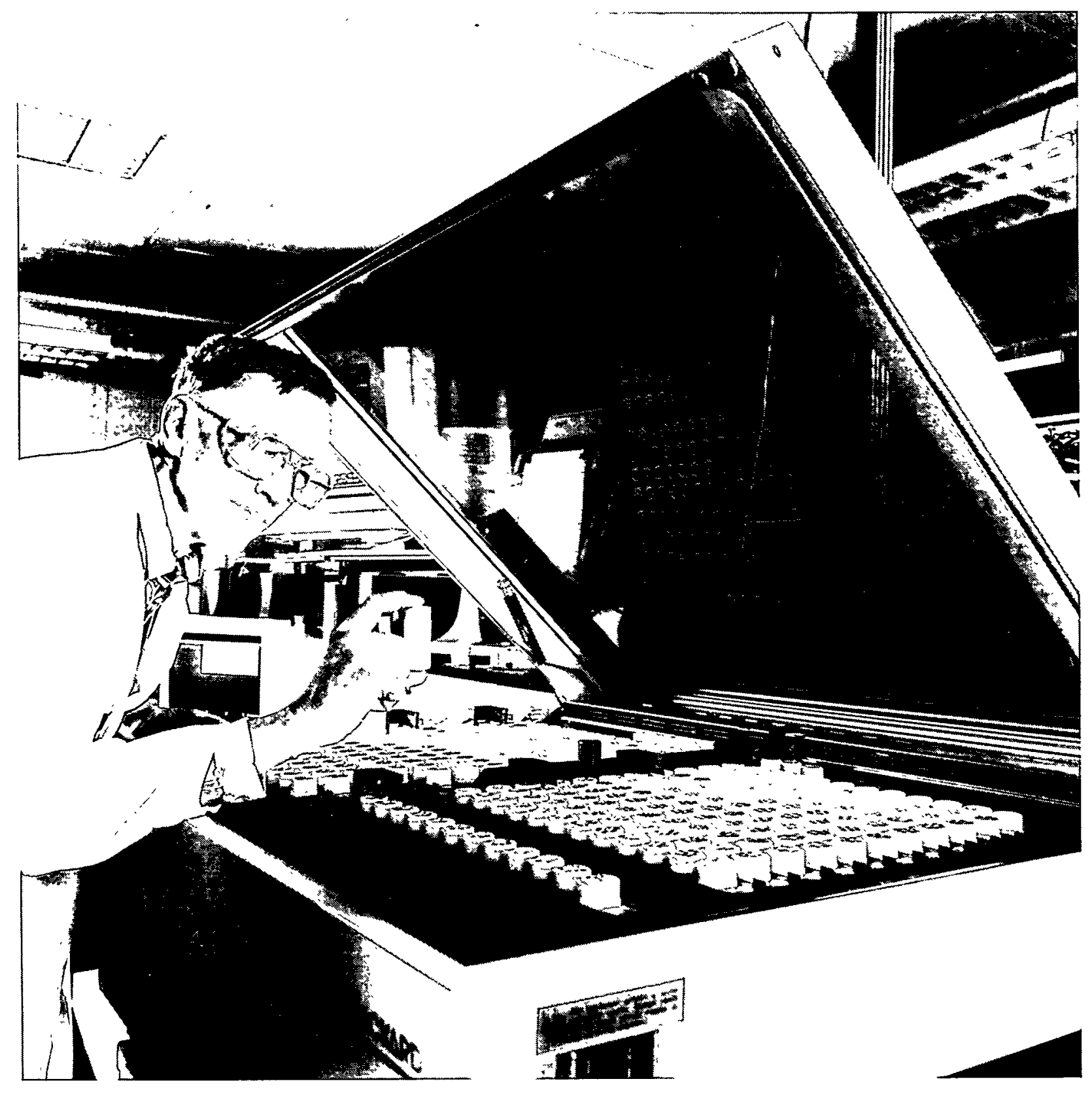

ANL-E Site Environmental Report 


\section{QUALITY ASSURANCE}




\section{QUALITY ASSURANCE}

QA plans exist for both radiological and nonradiological analyses; these QA documents were prepared in accordance with DOE Order $5700.6 \mathrm{C}^{29}$ and discuss who is responsible for QA and for auditing analyses. Both documents are supplemented by operating manuals.

\subsection{Sample Collection}

Many factors enter into an overall QA program other than the analytical quality control. Representative sampling is of prime importance. Appropriate sampling protocols are followed for each type of sampling being conducted. Water samples are pretreated in a manner designed to maintain the integrity of the analytical constituent. For example, samples for trace radionuclide analyses are acidified immediately after collection to prevent hydrolytic loss of metal ions and are filtered to reduce leaching from suspended solids.

The monitoring wells are sampled using the protocols listed in the RCRA Ground-Water Monitoring Technical Enforcement Guidance Document. ${ }^{28}$ The volume of water in the casing is determined by measuring the water depth from the surface and the depth to the bottom of the well. This latter measurement also determines whether siltation has occurred that might restrict water movement in the screened area. For those wells in the glacial till that do not recharge rapidly, the well is emptied, and the volume removed is compared with the calculated volume. In most cases, these volumes are nearly identical. The well is then sampled by bailing with a Teflon bailer. If samples for parameters such as priority pollutants are collected, field parameters for these samples ( $\mathrm{pH}$, specific conductance, redox potential, and temperature) are measured per well volume while purging. For samples in the porous, saturated zone that recharges rapidly, three well volumes are purged by using submersible pumps. If field parameters are measured, samples are collected as soon as these readings stabilize. All samples are placed in precleaned bottles, labeled, and preserved. All field measurement and sampling equipment is cleaned by field rinsing with Type II deionized water. The samples are transferred to the analytical laboratory via a computer floppy disk that generates a one-page list of all samples. This list acts as the chain of custody transfer document. 


\subsection{Radiochemical Analysis and Radioactivity Measurements}

All nuclear instrumentation is calibrated with standard sources obtained from or traceable to the National Institute of Standards and Technology (NIST). The equipment is usually checked daily with secondary counting standards to ensure proper operation. Samples are periodically analyzed in duplicate or with the addition of known amounts of a radionuclide to check precision and accuracy. When a nuclide is not detected, the result is given as "less than" $(<)$ the detection limit by the analytical method used. The detection limits are chosen so that the measurement uncertainty at the $95 \%$ confidence level is equal to the measured value. The air and water detection limits for all radionuclides for which measurements were made in 1998 are given in Table 7.1. The relative error in a result decreases with increasing concentration. At a concentration equal to twice the detection limit, the error is approximately $50 \%$ of the measured value; at 10 times the detection limit, the error is approximately $10 \%$.

Average values are usually accompanied by a plus-or-minus $( \pm)$ limit value. Unless otherwise stated, this value is the standard error at the $95 \%$ confidence level calculated from the standard deviation of the average. The \pm limit value is a measure of the range in the concentrations encountered at that location; it does not represent the conventional uncertainty in the average of repeated measurements on the same or identical samples. Because many of the variations observed in environmental radioactivity are not random but occur for specific reasons (e.g., seasonal variations), samples collected from the same location at different times are not replicates. The more random the variation in activity at a particular location, the closer the confidence limits will represent the actual distribution of values at that location. The averages and confidence limits should be interpreted with this in mind. When a \pm value accompanies an individual result in this report, it represents the statistical counting error at the $95 \%$ confidence level. 
TABLE 7.1

Air and Water Detection Limits

\begin{tabular}{lll}
\multicolumn{1}{c}{\begin{tabular}{c} 
Nuclide or \\
\multicolumn{1}{c}{ Activity }
\end{tabular}} & $\begin{array}{c}\text { Air } \\
\left(\mathrm{fCi} / \mathrm{m}^{3}\right)\end{array}$ & $\begin{array}{c}\text { Water } \\
(\mathrm{pCi} / \mathrm{L})\end{array}$ \\
\hline Americium-241 & - $^{\mathrm{a}}$ & 0.001 \\
Beryllium-7 & 5 & - \\
Californium-249 & - & 0.001 \\
Californium-252 & - & 0.001 \\
Cesium-137 & 0.1 & 1 \\
Curium-242 & - & 0.001 \\
Curium-244 & - & 0.001 \\
Hydrogen-3 & - & 100 \\
Lead-210 & 1 & - \\
Neptunium-237 & - & 0.001 \\
Plutonium-238 & 0.0001 & 0.001 \\
Plutonium-239 & 0.0001 & 0.001 \\
Radium-226 & - & 0.1 \\
Radium-228 & - & 0.1 \\
Strontium-89 & 0.1 & 2 \\
Strontium-90 & 0.01 & 0.25 \\
Thorium-228 & 0.001 & - \\
Thorium-230 & 0.001 & - \\
Thorium-232 & 0.001 & - \\
Uranium-234 & 0.001 & 0.01 \\
Uranium-235 & 0.001 & 0.01 \\
Uranium-238 & 0.001 & 0.01 \\
Uranium - natural & 0.02 & 0.2 \\
Alpha & 0.2 & 0.2 \\
Beta & 0.5 & 1 \\
\hline & & \\
\hline
\end{tabular}

a A hyphen indicates that a value is not required. 


\section{QUALITY ASSURANCE}

ANL-E continues to participate in the DOE Environmental Measurements Laboratory Quality Assurance Program (DOE-EML-QAP), which consists of semiannual distribution of three different sample matrices containing various combinations of radionuclides that are analyzed. Table 7.2 summarizes the results for 1998. In the table, the EML value, which is the result of duplicate determinations by that laboratory, is compared with the average value obtained in the ANL-E laboratory. Information that will assist in judging the quality of the results includes the fact that typical uncertainties for ANL-E's analyses are 2 to $50 \%$, and that the uncertainties in the EML results are 1 to $30 \%$ (depending on the nuclide and the amount present). For most analyses for which the differences are large ( $>20 \%$ ), the concentrations were quite low and the differences were within the measurement uncertainties.

Overall, the ANL-E performance in the EML intercomparison studies on the three matrices resulted in over $93 \%$ (54 out of 58) of the analysis being in the DOE-EML-QAP acceptable range. Two samples analyzed by gamma-ray spectrometry fell within the warning category, while one soil sample analyzed for uranium-234 and -238 produced unacceptable results. The ANL-E performance on these samples indicated that the reported results are accurate.

\subsection{Chemical Analysis}

The documentation for nonradiological analyses is contained in the ESH-ASCL Procedure Manual. All samples for NPDES and groundwater are collected and analyzed in accordance with EPA regulations found in 40 CFR Part $136,{ }^{23}$ EPA-600/4-84-017, ${ }^{30}$ and SW-846. ${ }^{8}$

Standard reference materials, traceable to the NIST, exist for most inorganic analyses (see Table 7.3). These are replaced annually. Detection limits are determined with techniques listed in 40 CFR Part $136^{23}$ and are given in Table 7.4. In general, the detection limit is the measure of the variability of a standard material measurement at 5 to 10 times the instrument detection limit as measured over an extended time period. Recovery of inorganic metals, as determined by "spiking" unknown solutions, must be within the range of 75 to $125 \%$. The precision, as determined by analysis of duplicate samples, must be within $20 \%$. These measurements must be 


\section{TABLE 7.2}

Summary of DOE-EML-QAP Samples, 1998

\begin{tabular}{|c|c|c|c|c|c|c|c|}
\hline Matrix & Constituent & Date & Units & EML & ANL-E & Ratio & Comments \\
\hline \multirow[t]{23}{*}{ Air Filter } & Manganese-54 & March & Bq/Filter & 5.44 & 5.94 & 1.09 & Acceptable \\
\hline & & Sept. & & 4.92 & 5.3 & 1.08 & Acceptable \\
\hline & Cobalt-57 & March & & 11.11 & 12.57 & 1.13 & Warning \\
\hline & Cobalt- 60 & March & & 9.09 & 10.06 & 1.11 & Warning \\
\hline & & Sept. & & 9.16 & 9.72 & 1.06 & Acceptable \\
\hline & Strontium-90 & March & & 17.58 & 15.8 & 0.9 & Acceptable \\
\hline & & Sept. & & 1.12 & 1.22 & 1.09 & Acceptable \\
\hline & Antimony-125 & March & & 12.16 & 13.79 & 1.13 & Acceptable \\
\hline & & Sept. & & 8.89 & 10.58 & 1.19 & Acceptable \\
\hline & Cesium-134 & March & & 19.74 & 19.5 & 0.99 & Acceptable \\
\hline & Cesium-137 & March & & 11.86 & 13.22 & 1.12 & Acceptable \\
\hline & & Sept. & & 22.47 & 22.6 & 1.01 & Acceptable \\
\hline & Cerium-144 & March & & 8.21 & 8.71 & 1.06 & Acceptable \\
\hline & Uranium-234 & March & & 0.031 & 0.033 & 1.07 & Acceptable \\
\hline & & Sept. & & 0.26 & 0.29 & 1.12 & Acceptable \\
\hline & Uranium-238 & March & & 0.03 & 0.033 & 1.08 & Acceptable \\
\hline & & Sept. & & 0.26 & 0.28 & 1.08 & Acceptable \\
\hline & Plutonium-238 & March & & 0.069 & 0.072 & 1.04 & Acceptable \\
\hline & & Sept. & & 0.46 & 0.52 & 1.13 & Acceptable \\
\hline & Plutonium-239 & March & & 0.062 & 0.069 & 1.11 & Acceptable \\
\hline & & Sept. & & 0.42 & 0.47 & 1.12 & Acceptable \\
\hline & Americium-241 & March & & 0.069 & 0.071 & 1.03 & Acceptable \\
\hline & & Sept. & & 0.51 & 0.53 & 1.04 & Acceptable \\
\hline \multirow[t]{11}{*}{ Soil } & Potassium-40 & March & $\mathrm{Bq} / \mathrm{kg}$ & 313.5 & 327 & 1.04 & Acceptable \\
\hline & & Sept. & & 314 & 363 & 1.16 & Acceptable \\
\hline & Strontium-90 & March & & 13.09 & 13.22 & 1.01 & Acceptable \\
\hline & & Sept. & & 39.63 & 44.8 & 1.13 & Acceptable \\
\hline & Cesium-137 & March & & 329.5 & 371 & 1.13 & Acceptable \\
\hline & & Sept. & & 954 & 1092 & 1.14 & Acceptable \\
\hline & Thorium-228 & Sept. & & 52.7 & 55.8 & 1.06 & Acceptable \\
\hline & Uranium-234 & March & & 31.13 & 30.26 & 0.97 & Acceptable \\
\hline & & Sept. & & 113 & 174 & 1.54 & Not Acceptable \\
\hline & Uranium-238 & March & & 31.9 & 31.35 & 0.98 & Acceptable \\
\hline & & Sept. & & 120 & 186 & 1.55 & Not Acceptable \\
\hline
\end{tabular}


TABLE 7.2 (Cont.)

\begin{tabular}{|c|c|c|c|c|c|c|c|}
\hline Matrix & Constituent & Date & Units & EML & ANL-E & Ratio & Comments \\
\hline & Plutonium-239 & March & & 5.305 & 5.86 & 1.1 & Acceptable \\
\hline & & Sept. & & 13.09 & 13.64 & 1.04 & Acceptable \\
\hline & Americium-241 & March & & 2.678 & 3.03 & 1.13 & Acceptable \\
\hline & & Sept. & & 7.47 & 7.4 & 0.99 & Acceptable \\
\hline \multirow[t]{20}{*}{ Water } & Hydrogen-3 & March & $\mathrm{Bq} / \mathrm{L}$ & 218.3 & 221.5 & 1.02 & Acceptable \\
\hline & & Sept. & & 75.2 & 79.4 & 1.04 & Acceptable \\
\hline & Manganese-54 & March & & 57 & 65.48 & 1.15 & Acceptable \\
\hline & & Sept. & & 32.4 & 34.8 & 1.07 & Acceptable \\
\hline & Cobalt- 60 & March & & 13.6 & 14.89 & 1.1 & Acceptable \\
\hline & & Sept. & & 49.4 & 50.6 & 1.02 & Acceptable \\
\hline & Strontium-90 & March & & 4.357 & 4.17 & 0.96 & Acceptable \\
\hline & & Sept. & & 2.11 & 2.16 & 1.02 & Acceptable \\
\hline & Cesium-137 & March & & 46 & 50.59 & 1.1 & Acceptable \\
\hline & & Sept. & & 50 & 50.8 & 1.02 & Acceptable \\
\hline & Uranium-234 & March & & 0.396 & 0.43 & 1.08 & Acceptable \\
\hline & & Sept. & & 0.51 & 0.52 & 1.02 & Acceptable \\
\hline & Uranium-238 & March & & 0.396 & 0.43 & 1.08 & Acceptable \\
\hline & & Sept. & & 0.52 & 0.51 & 0.98 & Acceptable \\
\hline & Plutonium-238 & March & & 2.526 & 2.48 & 0.98 & Acceptable \\
\hline & & Sept. & & 1.1 & 1.17 & 1.06 & Acceptable \\
\hline & Plutonium-239 & March & & 1.65 & 1.69 & 1.02 & Acceptable \\
\hline & & Sept. & & 1.41 & 1.57 & 1.11 & Acceptable \\
\hline & Americium-241 & March & & 1.226 & 1.2 & 0.98 & Acceptable \\
\hline & & Sept. & & 1.25 & 1.25 & 1.00 & Acceptable \\
\hline
\end{tabular}

taken for at least $10 \%$ of the samples. Comparison samples for organic constituents were formerly available from the EPA; they are now commercially available under the Cooperative Research and Development Agreement that exists between the EPA and commercial laboratories. In addition, standards are available that are certified by the American Association for Laboratory Accreditation, under a memorandum of understanding with the EPA. Many of these standards were used in this work. At least one standard mixture is analyzed each month; Tables 7.5 and 7.6 show the 1998 results for VOCs and SVOCs, respectively. The recoveries listed are those required by the respective methods. 


\section{TABLE 7.3}

Standard Reference Materials Used for Inorganic Analysis

\begin{tabular}{lc}
\hline Constituent & Reference Material \\
\hline Antimony & HPS-10002-2 \\
Arsenic & HPS-10003-1 \\
Barium & HPS-10004-1 \\
Beryllium & HPS-10005-1 \\
Boron & HPS-10007-4 \\
Cadmium & HPS-10008-1 \\
Chromium & HPS-100012-1 \\
Cobalt & HPS-100013-1 \\
Copper & HPS-100014-1 \\
Iron & HPS-100026-1 \\
Lead & HPS-100028-1 \\
Manganese & HPS-100032-1 \\
Mercury & HPS-100033-1 \\
Nickel & HPS-100036-1 \\
Selenium & HPS-100049-1 \\
Silver & HPS-100051-1 \\
Thallium & HPS-100058-1 \\
Vanadium & HPS-100065-1 \\
Zinc & HPS-100068-1 \\
Sulfate & NIST-SRM 3181 \\
Chloride & NIST-SRM 3182 \\
Fluoride & NIST-SRM 3183 \\
\hline
\end{tabular}

a HPS = High Purity Standards, Inc.; NIST-SRM = National Institute of Standards and Technology - Standard Reference Materials. 
TABLE 7.4

Detection Limit for Metals Analysis, 1998

\begin{tabular}{|c|c|c|}
\hline \multirow[b]{2}{*}{ Constituent } & \multicolumn{2}{|c|}{$\begin{array}{c}\text { Detection Limit } \\
(\mathrm{mg} / \mathrm{L})\end{array}$} \\
\hline & $\mathrm{AA}^{\mathrm{a}}$ & $\mathrm{ICP}^{\mathrm{b}}$ \\
\hline Antimony & 0.0030 & $N A^{c}$ \\
\hline Arsenic & 0.0025 & 0.111 \\
\hline Barium & NA & 0.023 \\
\hline Beryllium & 0.0002 & 0.013 \\
\hline Boron & NA & 0.019 \\
\hline Cadmium & 0.0001 & 0.018 \\
\hline Chromium & 0.020 & 0.015 \\
\hline Cobalt & 0.025 & 0.025 \\
\hline Copper & 0.010 & 0.012 \\
\hline Hexavalent chromium $^{d}$ & 0.006 & $\mathrm{NA}$ \\
\hline Iron & 0.025 & 0.020 \\
\hline Lead & 0.0010 & 0.104 \\
\hline Manganese & 0.015 & 0.007 \\
\hline Mercury & 0.0001 & $\mathrm{NA}$ \\
\hline Nickel & 0.020 & 0.030 \\
\hline Selenium & 0.0030 & 0.138 \\
\hline Silver & 0.0005 & NA \\
\hline Thallium & 0.0015 & 0.167 \\
\hline Vanadium & NA & 0.029 \\
\hline Zinc & 0.010 & 0.015 \\
\hline
\end{tabular}

a $\mathrm{AA}=$ Atomic Absorption Spectroscopy.

b ICP = Inductively Coupled Plasma-Atomic Emission Spectroscopy.

c $\mathrm{NA}=$ not analyzed.

d Spectrophotometric measurement. 
TABLE 7.5

Quality Check Sample Results: Volatile Analyses, 1998

\begin{tabular}{|c|c|c|}
\hline Constituent & $\begin{array}{c}\text { Recovery } \\
(\%)\end{array}$ & $\begin{array}{l}\text { Quality Limit } \\
(\%)\end{array}$ \\
\hline Benzene & 93 & $73-126$ \\
\hline Bromobenzene & 102 & $76-133$ \\
\hline Bromodichloromethane & 103 & $101-138$ \\
\hline Bromoform & 65 & $57-156$ \\
\hline Butylbenzene & 97 & $71-125$ \\
\hline sec-Butylbenzene & 82 & $71-145$ \\
\hline t-Butylbenzene & 91 & $69-134$ \\
\hline Carbon Tetrachloride & 95 & $86-118$ \\
\hline Chlorobenzene & 103 & $80-137$ \\
\hline Chloroform & 111 & $68-120$ \\
\hline o-Chlorotoluene & 110 & $81-146$ \\
\hline p-Chlorotoluene & 98 & $73-144$ \\
\hline 1,2-Dibromo-3-chloropropane & 70 & $36-154$ \\
\hline Dibromochloromethane & 91 & $68-130$ \\
\hline 1,2-Dibromoethane & 109 & $75-149$ \\
\hline Dibromomethane & 89 & $65-143$ \\
\hline 1,2-Dichlorobenzene & 115 & $59-174$ \\
\hline 1,3-Dichlorobenzene & 104 & $84-143$ \\
\hline 1,4-Dichlorobenzene & 99 & $58-172$ \\
\hline 1,1-Dichloroethane & 107 & $71-142$ \\
\hline 1,2-Dichloroethane & 109 & $70-134$ \\
\hline 1,1-Dichloroethene & 100 & $18-209$ \\
\hline cis-1,2-Dichloroethene & 95 & $85-124$ \\
\hline trans-1,2-Dichloroethene & 101 & $67-141$ \\
\hline 1,2-Dichloropropane & 106 & $19-179$ \\
\hline 1,3-Dichloropropane & 106 & $73-145$ \\
\hline 1,1-Dichloropropene & 105 & $71-133$ \\
\hline Ethyl Benzene & 98 & $84-130$ \\
\hline Isopropylbenzene & 92 & $70-144$ \\
\hline 4-Isopropyltoluene & 92 & $72-140$ \\
\hline Methylene Chloride & 81 & $\mathrm{D}-197^{\mathrm{b}}$ \\
\hline n-Propylbenzene & 95 & $78-139$ \\
\hline 1,1,1,2-Tetrachloroethane & 98 & $88-133$ \\
\hline Tetrachloroethene & 99 & $84-132$ \\
\hline Toluene & 113 & $81-130$ \\
\hline 1,1,1-Trichloroethane & 98 & $68-149$ \\
\hline 1,1,2-Trichloroethane & 108 & $70-133$ \\
\hline Trichloroethene & 116 & $91-135$ \\
\hline 1,2,3-Trichloropropane & 97 & $50-158$ \\
\hline 1,2,4-Trimethylbenzene & 85 & $80-144$ \\
\hline 1,3,5-Trimethylbenzene & 87 & $76-142$ \\
\hline o-Xylene & 110 & $79-141$ \\
\hline $\mathrm{p}$-Xylene & 102 & $74-138$ \\
\hline
\end{tabular}


TABLE 7.6

\begin{tabular}{|c|c|c|}
\hline Constituent & $\begin{array}{c}\text { Recovery }^{\mathrm{a}} \\
(\%)\end{array}$ & $\begin{array}{l}\text { Quality Limit } \\
\text { (\%) }\end{array}$ \\
\hline 2-Fluorophenol ${ }^{\mathrm{b}}$ & 56.5 & $21-100$ \\
\hline Phenol-d $5^{b}$ & 43.4 & $10-94$ \\
\hline Phenol & 45.2 & $17-100$ \\
\hline 2-Chlorophenol. & 86.5 & $36-120$ \\
\hline 1,4-Dichlorobenzene & 57.5 & $37-106$ \\
\hline n-Nitroso-n-Propylamine & 51.2 & 24-198 \\
\hline Nitrobenzene-d $5^{b}$ & 79.2 & $35-114$ \\
\hline 1,2,4-Trichlorobenzene & 66.7 & $57-129$ \\
\hline 4-Chloro-3-Methylphenol & 90.3 & $41-128$ \\
\hline 2-Fluorobiphenyl ${ }^{\mathrm{b}}$ & 89.3 & $43-116$ \\
\hline Acenaphthene & 93.2 & $47-145$ \\
\hline 2,4-Dinitrotoluene & 91.5 & $48-127$ \\
\hline 2,4,6-Tribromophenol ${ }^{b}$ & 82.5 & $10-123$ \\
\hline Pentachlorophenol & 107.5 & $38-152$ \\
\hline Pyrene & 87.8 & $70-100$ \\
\hline Terphenyl-d14 ${ }^{\mathrm{b}}$ & 103.0 & $33-141$ \\
\hline
\end{tabular}

a Average of five determinations.

b Required surrogates.

\subsection{NPDES Analytical Quality Assurance}

ANL-E conducts the majority of the analyses required for inclusion in the DMR. These analyses are conducted in accordance with EPA-approved methods set out in 40 CFR Part $136 .{ }^{23}$ To demonstrate the capabilities of the ANL-E laboratory for these analyses, the EPA requires that ANL-E participate in the DMR Quality Assurance program. The EPA sends a series of intercomparison samples to ANL-E annually, and the ensuing analytical results are submitted to the EPA for review. The proficiency of the laboratory is determined by comparing the analytical 
results for the submitted samples with the EPA values. The ANL-E laboratory has consistently performed very well on these tests. In 1998, the ANL-E analytical results were all found to be acceptable. 


\section{QUALITY ASSURANCE}




\section{APPENDIX}

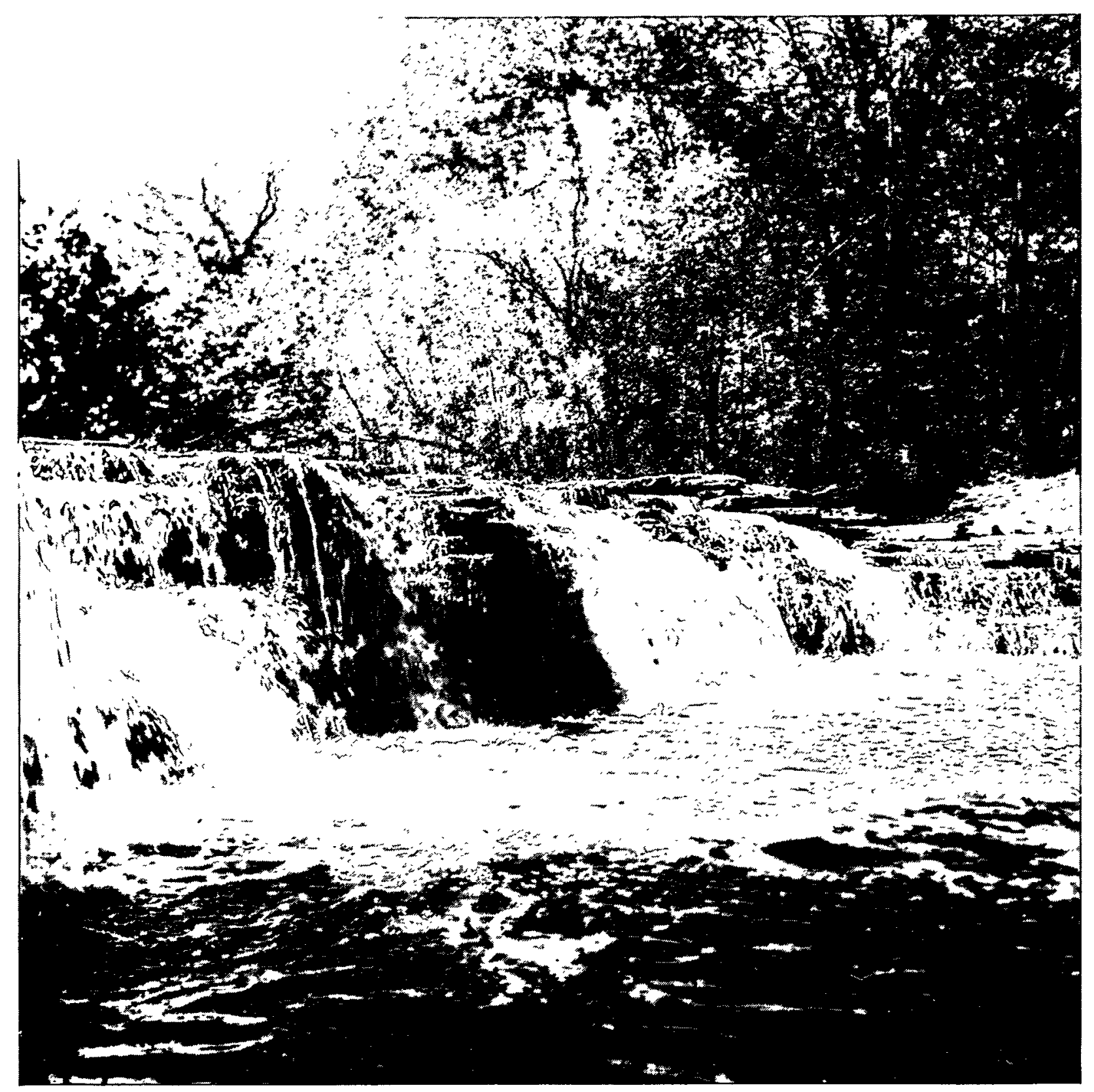

ANL-E Site Environmental Report 
8. APPENDIX 


\subsection{References}

1. U.S. Department of Energy, 1988, "General Environmental Protection Program," DOE Order 5400.1, Nov. 9.

2. U.S. Department of Energy, 1995, "Environment, Safety, and Health Reporting," DOE Order 231.1, Sept. 30.

3. Moses, H., and M.A. Bogner, 1967, Fifteen-Year Climatological Summary, January 1, 1950 - December 31, 1964, ANL-7084, Argonne National Laboratory, IL.

4. U.S. Environmental Protection Agency, 1998, User's Manual Landfill Gas Emissions Model, Version 2.0, Office of Research and Development, Washington, DC, Feb.

5. U.S. Army Corps of Engineers, 1987, Corps of Engineers Wetlands Delineation Manual, Technical Report Y-87-1, Washington, DC.

6. U.S. Department of Enegy, 1998, Accelerating Cleanup - Paths to Closure, DOE/EM0342, Washington, DC, Feb.

7. Parks, B.S., 1992, User's Guide for CAP88-C, Version 1.0, EPA402-B-92-001, Office of Radiation Programs, U.S. Environmental Protection Agency, Las Vegas, NV.

8. U.S. Environmental Protection Agency, 1986, Test Methods for Evaluating Solid Waste: Physical/Chemical Methods, EPA-530-SW-846, 3rd ed., Nov. 1986 and subsequent updates, Office of Solid Waste, Washington, DC.

9. U.S. Department of Energy, 1988, "Radioactive Waste Management," DOE Order 5820.2A, Sept. 26. 
10. U.S. Department of Energy, 1991, Environmental Regulatory Guide for Radiological Effluent Monitoring and Environmental Surveillance, DOE/EH-0173T, Washington, DC.

11. U.S. Department of Energy, 1990, "Radiation Protection of the Public and the Environment," DOE Order 5400.5, Feb. 8.

12. International Commission on Radiological Protection, 1977, Recommendations of the International Commission on Radiological Protection, ICRP Publication 26, Annals of the ICRP, 1(2), Pergamon Press, New York, NY.

13. International Commission on Radiological Protection, 1979-1982, Limits for Intakes of Radionuclides by Workers, ICRP Publication 30, Part 1 (and Supplement), Part 2 (and Supplement), Part 3 (and Supplements A and B), and Index, Annals of the ICRP, Pergamon Press, New York, NY.

14. U.S. Department of Energy, 1988, Internal Dose Conversion Factors for Calculation of Dose to the Public, DOE/EH-0071, Washington, DC.

15. Larsen, R.J., 1993, "Global Decrease of Beryllium-7 in Surface Air," Journal of Environmental Radioactivity 18:85-87.

16. Golchert, N.W., and R.G. Kolzow, 1998, Argonne National Laboratory-East Site Environmental Report for Calendar Year 1997, ANL 98/2, Argonne National Laboratory, Argonne, IL.

17. U.S. Environmental Protection Agency, 1990, "National Standards for Hazardous Air Emissions: Standards for Radionuclides," Code of Federal Regulations, Title 40, Part 61, Subpart H. 
18. National Council on Radiation Protection and Measurements, 1987, Ionizing Radiation Exposure of the Population of the United States, NCRP Report No. 93, Washington, DC.

19. International Commission on Radiological Protection, 1975, Reference Man: Anatomical, Physiological, and Metabolic Characteristics, ICRP Publication 23, Pergamon Press, New York, NY.

20. U.S. Environmental Protection Agency, 1993, "National Primary Drinking Water Regulations," Code of Federal Regulations, Title 40, Part 141.

21. U.S. Environmental Protection Agency, 1984, "EPA Administered Permit Program : The National Pollutant Discharge Elimination System," Code of Federal Regulations, Title 40, Part 122.

22. State of Illinois, Rules and Regulations, 1985, Title 35, "Environmental Protection," Subtitle C, Water Pollution, Chapter 1.

23. U.S. Environmental Protection Agency, 1986, "Test Procedures for the Analysis of Pollutants Under the Clean Water Act," Code of Federal Regulations, Title 40, Part 136.

24. State of Illinois, Rules and Regulations, 1991, Title 35, "Environmental Protection," Subtitle C, Part 304, Jan. 22.

25. State of Illinois, Rules and Regulations, 1990, Title 35, "Environmental Protection," Subtitle C, Part 302.

26. State of Illinois, Rules and Regulations, 1991, Title 35, "Groundwater Quality Standards," Subtitle F, Part 620. 


\section{APPENDIX}

27. U.S. Environmental Protection Agency, 1992, Methods for the Determination of Organic Compounds in Drinking Water, Supplement II, EPA-600/R-92/129, Washington, DC.

28. U.S. Environmental Protection Agency, 1986, RCRA Ground-Water Monitoring Technical Enforcement Guidance Document, OSWER-9950.1, Office of Solid Waste and Emergency Response, Washington, DC.

29. U.S. Department of Energy, 1991, “Quality Assurance,” DOE Order 5700.6C, Aug. 21.

30. U.S. Environmental Protection Agency, 1984, Methods for Chemical Analysis of Water and Wastes, EPA-600/4-84-017, Washington, DC. 


\subsection{Distribution for $99 / 3$}

Internal:

S.I. Baker

P.E. Hollopeter

G.L. Barrett

M.A. Kamiya

R.M. Beaver

R.G. Kolzow (5)

G.A. Borland

G.A. Kulma

R. Bouie

W.D. Luck

J.C. Burton

L.P. Moos

M.C. Cole

H.S. Morss

T.M. Davis

G.D. Mosho

A.J. Dvorak

W.J. Munyon

F.Y. Fradin

B.G. Pierce

N.W. Golchert (25)

R.E. Piorkowski

M.E. Goodkind

M.J. Robinet

C. Grandy

R.A. Schlenker

G.E. Griffin

V.C. Stamoudis

M.R. Hale

R.E. Swale

W.H. Hannum

K. Trychta

B.A. Harvey

J.L. Tucker

D.A. Haugen

J.L. Walker

J.A. Heine

R.A. Wynveen

J.E. Helt

T.J. Yule

R.D. Hislop

\section{External:}

DOE OSTI (2)

ANL-E Library

ANL-W, AW-IS 
DOE-HQ Assistant Secretary for Environment, Safety and Health, EH-1 (2) DOE-HQ, Glenn Podonsky, Deputy Assistant Secretary of Oversight, EH-2 DOE-HQ, Richard Day, Office of Operating Experience, Analysis and Feedback, EH-33 DOE-HQ, Ross Natoli, Office of Environmental Policy and Assistance, EH-41 (3)

DOE-HQ, Caryle Miller, Office of Science, SC-82

DOE-HQ, Van Nguyen, Office of Science, SC-82 (3)

P.M. Neeson, DOE-CH, STS

G. Walach, DOE-CH, GLD

T.S. Crawford, DOE-ARG (15)

David Antonacchi, Illinois Department of Public Health, Springfield, Illinois Derek Rompot, Illinois Environmental Protection Agency, Springfield, Illinois

Tom F. Brown, West Valley Nuclear Services, West Valley, New York

Stuart Black, Nevada Test Site, Las Vegas, Nevada

Daniel G. Carfagno, Mound Laboratory, Miamisburg, Ohio

Larry Eastep, Illinois Environmental Protection Agency, Springfield, Illinois

Isabel M. Fisenne, DOE-EML, New York, New York

William Griffing, Fermi National Accelerator Laboratory, Batavia, Illinois

James D. Heffner, Westinghouse Savannah River Company, Aiken, South Carolina

Robert C. Holland, Sandia National Laboratories, Livermore, California

Hue-Su Hwang, Sandia National Laboratories, Albuquerque, New Mexico

Illinois Department of Nuclear Safety, Springfield, Illinois

William Isherwood, Lawrence Livermore National Laboratory, Livermore, California

Julie A. Johnston, Los Alamos National Laboratory, Los Alamos, New Mexico

Betsy Jonker, DOE Idaho Operations Office, Idaho Falls, Idaho

Chris Kallis, Illinois Environmental Protection Agency, Maywood, Illinois

Jennifer Larson, Lawrence Livermore National Laboratory, Livermore, California

Bob Lorenz, Westinghouse Savannah River Company, Aiken, South Carolina

Dennis Luehring, DuPage County (IL) Health Department, Westmont, Illinois

Chris Martin, Argonne National Laboratory-West, Idaho Falls, Idaho

John B. Murphy, Oak Ridge National Laboratory, Oak Ridge, Tennessee 


\section{APPENDIX}

Michael Murphy, U.S. Environmental Protection Agency, Region 5, Chicago, Illinois

J.R. Naidu, Brookhaven National Laboratory, Upton, New York

J. O'Connor, Illinois Department of Public Health, West Chicago, Illinois

Ted Poston, Battelle-Pacific Northwest Laboratories, Richland, Washington

C. Lyle Roberts, Dames and Moore, Orchard Park, New York

Kenneth Rogers, Water Compliance, Illinois Environmental Protection Agency, Springfield, Illinois

Gary Schroeder, Brookhaven National Laboratory, Upton, New York

Lars Soholt, Los Alamos National Laboratory, Los Alamos, New Mexico

Michael Palazzetti, DuPage County Forest Preserve District, Glen Ellyn, Illinois

David H. Stoltenberg, U.S. Environmental Protection Agency, Region 5, Chicago, Illinois

Patrick Thorson, Lawrence Berkeley Laboratory, Berkeley, California 
